\author{
UNIVERSIDADE DE SÃO PAULO \\ ESCOLA DE ENGENHARIA DE SÃO CARLOS
}

RAFAEL HENRIQUE DUPIM

RESISTÊNCIA RESIDUAL DE COMPRESSÃO DE BLOCOS, PRISMAS E PEQUENAS PAREDES DE ALVENARIA ESTRUTURAL DE BLOCOS DE CONCRETO SUBMETIDOS À SITUAÇÃO DE INCÊNDIO

SÃO CARLOS

2019 



\title{
RESISTÊNCIA RESIDUAL DE COMPRESSÃO DE BLOCOS, PRISMAS E PEQUENAS PAREDES DE ALVENARIA ESTRUTURAL DE BLOCOS DE CONCRETO SUBMETIDOS À SITUAÇÃO DE INCÊNDIO
}

\author{
VERSÃO CORRIGIDA
}

A versão original encontra-se na Escola de Engenharia de São Carlos

Texto apresentado ao Departamento de Engenharia de Estruturas da Escola de Engenharia de São Carlos, Universidade de São Paulo, como parte dos requisitos necessários para obtenção do título de Mestre em Engenharia Civil (Estruturas).

Orientador: Prof. Dr. Márcio Roberto Silva Corrêa

SÃO CARLOS 
AUTORIZO A REPRODUÇÃO TOTAL OU PARCIAL DESTE TRABALHO, POR QUALQUER MEIO CONVENCIONAL OU ELETRÔNICO, PARA FINS DE ESTUDO E PESQUISA, DESDE QUE CITADA A FONTE.

Ficha catalográfica elaborada pela Biblioteca Prof. Dr. Sérgio Rodrigues Fontes da EESC/USP com os dados inseridos pelo(a) autor(a).

Dupim, Rafael Henrique

Resistência residual de compressão de blocos, prismas D934r e pequenas paredes de alvenaria estrutural de blocos de
concreto submetidos à situação de incêndio / Rafael Henrique Dupim; orientador Márcio Roberto Silva Corrêa. São Carlos, 2019.

Dissertação (Mestrado) - Programa de Pós-Graduação em Engenharia Civil(Engenharia de Estruturas) e Área de Concentração em Estruturas -- Escola de Engenharia de São Carlos da Universidade de São Paulo, 2019.

1. Alvenaria estrutural. 2. Blocos de concreto. 3. Incêndio. 4. Resistência residual. 5. Análise experimental. 6. Incêndio-padrão. 7. Isolamento térmico. I. Título. 


\section{FOLHA DE JULGAMENTO}

Candidato: Engenheiro RAFAEL HENRIQUE DUPIM.

Título da dissertação: "Resistência residual de compressão de blocos, prismas e pequenas paredes de alvenaria estrutural de blocos de concreto submetidos à situação de incêndio".

Data da defesa: 03/06/2019.

\section{Comissão Julgadora:}

Prof. Associado Marcio Roberto Silva Corrêa

\section{(Orientador)}

(Escola de Engenharia de São Carlos/EESC)

Prof. Dr. Roberto Marcio da Silva

(Universidade Federal de Minas Gerais/UFMG)

Prof. Dr. Armando Lopes Moreno Junior

(Universidade Estadual de Campinas/UNICAMP)

\footnotetext{
(Universidade Federal de Minas Gerais/UFMG)
}

Resultado:

APROXADO 

"O mais corajoso dos atos ainda é pensar com a própria cabeça" (Coco Chanel) 



\section{AGRADECIMENTOS}

Agradeço primeiramente a Deus pela vida e por sempre guiar minhas escolhas iluminando meu caminho.

À minha mãe, Marli, por seu amor e dedicação incondicionais. Obrigado por sempre me apoiar, me aconselhar e me incentivar a buscar novos desafios. A sua força é inspiradora. Agradeço por sempre me garantir suporte emocional e financeiro, sem você nada disso seria possível. Te amo.

Ao meu orientador Márcio Corrêa, pela confiança em meu trabalho e pela excelente orientação com disponibilidade e paciência para transmitir conhecimento e contribuir para a realização deste trabalho.

Ao meu namorado, Pedro, por toda paciência, carinho, companheirismo e muitos momentos de alegria que tornaram essa jornada muito mais tranquila.

Ao meu pai, Vital, por sempre acreditar no meu potencial, me apoiar e fornecer preciosos conselhos para ir em busca de uma trajetória de sucesso.

Ao meu cachorro, Buddy, que já não está mais neste plano, por seu amor incondicional. Obrigado por tantos momentos de alegria nestes 9 anos que estivemos juntos, o seu carinho sempre me deu ânimo para enfrentar qualquer desafio sem estresse.

A todos que fizeram parte do grupo de pesquisa e contribuíram para a realização deste trabalho. O professor Jorge Jorge Munaiar Neto, que sempre esteve acompanhando de perto o andamento dos ensaios, e os professores Vladimir Guilherme Haach e Carlito Calil Júnior. Aos meus amigos Paulo e Darlan, sempre dispostos a ajudar, e principalmente ao Davi Leal, pelas valorosas contribuições nas discussões dos resultados e por coordenar brilhantemente a execução dos ensaios me orientando para garantir o melhor trabalho possível.

Aos demais professores que me transmitiram um pouco de conhecimento e aos funcionários do Departamento de Estruturas pelo suporte.

A todos os funcionários do Laboratório de Estruturas pela ajuda e compreensão nos ensaios experimentais.

Aos todos meus amigos do Departamento de Estruturas, principalmente àqueles que sempre estiveram comigo compartilhando os momentos bons e rindo dos momentos difíceis. Murilo, Mariana, Daniele, Gabriela, Yagho, Ana Carolina e Marcela, vocês estarão sempre comigo. 
Às minhas amigas de Franca, Ana Carolina, Maria Fernanda e Sofia que mesmo com a distância estão constantemente presentes e fazem eu ter a certeza de sempre poderei contar com vocês.

A todos meus amigos da graduação na Unesp de Bauru, que mesmo com a distância e o passar dos anos não deixam que as vidas cada vez mais agitadas a apaguem o que construímos na cidade sem limites. Agradeço especialmente à Isabela, Camila, Suellen, Tati, Carol, Raquel, Lucas Barile e Gustavo.

À empresa TATU Pré-Moldados por financiar e fornecer os blocos utilizados nesta pesquisa.

À FAPESP pelo financiamento da pesquisa.

Por fim agradeço ao Conselho Nacional de Desenvolvimento Científico e Tecnológico pela bolsa concedida. 


\section{RESUMO}

DUPIM, R. H. Resistência residual de compressão de blocos, prismas e pequenas paredes de alvenaria estrutural de blocos de concreto submetidos à situação de incêndio. Dissertação (Mestrado em Engenharia de Estruturas). Escola de Engenharia de São Carlos, Universidade de São Paulo, São Carlos, Brasil, 2019.

Alvenaria estrutural é um sistema construtivo em que paredes exercem tanto função estrutural como de vedação. Apesar de ser largamente utilizada no Brasil atualmente, não há uma norma nacional com procedimentos para o dimensionamento deste sistema em situação de incêndio. Muito se deve pelo fato de as pesquisas nesta área serem substancialmente escassas se comparadas com os sistemas construtivos em concreto armado ou aço. Neste contexto, este trabalho tem por objetivo realizar ensaios experimentais para avaliar a resistência residual de compressão da alvenaria estrutural com blocos de concreto. Foram avaliadas duas variações de blocos de concreto, com resistências características de 4,0 e de 10,0 MPa, ambos com espessura nominal de $140 \mathrm{~mm}$ e os corpos de prova estudados foram os prismas e as pequenas paredes. Realizou-se a caracterização física, geométrica e mecânica da alvenaria em temperatura ambiente e na sequência os corpos de prova foram submetidos a uma simulação de incêndiopadrão normalizado pela ISO 834-1:1999, durante 120 minutos que é o TRRF máximo recomendado pela ABNT NBR 14432:2001. Na primeira fornada foram avaliados os elementos de $140 \mathrm{~mm}$ sem revestimento e segunda fornada todos os elementos revestidos com uma camada de $5 \mathrm{~mm}$ de gesso. Após o resfriamento lento até a temperatura ambiente, os corpos de prova foram submetidos ao ensaio de compressão simples para avaliar a resistência residual de compressão dos blocos, prismas e pequenas paredes. Em todos os casos as resistências encontradas ficaram abaixo do suficiente para garantir a segurança durante a ação de um incêndio, uma vez que o máximo de resistência residual encontrado foi de $22 \%$. A influência da compartimentação na resistência residual das pequenas paredes, foi brevemente avaliada, para isso três pequenas paredes de 4,0 MPa e $140 \mathrm{~mm}$ com o interior isolado dos gases externos foram submetidas ao incêndio-padrão e compressão pós resfriamento, verificou-se que a perda de resistência neste caso foi de $54 \%$ enquanto nas pequenas paredes com fogo em todas as faces e expostas ao fogo pelo mesmo período a perda foi de $86 \%$. Estas pequenas paredes compartimentadas foram instrumentadas com a finalidade de avaliar a transferência de calor ao longo da sessão transversal e verificar o tempo de atendimento do critério de isolamento, que neste caso foi de 62 minutos, abaixo do TRRF máximo de 120 minutos.

Palavras-chave: Alvenaria estrutural. Blocos de concreto. Incêndio. Resistência residual. Análise Experimental. Incêndio-padrão. Isolamento térmico. 



\begin{abstract}
DUPIM, R. H. Residual compressive strength of blocks, prisms and walls of concrete structural masonry under fire situation. Master Course Dissertation (M. Sc. In Structural Engineering). São Carlos School of Engineering, University of São Paulo, São Carlos, Brazil, 2019.

Structural masonry is a building system that walls work as structure and has sealing function too. Even though it is widely used in Brazil nowadays, there is no national standardization for the masonry design in fire situation. One of the reasons is that researches in this area are substantially sparse if compared with other building systems like reinforced concrete and steel. In this context, the purpose of this work is to evaluate the residual compressive strength of concrete structural masonry by experimentally tests. Two concrete block variations were evaluated, with strengths of 4,0 and $10,0 \mathrm{MPa}$, both with $140 \mathrm{~mm}$ nominal thickness, the elements studied were prisms and walls, beyond blocks. In the first stage, the masonry was characterized in ambient temperature and in the second stage, the elements were submitted to fire simulation standardized by ISO 834-1: 1999 for 120 minutes, which is the maximum TRRF recommended by ABNT NBR 14432: 2001. In the first fire simulation the $140 \mathrm{~mm}$ elements were evaluated without covering and in the second one, all the elements were covered with 5 mm layer of plaster. Then, after slow cooling until ambient temperature, the residual compressive strength of the blocks, prisms and walls was evaluated by compression test. In all cases the resistances were not enough to ensure safety during the fire, since the maximum residual resistance found was $22 \%$. Still in this stage, the influence of the compartmentation on the residual resistance of the walls was briefly evaluated. Three walls of $4.0 \mathrm{MPa}$ and $140 \mathrm{~mm}$ were placed in a triangle that was thermally insulated inside, and after the fire simulation were subjected in a post-cooling compression test. The loss of resistance found in this case was $54 \%$ while in the walls with fire on all faces and exposed to fire for the same period the loss was $86 \%$. These compartmentalized walls were instrumented with the purpose of evaluating the heat transfer along the cross section and to check the time of the isolation criterion attendance, which in this case was 62 minutes, below the 120-minute established as maximum TRRF.
\end{abstract}

Keywords: Structural masonry. Concrete blocks. Fire. Residual strength. Experimental analysis. Standard fire. Thermal insulation. 



\section{SUMÁRIO}

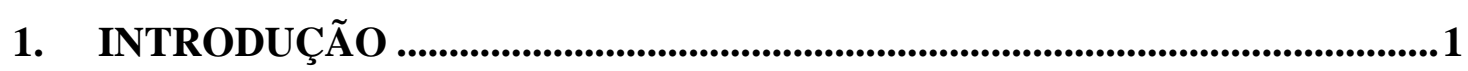

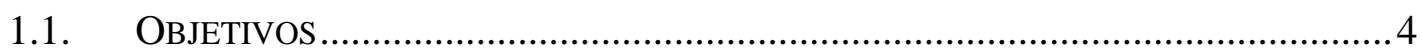

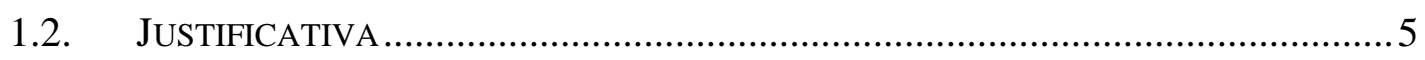

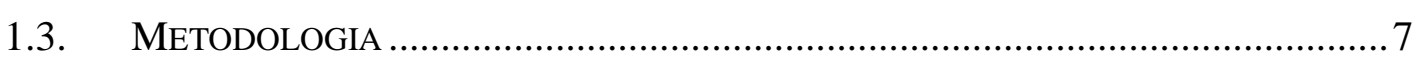

2. REVISÃO BIBLIOGRÁFICA .......................................................................... 11

2.1. ALVENARIA ESTRUTURAL.................................................................. 11

2.1.1. Breve histórico sobre alvenaria estrutural.................................................... 11

2.1.2. Características dos principais componentes da alvenaria estrutural................. 14

2.1.2.1. Unidades - Blocos de Concreto ................................................................... 14

2.1.2.2. Argamassa, aderência e tipo de assentamento.............................................. 16

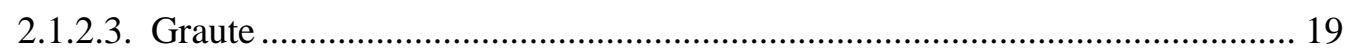

2.1.3. Resistência a compressão da alvenaria .......................................................... 20

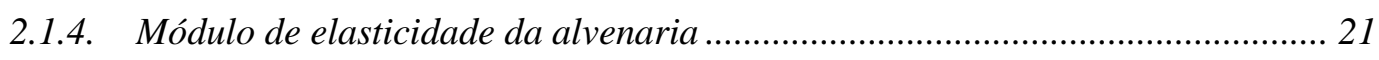

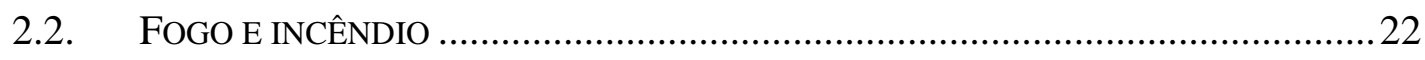

2.2.1. Breve histórico sobre incêndio em edificações .................................................. 22

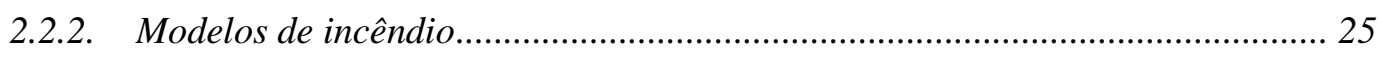

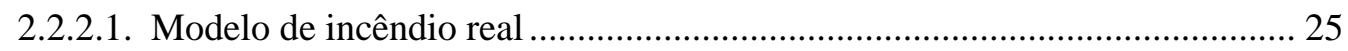

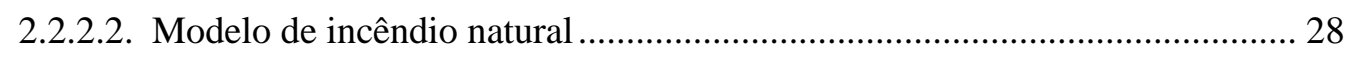

2.2.2.3. Modelo de incêndio-padrão ........................................................................ 31

2.2.3. Tempo requerido de resistência ao fogo $(T R R F)$............................................ 35

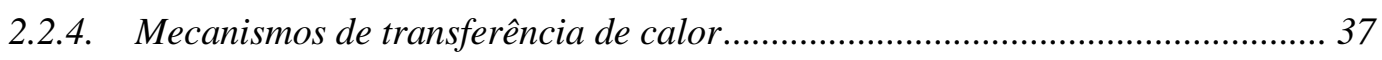

2.2.5. Transferência de calor entre as chamas e o material ........................................ 39

2.2.6. Compartimentação horizontal e vertical ............................................................. 40

2.3. ALVENARIA ESTRUTURAL EM SITUAÇÃO DE INCÊNDIO .................................. 42

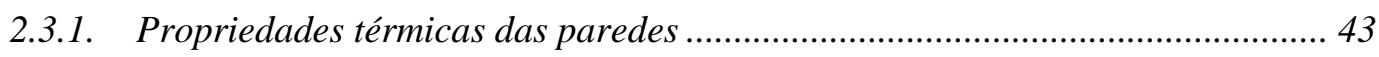

2.3.2. Fatores que influenciam o desempenho alvenaria em elevadas temperaturas .. 46

2.3.3. Estudo dos materiais em elevadas temperaturas .............................................. 49

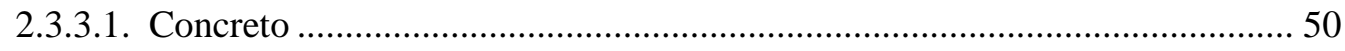

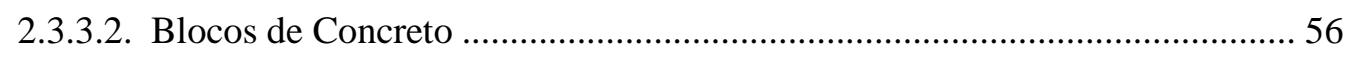


2.4. REGULAMENTAÇÃO NACIONAL DE RESISTÊNCIA AO FOGO PARA ALVENARIA ESTRUTURAL

2.5. REGULAMENTAÇÃO INTERNACIONAL DE RESISTÊNCIA AO FOGO PARA ALVENARIA ESTRUTURAL 65

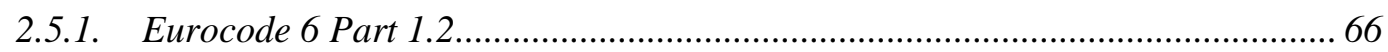

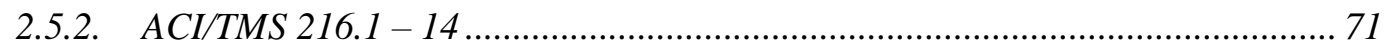

2.5.3. Standards Australia AS 3700............................................................................... 75

2.6. ESTUDO SOBRE TRABALHOS REALIZADOS COM ALVENARIA EM SITUAÇÃO DE INCÊNDIO. .77

\section{PROGRAMA EXPERIMENTAL I: CARACTERIZAÇÃO DOS}

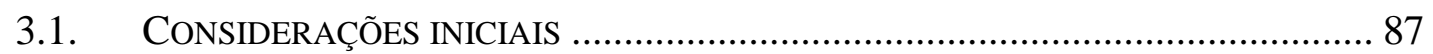

3.2. CARACTERIZAÇÃO FÍSICA E MECÂNICA DAS UNIDADES DE CONCRETO ........... 87

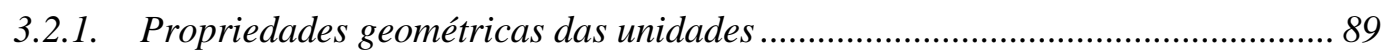

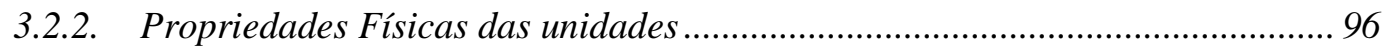

3.2.3. Propriedades mecânicas das unidades - resistência à compressão....................97

3.3. CARACTERIZAÇÃO FÍSICA E MECÂNICA DA ARGAMASSA ............................. 101

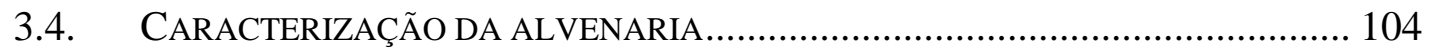

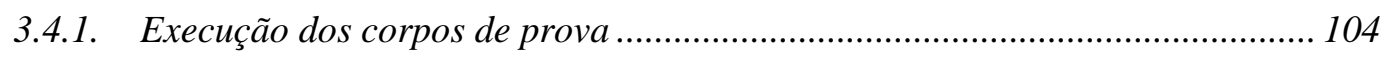

3.4.2. Ensaio dos corpos de prova à compressão..................................................... 106

3.5. FATORES DE EFICIÊNCIA ENTRE OS ELEMENTOS DE ALVENARIA ................... 111

4. PROGRAMA EXPERIMENTAL II: TEMPERATURAS ELEVADAS E RESISTÊNCIA RESIDUAL ................................................................................... 113

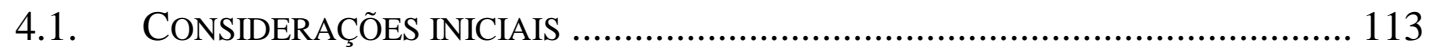

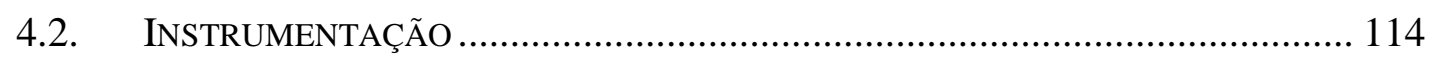

4.3. TESTE PARA INSTRUMENTAÇÃO DOS CORPOS DE PROVA ….......................... 116

4.4. SIMULAÇÃO DE INCÊNDIO-PADRÃO - SEM REVESTIMENTO (PRIMEIRA

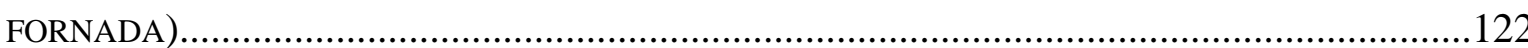

4.4.1. Corpos de prova - quantidade, execução e preparação da fornada................. 123

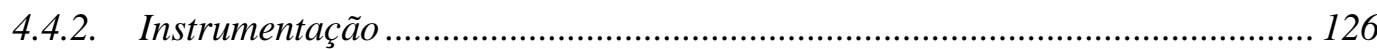


4.4.3. Análise térmica

4.4.3.1. Critério de isolamento - Trio de pequenas paredes compartimentadas ...... 134

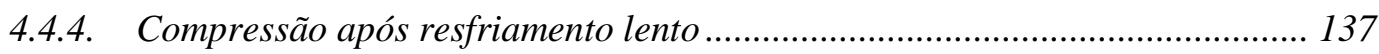

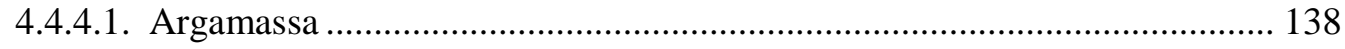

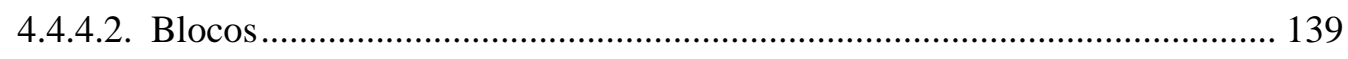

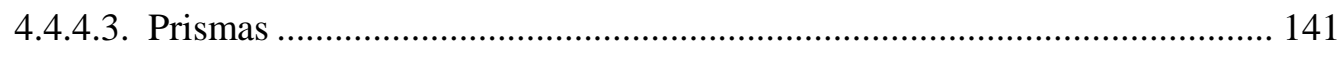

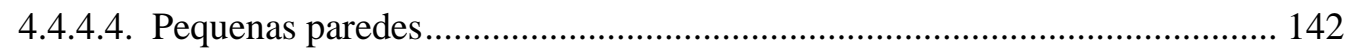

4.4.4.5. Trio de pequenas paredes (compartimentadas) ......................................... 144

4.4.5. Considerações sobre os resultados da $1^{a}$ fornada (sem revestimento) ............. 147

4.5. SIMULAÇÃO DE INCÊNDIO-PADRÃO - REVESTIDOS COM GESSO (SEGUNDA FORNADA)

4.5.1. Corpos de prova - quantidade, execução e preparação da fornada ................ 149

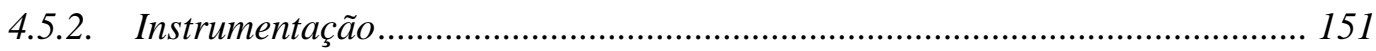

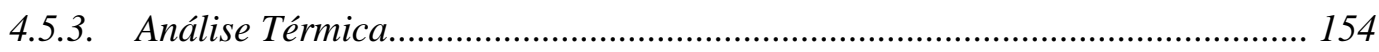

4.5.4. Compressão após resfriamento lento ……………………………………..... 160

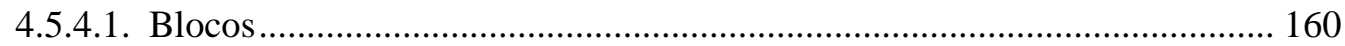

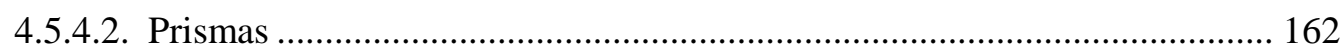

4.5.4.3. Pequenas Paredes ....................................................................................... 164

4.5.5. Considerações sobre os resultados da $2^{a}$ fornada (com revestimento)............ 166

4.6. ANÁLISE DOS RESULTADOS E COMPARAÇÃO DOS FATORES DE EFICIÊNCIA .. 167

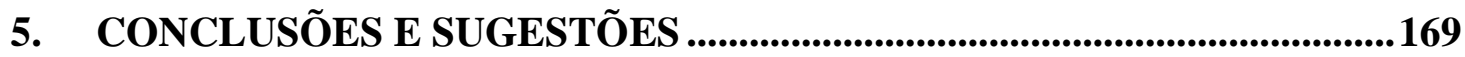

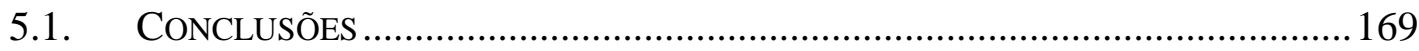

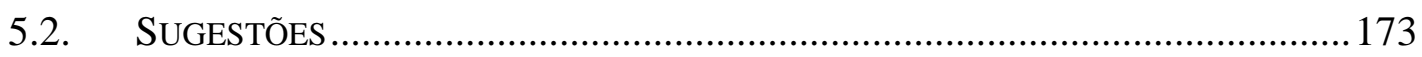

6. REFER̂̂NCIAS BIBLIOGRÁFICAS .....................................................175

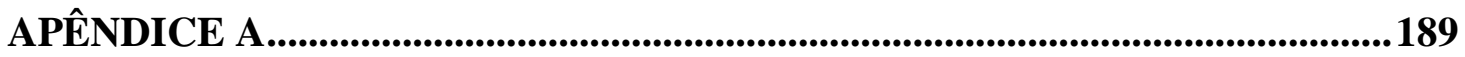

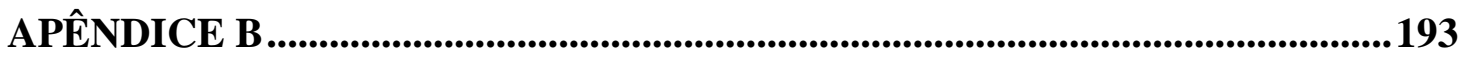

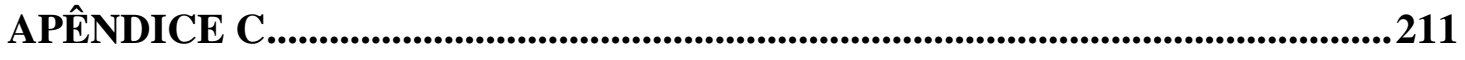

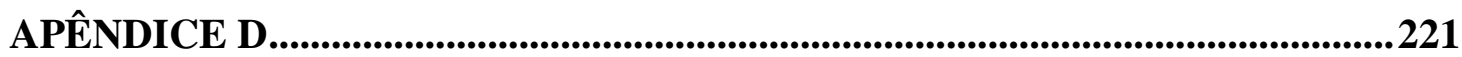

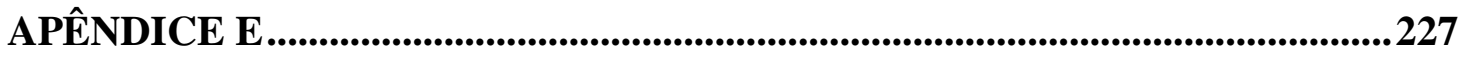





\section{LISTA DE FIGURAS}

Figura 1.1 - Distribuição de incêndio no mundo em 2015, conforme sua origem .....................2

Figura 1.2 - Esquema do ensaio de compressão simples do prisma e da pequena parede .........9

Figura 1.3 - Trio de pequenas paredes com interior isolado termicamente............................ 10

Figura 1.4 - Esquema de organização dos corpos de prova dentro do forno............................ 10

Figura 2.1 - Condomínio Central Parque Lapa em São Paulo .............................................. 12

Figura 2.2 - Condomínio Fit Terra Bonita em Londrina (a); Hotel Excalibur em Las Vegas (b)

Figura 2.3 - (a) Argamassamento total; (b) Argamassamento parcial. 18

Figura 2.4 - Modo de ruptura e mecanismo gerador de tensões horizontais em prismas de blocos de concreto, com assentamento nas faces longitudinais 19

Figura 2.5 - Incêndios nos edifícios Andraus (a) e Joelma (b) 23

Figura 2.6 - Edifício Wilton Paz de Almeida em chamas (a); Escombros do edifício após o incêndio (b) 25

Figura 2.7 - Triângulo da Combustão. 26

Figura 2.8 - Curva de Incêndio Real 27

Figura 2.9 - Modelo de um incêndio natural 28

Figura 2.10 - Principais curvas de incêndio-padrão dos códigos normativos internacionais ... 34

Figura 2.11 - Conceito de Tempo Requeiro de Resistência ao Fogo (TRRF). 35

Figura 2.12 - Esquema da transferência de calor de uma parede submetido a incêndio compartimentado 38

Figura 2.13 - Condições de contorno para vinculações de paredes 49

Figura 2.14 - Condutividade térmica do concreto 52

Figura 2.15 - Calor específico do concreto 53

Figura 2.16 - Densidade do concreto 53

Figura 2.17 - Coeficiente de dilatação térmica do concreto silicoso .........................................54

Figura 2.18 - Redução à compressão do concreto em função da temperatura ...........................55

Figura 2.19 - Valores de variação das propriedades e função da elevação de temperatura para blocos de concreto com silicato de cálcio

Figura 2.20 - Ilustração das isotermas do procedimento simplificado para um pilar de alvenaria estrutural 
Figura 2.21 - Esquema de paredes múltiplas

Figura 2.22 - Evolução da temperatura em função do tempo para pontos de medição na seção do bloco 78

Figura 2.23 - Disposição dos corpos de prova em planta 79

Figura 2.24 - Ensaio das pequenas paredes durante o aquecimento em apenas uma face 82

Figura 3.1 - Variações de blocos e meios-blocos para a resistência de 10,0 MPa. 88

Figura 3.2 - Esquema representativo das dimensões dos blocos 89

Figura 3.3 - Determinações das dimensões efetivas dos blocos e meios-blocos 90

Figura 3.4 - Determinação: espessuras das paredes e dos septos, dimensões dos furos e raios das mísulas 92

Figura 3.5 - Determinação da massa aparente e massa saturada 95

Figura 3.6 - Procedimento de saturação e secagem em estufa, para determinação do índice de absorção 96

Figura 3.7 - Compressão dos blocos e meios-blocos 99

Figura 3.8 - Ruptura das unidades 100

Figura 3.9 - Ensaio de consistência para a argamassa ("Flow Table") 101

Figura 3.10 - Misturador mecânico de eixo inclinado utilizado na confecção da argamassa 102

Figura 3.11 - Esquema de ensaios da argamassa à compressão com instrumentação ........... 103

Figura 3.12 - Curvas de tensão por deformação específica da argamassa de assentamento.. 103

Figura 3.13 - Corpos de prova: prismas de dois blocos e pequenas paredes 105

Figura 3.14 - Esquema geométrico e concretagem das de concreto 106

Figura 3.15 - Instrumentação da pequena parede 107

Figura 3.16 - Máquina servo-hidráulica Instron 8506 do Laboratório de Estruturas da EESC 107

Figura 3.17 - Ensaio de compressão de prismas e pequenas paredes .................................... 108

Figura 3.18 - Curvas médias de tensão $x$ deformação específica das pequenas paredes....... 110

Figura 3.19 - Modo de ruptura dos prismas de 4,0 $\mathrm{MPa}$ 111

Figura 3.20 - Modo de ruptura das pequenas paredes. 111

Figura 4.1 - Forno a gás do Laboratório de Estruturas da EESC 113

Figura 4.2 - Procedimento de soldagem do cabo termopar tipo K 115

Figura 4.3 - Equipamento de solda por descarga capacitiva, junto com a placa de cobre utilizada 
Figura 4.4 - Fixação dos termopares no bloco para teste de instrumentação 116

Figura 4.5 - Posições dos termopares para o teste de instrumentação

Figura 4.6 - Posicionamento dos elementos do teste de instrumentação no forno 118

Figura 4.7 - Ação do fogo durante o teste de instrumentação 118

Figura 4.8 - Gráfico dos resultados do teste de instrumentação para o bloco de 10,0 MPa... 119

Figura 4.9 - Gráfico dos resultados do teste de instrumentação para o bloco de 4,0 MPa.....119

Figura 4.10 - Situação dos blocos do teste de instrumentação após o ensaio. 121

Figura 4.11 - Temperatura do forno na primeira fornada 122

Figura 4.12 - Disposição dos corpos de prova da primeira fornada 124

Figura 4.13 - Proteção térmica das bases de concreto com manta cerâmica. 125

Figura 4.14 - Isolamento lateral do trio de pequenas paredes com manta cerâmica 125

Figura 4.15 - Corpos de prova posicionados no forno para a primeira fornada. 126

Figura 4.16 - Instrumentação de blocos e prismas ( $1^{a}$ Fornada) 127

Figura 4.17 - Instrumentação das pequenas paredes de 10,0 MPa ( $1^{\mathrm{a}}$ Fornada) 128

Figura 4.18 - Instrumentação das pequenas paredes de 4,0 MPa ( $1^{\mathrm{a}}$ Fornada) 128

Figura 4.19 - Instrumentação do trio de pequenas paredes ( $1^{\text {a }}$ Fornada) 129

Figura 4.20 - Situação das paredes logo após desligamento e após abertura do forno 130

Figura 4.21 - Gráfico com curvas dos termopares dos elementos de 10,0 MPa e $140 \mathrm{~mm}\left(1^{\mathrm{a}}\right.$ Fornada) 132

Figura 4.22 - Gráfico com curvas dos termopares dos elementos de 4,0 MPa e $140 \mathrm{~mm}\left(1^{\mathrm{a}}\right.$ Fornada).

Figura 4.23 - Gráfico das curvas de temperatura em função do tempo para o trio de pequenas paredes compartimentado 135

Figura 4.24 - Gráfico do comportamento do trio de pequenas paredes compartimentados até os 300 minutos 137

Figura 4.25 - Situação dos corpos de prova de argamassa pós-fogo . 138

Figura 4.26 - Ensaio de compressão pós-fogo dos blocos. 139

Figura 4.27 - Situação dos blocos pós-fogo ( $1^{\mathrm{a}}$ fornada) 140

Figura 4.28 - Ruptura dos prismas após ação do fogo ( $1^{\mathrm{a}}$ fornada) 142

Figura 4.29 - Ruptura das pequenas paredes após a ação do fogo ( $1^{\mathrm{a}}$ fornada $)$ 144

Figura 4.30 - Curvatura apresentada por uma das paredes do trio compartimentado 145

Figura 4.31 - Modo de ruptura das pequenas paredes compartimentadas da $1^{\text {a }}$ Fornada....... 146

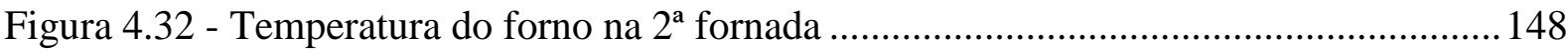

Figura 4.33 - Disposição dos corpos de prova da $2^{\mathrm{a}}$ fornada. 


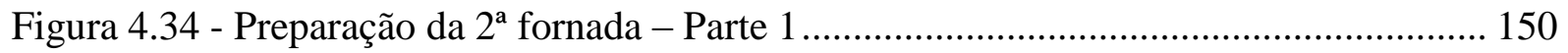

Figura 4.35 - Preparação da $2^{\mathrm{a}}$ fornada - Parte 2 2............................................................... 151

Figura 4.36 - Exemplos de instrumentação para a $2^{\mathrm{a}}$ fornada.............................................. 152

Figura 4.37 - Instrumentação das pequenas paredes de 10,0 MPa / $140 \mathrm{~mm}$ com revestimento ( $2^{\mathrm{a}}$ Fornada).... 153

Figura 4.38 - Instrumentação das pequenas paredes de 4,0 MPa / $140 \mathrm{~mm}$ com revestimento (2a Fornada) 153

Figura 4.39 - Situação do revestimento de gesso durante e após a ação do fogo 155

Figura 4.40 - Coloração dos blocos alterada pela ação térmica 157

Figura 4.41 - Gráfico com curvas dos termopares das pequenas paredes de 10,0 MPa e $140 \mathrm{~mm}$ com revestimento de gesso ( $2^{\text {a }}$ Fornada). 158

Figura 4.42 - Gráfico com curvas dos termopares das pequenas paredes de 4,0 MPa e $140 \mathrm{~mm}$ com revestimento de gesso ( $2^{\mathrm{a}}$ Fornada). 159

Figura 4.43 - Situação dos blocos de 4,0 MPa antes do ensaio de compressão simples pós-fogo 162

Figura 4.44 - Modo de ruptura dos prismas com revestimento de gesso ( $2^{\text {a }}$ Fornada) 164 Figura 4.45 - Modo de ruptura das pequenas paredes pós-fogo ( $2^{\mathrm{a}}$ Fornada) 166

Figura A.1 - Gráfico de fluxo de calor passando por uma parede infinita e plana composta por camadas 190

Figura B.1 - Gráfico de tensão x deformação das pequenas paredes de 10,0 MPa e $140 \mathrm{~mm}$ 206

Figura B.2 - Gráfico de tensão x deformação das pequenas paredes de 10,0 MPa e 190 mm 206

Figura B.3 - Gráfico de tensão x deformação das pequenas paredes de 4,0 MPa e $140 \mathrm{~mm} 207$ Figura B.4 - Gráfico de tensão x deformação das pequenas paredes de 4,0 MPa e 190 mm 207 Figura B.5 - Ensaios de compressão das pequenas paredes de 4,0 MPa e $140 \mathrm{~mm}$.............. 208 Figura B.6 - Ensaios de compressão das pequenas paredes de 4,0 MPa e $190 \mathrm{~mm}$ 209

Figura C. 1 - Gráfico de temperatura por tempo dos termopares trio de paredes de 4,0 $\mathrm{MPa}$ ( $\left.1^{\mathrm{a} F o r n a d a}\right)$. 211

Figura C.2 - Gráfico de temperatura por tempo dos termopares dos blocos de 10,0 MPa ( $1^{\mathrm{a}}$ Fornada). 
Figura C.3 - Gráfico de temperatura por tempo dos termopares dos blocos e prisma de 4,0 MPa ( $1^{\mathrm{a} F o r n a d a)}$

Figura C.4 - Gráfico de temperatura por tempo dos termopares das pequenas paredes de 10,0 $\operatorname{MPa}\left(1^{\mathrm{a} F o r n a d a}\right)$

Figura C. 5 - Gráfico de temperatura por tempo dos termopares das pequenas paredes de 4,0 $\mathrm{MPa}\left(1^{\mathrm{a} F o r n a d a}\right)$ 213

Figura C.6 - Preparação da primeira fornada (posicionamento dos corpos de prova) 216

Figura C.7 - Primeira fornada durante a execução do ensaio. 217

Figura C.8 - Situação dos corpos de prova logo após a abertura do forno 217

Figura C. 9 - Trio de pequenas paredes de 4,0 MPa e $140 \mathrm{~mm}$ após a simulação de incêndio 



\section{LISTA DE TABELAS}

Tabela 1.1 - Quantidades e normas para os ensaios à compressão.......................................... 8

Tabela 2.1 - Requisitos para resistência característica à compressão, absorção e retração...... 15

Tabela 2.2 - Valores de eficiência para blocos de concreto ..................................................... 15

Tabela 2.3 - Valores característicos da resistência à tração na flexão - ftk............................. 18

Tabela 2.4 - Temperaturas dos gases no ambiente em chamas em função do tempo ............... 32

Tabela 2.5 - Temperaturas dos gases no ambiente em chamas em função do tempo ...............32

Tabela 2.6 - Temperaturas dos gases em função do tempo para combustíveis formados por

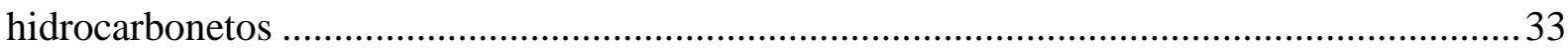

Tabela 2.7 - Tempo Requerido de Resistência ao Fogo (TRRF) em minutos. ........................ 36

Tabela 2.8 - Propriedades térmicas dos blocos de concreto ...................................................58

Tabela 2.9 - Propriedades térmicas da argamassa em temperatura ambiente .........................59

Tabela 2.10 - Resistência média a compressão com resfriamento lento .................................60

Tabela 2.11 - Propriedades mecânicas residuais das argamassas aquecidas ........................... 61

Tabela 2.12 - Resistência ao fogo para alvenarias pelo IT - 08 de São Paulo.......................... 63

Tabela 2.13 - Resistência ao fogo de blocos de concreto e cerâmicos pela ABCI................... 64

Tabela 2.14 - Espessura mínima equivalente de paredes de alvenaria com blocos de concreto em função do tempo

Tabela 2.15 - Espessuras mínimas de paredes carregadas para concreto denso e leve pelo critério $\mathrm{R}$

Tabela 2.16 - Espessuras mínimas de paredes carregadas para blocos de concreto denso e leve pelo critério REI 68

Tabela 2.17 - Blocos cujo método é aplicável e valores das temperaturas $\theta 1$ e $\theta 2$ de cada um

Tabela 2.18 - Espessura mínima equivalente para paredes de alvenaria de blocos de concreto

Tabela 2.19 - Fator multiplicador da espessura dos acabamentos aplicados na face não exposta ao fogo das paredes

Tabela 2.20 - Tempo de contribuição de cada material de acabamento aplicado na face exposta ao fogo 73

Tabela 2.21 - Índice de esbeltez máximo para adequabilidade estrutural 76

Tabela 2.22 - Espessura mínima das paredes considerando o critério de isolamento térmico. 77 Tabela 2.23 - Resumo dos ensaios do IPT 
Tabela 2.24 - Resumo das simulações termomecânicas 84

Tabela 2.25 - Resultados dos ensaios de Lopes et al. (2018) 86

Tabela 3.1 - Descrição das unidades recebidas para ensaio.................................................. 88

Tabela 3.2 - Propriedades avaliadas e quantidades ensaiadas para cada tipo de unidade........ 89

Tabela 3.3 - Dimensões efetivas dos blocos e meios-blocos de concreto................................ 91

Tabela 3.4 - Tolerâncias de espessura mínima das paredes do bloco e dimensões mínimas dos furos e do raio das mísulas 92

Tabela 3.5 - Espessuras, dimensões dos furos e raios das mísulas para os blocos de 10,0 MPa e $140 \mathrm{~mm}$ 93

Tabela 3.6 - Espessuras, dimensões dos furos e raios das mísulas para os blocos de 10,0 MPa e $190 \mathrm{~mm}$ 93

Tabela 3.7 - Espessuras, dimensões dos furos e raios das mísulas para os blocos de 4,0 MPa e $140 \mathrm{~mm}$ 93

Tabela 3.8 - Espessuras, dimensões dos furos e raios das mísulas para os blocos de 4,0 MPa e $190 \mathrm{~mm}$ 94

Tabela 3.9 - Resultados para área bruta, área líquida e a proporção entre elas 95

Tabela 3.10 - Resultados para massa seca, massa saturada e índice de absorção 97

Tabela 3.11 - Resultados de umidades relativas das unidades 98

Tabela 3.12 - Resultados de resistência à compressão das unidades 99

Tabela 3.13 - Resistência à compressão, módulo de elasticidade e resistência à tração por compressão diametral da argamassa de assentamento. . 103

Tabela 3.14 - Quantidades de corpos de prova e tipos de ensaios 104

Tabela 3.15 - Resultados médios e característicos da resistência à compressão dos prismas 109 Tabela 3.16 - Resultados médios e característicos da resistência à compressão das pequenas paredes 109

Tabela 3.17 - Relações de resistência entre os elementos de alvenaria estrutural em temperatura ambiente.

Tabela 4.1 - Relação de termopares do teste de instrumentação e suas respectivas posições 117

Tabela 4.2 - Umidade relativa dos blocos da primeira fornada 123

Tabela 4.3 - Resistência à compressão pós-fogo dos blocos ( $1^{\mathrm{a}}$ Fornada) ............................ 140

Tabela 4.4 - Resistência à compressão pós-fogo dos prismas ( $1^{\mathrm{a}}$ Fornada) ........................... 141

Tabela 4.5 - Resistência à compressão pós-fogo das pequenas paredes ( $1^{\mathrm{a}}$ Fornada) 143 
Tabela 4.6 - Resistência à compressão pós-fogo das pequenas paredes compartimentadas $\left(1^{\text {a }}\right.$ Fornada)....

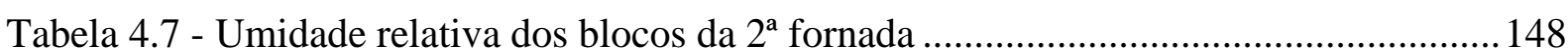

Tabela 4.8 - Resistência à compressão pós-fogo dos blocos ( $2^{\mathrm{a}}$ Fornada $)$............................. 161

Tabela 4.9 - Resistência à compressão pós-fogo dos prismas ( $2^{\mathrm{a}}$ Fornada) ............................163

Tabela 4.10 - Resistência à compressão pós-fogo das pequenas paredes (2 ${ }^{\mathrm{a}}$ Fornada).......... 164

Tabela 4.11 - Relações de resistência entre os corpos de prova da primeira fornada ............. 167

Tabela 4.12 - Relações de resistência entre os corpos de prova da segunda fornada

Tabela B.1 - Resultados da análise dimensional das unidades de 10,0 MPa e espessura de 140 $\mathrm{mm}$.

Tabela B.2 - Resultados da análise dimensional das unidades de 10,0 MPa e espessura de 190 $\mathrm{mm}$.

Tabela B.3 - Resultados da análise dimensional das unidades de 4,0 MPa e espessura de 140 $\mathrm{mm}$

Tabela B.4 - Resultados da análise dimensional das unidades de 4,0 MPa e espessura de 190 $\mathrm{mm}$

Tabela B.5 - Resultados para espessuras, dimensões dos furos e raios das mísulas dos blocos de $10,0 \mathrm{MPa}$ e $140 \mathrm{~mm}$ 194

Tabela B.6 - Resultados para espessuras, dimensões dos furos e raios das mísulas dos blocos de 10,0 MPa e $190 \mathrm{~mm}$

Tabela B.7 - Resultados para espessuras, dimensões dos furos e raios das mísulas dos blocos de 4,0 MPa e $140 \mathrm{~mm}$

Tabela B.8 - Resultados para espessuras, dimensões dos furos e raios das mísulas dos blocos de 4,0 MPa e $190 \mathrm{~mm}$

Tabela B.9 - Resultados para espessuras e dimensões dos furos dos meios-blocos de 10,0 MPa e $140 \mathrm{~mm}$

Tabela B.10 - Resultados para espessuras e dimensões dos furos dos meios-blocos de 10,0 MPa e $190 \mathrm{~mm}$

Tabela B.11 - Resultados para espessuras e dimensões dos furos dos meios-blocos de 4,0 MPa e $140 \mathrm{~mm}$

Tabela B.12 - Resultados para espessuras e dimensões dos furos dos meios-blocos de 4,0 MPa e $190 \mathrm{~mm}$ 196

Tabela B.13 - Resultados de área bruta e área liquida dos blocos de 10,0 MPa e 140 mm ... 197 
Tabela B.14 - Resultados de área bruta e área liquida dos blocos de 10,0 MPa e 190 mm... 197

Tabela B.15 - Resultados de área bruta e área liquida dos blocos de 4,0 MPa e 140 mm.... 197

Tabela B.16 - Resultados de área bruta e área liquida dos blocos de 4,0 MPa e 190 mm..... 198

Tabela B.17 - Resultados de área bruta e área liquida dos meios-blocos de 10,0 MPa e $140 \mathrm{~m}$ 198

Tabela B.18 - Resultados de área bruta e área liquida dos meios-blocos de 10,0 MPa e 190 mm 198

Tabela B.19 - Resultados de área bruta e área liquida dos meios-blocos de 4,0 MPa e $140 \mathrm{~mm}$ 199

Tabela B.20 - Resultados de área bruta e área liquida dos meios-blocos de 4,0 MPa e 190 mm 199

Tabela B.21 - Resultados da absorção das unidades de 10,0 MPa e $140 \mathrm{~mm}$ 199

Tabela B.22 - Resultados da absorção das unidades de 10,0 MPa e $190 \mathrm{~mm}$ 200

Tabela B.23 - Resultados da absorção das unidades de 4,0 MPa e $140 \mathrm{~mm}$ 200

Tabela B.24 - Resultados da absorção das unidades de 4,0 MPa e $190 \mathrm{~mm}$ 200

Tabela B.25 - Resultados de resistência à compressão das unidades de 10,0 MPa e 140 mm 201

Tabela B.26 - Resultados de resistência à compressão das unidades de 10,0 MPa e 190 mm 201

Tabela B.27 - Resultados de resistência à compressão das unidades de 4,0 MPa e 140 mm 201 Tabela B.28 - Resultados de resistência à compressão das unidades de 4,0 MPa e 190 mm 202 Tabela B.29 - Resultados de resistência à compressão e módulo de elasticidade da argamassa de assentamento 202

Tabela B.30 - Resultados de resistência à tração por compressão diametral da argamassa de assentamento 202

Tabela B.31 - Resultados do ensaio de compressão dos prismas de 10,0 MPa e 140 mm .... 203 Tabela B.32 - Resultados do ensaio de compressão dos prismas de 10,0 MPa e 140 mm .... 203 Tabela B.33 - Resultados do ensaio de compressão dos prismas de 10,0 MPa e 140 mm .... 203 Tabela B.34 - Resultados do ensaio de compressão dos prismas de 10,0 MPa ..................... 204 Tabela B.35 - Resultados do ensaio de compressão das pequenas paredes de 10,0 MPa e 140 $\mathrm{mm}$ 204

Tabela B.36 - Resultados do ensaio de compressão das pequenas paredes de 10,0 MPa e 140 $\mathrm{mm}$ 204 
Tabela B.37 - Resultados do ensaio de compressão das pequenas paredes de 4,0 MPa e $140 \mathrm{~mm}$ 205

Tabela B38 - Resultados do ensaio de compressão das pequenas paredes de 4,0 MPa e $190 \mathrm{~mm}$

Tabela C.1 - Resultados da resistência à compressão pós-fogo dos blocos de 10,0 MPa e 140 $\mathrm{mm}$

Tabela C.2 - Resultados da resistência à compressão pós-fogo dos blocos de 4,0 MPa e $140 \mathrm{~mm}$

Tabela C.3 - Resultados da resistência à compressão pós-fogo dos prismas de 4,0 MPa e 140 $\mathrm{mm}$.

Tabela C.4 - Resultados da resistência à compressão pós-fogo das pequenas paredes de 10,0 MPa e $140 \mathrm{~mm}$

Tabela C.5 - Resultados da resistência à compressão pós-fogo das pequenas paredes de 4,0 MPa e $140 \mathrm{~mm}$

Tabela C.6 - Resultados da resistência à compressão pós-fogo do trio de pequenas paredes compartimentadas de 4,0 MPa e $140 \mathrm{~mm}$

Tabela C.7 - Resultados da resistência à compressão pós-fogo dos blocos de 10,0 MPa e 140 $\mathrm{mm}$ com gesso

Tabela C.8 - Resultados da resistência à compressão pós-fogo dos blocos de 4,0 MPa e $140 \mathrm{~mm}$ com gesso

Tabela C.9 - Resultados da resistência à compressão pós-fogo dos prismas de 10,0 MPa e 140 mm com gesso

Tabela C.10 - Resultados da resistência à compressão pós-fogo dos prismas de 4,0 MPa e 140 $\mathrm{mm}$ com gesso

Tabela C.11 - Resultados da resistência à compressão pós-fogo das pequenas paredes de 10,0 MPa e $140 \mathrm{~mm}$ com gesso

Tabela C.12 - Resultados da resistência à compressão pós-fogo das pequenas paredes de 4,0 MPa e $140 \mathrm{~mm}$ com gesso

Tabela D.1 - Tabela de valores críticos de Grubbs (Zc)

Tabela D.2 - Resultados do teste de Grubbs para o índice de absorção dos meios-blocos de 10,0 MPa e $190 \mathrm{~mm}$ 
Tabela D.3 - Resultados do teste de Grubbs para o módulo de elasticidade das pequenas paredes de 10,0 MPa e $190 \mathrm{~mm}$

Tabela D.4 - Resultados do teste de Grubbs para a resistência a compressão dos prismas de blocos de 4,0 MPa e $140 \mathrm{~mm}$ da $1^{\mathrm{a}}$ fornada.....

Tabela D.5 - Resultados do teste de Grubbs para a resistência a compressão das pequenas paredes de blocos de 10,0 MPa e $140 \mathrm{~mm}$ da $1^{\mathrm{a}}$ fornada

Tabela D.6- Resultados do teste de Grubbs para a resistência a compressão do trio de pequenas paredes compartimentadas com blocos de 4,0 MPa e $140 \mathrm{~mm}$ da $1^{a}$ fornada 224

Tabela D.7- Resultados do teste de Grubbs para a resistência a compressão dos prismas de 10,0 MPa e $140 \mathrm{~mm}$ revestidos com gesso da $2^{\mathrm{a}}$ fornada.

Tabela D.8- Resultados do teste de Grubbs para a resistência a compressão dos prismas de 4,0 MPa e $140 \mathrm{~mm}$ revestidos com gesso da $2^{\mathrm{a}}$ fornada 225

Tabela D.9- Resultados do teste de Grubbs para a resistência a compressão das pequenas paredes de 10,0 MPa e $140 \mathrm{~mm}$ revestidos com gesso da $2^{\mathrm{a}}$ fornada 225

Tabela E.1- Valores de $\Psi$ em função da quantidade de blocos 228 


\section{INTRODUÇÃO}

Atualmente o Brasil conta com uma expressiva quantidade de edificações executadas em alvenaria estrutural, consequência de vantagens técnicas e econômicas relacionadas principalmente à padronização da execução, racionalização dos materiais, bom desempenho, custo competitivo e prazos de execução menores se comparados com outros sistemas construtivos. Trata-se de um sistema que foi inserido no país em meados da década de 60 , com blocos vazados de concreto em prédios de até quatro pavimentos, em que os procedimentos de dimensionamento e execução eram baseados em normas americanas.

Segundo Corrêa (2012) a alvenaria estrutural foi pouco utilizada, durante anos, devido a muitos fatores, tais como preconceito, maior domínio da tecnologia do concreto armado por parte de construtoras e projetistas e pouca divulgação do assunto nas universidades durante o processo de formação profissional. Mais recentemente, visando o aumento da produtividade e a redução dos custos, tem havido uma forte busca pela racionalização dos processos construtivos. Isso influi na crescente demanda dos projetos de edificações em alvenaria estrutural uma vez que este sistema conta com particularidades em relação à rapidez de execução, à coordenação modular, à redução de desperdício e ao rígido controle de qualidade.

A alvenaria estrutural é um sistema construtivo formado por blocos normalmente vazados de concreto ou cerâmica, unidos por juntas de argamassa e preenchidos de graute em posições adequadas, eventualmente contam com armadura de aço e revestimento. Possui função de vedação e também age como elemento estrutural, por isso é dimensionado para suportar cargas além de seu peso próprio, resistindo predominantemente à compressão. De acordo com a ABNT NBR 15812:2010, os elementos de alvenaria podem ser definidos segundo a função desempenhada pelas armaduras, podendo ser:

- Não armado - elemento no qual a armadura não é considerada para resistir aos esforços solicitantes;

- Armado - quando armaduras passivas são consideradas para resistir aos esforços solicitantes;

- Protendida - quando o elemento possui armaduras ativas, ou seja, tensionadas;

O cálculo de estruturas de alvenaria estrutural é normalizado pela Associação Brasileira de Normas Técnicas (ABNT) que publicou em 2010 a ABNT NBR 15812 “Alvenaria estrutural - Blocos Cerâmicos" e em 2011 a norma brasileira para cálculo de alvenaria estrutural de blocos 
vazados de concreto a ABNT NBR 10837 (1989) foi substituída pela ABNT NBR 15961 “Alvenaria Estrutural - Blocos de Concreto". As normas consideram no dimensionamento a segurança com base no método dos estados limites últimos (ELU) e de serviço (ELS), ou seja, deve-se levar em consideração todas as ações que podem, de alguma forma, atuar durante a sua vida útil.

Uma dessas ações, que sempre foi deixada de lado durante muitos anos, é a situação de incêndio, e no caso da alvenaria estrutural, a norma brasileira não prescreve um dimensionamento em temperaturas elevadas. Algumas normas internacionais contam com procedimentos para tal dimensionamento mas há uma grande variabilidade dos materiais utilizados na construção em função da região de execução da edificação. Diante disto, torna-se clara a necessidade de aprofundar os conhecimentos, em âmbito nacional, sobre o comportamento da alvenaria estrutural, tanto de blocos cerâmicos como de concreto, em situação de incêndio.

Segundo o Center of Fire Statistics - CTIF (2017), os incêndios em edificações são muito frequentes em todo o mundo e correspondem a quase $40 \%$ das ocorrências registradas, conforme observado na Figura 1.1. Há certa tendência do maior número de mortes por incêndio ser em locais de elevada densidade demográfica, ou seja, representa um desafio tão maior à segurança humana conforme aumenta a proporção de pessoas morando e trabalhando nos edifícios.

Figura 1.1 - Distribuição de incêndio no mundo em 2015, conforme sua origem

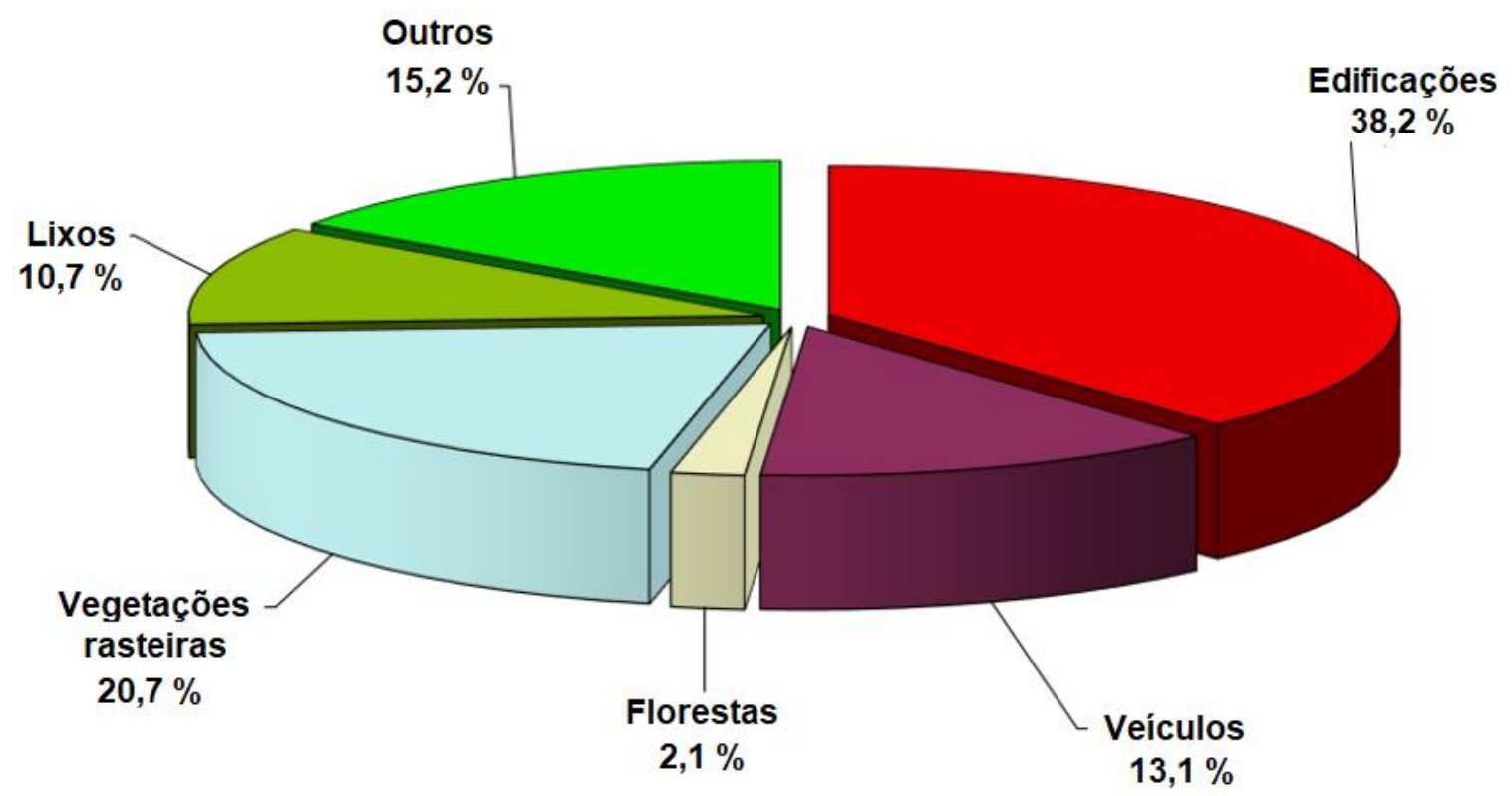

Fonte: Adaptado de Centre of Fire Statistics - CTIF (2017) 
De acordo com Wang (2002), quando não controlado de forma adequada, o fogo é um fenômeno natural que pode causar enormes prejuízos, tanto na esfera financeira como referente às vidas humanas. Nas estruturas de maneira geral, a prevenção da ocorrência do incêndio ou, pelo menos, a minimização dos danos que ele pode causar é muito mais importante que as formas de combate ao fogo.

Em função da pouca divulgação dos dados apurados pelas pesquisas de combate a incêndio, aparenta-se que no Brasil o incêndio não é um problema grave, no entanto, se forem comparadas as causas de mortes mencionadas nos relatórios do Sistema Único de Saúde (SUS), o Brasil ficaria em terceiro com o maior número de mortes por incêndio ou inalação de fumaça no mundo, atrás apenas do Japão e dos Estados Unidos considerando os dados do ano de 2011. (ALVES E BORBOREMA, 2015).

A partir de tragédias ocorridas em todo o mundo observou-se a necessidade pesquisar sobre a temática do incêndio. Isso estimulou a criação de normas internacionais e nacionais, com destaque para os Eurocodes 3 e 4 Part 1-2 (2005) e a ABNT NBR 14323:2013 respectivamente, tendo como intuito, inserir a ação excepcional no dimensionamento das estruturas para garantir a segurança estrutural.

A resistência ao fogo de uma estrutura está ligada ao tempo em que ela é capaz de oferecer resistência adequada às solicitações para as quais foi projetada na situação de incêndio. A norma nacional de segurança contra incêndio ABNT NBR 14432:2011 define o tempo de resistência ao fogo das paredes e elementos de vedação, de acordo com o tipo de ocupação da edificação e com a sua altura total. Este tempo é definido para que seja possível a fuga dos ocupantes em segurança, seja garantida a segurança das equipes de combate ao incêndio e também para minimizar danos às edificações adjacentes.

No caso da alvenaria estrutural, o Eurocode 6 Part 1-2 (2005) define alguns critérios de resistência de acordo com a sua finalidade:

- Resistência mecânica (R), o qual é satisfeito quando a função de suporte de carga é mantida na exposição ao fogo durante um determinado intervalo de tempo;

- Estanqueidade (E), quando não ocorrem rachaduras ou aberturas que permitam a passagem de chamas e gases através do elemento;

- Isolamento térmico (I), o qual é considerado atendido quando em qualquer ponto da superfície não exposta ao fogo a variação de temperatura não exceda $180^{\circ} \mathrm{C}$ e a variação de temperatura média nesta mesma superfície não exceda $140^{\circ} \mathrm{C}$; 
- Impacto mecânico (M), quando um elemento de separação vertical resistir a uma carga concentrada horizontal de características especificadas em EN 1363 Parte 2.

São considerados essenciais ao dimensionamento de alvenaria estrutural em situação de incêndio os três primeiros critérios (R, E, e I). Entretanto, no Brasil consideram-se apenas os critérios de estanqueidade e isolamento térmico, presentes na ABNT NBR 10636:1989 (LEITE, MORENO Jr. e TORRES, 2016).

Este trabalho busca realizar um estudo experimental com blocos, prismas e pequenas paredes de alvenaria estrutural de blocos de concreto, visando elucidar o comportamento deste sistema estrutural quando submetido a elevadas temperaturas. O foco principal é no critério de resistência mecânica, analisando a resistência residual destes elementos. Este trabalho constitui um avanço no estudo sistemático da alvenaria estrutural, pois fornece subsídios colaborativos para a elaboração de normas nacionais de procedimentos de verificação da segurança estrutural, beneficiando a aplicação da alvenaria estrutural na construção civil.

\subsection{Objetivos}

No contexto geral, este trabalho tem como objetivo contribuir com parâmetros necessários à normalização dos procedimentos de dimensionamento e verificação de segurança da alvenaria estrutural com blocos de concreto em situação de incêndio. Tais parâmetros serão alcançados por meio de ensaios que irão avaliar a resistência residual dos corpos de prova submetidos a elevadas temperaturas nas duas faces e o efeito da compartimentação do incêndio para a resistência residual.

Como objetivos específicos tem-se:

- Realizar os ensaios de simulação do incêndio-padrão seguindo a curva da ISO 8341:1999;

- Avaliar a resistência residual de compressão dos corpos de prova após submetidos ao incêndio-padrão e comparar com a resistência inicial à temperatura ambiente;

- Analisar o comportamento ao fogo dos corpos de prova revestidos com gesso e avaliar a influência do revestimento na resistência residual dos elementos;

- Submeter ao ensaio de incêndio-padrão três pequenas paredes com blocos de concreto de 4,0 MPa e espessura de $140 \mathrm{~mm}$. Elas serão posicionadas formando em planta um triângulo equilátero com o interior isolado termicamente para simular a compartimentação de um ambiente e aquecimento em apenas uma face. 
- Verificar a diferença de resistência residual entre as pequenas paredes aquecidas em apenas uma face e em ambas as faces.

- Balizar os modelos experimentais a serem ensaiados em laboratório com base em simulações numéricas já realizadas em trabalhos anteriores. Também, visa-se contribuir para calibração em ajuste fino dos modelos numéricos já existentes e que estão sendo desenvolvidos pelo grupo de pesquisa.

\subsection{Justificativa}

A alvenaria estrutural é um dos sistemas construtivos mais vantajosos economicamente para construção de edificações atualmente. Seus benefícios apresentam-se por fatores como a economia de formas, significativa redução de desperdícios, uso de revestimentos mais finos em função da melhor qualidade de prumo das paredes, além da redução do número de especialidades na obra. Tais vantagens conduzem, na maioria das vezes, a uma economia financeira significativa da construção.

Apesar de apresentar pontos negativos como a dificuldade de se alterar a arquitetura após a construção e a necessidade de mão-de-obra qualificada, o uso da alvenaria estrutural tem crescido no Brasil nos últimos anos. Tal aumento na utilização deste sistema se dá principalmente por recentes políticas públicas de incentivo à construção de apartamentos populares para financiamento, mesmo que a alvenaria estrutural não seja característica inerente às construções de baixo padrão.

A disseminação da alvenaria estrutural neste tipo de edificação se deve a razões econômicas, pois permite uma produção em série de edifícios padronizados com velocidade dificilmente alcançada por outras modalidades construtivas. Neste âmbito, muitas construtoras brasileiras têm investido no desenvolvimento de técnicas de produção e de novos materiais que possibilitem melhorias de qualidade e segurança. Como consequência, tem-se geração de empregos e também maior incentivo à pesquisa.

Uma vez que a estrutura passa a ser utilizada, ela está exposta a processos de degradação e também a situações acidentais como incêndios. Apesar da vasta utilização da alvenaria estrutural no Brasil, poucas pesquisas nacionais foram feitas sobre o comportamento da alvenaria estrutural em situação de incêndio e sobre os devidos procedimentos de verificação da segurança no dimensionamento. Também, as propriedades térmicas e mecânicas dos materiais que compõem os blocos e argamassas produzidos no país foram pouco estudadas sob temperaturas elevadas, tanto com como sem carga aplicada. 
A resistência ao fogo é uma condição crítica no dimensionamento das estruturas de alvenaria estrutural. A integridade da estrutura está condicionada ao bom desempenho das paredes autoportantes, sendo assim, o atendimento às condições de segurança ao incêndio é indispensável. O aumento da temperatura reduz as propriedades mecânicas (rigidez e resistência) do concreto e da argamassa, podendo conduzir ao colapso de elementos estruturais.

Em comparação com os estudos elaborados nas áreas de concreto armado, de estruturas de aço e de estruturas de madeira em situação de incêndio é substancialmente escassa a literatura disponível para edificações em alvenaria estrutural no Brasil. A normalização nacional referente à alvenaria estrutural menciona apenas a necessidade de avaliação do isolamento e da estanqueidade das edificações em situação de incêndio, sem propor qualquer tipo de prescrição normativa para dimensionamento mecânico em temperaturas elevadas.

$\mathrm{O}$ atual comitê da ABNT que revisa as normas de alvenaria no Brasil pretende incluir o assunto no seu escopo, o que aumenta a necessidade e a relevância da proposta apresentada no presente trabalho. Esta pesquisa também vem com o intuito de colaborar com futuras propostas de normalização do dimensionamento de alvenaria estrutural em situação de incêndio, por meio de resultados experimentais. Julga-se relevante a elaboração de um trabalho de pesquisa amplo, no qual sejam referenciados os principais critérios e procedimentos de verificação de segurança adotados mundialmente, de tal forma que estes critérios sejam confrontados com resultados experimentais e numéricos obtidos com o emprego de materiais correntes em nosso país.

A maioria das pesquisas realizadas no país sobre este tema são fundamentadas em simulações numéricas, no entanto os modelos numéricos sofisticados requerem resultados experimentais específicos para obter dados quanto às propriedades mecânicas e térmicas dos materiais. No Brasil, não foram realizados muitos ensaios com alvenaria de blocos de concreto em elevadas temperaturas. O presente trabalho faz parte do projeto FAPESP 2017/20155-4 que é uma parceria entre pesquisadores do Departamento de Engenharia de Estruturas da Escola de Engenharia de São Carlos da Universidade de São Paulo (USP) e do Departamento de Estruturas da Faculdade de Engenharia Civil da Universidade de Campinas (UNICAMP). Serão desenvolvidas pesquisas concomitantes em ambas universidades, onde serão realizados ensaios experimentais e simulações numéricas em trabalhos de mestrado e doutorado. Portanto, os resultados experimentais pontuais a serem obtidos nesta pesquisa são relevantes para os resultados da macroabordagem do grupo. 


\subsection{Metodologia}

A metodologia proposta consiste basicamente de três etapas: revisão bibliográfica, ensaios de caracterização em temperatura ambiente e ensaios em elevadas temperaturas.

$\mathrm{Na}$ etapa de revisão bibliográfica foi realizada uma pesquisa a respeito de alvenaria estrutural, relacionando os principais trabalhos disponíveis na literatura, as normas nacionais e as internacionais. Portanto, busca-se, primeiramente, os estudos a respeito de alvenaria estrutural e seus componentes, particularizando para as executadas com blocos de concreto. A partir disso, o estudo parte para o campo do incêndio e da segurança estrutural, relacionando os modelos de representação do incêndio presentes na literatura e também os principais aspectos para estruturas em situação de incêndio. Ao longo da pesquisa foi realizado um levantamento bibliográfico dos trabalhos relevantes ao comportamento da alvenaria em elevadas temperaturas e das principais normas internacionais que tratam do dimensionamento da alvenaria sob incêndio.

A segunda etapa consiste nos ensaios realizados em temperatura ambiente com corpos de prova que não foram submetidos a elevadas temperaturas. Primeiramente foram realizados ensaios de caracterização geométrica, física e mecânica de todos os tipos de blocos e meioblocos que serão utilizados na pesquisa e também da areia que será utilizada na argamassa de assentamento dos blocos. Em seguida foi realizada a caracterização da alvenaria com a execução de prismas e pequenas paredes e ensaios de compressão simples de ambos e módulo de elasticidade das pequenas paredes.

Foram consideradas duas resistências de blocos $\left(f_{b k}\right): 4,0 \mathrm{MPa}$ e 10,0 MPa e de duas espessuras: 140 e $190 \mathrm{~mm}$. Optou-se por ensaiar blocos usuais nas construções e que tenham a resistência mais baixa e uma que traduz a média das mais altas, pois o comportamento dos demais blocos deve compreender na faixa de resultados obtidas para estes dois. Em resumo, tem-se 4 variações dos blocos caracterizados em temperatura ambiente, os parâmetros dos blocos de $190 \mathrm{~mm}$ estão dispostos neste texto para fornecer dados para modelagens de outras pesquisas do grupo. Para cada uma dessas variações foram ensaiados uma quantidade mínima de corpos de prova exigidas pelas normas. Os corpos de prova para o ensaio de compressão simples estão especificados na Tabela 1.1, juntamente com as quantidades e normas da ABNT que regulamentam os ensaios. 
Tabela 1.1 - Quantidades e normas para os ensaios à compressão

\begin{tabular}{|c|c|c|c|c|}
\hline \multicolumn{3}{|c|}{ Elemento } & \multirow[b]{2}{*}{$\begin{array}{c}\text { Numero de } \\
\text { CP's }\end{array}$} & \multirow[b]{2}{*}{ Norma da ABNT } \\
\hline & $\begin{array}{c}f_{b k} \\
(\mathrm{Mpa})\end{array}$ & $\begin{array}{l}\text { Espessura } \\
(\mathrm{mm})\end{array}$ & & \\
\hline Argamassa & - & - & 6 & NBR 7215:1996 \\
\hline \multirow{4}{*}{ Bloco } & \multirow{2}{*}{4,0} & 140 & 6 & \multirow{4}{*}{ NBR 12118:2013 } \\
\hline & & 190 & 6 & \\
\hline & \multirow{2}{*}{10,0} & 140 & 6 & \\
\hline & & 190 & 6 & \\
\hline \multirow{4}{*}{ Prisma } & \multirow{2}{*}{4,0} & 140 & 6 & \multirow{4}{*}{ NBR 16522:2016 } \\
\hline & & 190 & 6 & \\
\hline & \multirow{2}{*}{10,0} & 140 & 6 & \\
\hline & & 190 & 6 & \\
\hline \multirow{4}{*}{$\begin{array}{c}\text { Pequena } \\
\text { Parede }\end{array}$} & \multirow{2}{*}{4,0} & 140 & 3 & \multirow{4}{*}{ NBR 16522:2016 } \\
\hline & & 190 & 3 & \\
\hline & \multirow{2}{*}{10,0} & 140 & 3 & \\
\hline & & 190 & 3 & \\
\hline
\end{tabular}

$\mathrm{Na}$ execução dos corpos de prova foram utilizadas argamassas tradicionais à base de cimento, cal e areia, com traços usuais em obras de alvenaria, nas proporções em volume $(1: 0,5: 4,5)$. O argamassamento foi total, ou seja, os cordões de argamassas serão dispostos nos septos longitudinais e transversais dos blocos. Nesta pesquisa não foi adotado revestimento de argamassa nos corpos de prova, apenas na etapa de avaliação do comportamento em elevadas temperaturas, em que parte dos elementos foram revestidos com uma camada de $5 \mathrm{~mm}$ de gesso.

O bloco se justifica por ser a unidade básica da alvenaria e principal componente que determina a resistência da mesma, também é importante conhecer o comportamento de suas propriedades frente ao fogo permitindo calibragens de trabalhos futuros. Os prismas de dois blocos e as pequenas paredes foram escolhidas por serem os corpos de prova que a ABNT 15961:2011 adota para caracterizar a resistência das paredes de alvenaria de blocos de concreto, e, portanto, são os mais adequados para o estudo de resistência residual deste sistema construtivo após submetido ao incêndio. A Figura 1.2 apresenta um esquema do ensaio de compressão dos corpos de prova.

A terceira etapa da pesquisa conta com os ensaios em temperaturas elevadas dos corpos de prova e posterior ensaio de compressão simples dos mesmos para avaliar a resistência residual. A simulação de incêndio foi realizada no forno a gás do Laboratório de Estruturas da Escola de Engenharia de São Carlos em que o controle de temperatura dos gases no seu interior atenderá à curva de incêndio-padrão da ISO 834-1:1999. Nesta etapa foram ensaiados apenas elementos com espessura de $140 \mathrm{~mm}$, o número de elementos para cada tipo de corpo de prova 
ensaiados foi a mesma do programa experimental em temperatura ambiente, mostrados na Tabela 1.1. Todos os corpos de prova foram submetidos ao resfriamento lento em temperatura ambiente antes do ensaio de compressão simples pós-aquecimento.

Figura 1.2 - Esquema do ensaio de compressão simples do prisma e da pequena parede

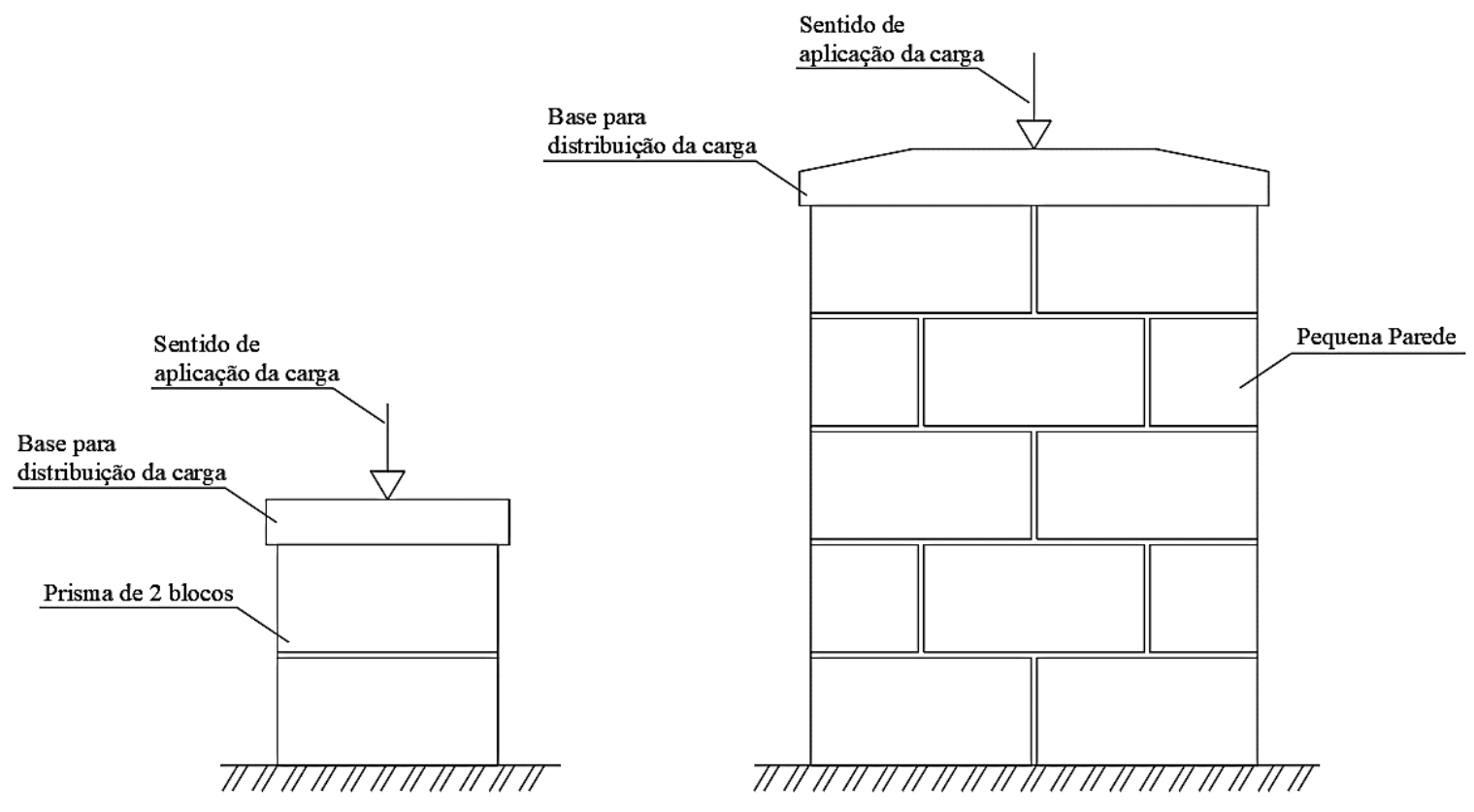

Fonte: Adaptado da ABNT NBR 16522:2016

Nesta etapa foram ensaiados elementos com e sem revestimento de gesso, com o intuito de avaliar a contribuição de uma camada de $5 \mathrm{~mm}$ de gesso na resistência residual dos corpos de prova. A primeira fornada conta com todos os elementos sem revestimentos e segunda fornada conta com todos os elementos com revestimento de gesso.

Também foi ensaiado um trio de pequenas paredes com espessura de $140 \mathrm{~mm}$ e resistência de 4,0 MPa, posicionadas formando em planta um triângulo equilátero com o interior isolado termicamente para simular a compartimentação de um ambiente e aquecimento em apenas uma face, como mostrado na Figura 1.3. Estas três paredes também foram submetidas ao ensaio de compressão simples após resfriamento em temperatura ambiente com o intuito de avaliar a influência do aquecimento em apenas uma face na resistência residual da alvenaria. Foi ensaiada apenas uma variação deste trio por questões de prazo da pesquisa; no entanto os ensaios com as outras opções de bloco e resistência serão realizados por outro integrante do grupo de pesquisa. 
Figura 1.3 - Trio de pequenas paredes com interior isolado termicamente

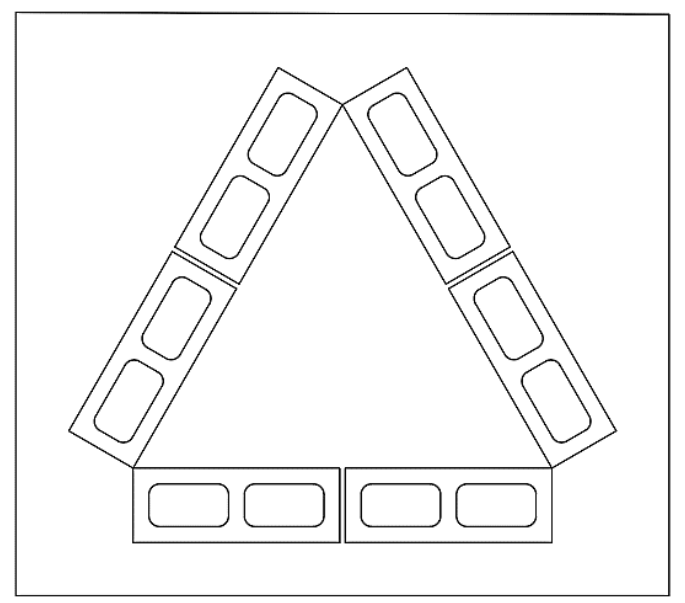

A disposição dos corpos de prova no forno foi pensada de maneira a evitar que fiquem próximos dos queimadores, permitindo que os gases se aqueçam de maneira uniforme. Foram realizadas duas fornadas, a Figura 1.4 mostra a distribuição e quantidades dos corpos de prova em cada fornada, o traçado externo delimita a área do forno e os círculos em cor laranja indicam as posições dos queimadores.

Figura 1.4 - Esquema de organização dos corpos de prova dentro do forno

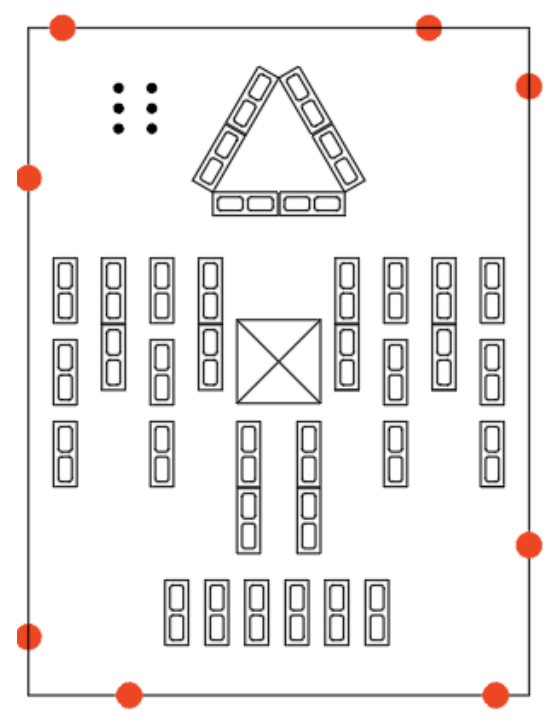

$1^{\text {a }}$ Fornada

1 Par. Trio $140 \mathrm{~mm} / 4,0 \mathrm{MPa}$

3 P.Paredes $140 \mathrm{~mm} / 10,0 \mathrm{MPa}$

3 P.Paredes $140 \mathrm{~mm} / 4,0 \mathrm{MPa}$

6 Prismas $140 \mathrm{~mm} / 4,0 \mathrm{MPa}$

6 Blocos $140 \mathrm{~mm} / 10,0 \mathrm{MPa}$

6 Blocos $140 \mathrm{~mm} / 4,0 \mathrm{MPa}$

6 CP's de argamassa

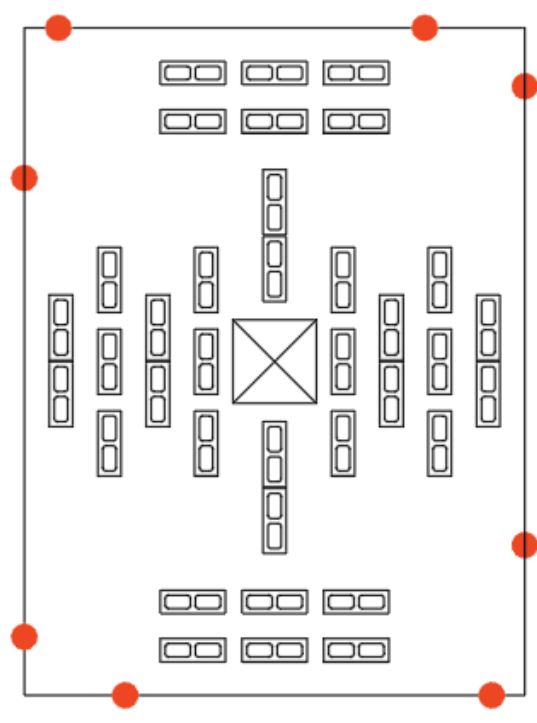

$2^{\mathrm{a}}$ Fornada (com revestimento)

3 P.Paredes $140 \mathrm{~mm} / 4,0 \mathrm{MPa}$

3 P.Paredes $140 \mathrm{~mm} / 10,0 \mathrm{MPa}$

6 Prismas $140 \mathrm{~mm} / 4,0 \mathrm{MPa}$

6 Prismas $140 \mathrm{~mm} / 10,0 \mathrm{MPa}$

6 Blocos $140 \mathrm{~mm} / 4,0 \mathrm{MPa}$

6 Blocos $140 \mathrm{~mm} / 10,0 \mathrm{MPa}$ 


\section{REVISÃO BIBLIOGRÁFICA}

\subsection{Alvenaria estrutural}

\subsubsection{Breve histórico sobre alvenaria estrutural}

A mistura de argila, areia e um agente estabilizante foi utilizada em construções habitacionais desde os primeiros registros históricos, isso demonstra que a alvenaria é um dos sistemas estruturais mais antigos da humanidade. Segundo Schneider e Dickey (1994), o uso de alvenaria de tijolo simples foi feito por egípcios, romanos e gregos, a exemplo tem-se a pirâmide de Quéops no Egito, com aproximadamente 145 metros de altura e cerca de 2,3 milhões de blocos de rochas.

De acordo com Ramalho e Corrêa (2003), o Farol de alexandrina era um engenhoso sistema de iluminação para guiar navegantes do mar Mediterrâneo e foi construído com as premissas da alvenaria estrutural. Possuía 134 metros de altura e teve sua construção datada em 280 anos antes de Cristo, durou mais de 1500 anos quando foi destruído por um terremoto no século XIV.

Outras evidencias históricas de utilização da alvenaria estrutural foram os castelos e catedrais na Idade Média, em que paredes variavam entre 2 e 2,5 metros de espessura. Conforme Oliveira Jr. (1992), nessa época o dimensionamento era feito de forma empírica baseado na experiência adquirida pelos construtores devido ao desconhecimento do comportamento resistente dos materiais e a falta de métodos racionais de cálculo.

Ainda segundo o mesmo autor, com a evolução dos procedimentos de cálculo e desenvolvimento técnico do metal, as estruturas em aço e em concreto armado tornaram-se predominantes nas grandes obras na segunda metade do século 20. Em função, principalmente, da possibilidade de utilização de elementos com maior esbeltez, desta forma a alvenaria estrutural destinou-se a obras de pequeno porte.

De acordo com Mata (2006) em meados do século XX, as obras de alvenaria voltaram novamente a ser erguidas pois o mercado viu necessidade de buscar novas técnicas alternativas de construção. Por volta de 1950 o sistema construtivo em alvenaria estrutural ganhou novo impulso, estimulando o desenvolvimento de normas principalmente na Suíça, que tornou possível determinar a resistência da alvenaria e a espessura necessária das paredes, permitindo o surgimento de prédios altos com este sistema construtivo (CAVALHEIRO, 2009). 
Oliveira Jr. (1992) afirma que no Brasil surgiram os primeiros edifícios em alvenaria armada no ano de 1966, construídos em São Paulo com blocos vazados de concreto e quatro pavimentos. Em 1972 foi erguido um edifício com quatro torres e doze pavimentos, o condomínio Central Parque Lapa (Figura 2.1), também em alvenaria armada e blocos de concreto. Já os blocos cerâmicos passaram a ser fabricados em escala industrial somente a partir de 1980. Mas de acordo com Gomes (2001), muitas patologias e problemas com conforto térmico foram retratados nas obras das décadas de 60 e 70 pois os materiais utilizados eram de péssima qualidade. Isso fez com que o mercado recuasse na utilização deste sistema construtivo, que passou anos praticamente abandonado.

Figura 2.1 - Condomínio Central Parque Lapa em São Paulo

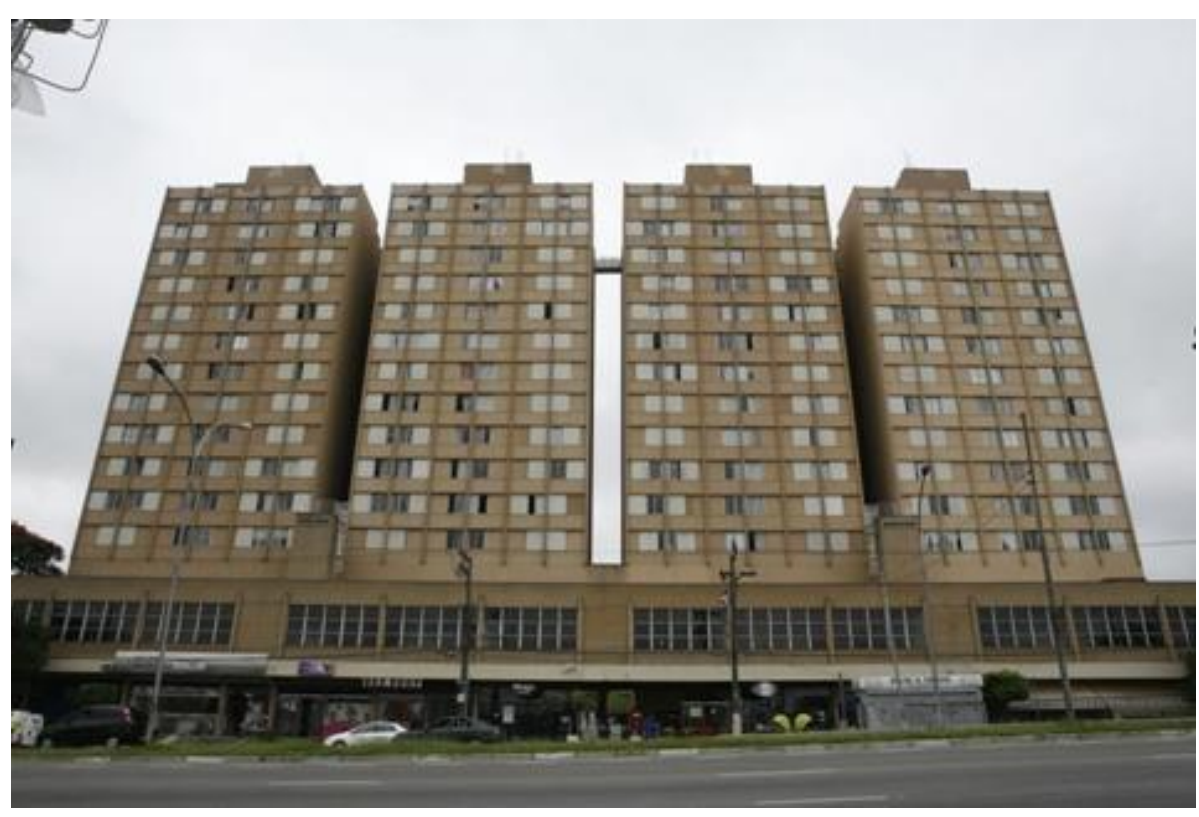

Fonte: http://www.comunidadedaconstrucao.com.br/

A aceitação e reconhecimento da alvenaria estrutural não eram disseminados no Brasil como em outros países, também pelo fato de seu dimensionamento ainda ser empírico. Com a vantagem competitiva, tanto de tempo como financeiramente, trazida por esse sistema construtivo, as construtoras e incorporadoras passaram a investir em pesquisa e desenvolvimento científico para a alvenaria estrutural. Assim, na década de 70 foi criada a normalização deste sistema construtivo, que ganhou maior confiabilidade e na década de 80 e início da década de 90 passaram a ser desenvolvidas nas universidades pesquisas a respeito do comportamento estrutural de prismas e paredes em alvenaria estrutural.

Em função do maior domínio das técnicas de construção em concreto armado e estruturas metálicas, a projeção da alvenaria estrutural no mercado brasileiro ocorreu, a 
princípio, de forma lenta e restrita. No entanto, com o desenvolvimento de normas brasileiras e estudos sobre dimensionamento dos elementos em alvenaria estrutural, que permitiram padronizar os procedimentos de cálculo e aproveitar melhor a capacidade resistente do material, este método construtivo ganhou força e aceitação no mercado a partir do final da década de 90 e início dos anos 2000.

Para Ramalho e Corrêa (2003), o lançamento do Manual Técnico de Alvenaria pela Associação Brasileira de Construção Industrializada na década de 90 foi marcante para o cenário nacional. Ainda de acordo com os mesmos autores, este sistema mostrou ser uma opção econômica e eficiente para construção de edificações industriais e residenciais no cenário atual, aumentando o incentivo às pesquisas com alvenaria estrutural.

A maioria dos autores não recomendam a construção de prédios com mais de 25 pavimentos por questões econômicas. Tauil e Nese (2010) destacam que a economia para edifícios de quatro pavimentos é de $30 \%$ em relação ao sistema convencional, mas essa economia diminui conforme se aumenta o número de pavimentos, chegando a $10 \%$ em edifício de 20 andares. Nos últimos anos, no Brasil, as construtoras estão ousando na altura destas edificações, em 2017 foi lançado em na cidade de Londrina no Paraná o condomínio Fit Terra Bonita (Figura 2.2.a) com 19 pavimentos. No mundo a edificação mais alta em alvenaria estrutural é o hotel Excalibur em Las Vegas (EUA) (Figura 2.2.b) com 30 pavimentos que foi inaugurado no início da década de 90.

Figura 2.2 - Condomínio Fit Terra Bonita em Londrina (a); Hotel Excalibur em Las Vegas (b)

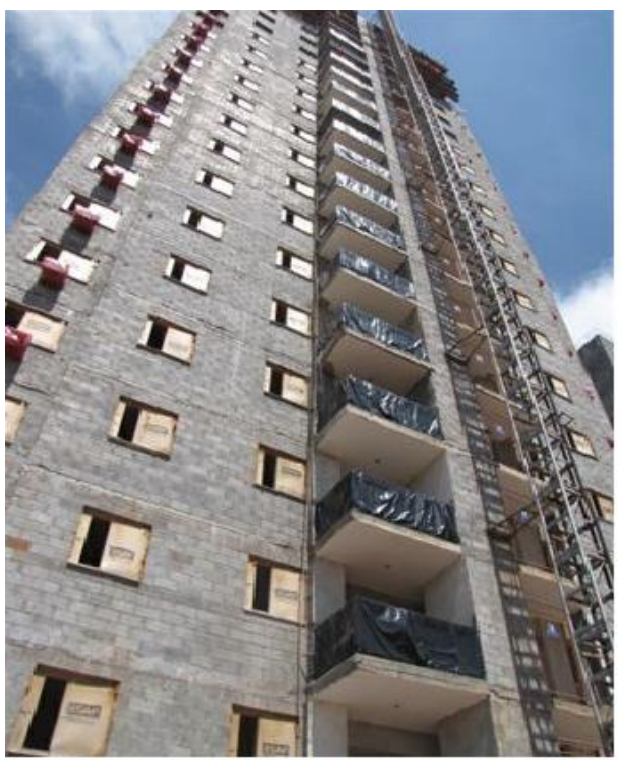

(a)

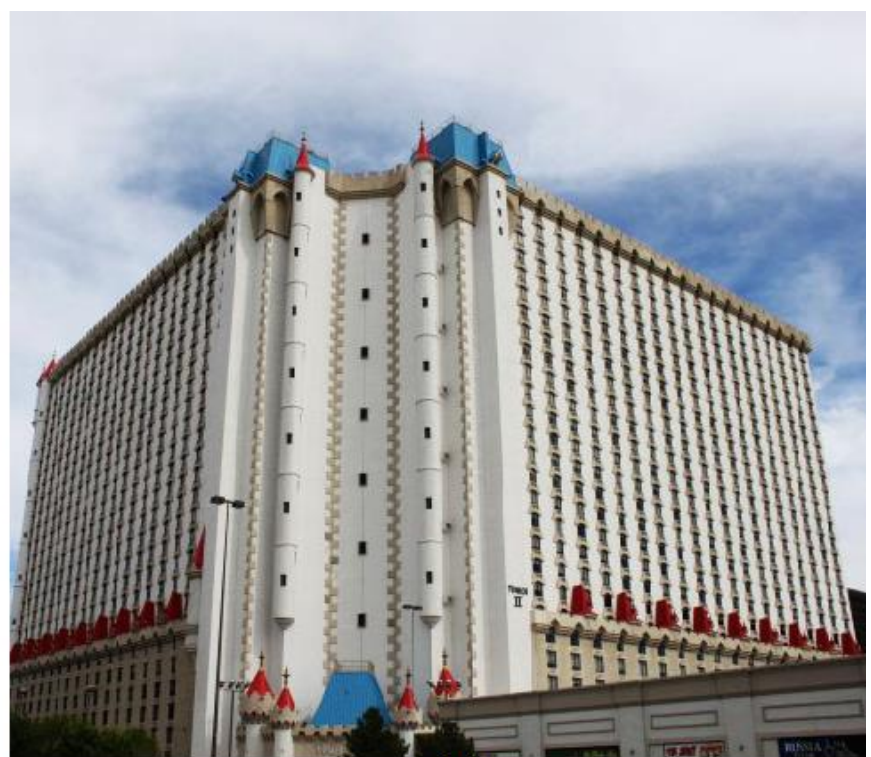

(b)

Fonte: (a) http://maringa.odiario.com/; (b) https://app.falandodeviagem.com.br/ 
Recentemente a alvenaria estrutural passou a representar uma fatia maior na construção civil brasileira devido ao lançamento do programa de financiamento habitacional do governo Minha Casa Minha Vida. A demanda por imóveis de baixo custo aumentou muito após o início deste programa em 2009, pois se trata de uma política que facilita e oferece subsídios para a compra financiada de casas e apartamentos por famílias com renda mensal relativamente baixas. Sendo assim as construtoras enxergaram na alvenaria estrutural uma alternativa rápida e econômica para suprir a necessidade de imóveis novos que apontava no mercado nacional.

\subsubsection{Características dos principais componentes da alvenaria estrutural}

Alvenaria estrutural apresenta um comportamento mecânico bastante complexo, pois é um sistema construtivo formado a partir da associação de elementos estruturais e são eles: unidades (blocos e meios-blocos), argamassa de assentamento, graute e eventualmente armadura. Portanto, para entender seu comportamento é necessário estudar os componentes individualmente, e posteriormente, a forma como trabalham em conjunto.

Esta pesquisa trabalha com alvenaria estrutural de blocos de concreto, na sequência, estão dispostas as principais características de interesse para cada componente.

\subsubsection{Unidades - Blocos de Concreto}

Como na alvenaria estrutural seus elementos trabalham predominantemente à compressão, a principal característica dos blocos de concreto a ser conhecida e que mais contribui para a resistência final do conjunto é a resistência a compressão. Mas também é importante conhecer outras propriedades mecânicas importantes para caracterização dos blocos como a resistência à tração, o módulo de elasticidade e o coeficiente de Poisson.

O ganho de resistência das unidades não é diretamente proporcional ao ganho de resistência das paredes pois a diferença entre as resistências do bloco e da argamassa exerce grande influência na alvenaria. Analogamente, o módulo de elasticidade das unidades também não pode ser relacionado com o do conjunto devido à presença de juntas de argamassa.

A ABNT NBR 6136:2016 classifica os blocos de concreto com e sem função estrutural de acordo com a sua resistência característica à compressão axial em relação à área bruta (aos 28 dias) e limita a absorção e retração linear por secagem, sendo este último um ensaio facultativo. A Tabela 2.1 mostra a classificação da norma. 
Tabela 2.1 - Requisitos para resistência característica à compressão, absorção e retração

\begin{tabular}{|c|c|c|c|c|c|c|c|}
\hline \multirow{3}{*}{ Classificação } & \multirow{3}{*}{ Classe } & \multirow{3}{*}{$\begin{array}{c}\text { Resistência } \\
\text { característica à } \\
\text { compressão axial } \\
(\mathrm{MPa})\end{array}$} & \multicolumn{4}{|c|}{ Absorção (\%) } & \multirow{3}{*}{$\begin{array}{c}\text { Retração } \\
(\%)\end{array}$} \\
\hline & & & \multicolumn{2}{|c|}{ Agregado normal } & \multicolumn{2}{|c|}{ Agregado leve } & \\
\hline & & & Individual & Média & Individual & Média & \\
\hline \multirow{3}{*}{$\begin{array}{c}\text { Com função } \\
\text { estrutural } \\
\text { Com ou sem } \\
\text { função } \\
\text { estrutural }\end{array}$} & A & $f_{b k} \geq 8,0$ & $\leq 9,0$ & $\leq 8,0$ & \multirow{3}{*}{$\leq 16,0$} & \multirow{3}{*}{$\leq 13,0$} & \multirow{3}{*}{$\leq 0,065$} \\
\hline & B & $4,0 \leq f_{b k}<8,0$ & $\leq 10,0$ & $\leq 9,0$ & & & \\
\hline & $\mathrm{C}$ & $f_{b k} \geq 3,0$ & $\leq 11,0$ & $\leq 10,0$ & & & \\
\hline
\end{tabular}

Fonte: Adaptado da ABNT NBR 6136:2016

Ramalho e Corrêa (2003) relacionaram as resistências dos blocos, primas e paredes de blocos de concreto por meio das eficiências parede-bloco e prisma-bloco, apresentadas na Tabela 2.2.

Tabela 2.2 - Valores de eficiência para blocos de concreto

\begin{tabular}{|c|c|c|}
\hline Eficiência & Valor mínimo & Valor máximo \\
\hline$f_{p a r} / f_{b}$ & 0,4 & 0,6 \\
\hline$f_{p} / f_{b}$ & 0,5 & 0,9 \\
\hline
\end{tabular}

Fonte: Ramalho e Corrêa (2003)

Mesmo que a norma brasileira não classifique os blocos de concreto quanto à sua resistência a tração, é interessante conhecer este parâmetro pois o conforme Mohamad (2007) o carregamento vertical de compressão na alvenaria gera tensões horizontais de tração na direção transversal do bloco. Esta resistência pode ser apurada tanto por testes diretos como indiretos, sendo que o mais utilizado na literatura é o teste indireto com o ensaio de compressão diametral, regulamentado pela ASTM C496 (2012), em função da dificuldade de execução dos testes diretos.

A ABNT NBR 6118:2014 afirma que a resistência à tração de concretos convencionais pode ser correlacionada com os ensaios indiretos ou pela resistência à tração na flexão, sendo equivalente a $90 \%$ da resistência à tração indireta, ou $70 \%$ da resistência a tração na flexão. Na carência de testes experimentais, a resistência à tração do concreto pode ser relacionada com a sua resistência característica à compressão, conforme equação 2.1. 


$$
f_{t}=0,3 \cdot f_{c k}^{2 / 3}
$$

Em que:

$f_{t}$ é a resistência à tração do concreto [MPa];

$f_{c k}$ é a resistência característica à compressão do concreto [Mpa].

Não existem ensaios normatizados nacionalmente para obter o módulo de elasticidade e o coeficiente de Poisson das unidades. Mas a ABNT NBR 15961-1:2011 recomenda que seja utilizado para a alvenaria estrutural o mesmo coeficiente de Poisson do concreto, que é de 0,20, e que o módulo de elasticidade seja adotado como 800 vezes a resistência característica à compressão do prisma. Segundo Drysdale, Hamid e Baker (1994) a resistência à tração de blocos de concreto é aproximadamente $10 \%$ da resistência à compressão e o módulo de elasticidade está entre 500 e 1000 vezes a resistência à compressão do bloco.

\subsubsection{Argamassa, aderência e tipo de assentamento}

A argamassa de assentamento é utilizada para unir os blocos e tem as funções de unir transmitir e uniformizar as tensões atuantes ao longo das paredes, além de absorver pequenas deformações, solidarizando as unidades. Ela garante que a alvenaria estrutural seja um conjunto monolítico, portanto as propriedades mecânicas da argamassa são fortes influenciadores do comportamento da alvenaria.

Para que a argamassa apresente bom desempenho é importante que ela seja durável e apresente boa trabalhabilidade, plasticidade e resistência. Normalmente a argamassa é composta de cimento, cal, areia, e água sendo que sua resistência à compressão está diretamente ligada à quantidade de cimento e a cal contribui para a retenção de água e trabalhabilidade. De acordo com Ramalho e Corrêa (2003) a resistência à compressão das paredes de alvenaria não é influenciada predominantemente pela resistência à compressão da argamassa.

A ABNT NBR 15961-1:2011 recomenda que a argamassa não apresente resistência à compressão inferior a 1,5 MPa e nem superior a 70\% da resistência característica à compressão dos blocos em relação à área liquida, sendo que esta condição garante que não ocorra ruptura frágil da alvenaria. Com o aumento da resistência da argamassa, as deformações decorrentes do carregamento não são acomodadas pela alvenaria, levando a parede à ruptura frágil (GOMES, 1983). Drysdale, Hamid e Backer (1994) recomendam que não seja utilizada uma resistência na argamassa maior que o necessário para que não seja comprometida a absorção de pequenas 
deformações pelas paredes e também mostram que um aumento de $100 \%$ na resistência à compressão da argamassa usualmente leva a apenas um aumento de $10 \%$ na resistência à compressão da parede.

A ABNT NBR 15961-1:2011 estabelece que a espessura das juntas verticais e horizontais de argamassa seja de $10 \mathrm{~mm}$ Como as juntas de argamassa apresentam espessura pequena em relação às dimensões do bloco ocorre um confinamento que a deixa menos vulnerável à ruptura, isso possibilita que a resistência à compressão das argamassas seja relativamente baixa se comparadas com os blocos. Além de influenciar no comportamento à compressão da alvenaria, as propriedades da argamassa estão diretamente ligadas à aderência bloco-argamassa que controlam a resistência à tração e ao cisalhamento da alvenaria, solicitações presentes principalmente quando há forças laterais e que podem ser predominantes na estrutura.

A aderência está relacionada com a capacidade de transferir tensões de tração e de cisalhamento entre dois materiais adjacentes sem que ocorre separação entre eles. Na alvenaria estrutural a falta de aderência entre bloco e junta de argamassa pode prejudicar grande parte das propriedades de uma parede (MEDEIROS e SABBATINI, 1993). Os principais fatores que afetam a aderência da argamassa na alvenaria são: relação água/cimento, tipo de argamassa, condições de cura, teor de ar incorporado e também as propriedades do bloco como o índice de absorção e as condições superficiais (partículas soltas, textura e capilaridade).

De acordo com Carasek (1996) a aderência deriva de três propriedades da interface argamassa-bloco: resistência de aderência à tração, resistência de aderência ao cisalhamento e extensão de aderência, que é a relação entre a área de contato efetiva e a área superficial da unidade. A resistência à tração da alvenaria pode ser avaliada por diferentes tipos de ensaio, divididos em duas categorias, os ensaios de resistência de aderência à tração direta e os ensaios de resistência de aderência à tração na flexão.

A ABNT NBR 15961-1:2011 estabelece que para o caso de ações temporárias, como o vento por exemplo, é possível considerar a resistência à tração da alvenaria sob flexão conforme a Tabela 2.3, onde os valores são relativos à área bruta. Os valores são válidos para argamassa de cimento, cal e areia e juntas verticais preenchidas, sendo que em outras situações a resistência à tração na flexão deve ser determinada por meio do ensaio de flexão em quatro pontos. Para Parsekian et al. (2012), esse ensaio permite que seja obtido um valor limite inferior, apesar de gerar resultados muito dispersos, pois a ruptura se dá na junta de momento máximo sem nenhum outro mecanismo de resistência a não ser a aderência bloco-argamassa. 
Tabela 2.3 - Valores característicos da resistência à tração na flexão - $f_{t k}$

\begin{tabular}{cccc}
\hline \hline \multirow{2}{*}{ Direção da tração } & \multicolumn{3}{c}{ Resistência média de compressão da argamassa } \\
& \multicolumn{3}{c}{ (MPa) } \\
\cline { 2 - 4 } & 1,5 a 3,4 & 3,5 a 7,0 & Acima de 7,0 \\
\hline Normal à fiada & 0,1 & 0,2 & 0,25 \\
Paralela à fiada & 0,2 & 0,4 & 0,5 \\
\hline \hline
\end{tabular}

Fonte: Adaptado da ABNT NBR 15961-1:2011

O tipo de assentamento da argamassa ou argamassamento também é um fator importante a ser considerado durante a execução da alvenaria estrutural pois é determinante para a produção e o rendimento da obra. São utilizados dois tipos na prática, o argamassamento total em que todas as faces das paredes dos blocos incluindo os septos transversais são preenchidos de argamassa (Figura 2.3.a), e o argamassamento parcial em que somente as paredes longitudinais dos blocos são preenchidas de argamassa (Figura 2.3.b) é colocada apenas nas

Figura 2.3 - (a) Argamassamento total; (b) Argamassamento parcial.

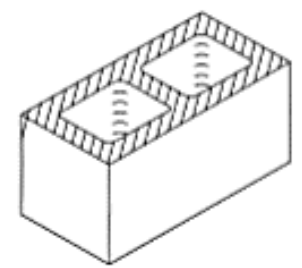

(a)

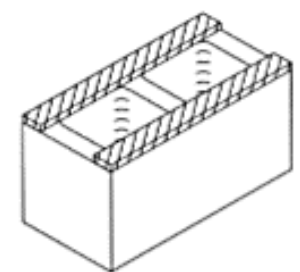

(b)

Fonte: Oliveira (2014)

O tipo de argamassamento pode influenciar na resistência da alvenaria, na distribuição de tensões, na fissuração e na ruptura de paredes estruturais. No aragamassamento total a distribuição das tensões é mais uniforme, a ausência de argamassa nos septos reduz a resistência da alvenaria por provocar concentração de tensões. No entanto, o aragamassamento parcial apresenta algumas vantagens, além de gerar maior economia e produtividade na obra, ele promove maior estanqueidade à água em alvenarias aparentes, pois a falta de ligação entre os cordões de argamassa diminui a transferência de umidade externa (PARSEKIAN, 2002).

Quando a resistência característica à compressão da alvenaria for determinada com base no ensaio de prisma ou pequena parede, a ABNT NBR 15961-1:2011 recomenda que esta resistência seja corrigida por um fator de 0,80 no caso de assentamento lateral da argamassa. Shrive (1982) ${ }^{1}$ apud Mohamad (2007) ensaiou primas de blocos de concreto com argamassamento parcial à compressão e notou o aparecimento de tensões de tração na face lateral dos prismas conforme mostrado na Figura 2.4 juntamente com a ruptura do prisma. As 
tensões de tração foram provocadas pela rotação e esmagamento da argamassa, que trabalhava como apoio dos blocos e levou o elemento à ruptura por flexão.

Figura 2.4 - Modo de ruptura e mecanismo gerador de tensões horizontais em prismas de blocos de concreto, com assentamento nas faces longitudinais
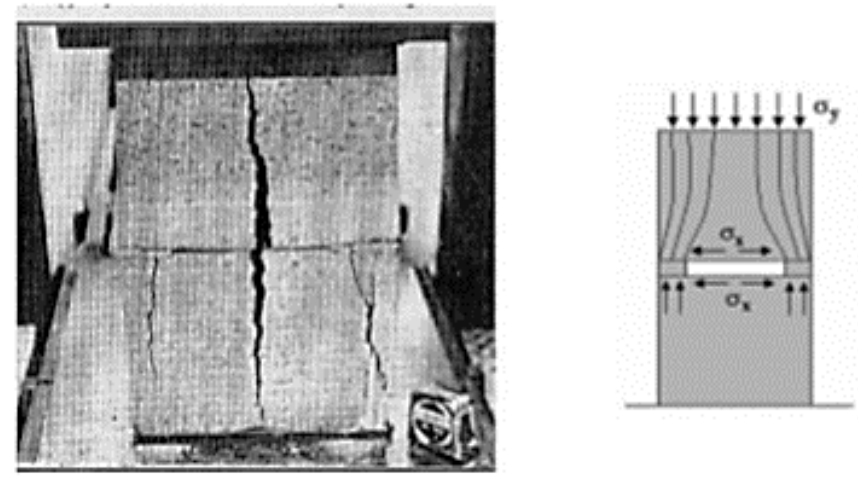

Fonte: Shrive (1982) apud Mohamad (2007).

Em Izquierdo (2011) foram comparados prismas e pequenas paredes submetidos a ensaios de compressão e constituídos com argamassamento total e com argamassamento parcial e a conclusão foi de que o efeito do tipo de assentamento da argamassa exerce forte influência na resistência a compressão. A diferença média de resistência foi de 36\% e 14\% para prismas e pequenas paredes, respectivamente, sendo que o argamassamento total foi o que apresentou melhor resistência e eficiência. Além disso, a ruptura dos prismas foi caracterizada pelo surgimento de uma fissura vertical ao longo da espessura dos corpos de prova, dividindo a unidade através dos septos transversais. Foi observado que essa fissura ocorreu de forma mais acentuada nos modelos com argamassamento parcial, em função do desenvolvimento de tensões de tração na face lateral, parecido com o descrito por Shrive (1982).

\subsubsection{Graute}

Este trabalho não conta com nenhum modelo a ser ensaiado com graute e, por isso, suas propriedades não serão aprofundadas, mas tendo em vista sua ampla utilização na pratica é importante conceituá-lo. O graute tem a função de melhorar a resistência a compressão das paredes pois ele aumenta a área líquida dos elementos estruturais e também solidarizar as armaduras aos blocos preenchendo os furos onde elas se encontram.

${ }^{1}$ SHRIVE, N. G. The failure mechanism of face-shell bedded (ungrouted and unreinforced) masonry subjected to compressive loading. The International Journal of Masonry Construction. Vol 2, $\mathrm{N}^{\circ} 3$, p. 115$128,1982$. 
Normalmente o graute é utilizado quando a argamassa e o bloco não suportam sozinhos os esforços à compressão e quando deseja-se tornar o conjunto ainda mais monolítico. De acordo com Castro (2015) algumas pesquisas mostram que o aumento da resistência da parede não é proporcional ao aumento da ária liquida gerada pelo grauteamento. A eficiência do graute é maior em casos com blocos de menor resistência associados com grautes de maior resistência, podendo variar de 60 a 100\% no caso de blocos cerâmicos. Quando as informações de eficiência não são seguras, Parsekian e Soares (2010) sugerem adotar 60\% e o traço do graute com resistência próxima à resistência do bloco na área liquida.

2.1.3. Resistência a compressão da alvenaria

O comportamento estrutural das paredes de alvenaria estrutural é definido pelas características de cada um dos materiais que a compõe. Por ser basicamente uma associação e blocos e argamassa a sua resistência a compressão pode ser estimada pelas resistências a compressão destes materiais.

Segundo Ramalho e Corrêa (2003), a resistência da parede de alvenaria está entre 50 e 90\% da resistência à compressão dos blocos de concreto. No Brasil, a ABNT 15961-1:2011 fornece a equação 2.2 que relaciona a resistência da parede com a resistência de prismas de 2 blocos, que podem ser mais facilmente ensaiados. Esta equação é válida somente para construções que utilizam o mesmo tipo de argamassamento ensaiado no prisma.

$$
f_{k}=0,7 \cdot f_{p k}
$$

Em que:

$f_{k}$ é a resistência característica à compressão da alvenaria;

$f_{p k}$ é a resistência característica à compressão dos prismas.

Internacionalmente, para determinar a resistência característica à compressão da alvenaria $\left(f_{k}\right)$ o Eurocode 6 Part 1.1 estabelece a equação 2.3 .

$$
f_{k}=K \cdot f_{b}^{0,7} \cdot f_{m}^{0,3}
$$

Em que:

$f_{b}$ é a resistência média à compressão da unidade;

$f_{m}$ é a resistência média à compressão da argamassa;

$K$ é uma constante tabelada que varia de acordo com o tipo de alvenaria utilizada. 
Para obter o máximo de aproveitamento dos materiais utilizados na alvenaria (blocos e argamassa) é necessário compatibilizar a resistência da argamassa com a do bloco na área liquida, pois como citado por diversos autores que ensaiaram prismas e paredes, a ruptura de paredes isoladas pode ocorrer por tensões de tração ou compressão no bloco ou por esmagamento da junta de argamassa.

\subsubsection{Módulo de elasticidade da alvenaria}

O módulo de elasticidade é uma propriedade importante da alvenaria pois ele determina suas deformações e também o mecanismo de ruptura. Normalmente o módulo de elasticidade tangente é encontrado a partir do traçado do gráfico de tensão por deformação, mas depende de ensaios experimentais e como a alvenaria é formada por diferentes tipos de unidades e argamassas este parâmetro é bastante variável.

Muitos pesquisadores consideram relações entre a resistência da alvenaria com o módulo de elasticidade através da simples relação: $E_{m}=k \cdot f^{\prime}{ }_{m}$, mas nesta aproximação não há um consenso do valor de $k$ a ser utilizado para alvenaria de blocos de concreto. Colville $e t$ al. (1993) chegaram à equação 2.4 por meio de um estudo experimental, em que $E_{a l v}$ é o módulo de elasticidade da alvenaria de blocos vazados de concreto e $f_{a l v}$ é a resistência da alvenaria determinada por ensaios de prismas.

$$
E_{a l v}=666 \cdot f_{a l v}
$$

O Eurocode 6 Part 1.1 recomenda que o modulo de elasticidade seja obtido experimentalmente a um terço da resistência da alvenaria. Se os ensaios sugeridos pela norma não puderem ser realizados, a norma fornece a equação 2.5 que relaciona o módulo de elasticidade $E_{a l v}$ com a resistência a compressão característica da alvenaria $f_{a l v, k}$. A norma europeia também recomenda que seja utilizado um fator de 0,6 aplicado ao módulo de elasticidade para verificações de estado limite de serviço.

$$
E_{a l v}=1000 \cdot f_{a l v, k}
$$

A ABNT NBR 15961-1:2011 apresenta a equação 2.6 para o módulo de elasticidade da alvenaria de blocos de concreto $\left(E_{a l v}\right)$, em que $f_{p k}$ é a resistência característica de compressão simples do prisma. Assim como o Eurocode, a norma brasileira também sugere uma redução 
de 40\% no módulo de elasticidade da alvenaria para as verificações de estado limite de serviço, considerando o efeito da fissuração da alvenaria de forma aproximada.

$$
E_{a l v}=800 \cdot f_{p k}
$$

O ACI 530:2011 sugere que para projetos de alvenaria de blocos de concreto deve ser considerado para o módulo de elasticidade da alvenaria $\left(E_{a l v}\right)$ o valor fornecido pela equação 2.7 em que $f_{a l v}$ é a resistência da alvenaria determinada por ensaios de prismas.

$$
E_{a l v}=900 \cdot f_{a l v}
$$

Dhanasekar (1985) ${ }^{1}$ apud Mohamad et al. (1998) recomenda a equação 2.8 para definir o módulo de elasticidade da alvenaria $\left(E_{a l v}\right)$ em função da resistência a compressão uniaxial da alvenaria $\left(f_{c, a l v}\right)$

$$
E_{\text {alv }}=1180 \cdot\left(f_{\text {alv }}\right)^{0,83}
$$

\subsection{Fogo e incêndio}

\subsubsection{Breve histórico sobre incêndio em edificações}

O incêndio em edificações é um problema antigo e que pode acontecer de forma natural, acidental ou até mesmo criminosa. Sua ocorrência é bastante perigosa e quando não controlada pode causar danos materiais e à saúde, podendo provocar até mesmo mortes. Historicamente, o primeiro incêndio catastrófico noticiado foi o ocorrido em Roma, em 64 d.C. Segundo Santos (2014), devido ao formato da cidade e do tipo de estrutura das casas (madeira), o incêndio tomou uma proporção tão absurda, que acabou com a vida de milhares de pessoas.

No ano de 1666 em Londres, mais de 13 mil casas foram incendiadas e conforme Kirchhof (2004) este incêndio permitiu que as primeiras condições de combate ao mesmo fossem estabelecidas. Em 1755 a cidade de Lisboa foi devastada por um incêndio e em 1863, a capital chilena, foi atingida por um incêndio ocorrido na Igreja da Companhia de Jesus deixando mais de 1800 pessoas mortas. No ano 1871 mais de 300 mortes foram registradas devido a um incêndio na cidade de Chicago, nos Estados Unidos da América (SANTOS, 2014).

A preocupação com a segurança estrutural em relação ao incêndio, no Brasil, passou a ocorrer a partir da década de 70, com o acontecimento dos incêndios no Gran Circo Norte- 
Americano no Rio de Janeiro e nos edifícios Andraus e Joelma em São Paulo. De acordo com Kimura (2009), o incêndio no edifício Andraus (Figura 2.5.a) ocorrido em 1972 registrou 16 mortes e foi constatada ausência de qualquer sistema de segurança, como por exemplo sinalização de saídas de emergência, alarmes de detecção automática e os chuveiros automáticos. Já a tragédia do edifício Joelma (Figura 2.5.b) resultou em 180 vítimas, segundo Rocha (2016), as telhas de amianto que impossibilitavam o pouso de helicópteros no telhado e a escada central em formato triangular foram fatores determinantes no volume de vítimas pois dificultavam a evacuação.

Figura 2.5 - Incêndios nos edifícios Andraus (a) e Joelma (b)

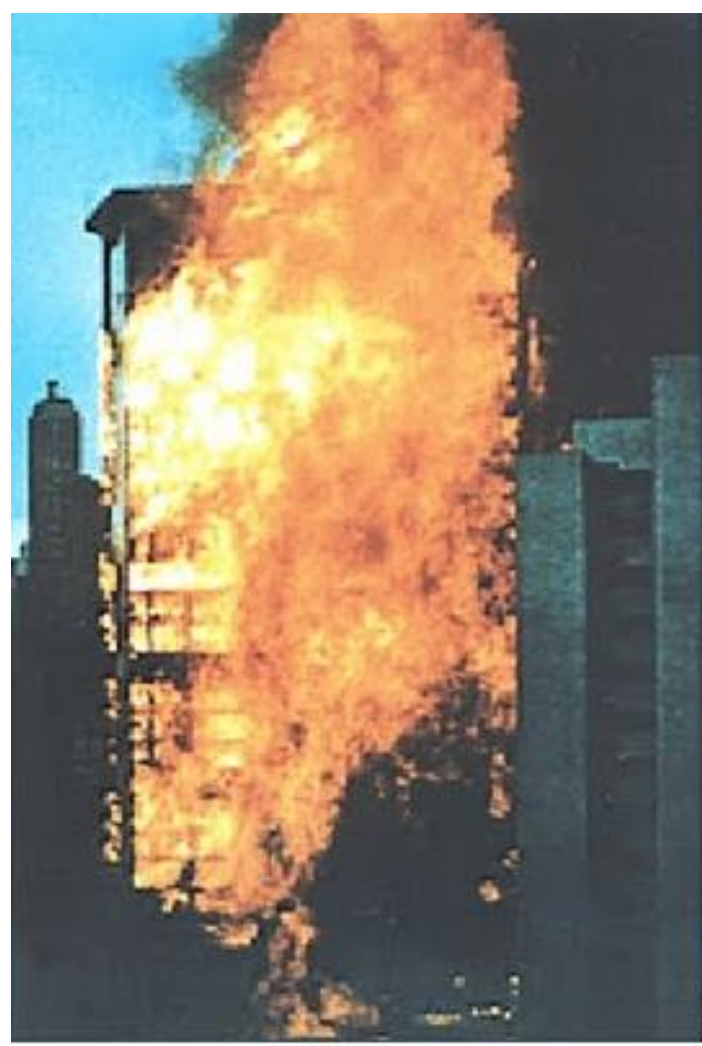

(a)

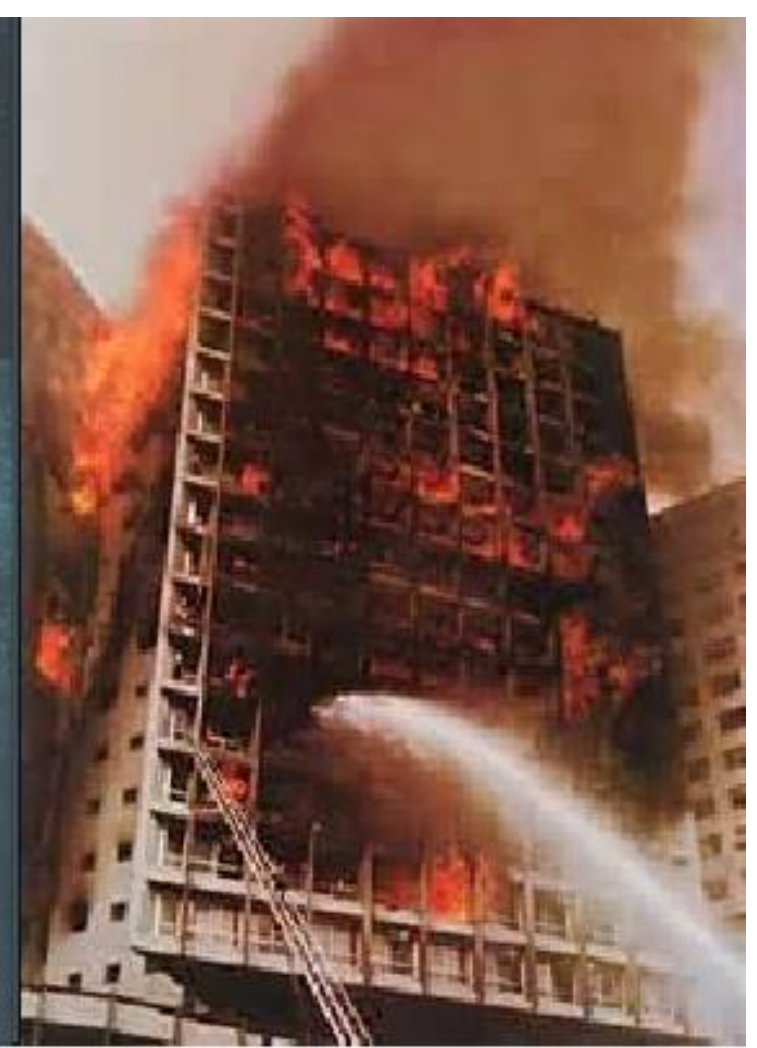

(b)

Fonte: http://culturaaeronautica.blogspot.com/

Dentre as consequências geradas pelas tragédias foram as alterações nas normas vigentes até então, buscando soluções voltadas à prevenção de incêndios e minimização dos danos pessoais e materiais. Em 1974, a ABNT publica a NB 208 - Saídas de Emergência para Edifícios Altos; em 1978 é instaurada a Norma Regulamentadora 23 (NR 23) - Proteção contra incêndios, pelo Ministério do Trabalho; e em 1979 o Laboratório de Ensaios ao Fogo no Instituto de Pesquisas Tecnológicas (IPT) foi criado. 
Já no ano de 1980, foi criada a norma ABNT NBR 5627 - Exigências particulares das obras de concreto armado e protendido em relação à resistência ao fogo -, que foi extinta no ano de 2001 por adotar parâmetros que tornava a construção onerosa. Hoje, a ABNT, conta com diversas normas relacionadas à segurança estrutural em incêndio, elencadas a seguir, mas para a alvenaria estrutural ainda não há uma normalização específica.

- ABNT NBR 5628:2001 - Componentes construtivos estruturais - Determinação da resistência ao fogo.

- $\quad$ ABNT NBR 10636:1989 - Paredes Divisórias sem função estrutural - Determinação da resistência ao fogo.

- $\quad$ ABNT NBR 14323:2013 - Projeto de estruturas de aço e de estruturas mistas de aço e concreto de edifícios em situação de incêndio.

- $\quad$ ABNT NBR 14432:2001 - Exigências de resistência ao fogo de elementos construtivos de edificações - Procedimento.

- $\quad$ ABNT NBR 15200:2012 - Projeto de estruturas de concreto em situação de incêndio.

De acordo com Mitidieri (2008), para que a edificação seja capaz de garantir segurança no desempenho estrutural quando submetida a um incêndio, ela deve atender aos seguintes requisitos: prevenir o início do incêndio; ocorrido o princípio do incêndio, limitar seu crescimento; possibilitar a extinção do incêndio no ambiente de origem; limitar a propagação de incêndio para outros ambientes; permitir a desocupação segura dos usuários do edifício; dificultar a propagação de incêndio para edifícios adjacentes; manter o edifício integro, sem danos, sem ruína parcial ou total; permitir operações de natureza de combate ao fogo e de resgate de vítimas.

Recentemente, na madrugada de 01 de maio de 2018 o edifício Wilton Paes de Almeida, localizado no centro da cidade de São Paulo, desabou após um incêndio de grandes proporções (Figura 2.6.a e Figura 2.6.b). O fogo iniciou-se no quinto andar do edifício e em menos de uma hora e meia já havia se alastrado por quase todos os pavimentos quando então a estrutura foi à ruína. Em entrevista para o site G1 São Paulo (2018) o capitão do Corpo de Bombeiros de São Paulo, Marcos Palumbo, disse que o fogo espalhou tão rápido pelo edifício pois os elevadores foram retirados e suas caixas formaram dutos de ar que transportaram os gases quentes e não permitiam a compartimentação vertical, além disso no local havia muito material combustível (madeira, papel, papelão) que contribuiu para a propagação rápida das chamas. 
Figura 2.6 - Edifício Wilton Paz de Almeida em chamas (a); Escombros do edifício após o incêndio (b)

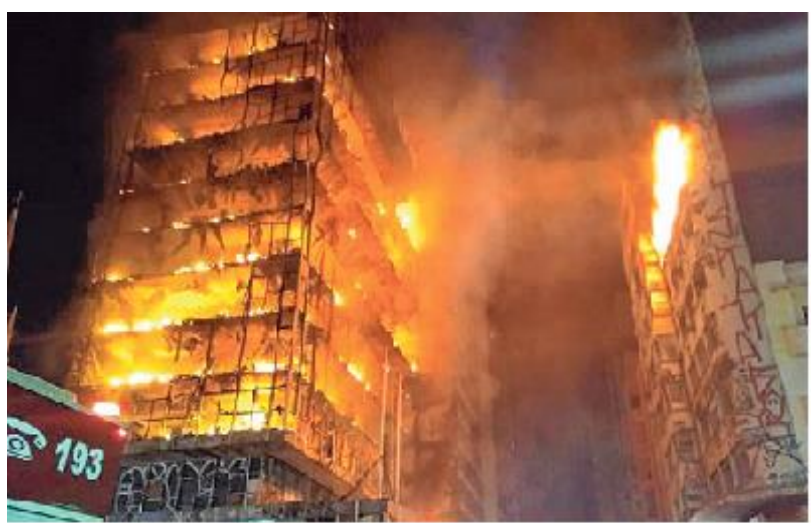

(a)

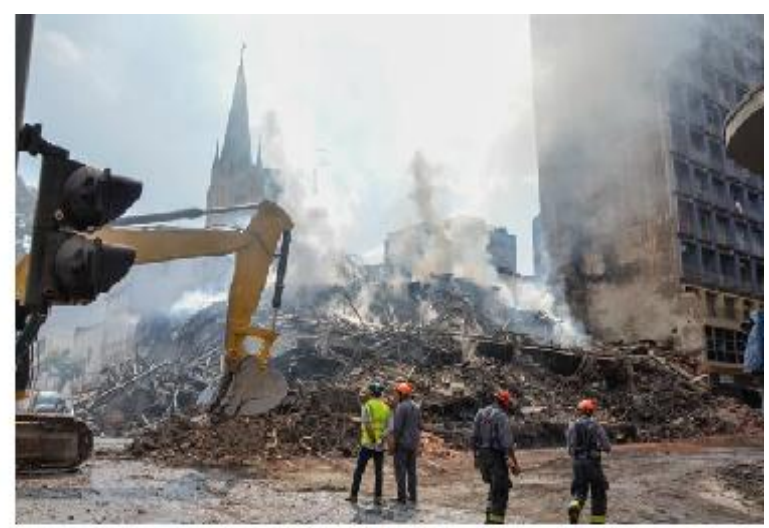

(b)

Fonte: (a) http://imirante.com/oestadoma; (b) http://www.creasp.org.br

\subsubsection{Modelos de incêndio}

\subsubsection{Modelo de incêndio real}

Segundo o National Fire Protection Association - NFPA (2016) o fogo é um processo de oxidação que ocorre de maneira rápida emitindo luz, fumaça e calor provocando elevação de temperatura. Uma reação em cadeia é gerada como resultado do processo químico denominado combustão, ela transforma os materiais combustíveis e inflamáveis (sólidos ou líquidos) em gases, a partir da combinação com um comburente.

A definição de fogo para a NBR 13860:1997 é: "processo de combustão caracterizado pela emissão de calor e luz". Enquanto isso a definição de incêndio pode ser tida pela ISO 8341 como "Incêndio é a combustão rápida disseminando-se de forma descontrolada no tempo e espaço" e a NBR 13860:1997 aponta que "Incêndio é o fogo fora de controle".

De acordo com Seito et al. (2008) o aquecimento do material precede a etapa de ignição, independentemente do estado físico do combustível, causando a liberação de gases e vapores inflamáveis e após esta etapa a reação passa a ser autossuficiente. Ou seja, ocorre uma retroalimentação do sistema com o calor desprendido pela reação exotérmica inicial do material, neste processo o aquecimento do material no entorno das chamas provoca desprendimento de vapores voláteis que dão continuidade à reação de pirólise. Esta reação em cadeia aumenta o calor desprendido e consequentemente aumenta a velocidade do processo.

Desta forma, um incêndio só iniciará e permanecerá existindo enquanto houver a combinação de três fatores: um material que sirva de combustível, uma fonte de calor e o comburente (oxigênio), como apresentado no triângulo da combustão da Figura 2.7. 
Figura 2.7 - Triângulo da Combustão

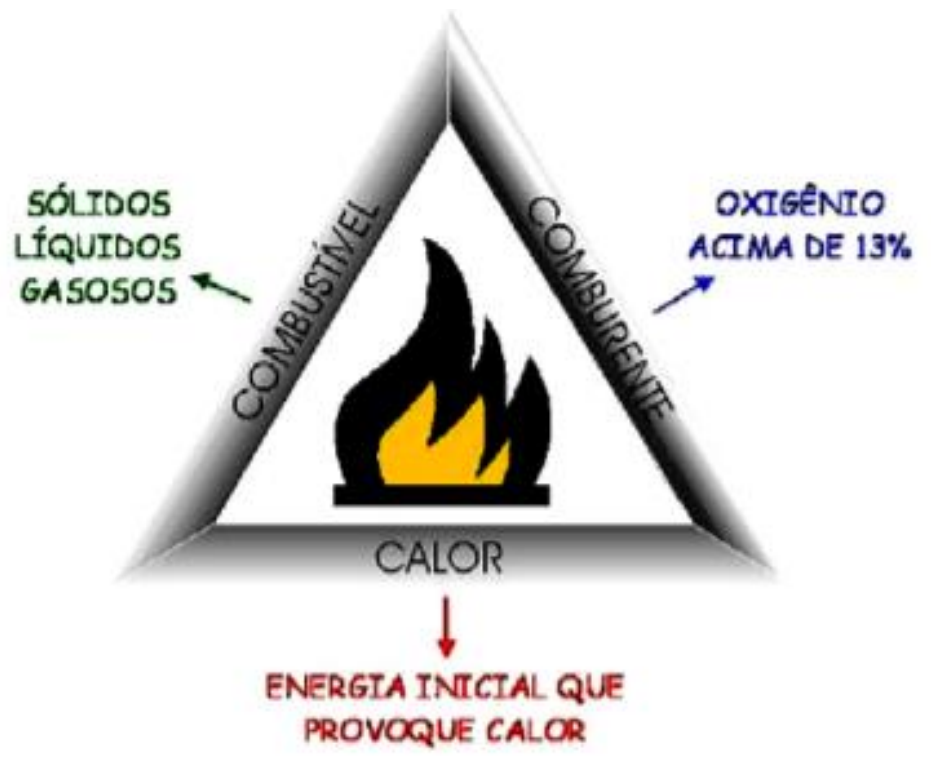

Fonte: http://7gcir.blogspot.com/

Kumar e Kameswara Rao (1995) relacionaram a quantidade e distribuição de materiais combustíveis com os ambientes de uma edificação, este estudo mostrou que cozinha e despensa são os compartimentos com maiores cargas de incêndio e os menores são banheiro e varanda.

Com o início do fogo, um incêndio real apresenta grande variabilidade no modo como se manifesta, podendo ser brusco e de curta duração, em que a temperatura se eleva e diminui rapidamente, ou mais brando e de longa duração, em que a temperatura demora para aumentar. É difícil definir um comportamento para a curva de tempo-temperatura de um incêndio real, pois segundo Costa e Silva (2006) depende de muitos fatores como:

- Carga de incêndio - correspondente a todo material combustível presente no local do incêndio;

- Grau de ventilação - representa a quantidade de comburente do local. Define-se que quanto maior o fator de abertura mais rápida é a combustão, mais elevada é a temperatura máxima e menor é a duração do incêndio, pois o combustível é consumido mais rapidamente;

- Características dos materiais da compartimentação - a propagação do fogo faz com que ocorra a diminuição da temperatura máxima do incêndio, no compartimento onde o incêndio se iniciou porque ocorre uma menor duração das chamas. Portanto, quanto mais resistentes à ação do fogo forem os materiais, maior será a temperatura máxima do incêndio.

Existe uma diferença entre a temperatura dos componentes da estrutura e dos gases no ambiente em chamas, a temperatura dos elementos depende de suas propriedades térmicas e a absorção de calor é diferente para cada material. O estudo do comportamento de incêndios é 
feito a partir de curvas que relacionam a temperatura dos gases no ambiente com o tempo de ocorrência do incêndio. A representação do incêndio é simplificada por meio dos modelos de incêndio natural e padrão, que permitem estimar a temperatura máxima atingida durante a ação o fogo.

Em incêndios reais a curva de evolução da temperatura no ambiente ocorre como na Figura 2.8, é composta de três etapas distintas: ignição, aquecimento e resfriamento. A fase de ignição corresponde ao período pré-flashover e representa o início da combustão, as temperaturas apresentam-se baixas e por isso o incêndio é considerado de baixas proporções, não oferecendo grandes riscos à vida humana ou à integridade da estrutura. É possível evitar seu alastramento se houver medidas capazes de detectar e extinguir o foco do fogo, é uma etapa que tem efeito localizado e de baixa taxa de aumento de temperatura (SILVA, 2001).

Figura 2.8 - Curva de Incêndio Real

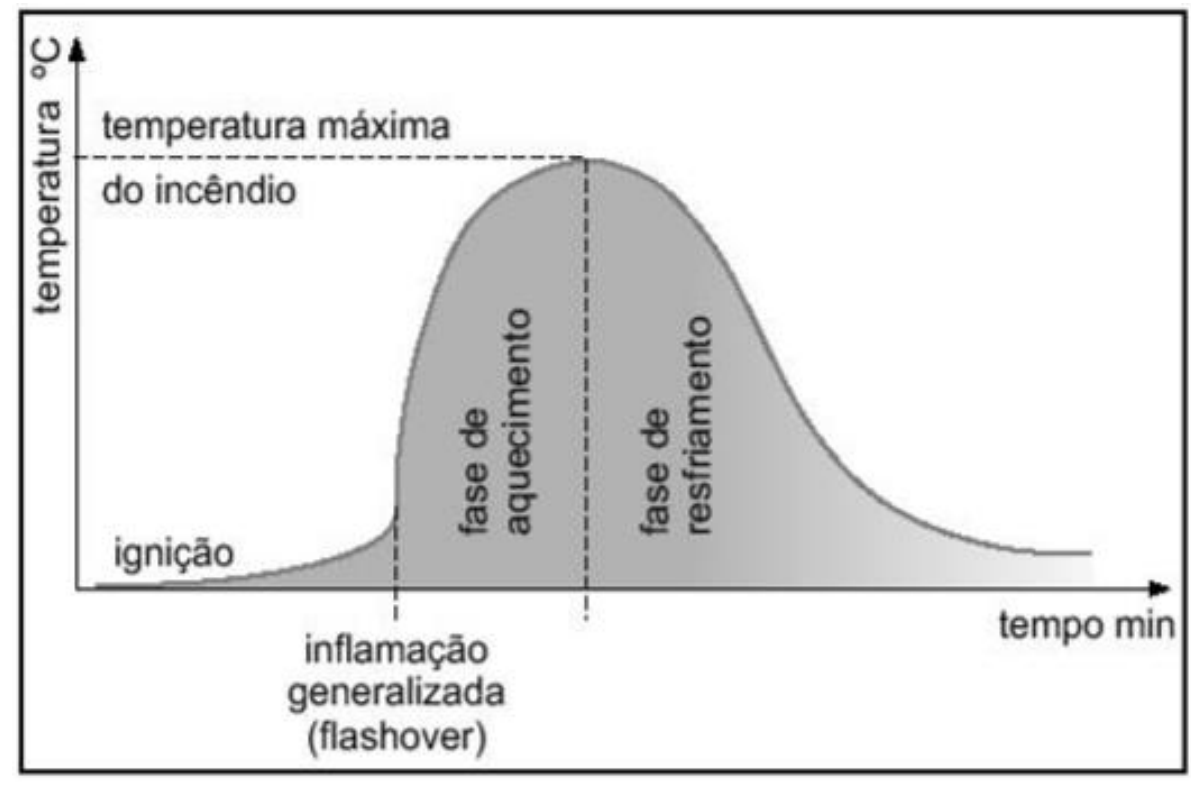

Fonte: LIMA (2005)

A definição de "flashover" pelo Eurocode 1 Part 1-2 é dada como uma ignição simultânea de toda a carga de incêndio do compartimento.

Ainda segundo Silva (2001) após a ignição pode ocorrer a inflamação generalizada ou flashover que ocorre quando a temperatura dos gases atinge aproximadamente $600^{\circ} \mathrm{C}$ e há um aumento brusco na temperatura e na taxa de aquecimento. Neste instante o fogo toma conta do compartimento e podem ocorrer explosões que, geralmente, provocam o rompimento das janelas e vidros. Caso o flashover não seja evitado o incêndio passa a ser de grandes proporções, influenciando estruturalmente na edificação e por isso o dimensionamento deve ser feito de acordo com as prescrições da norma de segurança contra incêndio. 
No momento em que os vidros se quebram há uma entrada de oxigênio em grande quantidade no ambiente, alimentando e fortalecendo as chamas existentes no compartimento e provocando uma liberação maior de calor, consequentemente a temperatura se eleva ainda mais (BUCHANAN, 2002). A temperatura dos gases aumenta até que grande parte da carga de incêndio (combustível) seja consumida e o pico da curva seja atingido, dando início à terceira fase de um incêndio real, o resfriamento, que se difere até que todo combustível seja queimado.

\subsubsection{Modelo de incêndio natural}

O modelo de incêndio real trata-se de uma simplificação das condições de um incêndio real. A curva temperatura x tempo de um incêndio natural mostrada na Figura 2.9 aborda desde a fase de inflamação generalizada até o resfriamento dos gases, mas a fase inicial de ignição é desconsiderada por entender-se que esta fase não altera a capacidade estrutural da edificação. A temperatura tem crescimento exponencial e atinge um valor máximo, após isto ocorre a fase de resfriamento que, por simplificação, é linearizada.

Figura 2.9 - Modelo de um incêndio natural

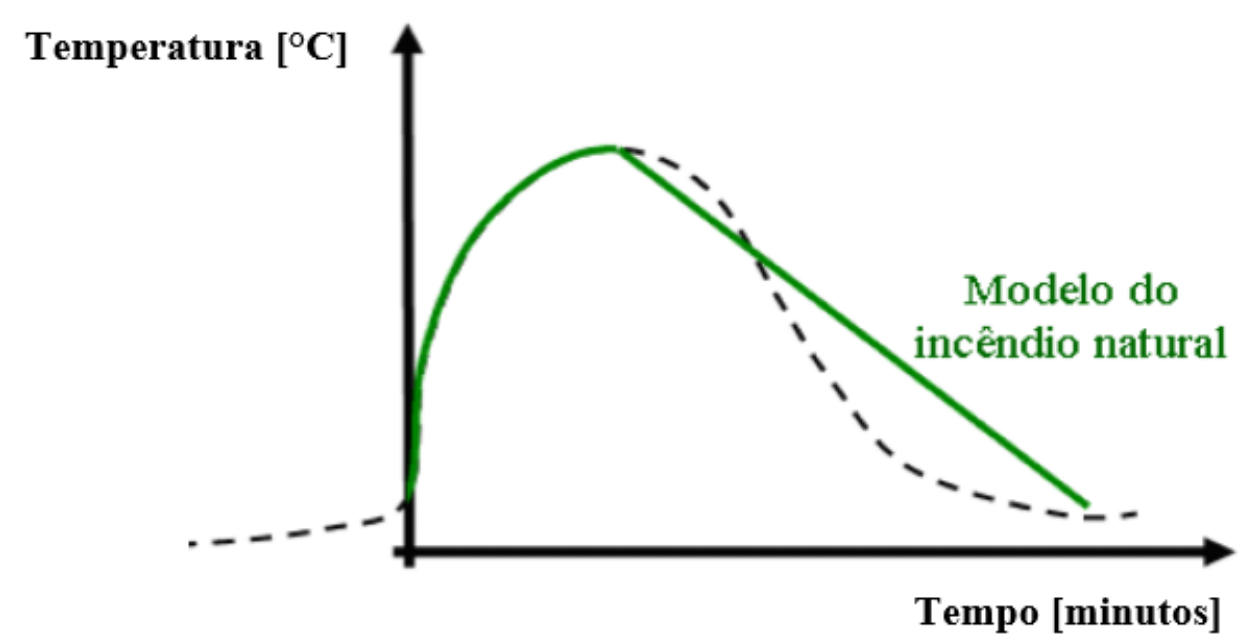

Fonte: KIMURA (2009)

Esta curva utiliza o conceito de tempo efetivo para que se atinja os mesmos efeitos de um incêndio real, abordando tanto a fase de resfriamento após o flashover como a fase de resfriamento dos gases. As curvas temperatura x tempo naturais são constituídas a partir de ensaios de incêndios que simulam a situação real de um compartimento em chamas, portanto o incêndio denominado natural é aquele cuja temperatura dos gases respeitas estas curvas. 
O Eurocode 1 Part 1.2 apresenta dois modelos para o cálculo das relações de temperatura em função do tempo de incêndios naturais: o modelo simplificado e o modelo avançado.

O modelo avançado leva em consideração em suas complexas análises computacionais baseadas na dinâmica dos fluídos a troca de massa e energia e as propriedades dos gases para determinação do incêndio natural. Sua modelagem pode ocorrer de duas maneiras: uma e duas zonas. Na implementação de uma zona a distribuição uniforme de temperatura varia no tempo e na de duas zonas, define-se uma espessura variável de aquecimento ao longo do tempo para camada inferior e superior. Por ser um modelo necessita de implementação computacional a obtenção dos parâmetros necessários é feito por meio de ensaios ou modelos matemáticos aferidos com ensaios. (KIMURA, 2009)

O modelo simplificado é utilizado em função da complexidade dos métodos avançados mas possui limitada aplicação pois é baseado em parâmetros físicos específicos, como a densidade de carga de incêndio e o fator de ventilação do compartimento. Ele assume uma distribuição de temperatura uniforme incêndio compartimentado e o comportamento da curva é definia por equações parametrizadas apresentadas no anexo A do Eurocode 1 Part 1.2. A aplicação deste equacionamento se limita a compartimentos com menos de $500 \mathrm{~m}^{2}$ de área de piso, sem aberturas no teto e altura máxima de 4 metros, o cálculo é feito como mostrado a seguir:

$\theta_{g}=20+1325\left(1-0,324 e^{-0,2 t^{*}}-0,204 e^{-1,7 t^{*}}-0,472 e^{-19 t^{*}}\right)$

Em que na equação 2.9:

$\theta_{g}$ é a temperatura dos gases no compartimento em chamas em ${ }^{\circ} \mathrm{C}$;

$t^{*}$ é o tempo fictício em horas, calculado por:

$t^{*}=t$

Em que:

$t$ é o tempo em horas;

O parâmetro $\Gamma$ na equação 2.10 é adimensional e representa o fator de correção do tempo, é calculado como mostrado na equação 2.11 e depende do fator de abertura $(0)$ e da absorção térmica do compartimento (b):

$$
\Gamma=\frac{(O / b)^{2}}{(0,04 / 1160)^{2}}
$$


Em que:

$$
\begin{aligned}
& \mathrm{O}=A_{V} \frac{\sqrt{h_{e q}}}{A_{t}} \\
& \mathrm{~b}=\sqrt{\rho c \lambda}
\end{aligned}
$$

Das equações 2.12 e 2.13 , valem as definições:

O: grau de ventilação, que varia dentro dos limites $0,02 \leq 0 \leq 0,20\left[\mathrm{~m}^{1 / 2}\right]$;

$A_{V}$ : área total das aberturas verticais nas paredes $\left[\mathrm{m}^{2}\right]$;

$h_{e q}$ : média ponderada das alturas das aberturas nas paredes $[\mathrm{m}]$;

$A_{t}$ : área total do compartimento (paredes. piso. teto, incluindo as aberturas) $\left[\mathrm{m}^{2}\right]$;

b: absorção térmica do material de vedação do compartimento, e deve estar dentro do intervalo $100 \leq b \leq 2200\left[\mathrm{~J} / \mathrm{m}^{2} \mathrm{~s}^{1 / 2} \mathrm{~K}\right]$

$\rho$ : densidade do material de revestimento do compartimento $\left[\mathrm{kg} / \mathrm{m}^{3}\right]$;

$c$ : calor específico do material de revestimento do compartimento[J/ $\mathrm{kgK}]$;

$\lambda$ : condutividade térmica do material de revestimento do compartimento[ $\mathrm{W} / \mathrm{mK}]$.

Caso o cálculo do fator de correção resulte igual a $1(\Gamma=1)$ a curva temperatura $\mathrm{x}$ tempo do modelo simplificado se aproxima das curvas de incêndio-padrão, descritas no Item 2.2.2.3. O Eurocode 1 Part1.2, apresenta métodos de cálculo para a absorção térmica nos casos em que a superfície é composta por diferentes camadas de materiais e também destaca que as propriedades físicas e térmicas dos materiais de revestimento devem ser adotadas com seus valores à temperatura ambiente.

A temperatura máxima $\left(\theta_{\text {máx }}\right)$ ocorre para $t^{*}=t^{*}{ }_{\text {máx }}$ sendo que:

$$
\begin{aligned}
& t_{\text {máx }}^{*}=t_{\text {máx }} \Gamma \\
& t_{\text {máx }}=\max \left[\left(0,2 \cdot 10^{-3} \cdot \frac{q_{t, d}}{O}\right) ; t_{\text {lim }}\right]
\end{aligned}
$$

Em que:

$q_{t, d}$ é o valor de cálculo da densidade da carga de incêndio relacionada à toda área da superfície do compartimento $\left(A_{t}\right)$, devendo obedecer os limites $50 \leq q_{t, d} \leq 1000\left[\mathrm{MJ} / \mathrm{m}^{2}\right]$;

$t_{\text {lim }}$ é o tempo limite para o incêndio é dado conforme as equações 2.16 e 2.17 : 


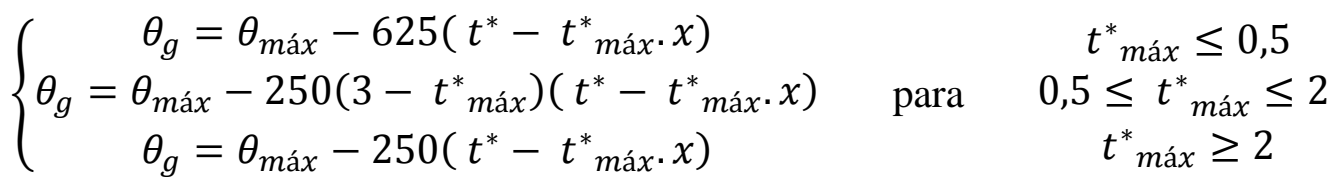

Em que:

$$
\left\{\begin{array}{c}
x=1,0 \\
x=t_{\text {lim }} \cdot \frac{\Gamma}{t^{*} \text { máx }}
\end{array} \quad \text { se } \begin{array}{c}
t_{\text {máx }}>t_{\text {lim }} \\
t_{\text {máx }}=t_{\text {lim }}
\end{array}\right.
$$

\subsubsection{Modelo de incêndio-padrão}

Tendo em vista que a curva temperatura $\mathrm{x}$ tempo de incêndios naturais apresenta um grande número de fatores envolvidos na sua determinação são propostas curvas de incêndiopadrão com o intuído de simplificar e padronizar a situação de incêndio para a execução de ensaios e análises numéricas. Estas curvas não consideram as características particulares de cada ambiente e apresentam somente o trecho ascendente, não considerando a redução de temperatura após o pico.

De acordo com Velarde (2008) os modelos de curvas-padrão foram criados com o propósito de representar o incêndio de maneira simples e aproximada, não representando o incêndio real. Nos ensaios de simulação de incêndio a temperatura dos gases no forno em função do tempo é definida pelas curvas de incêndio-padrão, segundo Moreno Jr. e Molina (2012), a curva sugerida pela International Organization for Standardization - ISO 834-1:1999 é a mais utilizada no Brasil e internacionalmente. Buchanan (2002) destaca que a curva da ASTM E119:2000 também é muito utilizada e ambas servem como base para diversas normas em outros países.

Além das duas curvas citadas serão apresentadas as prescrições do Eurocode 1 Part 1.2 para a padronização do incêndio. A normalização brasileira que estabelece medidas a serem tomadas durante o ensaio de determinação de resistência ao fogo de alguns elementos estruturais é a ABNT NBR 5628:2001, que recomenda como curva-padrão de temperatura x tempo a sugerida pela ISO 834-1:1999.

A curva segundo a ISO 834-1:1999 - "Fire-resistance tests - Elements of building construction" para o aumento da temperatura dos gases em um incêndio é representada por uma equação logarítmica que depende do tempo de exposição ao fogo e da temperatura inicial, normalmente adotada com o valor de $20^{\circ} \mathrm{C}$, como mostrado na equação (2.18). 
$\theta_{g}=20+345 \log (8 t+1)$

Em que, $\theta_{g}$ é a temperatura dos gases $\left(\mathrm{em}^{\circ} \mathrm{C}\right)$ e t é o tempo decorrido em minutos. A relação de pontos desta curva segue apresentada na Tabela 2.4 e o seu comportamento gráfico pode ser observado na Figura 2.10 juntamente com as demais curvas que serão descritas.

Tabela 2.4 - Temperaturas dos gases no ambiente em chamas em função do tempo

\begin{tabular}{cc|cc}
\hline Tempo $(\min )$ & $\theta_{g}\left({ }^{\circ} \mathrm{C}\right)$ & Tempo $(\min )$ & $\theta_{g}\left({ }^{\circ} \mathrm{C}\right)$ \\
\hline \hline 0 & 20 & 80 & 988 \\
10 & 678 & 90 & 1006 \\
20 & 781 & 100 & 1022 \\
30 & 842 & 110 & 1036 \\
40 & 885 & 120 & 1049 \\
50 & 918 & 240 & 1153 \\
60 & 945 & 480 & 1257 \\
70 & 968 & & \\
\hline
\end{tabular}

Fonte: Adaptado da ISO 834-1:1999

A curva da norma americana ASTM E119:2000 - "Standard test methods for fire tests of building construction and materials", é definida por um número discreto de pontos, como mostrado na Tabela 2.5, e o seu comportamento gráfico também pode ser observado na Figura 2.10. Dentre muitas equações desenvolvidas para descrever a curva, para Buchanan (2002) a equação 2.19 é a que melhor representa o comportamento da curva.

Tabela 2.5 - Temperaturas dos gases no ambiente em chamas em função do tempo

\begin{tabular}{cc|cc}
\hline Tempo $(\mathrm{min})$ & $\theta_{\mathcal{g}}\left({ }^{\circ} \mathrm{C}\right)$ & Tempo $(\mathrm{min})$ & $\theta_{\mathcal{g}}\left({ }^{\circ} \mathrm{C}\right)$ \\
\hline \hline 0 & 20 & 55 & 916 \\
5 & 538 & 60 & 927 \\
10 & 704 & 65 & 937 \\
15 & 760 & 70 & 946 \\
20 & 795 & 75 & 955 \\
25 & 821 & 80 & 963 \\
30 & 843 & 85 & 971 \\
35 & 862 & 90 & 978 \\
40 & 878 & 120 & 1010 \\
45 & 892 & 240 & 1093 \\
50 & 905 & 480 & 1260 \\
\hline
\end{tabular}

Fonte: Adaptado da ASTM E119:2000 


$$
\theta_{g}=750\left[1-e^{-3,79552 \sqrt{t_{h}}}\right]+170,41 \sqrt{t_{h}}+20
$$

Em que, $\theta_{g}$ é a temperatura dos gases $\left(\mathrm{em}^{\circ} \mathrm{C}\right)$ e $t_{h}$ é o tempo decorrido em horas.

Além do equacionamento para incêndios naturais, o método proposto pelo Eurocode 1 Part 1.2 ainda apresenta outras três curvas de incêndio:

a) Curva “temperatura $\left[{ }^{\circ} \mathrm{C}\right] x$ tempo [min] " de incêndio-padrão da ISSO 834:1999 (equação 2.10). Esse modelo é destinado a incêndios em que o combustível é formado principalmente por materiais celulósicos;

b) Curva “temperatura $\left[{ }^{\circ} \mathrm{C}\right] x$ tempo $[\mathrm{min}]$ " descrita pela equação 2.20 , designada ao dimensionamento dos elementos estruturais externos das paredes de divisórias que podem apresentar exposição ao fogo em diferentes partes da fachada.

$$
\theta_{g}=660\left(1-0,687 \mathrm{e}^{-0,32 t}-0,313 \mathrm{e}^{-3,8 t}\right)+20
$$

c) Curva “temperatura $\left[{ }^{\circ} \mathrm{C}\right] \times$ tempo $[\mathrm{min}]$ " descrita pela equação 2.21 , designada ao dimensionamento dos elementos estruturais internos ao compartimento. Esta é a curva de elevação de temperatura dos gases para incêndios cujo combustível predominante é formado por hidrocarbonetos. Por ser a curva de maior interesse dentre as duas equacionadas pelo Eurocode o seu comportamento gráfico segue apresentado na Figura 2.10 juntamente com as curvas das normas supracitadas e a sua relação de pontos está disposta na Tabela 2.6.

$$
\theta_{g}=1080\left(1-0,325 \mathrm{e}^{-0,167 t}-0,675 \mathrm{e}^{-2,5 t}\right)+20
$$

Nas equações 2.12 e $2.13, \theta_{g}$ é a temperatura dos gases $\left(\mathrm{em}^{\circ} \mathrm{C}\right)$ e $t$ é o tempo decorrido em minutos.

Tabela 2.6 - Temperaturas dos gases em função do tempo para combustíveis formados por hidrocarbonetos

\begin{tabular}{cc|cc}
\hline Tempo $(\mathrm{min})$ & $\theta_{g}\left({ }^{\circ} \mathrm{C}\right)$ & Tempo $(\mathrm{min})$ & $\theta_{g}\left({ }^{\circ} \mathrm{C}\right)$ \\
\hline \hline 0 & 20 & 9 & 1022 \\
1 & 743 & 10 & 1034 \\
2 & 844 & 15 & 1071 \\
3 & 887 & 20 & 1088 \\
4 & 920 & 40 & 1100 \\
5 & 948 & 60 & 1100 \\
6 & 971 & 120 & 1100 \\
7 & 991 & 240 & 1100 \\
8 & 1008 & 480 & 1100 \\
\hline
\end{tabular}


Na Figura 2.10 as curvas de incêndio-padrão para elementos internos apresentadas acima são comparadas graficamente.

Figura 2.10 - Principais curvas de incêndio-padrão dos códigos normativos internacionais

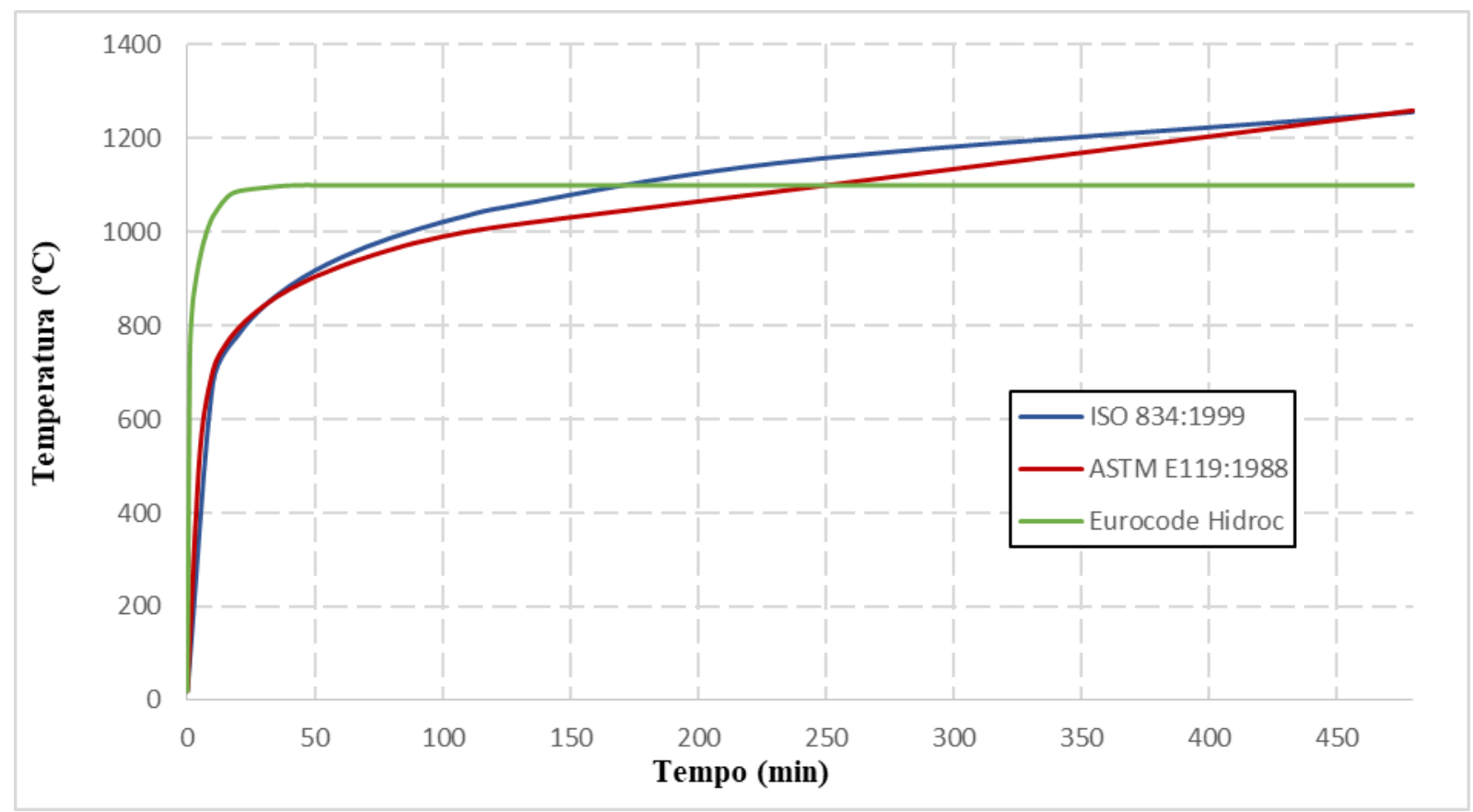

Como estas curvas não correspondem ao comportamento real do incêndio ou das estruturas expostas ao fogo, as conclusões feitas com base em ensaios e análises numéricas que as utilizam devem ser empregadas com cautela e atenção. As curvas de incêndio-padrão determinam a relação da temperatura dos gases do compartimento em chama em função a temperatura, mas não permitem determinar a máxima temperatura atingida pelo elemento estrutural. Portanto as normas pré-estabelecem os tempos padronizados que permitam o dimensionamento estrutural em função das dimensões e tipo de utilização da edificação (SILVA, 2001).

Observa-se que a curva de incêndio-padrão não considera a fase de extinção natural do fogo, na qual haveria resfriamento da estrutura. No caso de resfriamento natural em temperatura ambiente, pode ocorrer nesta etapa uma relativa recuperação de rigidez de resistência mecânica dos materiais utilizados em elementos estruturais segundo Moreno Jr. e Molina (2012). Enquanto que Cánovas (1988) ressalta que como o combate ao fogo nas estruturas geralmente é feito com resfriamento repentino no lançamento de água, o efeito desse processo pode causar tantos danos à estrutura como o próprio fogo, pois os materiais dilatam por absorver calor e água, contraindo bruscamente devido às diferenças de temperatura. 


\subsubsection{Tempo requerido de resistência ao fogo (TRRF)}

Os códigos de edificações estabelecem para as paredes de alvenaria um determinado nível de resistência ao fogo, que é mensurado pelo tempo requerido de resistência ao fogo (TRRF) e visa proteger os ocupantes e prover meios de escape e regaste. O TRRF é definido pela ABNT NBR 14432:2001 como o tempo mínimo que um elemento estrutural ou elemento de compartimentação resiste ao fogo durante um incêndio, sendo este de acordo com a curva de incêndio-padrão. Durante o tempo requerido de resistência ao fogo, o elemento estrutural deve manter adequabilidade estrutural, estanqueidade e isolamento.

Tanto no incêndio real como no incêndio padronizado a temperatura máxima atingida pelos elementos da edificação não é igual à temperatura dos gases aquecidos, pois esta depende de fatores relacionados com a quantidade de materiais combustíveis e comburentes. O TRRF associa a temperatura média do elemento estrutural no incêndio-padrão de tal forma que assemelhe àquela encontrada no incêndio real ou natural, conceituação que está ilustrada na Figura 2.11.

Figura 2.11 - Conceito de Tempo Requeiro de Resistência ao Fogo (TRRF).

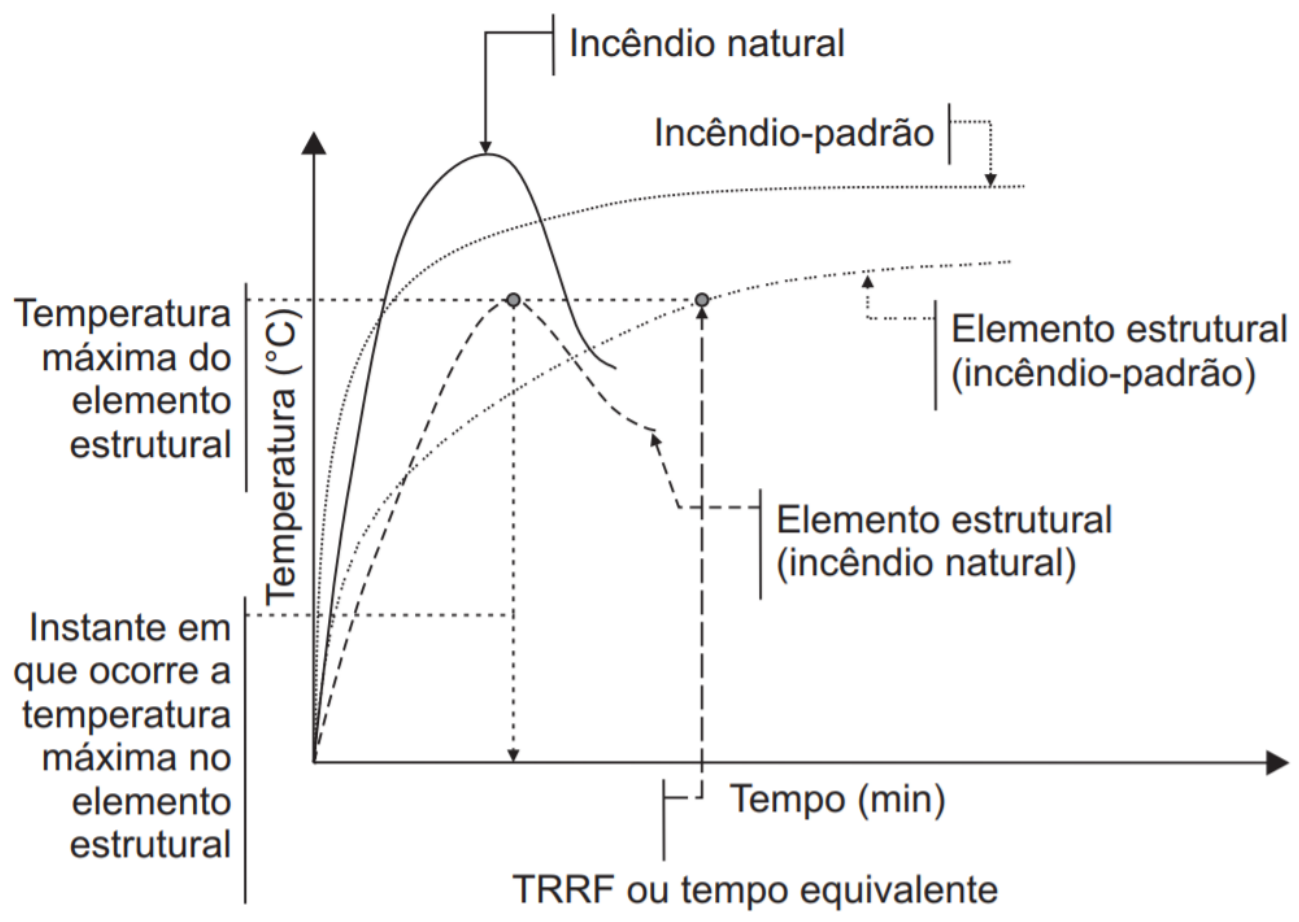

Fonte: Silva (2008)

A norma ABNT NBR 14432:2001 permite a obtenção simplificada do tempo requerido de resistência ao fogo por meio de tabelas que leva em consideração o uso predominante da 
edificação e sua altura. O Tabela 2.7 tirado da norma apresenta o TRRF de acordo com os parâmetros supracitados.

Tabela 2.7 - Tempo Requerido de Resistência ao Fogo (TRRF) em minutos.

\begin{tabular}{|c|c|c|c|c|c|c|}
\hline \multirow[b]{2}{*}{$\begin{array}{c}\text { Ocupaçãol } \\
\text { Uso }\end{array}$} & \multirow[b]{2}{*}{$\begin{array}{c}\text { Divisão } \\
\text { (NBR 9077) }\end{array}$} & \multicolumn{5}{|c|}{ Altura da edificação $(\mathrm{m})$} \\
\hline & & $\underset{h \leq 6}{\text { Classe }} P_{1}$ & $\begin{array}{c}\text { Classe } P_{2} \\
6<h \leq 12\end{array}$ & $\begin{array}{l}\text { Classe } P_{3} \\
12<h \leq 23\end{array}$ & $\begin{array}{l}\text { Classe } P_{4} \\
23<h \leq 30\end{array}$ & $\begin{array}{c}\text { Classe } \mathbf{P}_{\mathbf{5}} \\
\mathbf{h} \geq \mathbf{3 0}\end{array}$ \\
\hline Residencial & A1 a A-3 & 30 & 30 & 60 & 90 & 120 \\
\hline $\begin{array}{c}\text { Serviços de } \\
\text { hospedagem }\end{array}$ & B-1 e B-2 & 30 & $60(30)$ & 60 & 90 & 120 \\
\hline $\begin{array}{c}\text { Comercial } \\
\text { varejista }\end{array}$ & $\mathrm{C}-1$ a $\mathrm{C}-3$ & $60(30)$ & $60(30)$ & 60 & 90 & 120 \\
\hline $\begin{array}{c}\text { Serviços } \\
\text { profissionais, } \\
\text { pessoais e } \\
\text { técnicos }\end{array}$ & D-1 a D-3 & 30 & $60(30)$ & 60 & 90 & 120 \\
\hline $\begin{array}{c}\text { Educacional } \\
\text { e cultura } \\
\text { física }\end{array}$ & $\mathrm{E}-1$ a $\mathrm{E}-6$ & 30 & 30 & 60 & 90 & 120 \\
\hline $\begin{array}{l}\text { Locais de } \\
\text { reunião de } \\
\text { público }\end{array}$ & $\begin{array}{c}\mathrm{F}-1, \mathrm{~F}-2, \mathrm{~F}-5, \\
\mathrm{~F}-6 \text { a } \mathrm{F}-8\end{array}$ & $60(30)$ & 60 & 60 & 90 & 120 \\
\hline \multirow{2}{*}{$\begin{array}{c}\text { Serviços } \\
\text { automotivos }\end{array}$} & $\begin{array}{c}\text { G-1 e G-2 } \\
\text { não abertos } \\
\text { lateralmente } \\
\text { e G-3 a G-5 }\end{array}$ & 30 & $60(30)$ & 60 & 90 & 120 \\
\hline & $\begin{array}{c}\text { G-1 e G-2 } \\
\text { abertos } \\
\text { lateralmente }\end{array}$ & 30 & 30 & 30 & 30 & 60 \\
\hline $\begin{array}{l}\text { Serviços de } \\
\text { saúde e } \\
\text { institucionais }\end{array}$ & $\mathrm{H}-1$ a H-5 & 30 & 60 & 60 & 90 & 120 \\
\hline \multirow{2}{*}{ Industrial } & $\mathrm{I}-1$ & 30 & 30 & 60 & 90 & 120 \\
\hline & $\mathrm{I}-2$ & $60(30)$ & $60(30)$ & $90(60)$ & $120(90)$ & 120 \\
\hline \multirow{2}{*}{ Depósitos } & $\mathrm{J}-1$ & 30 & 30 & 30 & 30 & 60 \\
\hline & $\mathrm{J}-2$ & 60 & 60 & $90(60)$ & $120(90)$ & 120 \\
\hline
\end{tabular}

Fonte: ABNT NBR 14432:2001

O TRRF pode ser definido mais refinadamente por cálculos analíticos por base no método do tempo equivalente conforme:

$$
t_{e}=q_{f i, k} \cdot \gamma_{n} \cdot \gamma_{s} \cdot W \cdot K \cdot M
$$

Onde:

$t_{e}$ é o tempo equivalente [min];

$q_{f i, k}$ é o valor característico da carga de incêndio específica $\left[\mathrm{MJ} / \mathrm{m}^{2}\right]$;

$\gamma_{n}$ é o coeficiente adimensional que leva em conta a presença de medidas de proteção ativa da edificação; 
$\gamma_{S}$ é o coeficiente de segurança que depende do risco de incêndio e das consequências do colapso da edificação;

$W$ é o fator associado à ventilação e à altura do compartimento;

$K$ é o fator associado às características do material de vedação do compartimento [min $\mathrm{m} 2 / \mathrm{MJ}]$; $M$ é o fator que depende do material da estrutura: define-se $\mathrm{M}=1$, para aço proteção ao fogo ou concreto, e $\mathrm{M}=13,7 \mathrm{v}$, para aço sem revestimento em que v é o grau de ventilação da edificação.

Vale ressaltar que o tempo que a estrutura deve resistir ao fogo engloba o tempo de evacuação e o tempo de combate ao fogo, e deve ser tal que minimize os danos causados nas edificações adjacentes.

\subsubsection{Mecanismos de transferência de calor}

Tanto nas curvas referentes ao modelo de incêndio-padrão como nas de incêndio natural o aumento da temperatura não se refere aos elementos da edificação, mas sim aos gases do ambiente em chamas que os envolvem. Após um certo intervalo de tempo a temperatura dos elementos tende a se aproximar da temperatura dos gases quentes do ambiente e são os parâmetros associados às leis de transferência de calor que regem o comportamento de aumento de temperatura nestes elementos.

Portanto, o conhecimento básico dos mecanismos de transferência de calor é fundamental para analisar o comportamento das estruturas em situação de incêndio. De acordo com Wang (2002) a transferência de calor pode ser definida fenomenologicamente como a interação que ocorre quando um determinado sistema e o meio, ou dois sistemas apresentam temperaturas diferentes e são colocados em contato. O calor pode ser transferido de três modos: condução, convecção e radiação, que podem ocorrer simultaneamente ou de forma isolada. Mas para Drysdale (1998), mesmo que os modos de transferência possam ocorrer juntos no incêndio, usualmente um deles é predominante em cada etapa de aquecimento.

A transferência de calor na alvenaria estrutural pode ocorrer pelos processos de condução, convecção e radiação conforme a camada da parede atravessada pelo calor. É um fenômeno transiente, portanto a maneira como estes processos ocorrem dependem das variações das condições de contorno e do campo de temperaturas no interior do material.

A transferência de calor ocorre de maneira distinta ao longo das camadas da parede de alvenaria estrutural, uma vez que o bloco não e maciço. Nas camadas maciças, a condução é responsável pela transferência de calor, já nos vazios, ocorre transferência por radiação e 
convecção (AL-HADHRAMI e AHMAD, 2008). Conforme pode ser observado na Figura 2.12, em que o incêndio é compartimentado e ocorre transferência de calor do ambiente aquecido para a parede, ao longo da espessura da parede e da parede para o ambiente não exposto ao incêndio.

Figura 2.12 - Esquema da transferência de calor de uma parede submetido a incêndio compartimentado

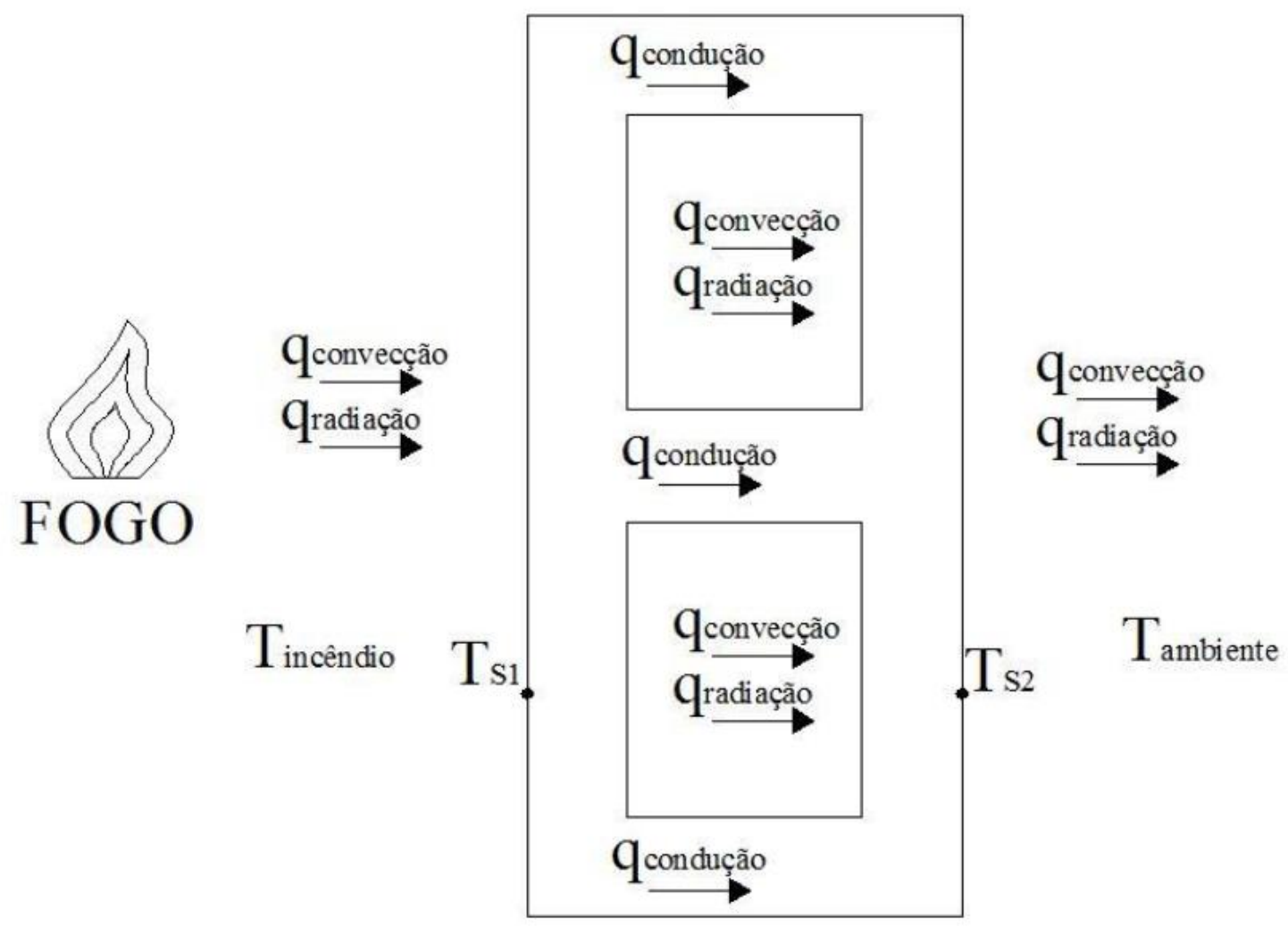

Fonte: Rosemann (2011)

Se o interior dos blocos for preenchido por algum material sólido como graute, areia ou materiais de baixa massa específica, a transferência de calor passa a ocorrer por condução nos septos dos blocos. Se a parede possuir revestimento de argamassa ou gesso, nestas camadas a transferência de calor se dá por condução. Uma vez que o calor passou a atingir a face não aquecida do bloco, passa a ocorrer transferência de calor da parede para o ambiente através de convecção e radiação, consequentemente o ambiente passa a esquentar por absorver calor.

A transmissão de calor ocorre em regime transiente e portanto o perfil de distribuição das temperaturas na seção transversal da parede assume uma configuração não linear, o que foi constatado por O'Connor; Silcock; Morris (1995); Nadjai et al (2006) e Nguyen et al (2009) em ensaios de resistência ao fogo de paredes de alvenaria. Esta distribuição depende de fatores como a espessura das paredes e taxa de aquecimento, e quanto maior este dois fatores, maior é a concavidade da curva de temperatura ao longo da espessura (NADJAI et al, 2006). 
Os três mecanismos de calor são descritos no APÊNDICE B, cujas informações foram retiradas de Rocha (2012) e Kimura (2009). Estas referências que podem ser consultados para melhor entendimento do assunto.

\subsubsection{Transferência de calor entre as chamas e o material}

Quando estruturas de concreto sofrem ações térmicas desenvolve-se um fluxo de calor na superfície exposta ao fogo, produzindo gradientes de temperatura, umidade e pressão no interior do elemento. Tensões devido à dilatação dos materiais e fissuras podem ocorrer neste processo, além disso, o concreto sofre modificações em suas propriedades físicas e mecânicas quando submetido a um aquecimento acelerado (incêndios). A propagação do calor no interior do concreto ocorre de maneira lenta visto que este material não é um bom condutor de calor.

A transferência de calor entre os gases quentes, as chamas, e a superfície de pisos, paredes e forros de uma edificação ocorre por um fluxo de calor $\left(h_{n e t}\right)$ que é governado predominantemente por convecção e radiação. Segundo o Eurocode 1 Part 1-2 este processo do fluxo de transferência de calor pode ser definido pela equação 2.23.

$$
h_{n e t}=h_{n e t, c}+h_{n e t, r}
$$

Em que o fluxo de transferência de calor $h_{n e t}\left[\mathrm{~W} / \mathrm{m}^{2}\right]$ é formado pela parcela $h_{n e t, c}$ referente à transferência de calor convectiva, determinada pela equação 2.24 , e pela parcela $h_{n e t, r}$ referente à transferência de calor radiativa, definida pela equação 2.25.

$$
h_{n e t, c}=\alpha_{c} \cdot\left(\theta_{g}-\theta_{m}\right)
$$

Em que:

$\alpha_{c}$ é o coeficiente de transferência de calor por convecção $\left[\mathrm{W} / \mathrm{m}^{2{ }^{\circ}} \mathrm{C}\right]$;

$\theta_{g}$ é a temperatura do gás ao redor do elemento exposto ao fogo $\left[{ }^{\circ} \mathrm{C}\right]$;

$\theta_{m}$ é a temperatura na superfície do elemento estrutural $\left[{ }^{\circ} \mathrm{C}\right]$.

$$
h_{n e t, r}=\Phi \cdot \varepsilon_{m} \cdot \varepsilon_{f} \cdot \Omega \cdot\left[\left(\theta_{r}+273\right)^{4}-\left(\theta_{m}+273\right)^{4}\right]
$$

Em que:

$\Phi$ é o fator de configuração;

$\varepsilon_{m}$ é a emissividade do compartimento incêndiado [adimensional]; 
$\varepsilon_{f}$ é a emissividade da superfície do elemento estrutural [adimensional];

$\Omega$ é a constante de Stefan-Boltzmann dada por $5,67 \times 10^{-8}\left[\mathrm{~W} /\left(\mathrm{m}^{2} / \mathrm{o} C^{4}\right)\right]$;

$\theta_{r}$ é a temperatura de radiação efetiva no ambiente de incêndio $\left[{ }^{\circ} \mathrm{C}\right]$;

$\theta_{m}$ é a temperatura na superfície do elemento estrutural $\left[{ }^{\circ} \mathrm{C}\right]$.

Leonardo (2005) apresenta algumas considerações que podem ser adotadas para efeito de simplificação: o valor do fator de configuração varia de 0 a 1 , portanto, na falta de dados pode ser adotado conservadoramente como $\Phi=1$; o valor do coeficiente de emissividade do fogo é normalmente adotado como $\varepsilon_{f}=1$; para superfícies de concretos o coeficiente de emissividade do compartimento pode ser considerado $\varepsilon_{m}=0,7$; caso o incêndio envolva totalmente os elementos a temperatura de radiação $\theta_{r}$ pode ser adotada como a temperatura do gás $\theta_{g}$. Além disso, para curvas padronizadas o coeficiente de transferência de calor por convecção pode ser considerado como $\alpha_{c}=25 \mathrm{~W} / \mathrm{m}^{2 \circ} \mathrm{C}$, e se houver um lado não exposto ao fogo, o fluxo de calor é dado apenas pela parcela de convecção e o coeficiente pode ser adotado como $\alpha_{c}=4 \mathrm{~W} / \mathrm{m}^{2 \circ} \mathrm{C}$.

\subsubsection{Compartimentação horizontal e vertical}

A compartimentação de uma edificação é feita com o objetivo de minimizar a propagação do fogo, calor e gases aquecidos, entre os ambientes da edificação, evitando que o incêndio se torne de maiores proporções e consequentemente com maior potencial destrutivo. Esta compartimentação consiste na interposição de elementos construtivos que possuam resistência ao fogo, incombustibilidade e estanqueidade para retardar a propagação das chamas à ambientes adjacentes. (MARCATTI; COELHO FILHO; BERQUÓ FILHO, 2008)

A ABNT NBR 14432:2013 define a compartimentação como uma medida de proteção passiva realizada por meio de vedações fixas ou móveis com finalidade de evitar propagação do fogo, calor e gases dentro e fora da edificação, tanto no mesmo pavimento como para outros pavimentos e edifícios circundantes. Segundo Buchanan (2002) a compartimentação proporciona rotas de fuga e saídas de emergência que proporcionam segurança na evacuação e também no acesso de equipes de salvamento e combate ao fogo

Desta maneira a compartimentação pode ser classificada como uma medida de proteção passiva, conforme destacado por Ono (2007), pois ela é de fundamental importância na segurança de edificações em situação de incêndio. O confinamento das chamas em partes isoladas entre si condiciona uma distribuição não uniforme da temperatura nos elementos 
estruturais, principalmente na fase pré-flashover. Como a compartimentação pode ser feita com elementos dentro de um mesmo pavimento ou entre pavimentos adjacentes, este tipo de controle da propagação do incêndio pode ser dividido em duas categorias: a compartimentação horizontal e a compartimentação vertical.

A compartimentação horizontal visa impedir ou retardar a propagação do calor e chamas para os ambientes adjacentes de um mesmo pavimento, ou seja, consiste em dividir um a edificação em várias células no plano horizontal (SEITO et al., 2008). Esta compartimentação é composta, em geral, de paredes divisórias, portas corta-fogo, selagem corta-fogo nas passagens das instalações prediais e dos registros corta-fogo nas tubulações de ventilação e arcondicionado. As paredes podem ser constituídas de qualquer material incombustível desde que seja comprovado experimentalmente o desempenho estrutural em situação de incêndio.

As paredes de alvenaria construídas com blocos de concreto podem ser utilizadas como divisórias corta-fogo desempenhando satisfatoriamente a função de compartimentação horizontal. Desde que atendam às exigências normativas de dimensões mínimas necessárias para garantir a estanqueidade e o isolamento térmico. No entanto, os resultados encontrados nesta pesquisa para avaliação do critério de isolamento mostram que as pequenas paredes avaliadas não atingiram o esperado seguindo as prescrições normativas.

A compartimentação vertical, pode ser alcançada com o uso de lajes de concreto armado ou protendido resistentes ao fogo, ou podem ser conseguidas através da utilização de isolantes térmicos fixados no forro do pavimento inferior, reduzindo a propagação de calor entre pavimentos. Conforme a Instrução Técnica 09/2004 do Corpos de Bombeiros de São Paulo a compartimentação vertical é destinada a evitar a propagação do incêndio no sentido vertical, ou seja, entre pavimentos elevados consecutivos.

Internamente a compartimentação vertical é atendida com o uso dos artifícios supracitados, mas externamente o fogo pode se propagar entre os pavimentos por meio de janelas abertas. Neste caso, a utilização de abas, platibandas e marquises podem auxiliar na compartimentação vertical, pois afastam as chamas da face da edificação e dificultam a propagação do fogo.

No Brasil cada legislação estadual fornece diferentes diretrizes para que seja garantida efetivamente a compartimentação. Para o estado de São Paulo a IT 09/2004 é a legislação imperante, ela afirma que a compartimentação pode ser atendida se as lajes e paredes forem dimensionadas para o TRRF necessário, desde que garantido os valores de afastamento mínimo entre aberturas verticais de pavimentos consecutivos e aberturas em um mesmo alinhamento horizontal. 


\subsection{Alvenaria estrutural em situação de incêndio}

De um modo geral, diferença de temperatura entre materiais da estrutura ou entre os elementos e os gases no ambiente originam as ações térmicas, que é a resposta da estrutura para o fluxo de calor apresentado. O incêndio ao elevar a temperatura dos elementos estruturais reduz tanto a rigidez como a resistência dos mesmos. Além disso, quando as estruturas são hiperestáticas, provocam esforços solicitantes adicionais provenientes do impedimento à deformação térmica.

Normalmente o fogo está presente em apenas um lado da parede e devido à expansão térmica diferencial, a parede curva-se. Este efeito, juntamente com a degradação dos materiais, pode levar a parede à ruína, dependendo das condições de vinculação e magnitude de carregamentos. (NADJAI et al., 2006). Portanto, verifica-se a necessidade de dimensionar as estruturas necessitam para a situação de incêndio, de forma a minimizar os danos materiais e pessoais que podem ocorrer.

Segundo Inghan (2009), quando a temperatura do incêndio se eleva, entre $600^{\circ} \mathrm{C} \mathrm{e}$ $800^{\circ} \mathrm{C}$, a resistência da parede à compressão é seriamente comprometida, principalmente em função da deterioração da argamassa de assentamento. Se o resfriamento for feito com água ocorre o choque térmico que eventualmente contrai o material e pode gerar um intenso panorama de fissuração na parede.

De acordo com Thomaz e Helene (2000) as características físicas dos materiais, como condutibilidade térmica e porosidade, as características construtivas, como peso próprio e espessura das juntas de assentamento, além das características estruturais, como esbeltez e restrições existentes, influenciam diretamente no desempenho ao fogo das paredes de alvenaria estrutural. O nível de carregamento na alvenaria e as possíveis excentricidades de aplicação das cargas também exercem influência na resistência deste sistema construtivo, tendo em vista o arqueamento que pode surgir em paredes com aquecimento diferencial.

O desempenho dos blocos de concreto frente ao fogo depende também do tipo de agregado, da espessura dos mesmos e de eventuais preenchimentos nos furos. De acordo com o Brick Industry Association (2008) para blocos cerâmicos ocos ao aumentar a espessura ou preencher os furos (com graute, vermiculita ou agregado de argila expandida) o tempo de resistência ao fogo aumenta. De maneira análoga, o mesmo ocorre com os blocos de concreto, sendo que estes blocos são considerados ocos quando possuem mais de $25 \%$ da área vazia.

Andreini e Sassu (2011) destacam no comportamento da alvenaria em situação de incêndio a capacidade de isolar um ambiente tanto do fogo em si como dos efeitos da fumaça. 
Os autores também ressaltam o bom comportamento térmico da argamassa de assentamento e dos blocos cerâmicos e de concreto utilizados neste tipo de estrutura, o que não foi constatado nos resultados obtidos nesta pesquisa. Ou seja, em um incêndio as paredes de alvenaria exercem tanto a função de sustentação estrutural como a de compartimentação horizontal, inibindo a propagação descontrolada do fogo entre os diferentes ambientes da edificação. De acordo com o Think Brick Australia (2013), em uma parede de alvenaria, a resistência ao fogo compreende três níveis de segurança: adequação estrutural, estanqueidade e isolamento térmico.

As principais normas nacionais e internacionais sobre realização de ensaios para determinação da resistência ao fogo contemplam estes três requisitos. É muito importante que haja resistência ao fogo das paredes de uma edificação tanto pelos critérios de resistência como pelos de estanqueidade e isolamento térmico, uma vez que em edifícios altos as vias de circulação apresentam grande vulnerabilidade à fumaça, ao calor e às chamas, dificultando o abandono à edificação (ONO, 2007).

A adequação estrutural define a capacidade da parede de preservar sua resistência mecânica de tal forma que continue a desempenhar sua função estrutural na edificação durante todo o período de resistência ao fogo. A estanqueidade é a capacidade da parede de manter sua continuidade, ou seja, previne a passagem de chamas e gases quentes nas fissuras que venham a surgir, além de auxiliar no controle de espalhamento de fumaça. E o isolamento térmico diz respeito à capacidade da parede de garantir isolamento suficiente para que a temperatura do lado oposto ao fogo não exceda um valor predefinido por norma durante determinado período.

\subsubsection{Propriedades térmicas das paredes}

Para entender o comportamento de paredes de alvenaria estrutural submetidas a variações de temperaturas é importante conhecer os parâmetros que influenciam no seu desempenho térmico. A seguir são mostradas equações de acordo com a ABNT NBR 15220-3 e definições tiradas da ABNT 15220-1 para as principais propriedades térmicas de sistemas de fechamento.

É comum a utilização da resistência ao fluxo de calor, ou resistência térmica para avaliar a eficiência térmica de um material na construção civil. A resistência térmica $(R)$ pode ser definida pelo quociente da diferença de temperatura verificada entre superfícies de um elemento pela densidade de fluxo de calor. Este parâmetro obtido a partir da equação 2.26 depende da espessura do material $(e)$ e da condutividade térmica $(\lambda)$. 


$$
R=e / \lambda
$$

A alvenaria possui vazios que auxiliam na inibição da transferência de calor, pois nos septos vazados essa transferência passa a ser por convecção e não por condução como ocorre na parte maciça do bloco. Torna-se necessário determinar o caminho do fluxo de calor e introduzir camadas de ar dentro e fora das superfícies da parede para avaliar o comportamento da transferência de calor ao longo de sua espessura. A análise térmica das paredes de blocos de concreto passa a ser feita em camadas, onde o fluxo de calor ocorre em série. A resistência térmica total $\left(R_{T}\right)$ pode ser calculada somando as resistências térmicas de cada camada, como mostrado na equação 2.27 .

$$
R_{T}=\frac{A_{a}+A_{b}+\cdots+A_{n}}{\frac{A_{a}}{R_{a}}+\frac{A_{b}}{R_{b}}+\cdots+\frac{A_{n}}{R_{n}}}
$$

Em que, $R_{a}, R_{b}, \ldots, R_{n}$ são as resistências térmicas de superfície à superfície para cada seção $(a, b, \ldots, n)$ calculadas somando-se as resistências térmicas das camadas homogêneas, das superfícies interna e externa e das câmaras de ar. $A_{a}+A_{b}+\cdots+A_{n}$ são as áreas de cada seção.

Também é possível conhecer transmitância térmica $(U)$ que é o inverso da resistência, dado pela equação 2.28 .

$$
U=\frac{1}{R_{T}}
$$

Outro parâmetro importante é a capacidade térmica, que é definida como a quantidade de calor necessária para variar em uma unidade a temperatura de um sistema e pode ser calculada pela equação 2.29 .

$$
C_{T}=\sum_{i=1}^{n} \lambda_{i} \cdot R_{i} \cdot c_{i} \cdot \rho_{i}=\sum_{i=1}^{n} e_{i} \cdot c_{i} \cdot \rho_{i}
$$

Em que:

$\lambda_{i}$ é a condutividade térmica do material da camada $\mathrm{i}^{\mathrm{a}}$;

$R_{i}$ é a resistência térmica da camada $\mathrm{i}^{\mathrm{a}}$;

$e_{i}$ é a espessura da camada ia ;

$c_{i}$ é o calor específico do material da camada $\mathrm{i}^{\mathrm{a}}$;

$\rho_{i}$ é a densidade de massa aparente do material da camada $\mathrm{i}^{\mathrm{a}}$. 
Para situações compostas de camadas homogêneas e não homogêneas perpendiculares ao fluxo de calor, como é o caso da alvenaria estrutural, a capacidade térmica $\left(C_{T}\right)$ de um componente pode ser calculada pela equação 2.30 .

$$
C_{T}=\frac{A_{a}+A_{b}+\cdots+A_{n}}{\frac{A_{a}}{C_{T_{a}}}+\frac{A_{b}}{C_{T_{b}}}+\cdots+\frac{A_{n}}{C_{T_{n}}}}
$$

Em que, $C_{T_{a}}, C_{T_{b}}, \ldots, C_{T_{n}}$ são as capacidades térmicas do componente para cada seção $(\mathrm{a}, \mathrm{b}, \ldots, \mathrm{n})$ determinadas pela expressão $2.34 . A_{a}+A_{b}+\cdots+A_{n}$ são as áreas de cada seção.

O último parâmetro de interesse para o desempenho térmico de paredes de alvenaria estrutural é o atraso térmico $(\varphi)$, ou inércia térmica, que pode ser descrita como a capacidade de um material em armazenar e dissipar calor. É definido como o tempo transcorrido entre uma variação térmica em um meio e sua manifestação na superfície oposta de um componente construtivo submetido a um regime periódico de transmissão de calor.

Ou seja, um material sólido ao sofrer aquecimento apresenta um atraso no tempo para iniciar seu aumento de temperatura em relação ao instante em que passa a receber calor. Esta propriedade depende da densidade e da massa do material, quando são elevadas a absorção de calor é mais lenta e a retenção deste é mais prolongada (BEALL, 2003).

Outros fatores influenciam o atraso térmico de uma parede, como por exemplo a espessura, o calor específico e a condutibilidade do material. De acordo com Beall (2003) sendo o atraso térmico definido como a velocidade com que a parede aquece ou resfria, este é um fenômeno que agrega à segurança ao fogo nas paredes de alvenaria, pois retarda a transferência de calor. Esta propriedade pode ser calculada para elementos heterogêneos pelo equacionamento a seguir:

$$
\varphi=1,382 \cdot R_{t} \cdot \sqrt{B_{1}+B_{2}}
$$

Em que, $R_{t}$ é a resistência térmica de superfície a superfície do componente e $B_{1}$ e $B_{2}$ são calculados pelas equações 2.32 e 2.33 respectivamente.

$$
\begin{aligned}
& B_{1}=0,226 \cdot \frac{B_{0}}{R_{t}} \\
& B_{2}=0,205 \cdot\left(\frac{(\lambda . \rho \cdot c)_{e x t}}{R_{t}}\right) \cdot\left(R_{e x t}-\frac{R_{t}-R_{e x t}}{10}\right)
\end{aligned}
$$

Em que o índice "ext" indica os parâmetros referentes à camada externa do componente e $B_{0}$ é calculado pela equação 2.34 . 


$$
B_{0}=C_{T}-C_{T_{\text {ext }}}
$$

Em que:

$C_{T}$ é a capacidade térmica total do componente;

$C_{T_{\text {ext }}}$ é a capacidade térmica da camada externa do componente.

2.3.2. Fatores que influenciam o desempenho alvenaria em elevadas temperaturas

Um dos principais fatores que influenciam a resistência ao fogo das paredes de alvenaria são os tipos de blocos utilizados, tanto em questões de materiais de composição como de geometria. Outros fatores importantes estão relacionados ao tipo de juntas de assentamento, revestimentos e o preenchimento dos septos dos blocos (THOMAZ e HELENE, 2000; MEYER, 2006). De acordo com Meyer (2006), fatores ligados à estabilidade estrutural dos elementos de alvenaria também influenciam no desempenho ao fogo da estrutura, são estes: arqueamento por dilatação diferencial, o índice de esbeltez da parede e o carregamento.

A seguir são apresentados os principais fatores agrupados em: materiais utilizados na execução, características geométricas dos blocos, disposições construtivas e arqueamento, vinculação e esbeltez das paredes.

Para os fatores relativos aos materiais utilizados na execução o Think Brick Australia (2013) afirma que as características termofísicas dos blocos podem apresentar diferenças em função das diferenças na matéria-prima e no processo de fabricação. Fornecendo variações nos graus de isolamento térmico das paredes e no comportamento mecânico dos materiais em elevadas temperaturas.

Segundo Nahhas et al. (2007) a umidade presente no interior do bloco consome uma parte considerável do calor que atravessa a parede para que ocorra a evaporação da água, portanto a densidade e a porosidade do bloco são propriedades importante na resistência ao fogo do material. A eficiência de uma parede em proporcionar isolamento térmico está diretamente relacionada a uma combinação de baixa condutividade térmica e alto calor específico, ou seja, baixa difusividade térmica, pois absorve grandes quantidades de calor e dificultam sua transmissão ao longo da espessura da parede (ROSEMANN, 2011).

Trabalhos realizados por Thomaz, Helene (2000) e Chichierchio (1990) mostram ensaios considerando os requisitos de isolamento térmico, estanqueidade e resistência mecânica em paredes de blocos cerâmicos e de concreto com espessuras de $14 \mathrm{~cm}$. Verificaram que paredes de blocos cerâmicos apresentam maior resistência ao fogo (90 minutos) que paredes de 
blocos de concreto (80 minutos), e isso pode ser explicado em função da boa resistência térmica da cerâmica.

Segundo Nguyen et al. (2009) a geometria do bloco influencia diretamente no desempenho deste quando submetidos à elevadas temperaturas, o tipo de bloco (maciço ou vazado) a porcentagem e formato dos septos vazados e a espessura são os principais fatores. Quando um bloco é maciço a transferência de calor ocorre apenas por condução, portanto quanto maior a espessura maior será o isolamento térmico e a resistência o fogo. No caso de blocos vazados o mecanismo de transferência de calor se altera, passa a ocorrer por convecção e radiação nos septos vazados, reduzindo a condutividade térmica efetiva e também o calor absorvido pela parede.

O formato, a distribuição e o volume dos septos vazados no interior dos blocos altera o isolamento térmico, que também pode ser alterado pelas dimensões externas dos blocos que está diretamente relacionada à quantidade de juntas de argamassa de assentamento, as quais possuem características termofísicas diferentes dos blocos.

As disposições construtivas determinadas em projeto podem afetar diretamente o desempenho da parede de alvenaria estrutural quando submetida ao fogo. Um dos fatores influenciadores da capacidade de isolamento térmico total da parede são as juntas de argamassa que constituem um material de propriedades diferentes dos blocos. A argamassa pode ser comum ou confeccionada com materiais isolantes adicionados em sua composição para aumentar seu isolamento térmico (AL-HADHRAMI e AHMAD, 2008).

É muito comum utilizar o preenchimento dos septos vazados dos blocos com graute para melhorar características mecânicas e estruturais das paredes, mas também se trata de outro fator que influencia na resistência ao fogo. Segundo Oliveira (1998) este processo também auxilia na obtenção de maior isolamento térmico, pois a quantidade de calor absorvido pela parede aumenta em uma proporção maior que ocorre o aumento da condutividade térmica. Os vazios também podem ser preenchidos com areia, escória, pedra-pomes, argila expandida, vermiculita e outros materiais de baixa massa específica para melhorar o desempenho da alvenaria contra o fogo (BRICK INDUSTRY ASSOCIATION, 2008).

Outra questão relacionada às disposições construtivas que influenciam desempenho em elevadas temperaturas é a utilização de revestimentos, o mais comum é o de argamassa em um ou ambos os lados da parede. De acordo com Oliveira (1998) este revestimento aumenta a espessura da parede, melhorando o isolamento térmico e consequentemente a resistência ao fogo, no entanto, deve-se atentar para o fato de que este ganho de resistência térmica fica 
limitado ao tempo em que a argamassa do lado oposto ao fogo mante-se solidária à parede durante o incêndio.

Como a alvenaria estrutural é composta de elementos que garantem tanto o isolamento térmico como a resistência mecânica da edificação é importante conhecer fatores relacionados à estabilidade estrutural que podem influenciar no seu comportamento em elevadas temperaturas, como o arqueamento, vinculação e esbeltez das paredes.

Quando uma parede é submetida a uma fonte de calor em apenas uma face surge um gradiente de temperatura ao longo de sua espessura. A deformação é desigual nos diversos pontos da seção transversal ocorrendo arqueamento com concavidade para o lado de menor temperatura. A parede pode ser considerada como um elemento unidimensional quando não sofre influência de paredes laterais de travamento, neste caso a deflexão lateral da parede pode ser definida analiticamente, a equação 2.35 é utilizada quando a parede é definida como um balanço e a equação 2.36 quando a parede é definida como uma viga simplesmente apoiada.

$$
\begin{aligned}
& \delta_{b o w, c}=\frac{\alpha_{m} \cdot h_{\text {wall }}^{2} \cdot \Delta \theta}{2 \cdot d_{\text {wall }}} \\
& \delta_{\text {bow }, b}=\frac{\alpha_{m} \cdot h_{\text {wall }}^{2} \cdot \Delta \theta}{8 \cdot d_{\text {wall }}}
\end{aligned}
$$

Em que:

$\delta_{b o w, c}$ é a deflexão para parede definida como balanço;

$\delta_{b o w, b}$ é a deflexão para parede definida como viga simplesmente apoiada;

$\alpha_{m}$ é o coeficiente de expansão térmica do material;

$h_{\text {wall }}$ é a altura da parede;

$\Delta \theta$ é o gradiente térmico;

$d_{\text {wall }}$ é a espessura da parede.

Na prática, essas deflexões calculadas não são alcançadas pois o arqueamento sempre é parcialmente restringido pelas paredes transversais que se interceptam e também pela carga de compressão aplicada nas paredes que possuem função de sustentar a edificação. Nahhas et al. (2007) realizou um ensaio com parede de alvenaria de blocos de concreto sob carregamento de serviço e submetido a um incremento de temperatura em uma das faces que seguia a curva de incêndio-padrão, o elemento ensaiado possuía 2,82 metros de altura e 19,7 centímetros de espessura. A temperatura alcançada foi na ordem de $770^{\circ} \mathrm{C}$ e a deflexão lateral foi de $43 \mathrm{~mm}$, enquanto o resultado analítico foi de $62 \mathrm{~mm}$, evidenciando o conservadorismo das equações. 
O carregamento vertical de compressão aplicado em uma parede de alvenaria submetida à simulação de incêndio não inibe mas reduz a deflexão. Desta forma o carregamento torna-se benéfico nos estágios iniciais, mas após um longo período de exposição ao fogo a parede tende a apresentar certa instabilidade lateralmente, gerando altas tensões em função do aparecimento de momentos induzidos pela deformação lateral.

A Figura 2.13 mostra 3 tipos de paredes estudadas utilizando simulação numérica por Nadjai et al. (2003) considerando a esbeltez da parede, o tipo de vinculação e a influência de excentricidade da carga aplicada. Contatou-se que quando maior a esbeltez menor era a temperatura de falha das paredes e ao considerar o carregamento excêntrico na face oposta ao fogo houve um aumento da deflexão e redução da temperatura de falha nas paredes de tipo A e $\mathrm{B}$, enquanto que na parede de tipo $\mathrm{C}$ nenhuma modificação significativa foi observada.

Figura 2.13 - Condições de contorno para vinculações de paredes
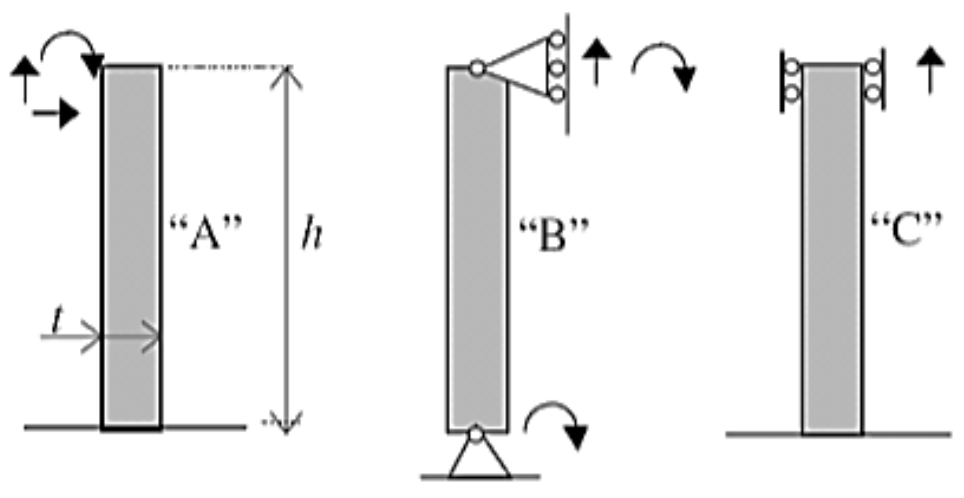

Fonte: Nadjai et al. (2003)

\subsubsection{Estudo dos materiais em elevadas temperaturas}

A alvenaria é um material compósito formado pelo conjunto de blocos estruturais de concreto ou cerâmicos assentados sobre uma junta de argamassa, que deve absorver e distribuir esforços de compressão, cisalhamento e pequenas tensões de tração. A resistência ao fogo de paredes de alvenaria depende do desempenho térmico destes materiais, de acordo com Bailey (2004) a alvenaria submetida a incêndios reais tem desempenho muito bom, e caso ocorra falha, normalmente se deve ao deslocamento lateral excessivo.

Segundo Bonitese (2007) o comportamento de um elemento estrutural submetido a ações térmicas depende das propriedades térmicas e mecânicas de seus materiais e também de sua composição química. Isso se justifica pelo fato de a maioria dos materiais utilizados na 
construção civil ter suas propriedades físico-químicas e mecânicas alteradas durante o aquecimento do material.

Quando uma parede é submetida a uma situação de incêndio e há diferença de temperatura entre os lados desta, ocorrem os fenômenos de transferência de calor. O aquecimento dos materiais constituintes pode acarretar reações químicas que podem ser endotérmicas e/ou exotérmicas que influenciam diretamente nas propriedades dos materiais. $\mathrm{E}$ também, a mudança de umidade presente nos materiais transporta massa através do meio poroso parcialmente saturado, gerando mudanças na transferência de calor (ROSEMANN, 2011)

A alteração dos materiais ocorre em sua microestrutura, portanto os parâmetros de condutividade térmica, módulo de elasticidade e calor específico sofrem modificações em função da exposição ao fogo. Os principais materiais com função estrutural na alvenaria são os blocos que podem ser de concreto ou cerâmicos e a argamassa. As propriedades térmicas e mecânicas em elevadas temperaturas dos materiais de composição da alvenaria estrutural ainda são pouco conhecidas em âmbito nacional.

Por se tratar de uma pesquisa de alvenaria estrutural de blocos de concreto, mesmo que a composição físico-química dos blocos não seja a mesma do concreto convencional é importante entender o comportamento do concreto em elevadas temperaturas. Em seguida serão apresentados os dados que constam no Eurocode 6 Part 1-2 acerca das propriedades termofísicas de blocos de concreto com agregado silicoso.

\subsubsection{Concreto}

O comportamento do concreto submetido a temperaturas elevadas depende de suas propriedades após o aquecimento, pois trata-se de um material altamente heterogêneo e com características que variam com o tipo de agregado utilizado, da resistência e da porosidade da pasta. De acordo com Rigão (2012), quando aquecidos, os concretos de resistências convencionais não apresentam lascamentos significativos pois são porosos e permitem a fácil migração de água livre do seu interior. Por outro lado, os concretos de alto desempenho (CAD) possuem porosidade bastante reduzida, a saída de água por seus canalículos é dificultada gerando pressões internas que podem prover lascamentos explosivos no elemento de concreto.

Dentre as principais propriedades termofísicas dos materiais está a condutividade térmica $(\mathrm{k})$ que indica a capacidade que determinado material tem de transportar calor. Esta propriedade representa a taxa de calor transferida ao longo da espessura de material por unidade de diferença de temperatura (INCROPERA e DEWITT, 1992). O concreto possui baixa 
condutividade térmica em comparação com os metais, portanto apresenta boa resistência quando submetido ao fogo. Mesmo assim, conforme Wang (2002), o concreto é um material que perde resistência e se torna mais flexível em elevadas temperaturas. Britez (2011) relata em seus estudos que o concreto perde cerca de $25 \%$ da sua resistência a temperaturas próximas de $300{ }^{\circ} \mathrm{C}$ e $75 \%$ quando submetidos a temperaturas da ordem de $600{ }^{\circ} \mathrm{C}$.

De acordo com Cànovas (1988), o comportamento do concreto sofre alterações importantes com a variação de temperatura. A evaporação da água capilar retarda o processo de aquecimento do concreto, sua perda total ocorre entre 200 e $300^{\circ} \mathrm{C}$ mas esta começa a evaporar a partir de $100^{\circ} \mathrm{C}$. Entre 300 e $400^{\circ} \mathrm{C}$ passa a ocorrer uma leve redução da resistência do concreto pois há perda de água da pasta de cimento, surgindo as primeiras fissuras. Até os $600^{\circ} \mathrm{C}$ o concreto começa a desagregar em função da diferença de dilatação entre os agregados.

O concreto em temperaturas inferiores a $300{ }^{\circ} \mathrm{C}$ não sofre modificações pertinentes, mas acima desta temperatura, em função da desagregação de seus componentes, passa a ocorrer decaimento dos valores de algumas propriedades como a resistência e o módulo de elasticidade (LANDI, 1986). O mesmo autor destaca que quando o aquecimento é brusco, ocorre o lascamento no concreto, também chamado de "spalling", o que deixa as armaduras sem a camada de proteção de concreto. Este comportamento pode ser causado por fatores como: diferenças nos coeficientes de dilatação da pasta de cimento e dos agregados; pressão interna gerada pela evaporação da água; dilatação do aço ocorre primeiro em função da diferença entre os coeficientes de condutibilidade térmica; tensões diferenciais internas que surgem no aquecimento não uniforme da seção; e o quartzo que apresenta aumento de volume ao mudar sua estrutura a partir de $500^{\circ} \mathrm{C}$.

Outro efeito observado é que em temperaturas entre $400^{\circ} \mathrm{C}$ e $600{ }^{\circ} \mathrm{C}$ ocorre a dessecação dos poros, a decomposição dos produtos de hidratação e também o início da destruição do gel C-S-H da pasta de concreto, a destruição total do gel ocorre a partir de $900{ }^{\circ} \mathrm{C}$. Após o resfriamento do concreto pode ocorrer reidratação ao absorver a umidade do ambiente (MEHTA e MONTEIRO, 1997).

Seito et al. (2008) mostra que o comportamento da condutividade térmica (W/m) de concretos silicosos e calcáreos é guiado pela temperatura, apresentando seus valores superiores $\left(\lambda_{c, \text { sup }}\right)$ e inferiores $\left(\lambda_{c, \text { inf }}\right)$ conforme apresentado nas equações 2.37 e 2.38 , validados para temperatura variando de $20^{\circ} \mathrm{C}$ a $1200{ }^{\circ} \mathrm{C}$.

$$
\lambda_{c, \text { sup }}=2-0,2451 \cdot\left(\frac{\theta}{100}\right)+0,0107 \cdot\left(\frac{\theta}{100}\right)^{2}
$$




$$
\lambda_{c, i n f}=1,36-0,136 \cdot\left(\frac{\theta}{100}\right)+0,0057 \cdot\left(\frac{\theta}{100}\right)^{2}
$$

Em que $\theta$ é a temperatura em determinado instante em ${ }^{\circ} \mathrm{C}$. Para cálculos simplificados, pode-se estimar o valor da condutividade térmica do concreto em $1,6 \mathrm{~W} / \mathrm{m}^{\circ} \mathrm{C}$.

O comportamento das equações 2.37 e 2.38 pode ser observado no gráfico da Figura 2.14, em que tanto para a condutividade superior como para a inferior, o seu valor é reduzido à medida que ocorre incrementos na temperatura tendendo a convergir em valores próximos de $0,5 \mathrm{~W} / \mathrm{m}^{\circ} \mathrm{C}$ quando a temperatura atinge a ordem de $1200^{\circ} \mathrm{C}$. Em relação ao valor médio, para temperaturas de até $100^{\circ} \mathrm{C}$ a sua diferença não é tão significativa mas para temperaturas mais elevadas, o seu valor se mostra muito superior às curvas de condutividade mostradas.

Figura 2.14 - Condutividade térmica do concreto

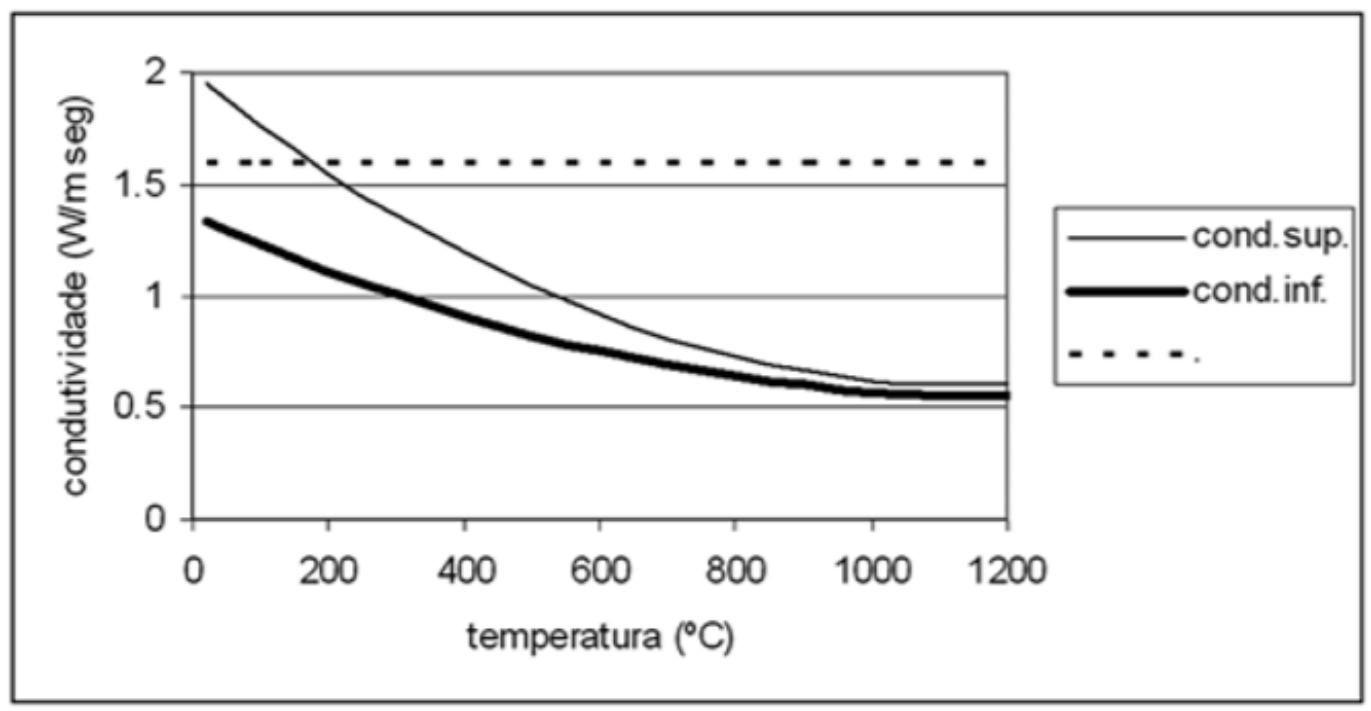

Fonte: Seito et al. (1998)

O calor específico é outra propriedade que se mostra importante no estudo do comportamento térmico dos materiais, uma vez que ela representa a quantidade de calor que cada grama de uma substância precisa trocar para variar sua temperatura em $1{ }^{\circ} \mathrm{C}$, a unidade de medida no sistema internacional é o J/kg.K (CHICHIERCHIO, 1990). De acordo com Seito et al. (2008) o comportamento do calor específico em função da temperatura aplicada no elemento também é regido por formulações matemáticas, mas esta propriedade depende da umidade do concreto. Para umidade em peso de $0 \%$ o calor específico do concreto em J/kg ${ }^{\circ} \mathrm{C}$ é $c_{p}=900$, para umidade de $1,5 \% c_{p}=1470$ e para umidade de $3 \% c_{p}=2020$.

O comportamento do calor espcífico para cada umidade em função a temperatura do concreto segue apresentado na Figura 2.15. 
Figura 2.15 - Calor específico do concreto

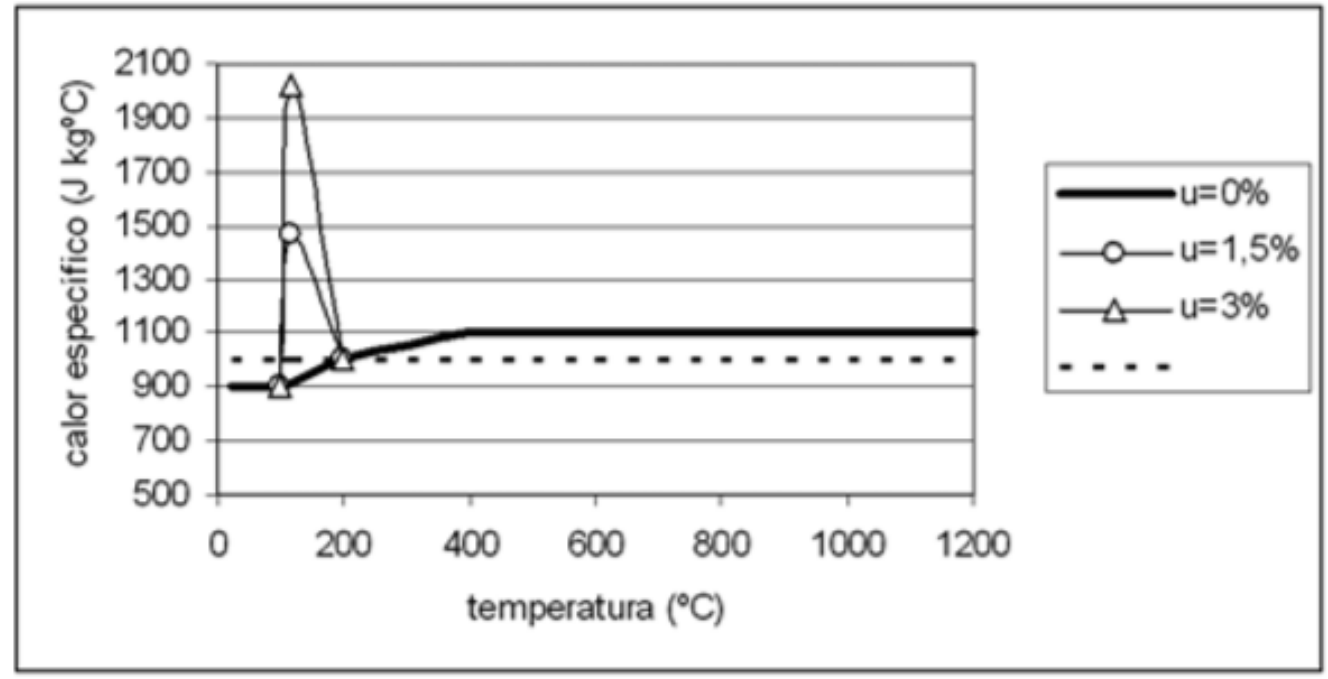

Fonte: Seito et al. (1998)

Quando a temperatura é elevada (acima de $115^{\circ} \mathrm{C}$ ) ocorre perda de água na massa de concreto e há transformação de constituintes minerais em gases, reduzindo sua densidade. A Figura 2.16 mostra um decréscimo quase linear da densidade em função da elevação de temperatura no material.

Figura 2.16 - Densidade do concreto

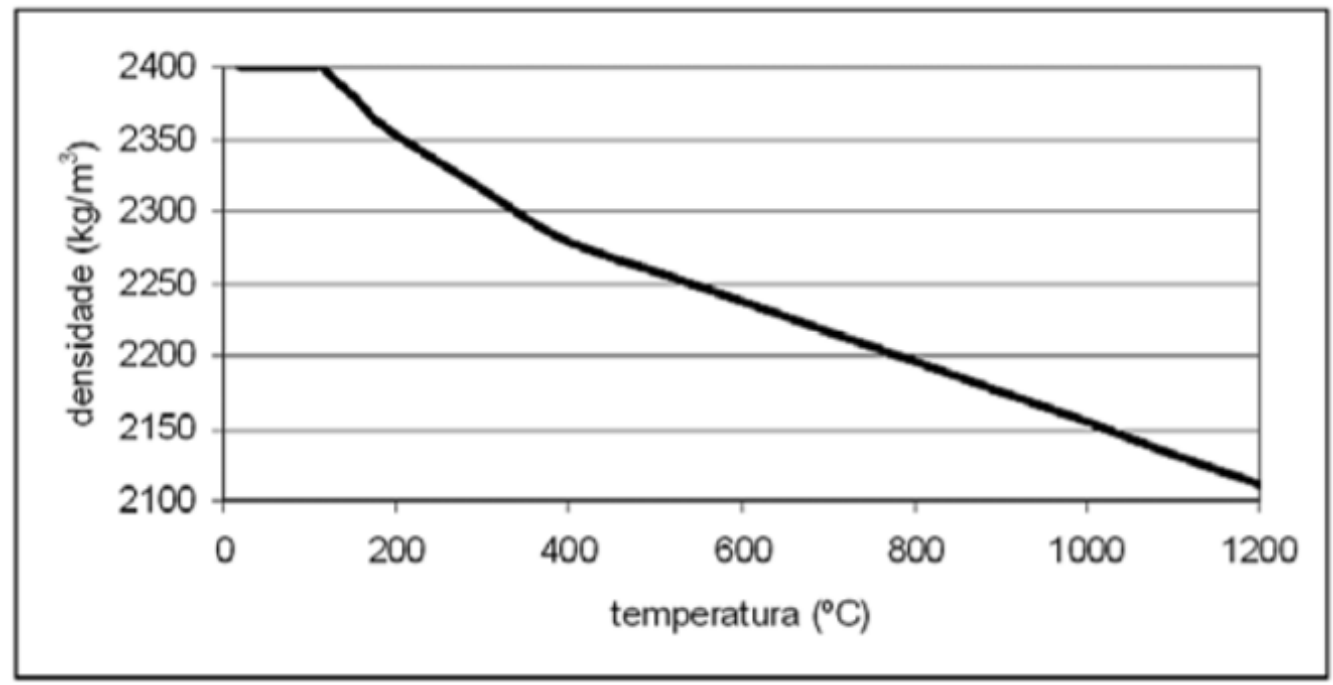

Fonte: Seito et al. (1998)

Além destas propriedades, o coeficiente de dilatação térmica também depende da variação de temperatura, conforme observado no gráfico da Figura 2.17 para o caso de concretos silicosos. Mas para métodos simplificados de cálculo, Seito et al. (2008) sugere que seja empregado um valor médio de $\alpha=1,6 \times 10^{-5}{ }^{\circ} C^{-1}$. 
Figura 2.17 - Coeficiente de dilatação térmica do concreto silicoso

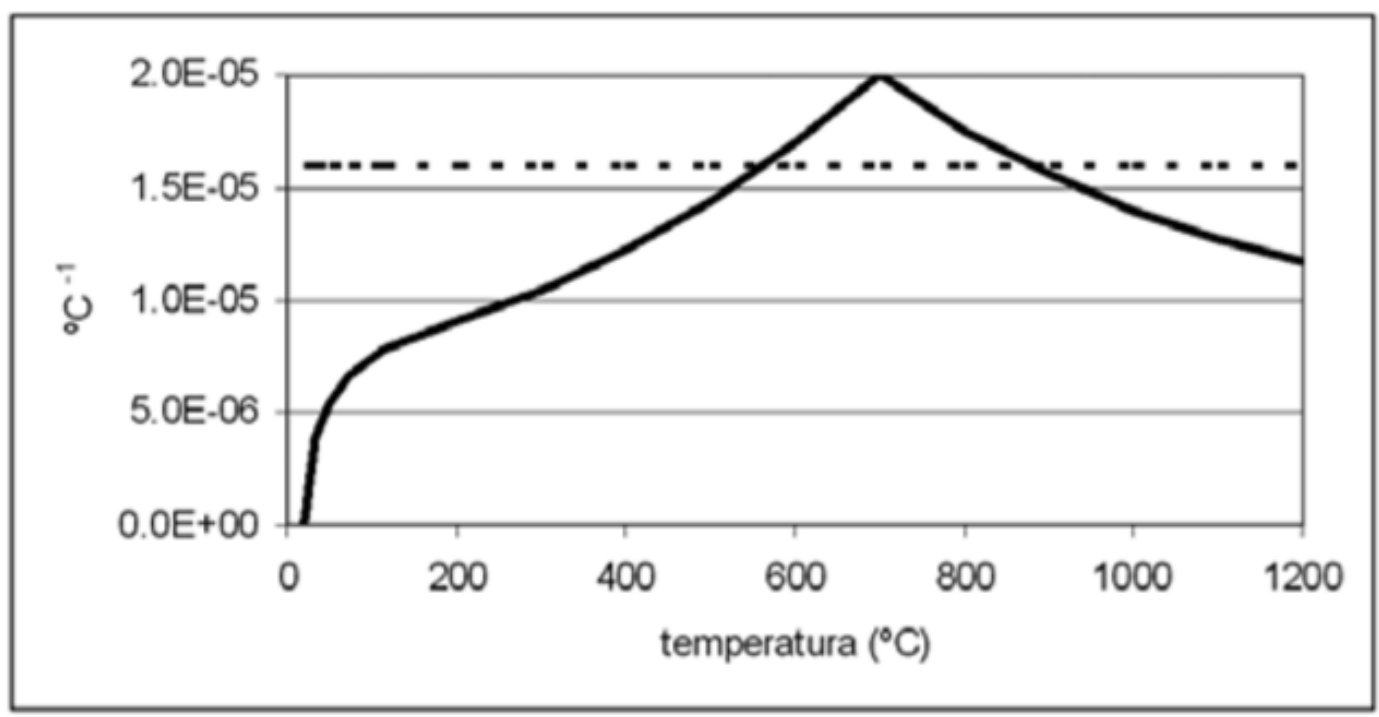

Fonte: Seito et al. (1998)

Como o cimento e os agregados apresentam componentes que se decompõe em elevadas temperaturas, é muito importante conhecer a composição da pasta do concreto, pois de acordo com Mehta e Monteiro (1997) este é um dos muitos fatores que controlam a resistência do concreto ao fogo. O calor pode enfraquecer o concreto endurecido pois desestrutura quimicamente sua pasta.

Com a elevação da temperatura a água presente nos poros da pasta de concreto evapora. No caso de concretos de alto desempenho e baixa porosidade (CAD) ou convencionais saturados, o vapor gerado pela água aquecida provoca pressões na massa de concreto que podem ultrapassar a capacidade de liberação deste vapor pelos poros. Dependendo da magnitude destas pressões, pode ocorrer lascamento no concreto, que é o maior fator de redução da resistência de concretos de alto desempenho (COSTA e SILVA, 2004 e LIMA, 2005).

$\mathrm{O}$ concreto submetido a elevadas temperaturas perde resistência à compressão e tem seu módulo de elasticidade longitudinal reduzido, mas estas perdas de propriedades mecânicas não são linearmente dependentes do incremento de temperatura. De acordo com Purkiss (2007) este comportamento não linear é devido às mudanças físico-quimicas que ocorrem nos agregados, visto que os silicosos possuem transformações das fases do quartzo em temperaturas de $570{ }^{\circ} \mathrm{C}$ e os calcáreos tem a decomposição próxima de $650{ }^{\circ} \mathrm{C}$. Além disso, a expansão da água evaporada no interior do concreto provoca fissurações que reduzem a resistência.

Neville (1997) também cita que a perda de resistência nos concretos com agregados silicosos é mais acentuada, mas em temperaturas próximas de $1200^{\circ} \mathrm{C}$ tende a convergir com os concretos que utilizam calcáreos, chegando à perda total de resistência. Este comportamento 
pode ser observado no gráfico da Figura 2.18 retirado do Eurocode 2 Part1.2 que mostra curvas de perda de resistência em função da temperatura: a curva (1) está relacionada a concretos com agregados silicosos e a curva (2) a concretos com agregados de calcário. O coeficiente $k_{c}(\theta)$ indica a relação entre a resistência a compressão na temperatura analisada $\left(f_{c, \theta}\right)$ e a resistência característica $\left(f_{c k}\right)$ à temperatura ambiente de $20^{\circ} \mathrm{C}$.

Figura 2.18 - Redução à compressão do concreto em função da temperatura

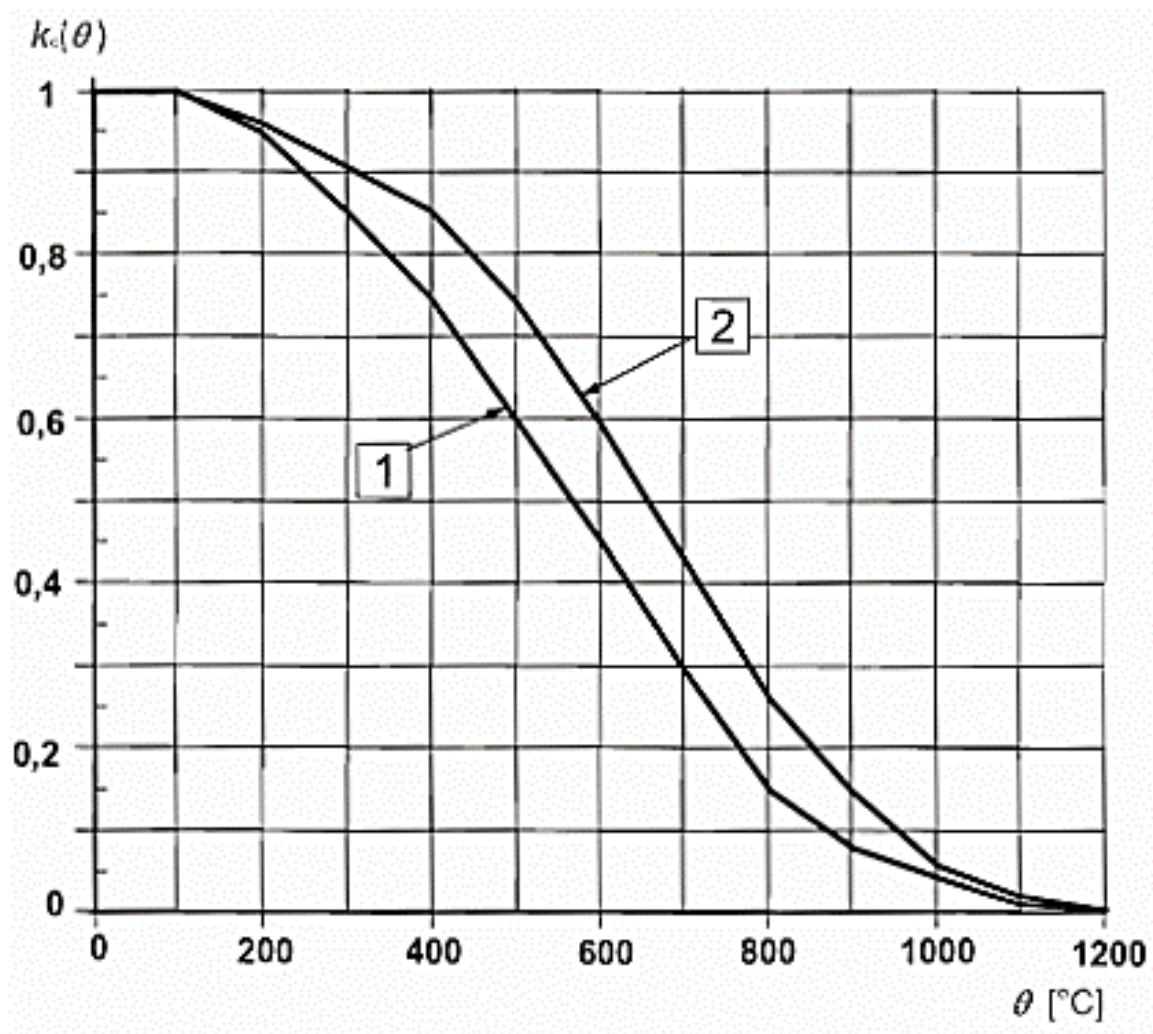

Fonte: Eurocode 2 Part 1.2

No Brasil é muito comum o uso de concreto com agregados basálticos, no entanto, na literatura e nos códigos internacionais não há definições explicitas do comportamento de suas propriedades térmicas (BRITEZ, 2011). Na literatura nacional o trabalho de Lima (2005) analisou o comportamento do concreto submetido a elevadas temperaturas utilizando agregados graúdos basálticos e graníticos e observou que a ocorrência de lascamento foi maior nos corpos de prova moldados com agregado basáltico.

A cor do concreto varia de acordo com a temperatura atingida pelo material, sendo possível estimar a temperatura alcançada por meio da coloração observada nos ensaios. Morales et al. (2011) e Georgali e Tsakiridis (2005) apresentaram que para temperaturas de $300{ }^{\circ} \mathrm{C}$ a $600{ }^{\circ} \mathrm{C}$ o concreto adquiri uma coloração de tons rosáceos, na faixa de $600{ }^{\circ} \mathrm{C}$ a $900{ }^{\circ} \mathrm{C}$ passa 
para tons de cinza claro e no caso de temperaturas elevadas acima de $900{ }^{\circ} \mathrm{C}$ o concreto chega a tons esbranquiçados e cremes.

Casonato (2007) cita que as pequenas quantidades de ferro contido nos minerais dos agregados são os principais fatores que levam o concreto a alterar a coloração em função do calor, portanto esta cor depende do tipo de agregado utilizado. A mudança de cor no concreto é um bom indicativo das alterações de suas propriedades mecânicas, quando o agregado é silicoso possui constituintes ferrosos que oxidam à temperatura de $300{ }^{\circ} \mathrm{C}$ e levam a cor amarelada para tons róseos (WENDT, 2006).

Em parte do seu trabalho, Wendt (2006) estudou a alteração da coloração no concreto quando submetido a elevadas temperaturas, foram utilizados agregados graúdos graníticos, basálticos e areia natural quartzosa. Não foram verificadas alterações na coloração do concreto em função do tipo de agregado utilizado mas observou-se um clareamento nos tons de cinza em temperaturas de $400{ }^{\circ} \mathrm{C}$, a partir dos $600^{\circ} \mathrm{C}$ o concreto passou a amarelar-se, chegando à cor amarela na temperatura próxima dos $900{ }^{\circ} \mathrm{C}$. Diferentemente de outras literaturas que constataram tons róseos a temperaturas entre 300 e $600^{\circ} \mathrm{C}$.

\subsubsection{Blocos de Concreto}

Os blocos de concreto utilizados na alvenaria estrutural possuem grande variabilidade de composição dos agregados utilizados em sua fabricação, assim como no concreto armado. Isso ocorre principalmente pela disponibilidade geográfica de materiais inertes que podem ser utilizados como agregados, sendo assim suas propriedades termo-físicas variam de acordo com a fabricação e seu comportamento em elevadas temperaturas também.

O Eurocode 6 Part 1-2 apresenta em seu Anexo D gráficos que tratam da variação da condutividade térmica $\left(\lambda_{a}\right)$, do calor específico $\left(c_{a}\right)$ e da densidade $(\rho)$ para diversos tipos de blocos estruturais em função da elevação da temperatura. A Figura 2.19 mostra as curvas de comportamento destas propriedades para os blocos de concreto com silicatos de cálcio como agregados, que são os que mais se aproximam dos blocos produzidos no Brasil. Os valores contidos no eixo vertical do gráfico indicam a relação entre o valor em determinada temperatura (T) e o valor de referência à $20^{\circ} \mathrm{C}$. 
Figura 2.19 - Valores de variação das propriedades e função da elevação de temperatura para blocos de concreto com silicato de cálcio

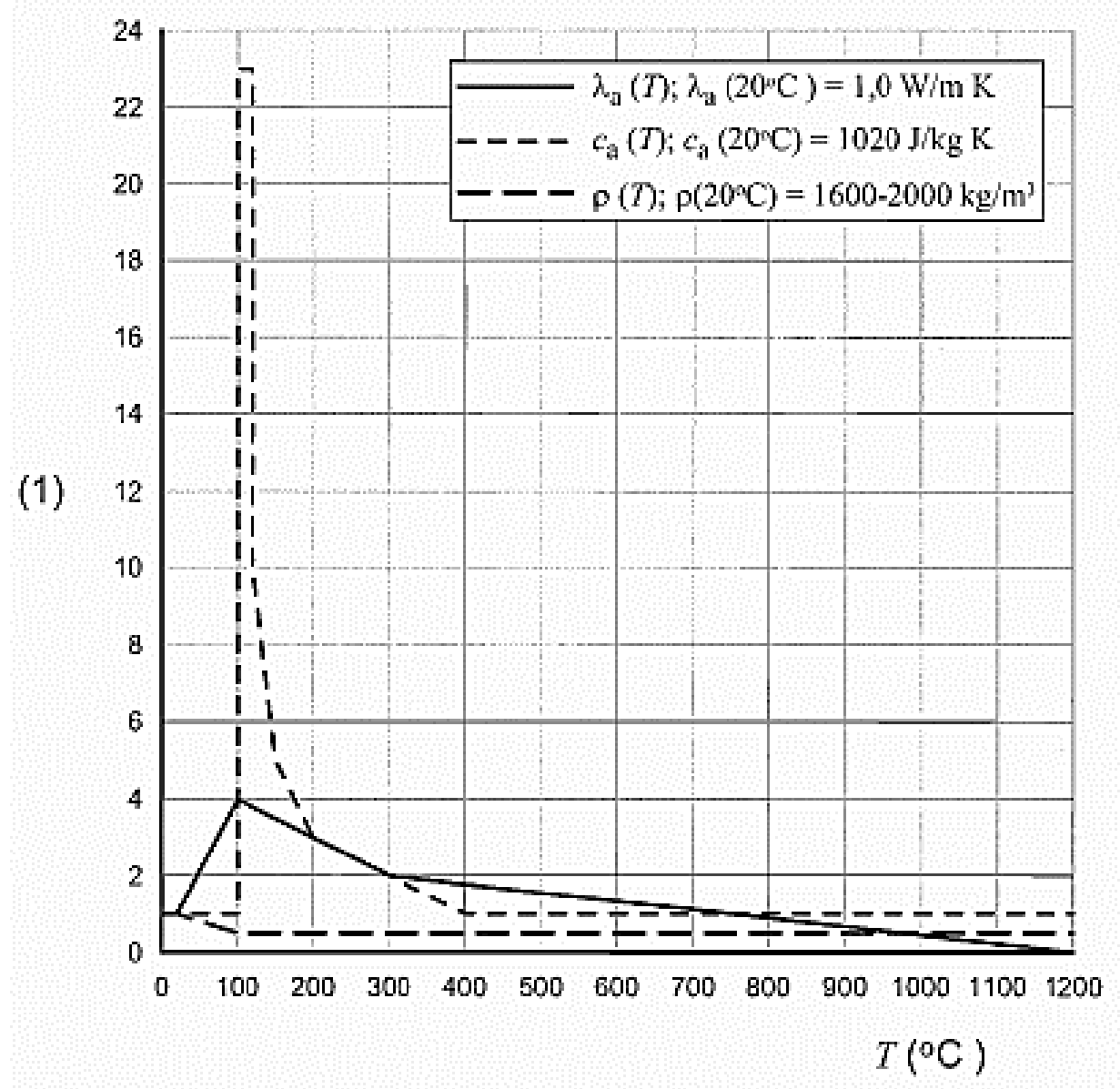

Fonte: Eurocode 2 Part 1.2

Percebe-se pela Figura 2.19 que ocorre um aumento súbito do calor específico para temperaturas em torno e $100^{\circ} \mathrm{C}$. De acordo com Nguyen et al (2009) o motivo deste aumento é o calor latente de evaporação da umidade incorporada nos poros do material, que é somado ao calor específico do próprio concreto. Observa-se também um aumento acentuado da condutividade até os $100^{\circ} \mathrm{C}$ que em seguida passa a reduzir suavemente até que a partir dos $800^{\circ} \mathrm{C}$ passa a ser menor que a condutividade em temperatura ambiente. Para a densidade observa-se leve redução até $100^{\circ} \mathrm{C}$ e praticamente mantém-se estável em seguida.

Tendo em vista a importância de conhecer as propriedades de condutividade térmica e calor específico dos materiais para análise no campo térmico, a Tabela 2.8 apresenta valores destas propriedades sugeridos por diferentes autores e para blocos de concreto de diferentes densidades. 
Tabela 2.8 - Propriedades térmicas dos blocos de concreto

\begin{tabular}{ccccc}
\hline Material & $\begin{array}{c}\text { Massa } \\
\text { específica } \\
\mathrm{kg} / \mathrm{m}^{3}\end{array}$ & $\begin{array}{c}\text { Calor } \\
\text { específico } \\
\mathrm{J} /(\mathrm{kg} . \mathrm{K})\end{array}$ & $\begin{array}{c}\text { Condutividade } \\
\text { térmica } \\
\mathrm{W} /(\mathrm{m} . \mathrm{K})\end{array}$ & Fonte \\
\hline Blocos de concreto & 1800 & - & 1,100 & Chichierchio (1990) \\
Blocos de concreto & 2000 & - & 1,510 & Chichierchio (1990) \\
Blocos de concreto & 2150 & - & 1,690 & Chichierchio (1990) \\
Blocos de concreto & 2200 & - & 1,740 & Chichierchio (1990) \\
Blocos de concreto & 2300 & - & 1,810 & Chichierchio (1990) \\
Blocos de concreto & 2000 & 900 & 2,000 & Nahhas et al. (2007) \\
Blocos de concreto & 800 & 1170 & 0,210 & Andreini e Sssu (2011) \\
leve & 2200 & 1000 & 1,500 & Bloco Brasil (2016) \\
Blocos de concreto & & & & \\
\hline
\end{tabular}

Fonte: Autor (2018)

De acordo com Mendes et al (2001) a condutividade térmica dos materiais porosos, como a cerâmica e o cimento, sofre influência também do teor de umidade presente nos poros do material. Em seu estudo mostraram resultados de ensaios realizados com tijolos cerâmicos e argamassa, nestes ensaios a condutividade térmica do tijolo seco era cerca de 0,98 e saturado era de $2,08 \mathrm{~W} / \mathrm{m}$.k. No caso de uma argamassa com porosidade de $31 \%$ o resultado seco foi de 0,70 e saturada de $2,95 \mathrm{~W} / \mathrm{m} . \mathrm{k}$, e para argamassa de porosidade $18 \%$ os resultados seco e saturado foram de 1,92 e 2,57 W/m.K, respectivamente.

A condutividade térmica do material aumenta quando saturado, este fato não se restringe apenas em função de a condutividade térmica da água ser maior que do ar, mas de acordo com Mingzhi et al (2009), em elevadas temperaturas a água presente nos poros começa a evaporar, fazendo com que o vapor difunda-se na rede de poros do material transportando calor e gerando aumento na condutividade térmica.

\subsubsection{Argamassa}

A argamassa é um produto que resulta da mistura de areia com um ou mais materiais de propriedades aglomerantes (cimento e cal) e pode conter ou não aditivos. O principal componente que confere resistência mecânica à argamassa é o cimento, em função de suas reações pozolânicas. A cal reage com o gás carbônico formando compostos que promovem o endurecimento mas possui resistência muito menor se comparado ao concreto. Segundo Hendry (2001) e Sabbatini (1986) o desempenho da argamassa tem grande influência no conjunto 
resistente formado pela alvenaria, mesmo que neste sistema construtivo ela represente pouco mais de $7 \%$ do volume total.

Apesar de não contribuir para resistência mecânica, a cal é utilizada para melhorar o desempenho de fatores ligados à argamassa como por exemplo a trabalhabilidade, deformabilidade, plasticidade e capacidade de retenção de água. Em termos termo-estruturais existem pouco trabalhos que avaliam o comportamento da argamassa associada à alvenaria estrutural em elevadas temperaturas.

No campo térmico é importante conhecer propriedades como a condutividade térmica e o calor específico dos materiais. A Tabela 2.9 apresenta valores destas propriedades para argamassas com diferentes massas específicas em temperatura ambiente.

Tabela 2.9 - Propriedades térmicas da argamassa em temperatura ambiente

\begin{tabular}{|c|c|c|c|c|}
\hline Material & $\begin{array}{c}\text { Massa } \\
\text { específica } \\
\mathrm{kg} / \mathrm{m}^{3} \\
\end{array}$ & $\begin{array}{c}\text { Calor } \\
\text { específico } \\
\mathrm{J} /(\mathrm{kg} . \mathrm{K}) \\
\end{array}$ & $\begin{array}{c}\text { Condutividade } \\
\text { térmica } \\
\mathrm{W} /(\mathrm{m} . \mathrm{K}) \\
\end{array}$ & Fonte \\
\hline $\begin{array}{c}\text { Argamassa } \\
\text { convencional } 1: 3: 0,8\end{array}$ & 1828 & - & 0,946 & Stancato (2000) \\
\hline $\begin{array}{c}\text { Argamassa } \\
\text { convencional } 1: 3: 0,62\end{array}$ & 1928 & - & 1,095 & Stancato (2000) \\
\hline $\begin{array}{c}\text { Argamassa } \\
\text { convencional } 1: 3: 0,63\end{array}$ & 2001 & - & 1,175 & Stancato (2000) \\
\hline Argamassa celular & $600-1000$ & 1000 & 0,400 & $\begin{array}{c}\text { ABNT NBR 15220-2: } \\
2005\end{array}$ \\
\hline Argamassa de gesso & 1200 & 840 & 0,700 & $\begin{array}{c}\text { ABNT NBR 15220-2 : } \\
2005\end{array}$ \\
\hline Argamassa comum & $1800-2100$ & 1000 & 1,150 & $\begin{array}{c}\text { ABNT NBR 15220-2 : } \\
2005\end{array}$ \\
\hline Argamassa & 1500 & 1170 & 1,500 & Nguyen et al. (2009) \\
\hline Argamassa & 2100 & 800 & 1,500 & Roseman (2011) \\
\hline
\end{tabular}

Fonte: Adaptado de Rodovalho (2018)

Morales, Campos e Faganello (2011) realizaram ensaios moldando corpos de prova de argamassa de cimento $\mathrm{CP}-\mathrm{V}$ e areia silicosa no traço 1:3. O ensaio de aquecimento foi realizado 7 dias após a confecção das amostras variando a temperatura com taxa de aquecimento de $20^{\circ} \mathrm{C} /$ min alcançando patamares entre $300^{\circ} \mathrm{C}$ e $750^{\circ} \mathrm{C}$. O resfriamento foi feito de duas maneiras, bruscamente em imersão na água e lentamente no ambiente para as amostras à $300^{\circ} \mathrm{C}$ e obteve-se como resultado uma redução da resistência à compressão de 30,5\% para o resfriamento brusco e de $5 \%$ para o resfriamento lento. 
Para os demais patamares de temperatura foi adotado apenas o resfriamento lento e a Tabela 2.10 apresenta as perdas de resistência para os patamares entre $300^{\circ} \mathrm{C}$ e $450^{\circ} \mathrm{C}$. $\grave{A}$ temperatura de $750^{\circ} \mathrm{C}$ houve desagregação do material, não apresentando resistência residual e também foi observado a alteração da cor das amostras para tons róseos.

Tabela 2.10 - Resistência média a compressão com resfriamento lento

\begin{tabular}{ccccc}
\hline $\begin{array}{c}\text { Temperatura } \\
\left({ }^{\circ} \mathrm{C}\right)\end{array}$ & $f_{c j, 7}(\mathrm{MPa})$ & $\begin{array}{c}\text { Perda de } \\
\text { Resistência }(\%)\end{array}$ & $E(\mathrm{GPa})$ & $\begin{array}{c}\text { Perda do Módulo de } \\
\text { Elasticidade }(\%)\end{array}$ \\
\hline \hline REF. & 18,70 & 0 & 34,40 & 0 \\
300 & 13,50 & 28 & 18,60 & 46 \\
350 & 13,00 & 30 & 17,10 & 50 \\
400 & 9,50 & 49 & 14,50 & 58 \\
450 & 6,80 & 64 & 9,40 & 73 \\
\hline
\end{tabular}

Fonte: Adaptado de Morales, Campos e Faganelli (2011)

No trabalho de Karahan (2010) foram apresentados ensaios de aquecimento de corpos de prova de argamassa com diferentes tipos de resfriamento, para avaliar as possíveis perdas de resistência. As amostras foram confeccionadas com cimento Portland e areia silicosa e aquecidas a temperaturas de $400,600,800$ e $1000^{\circ} \mathrm{C}$ após 28 dias de cura. Para todos os patamares de aquecimento adotou-se resfriamento lento dentro do forno, resfriamento lento ao ar livre e resfriamento brusco com imersão em água fria. A taxa de aquecimento não foi especificada no trabalho.

Em todas situações de aquecimento o resfriamento lento no forno ou ao ar livre apresentaram perda de resistência semelhante, enquanto o resfriamento rápido com imersão apresentou perdas significativamente maiores. Para temperaturas de $400^{\circ} \mathrm{C}$ a redução de resistência foi de $8 \%$ e $6 \%$ para as amostras deixadas ao ar livre e no forno respectivamente e de $43 \%$ para as imersas em água. À temperatura de $600^{\circ} \mathrm{C}$ as reduções foram de $48 \%, 45 \%$ e $70 \%$ para as resfriadas ao ar, no forno e na água respectivamente. As peças aquecidas à $800^{\circ} \mathrm{C}$ apresentaram redução de $72 \%$ para as resfriadas ao ar livre, $70 \%$ no forno e $91 \%$ na água. Em $1000^{\circ} \mathrm{C}$ as amostras resfriadas lentamente obtiveram resistência residual de $6 \%$ e as resfriadas na água não possuíam mais resistência.

Além disso, algumas amostras ensaiadas a cada patamar de temperatura e submetidas aos resfriamentos lento e brusco foram deixadas por sete dias em condições ambiente para em seguida avaliar a resistência residual. As amostras resfriadas lentamente apresentaram resistência menor para um mesmo nível de aquecimento, enquanto as imersas em água demonstraram um pequeno ganho de resistência. 
Cülfik e Özturan (2002) compararam a alteração das propriedades mecânicas de argamassas no traço 1:3 com e sem adição de 5\% de grafite em pó em seus estudos. Os patamares de aquecimento foram de 300,600 e $900^{\circ} \mathrm{C}$ e os ensaios foram realizados a uma taxa de aquecimento de $2^{\circ} \mathrm{C} / \mathrm{min}$ e $8^{\circ} \mathrm{C} / \mathrm{min}$ com tempo de exposição ao fogo de 1 hora e de 10 horas, com resfriamento lento em temperatura ambiente. Os resultados encontrados para todas as variações de ensaio estão dispostos na Tabela 2.11.

Tabela 2.11 - Propriedades mecânicas residuais das argamassas aquecidas

\begin{tabular}{|c|c|c|c|c|c|c|c|c|}
\hline \multirow{2}{*}{$\mathrm{T}\left({ }^{\circ} \mathrm{C}\right)$} & \multirow{2}{*}{$\begin{array}{c}\text { Taxa de } \\
\text { Aquecimen } \\
\text { to }\left({ }^{\circ} \mathrm{C} / \mathrm{min}\right)\end{array}$} & \multirow{2}{*}{$\begin{array}{c}\text { Tempo de } \\
\text { Exposição } \\
\text { (h) }\end{array}$} & \multicolumn{2}{|c|}{$\begin{array}{l}\text { Resist. Média à } \\
\text { compressão (Mpa) }\end{array}$} & \multicolumn{2}{|c|}{$\begin{array}{l}\text { Resist. Média à } \\
\text { Flexão (Mpa) }\end{array}$} & \multicolumn{2}{|c|}{$\begin{array}{c}\text { Módulo de } \\
\text { Elasticidade (Gpa) }\end{array}$} \\
\hline & & & $\begin{array}{l}\text { sem } \\
\text { grafite }\end{array}$ & $\begin{array}{l}\text { com } \\
\text { grafite }\end{array}$ & $\begin{array}{c}\text { sem } \\
\text { grafite }\end{array}$ & $\begin{array}{l}\text { com } \\
\text { grafite }\end{array}$ & $\begin{array}{c}\text { sem } \\
\text { grafite }\end{array}$ & $\begin{array}{c}\text { com } \\
\text { grafite }\end{array}$ \\
\hline 20 & 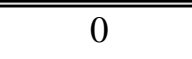 & 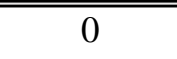 & "62,9 & 444,3 & 11,46 & $8,8,45$ & 33,73 & $\begin{array}{ll}17,89 \\
\end{array}$ \\
\hline 300 & 2 & 1 & 48,8 & 37,7 & 7,26 & 6,45 & 19,18 & 13,05 \\
\hline 300 & 2 & 10 & 44,7 & 39,3 & 7,29 & 5,45 & 19,1 & 10,12 \\
\hline 300 & 8 & 1 & 55,3 & 44,3 & 9,73 & 6,95 & 22,54 & 17,36 \\
\hline 300 & 8 & 10 & 50,7 & 40,4 & 7,76 & 5,55 & 21,67 & 14,4 \\
\hline 600 & 2 & 1 & 23,8 & 30 & 1,85 & 1,78 & 3,54 & 3,53 \\
\hline 600 & 2 & 10 & 21,7 & 17,8 & 1,62 & 1,49 & 3,42 & 3,2 \\
\hline 600 & 8 & 1 & 30,8 & 19,6 & 2,55 & 2,2 & 6,03 & 3,41 \\
\hline 600 & 8 & 10 & 24,4 & 16,9 & 1,51 & 1,51 & 4,24 & 3,39 \\
\hline 900 & 2 & 1 & 8 & 7,9 & 0,81 & 0,93 & - & - \\
\hline 900 & 2 & 10 & 6,5 & 7,1 & 0,69 & 0,76 & - & - \\
\hline 900 & 8 & 1 & 9 & 8,1 & 0,81 & 1,18 & - & - \\
\hline 900 & 8 & 10 & 7 & 8 & 0,69 & 0,69 & - & - \\
\hline
\end{tabular}

Fonte: Adaptado de Cülfik e Özturan (2002)

$\mathrm{Na}$ temperatura de $300^{\circ} \mathrm{C}$ a perda da resistência mecânica variou de 12 a $29 \%$ para argamassas sem grafite e de 0 a $15 \%$ nas com grafite. À temperatura de $600^{\circ} \mathrm{C}$ houve grande perda nas propriedades mecânicas da argamassa, nas com adição de grafite a redução da resistência a compressão foi de 55 a $62 \%$ e nas convencionais foi de 51 a $65 \%$. Em $900^{\circ} \mathrm{C}$ praticamente não havia mais resistência residual das amostras, algo em torno de $10 \%$ e a coloração foi alterada para um tom róseo. Em função das microfraturas causadas pelo aquecimento observou-se que a perda de resistência à flexão foi mais acentuada.

Outro trabalho que estuda a resistência residual de em função da temperatura atingida é o de Yüzer et al. (2004). Foram utilizadas argamassas convencionais de cimento e areia e com adição de sílica ativa a 10\%. O aquecimento foi realizado até os patamares de temperatura de $100,200,300,600,900$ e $1200^{\circ} \mathrm{C}$, mas as taxas de aquecimento não foram apresentadas, e os resfriamentos adotados foram o lento ao ar livre e o brusco com imersão em água. 
A redução da resistência à compressão passou a ocorrer desde as peças submetidas ao aquecimento de $100^{\circ} \mathrm{C}$ mas as perdas significativas ocorram a partir do aquecimento de $300^{\circ} \mathrm{C}$, que no caso do resfriamento com água foi de $40 \%$ e para a temperatura de $600^{\circ} \mathrm{C}$ com resfriamento em água a redução foi de $70 \%$. Com esta mesma temperatura as amostras resfriadas ao ar livre sem adição de sílica apresentam perda de $40 \%$ da resistência e com adição de sílica a perda foi de $50 \%$.

Os resultados mostraram que a partir dos $600^{\circ} \mathrm{C}$ as amostras com sílica ativa apresentaram perda da resistência à compressão mais acentuadas que as demais. Na temperatura de $900^{\circ} \mathrm{C}$ a redução de resistência foi de $55 \%$ e $65 \%$ para as amostras resfriadas naturalmente sem e com sílica ativa respectivamente. Para o resfriamento com água a perda de resistência foi de $75 \%$ para ambos os casos de amostras confeccionadas. Como nas demais pesquisas supracitadas, quando o resfriamento é brusco com imersão de água a redução da resistência a compressão dos corpos de prova é significativamente maior.

Aydin (2008) realizou um estudo utilizando argamassa com adição mineral de escória de alto forno substituindo de 0 a $80 \%$ o cimento e utilizou pedra-pome como agregado miúdo. Os resultados mostram que as resistências das argamassas com adição mineral em temperatura ambiente eram menores, no entanto, quando submetidas à elevadas temperaturas, a redução da resistência era menor. Tal qual em outros trabalhos as temperaturas de aquecimento foram de 300,600 e $900^{\circ} \mathrm{C}$ com resfriamento tanto lento ao ar livre como com choque em água fria.

Observou-se um ganho de resistência à compressão nas argamassas aquecidas a $300^{\circ} \mathrm{C}$ e resfriadas lentamente se comparadas com as argamassas de controle, o maior ganho foi para argamassa om adição mineral, 40\%. Esta incorporação de agregado mineral não causou praticamente nenhuma perda de resistência na compressão das amostras resfriadas lentamente e aquecidas à $600^{\circ} \mathrm{C}$. Segundo o autor, o maior benefício se mostrou no ensaio a $900^{\circ} \mathrm{C}$, pois percentualmente, a perda de resistência das argamassas com adição mineral foi significativamente inferior às argamassas moldadas apenas com cimento.

\subsection{Regulamentação nacional de resistência ao fogo para alvenaria estrutural}

Os requisitos necessários para dimensionamento e critérios de utilização dos elementos construtivos de determinado tipo de edificação são expostos nos códigos de edificações e normas técnicas. Além do dimensionamento para suportar as cargas no estado limite último e de serviço, Mitidieri (2008) afirma que as estruturas também devem ser dimensionadas com 
base nos princípios de segurança contra incêndio, visando a proteção da vida humana e de bens materiais.

Para a situação de incêndio, os códigos normativos estabelecem um nível de resistência ao fogo para paredes de alvenaria que, em geral, é mensurado pelo tempo requerido de resistência ao fogo (TRRF). No âmbito nacional, tem-se a ABNT NBR 14432, que fixa critérios de resistência ao fogo com base no tipo de edificação, área, altura, profundidade do subsolo e facilidade de acesso para combate ao fogo.

Mesmo possuindo uma norma que estabelece critérios para o tempo requerido de resistência ao fogo, o Brasil não possui uma regulamentação nacional que determina o dimensionamento de estruturas de alvenaria estrutural em situação de incêndio. Uma referência nacional importante para a normalização de estruturas em elevadas temperaturas é a Instrução Técnica 08 (IT-08) do Corpo de Bombeiros de São Paulo que tem o código de incêndio mais avançado do Brasil, segundo Tavares (2009) e é usado de modelo para outras cidades.

Ela utiliza o TRRF para a definição dos níveis de proteção dos elementos estruturais, de vedação e de compartimentação das edificações. A comprovação do TRRF pode ser feita por meio de ensaios em laboratório ou modelos matemáticos normalizados nacional ou internacionalmente. É apresentado no anexo B da IT-08 uma tabela com resultados de alguns ensaios realizados com diferentes alvenarias, mostrando a resistência destas pelos critérios de integridade (mecânica), estanqueidade e isolamento térmico, como mostrado na Tabela 2.12.

Tabela 2.12 - Resistência ao fogo para alvenarias pelo IT - 08 de São Paulo

\begin{tabular}{|c|c|c|c|c|c|c|c|}
\hline \multirow{2}{*}{\multicolumn{2}{|c|}{ Paredes ensaiadas }} & \multirow{2}{*}{$\begin{array}{l}\text { Espessura do } \\
\text { revestimento } \\
(\mathrm{cm})\end{array}$} & \multirow{2}{*}{$\begin{array}{c}\text { Duração } \\
\text { do ensaio } \\
\text { (min) }\end{array}$} & \multicolumn{3}{|c|}{$\begin{array}{c}\text { Tempo de atendimento aos critérios } \\
\text { de resistência ao fogo (horas) }\end{array}$} & \multirow{2}{*}{$\begin{array}{c}\text { Resistência } \\
\text { ao fogo } \\
\text { (horas) }\end{array}$} \\
\hline & & & & Integridade & Estanq. & $\begin{array}{c}\text { Isolamento } \\
\text { térmico }\end{array}$ & \\
\hline \multirow{4}{*}{$\begin{array}{c}\text { Tijolos de barro } \\
\text { cozido }\end{array}$} & Meio tijolo sem rev. & - & 120 & $\geq 2$ & $\geq 2$ & $11 / 2$ & $11 / 2$ \\
\hline & Um tijolo sem rev. & - & 395 & $\geq 6$ & $\geq 6$ & $\geq 6$ & $\geq 6$ \\
\hline & Meio tijolo com rev. & 2,5 & 300 & $\geq 4$ & $\geq 4$ & 4 & 4 \\
\hline & Um tijolo com rev. & 2,5 & 300 & $\geq 6$ & $\geq 6$ & $\geq 5$ & $\geq 5$ \\
\hline \multirow{4}{*}{$\begin{array}{l}\text { Blocos Vazados } \\
\text { de concreto } \\
(2 \text { furos })\end{array}$} & $14 \mathrm{~cm}$ sem rev. & - & 100 & $\geq 1,5$ & $\geq 1,5$ & $11 / 2$ & $11 / 2$ \\
\hline & $19 \mathrm{~cm}$ sem rev. & - & 120 & $\geq 2$ & $\geq 2$ & $11 / 2$ & $11 / 2$ \\
\hline & $14 \mathrm{~cm}$ com rev. & 1,5 & 150 & $\geq 2$ & $\geq 2$ & 2 & 2 \\
\hline & $19 \mathrm{~cm}$ com rev. & 1,5 & 185 & $\geq 3$ & $\geq 3$ & 3 & 3 \\
\hline \multirow{2}{*}{$\begin{array}{c}\text { Tijolos cerâmicos } \\
\text { de } 8 \text { furos }\end{array}$} & Meio tijolo com rev. & 1 & 150 & $\geq 2$ & $\geq 2$ & 2 & 2 \\
\hline & Um tijolo com rev. & 1 & 300 & $\geq 4$ & $\geq 4$ & $\geq 4$ & $\geq 4$ \\
\hline
\end{tabular}

Fonte: Adaptado da Instrução Técnica 08 do Corpo de Bombeiros de São Paulo (POLÍCIA..., 2004) 
Como o Brasil carece de uma legislação nacional sobre o assunto, o Corpo de Bombeiros de São Paulo recomenda que sejam seguidas as recomendações do Eurocode 6 (2005) ou outra norma internacional similar. Questiona-se sobre esta recomendação que a aplicabilidade de normas internacionais pode não garantir a segurança de obras nacionais por haver divergências nas dimensões e composições de blocos produzidos nos diferentes países.

Outra referência que trata da resistência ao fogo de alvenarias é o Manual Técnico de Alvenaria da Associação Brasileira da Construção Industrializada (1990) que apresenta ensaios realizados em paredes de alvenaria estrutural seguindo aos critérios da ABNT NBR 5628:2001. As paredes foram categorizadas em função dos requisitos de resistência atendidos: corta-fogo (resistência mecânica, estanqueidade e isolamento térmico), para-chamas (resistência mecânica e estanqueidade) e estável ao fogo (resistência mecânica). A Tabela 2.13 traz o tempo que cada tipo de parede apresentou ao atender os requisitos das categorias supracitadas.

Tabela 2.13 - Resistência ao fogo de blocos de concreto e cerâmicos pela ABCI

\begin{tabular}{|c|c|c|c|c|c|}
\hline \multirow[b]{2}{*}{ Bloco } & \multirow[b]{2}{*}{$\begin{array}{l}\text { Espessura } \\
(\mathrm{cm})\end{array}$} & \multirow[b]{2}{*}{ Revestimento } & \multicolumn{3}{|c|}{ Tempo de resistência (horas) } \\
\hline & & & Corta-fogo & Para-fogo & $\begin{array}{c}\text { Estável ao } \\
\text { fogo }\end{array}$ \\
\hline Concreto vedação & 19 & $\begin{array}{c}\text { Argamassa: } 2 \mathrm{~cm} \text { na face de } \\
\text { exposição ao fogo }\end{array}$ & 4 & - & - \\
\hline Concreto estrutural & 14 & 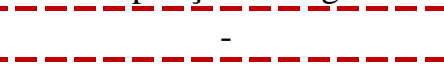 & 1 & 4 & $\overline{4}$ \\
\hline Cerâmico vedação & 9 & $\begin{array}{c}\text { Aragamassa: } 1,5 \mathrm{~cm} \text { em cada } \\
\text { face }\end{array}$ & 1,5 & 2 & 2 \\
\hline Cerâmico estrutural & 14 & $\begin{array}{c}\text { Gesso: } 3 \mathrm{~mm} \text { na face de } \\
\text { exposição ao fogo }\end{array}$ & 2 & 4 & 4 \\
\hline Cerâmico estrutural & 14 & - & 1,5 & 2 & 2 \\
\hline Cerâmico estrutural & 14 & $\begin{array}{c}\text { Aragamassa: } 1,5 \mathrm{~cm} \text { em cada } \\
\text { face }\end{array}$ & 2 & 3 & 3 \\
\hline
\end{tabular}

Fonte: Adaptado o Manual Técnico de Alvenaria (ASSOCIAÇÃO..., 1990)

Atualmente o dimensionamento e verificação da segurança da alvenaria estrutural em situação de incêndio depende de métodos experimentais, que consistem basicamente em submeter os elementos de alvenaria a uma simulação de incêndio padronizado. Existem normas regulamentadoras nacionais e internacionais para realização e ensaios de exposição ao fogo, no Brasil a ABNT NBR 5628 especifica as principais exigências no ensaio de determinação de resistência ao fogo de componentes construtivos, utilizando como base a curva de incêndiopadrão da ISO 834-1:1999. No entanto, não há uma norma nacional que permita o projeto de estruturas de alvenaria estrutural considerando a verificação de segurança ao incêndio para os critérios resistência mecânica, estanqueidade e isolamento térmico. 


\subsection{Regulamentação internacional de resistência ao fogo para alvenaria estrutural}

Cada país possui particularidades relacionados a especificações geométricas, particularidades mineralógicas dos materiais constituintes dos blocos, argamassa, revestimentos, espessuras de paredes e também capacidade resistiva da alvenaria. Portanto, mesmo que funcionem como diretrizes para o dimensionamento das paredes de alvenaria estrutural no Brasil, as normas internacionais não são perfeitamente adequadas para os projetos de dimensionamento e verificação da segurança.

Mas as principais normas internacionais que apresentam procedimentos de dimensionamento das estruturas de alvenaria em situação de incêndio e que são utilizadas como referências pelos projetistas nacionais são o código europeu Eurocode 6 Part 1,2 (2005), o código americano ACI/TMS 216.1 (2014) e o código australiano AS 3700 (2011). Nos tópicos a seguir serão descritas as principais recomendações de cada um deste códigos internacionais.

Além destas normas, o Standard Building Code (2003) apud Rigão (2012) apresenta uma tabela (Tabela 2.14) com a espessura mínima equivalente que os blocos de concreto devem ter para satisfazer os tempos de resistência ao fogo, considerando diferentes tipos de agregados. Nos blocos de concreto os agregados são de grande importância na resistência ao fogo, no caso dos leves como argila expandida ou xisto há maior resistência à transferência de calor em função do ar confinado nestes materiais. Portanto, blocos de agregados leves necessitam menor espessura que os com agregados densos para alcançar a mesma resistência ao fogo.

Tabela 2.14 - Espessura mínima equivalente de paredes de alvenaria com blocos de concreto em função do tempo

\begin{tabular}{|c|c|c|c|c|c|c|c|c|c|c|c|c|c|c|c|}
\hline \multirow{2}{*}{$\begin{array}{c}\text { Tipo de } \\
\text { Agregado }\end{array}$} & \multicolumn{15}{|c|}{ Avaliação da Resistência ao fogo (min) } \\
\hline & 30 & 45 & 60 & 75 & 90 & 105 & 120 & 135 & 150 & 165 & 180 & 195 & 210 & 225 & 240 \\
\hline $\begin{array}{l}\text { Pedra-pome ou } \\
\text { escória expandiga }\end{array}$ & 3,81 & 4,83 & 5,33 & 6,35 & 6,86 & 7,62 & 8,13 & 8,64 & 9,14 & 9,65 & 10,16 & 10,67 & 11,18 & 11,43 & 11,94 \\
\hline $\begin{array}{l}\text { Xisto expandido, } \\
\text { argila ou ardósia }\end{array}$ & 4,57 & 5,59 & 6,60 & 7,37 & 8,38 & 8,64 & 9,14 & 9,65 & 10,16 & 10,67 & 11,18 & 11,68 & 12,19 & 12,45 & 12,95 \\
\hline $\begin{array}{c}\text { Calcário, cinzas } \\
\text { ou escória não } \\
\text { expandida }\end{array}$ & 4,83 & 5,84 & 6,86 & 7,87 & 8,64 & 9,40 & 10,16 & 10,92 & 11,43 & 12,19 & 12,70 & 13,21 & 13,97 & 14,48 & 14,99 \\
\hline $\begin{array}{l}\text { Cascalhos } \\
\text { calcáreos ou } \\
\text { silicosos }\end{array}$ & 5,08 & 6,10 & 7,11 & 8,13 & 9,14 & 9,91 & 10,67 & 11,43 & 12,19 & 12,70 & 13,46 & 13,97 & 14,73 & 15,24 & 15,75 \\
\hline
\end{tabular}


Como visto na Tabela 2.14 a avaliação da resistência ao fogo da alvenaria pode ser relacionada com a espessura sólida equivalente dos blocos $\left(E_{T}\right)$. Esta espessura pode ser encontra pela equação 2.39 que relaciona o volume liquido de uma unidade da parede (volume total menos o volume de vazios ou furos dos septos) com a área exposta desta unidade.

$$
E_{T}=\mathrm{V} / l . h
$$

Em que:

V é o volume líquido da unidade;

$l$ é o comprimento da unidade;

$h$ é a altura da unidade.

\subsubsection{Eurocode 6 Part 1.2}

O Eurocode 6 Parte 1-2 (2005) é o código europeu que descreve as exigências necessárias a serem seguidas no dimensionamento de estruturas de alvenaria estrutural em situação de incêndio. Neste código é permitida a verificação das estruturas por métodos prescritivos ou por métodos baseados no desempenho. De maneira geral, os cálculos podem ser feitos por três métodos: os tabulares, os baseados em experimentos e os analíticos.

Os métodos analíticos podem ser divididos em dois procedimentos distintos, o primeiro é simplificado, que será abordado neste trabalho, e o segundo é mais avançado e depende de simulações do comportamento dos materiais submetidos a elevadas temperaturas. De acordo com Johnson (2009), o método de análise baseado na seção transversal residual deriva do método apresentado no Eurocode 5 Part 1.2 para estruturas de madeira, e também do método apresentado no Eurocode 2 Part 1.2, na forma de ábacos para a verificação das estruturas de concreto em situação de incêndio.

O dimensionamento através do uso de tabelas é um modelo de cálculo feito a partir da definição dos parâmetros referentes aos materiais constituintes da parede. Em função disso encontra-se a variabilidade dos resultados para edificações de regiões diferentes em que os elementos estruturais possuem composições diferentes.

O Eurocode 6 Part 1.2 especifica exigências necessárias ao dimensionamento de paredes estruturais de alvenaria em situação de incêndio. As paredes estruturais são definidas como aquelas projetadas para suportar principalmente esforços de compressão vertical provenientes dos pavimentos superiores e também ações horizontais como é o caso do vento. 
A determinação do tempo de resistência ao fogo depende das propriedades dos materiais empregados: blocos, argamassa e revestimento. O código europeu relaciona que para a exposição ao fogo, as estruturas devem cumprir três critérios: de resistência mecânica (R), de estanqueidade (E) e de isolamento térmico (I). Há também a adição de um novo critério, o de impacto mecânico (M). Baseado nas funções desempenhadas pelas paredes nas estruturas, elas podem ser agrupadas nas seguintes classificações:

- Paredes com função resistente unicamente: critério R;

- Paredes com função de isolamento térmico e estanqueidade: critérios EI;

- Paredes com função resistente, de isolamento térmico e de estanqueidade: critérios REI;

- Paredes com função resistente, de isolamento térmico, de estanqueidade e de resistência mecânica: critérios REI-M;

- Paredes com função de isolamento térmico, de estanqueidade e de resistência mecânica: critérios EI-M;

A avaliação da parede pode ser feita pelo método tabular, cujas tabelas estão contidas no Anexo B do código europeu e fornecem a espessura mínima necessária da parede de alvenaria para determinado tempo de resistência ao fogo. Estas tabelas são divididas primeiramente pela função da parede na edificação e pelo tipo de material do bloco da parede, que pode ser cerâmico, de concreto com agregado leve ou denso, auto clavado, etc. Na sequência, cada tabela se divide em função do intervalo de resistência à compressão do bloco $\left(f_{b}\right)$, da densidade das unidades $(\rho)$ e também da relação entre a solicitação de cálculo da parede em situação de incêndio e as solicitações de cálculo em situação normal $(\alpha)$.

As tabelas de maior interesse para este trabalho são as que contemplam as espessuras mínimas de blocos de concreto para paredes de alvenaria estrutural com função apenas $\mathrm{R}$ (resistência mecânica) e também as com função REI (resistência mecânica, estanqueidade e isolamento térmico) como apresentado na Tabela 2.15 e na Tabela 2.16 respectivamente, para blocos do grupo 1. Os valores indicados nas tabelas são as espessuras mínimas e o intervalo recomendado, por exemplo, quando for encontrada a indicação "90/170" quer dizer que a espessura mínima a ser adotada é de $90 \mathrm{~mm}$ e recomenda-se utilizar espessuras no intervalo entre 90 e $170 \mathrm{~mm}$.

Nos valores entre parênteses, as tabelas trazem o intervalo recomendado de espessura para as paredes quando estas utilizam acabamentos. Desde que estes acabamentos estejam de acordo com as exigências do código europeu, espessura mínima de $10 \mathrm{~mm}$ nas duas faces de uma parede simples ou na face exposta ao fogo de uma parede dupla. 
Tabela 2.15 - Espessuras mínimas de paredes carregadas para concreto denso e leve pelo critério $\mathrm{R}$

\begin{tabular}{|c|c|c|c|c|c|c|c|c|}
\hline \multirow[b]{2}{*}{$\begin{array}{l}\mathrm{N}^{\mathrm{o}} \mathrm{da} \\
\text { linha }\end{array}$} & \multirow{2}{*}{$\begin{array}{l}\text { Propriedades dos } \\
\text { materiais: } \\
\text { Resistência à } \\
\text { compressão }\left(f_{b}\right) \\
{\left[\mathrm{N} / \mathrm{mm}^{2}\right]} \\
\text { Massa específica } \\
(\rho)\left[\mathrm{kg} / \mathrm{m}^{3}\right]\end{array}$} & \multicolumn{7}{|c|}{$\begin{array}{c}\text { Mínima espessura (mm) } t_{F} \begin{array}{c}\text { para o tempo (minutos) de resistência ao fogo para a } \\
\text { classificação REI }\end{array} \\
\end{array}$} \\
\hline & & 30 & 45 & 60 & 90 & 120 & 180 & 240 \\
\hline 1 & \multicolumn{8}{|c|}{$\begin{array}{l}\text { Unidades do Grupo } 1 \\
\text { Argamassa: uso geral, camada fina, leve }\end{array}$} \\
\hline 1.1 & \multicolumn{8}{|c|}{ 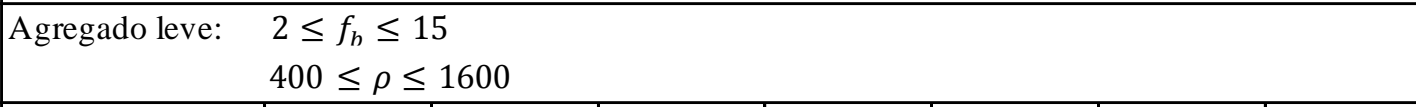 } \\
\hline $\begin{array}{l}1.1 .1 \\
1.1 .2\end{array}$ & $\alpha \leq 1,0$ & $\begin{array}{l}90 / 170 \\
(90 / 140)\end{array}$ & $\begin{array}{c}90 / 170 \\
(90 / 140)\end{array}$ & $\begin{array}{l}90 / 170 \\
(90 / 140)\end{array}$ & $\begin{array}{l}100 / 170 \\
(90 / 140)\end{array}$ & $\begin{array}{l}100 / 190 \\
(90 / 170)\end{array}$ & $\begin{array}{c}140 / 240 \\
(100 / 190)\end{array}$ & $\begin{array}{l}150 / 300 \\
(100 / 240)\end{array}$ \\
\hline $\begin{array}{l}1.1 .3 \\
1.1 .4 \\
\end{array}$ & $\alpha \leq 0,6$ & $\begin{array}{r}70 / 140 \\
(60 / 100) \\
\end{array}$ & $\begin{array}{c}70 / 140 \\
(60 / 100)\end{array}$ & $\begin{array}{c}70 / 140 \\
(60 / 100) \\
\end{array}$ & $\begin{array}{c}90 / 170 \\
(70 / 100)\end{array}$ & $\begin{array}{c}90 / 170 \\
(70 / 140)\end{array}$ & $\begin{array}{l}100 / 190 \\
(90 / 170)\end{array}$ & $\begin{array}{l}100 / 240 \\
(90 / 190) \\
\end{array}$ \\
\hline 1.2 & \multicolumn{8}{|c|}{$\begin{array}{ll}\text { Agregado denso: } & 6 \leq f_{b} \leq 35 \\
& 1200 \leq \rho \leq 2400\end{array}$} \\
\hline $\begin{array}{l}1.2 .1 \\
1.2 .2\end{array}$ & $\alpha \leq 1,0$ & $\begin{array}{r}90 / 170 \\
(90 / 140)\end{array}$ & $\begin{array}{c}90 / 170 \\
(100 / 140)\end{array}$ & $\begin{array}{c}90 / 170 \\
(90 / 140)\end{array}$ & $\begin{array}{c}90 / 170 \\
(90 / 140)\end{array}$ & $\begin{array}{l}100 / 190 \\
(90 / 170)\end{array}$ & $\begin{array}{c}140 / 240 \\
(100 / 190)\end{array}$ & $\begin{array}{c}150 / 300 \\
(100 / 240)\end{array}$ \\
\hline $\begin{array}{l}1.2 .3 \\
1.2 .4\end{array}$ & $\alpha \leq 0,6$ & $\begin{array}{c}70 / 140 \\
(60 / 100)\end{array}$ & $\begin{array}{c}90 / 140 \\
(70 / 100)\end{array}$ & $\begin{array}{c}70 / 140 \\
(70 / 100)\end{array}$ & $\begin{array}{c}90 / 170 \\
(70 / 100)\end{array}$ & $\begin{array}{c}90 / 170 \\
(70 / 140)\end{array}$ & $\begin{array}{l}100 / 190 \\
(90 / 170)\end{array}$ & $\begin{array}{c}140 / 240 \\
(100 / 190)\end{array}$ \\
\hline
\end{tabular}

Fonte: Eurocode 6 Part 1.2 (2005) (tradução própria).

Tabela 2.16 - Espessuras mínimas de paredes carregadas para blocos de concreto denso e leve pelo critério REI

\begin{tabular}{|c|c|c|c|c|c|c|c|c|}
\hline \multirow[b]{2}{*}{$\begin{array}{l}\mathrm{N}^{\mathrm{o}} \mathrm{da} \\
\text { linha }\end{array}$} & \multirow{2}{*}{$\begin{array}{l}\text { Propriedades dos } \\
\text { materiais: } \\
\text { Resistência à } \\
\text { compressão }\left(f_{b}\right) \\
{\left[\mathrm{N} / \mathrm{mm}^{2}\right]} \\
\text { Massa específica } \\
(\rho)\left[\mathrm{kg} / \mathrm{m}^{3}\right]\end{array}$} & \multicolumn{7}{|c|}{$\begin{array}{c}\text { Mínima espessura (mm) } t_{F} \begin{array}{c}\text { para o tempo (minutos) de resistência ao fogo para a } \\
\text { classificação } \mathrm{R}\end{array} \\
\end{array}$} \\
\hline & & 30 & 45 & 60 & 90 & 120 & 180 & 240 \\
\hline 1 & \multicolumn{8}{|c|}{$\begin{array}{l}\text { Unidades do Grupo } 1 \\
\text { Argamassa: uso geral, camada fina, leve }\end{array}$} \\
\hline 1.1 & Agregado leve: & \multicolumn{7}{|c|}{$\begin{array}{l}2 \leq f_{h} \leq 8 \\
400 \leq \rho \leq 1400\end{array}$} \\
\hline $\begin{array}{ll}1.1 .1 \\
1.1 .2\end{array}$ & $\alpha \leq 1,0$ & $\begin{array}{c}170 \\
(170)\end{array}$ & $\begin{array}{c}170 \\
(170)\end{array}$ & $\begin{array}{c}170 \\
(170)\end{array}$ & $\begin{array}{c}240 \\
(170)\end{array}$ & $\begin{array}{c}300 \\
(240)\end{array}$ & $\begin{array}{c}300 \\
(240)\end{array}$ & $\begin{array}{c}365 \\
(300)\end{array}$ \\
\hline $\begin{array}{l}1.1 .3 \\
1.1 .4\end{array}$ & $\alpha \leq 0,6$ & $\begin{array}{r}170 \\
(140) \\
\end{array}$ & $\begin{array}{c}170 \\
(140) \\
\end{array}$ & $\begin{array}{c}170 \\
(140)\end{array}$ & $\begin{array}{c}190 \\
(170) \\
\end{array}$ & $\begin{array}{c}240 \\
(190) \\
\end{array}$ & $\begin{array}{c}240 \\
(240) \\
\end{array}$ & $\begin{array}{c}300 \\
(240) \\
\end{array}$ \\
\hline 1.2 & \multicolumn{8}{|c|}{$\begin{array}{ll}\text { Agregado denso: } & 6 \leq f_{b} \leq 20 \\
& 1400 \leq \rho \leq 2000\end{array}$} \\
\hline $\begin{array}{l}1.2 .1 \\
1.2 .2 \\
\end{array}$ & $\alpha \leq 1,0$ & $\begin{array}{r}170 \\
(170)\end{array}$ & $\begin{array}{c}170 \\
(170) \\
\end{array}$ & $\begin{array}{r}170 \\
(170)\end{array}$ & $\begin{array}{c}240 \\
(170)\end{array}$ & $\begin{array}{r}300 \\
(240)\end{array}$ & $\begin{array}{r}300 \\
(240)\end{array}$ & $\begin{array}{c}365 \\
(300)\end{array}$ \\
\hline $\begin{array}{l}1.2 .3 \\
1.2 .4\end{array}$ & $\alpha \leq 0,6$ & $\begin{array}{c}170 \\
(140)\end{array}$ & $\begin{array}{c}170 \\
(140)\end{array}$ & $\begin{array}{c}170 \\
(140)\end{array}$ & $\begin{array}{r}190 \\
(170)\end{array}$ & $\begin{array}{r}240 \\
(190)\end{array}$ & $\begin{array}{c}240 \\
(240)\end{array}$ & $\begin{array}{c}300 \\
(240) \\
\end{array}$ \\
\hline
\end{tabular}

Fonte: Eurocode 6 Part 1.2 (2005) (tradução própria). 
Oura forma de avaliar o dimensionamento das paredes de alvenaria estrutural em situação de incêndio é através de métodos analíticos simplificados, que são restritos às paredes executadas com os blocos e argamassas especificados na Tabela 2.17.

Este método consiste em traçar duas isotermas na seção da parede de alvenaria. A primeira com temperatura $\theta_{1}$ que define o ponto até onde se pode considerar resistência residual à compressão e a outra isoterma com temperatura $\theta_{2}$ acima da qual pode ser considerada nula a resistência à compressão. Com este traçado, a parede de alvenaria é avaliada, em situação de incêndio, com seção reduzida (descartando toda área da seção com temperatura maior que $\theta_{2}$ ) e resistência reduzida em relação àquela encontrada em temperatura ambiente na área com temperatura entre $\theta_{1}$ e $\theta_{2}$.

Tabela 2.17 - Blocos cujo método é aplicável e valores das temperaturas $\theta_{1}$ e $\theta_{2}$ de cada um

\begin{tabular}{c|c|c}
\hline \multirow{2}{*}{$\begin{array}{c}\text { Bloco de alvenaria e argamassa (supe rfície } \\
\text { desprotegida) }\end{array}$} & $\boldsymbol{\theta}_{\mathbf{1}}$ & $\boldsymbol{\theta}_{\mathbf{2}}$ \\
\cline { 2 - 3 } & 100 & 600 \\
\hline \hline $\begin{array}{c}\text { Blocos cerâmicos com argamassa comum } \\
\text { Blocos de silicato de cálcio com uma fina camada de } \\
\text { argamassa }\end{array}$ & 100 & 500 \\
\hline $\begin{array}{c}\text { Bloco de agregado leve (pedra-pome) com } \\
\text { argamassa comum }\end{array}$ & 100 & 400 \\
\hline $\begin{array}{c}\text { Bloco de agregado denso com argamassa comum } \\
\text { Bloco celular auto clavado com uma fina camada de } \\
\text { argamassa }\end{array}$ & 100 & 500 \\
\hline \begin{tabular}{c} 
argara \\
\hline
\end{tabular}
\end{tabular}

Fonte: Eurocode 6 Part 1.2 (2005) (tradução própria).

A Figura 2.20 retirada do Eurocode mostra esquematicamente o procedimento das isotermas para um pilar de alvenaria estrutural com incêndio nas quatro faces.

A partir desta redução a verificação da seção é feita no Estado Limite Último (ELU) com ações combinadas de acordo com as recomendações usuais do código europeu. Desta forma, em situação de exposição ao fogo a solicitação de cálculo $\left(N_{S d}\right)$ na parede de alvenaria deve ser menor ou igual à força resistente de cálculo deste elemento estrutural considerando a redução de seção $\left(N_{R d, f i \theta_{2}}\right)$, conforme equação 2.40 .

$N_{S d} \leq N_{R d, f i \theta_{2}}$

E o valor da força resistente de cálculo da parede ou pilar de alvenaria é calculado pela equação 2.41 .

$N_{R d, f i \theta_{2}}=\Phi\left(f_{d \theta_{1}} A_{\theta_{1}}+f_{d \theta_{2}} A_{\theta_{2}}\right)$ 


\section{Em que:}

$\Phi$ é o fator de minoração da capacidade resistente da parede, encontrado no item 6.1.2.2 do Eurocode 6 Part 1.1, que considera uma eventual excentricidade adicional $\left(e_{\Delta \theta}\right)$;

$f_{d \theta_{1}}$ é a resistência a compressão de cálculo da alvenaria até a temperatura $\theta_{1}$;

$f_{d \theta_{2}}$ é a resistência a compressão de cálculo da alvenaria entre as temperaturas $\theta_{1}$ e $\theta_{2}$;

$A_{\theta_{1}}$ é a área de alvenaria com temperatura até $\theta_{1}$;

$A_{\theta_{2}}$ é a área de alvenaria com temperatura entre $\theta_{1}$ e $\theta_{2}$.

Figura 2.20 - Ilustração das isotermas do procedimento simplificado para um pilar de alvenaria estrutural

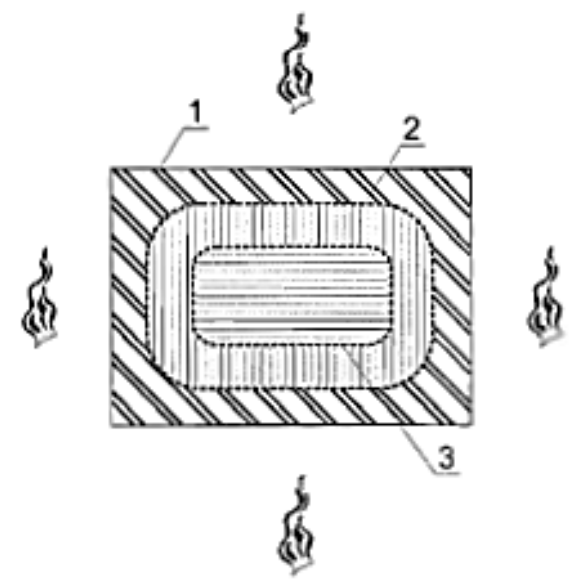

(a) seção transversal do pilar exposto ao fogo com com curvas isotérmicas idealizadas pelo curvas isotérmicas reais

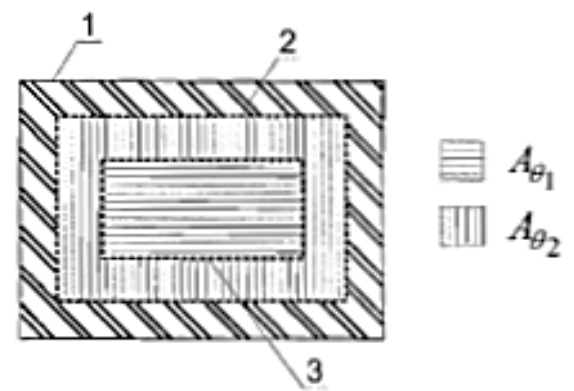

(b) seção transversal do pilar exposto ao fogo método de cálculo simplificado

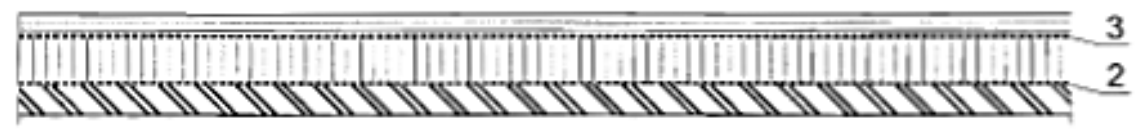

\section{Legenda}

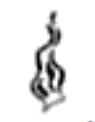

(c) corte separado da seção

1 limite da seção transversal original

2 curva isotérmica para $\theta=\theta_{2}$

3 curva isotérmica para $\theta=\theta_{1}$

Fonte: Eurocode 6 Part 1.2 (2005) (tradução própria).

Em função do perfil não linear de temperaturas, que ocorre na seção da alvenaria em consequência da variação térmica no elemento, ocorre uma excentricidade $\left(e_{\Delta \theta}\right)$ que pode ser calculada pela equação 2.42 .

$e_{\Delta \theta}=\frac{1}{8} h_{e f}^{2} \frac{\alpha_{t}\left(\theta_{2}-20\right)}{t_{F r}} \leq h_{e f} / 20$ 
Em que:

$\alpha_{t}$ é o coeficiente de expansão térmica;

$h_{e f}$ é a altura efetiva da parede;

$\theta_{2}$ é a temperatura acima da qual descarta-se a resistência do material [ $\left.{ }^{\circ} \mathrm{C}\right]$;

$t_{F r}$ é a espessura da seção da alvenaria em que a temperatura não exceda $\theta_{2}$.

A recomendação do código europeu é para que se obtenha a distribuição de temperaturas na seção transversal da alvenaria por meio de ensaios do elemento em laboratório, onde é possível obter as isotermas ao longo do tempo de exposição ao fogo. Se não for possível realizar os ensaios, deve-se buscar uma base de dados confiável para as isotermas.

\subsubsection{ACI/TMS $216.1-14$}

O ACI/TMS 216.1-14 (2014) baseia-se na verificação das paredes em função da garantia de valores mínimos para a espessura efetiva das paredes ao apresentar o procedimento para dimensionar estruturas de alvenaria em situação de incêndio. Esta espessura é determinada com base no tipo de bloco e do tempo requerido de resistência ao fogo e em seu cálculo são levados em conta fatores como tipo de acabamento e configuração dos vazios do bloco.

A espessura equivalente mínima necessária para resistência ao fogo de 0,5 a 4 horas de parede de blocos de concreto, blocos cerâmicos, vergas e pilares de alvenaria estrutural são apresentadas por meio de tabelas no código americano. Como este trabalho possui como objetivo estudar o comportamento da alvenaria estrutural não armada de blocos de concreto em situação de incêndio, será disposta apenas a tabela referente a esta situação. A Tabela 2.18 apresenta as mínimas espessuras equivalentes em função do tempo para blocos de concreto com diferentes tipos de agregado.

A espessura equivalente das paredes de alvenaria $\left(T_{\text {ea }}\right)$ representa uma espessura que desconsidera os vazios dos blocos e é dada pela soma da espessura equivalente do bloco $\left(T_{\mathrm{e}}\right)$ com a espessura equivalente do seu acabamento $\left(T_{\mathrm{ef}}\right)$, como mostrado na equação 2.43 .

$T_{\text {ea }}=T_{\mathrm{e}}+T_{\mathrm{ef}}$

A espessura equivalente do bloco $\left(T_{\mathrm{e}}\right)$ é calculada para estruturas não grauteadas ou parcialmente grauteadas pela equação 2.44 , que relaciona o volume liquido do bloco $\left(V_{n}\right)$ com a área da face do bloco ( em que, $L$ é o comprimento e $H$ a altura do bloco), assim como 
recomenda o Sandard Building Code. Se a estrutura for totalmente grauteada a espessura equivalente é a própria espessura do bloco. E caso os vazados dos blocos sejam preenchidos com areia, cascalho, brita, escória, pedra-pomes, ardósia expandida, xisto expandido, argila expandida, cinzas volantes expandidas, cinzas, perlita ou vermiculita, a espessura equivalente deve ser considerada como a espessura do bloco.

$T_{\mathrm{e}}=V_{n} / L . H$

Tabela 2.18 - Espessura mínima equivalente para paredes de alvenaria de blocos de concreto

\begin{tabular}{|c|c|c|c|c|c|c|c|}
\hline \multirow[t]{2}{*}{ Tipo de agregado } & \multicolumn{7}{|c|}{$\begin{array}{c}\text { Mínima espessura equivalente } T_{e a}(\mathrm{~cm}) \text { em função do tempo } \\
\text { requerido de resistência ao fogo } * * *\end{array}$} \\
\hline & $30 \mathrm{~min}$ & $45 \mathrm{~min}$ & $60 \mathrm{~min}$ & $90 \mathrm{~min}$ & $120 \mathrm{~min}$ & $180 \mathrm{~min}$ & $240 \mathrm{~min}$ \\
\hline $\begin{array}{c}\text { Cascalho de calcário ou } \\
\text { silício } \\
\end{array}$ & 5,1 & 6,1 & 7,1 & 9,1 & 10,7 & 13,5 & 15,7 \\
\hline $\begin{array}{l}\text { Pedra calcária, cinzas ou } \\
\text { escória resfriada a ar }\end{array}$ & 4,8 & 5,8 & 6,9 & 8,6 & 10,2 & 12,7 & 15,0 \\
\hline $\begin{array}{c}\text { Argila expandida, xisto } \\
\text { expandido ou ardósia } \\
\text { expandida }\end{array}$ & 4,6 & 5,6 & 6,6 & 8,4 & 9,1 & 11,2 & 13,0 \\
\hline $\begin{array}{l}\text { Escória expandida ou pedra- } \\
\text { pomes }\end{array}$ & 3,8 & 4,8 & 5,3 & 6,9 & 8,1 & 10,2 & 11,9 \\
\hline
\end{tabular}

Fonte: ACI/TMS 216.1-14 (2014) (tradução própria e conversão para centímetros).

A contribuição na resistência ao fogo do acabamento em paredes de alvenaria depende do tipo de material, de sua espessura e se a face onde se encontra aplicado está exposta ao fogo ou não. Quando o acabamento é aplicado na face não exposta ao fogo o código americano recomenda que sua espessura seja ajustada por um fator tabelado para encontrar a espessura equivalente do acabamento $\left(T_{\text {ef }}\right)$. A Tabela 2.19 apresenta estes fatores que consideram os materiais de fabricação do bloco e o material utilizado para acabamento. A espessura equivalente encontrada deve ser somada à espessura equivalente do bloco de concreto $\left(T_{\mathrm{e}}\right)$ para o cálculo da espessura equivalente da parede $\left(T_{\text {ea }}\right)$, que será utilizada para verificar a resistência ao fogo segundo os dados da Tabela 2.18 .

Para os acabamentos aplicados na face exposta ao fogo tanto de paredes de blocos de concreto como cerâmicos, a recomendação do código americano é calcular a resistência ao fogo considerando incrementos de tempo fornecidos pela Tabela 2.20 para cada tipo de acabamento isoladamente. 
Tabela 2.19 - Fator multiplicador da espessura dos acabamentos aplicados na face não exposta ao fogo das paredes

\begin{tabular}{c|c|c|c|c}
\hline \hline \multirow{2}{*}{ Tipo de material utilizado na parede } & \multicolumn{3}{|c}{ Tipo de acabamento aplicado à parede } \\
\cline { 2 - 5 } & $\begin{array}{c}\text { Reboco de cimento } \\
\text { Portland e areia* ou } \\
\text { ladrilho hidráulico }\end{array}$ & $\begin{array}{c}\text { Reboco de } \\
\text { gesso e areia }\end{array}$ & $\begin{array}{c}\text { Reboco de gesso } \\
\text { com vermiculita ou } \\
\text { perlita }\end{array}$ & $\begin{array}{c}\text { Drywall } \\
\text { (Gesso } \\
\text { acartonado) }\end{array}$ \\
\hline \hline \multicolumn{4}{c|}{ Paredes de alvenaria de concreto } & \multirow{2}{*}{3} \\
\hline \hline $\begin{array}{c}\text { Alvenaria de concreto - Silicoso, } \\
\text { calcário, cal, cinzas, escória de alto } \\
\text { forno resfriada a ar }\end{array}$ & 1 & 1,25 & 1,75 & 2,25 \\
\hline $\begin{array}{c}\text { Alvenaria de concreto - feito com 80\% } \\
\text { ou mais de xisto expandido, ardósia } \\
\text { expandida, argila expandida, escória } \\
\text { expandida ou pedra-pomes }\end{array}$ & 0,75 & 1 & 1,25 & \\
\hline \hline
\end{tabular}

Fonte: Adaptado do ACI/TMS 216.1-14 (2014) (tradução própria).

Tabela 2.20 - Tempo de contribuição de cada material de acabamento aplicado na face exposta ao fogo

\begin{tabular}{l|c}
\hline \multicolumn{1}{c}{ Acabamento } & Tempo (min) \\
\hline \hline \multicolumn{2}{c}{ Drywall (gesso acartonado) } \\
\hline \hline $9,5 \mathrm{~mm}$ & 10 \\
$12,7 \mathrm{~mm}$ & 15 \\
$15,9 \mathrm{~mm}$ & 20 \\
Duas camadas de 9,5 mm & 25 \\
Uma camada de 9,5 mm e uma camada de 12,7 mm & 35 \\
Duas camadas de 12,7 mm & 40 \\
\hline \hline \multicolumn{2}{c}{ Drywall tipo "X" (resistente ao fogo) } \\
\hline \hline $12,7 \mathrm{~mm}$ & 25 \\
$15,9 \mathrm{~mm}$ & 40 \\
\hline \hline Argamassa de cimento Portland e areia aplicada diretamente sobre a alvenaria* \\
\hline \hline \multicolumn{2}{c}{ Argamassa de cimento Portland e areia sobre tela de metal } \\
\hline \hline $19 \mathrm{~mm}$ & 20 \\
$22,2 \mathrm{~mm}$ & 25 \\
$25,4 \mathrm{~mm}$ & 30 \\
\hline \hline
\end{tabular}

Fonte: Adaptado do ACI/TMS 216.1-14 (2014) (tradução própria e convertido para milímetro). 
Caso uma parede seja exposta ao fogo em ambas as faces e possua materiais de acabamento diferentes em suas faces, deve-se verificar considerando cada uma como sendo a face de exposição ao fogo e a resistência será fornecida pelo menor tempo obtido nos cálculos. E se o acabamento for aplicado em ambas as faces, contribuindo para a resistência ao fogo, essa contribuição total deve ser limitada à metade do que foi atribuído à parede sem acabamento.

Quando houver paredes múltiplas de alvenaria de blocos de concreto e/ou cerâmica (Figura 2.21), a resistência ao fogo do conjunto $(R)$ deve ser calculada considerando a resistência ao fogo de cada parede e também a influência do espaço entre elas, se houver. A equação 2.45 fornecida pelo código americano permite o cálculo da resistência total do conjunto e é válida tanto para paredes de bloco de concreto e blocos cerâmicos como para a combinação dos dois materiais.

$R=\left(R_{1}^{0,59}+R_{2}^{0,59}+\cdots+R_{n}^{0,59}+A_{1}+A_{2}+\cdots+A_{n}\right)^{1,7}$

Em que:

$R_{1}, R_{2}, \ldots, R_{n}$ representam a resistência ao fogo das camadas $1,2, \ldots, \mathrm{n}$, respectivamente [horas]; $A_{1}, A_{2}, \ldots, A_{n}$ são os fatores que levam em consideração o espaço entre as camadas e podem ser considerados com valor igual a 0,30. São válidos para espaços preenchidos com ar e com dimensão entre 1,27 e $8,89 \mathrm{~cm}$.

Figura 2.21 - Esquema de paredes múltiplas

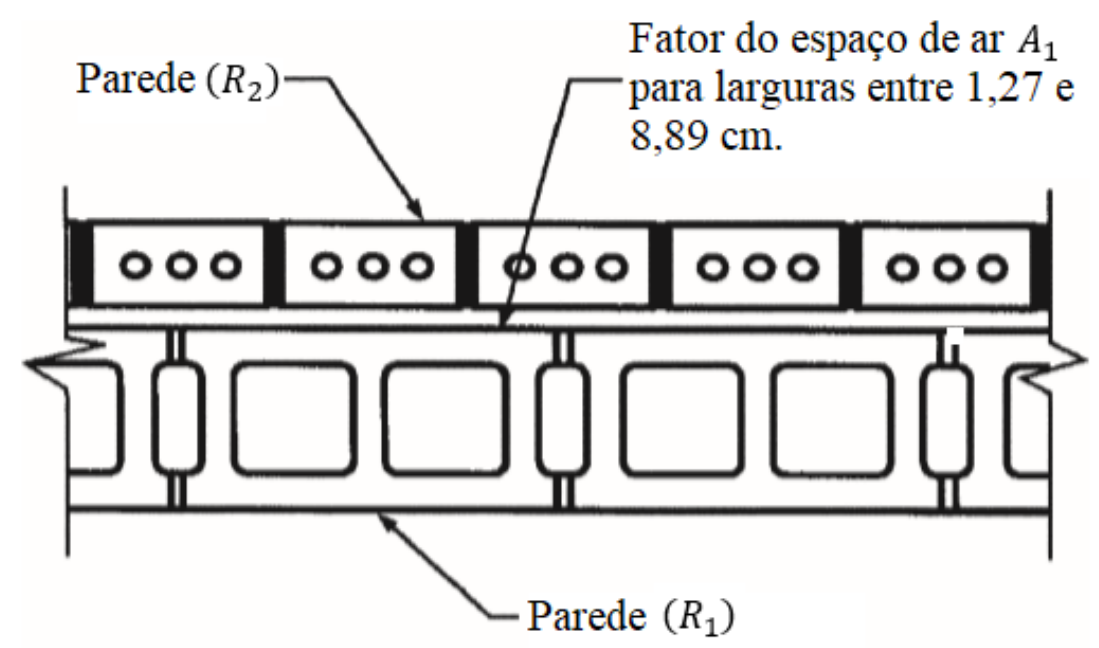

$\left(R_{1}\right)=$ tempo de resistência ao fogo da parede 1

$\left(R_{2}\right)=$ tempo de resistência ao fogo da parede 2

$A_{1}=$ fator do espaço de $\operatorname{ar}=0,3$

Fonte: ACI/TMS 216.1-14 (2014) (tradução própria). 


\subsubsection{Standards Australia AS 3700}

O código australiano AS 3700 (2011) é o único que considera explicitamente todos os três critérios para o dimensionamento da alvenaria estrutural em situação de incêndio. Nele são especificados níveis de resistência ao fogo (Fire Resistance levels - FRLs) para as paredes com base em critérios ligados à adequabilidade estrutural (estabilidade), integridade/estanqueidade (resistência à fissuração excessiva e passagem de gases e chamas), e isolamento térmico (resistência à passagem de calor).

O critério de adequabilidade estrutural é influenciado por fatores como a expansão térmica dos materiais utilizados na fabricação dos blocos, as vinculações das paredes em suas extremidades e a sua esbeltez (que depende da espessura dos blocos e da distância entre os apoios verticais e horizontais das paredes). A integridade/estanqueidade é afetada tanto pela espessura dos blocos adotados na alvenaria como pelos materiais utilizados na fabricação das unidades. A questão do isolamento térmico fornecido pela parede está diretamente ligada à densidade e composição dos blocos, à espessura das paredes e existência de grauteamento, e também a quaisquer possíveis revestimentos ou acabamentos aplicados na superfície.

O código fornece duas recomendações para o dimensionamento das paredes de alvenaria em situação de incêndio. A primeira delas é projetar para que os critérios de adequabilidade estrutural, integridade e isolamento térmico sejam atendidos e para isso são tabelados valores relacionados à espessura dos blocos, esbeltez das paredes e cobrimento das armaduras. A segunda opção é projetar a partir de resultados obtidos em ensaios laboratoriais, associando-os com ábacos de dimensionamento fornecidos pelos fabricantes dos blocos. Diferentemente da Austrália, em geral, os fabricantes de blocos brasileiros não fornecem tais ábacos de dimensionamento, portanto convém focar apenas nas recomendações para o método tabelado fornecido pelo código australiano, como referência de critério de cálculo.

De acordo com o Manual M55¹ apud Leite; Moreno e Torres (2016) este método tabelado é bastante conservador por ser representativo de qualquer tipo de alvenaria fabricada na Austrália, inclusiva as de má adequabilidade estrutural e baixo isolamento térmico. Para o dimensionamento pelo método de adequabilidade estrutural, a norma limita o índice de esbeltez da parede pelos valores de referência da Tabela 2.21, de acordo com o tipo de alvenaria (armada ou não armada) e do tipo de material empregado na fabricação dos blocos.

${ }^{1}$ CONCRETE MASONRY ASSOCIATION OF AUSTRALIA. Part B, Chapter 4, Fire. Manual M55: design and construction of concrete masonry buildings. Australia, 2012. 
O cálculo do índice de esbeltez varia em função do tipo de vinculação: a equação 2.46 é utilizada para os casos em que as paredes não possuem apoio nas laterais; paredes com vinculação em uma ou nas duas laterais têm seu índice de esbeltez fornecido pelo menor valor calculado nas equações de 2.46 a 2.48 .

$$
\begin{aligned}
& S_{r f}=a_{v f} \cdot H / t \\
& S_{r f}=\frac{0,7}{t} \sqrt{a_{v f} \cdot H \cdot a_{k} \cdot L} \\
& S_{r f}=a_{k} \cdot L / t
\end{aligned}
$$

Em que:

$S_{r f}$ é o índice de esbeltez da parede submetida ao incêndio;

$a_{v f}$ é um fator que vale 0,75 se o elemento possuir apoio em toda sua extensão lateral e 2,0 caso não haja esta restrição;

$H$ é a altura entre sues travamento verticais da parede;

$t$ é a espessura total da parede perpendicular ao seu eixo principal;

$a_{k}$ é um fator que vale 1,0 se a parede possuir apoio superior e inferior e 2,5 caso a parede possua apenas apoio inferior;

$L$ é o comprimento da parede que pode ser: entre as faces laterais restringidas da parede; o comprimento da parede que possua travamento lateral somente em uma das faces; ou se houver

\begin{tabular}{|c|c|c|c|c|c|c|c|}
\hline & \multirow{2}{*}{ Tipo de unidade da alvenaria } & \multicolumn{6}{|c|}{ "Tempo de resistência ao fogo (min) } \\
\hline & & 30 & 60 & 90 & 120 & 180 & 240 \\
\hline \multirow[t]{8}{*}{1} & Alvenaria não armada & & & & & & \\
\hline & (i) Blocos cerâmicos & 25,0 & 22,5 & 21,0 & 20,0 & 18,0 & 17,0 \\
\hline & (ii) Blocos de silicato de cálcio com agregado basáltico & & & & & & \\
\hline & (A) menos de $45 \%$ de todos os agregados & 20,5 & 19,0 & 18,0 & 17,5 & 16,5 & 15,5 \\
\hline & (B) pelo menos de $45 \%$ de todos os agregados & 25,0 & 22,5 & 21,0 & 20,0 & 18,0 & 17,0 \\
\hline & (iii) Blocos de concreto com agregado basálticos & & & & & & \\
\hline & (A) menos de $45 \%$ de todos os agregados & 19,5 & 18,0 & 17,0 & 16,0 & 15,5 & 15,0 \\
\hline & (B) pelo menos de $45 \%$ de todos os agregados & 25,0 & 22,5 & 21,0 & 20,0 & 18,0 & 17,0 \\
\hline & Alvenaria armada & 36,0 & 36,0 & 36,0 & 36,0 & 36,0 & 36,0 \\
\hline
\end{tabular}
aberturas ou juntas de prumo na parede, o comprimento é medido até esta abertura ou junta.

Tabela 2.21 - Índice de esbeltez máximo para adequabilidade estrutural 
O código australiano fornece também uma tabela com os valores de espessura mínima das paredes de alvenaria para a verificação do critério de isolamento térmico. A Tabela 2.22 apresenta estes valores de referência e leva em consideração o tipo de material utilizado nos blocos.

Tabela 2.22 - Espessura mínima das paredes considerando o critério de isolamento térmico

\begin{tabular}{l|c|c|c|c|c|c}
\hline \hline \multirow{2}{*}{$\begin{array}{c}\text { Tipo de unidade da } \\
\text { alvenaria }\end{array}$} & \multicolumn{6}{|c}{ Espessura mínima da parede (mm) } \\
\cline { 2 - 7 } & 30 & 60 & 90 & 120 & 180 & 240 \\
\cline { 2 - 7 } & 60 & 90 & 110 & 130 & 160 & 180 \\
\hline \hline Cerâmica & 50 & 70 & 90 & 110 & 135 & 160 \\
\hline Silicato de Calcio & & & & & & \\
\hline Concreto com densidade: & 55 & 80 & 100 & 120 & 150 & 180 \\
(a) $>1800 \mathrm{~kg} / \mathrm{m}^{3}$ & 55 & 75 & 90 & 110 & 135 & 160 \\
\hline \hline
\end{tabular}

Fonte: AS 3700 (2011) (tradução própria).

Para o critério de integridade/estanqueidade, quando não for possível obter os resultados dos testes em laboratório, a parede de alvenaria poderá ser considerada como tendo um nível de resistência ao fogo satisfatório para este critério se atender aos requisitos da Tabela 2.21 para adequação estrutural (no nível de resistência ao fogo exigido para o critério de integridade) e aos requisitos da Tabela 2.22 para isolamento térmico (no nível de resistência ao fogo exigido para o critério de integridade).

\subsection{Estudo sobre trabalhos realizados com alvenaria em situação de incêndio}

Al Nahhas et al. (2007) analisaram experimental e numericamente o comportamento de uma parede com blocos de concreto celulares submetida a elevadas temperaturas e carregamento durante o aquecimento. Os blocos possuíam resistência nominal característica de 4,0 MPa, como usados na maioria das construções de alvenaria na França, a parede (corpo de prova) foi executada com juntas de assentamento de argamassa com espessura de $12 \mathrm{~mm}$ resultando nas dimensões de 2,82 m de altura, 2,80 m de comprimento e 19,7 cm de espessura. Para o ensaio de simulação de incêndio foi utilizado um forno a gás com elevação da temperatura seguindo a curva de incêndio-padrão da ISO 834-1:1999. Para a aplicação da carga distribuída de 13 ton/m na parede foi utilizado um atuador servo-controlado que aplicou uma carga vertical de $357 \mathrm{kN}$ em uma viga metálica de distribuição posicionada sobre a parede. 
Durante o ensaio foram medidos os deslocamentos verticais e horizontais de pontos das paredes por meio de transdutores do tipo LVTD. Com duração de 6 horas, a temperatura dos gases do forno chegou a $1200^{\circ} \mathrm{C}$, e para obter a curva temperatura $\mathrm{x}$ tempo no material dos blocos foram utilizados cabos termopares tipo K. As temperaturas foram medidas em três blocos diferentes, e em cada um deles foram posicionados termopares nas quatro faces internas dos blocos celulares, sendo o ponto 1 o mais próximo da face exposta ao fogo, os pontos 2 e 3 nas paredes do septo central e o ponto 4 o mais próximo da face não exposta. Como resultado foi observado que os deslocamentos vertical e horizontal apresentaram máximos de 25 e $45 \mathrm{~mm}$ respectivamente, e as temperaturas de cada ponto segue mostrada no gráfico da Figura 2.22.

Figura 2.22 - Evolução da temperatura em função do tempo para pontos de medição na seção do bloco

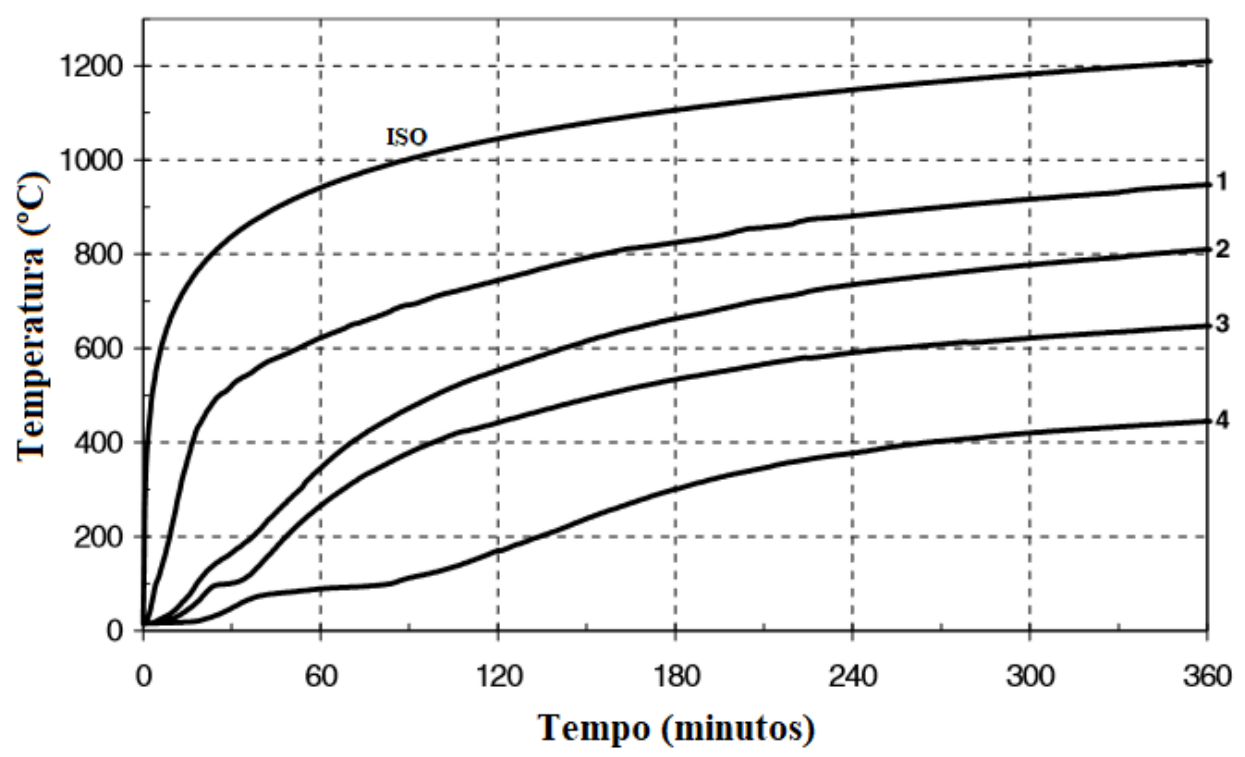

Fonte: Nahhas et al. (2007)

Observa-se que com 6 horas de ensaio as temperaturas no material do bloco variaram entre 450 e $950^{\circ} \mathrm{C}$ ao longo da seção transversal da parede. E também que próximo aos $100^{\circ} \mathrm{C}$ as curvas de elevação da temperatura dos pontos 2, 3 e 4 apresentaram patamares, que podem ser relacionados com a energia térmica absorvida pela mudança de fase da água livre contida nos poros dos blocos de concreto (evaporação).

Para a simulação numérica, os autores consideraram a transferência de calor por condução, convecção e radiação no interior da parede e entre as faces da mesma e os gases aquecidos do interior do forno e do ambiente. Também foi considerado um modelo de entalpia para a energia térmica absorvida durante a evaporação da água no interior dos poros dos blocos. Ao longo da espessura da parede os blocos foram divididos em 3 subseções, sendo a central com metade da espessura e as demais com um quarto cada, assim, a parede foi modelada 
termicamente com o balaço energético de cada subseção. Os resultados calculados para a evolução de temperatura em cada ponto foram próximos dos valores obtidos experimentalmente, portanto os parâmetros considerados na modelagem térmica mostraram-se satisfatórios.

Rosemann (2011) estudou a resistência ao fogo, pelo critério de isolamento térmico, de paredes de alvenaria estrutural de blocos cerâmicos, com os objetivos de: avaliar experimentalmente o comportamento das paredes de alvenaria; identificar os principais fatores que influenciam no desempenho em temperaturas elevadas; avaliar a variação da resistência pelo preenchimento dos vazados internos dos blocos; avaliar a influência de revestimentos de argamassa e verificar a adequação dos métodos de cálculo analíticos e numéricos.

Para isso ensaiou quatro variações de paredes de blocos cerâmicos com largura de 2,70 $\mathrm{m}$, altura de 2,60 $\mathrm{m}$ e espessura de $14 \mathrm{~cm}$, a primeira sem revestimento e sem preenchimento, a segunda apenas com revestimento em ambas as faces, a terceira somente com enchimento nos vazados e a última com revestimento e preenchimento. As paredes foram ensaiadas duas a duas de tal forma que funcionavam como as paredes do forno, posicionadas a uma distância $75 \mathrm{~cm}$ entre elas, como mostra Figura 2.23.

Figura 2.23 - Disposição dos corpos de prova em planta

PAREDE SEM REVESTIMENTO

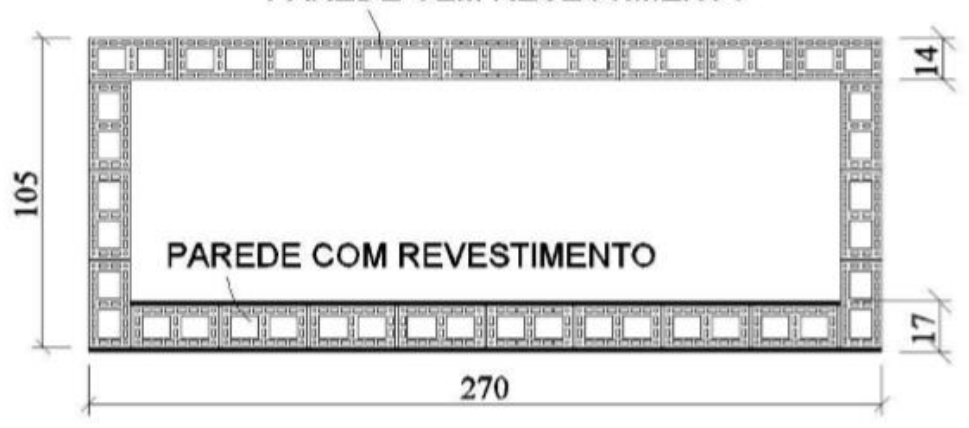

PAREDE SEM REVESTIMENTO

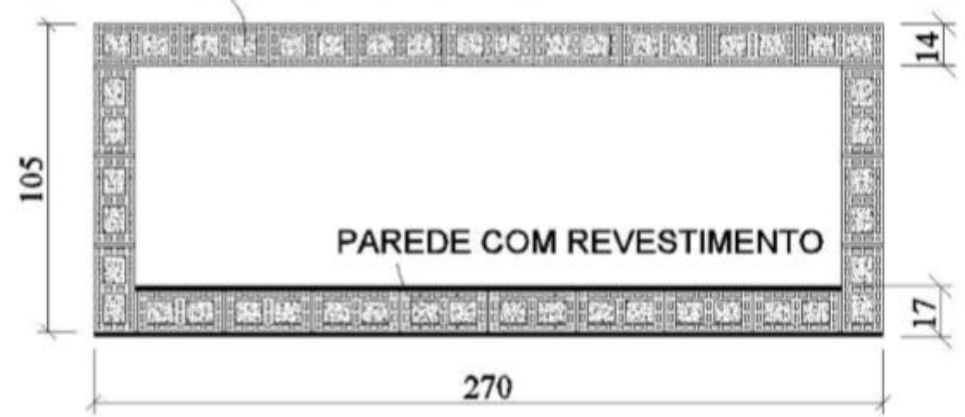

Fonte: Rosemann (2011) 
Foram utilizados quatro queimadores e o aquecimento dos gases internos foi controlado de forma a seguir a curva de incêndio-padrão da ISO 834-1:1999. O critério de isolamento térmico adotado foi o da ABNT NBR 5628:2011 que é um aumento de $140^{\circ} \mathrm{C}$ na temperatura média da parede ou de $180^{\circ} \mathrm{C}$ em qualquer ponto.

Para medir a temperatura da face não exposta ao fogo foram utilizados 5 termopares em cada parede, um no centro e cada um dos outros 4 no centro de cada quadrante da parede. A parede sem revestimento e sem preenchimento atingiu o critério de isolamento com 106 minutos de ensaio e a parede com revestimento de argamassa mista (cimento, cal e areia) em ambas as faces com espessura de $1,5 \mathrm{~cm}$ e sem preenchimento atingiu o limite após 196 minutos, representando um aumento de $85 \%$ na resistência pelo critério de isolamento térmico. A parede sem revestimento e com preenchimento de areia média e a parede com revestimento de argamassa mista em ambas as faces e preenchimento dos vazados com areia apresentaram um ganho de resistência ao fogo de $129 \%$ e $282 \%$ respectivamente se comparadas com a primeira variação estudada, pois resistiram pelo critério de isolamento por 243 e 405 minutos, respectivamente.

Para avaliar numericamente a resistência ao fogo das paredes de alvenaria estrutural de blocos cerâmicos pelo critério do isolamento térmico, o autor utilizou dois métodos, o analítico da Brick Industry Assocation (BIA) e o método dos elementos finitos através do programa CAST3M. O método analítico do BIA baseia-se no cálculo de uma espessura equivalente para cada tipo de parede, e o valor do tempo de resistência ao fogo pelo critério de isolamento é fornecido por tabelas, os resultados obtidos foram entre $16 \%$ e $29 \%$ menores que os valores encontrados experimentalmente.

Para o método dos elementos finitos adotou-se que a transferência de calor ocorre por condução nas partes sólidas e por convecção e radiação nos furos dos blocos, entre os gases quentes e a face exposta e também entre os a face não exposta e o ambiente. Foram utilizados elementos bidimensionais do tipo TRI6 e para cada caso apenas um bloco foi representado em função do custo computacional. Após uma boa calibração do modelo, foi possível simular as situações de ensaio chegando ao maior erro de $6,4 \%$ na parede com revestimento e preenchimento. Assim o autor também conseguiu traçar o perfil de temperaturas ao longo da seção transversal da parede e realizar uma análise paramétrica da influência da espessura da camada de revestimento de argamassa que resultou em uma relação quase linear, com aumento da resistência da parede em cerca de 35 minutos para cada $5 \mathrm{~mm}$ de revestimento. 
Rigão (2012) analisou experimentalmente o comportamento de pequenas paredes em alvenaria estrutural cerâmica frente às altas temperaturas, com os objetivos de: verificar a estanqueidade dos gases quentes e nível de fissuração devido ao aumento da temperatura; estudar o aumento da temperatura ao longo da seção transversal; analisar o aumento de carga devido à dilatação térmica e avaliar a redução da resistência da argamassa, prismas e pequenas paredes devido às temperaturas elevadas. Para isso confeccionou os corpos de prova (prismas de dois blocos e pequenas paredes de cinco fiadas) com argamassa industrializada e blocos cerâmicos de $29 \mathrm{~cm}$ de comprimento, $14 \mathrm{~cm}$ de largura e $19 \mathrm{~cm}$ de altura, fornecidos por fabricante local. Todos os corpos de prova foram submetidos ao aquecimento em um forno elétrico cuja taxa de aquecimento não atendia nenhuma curva de incêndio-padrão.

Os corpos de prova prismáticos de argamassa foram moldados com dimensões de 4 x 4 x 16 centímetros em três lotes. $O$ primeiro lote foi utilizado para a caracterização mecânica à temperatura ambiente resultando na resistência média à compressão de 4,10 MPa. O segundo lote foi submetido ao aquecimento até a temperatura de $400^{\circ} \mathrm{C}$ e comprimidos após resfriamento natural, a resistência à compressão residual média foi de $2,32 \mathrm{MPa}(56,6 \%)$, e o terceiro lote foi submetido ao aquecimento até $900^{\circ} \mathrm{C}$ e não apresentou resistência significativa quando comprimidos.

Os blocos e os prismas foram caracterizados mecanicamente à temperatura ambiente apresentando resistência média à compressão e 11,5 MPa e 5,30 MPa respectivamente. Um lote de prismas foi submetido ao aquecimento até $400^{\circ} \mathrm{C}$ e outro até a temperatura de $900^{\mathrm{a}} \mathrm{C}$ e as resistências residuais médias encontradas foram de 3,87 $\mathrm{MPa}(73 \%)$ e 2,58 $\mathrm{MPa}(48,7 \%)$ respectivamente. Já as pequenas paredes foram ensaiadas como mostrado na Figura 2.24, com aquecimento em apenas uma das faces por um período de 360 minutos chegando à temperatura de $900^{\circ} \mathrm{C}$ e carga aplicada de $78 \mathrm{kN} / \mathrm{m}$ durante todo este período, após o resfriamento lento em temperatura ambiente foram comprimidas, apresentando resistência residual média de 2,50 $\mathrm{MPa}$, a parede integra em temperatura ambiente apresentou resistência de 3,77 MPa, portanto a resistência residual foi de $63 \%$.

Estas pequenas paredes ensaiadas com aquecimento em apenas uma face por 360 minutos foram utilizadas para verificar o atendimento da estanqueidade pois não foi observado desprendimento de gases aquecidos pelas fissuras das paredes. Observou-se também que o incremento de carga devido à dilatação térmica das paredes provocou um aumento na tensão das pequenas paredes em torno de 0,60 MPa. E com o posicionamento dos termopares para avaliar o perfil de temperaturas na seção das paredes concluiu-se que, para a situação de aquecimento imposta, o critério de isolamento térmico foi atingido entre 220 e 270 min nas 
paredes, mas este parâmetro não pode ser comparado com as normas nacionais devido à não padronização da curva temperatura $\mathrm{x}$ tempo.

Figura 2.24 - Ensaio das pequenas paredes durante o aquecimento em apenas uma face

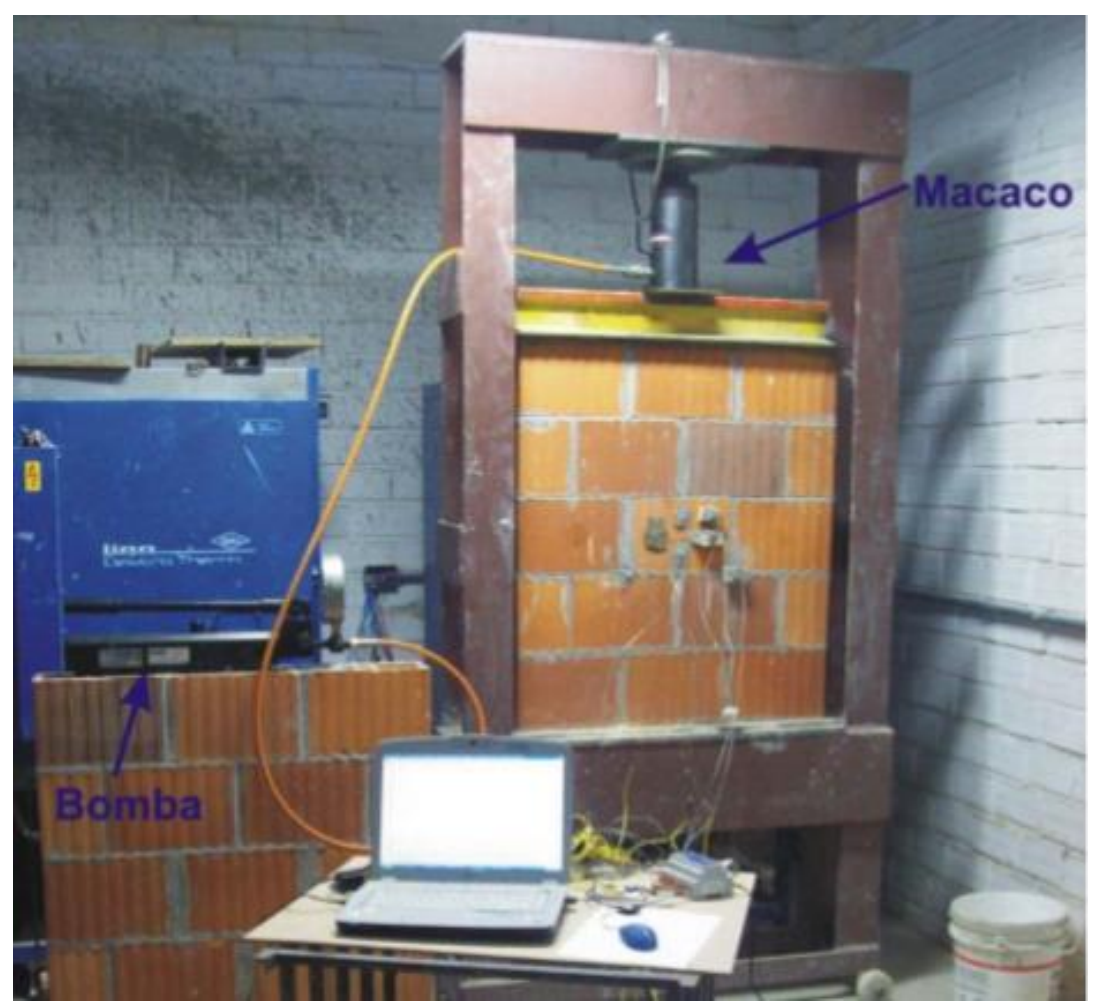

Fonte: Rigão (2012)

O Instituto de Pesquisas Tecnológicas (IPT) (2013) (2015) (2016) realizou três ensaios com paredes de alvenaria com blocos de concreto com o objetivo de verificar o atendimento dos critérios de isolamento, estanqueidade e integridade durante o período de ensaio. Em todos os ensaios os corpos de prova foram submetidos ao aquecimento com a curva de temperatura média do forno seguindo a curva de incêndio-padrão da ABNT NBR 10636:1989 com desvios dentro dos valores máximos permitidos.

A Tabela 2.23 a seguir apresenta um resumo das condições de cada um dos ensaios e os resultados obtidos para cada um dos critérios. Os corpos de prova dos ensaios 1 e 3 foram executados com blocos de concreto com largura de $190 \mathrm{~mm}$, comprimento de $390 \mathrm{~mm}$ e altura de $190 \mathrm{~mm}$ e o corpo de prova do ensaio 2 reproduzia uma parede com blocos de concreto com espessura de $140 \mathrm{~mm}$. Todas as paredes possuíam revestimento de argamassa com espessura de $15 \mathrm{~mm}$ na face exposta ao fogo.

Vale ressaltar que como não há normalização nacional que determine metodologias de ensaio para avaliação do critério de integridade (resistência mecânica), o IPT aplicou choques mecânicos nos corpos de prova 3 minutos antes do término dos ensaios e avaliou se a condição 
das paredes era satisfatória para este critério. Os limites dos critérios de isolamento e estanqueidade seguiram o prescrito na ABNT NBR 5628:2001.

Tabela 2.23 - Resumo dos ensaios do IPT

\begin{tabular}{|c|c|c|c|c|c|c|c|c|c|}
\hline \multirow{2}{*}{ Ensaio } & \multirow{2}{*}{$\begin{array}{c}\text { Data } \\
\text { do } \\
\text { ensaio }\end{array}$} & \multicolumn{3}{|c|}{$\begin{array}{c}\begin{array}{c}\text { Dimensões dos corpos de } \\
\text { prova }\end{array} \\
\end{array}$} & \multirow{2}{*}{ Graute } & \multirow{2}{*}{$\begin{array}{c}\text { Tempo } \\
\text { de ensaio } \\
\text { (minutos) }\end{array}$} & \multirow{2}{*}{$\begin{array}{l}\text { Critério de } \\
\text { Isolamento } \\
\text { Térmico }\end{array}$} & \multirow{2}{*}{$\begin{array}{c}\text { Critério de } \\
\text { Estanqueidade }\end{array}$} & \multirow{2}{*}{$\begin{array}{l}\text { Critério de } \\
\text { Integridade }\end{array}$} \\
\hline & & $\begin{array}{c}\text { Largura } \\
(\mathrm{m})\end{array}$ & $\begin{array}{c}\text { Altura } \\
(\mathrm{m})\end{array}$ & $\begin{array}{c}\text { Espessura } \\
(\mathrm{mm})\end{array}$ & & & & & \\
\hline 1 & $\operatorname{mar} / 13$ & 2,70 & 2,62 & 220 & - & 180 & $151 \mathrm{~min}$ & $\begin{array}{c}\text { Manteve-se } \\
\text { estanque durante } \\
\text { todo o ensaio }\end{array}$ & $\begin{array}{l}\text { Resultados } \\
\text { satisfatórios }\end{array}$ \\
\hline 2 & jun/15 & 2,60 & 2,60 & 160 & - & 120 & $106 \mathrm{~min}$ & $\begin{array}{c}\text { Manteve-se } \\
\text { estanque durante } \\
\text { todo o ensaio }\end{array}$ & $\begin{array}{l}\text { Resultados } \\
\text { satisfatórios }\end{array}$ \\
\hline 3 & mar/16 & 2,60 & 2,60 & 205 & $\begin{array}{c}\text { Todos os } \\
\text { furos }\end{array}$ & 240 & $\begin{array}{c}\text { Não foi atingido } \\
\text { durante o } \\
\text { ensaio }\end{array}$ & $\begin{array}{c}\text { Manteve-se } \\
\text { estanque durante } \\
\text { todo o ensaio }\end{array}$ & $\begin{array}{l}\text { Resultados } \\
\text { satisfatórios }\end{array}$ \\
\hline
\end{tabular}

Fonte: Adaptado dos relatórios de ensaio do IPT

Rodovalho (2018) estudou numericamente o comportamento termo estrutural de blocos e prismas de alvenaria de concreto em situação de incêndio, com os objetivos de: simular o comportamento térmico de prismas com e sem revestimento em elevadas temperaturas e também simular numericamente o comportamento termomecânico de prismas em situação de incêndio sob carregamento de compressão visando encontrar parâmetros relacionados ao critério de resistência mecânica. Para isso, a autora modelou computacionalmente, através do programa Abaqus, blocos e prismas de concreto submetidos à compressão e utilizou os parâmetros de Oliveira (2014) para balizar os seus modelos mecânicos. Os blocos possuíam resistência média característica de 8,68 MPa, comprimeto de $39 \mathrm{~cm}$, altura de $19 \mathrm{~cm}$, espessura de 14 cm e relação área líquida/área bruta de 54,76\%.

Para a simulação térmica dos prismas de blocos de concreto a malha do modelo mecânico foi mantida e foi adotado elementos para transferência de calor do tipo DC3D8. Adotou-se aquecimento apenas em uma face e seguindo a curva de incêndio-padrão da ISO 834-1:1999. A transferência de calor adotada para o meio sólido foi a condução e entre o ar e o material do bloco foi a convecção e a radiação, tanto na face exposta ao fogo como na face não exposta. Para o ar nas cavidades vazadas dos blocos foi utilizado a interação fluido-estrutura em que a transferência de calor ocorre por condução e convecção e os elementos adotados na malha foram do tipo FC3D8. Nesta etapa foram avaliadas três variações de prismas para o critério de isolamento térmico, a resistência encontrada para os prismas sem revestimento foi 
de 86 minutos, para os prismas com revestimento apenas na face aquecida foi de 106 minutos e para os prismas com revestimento em ambas as faces foi de $137 \mathrm{~min}$. O revestimento considerado foi argamassa mista de cimento, cal e areia com espessura de $1,5 \mathrm{~cm}$.

As simulações termomecânicas foram realizadas somente para prismas de blocos de concreto sem revestimento e o aquecimento aplicado foi tanto nas duas faces como em apenas uma. Foram modeladas situações com carregamentos de $20 \%$ e de $35 \%$ da resistência característica dos prismas $\left(f_{p k}\right)$. Além disso, foram analisados casos sem restrição de deslocamento vertical (S.R.D.V.) e com restrição de deslocamento vertical (C.R.D.V.) e nas situações de aquecimento diferencial entre as faces também foi analisado os casos com restrição rotacional (C.R.R.) e sem restrição rotacional (S.R.R.).

A falha pelo critério de resistência mecânica ocorre quando em um determinado tempo de incêndio o elemento não suporta mais o carregamento para o qual foi projetado, portanto para o caso sem restrição vertical (carga constante) a ruptura foi estimada pela capacidade resistente fornecida pelas curvas de tensão-deformação do bloco e da argamassa que variam em função da temperatura atingida pelo material. Para o caso com restrição vertical a carga aplicada aumenta em função da dilatação térmica até atingir um pico, em seguida decresce, assim a ruptura foi considera no instante em que a força atinge novamente o valor inicialmente aplicado. O resultado de resistência encontrado para cada situação segue mostrado na Tabela 2.24, somente para o caso de aquecimento em apenas uma face sem restrição vertical e carga de $20 \%$ $f_{p k}$ que o software não chegou à ruptura dentro do intervalo analisado de 300 minutos.

Tabela 2.24 - Resumo das simulações termomecânicas

\begin{tabular}{|c|c|c|c|c|c|c|c|}
\hline \multicolumn{3}{|c|}{ Esquema da simulação } & Carregamento & \multicolumn{2}{|c|}{ S.R.D.V. (min) } & \multicolumn{2}{|c|}{ C.R.D.V. (min) } \\
\hline 18 & * & $* 2$ & $20 \%$ fpk & & & & \\
\hline$\approx 2$ & s & 5. & $35 \%$ fpk & & & & \\
\hline & & & & C.R.R. & S.R.R. & C.R.R. & S.R.R. \\
\hline 2 & 2 & , & $20 \%$ fpk & - & - & 300 & \\
\hline 28 & s & 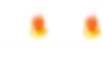 & $35 \%$ fpk & 208 & & 148 & \\
\hline
\end{tabular}


Uma vez que o critério de estanqueidade não foi analisado neste trabalho, é possível observar que para os modelos com incêndio em ambas as faces o critério que define a resistência ao fogo dos elementos é o da resistência mecânica. Mas para a situação de incêndio em apenas uma face, que apresentou resistência ao isolamento térmico de 106 minutos, a resistência ao fogo é definida pelo critério de resistência mecânica apenas nos casos circulados na Tabela 2.24 .

Lopes et al. (2018) analisaram experimentalmente paredes de alvenaria estrutural de blocos de concreto de três células em situação de incêndio. Para isso foram ensaiadas seis paredes com dimensões de 1,40 m de comprimento, 1,00 $\mathrm{m}$ de altura e $100 \mathrm{~mm}$ de espessura, sendo utilizados blocos de concreto de três células com dimensões de $200 \mathrm{~mm}$ de comprimento, $93 \mathrm{~mm}$ de altura e $100 \mathrm{~mm}$ de largura. Em função das limitações de ensaio as paredes foram confeccionadas na escala 1:2 3m relação à parede recomendada para ensaio pelos códigos europeus EM 1365-1 e EM 1363-1. Todas as paredes receberam aquecimento em apenas uma face através de um forno elétrico cujo aquecimento foi programado para acompanhar a curva de incêndio-padrão da ISO 834-1:1999. No entanto, em função da inércia térmica do forno, à capacitância térmica dos materiais dos corpos de prova e às perdas de calor pela superfície dos elementos, a temperatura dos gases dentro do forno não conseguiu acompanhar a curva padronizada com boa precisão.

Além do aquecimento, os corpos de prova foram submetidos à ação mecânica de compressão uniformemente distribuída por meio de um atuador servo-controlado conectado a um pórtico de reação e que aplicava a força em uma viga metálica de distribuição, apoiada sobre as paredes. Os corpos de prova foram enumerados de 1 a 6 , sendo que as paredes 1 e 2 foram submetidos a uma força de $208 \mathrm{kN}$ (30\% da carga de ruptura observada em Haach (2009), trabalho de referência que utilizou o mesmo tipo de blocos), as paredes 3 e 4 a uma força de $319 \mathrm{kN}$ (46\% do mesmo valor de referência) e as paredes 5 e 6 foram submetidas a uma força de $208 \mathrm{kN}$ por 90 minutos e posteriormente a carga foi aumentada a uma taxa constante de 0,05 $\mathrm{kN} / \mathrm{s}$ até o colapso.

$\mathrm{Na}$ instrumentação para medir as temperaturas na face não exposta ao fogo de cada parede foram utilizados cinco termopares do tipo K, um posicionado bem ao centro da parede e os outros quatro no centro de cada quadrante do corpo de prova. Para avaliar o comportamento da temperatura ao longo da seção transversal da parede em vários pontos, foram colocados termopares em alturas de $0,25 \mathrm{~m}, 0,50 \mathrm{~m}, 0,75 \mathrm{~m}$ e $0,98 \mathrm{~m}$ e em profundidades de meia largura 
da parede. Para obter o deslocamento lateral da parede em função do tempo foram utilizados transdutores de deslocamento (LVTD).

Com o resultado dos termopares colocados no interior da parede foi possível observar um patamar na curva temperatura x tempo próximo aos $100^{\circ} \mathrm{C}$ que ocorre em função da absorção de energia térmica para evaporação da água livre nos poros dos blocos. Com a leitura dos termopares na face não exposta ao fogo foi avaliado o período de atendimento ao critério de isolamento térmico pelo corpo de prova. Em relação ao deslocamento fora do plano (lateral), os autores observaram que nos corpos de prova 1, 2, 3 e 4 o aumento foi muito pequeno nos primeiros 15 a 30 minutos, aumentando acentuadamente após este período, mas não foi observado um padrão de deslocamento mesmo para os corpos de prova solicitados por forças de mesma intensidade. Nos corpos de prova 5 e 6 os autores apontam uma diminuição do deslocamento lateral até os 60 minutos passando a ser quase constante até os 90 minutos, e a partir daí há um aumento até o colapso da parede.

A Tabela 2.25 apresenta os tempos de falha para cada um dos critérios de resistência ao fogo, o deslocamento máximo central para fora do plano da parede e a carga de colapso nos ensaios de capacidade de carga em elevadas temperaturas. Neste caso o critério de resistência mecânica foi adotado pelo colapso estrutural, e o critério do isolamento térmico foi avaliado por uma temperatura média de $140^{\circ} \mathrm{C}$ ou temperatura máxima de $180^{\circ} \mathrm{C}$ na face oposta ao fogo. Os capôs sem dados indicam que os corpos de prova não atingiram a falha do critério durante o tempo ensaiado.

Tabela 2.25 - Resultados dos ensaios de Lopes et al. (2018)

\begin{tabular}{c|c|c|c|c|c|c|c}
\hline \hline \multirow{2}{*}{$\begin{array}{c}\text { Corpo de } \\
\text { prova }\end{array}$} & \multicolumn{4}{|c|}{ Tempo de falha } & \multirow{2}{*}{$\begin{array}{c}\text { Carga última } \\
\text { no plano da }\end{array}$} & \multicolumn{2}{c}{$\begin{array}{c}\text { Deslocamento } \\
\text { máximo central }\end{array}$} \\
\cline { 2 - 5 } & $\begin{array}{c}\text { Temperatura } \\
\text { média }\end{array}$ & $\begin{array}{c}\text { Temperatura } \\
\text { máxima }\end{array}$ & $\begin{array}{c}\text { Perda de } \\
\text { estanqueidade }\end{array}$ & $\begin{array}{c}\text { Colapso } \\
\text { estrutural }\end{array}$ & parede (kN) & $\begin{array}{c}\text { Leitura } \\
(\mathrm{mm})\end{array}$ & $\begin{array}{c}\text { Tempo } \\
(\mathrm{min})\end{array}$ \\
\hline \hline 1 & 80 & 72 & - & - & - & 5,52 & 74 \\
2 & 73 & 67 & - & - & - & 5,80 & 79 \\
3 & - & - & - & 83 & - & 9,52 & 80 \\
4 & - & - & - & 40 & - & 10,74 & 40 \\
5 & - & - & - & - & 273 & 11,58 & 68 \\
6 & - & - & - & - & 421 & 11,14 & 66 \\
\hline \hline
\end{tabular}

Em que: I - Isolamento térmico; E - Estanqueidade; $R$ - Resistência mecânica 


\section{PROGRAMA EXPERIMENTAL I: CARACTERIZAÇÃO DOS MATERIAIS E DA ALVENARIA}

\subsection{Considerações iniciais}

O programa experimental deste trabalho foi realizado no Laboratório de Estruturas da Escola de Engenharia de São Carlos em duas etapas. Na primeira etapa foram realizados os ensaios de caracterização dos blocos e meios-blocos de concreto, da argamassa e da alvenaria, em que os corpos de prova são determinados pela norma ABNT NBR 15961-1:2011 (prismas de duas fiadas e pequenas paredes). Nesta etapa foi realizada a caracterização em temperatura ambiente das unidades e dos elementos de alvenaria com resistência nominal de 4,0 e 10,0 MPa, ambas com espessuras de 140 e 190 mm. Mesmo que os blocos com espessura de 190 mm não façam parte dos ensaios em temperaturas elevadas desta pesquisa, eles foram caracterizados e os resultados dispostos neste texto para fornecer parâmetros de modelagem às outras pesquisas e trabalhos subsequentes do grupo de pesquisa.

A seguir serão apresentados os ensaios de caracterização e propriedades dos materiais realizados. Neste capítulo são apresentados os resultados médios e característicos, juntamente com o desvio-padrão e o coeficiente de variação $(C V)$. Quando pertinente são apresentados os valores individuais. Todos os resultados individuais estão expostos detalhadamente no APÊNDICE B. A nomenclatura adotada para especificar os blocos ensaiados foi: " $B X-R_{x}$ " em que, $B$ significa bloco, $X$ o número da unidade ensaiada e $R_{x}$ a resistência característica da unidade. Analogamente, para especificar os meios-blocos ensaiados foi utilizada a nomenclatura " $M B X-R_{x}$ " em que $M B$ significa meio-bloco. Não foi especificada a espessura do bloco na nomenclatura, pois esta característica pode ser distinguida visualmente.

\subsection{Caracterização física e mecânica das unidades de concreto}

Foram utilizados nesta pesquisa blocos e meios-blocos de concreto fornecidos pela empresa Tatu Pré-moldados de duas classes de resistência, das classes A e B com resistência característica nominal de 10,0 MPa e 4,0 MPa respectivamente. Ambos os tipos de blocos utilizados na pesquisa possuíam espessura nominal de 140 e $190 \mathrm{~mm}$, ou seja, ao todo foram recebidas 4 variações de blocos e 4 de meios-blocos conforme mostrado na Tabela 3.1. A Figura 3.1 mostra as variações das unidades para a resistência de 10,0 MPa. Foi pedido que as unidades 
fossem enviadas de um mesmo lote de fabricação para não haver divergências de composição nos materiais ensaiados. No instante de recebimento das unidades, os blocos e meios-blocos foram inspecionados visualmente conforme recomendações da ABNT NBR 6136:2016 e não foi revelada a presença de defeitos significativos, tais como quebras e superfícies irregulares.

Tabela 3.1 - Descrição das unidades recebidas para ensaio

\begin{tabular}{|c|c|c|c|c|c|}
\hline \multirow{2}{*}{$\begin{array}{l}\text { Tipo de } \\
\text { Unidade }\end{array}$} & \multirow{2}{*}{ Classe } & \multirow{2}{*}{$\begin{array}{c}\text { Resistência } \\
\text { característica } \\
\text { nominal } \\
(\mathrm{MPa})\end{array}$} & \multicolumn{3}{|c|}{ Dimensões nominais (mm) } \\
\hline & & & Largura & Altura & Comprimento \\
\hline \multirow{4}{*}{ Bloco } & \multirow{2}{*}{ A } & \multirow{2}{*}{10,0} & 140 & 190 & 390 \\
\hline & & & 190 & 190 & 390 \\
\hline & \multirow{2}{*}{ B } & \multirow{2}{*}{4,0} & 140 & 190 & 390 \\
\hline & & & & 190 & 390 \\
\hline \multirow{4}{*}{ Meio Blocc } & \multirow{2}{*}{ A } & \multirow{2}{*}{10,0} & 140 & 190 & 390 \\
\hline & & & 190 & 190 & 390 \\
\hline & \multirow{2}{*}{ B } & \multirow{2}{*}{4,0} & 140 & 190 & 390 \\
\hline & & & 190 & 190 & 390 \\
\hline
\end{tabular}

Figura 3.1 - Variações de blocos e meios-blocos para a resistência de 10,0 MPa.

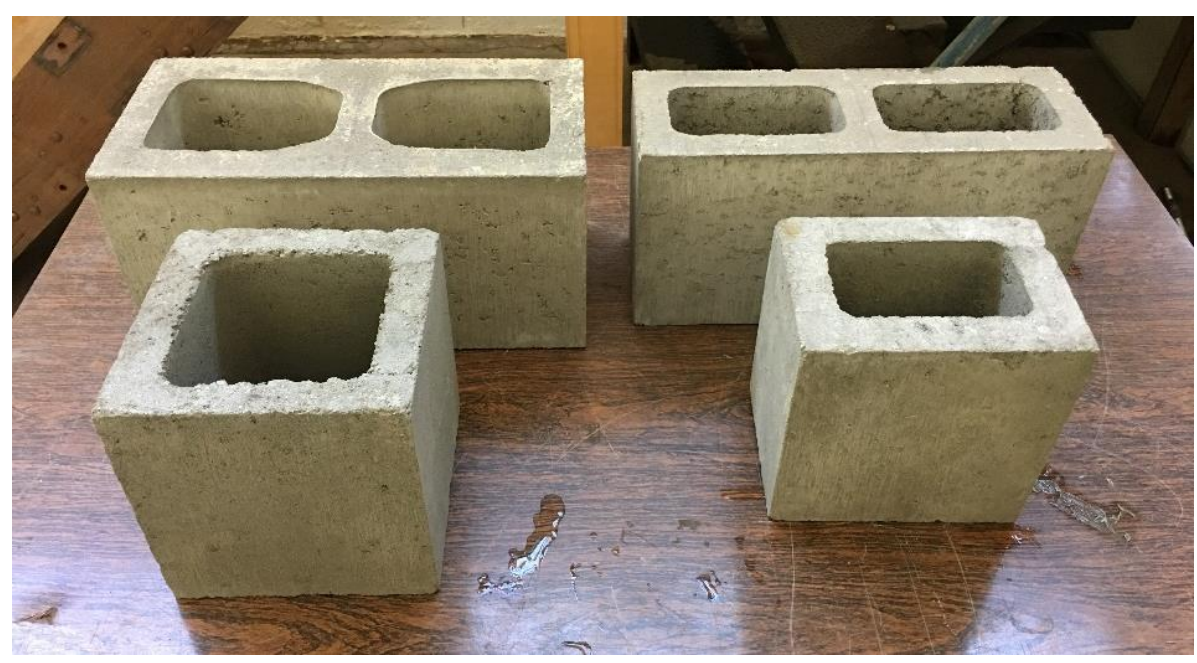

Em seguida as características geométricas, físicas e mecânicas das unidades foram avaliadas de acordo com a ABNT NBR 12118:2013 com a quantidade mínima de corpos de prova e as tolerâncias para aceitação dos lotes de unidades estabelecidas pela ABNT NBR 6136:2016. As propriedades estudadas e as quantidades adotadas de uma mesma variação das unidades para cada ensaio seguem apresentadas na Tabela 3.2. 
Tabela 3.2 - Propriedades avaliadas e quantidades ensaiadas para cada tipo de unidade

\begin{tabular}{|c|c|c|c|}
\hline \multirow{2}{*}{\multicolumn{2}{|c|}{ Propriedades Avaliadas }} & \multicolumn{2}{|c|}{ Quantidade da amostra } \\
\hline & & Bloco & Meio-bloco \\
\hline \multirow{6}{*}{ Geométricas } & Dimensões efetivas & 6 & 6 \\
\hline & $\begin{array}{c}\text { Espessura dos septos e das paredes } \\
\text { externas }\end{array}$ & 6 & 6 \\
\hline & Dimensões dos furos & 6 & 6 \\
\hline & Raio das mísulas & 6 & 6 \\
\hline & Área Bruta & 6 & 6 \\
\hline & Área Líquida & 6 & 6 \\
\hline \multirow[t]{2}{*}{ Físicas } & $\begin{array}{c}\text { Massa seca, massa saturada e } \\
\text { massa aparente }\end{array}$ & 6 & 6 \\
\hline & Absorção de água & 6 & 6 \\
\hline Mecânicas & Resistência à compressão & 6 & 6 \\
\hline
\end{tabular}

\subsubsection{Propriedades geométricas das unidades}

As propriedades geométricas foram obtidas em blocos e meios-blocos retirados aleatoriamente do lote, conforme recomendação da ABNT NBR 12118:2013. As medidas foram obtidas com o auxílio dos seguintes equipamentos: uma régua metálica com resolução de $1 \mathrm{~mm}$, um esquadro metálico de $90^{\circ}$, um paquímetro com resolução de 0,01 mm, um compasso e uma balança digital com resolução de $0,1 \mathrm{~g}$ com gancho para medidas hidrostáticas.

A Figura 3.2 apresenta um esquema da representação de cada face do bloco.

Figura 3.2 - Esquema representativo das dimensões dos blocos

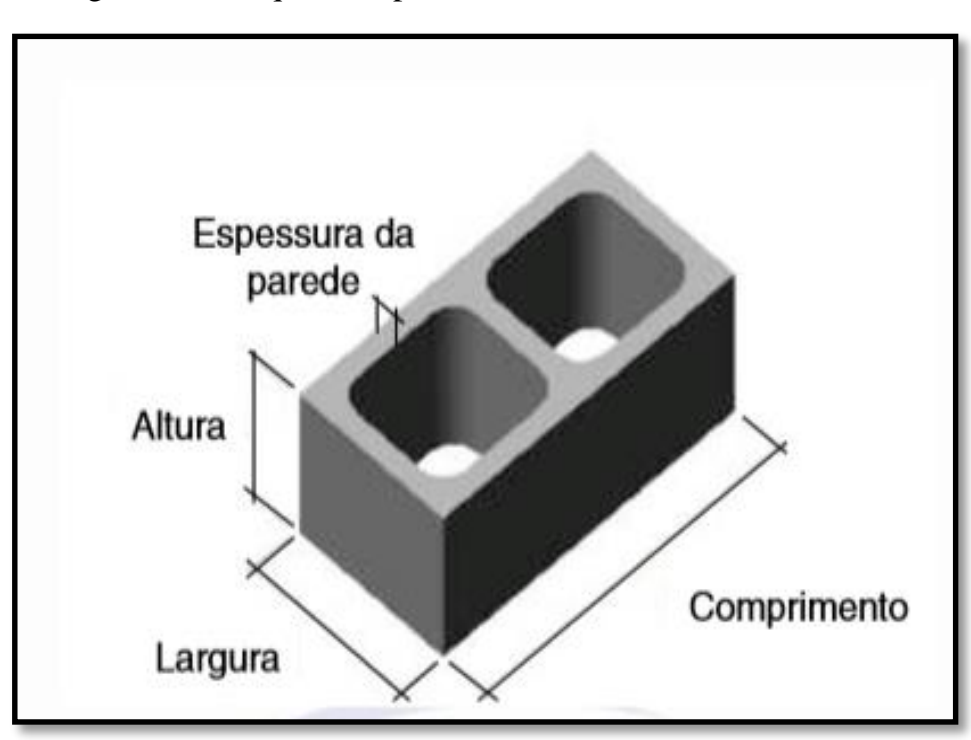

Fonte: ABNT NBR 6136:2016 
Para as dimensões efetivas foram realizadas medições em três pontos distintos de cada face da largura, altura e comprimento dos blocos e meios-blocos, conforme observado na Figura 3.3. As médias de cada bloco e as médias das leituras realizadas, bem como os valores de tolerância estabelecidos pela ABNT 6136:2016 estão apresentados na Tabela 3.3.

Figura 3.3 - Determinações das dimensões efetivas dos blocos e meios-blocos

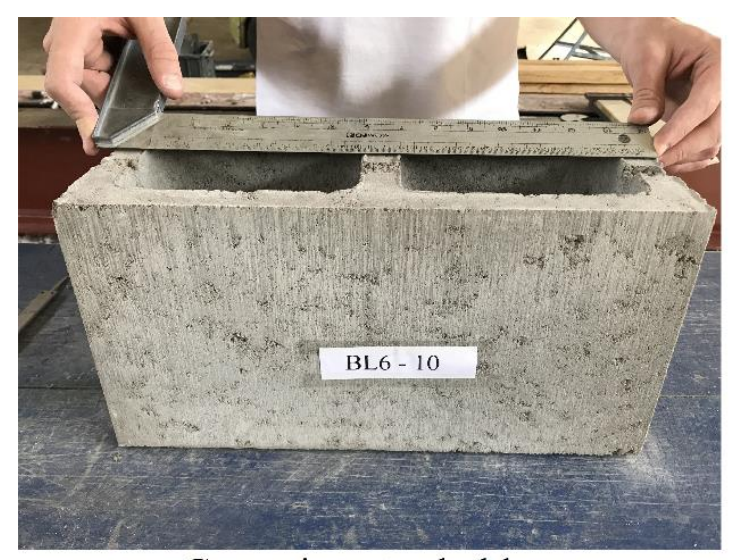

Comprimento do bloco

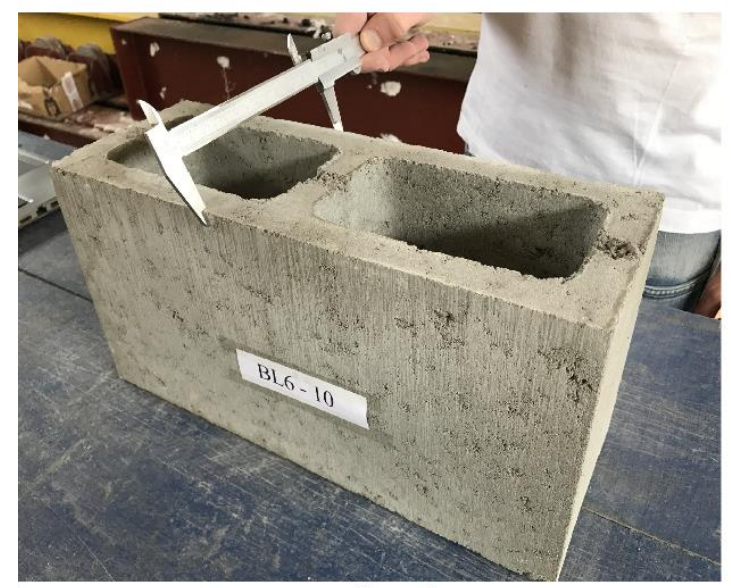

Largura do Bloco

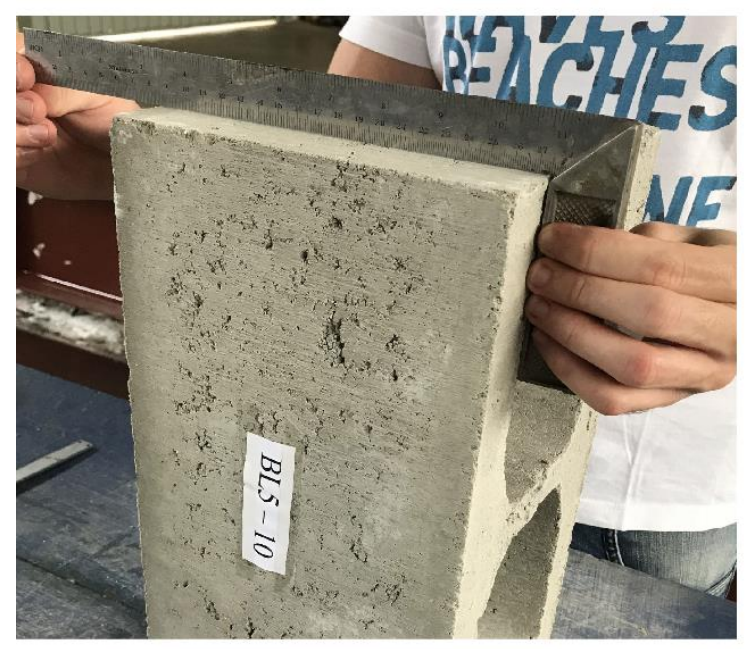

Altura do bloco

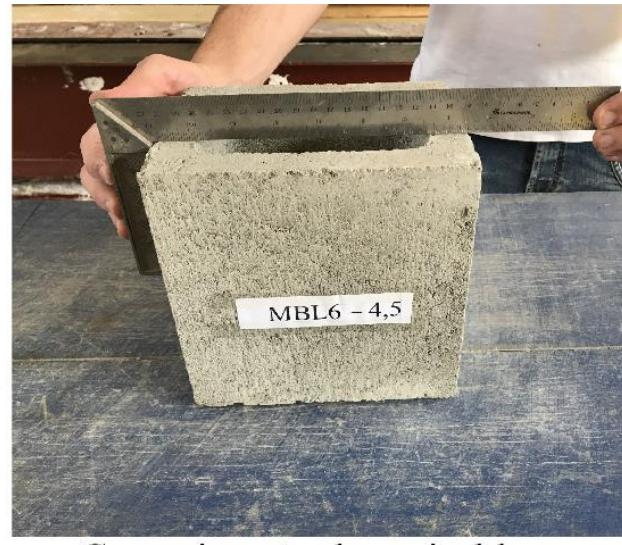

Comprimento do meio-bloco

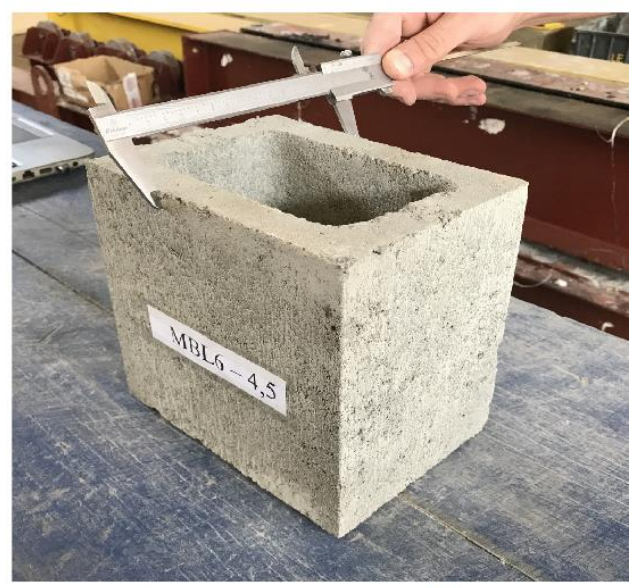

Largura do meio-bloco

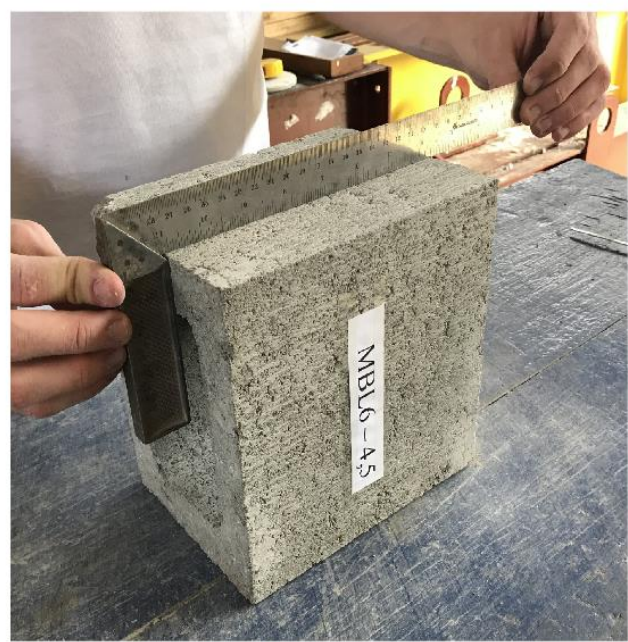

Altura do meio-bloco 
Tabela 3.3 - Dimensões efetivas dos blocos e meios-blocos de concreto

\begin{tabular}{|c|c|c|c|c|c|c|c|c|}
\hline \multicolumn{9}{|c|}{ Dimensões Efetivas } \\
\hline \multicolumn{2}{|c|}{ Tipo de unidade } & & \multicolumn{3}{|c|}{ Bloco } & \multicolumn{3}{|c|}{ Meio-bloco } \\
\hline $\begin{array}{c}\text { Resistência } \\
\text { característica } \\
\text { nominal }\end{array}$ & $\begin{array}{l}\text { Largura } \\
\text { nominal }\end{array}$ & & $\begin{array}{c}\text { Largura } \\
(\mathrm{mm})\end{array}$ & $\begin{array}{r}\text { Altura } \\
(\mathrm{mm})\end{array}$ & $\begin{array}{c}\text { Comprimento } \\
(\mathrm{mm})\end{array}$ & $\begin{array}{c}\text { Largura } \\
(\mathrm{mm})\end{array}$ & $\begin{array}{r}\text { Altura } \\
(\mathrm{mm})\end{array}$ & $\begin{array}{c}\text { Comprimento } \\
(\mathrm{mm})\end{array}$ \\
\hline \multirow{6}{*}{$10,0 \mathrm{MPa}$} & \multirow{3}{*}{$\begin{array}{l}140 \\
\mathrm{~mm}\end{array}$} & Média & 139,35 & 190,41 & 390,08 & 138,34 & 191,11 & 191,04 \\
\hline & & Desvio Padrão & 0,16 & 0,75 & 0,23 & 0,28 & 1,03 & 0,23 \\
\hline & & $\mathrm{CV}(\%)$ & 0,11 & 0,39 & 0,06 & 0,20 & 0,54 & 0,12 \\
\hline & \multirow{3}{*}{$\begin{array}{l}190 \\
\mathrm{~mm}\end{array}$} & Média & 191,14 & 191,86 & 391,81 & 191,68 & 190,11 & 191,69 \\
\hline & & Desvio Padrão & 0,29 & 0,32 & 0,20 & 0,32 & 0,75 & 0,56 \\
\hline & & $\mathrm{CV}(\%)$ & 0,15 & 0,17 & 0,05 & 0,17 & 0,39 & 0,29 \\
\hline \multirow{6}{*}{ 4,0 MPa } & \multirow{3}{*}{$\begin{array}{l}140 \\
\mathrm{~mm}\end{array}$} & Média & 139,25 & 189,80 & 390,22 & 138,20 & 188,00 & 190,58 \\
\hline & & Desvio Padrão & 0,12 & 0,35 & 0,32 & 0,57 & 0,32 & 0,33 \\
\hline & & $\mathrm{CV}(\%)$ & 0,09 & 0,18 & 0,08 & 0,41 & 0,17 & 0,17 \\
\hline & \multirow{3}{*}{$\begin{array}{l}190 \\
\mathrm{~mm}\end{array}$} & Média & 190,26 & 190,31 & 390,47 & 189,84 & 190,62 & 189,99 \\
\hline & & Desvio Padrão & 0,34 & 0,58 & 0,28 & 0,48 & 0,70 & 0,47 \\
\hline & & $\mathrm{CV}(\%)$ & 0,18 & 0,31 & 0,07 & 0,25 & 0,37 & 0,25 \\
\hline
\end{tabular}

Os valores de tolerância estabelecidos pela norma são de $\pm 2,0 \mathrm{~mm}$ para largura, e $\pm 3,0$ mm para altura e comprimento, expressas como a média das determinações executadas. Observa-se que as diferenças entre as medidas nominais e as medidas efetivas das unidades são menores que as tolerâncias prescritas pela ABNT NBR 6136:2016. Foram encontradas diferenças médias de até 2,0 $\mathrm{mm}$ nas dimensões efetivas, no entanto estas diferenças são corrigidas no instante de assentamento dos blocos.

Os blocos de concreto possuem formato tronco cônico, ou seja, as espessuras das paredes variam ao longo de sua altura, possuindo uma espessura maior na face superior (no instante do assentamento) para melhor acomodação da argamassa. As tolerâncias previstas pela norma estão expressas na Tabela 3.4.

Para verificar se as dimensões atendem a estas tolerâncias, foram determinadas, para cada uma das quatro variações de bloco estudados, as dimensões das paredes externas e dos septos de menor espessura, ou seja, na face inferior na ocasião do assentamento. E também as dimensões dos furos e o raio das mísulas na face de maior espessura, a superior na ocasião do assentamento em que os furos são menores. A Figura 3.4 traz algumas fotos destas medições realizadas. As tabelas a seguir apresentam os resultados de medições individuais e as médias para cada uma das 4 variações de blocos (Tabela 3.5, Tabela 3.6, Tabela 3.7 e Tabela 3.8). 
Tabela 3.4 - Tolerâncias de espessura mínima das paredes do bloco e dimensões mínimas dos furos e do raio das mísulas

\begin{tabular}{|c|c|c|c|c|c|c|}
\hline \multirow[b]{2}{*}{ Classe } & \multirow[b]{2}{*}{$\begin{array}{l}\text { Largura } \\
\text { Nominal } \\
(\mathrm{mm})\end{array}$} & \multirow[b]{2}{*}{$\begin{array}{l}\text { Paredes } \\
\text { Longitudinais } \\
(\mathrm{mm})^{1}\end{array}$} & \multicolumn{2}{|c|}{ Paredes Transversais } & \multirow[b]{2}{*}{$\begin{array}{l}\text { Dimensão dos } \\
\text { furos }(\mathrm{mm})^{3}\end{array}$} & \multirow[b]{2}{*}{$\begin{array}{c}\text { Raio das } \\
\text { mísulas }(\mathrm{mm}) *\end{array}$} \\
\hline & & & $\begin{array}{l}\text { Paredes } \\
(\mathrm{mm})^{1}\end{array}$ & $\begin{array}{c}\text { Transversal } \\
\text { equivalente } \\
(\mathrm{mm} / \mathrm{m})^{2} \\
\end{array}$ & & \\
\hline \multirow{2}{*}{ A } & 190 & 32 & 25 & 188 & 110 & 40 \\
\hline & 140 & 25 & 25 & 188 & 70 & 40 \\
\hline \multirow{2}{*}{ B } & 190 & 32 & 25 & 188 & 110 & 40 \\
\hline & 140 & 25 & 25 & 188 & 70 & 40 \\
\hline \multicolumn{7}{|c|}{$\begin{array}{l}{ }^{1} \text { média das medidas das paredes tomada no ponto mais estreito, com tolerância de }-1,0 \mathrm{~mm} \\
\text { para as medidas individuais }\end{array}$} \\
\hline \multicolumn{7}{|c|}{$\begin{array}{l}2 \text { soma das medidas de todas as paredes transversais aos blocos }(\mathrm{mm}) \text { dividida pelo } \\
\text { comprimento nominal do bloco }(\mathrm{m})\end{array}$} \\
\hline \multicolumn{7}{|c|}{3 valor limite da menor dimensão dos furos } \\
\hline \multicolumn{7}{|c|}{ * valor expresso individualmente } \\
\hline
\end{tabular}

Fonte: Adaptado da ABNT NBR 6136:2016

Figura 3.4 - Determinação: espessuras das paredes e dos septos, dimensões dos furos e raios das mísulas

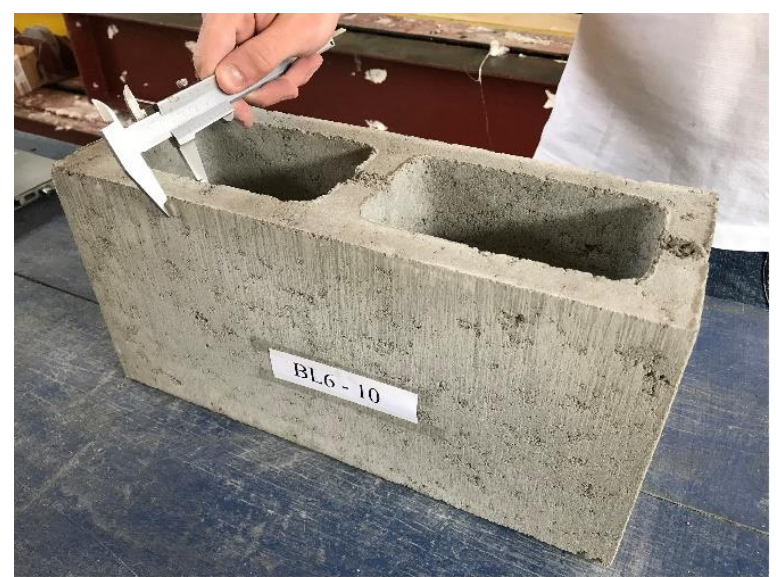

Espessura da parede longitudinal

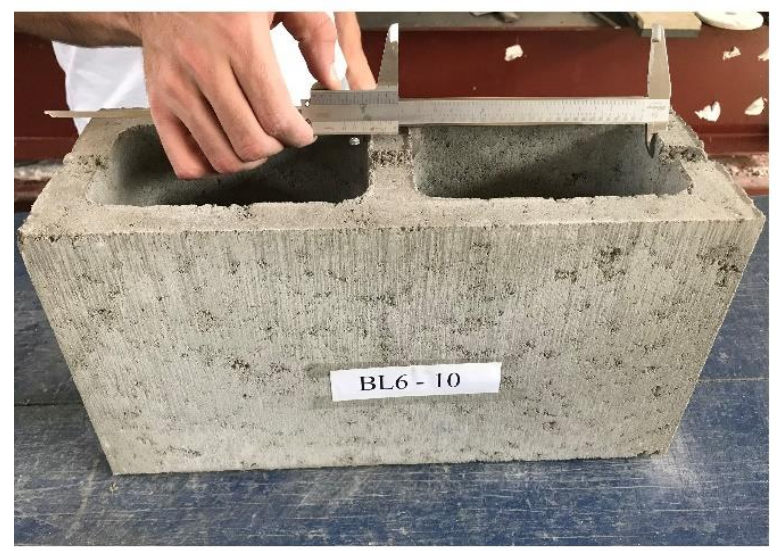

Dimensão longitudinal do furo

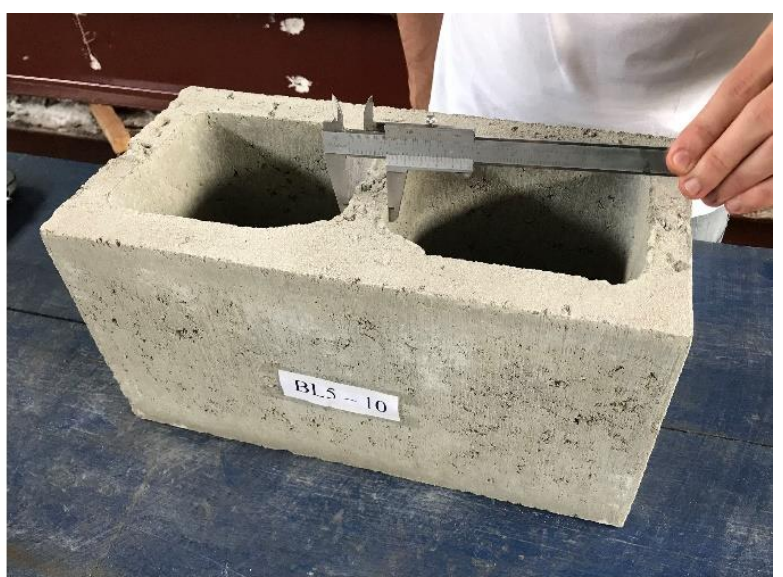

Espessura do septo

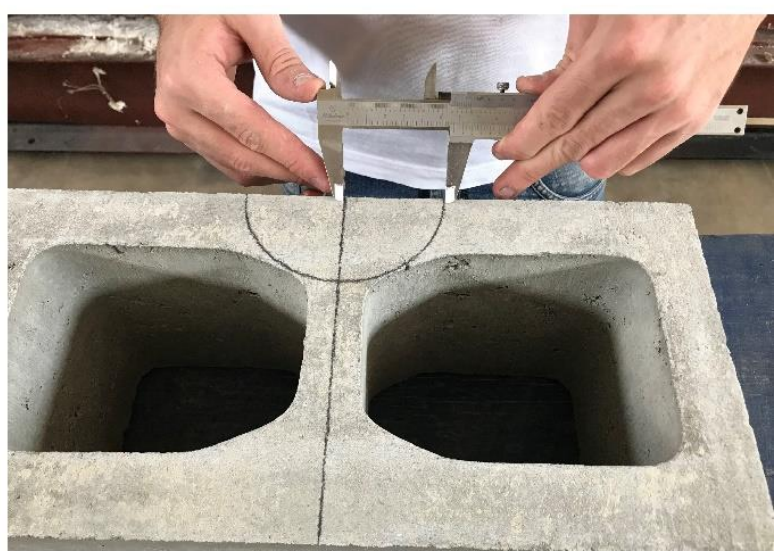

Raio da mísula 
Tabela 3.5 - Espessuras, dimensões dos furos e raios das mísulas para os blocos de 10,0 MPa e $140 \mathrm{~mm}$

\begin{tabular}{ccccc|ccc|c}
\hline \hline \multicolumn{7}{c}{ Bloco : espessuras, dimensões dos furos e raio das mísulas (10,0 MPa e 140 mm) } \\
\cline { 2 - 6 } & $\begin{array}{c}\text { Paredes } \\
\text { Longitudinais }\end{array}$ & $\begin{array}{c}\text { Paredes } \\
\text { Transversais }\end{array}$ & Septos & $\begin{array}{c}\text { Transversal } \\
\text { Equivalente }\end{array}$ & Longitudinal & Transversal & $\begin{array}{c}\text { Raísulas } \\
\text { (mm) }\end{array}$ \\
\hline \hline BL 1 & 25,22 & 25,68 & 26,35 & 263,22 & 148,90 & 79,25 & 40,40 \\
BL 2 & 25,60 & 25,78 & 26,85 & 264,25 & 149,45 & 79,45 & 40,80 \\
BL 3 & 25,43 & 25,78 & 26,40 & 264,13 & 149,40 & 79,65 & 39,90 \\
BL 4 & 25,76 & 25,46 & 26,24 & 260,97 & 149,36 & 79,92 & 41,00 \\
BL 5 & 25,97 & 25,66 & 26,06 & 263,35 & 149,22 & 79,66 & 40,00 \\
BL 6 & 25,65 & 25,45 & 26,65 & 261,03 & 149,09 & 79,46 & 40,30 \\
\hline \hline Média & $\mathbf{2 5 , 6 0}$ & $\mathbf{2 5 , 6 3}$ & $\mathbf{2 6 , 4 3}$ & - & $\mathbf{1 4 9 , 2 4}$ & $\mathbf{7 9 , 5 7}$ & - \\
Desvio Padrão & 0,26 & 0,15 & 0,28 & - & 0,21 & 0,23 & - \\
CV (\%) & 1,03 & 0,57 & 1,08 & - & 0,14 & 0,29 & - \\
\hline \hline
\end{tabular}

Tabela 3.6 - Espessuras, dimensões dos furos e raios das mísulas para os blocos de 10,0 MPa e $190 \mathrm{~mm}$

\begin{tabular}{ccccc|cc|c}
\hline \hline \multicolumn{7}{c}{ Bloco : espessuras, dimensões dos furos e raio das mísulas (10,0 MPa e 190 mm) } \\
\cline { 2 - 6 } & $\begin{array}{c}\text { Espessura (mm) } \\
\text { Longitudinais }\end{array}$ & $\begin{array}{c}\text { Paredes } \\
\text { Lransversais }\end{array}$ & Septos & $\begin{array}{c}\text { Transversal } \\
\text { Equivalente }\end{array}$ & Longitudinal & Transversal & $\begin{array}{c}\text { Raio das } \\
\text { (mulas }\end{array}$ \\
\hline \hline BL 1 & 33,09 & 25,58 & 25,35 & 261,08 & 149,40 & 114,35 & 60,00 \\
BL 2 & 32,76 & 25,36 & 25,85 & 258,83 & 149,60 & 114,25 & 59,90 \\
BL 3 & 32,96 & 25,90 & 24,64 & 264,46 & 150,14 & 114,21 & 60,10 \\
BL 4 & 32,59 & 25,40 & 25,90 & 259,46 & 149,95 & 114,25 & 59,90 \\
BL 5 & 32,58 & 25,82 & 25,35 & 263,49 & 150,01 & 114,71 & 58,26 \\
BL 6 & 32,18 & 25,99 & 25,21 & 265,16 & 149,71 & 114,47 & 58,96 \\
\hline \hline Média & $\mathbf{3 2 , 6 9}$ & $\mathbf{2 5 , 6 7}$ & $\mathbf{2 5 , 3 8}$ & - & $\mathbf{1 4 9 , 8 0}$ & $\mathbf{1 1 4 , 3 7}$ & - \\
Desvio Padrão & 0,32 & 0,27 & 0,46 & - & 0,28 & 0,19 & - \\
CV (\%) & 0,99 & 1,04 & 1,83 & - & 0,19 & 0,17 & - \\
\hline \hline
\end{tabular}

Tabela 3.7 - Espessuras, dimensões dos furos e raios das mísulas para os blocos de 4,0 MPa e $140 \mathrm{~mm}$

\begin{tabular}{|c|c|c|c|c|c|c|c|}
\hline \multicolumn{8}{|c|}{ Bloco : espessuras, dimensões dos furos e raio das mísulas $(4,0 \mathrm{MPa}$ e $140 \mathrm{~mm})$} \\
\hline & \multicolumn{4}{|c|}{ Espessura $(\mathrm{mm})$} & \multicolumn{2}{|c|}{ Dimensão dos Furos (mm) } & \multirow{2}{*}{$\begin{array}{c}\text { Raio das } \\
\text { Mísulas } \\
(\mathrm{mm})\end{array}$} \\
\hline & $\begin{array}{c}\text { Paredes } \\
\text { Longitudinais }\end{array}$ & $\begin{array}{c}\text { Paredes } \\
\text { Transversais }\end{array}$ & Septos & $\begin{array}{l}\text { Transversal } \\
\text { Equivalente }\end{array}$ & Longitudinal & Transversal & \\
\hline BL 1 & 25,46 & 25,48 & 26,58 & 261,51 & 1499,55 & $\overline{79,65}$ & 39,10 \\
\hline BL 2 & 25,56 & 25,53 & 26,14 & 261,46 & 149,87 & 79,75 & 41,00 \\
\hline BL 3 & 25,50 & 25,63 & 27,06 & 262,48 & 149,41 & 79,25 & 39,80 \\
\hline BL 4 & 25,79 & 25,43 & 26,16 & 260,52 & 149,65 & 79,80 & 39,90 \\
\hline BL 5 & 25,78 & 25,40 & 26,64 & 260,47 & 149,40 & 79,60 & 39,50 \\
\hline BL 6 & 25,69 & 25,48 & 26,63 & 261,13 & 149,30 & 79,75 & 40,80 \\
\hline "Média & $\overline{25,63}$ & 25,49 & 26,54 & - & $\overline{1449,53}$ & $\begin{array}{l}79,63 \\
\end{array}$ & - \\
\hline Desvio Padrão & 0,14 & 0,08 & 0,34 & - & 0,21 & 0,20 & - \\
\hline $\mathrm{CV}(\%)$ & 0,55 & 0,31 & 1,30 & - & 0,14 & 0,25 & - \\
\hline
\end{tabular}


Tabela 3.8 - Espessuras, dimensões dos furos e raios das mísulas para os blocos de 4,0 MPa e 190 mm

\begin{tabular}{|c|c|c|c|c|c|c|c|}
\hline \multicolumn{8}{|c|}{ Bloco : espessuras, dimensões dos furos e raio das mísulas (4,0 MPa e $190 \mathrm{~mm}$ ) } \\
\hline & \multicolumn{4}{|c|}{ Espessura $(\mathrm{mm})$} & \multicolumn{2}{|c|}{ Dimensão dos Furos (mm) } & \multirow{2}{*}{$\begin{array}{l}\text { Raio das } \\
\text { Mísulas } \\
(\mathrm{mm})\end{array}$} \\
\hline & $\begin{array}{c}\text { Paredes } \\
\text { Longitudinais }\end{array}$ & $\begin{array}{c}\text { Paredes } \\
\text { Transversais }\end{array}$ & Septos & $\begin{array}{l}\text { Transversal } \\
\text { Equivalente }\end{array}$ & Longitudinal & Transversal & \\
\hline BL 1 & 32,42 & 25,98 & 25,10 & 265,96 & 18149,10 & 1114,50 & 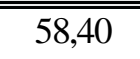 \\
\hline BL 2 & 32,55 & 25,15 & 26,25 & 257,64 & 150,25 & 115,00 & 59,20 \\
\hline BL 3 & 32,76 & 25,23 & 25,70 & 258,47 & 150,40 & 114,65 & 58,40 \\
\hline BL 4 & 32,67 & 25,53 & 26,20 & 261,79 & 150,30 & 115,31 & 59,00 \\
\hline BL 5 & 32,56 & 25,78 & 26,20 & 264,02 & 150,15 & 114,40 & 58,44 \\
\hline BL 6 & 32,31 & 26,07 & 25,40 & 266,81 & 149,85 & 115,00 & 59,00 \\
\hline Média & 32,54 & 25,62 & 2025,81 & - & ב150,01 & 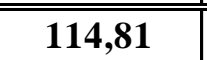 & - \\
\hline Desvio Padrão & 0,16 & 0,38 & 0,49 & - & 0,48 & 0,35 & - \\
\hline $\mathrm{CV}(\%)$ & 0,49 & 1,50 & 1,88 & - & 0,32 & 0,30 & - \\
\hline
\end{tabular}

Deve-se observar que apenas os raios das mísulas dos blocos de 4,0 MPa e largura de $140 \mathrm{~mm}$ não atenderam ao mínimo prescrito pela norma, que é de $40 \mathrm{~mm}$, mantendo-se muito próximas deste limite. Os demais resultados estão em conformidade com as tolerâncias da ABNT NBR 6136:2016. Mesmo não prescrito pela norma, realizou-se as medições de espessura das paredes e dimensões dos furos todas as variações de meios-blocos e os resultados encontram-se no APÊNDICE B.

A área bruta e a área líquida são parâmetros que permitem relacionar as cargas aplicadas com a resistência da unidade e a resistência do material da unidade, respectivamente. A equação 3.1 fornece o valor da área bruta $\left(A_{\text {bruta }}\right)$ e a equação 3.2 a área liquida $\left(A_{\text {liq }}\right)$. para a determinação da área liquida é necessário conhecer o peso submerso da unidade, conforme mostrado na Figura 3.5 juntamente com o processo de pesagem do bloco saturado.

$A_{\text {bruta }}=$ L.C

$A_{\text {liq }}=\frac{\left(m_{u}-m_{a}\right)}{\gamma \cdot H} \cdot 1000$

Em que,

$m_{u}$ é a massa do bloco saturado [g];

$m_{a}$ é a massa aparente do bloco $[\mathrm{g}]$;

$H$ é a altura do bloco $[\mathrm{mm}]$;

$L$ é a largura do bloco $[\mathrm{mm}]$;

$C$ é o comprimento do bloco $[\mathrm{mm}]$;

$\gamma$ é a massa específica da água, tomada como $0,001 \mathrm{~g} / \mathrm{mm}^{3}$. 
Figura 3.5 - Determinação da massa aparente e massa saturada
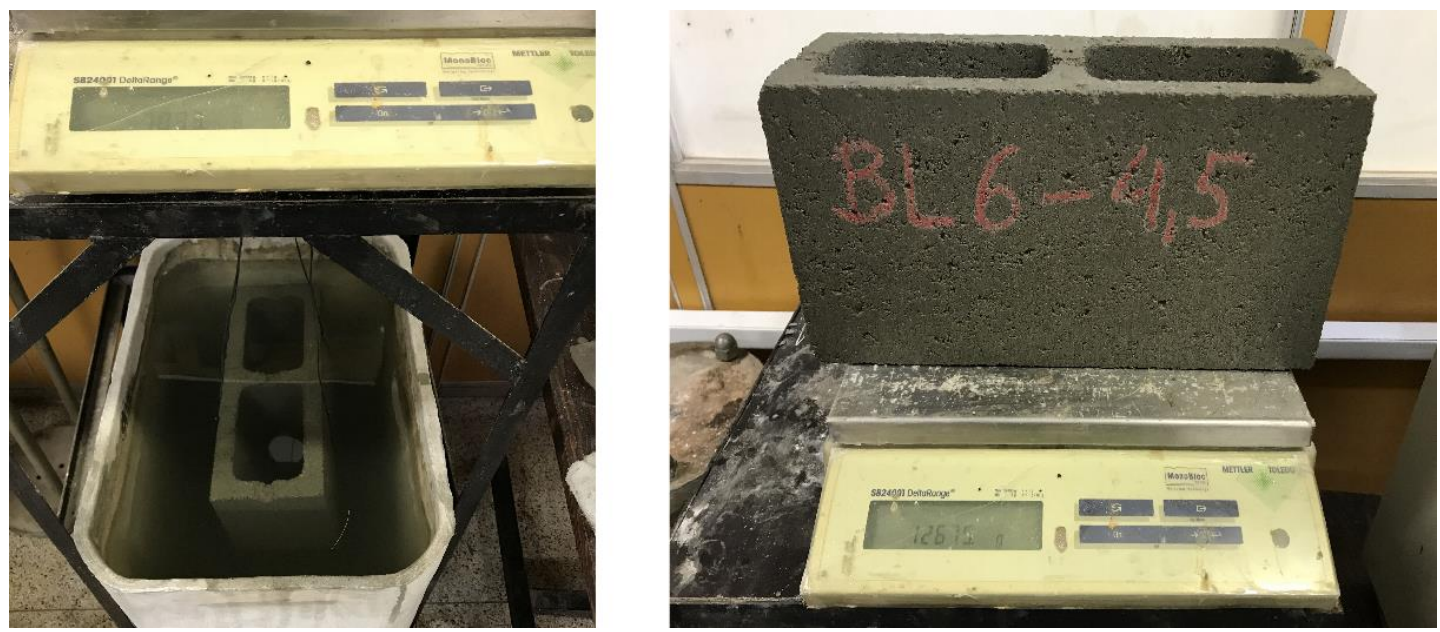

Os valores médios de área bruta e área líquida encontrados para os seis blocos e os seis meios-blocos da amostra de cada uma das quatro variações estão apresentados na Tabela 3.9 juntamente com a relação entre estas áreas. Os resultados individuais dos blocos são apresentados no APÊNDICE B.

Tabela 3.9 - Resultados para área bruta, área líquida e a proporção entre elas

\begin{tabular}{|c|c|c|c|c|c|c|c|c|}
\hline \multicolumn{9}{|c|}{ Área bruta e área líquida } \\
\hline \multicolumn{2}{|c|}{ Tipo de unidade } & & \multicolumn{3}{|c|}{ Bloco } & \multicolumn{3}{|c|}{ Meio-bloco } \\
\hline $\begin{array}{c}\text { Resistência } \\
\text { característica } \\
\text { nominal }\end{array}$ & $\begin{array}{l}\text { Largura } \\
\text { nominal }\end{array}$ & & $\begin{array}{l}\text { Área } \\
\text { bruta } \\
\left(\mathrm{mm}^{2}\right) \\
\end{array}$ & $\begin{array}{r}\text { Área } \\
\text { líquida } \\
\left(\mathrm{mm}^{2}\right) \\
\end{array}$ & $\begin{array}{c}A_{\text {liq }} / A_{\text {bruta }} \\
(\%)\end{array}$ & $\begin{array}{l}\text { Área } \\
\text { bruta } \\
\left(\mathrm{mm}^{2}\right) \\
\end{array}$ & $\begin{array}{r}\text { Área } \\
\text { líquida } \\
\left(\mathrm{mm}^{2}\right) \\
\end{array}$ & $\begin{array}{c}A_{\text {liq }} / A_{\text {bruta }} \\
(\%)\end{array}$ \\
\hline \multirow{6}{*}{$10,0 \mathrm{MPa}$} & \multirow{3}{*}{$\begin{array}{l}140 \\
\mathrm{~mm}\end{array}$} & Média & 54359,39 & 28356,32 & 52,16 & 26429,55 & 14912,49 & 56,42 \\
\hline & & Desvio Padrão & 44,43 & 59,51 & 0,13 & 77,85 & 104,82 & 0,38 \\
\hline & & $\mathrm{CV}(\%)$ & 0,08 & 0,21 & 0,24 & 0,29 & 0,70 & 0,67 \\
\hline & \multirow{3}{*}{$\begin{array}{l}190 \\
\mathrm{~mm}\end{array}$} & Média & 74890,33 & 39210,79 & 52,36 & 36742,53 & 17928,42 & 48,79 \\
\hline & & Desvio Padrão & 109,87 & 154,30 & 0,15 & 133,14 & 157,04 & 0,25 \\
\hline & & $\mathrm{CV}(\%)$ & 0,15 & 0,39 & 0,29 & 0,36 & 0,88 & 0,52 \\
\hline \multirow{6}{*}{ 4,0 MPa } & \multirow{3}{*}{$\begin{array}{l}140 \\
\mathrm{~mm}\end{array}$} & Média & 54336,70 & 28220,76 & 51,94 & 26338,19 & 14707,49 & 55,84 \\
\hline & & Desvio Padrão & 54,62 & 150,95 & 0,26 & 142,43 & 105,07 & 0,17 \\
\hline & & $\mathrm{CV}(\%)$ & 0,10 & 0,53 & 0,50 & 0,54 & 0,71 & 0,31 \\
\hline & \multirow{3}{*}{$\begin{array}{l}190 \\
\mathrm{~mm}\end{array}$} & Média & 74289,48 & $\mathbf{3 8 3 2 4 , 8 5}$ & 51,59 & 36068,39 & 17925,66 & 49,70 \\
\hline & & Desvio Padrão & 124,37 & 198,66 & 0,23 & 145,69 & 97,41 & 0,30 \\
\hline & & $\mathrm{CV}(\%)$ & 0,17 & 0,52 & 0,45 & 0,40 & 0,54 & 0,60 \\
\hline
\end{tabular}

Observa-se que a razão entre a área líquida e a área bruta resultou em um valor médio inferior a $75 \%$ para todos os blocos e meios-blocos, portanto, os mesmos foram classificados como blocos vazados conforme a ABNT NBR 6136:2016. 


\subsubsection{Propriedades Físicas das unidades}

Seguindo as prescrições da ABNT NBR 12118:2013 as características físicas obtidas para os blocos de concreto foram a massa seca, a massa aparente e também o índice de absorção de água calculado pela equação 3.3. A aparelhagem utilizada na execução destes ensaios foi: uma balança digital com resolução de $0,1 \mathrm{~g}$ e uma estufa com controle de temperatura ajustável.

$$
I A(\%)=\frac{m_{u}-m_{s}}{m_{s}} .100
$$

Em que $I A$ é o índice de absorção expresso em porcentagem, $m_{u}$ é a massa saturada do bloco e $m_{s}$ a massa seca do mesmo.

Primeiramente foi necessário determinar a massa seca dos blocos, para isso foram colocados na estufa por 24 horas à uma temperatura de $110^{\circ} \mathrm{C} \pm 5^{\circ} \mathrm{C}$ e após este período foram pesados em intervalos de 2 horas até que a diferença de massa em duas determinações sucessivas não superasse $0,5 \%$. Os blocos foram resfriados naturalmente em temperatura ambiente por 48 horas.

Em seguida, para determinação da massa saturada, os blocos foram submersos em água à temperatura ambiente de $23{ }^{\circ} \mathrm{C} \pm 5^{\circ} \mathrm{C}$ por 24 horas e passado este período foram pesados sem excesso de água em suas superfícies. A Figura 3.6 mostra as unidades em processo de saturação e de secagem.

Figura 3.6 - Procedimento de saturação e secagem em estufa, para determinação do índice de absorção
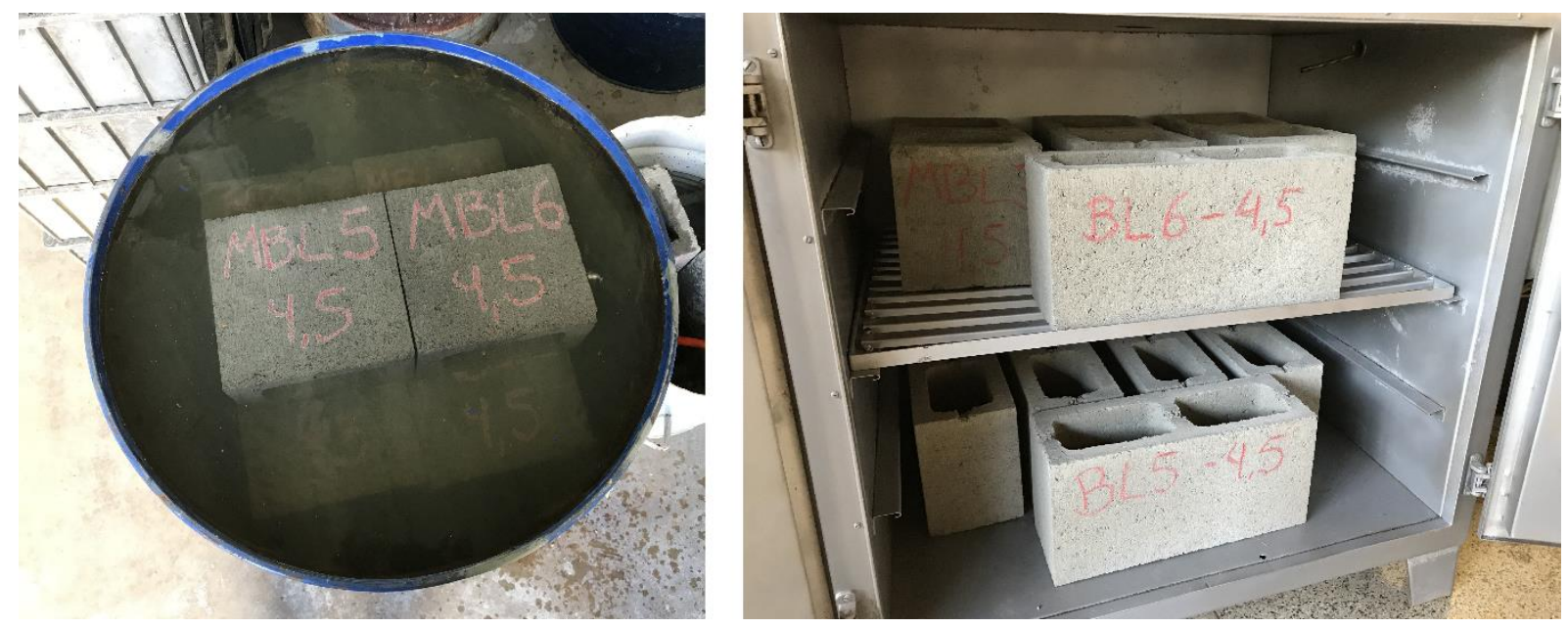

A Tabela 3.10 apresenta os resultados médios deste ensaio para as quatro variações de blocos e meios-blocos, os resultados individuais estão dispostos no APÊNDICE B. 
Tabela 3.10 - Resultados para massa seca, massa saturada e índice de absorção

\begin{tabular}{|c|c|c|c|c|c|c|c|c|}
\hline \multicolumn{9}{|c|}{ Massa seca, massa saturada e índice de absorção de água } \\
\hline \multicolumn{2}{|c|}{ Tipo de unidade } & & \multicolumn{3}{|c|}{ Bloco } & \multicolumn{3}{|c|}{ Meio-bloco } \\
\hline $\begin{array}{c}\text { Resistência } \\
\text { característica } \\
\text { nominal } \\
\end{array}$ & $\begin{array}{l}\text { Largura } \\
\text { nominal }\end{array}$ & & $\begin{array}{c}\text { Massa } \\
\text { seca }(\mathrm{g})\end{array}$ & $\begin{array}{c}\text { Massa } \\
\text { saturada } \\
(\mathrm{g}) \\
\end{array}$ & $\begin{array}{c}\text { Índice de } \\
\text { absorção } \\
(\%)\end{array}$ & $\begin{array}{c}\text { Massa } \\
\text { seca }(\mathrm{g})\end{array}$ & $\begin{array}{c}\text { Massa } \\
\text { saturada } \\
(\mathrm{g}) \\
\end{array}$ & $\begin{array}{c}\text { Índice de } \\
\text { absorção } \\
(\%) \\
\end{array}$ \\
\hline \multirow{6}{*}{$10,0 \mathrm{MPa}$} & \multirow{3}{*}{$\begin{array}{l}140 \\
\mathrm{~mm}\end{array}$} & Média & 12296,83 & 12836,67 & 4,39 & $\mathbf{6 5 1 6 , 0 0}$ & 6838,83 & 4,96 \\
\hline & & Desvio Padrão & 51,20 & 37,43 & 0,24 & 111,53 & 107,26 & 0,19 \\
\hline & & $\mathrm{CV}(\%)$ & 0,42 & 0,29 & 5,35 & 1,71 & 1,57 & 3,73 \\
\hline & \multirow{3}{*}{$\begin{array}{l}190 \\
\mathrm{~mm}\end{array}$} & Média & $\mathbf{1 7 6 9 7 , 5 0}$ & 18322,33 & 3,53 & 8156,67 & 8367,17 & 2,59 \\
\hline & & Desvio Padrão & 90,74 & 85,58 & 0,25 & 169,39 & 142,69 & 0,58 \\
\hline & & $\mathrm{CV}(\%)$ & 0,51 & 0,47 & 6,99 & 2,08 & 1,71 & 22,22 \\
\hline \multirow{6}{*}{ 4,0 MPa } & \multirow{3}{*}{$\begin{array}{l}140 \\
\mathrm{~mm}\end{array}$} & Média & 11685,33 & 12459,83 & 6,63 & 6127,50 & 6492,83 & 5,96 \\
\hline & & Desvio Padrão & 153,12 & 140,35 & 0,29 & 64,28 & 61,38 & 0,22 \\
\hline & & $\mathrm{CV}(\%)$ & 1,31 & 1,13 & 4,40 & 1,05 & 0,95 & 3,68 \\
\hline & \multirow{3}{*}{$\begin{array}{l}190 \\
\mathrm{~mm}\end{array}$} & Média & 15839,17 & 16947,17 & 7,00 & 7383,67 & 7929,67 & 7,40 \\
\hline & & Desvio Padrão & 174,72 & 150,58 & 0,32 & 61,04 & 46,39 & 0,37 \\
\hline & & $\mathrm{CV}(\%)$ & 1,10 & 0,89 & 4,53 & 0,83 & 0,58 & 4,96 \\
\hline
\end{tabular}

Observa-se que, em todos os casos, a absorção foi inferior ao limite estabelecido pela ABNT NBR 6136:2016 que para os blocos de concreto com função estrutural e agregado normal é de $8 \%$ para a média dos blocos e $9 \%$ para a absorção individual nos blocos de classe A e de $9 \%$ para a média dos blocos e $10 \%$ para a absorção individual nos blocos de classe B. O coeficiente de variação do índice de absorção dos meios-blocos de 10,0 MPa e espessura de $190 \mathrm{~mm}$ resultou relativamente alto, portanto, foi realizado o teste estatístico de Grubbs com o intuito de verificar a possível presença de valores extremos na amostra. O procedimento deste teste está descrito no APÊNDICE D e como resultou na inexistência de tais valores, mantevese os resultados obtidos.

\subsubsection{Propriedades mecânicas das unidades - resistência à compressão}

As resistências à compressão dos blocos e meios-blocos foram obtidas de acordo com as recomendações da ABNT NBR 12118:2014. As unidades não passaram por processo de retifica, pois, como observado em pesquisas anteriores no Laboratório de Estruturas da Escola de Engenharia de São Carlos a utilização de forro de fibra mineral como forma de capeamento é satisfatória para evitar a concentração de tensões devido aos agregados localizados nas superfícies de topo e base das unidades. Foi observado que este forro não permitia obter 
resultados de módulo de elasticidade para o bloco, no entanto esta pesquisa visa obter apenas a resistência a compressão para comparar com as resistências residuais após a simulação de incêndio.

No dia da realização dos ensaios de compressão foi determinada a umidade relativa das unidades para verificar o atendimento ao limite prescrito pela ABNT NBR 12118:2014 que é de 20 a $60 \%$ e para blocos de resistência característica superior a 8,0 MPa é de 10 a $40 \%$ para blocos de resistência característica inferior a 8,0 MPa. Os valores médios de umidade relativa obtidos para as unidades estão dispostos na Tabela 3.11, observa-se que em todos os casos as umidades relativas atenderam os limites prescritos pela norma.

Tabela 3.11 - Resultados de umidades relativas das unidades

\begin{tabular}{|c|c|c|c|c|}
\hline \multicolumn{5}{|c|}{ Umidade realtiva das unidades } \\
\hline \multicolumn{2}{|c|}{ Tipo de unidade } & & Bloco & Meio-bloco \\
\hline $\begin{array}{c}\text { Resistência } \\
\text { característica } \\
\text { nominal } \\
\end{array}$ & $\begin{array}{l}\text { Largura } \\
\text { nominal }\end{array}$ & & $\begin{array}{l}\text { Umidade Relativa } \\
\qquad(\%)\end{array}$ & $\begin{array}{l}\text { Umidade Relativa } \\
\qquad(\%)\end{array}$ \\
\hline \multirow{6}{*}{$10,0 \mathrm{MPa}$} & \multirow{3}{*}{$\begin{array}{l}140 \\
\mathrm{~mm}\end{array}$} & Média & 41,81 & 35,83 \\
\hline & & Desvio Padrão & 1,45 & 1,77 \\
\hline & & $\mathrm{CV}(\%)$ & 3,47 & 4,94 \\
\hline & \multirow{3}{*}{$\begin{array}{l}190 \\
\mathrm{~mm}\end{array}$} & Média & 33,57 & 32,07 \\
\hline & & Desvio Padrão & 4,22 & 1,64 \\
\hline & & $\mathrm{CV}(\%)$ & 12,58 & 5,10 \\
\hline \multirow{6}{*}{ 4,0 MPa } & \multirow{3}{*}{$\begin{array}{l}140 \\
\mathrm{~mm}\end{array}$} & Média & 20,21 & $\mathbf{2 4 , 5 7}$ \\
\hline & & Desvio Padrão & 2,61 & 1,20 \\
\hline & & $\mathrm{CV}(\%)$ & 12,93 & 4,89 \\
\hline & \multirow{3}{*}{$\begin{array}{l}190 \\
\mathrm{~mm}\end{array}$} & Média & 17,36 & 22,10 \\
\hline & & Desvio Padrão & 1,17 & 3,16 \\
\hline & & $\mathrm{CV}(\%)$ & 6,73 & 14,32 \\
\hline
\end{tabular}

Os ensaios para determinação da resistência à compressão foram realizados em uma máquina servo-hidráulica controlada da marca Instron, modelo 8506 com controle de deslocamento como mostrado na Figura 3.7. O carregamento foi aplicado a uma velocidade de $0,005 \mathrm{~mm} / \mathrm{s}$ de forma que a tensão aplicada nos blocos seja controlada em $0,15 \pm 0,03 \mathrm{MPa} / \mathrm{s}$ para blocos de resistência característica superior a 8,0 MPa e 0,05 $\pm 0,01 \mathrm{MPa} / \mathrm{s}$ para blocos de resistência característica inferior a $8 \mathrm{MPa}$. Como o capeamento foi substituído pelo forro de fibra mineral, foram aplicados dois ciclos com emprego de aproximadamente $10 \%$ da carga de ruptura prevista, para que haja acomodação do forro. 
Figura 3.7 - Compressão dos blocos e meios-blocos

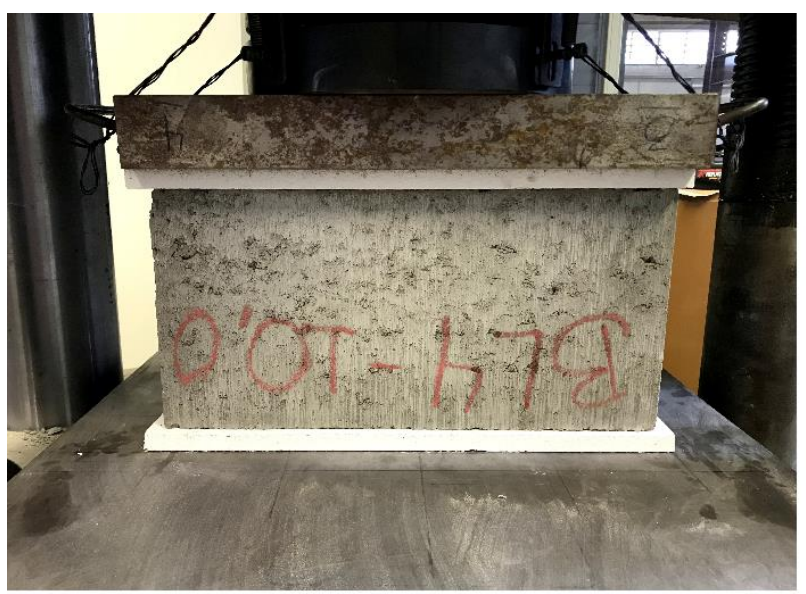

(a) Bloco de conceto

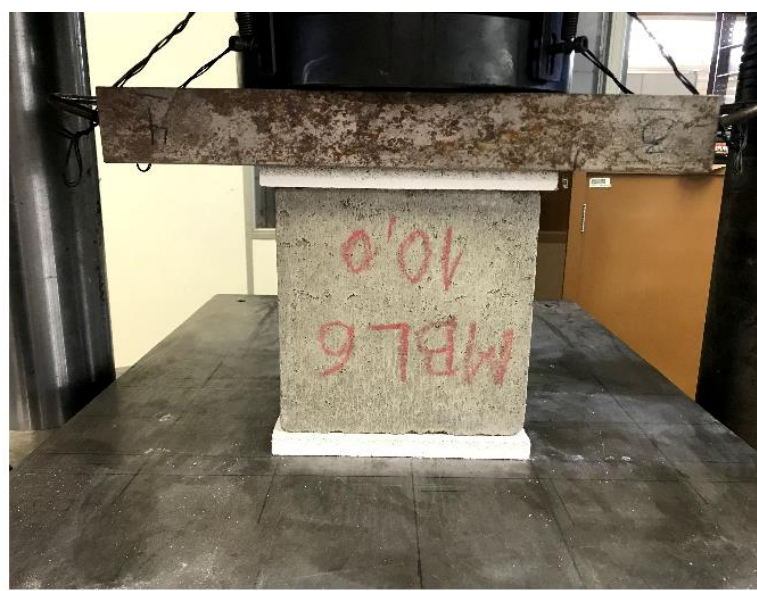

(b) Meio-bloco de concreto

Foram calculadas as resistências à compressão das unidades na área líquida e na área bruta a partir das cargas de ruptura obtidas. Os valores de resistência média e característica estão apresentados na Tabela 3.12. Os resultados individuais estão apresentados no APÊNDICE $\mathrm{B}$, e a resistência característica foi calculada de acordo com procedimento estabelecido pela ABNT NBR 16522:2016 e apresentado no APÊNDICE D.

Tabela 3.12 - Resultados de resistência à compressão das unidades

\begin{tabular}{|c|c|c|c|c|c|c|c|c|}
\hline \multicolumn{9}{|c|}{ Resistência à compressão } \\
\hline \multicolumn{2}{|c|}{ Tipo de unidade } & & \multicolumn{3}{|c|}{ Bloco } & \multicolumn{3}{|c|}{ Meio-bloco } \\
\hline $\begin{array}{c}\text { Resistência } \\
\text { característica } \\
\text { nominal }\end{array}$ & $\begin{array}{l}\text { Largura } \\
\text { nominal }\end{array}$ & & Força $(\mathrm{kN})$ & $\begin{array}{c}\text { Tensão na } \\
\text { área bruta } \\
(\mathrm{MPa}) \\
\end{array}$ & $\begin{array}{c}\text { Tensão na } \\
\text { área líquida } \\
(\mathrm{MPa}) \\
\end{array}$ & Força $(\mathrm{kN})$ & $\begin{array}{c}\text { Tensão na } \\
\text { área bruta } \\
(\mathrm{MPa}) \\
\end{array}$ & $\begin{array}{c}\text { Tensão na } \\
\text { área líquida } \\
(\mathrm{MPa}) \\
\end{array}$ \\
\hline \multirow{8}{*}{$10,0 \mathrm{MPa}$} & \multirow{4}{*}{$\begin{array}{l}140 \\
\mathrm{~mm}\end{array}$} & Média & 1197,77 & 22,03 & 42,24 & 485,27 & 18,36 & 32,55 \\
\hline & & Desvio Padrão & 68,27 & 1,24 & 2,39 & 53,02 & 1,98 & 3,61 \\
\hline & & $\mathrm{CV}(\%)$ & 5,70 & 5,64 & 5,65 & 10,93 & 10,78 & 11,11 \\
\hline & & $f_{\mathrm{bk}}(\mathrm{MPa})$ & & 20,76 & 39,65 & & 14,12 & 24,71 \\
\hline & \multirow{4}{*}{$\begin{array}{l}190 \\
\mathrm{~mm}\end{array}$} & Média & 1494,33 & 19,95 & 38,12 & 967,91 & 26,34 & 53,96 \\
\hline & & Desvio Padrão & 74,42 & 1,02 & 2,00 & 88,37 & 2,32 & 4,47 \\
\hline & & $\mathrm{CV}(\%)$ & 4,98 & 5,10 & 5,26 & 9,13 & 8,81 & 8,29 \\
\hline & & $f_{\text {bk }}(\mathrm{MPa})$ & & 17,32 & 32,93 & & 24,55 & $\mathbf{5 0 , 7 3}$ \\
\hline \multirow{8}{*}{ 4,0 MPa } & \multirow{4}{*}{$\begin{array}{l}140 \\
\mathrm{~mm}\end{array}$} & Média & 404,23 & 7,44 & 14,32 & 282,68 & 10,73 & 19,21 \\
\hline & & Desvio Padrão & 34,24 & 0,63 & 1,21 & 25,69 & 0,93 & 1,66 \\
\hline & & $\mathrm{CV}(\%)$ & 8,47 & 8,41 & 8,46 & 9,09 & 8,64 & 8,62 \\
\hline & & $f_{\mathrm{bk}}(\mathbf{M P a})$ & & 6,18 & 11,73 & & 9,39 & 16,80 \\
\hline & \multirow{4}{*}{$\begin{array}{l}190 \\
\mathrm{~mm}\end{array}$} & Média & 443,04 & 5,96 & 11,56 & 297,32 & 8,24 & 16,59 \\
\hline & & Desvio Padrão & 33,03 & 0,44 & 0,83 & 30,60 & 0,85 & 1,75 \\
\hline & & $\mathrm{CV}(\%)$ & 7,46 & 7,46 & 7,22 & 10,29 & 10,30 & 10,54 \\
\hline & & $f_{\mathrm{bk}}(\mathrm{MPa})$ & & 5,39 & 10,38 & & 6,97 & 14,08 \\
\hline
\end{tabular}


Observa-se que as resistências médias e características obtidas foram muito maiores que as resistências nominais dos blocos e meio-blocos. No caso dos blocos de 4,0 MPa a resistência foi pelo menos $35 \%$ maior e para os blocos de $10,0 \mathrm{MPa}$ foi pelo menos $41 \%$ maior. As variabilidades dos resultados foram relativamente baixas para blocos de concreto, uma vez que o maior coeficiente de variação foi de $11 \%$.

Não foram observados padrões de modos de ruptura muito nítidos nos corpos de prova. Os blocos com resistência nominal de 4,0 $\mathrm{MPa}$ apresentaram na maioria dos elementos esmagamento do material em um dos cantos com trincas diagonais na direção da maior face, já os meios-blocos apresentaram rompimento cônico, como mostrado na Figura 3.8.a e na Figura 3.8.b, sendo que esse modo de ruptura ocorre em função da restrição de deslocamento produzida pelo atrito entre a chapa e o bloco, que provoca um estado de tensões multiaxiais. Os blocos com resistência nominal de 10,0 MPa apresentaram ruptura explosiva devido às elevadas cargas alcançadas e à concentração de energia apresentada pela máquina. Os meios-blocos de 10,0 MPa apresentaram também ruptura explosiva ou com lascamento de parte dos elementos em algumas das quinas, como mostrado na Figura 3.8.c e na Figura 3.8.d.

Figura 3.8 - Ruptura das unidades

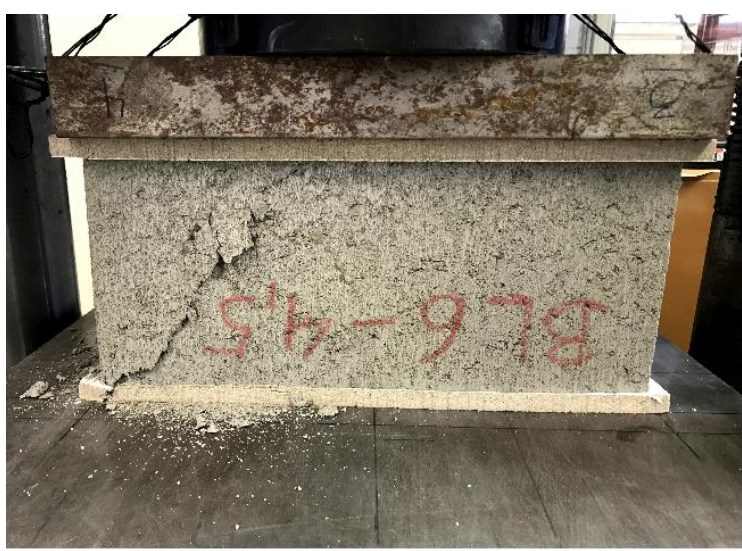

(a) bloco de 4,0 MPa

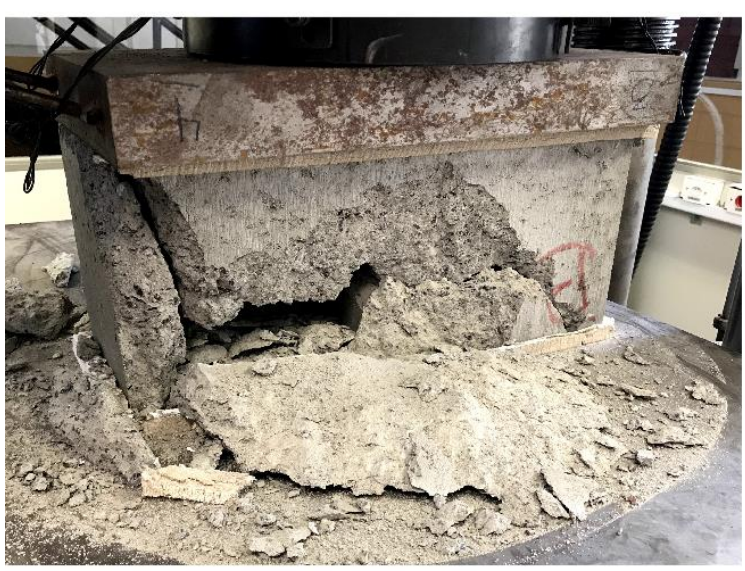

(c) bloco de 10,0 MPa

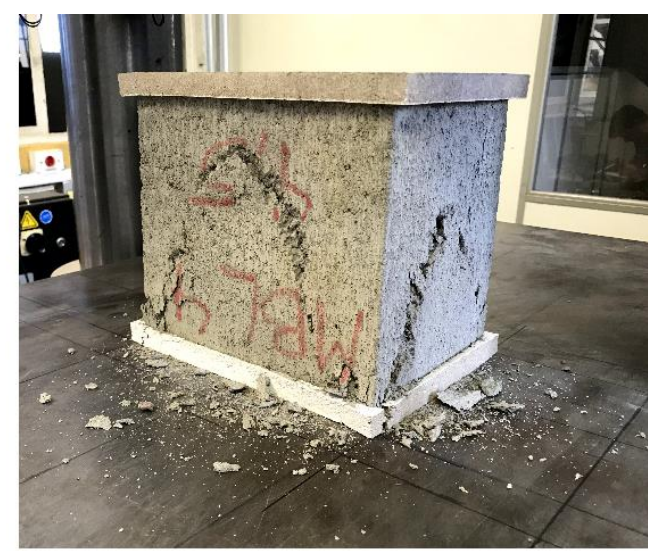

(b) meio-bloco de 4,0 MPa

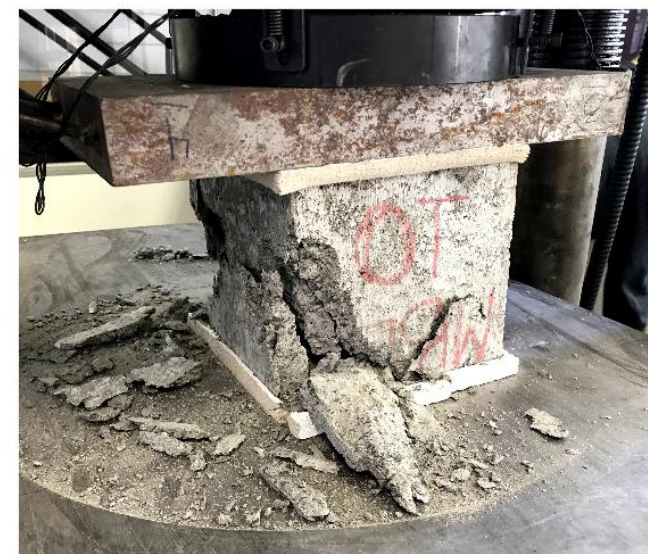

(d) meio-bloco de 10,0 MPa 


\subsection{Caracterização física e mecânica da argamassa}

Devido à ausência de uma norma brasileira que recomende uma composição para argamassa de assentamento das unidades de alvenaria estrutural, o traço da argamassa utilizada na confecção dos prismas e pequenas paredes foi definido seguindo as recomendações da BS 5628:2005. O traço adotado foi de $1: 0,5: 4,5$, correspondente à proporção em volume de cimento, cal e areia respectivamente, e a relação água/cimento foi de 1,50, definida pelo pedreiro responsável pela execução de acordo com a trabalhabilidade desejada.

As argamassas foram caracterizadas no estado fresco em função de sua consistência, para isso, na produção de cada argamassada realizou-se o ensaio de fluidez "flow table" prescrito pela ABNT NBR 13276:2016, como mostra a Figura 3.9. A fluidez limite foi fixada em $270 \mathrm{~mm} \pm 10 \mathrm{~mm}$ para garantir que a argamassa possua consistência adequada para manter constante a espessura de junta horizontal de $10 \mathrm{~mm}$. Para os corpos de prova já realizados foram executadas duas argamassadas com consistências médias de 250,2 mm e 249,7 mm respectivamente. Cada argamassada foi preparada em uma quantidade de 50 litros por meio de um misturador mecânico de eixo inclinado (betoneira) como mostra a Figura 3.10 e recomendado pela ABNT NBR 15812-2:2010.

Figura 3.9 - Ensaio de consistência para a argamassa ("Flow Table")
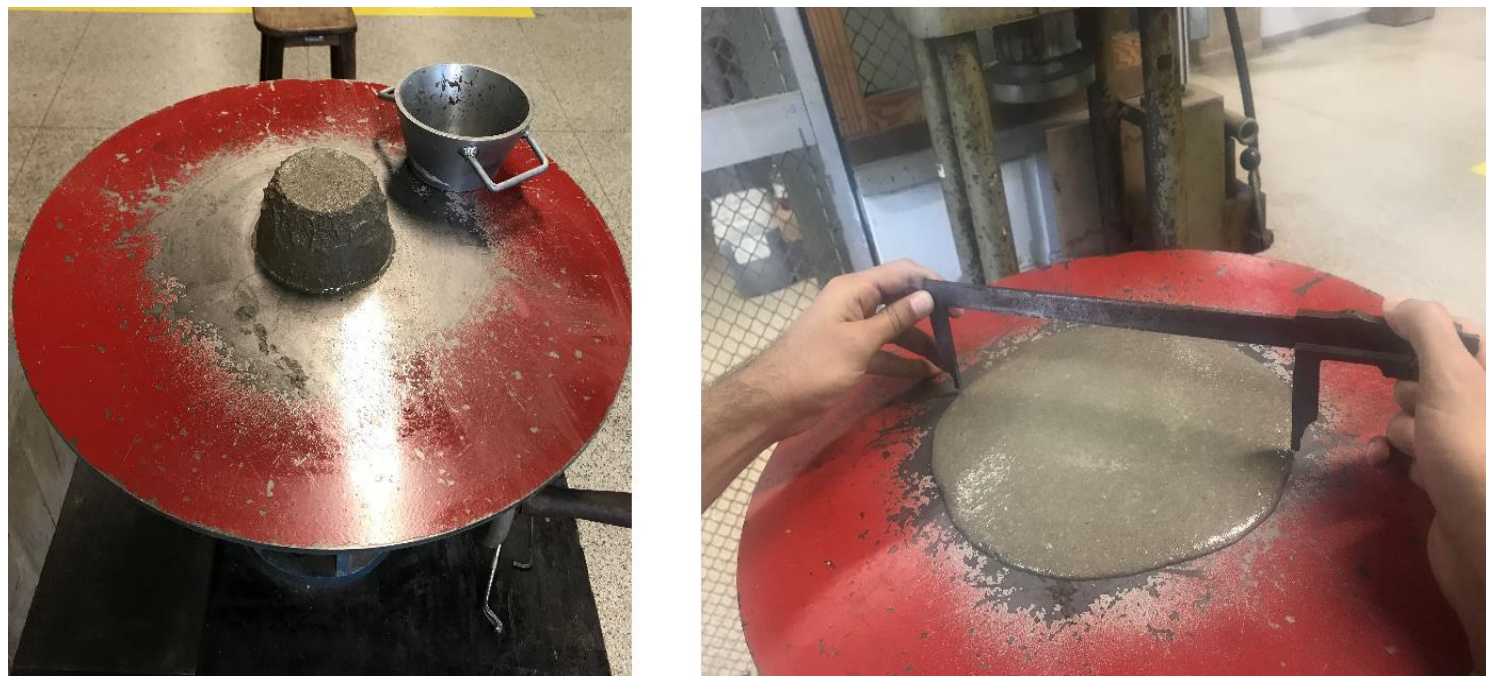

A caracterização mecânica da argamassa no estado endurecido foi feita através dos ensaios de compressão axial e módulo de elasticidade e pela determinação da resistência à tração por compressão diametral $\left(f_{c t, s p}\right)$. A ABNT NBR 15961:2011 recomenda que sejam utilizados cubos de argamassa com aresta de $40 \mathrm{~mm}$ como corpos de prova, no entanto, devido à disponibilidade no laboratório, foram utilizados moldes cilíndricos com diâmetro de $50 \mathrm{~mm}$ 
$\pm 2 \mathrm{~mm}$ e altura de $100 \mathrm{~mm} \pm 2 \mathrm{~mm}$ na confecção dos mesmos. Foram moldados 6 corpos de prova adensados em mesa vibratória e ensaiados à compressão simples.

Figura 3.10 - Misturador mecânico de eixo inclinado utilizado na confecção da argamassa

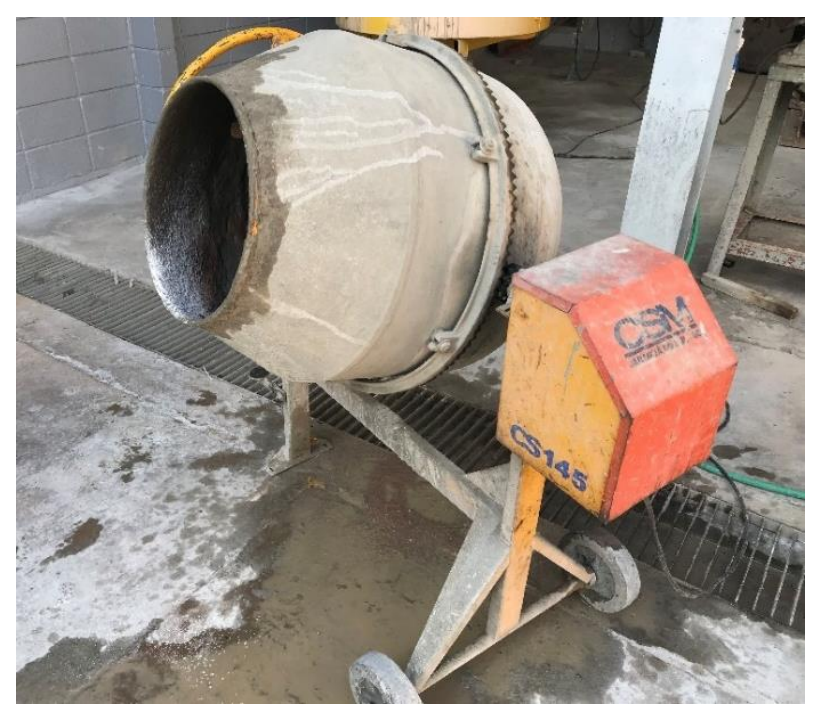

Os corpos de prova tiveram suas superfícies retificadas e foram mantidos em câmara úmida até a data do ensaio. Os ensaios de resistência à compressão foram realizados com a idade de 91 dias após a moldagem dos corpos de prova, com auxílio de uma máquina servohidráulica controlada da marca Instron, com controle de deslocamento, para se obter a curva tensão por deformação específica. Para isso foram posicionados dois clip-gages com curso de $50 \mathrm{~mm}$ no centro dos corpos de prova para medir as deformações como mostrado na Figura 3.11. O carregamento foi aplicado a uma velocidade de $0,01 \mathrm{~mm} / \mathrm{s}$.

O ensaio de resistência à tração por compressão diametral foi realizado com a mesma idade de 91 dias e seguiu as recomendações da ABNT NBR 7222:2011. Este ensaio foi realizado em uma máquina hidráulica da marca ELE com controle de carga a uma velocidade de $0,47 \mathrm{kN} / \mathrm{s}$.

Com as curvas de tensão por deformação dos corpos de prova de argamassa foi possível obter a resistência à compressão média pelos picos das curvas, e determinar o módulo de elasticidade secante no trecho de 5\% e 33\% da máxima resistência à compressão de acordo com o recomendado pela norma americana ASTM C469:2012. A Figura 3.12 apresenta as curvas de tensão por deformação específica dos corpos de prova de argamassa e a Tabela 3.13 traz um resumo dos valores médios de resistência à compressão, módulo de elasticidade e resistência à tração por compressão diametral $\left(f_{c t, s u p}\right)$. Os resultados individuais estão no APÊNDICE B. Apesar da recomendação da ABNT NBR 15961-1:2011 de limitar a resistência da argamassa 
em $70 \%$ da resistência característica do bloco na área líquida, optou-se por adotar a mesma argamassa em ambas classes de blocos para facilitar o processo de execução

Figura 3.11 - Esquema de ensaios da argamassa à compressão com instrumentação
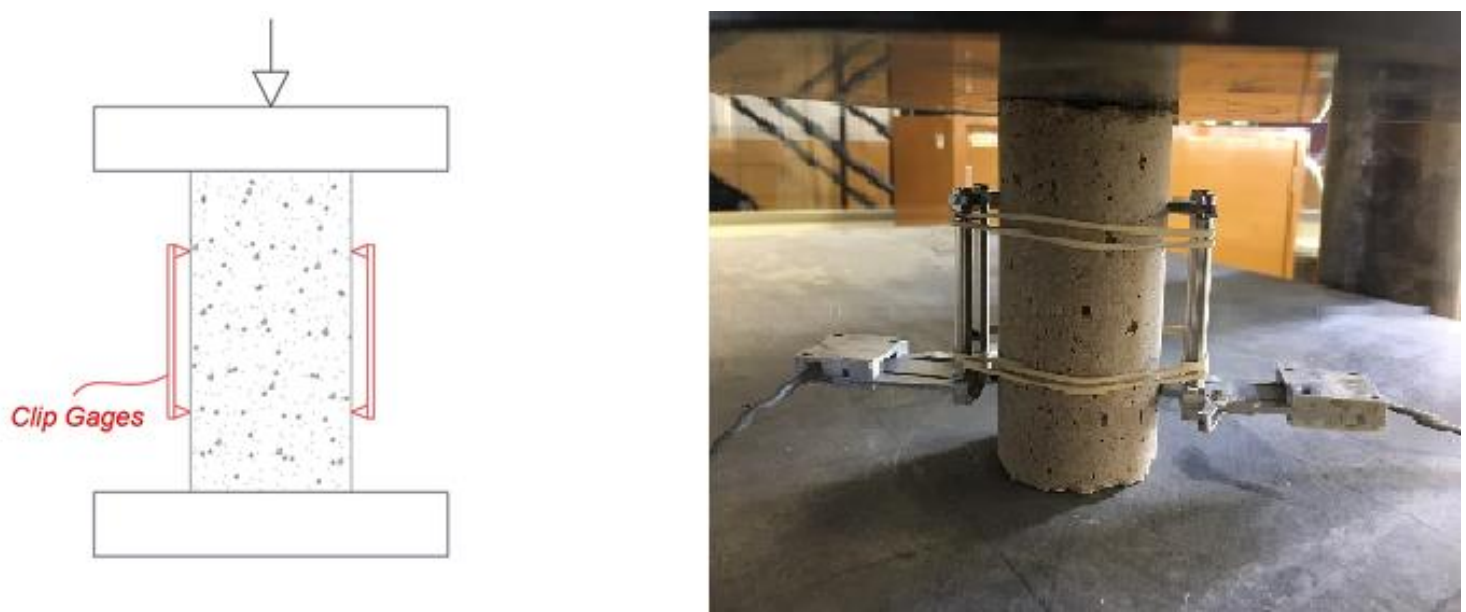

Figura 3.12 - Curvas de tensão por deformação específica da argamassa de assentamento

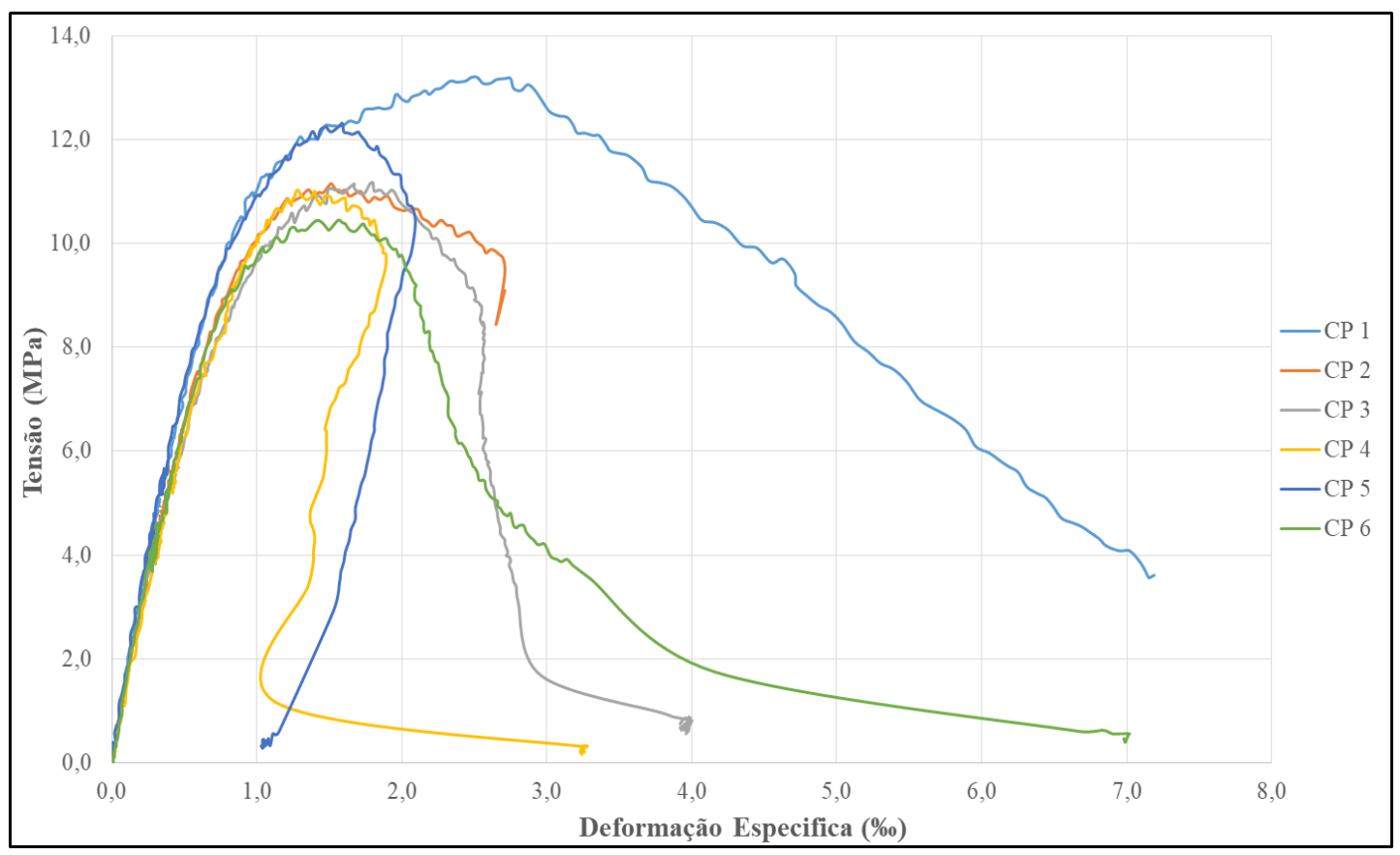

Tabela 3.13 - Resistência à compressão, módulo de elasticidade e resistência à tração por compressão diametral da argamassa de assentamento

\begin{tabular}{|c|c|c|c|}
\hline \multicolumn{4}{|c|}{ Caracterização da argamassa de assentamento } \\
\hline & $\begin{array}{c}\text { Resistência à } \\
\text { Compressão (MPa) }\end{array}$ & $\begin{array}{c}\text { Módulo de } \\
\text { Elasticidade (GPa) }\end{array}$ & $f_{c t, s p} \quad(\mathrm{MPa})$ \\
\hline Média & 11,55 & 14,86 & 1,08 \\
\hline Desvio Padrão & 1,01 & 1,41 & 0,20 \\
\hline $\mathrm{CV}(\%)$ & 8,74 & 9,50 & 18,89 \\
\hline
\end{tabular}




\subsection{Caracterização da alvenaria}

O objetivo desta primeira etapa do programa experimental foi estudar o comportamento da resistência à compressão da alvenaria estrutural de blocos de concreto em temperatura ambiente. Para isso foram ensaiados prismas de duas fiadas e pequenas paredes de cinco fiadas, confeccionadas com as quatro variações de blocos estuadas neste trabalho. A seguir tem-se uma descrição sobre como foram executados e ensaiados, juntamente com um resumo dos resultados obtidos.

\subsubsection{Execução dos corpos de prova}

Para esta etapa do programa experimental foram executados primas de dois blocos com uma junta de argamassa horizontal e pequenas paredes com $79 \mathrm{~cm}$ de comprimento por $99 \mathrm{~cm}$ de altura, ou seja, dois blocos na longitudinal e cinco fiadas. A quantidade de corpos de prova necessária para os ensaios de compressão foi definida conforme as recomendações da ABNT NBR 15961-1 e estão mostrados na Tabela 3.14 para cada variação de bloco analisada, juntamente com os ensaios que serão realizados.

Tabela 3.14 - Quantidades de corpos de prova e tipos de ensaios

\begin{tabular}{|c|c|c|c|c|}
\hline $\begin{array}{l}\text { Tipo de corpo } \\
\text { de prova }\end{array}$ & $\begin{array}{c}\text { Resistência } \\
\text { característica } \\
\text { nominal } \\
\end{array}$ & $\begin{array}{l}\text { Largura } \\
\text { nominal }\end{array}$ & Ensaios realizados & $\begin{array}{c}\text { Quantidade de } \\
\text { corpos de } \\
\text { prova }\end{array}$ \\
\hline \multirow{2}{*}{$\begin{array}{l}\text { Prismas de } 2 \\
\text { blocos }\end{array}$} & $10,0 \mathrm{MPa}$ & $\begin{array}{l}140 \mathrm{~mm} \\
190 \mathrm{~mm} \\
\end{array}$ & \multirow{2}{*}{ Resistência à compressão } & $\begin{array}{l}6 \\
6 \\
\end{array}$ \\
\hline & 4,0 MPa & $\begin{array}{l}140 \mathrm{~mm} \\
190 \mathrm{~mm}\end{array}$ & & $\begin{array}{l}6 \\
6\end{array}$ \\
\hline \multirow{2}{*}{$\begin{array}{l}\text { Pequenas } \\
\text { paredes }\end{array}$} & $10,0 \mathrm{MPa}$ & $\begin{array}{l}140 \mathrm{~mm} \\
190 \mathrm{~mm} \\
\end{array}$ & \multirow{2}{*}{$\begin{array}{l}\text { Resistência à compressão e } \\
\text { módulo de elasticidade }\end{array}$} & $\begin{array}{l}3 \\
3 \\
\end{array}$ \\
\hline & 4,0 MPa & $\begin{array}{l}140 \mathrm{~mm} \\
190 \mathrm{~mm}\end{array}$ & & $\begin{array}{l}3 \\
3 \\
\end{array}$ \\
\hline
\end{tabular}

Os prismas não foram ensaiados para o módulo de elasticidade, pois este trabalho visa obter apenas as suas resistências à compressão para relacionar com as resistências das pequenas paredes, estabelecendo fatores de eficiência. A instrumentação para obter o módulo de 
elasticidade foi realizada apenas na pequena parede por ser um elemento de maiores dimensões e retratar com maior proximidade o comportamento da parede de alvenaria.

Todos os prismas e pequenas paredes foram executados com argamassamento total e as juntas de argamassa com $10 \mathrm{~mm}$ tanto na horizontal como na vertical. A Figura 3.13 mostra os corpos de prova executados. No decorrer do assentamento dos blocos das pequenas paredes sempre foram verificados o nível e o prumo para obter o maior qualidade e uniformidade possível dos corpos de prova.

Figura 3.13 - Corpos de prova: prismas de dois blocos e pequenas paredes

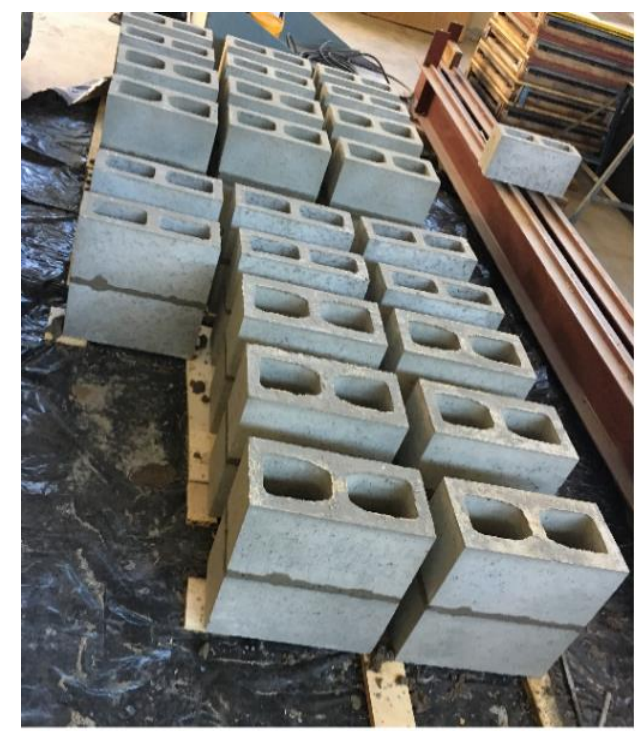

Prismas de dois blocos

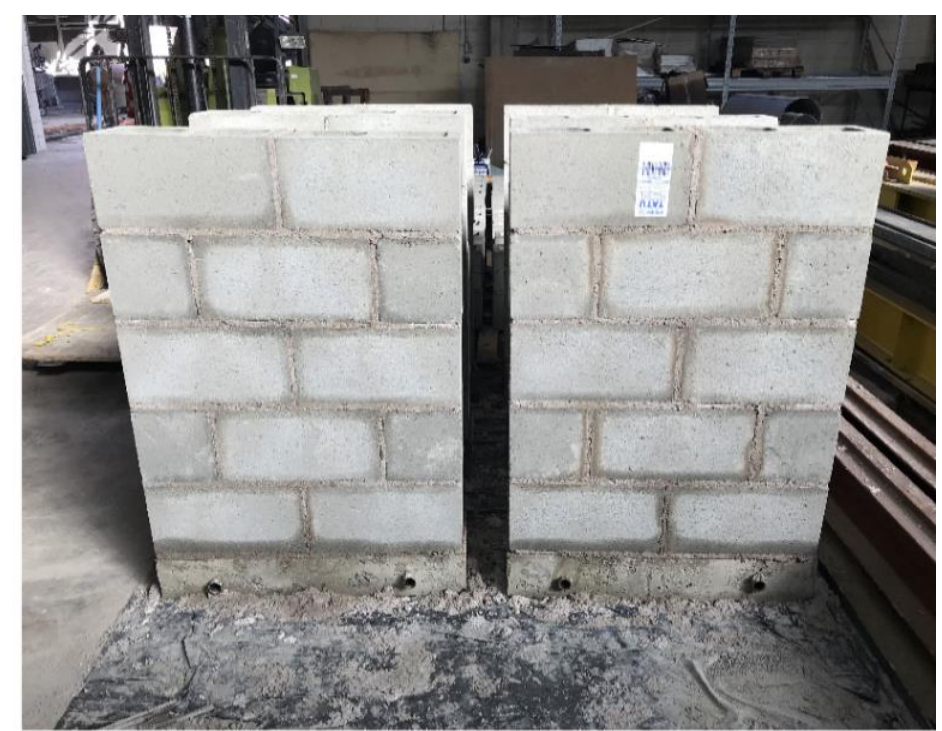

Pequenas paredes

Os prismas foram moldados sobre duas chapas de Madeirit cortadas em tiras e posicionadas nas extremidades dos corpos de prova para facilitar o manuseio até a máquina de ensaio que será feito manualmente e com auxílio de empilhadeira. Já as pequenas paredes, foram moldadas sobre bases de concreto feitas no Laboratório de Estruturas (Figura 3.14.b), idênticas às que serão utilizadas nos corpos de prova para ensaios em temperaturas elevadas.

As bases de concreto foram executadas com dimensões de $20 \mathrm{~cm}$ de largura, $80 \mathrm{~cm}$ de comprimento e $12 \mathrm{~cm}$ de altura pois assim acomodam tanto as pequenas paredes com blocos de $14 \mathrm{~cm}$ como as com blocos de $19 \mathrm{~cm}$ de largura (Figura 3.14.a). O traço em massa do concreto das bases foi de 1 : 2,55:2,66 de cimento, areia e brita 1 respectivamente, com fator água cimento de 0,56 e adição de $200 \mathrm{ml}$ de aditivo plastificante para cada $235 \mathrm{~kg}$ de concreto. Para armadura utilizou-se tela soldada do modelo Q138 com barras de 4,2 mm e espaçamentos longitudinais e transversais de $10 \mathrm{~cm}$, desta forma as telas foram cortadas de maneira a ficar em cada base de concreto 2 barras longitudinais e 7 barras transversais. 
Foram colocados tubos metálicos de parede fina com diâmetro externo de $32 \mathrm{~mm}$, como observado na Figura 3.14, atravessando toda a largura das bases. Estes tubos permitem que seja colocado duas barras de aço de $20 \mathrm{~mm}$ para o içamento e transporte das pequenas paredes, que será realizado com auxílio da ponte rolante e da empilhadeira. Os corpos de prova estão em local fechado do laboratório, protegidos de sol e da chuva, ficarão por um período mínimo de 28 dias para a cura antes de serem realizados os ensaios de compressão.

Figura 3.14 - Esquema geométrico e concretagem das de concreto
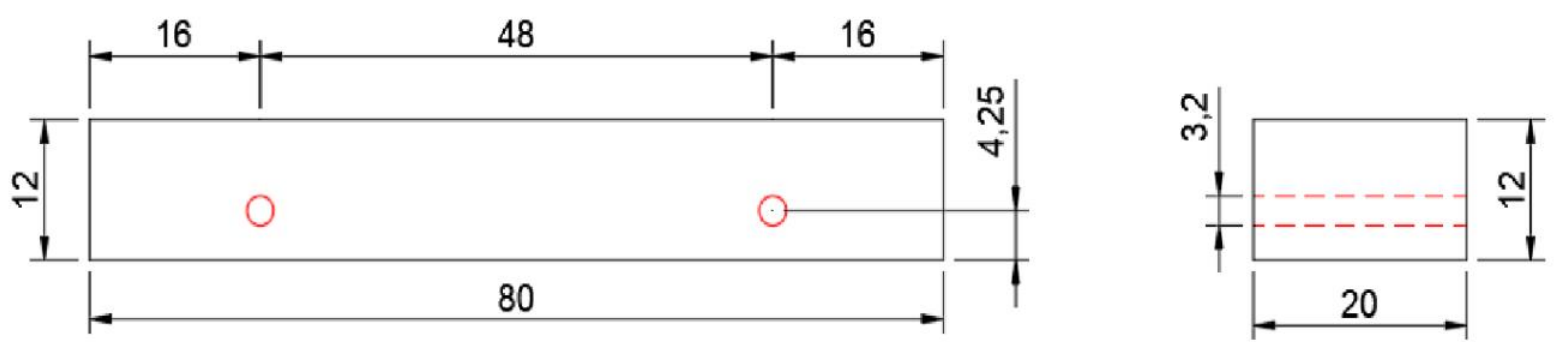

(a) Esquema das bases de concreto para apoio e transporte
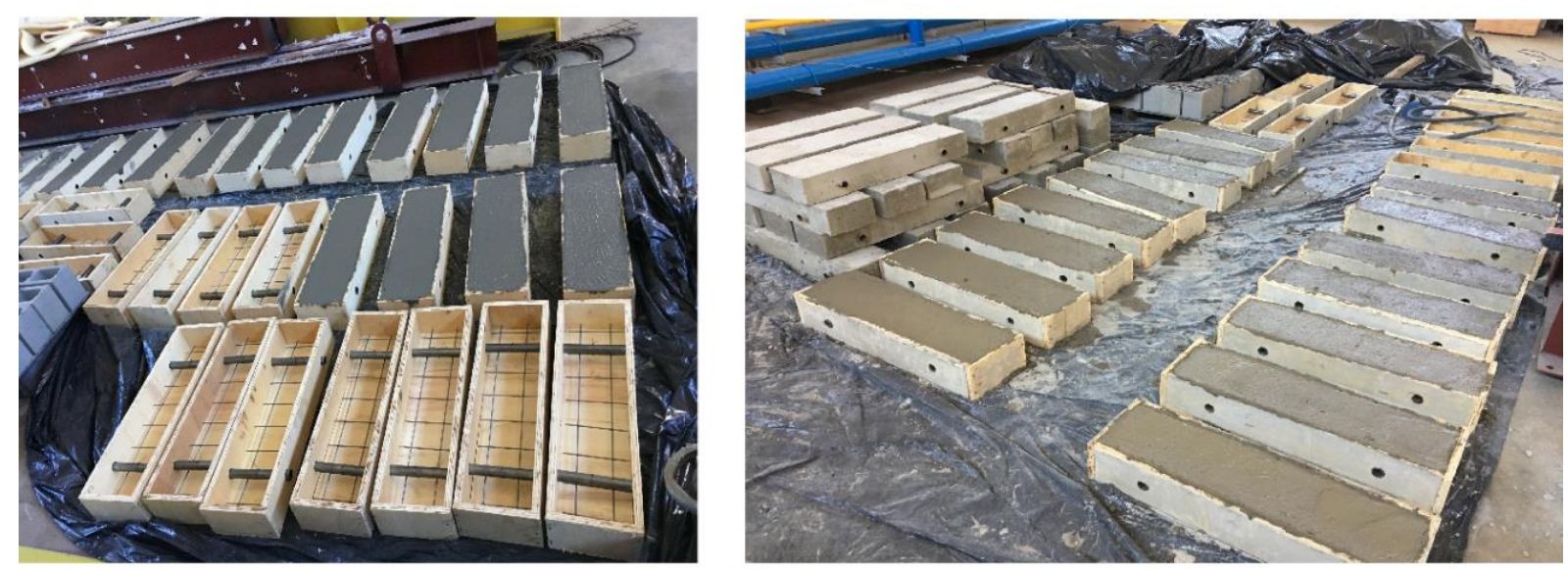

(b) montagem das formas com as telas soldadas e os tubos de aço, e concretagem das bases

\subsubsection{Ensaio dos corpos de prova à compressão}

Para determinação da resistência à compressão dos prismas e das pequenas paredes, os ensaios seguirão as recomendações da ABNT NBR 15961-2:2011.

Os prismas de dois blocos não foram instrumentados pois deseja-se obter apenas a sua resistência à compressão e não o módulo de elasticidade. Já as pequenas paredes foram instrumentadas com quatro transdutores de deslocamento posicionados na vertical, dois em cada face, como mostra a Figura 3.15, pois para estes corpos de prova deseja-se obter o valor do módulo de elasticidade a partir da curva de tensão por deformação. 
Figura 3.15 - Instrumentação da pequena parede

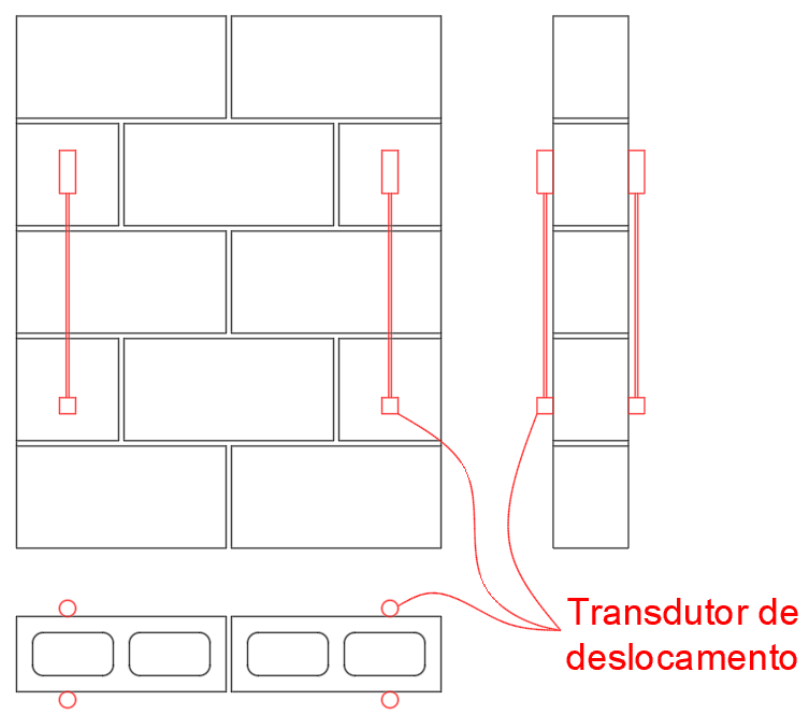

Os ensaios foram executados na máquina servo-hidráulica universal da marca Instron modelo 8506 presente no Laboratório de Estruturas da Escola de Engenharia de São Carlos (Figura 3.16), e as leituras dos dados dos transdutores das paredes foram realizadas com o sistema de aquisição de dados System 5000. O carregamento uniformemente distribuído foi aplicado com controle de deslocamento a uma velocidade de $0,02 \mathrm{~mm} / \mathrm{s}$ para os prismas e 0,01 $\mathrm{mm} / \mathrm{s}$ para as pequenas paredes. Assim como nos ensaios das unidades, aqui também foi utilizado forro de fibra mineral como capeamento, portanto, antes do início do ensaio foram aplicados dois ciclos com emprego de aproximadamente $10 \%$ da carga de ruptura para acomodação do forro mineral e também da instrumentação.

Figura 3.16 - Máquina servo-hidráulica Instron 8506 do Laboratório de Estruturas da EESC

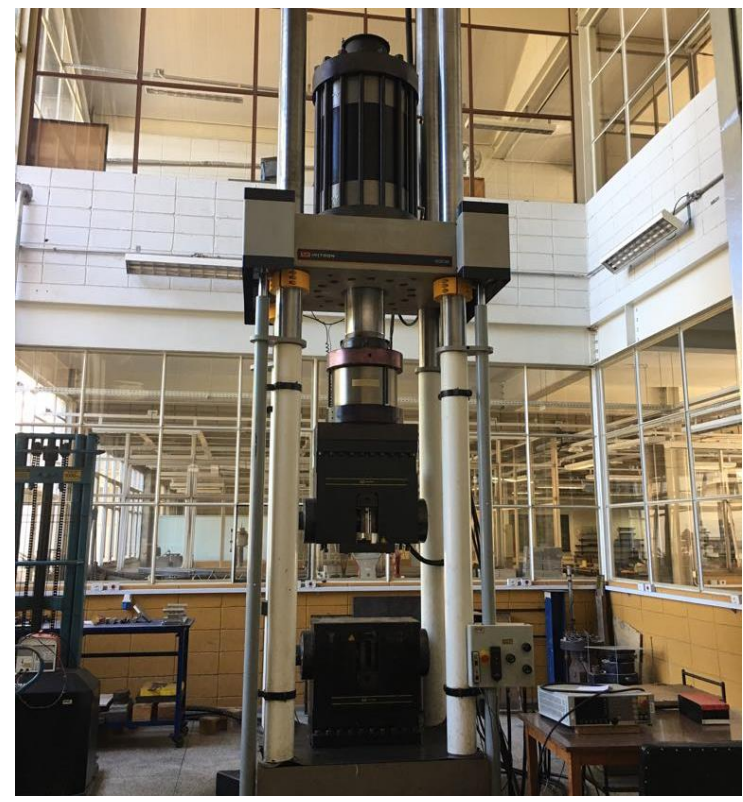


A Figura 3.17 mostra exemplos de execução dos ensaios dos prismas e das pequenas paredes. Para os prismas foi utilizada uma chapa metálica de $50 \mathrm{~mm}$ de espessura para distribuição uniforme do carregamento e para as pequenas paredes foi adotado um perfil I de chapa grossa com enrijecedores na alma.

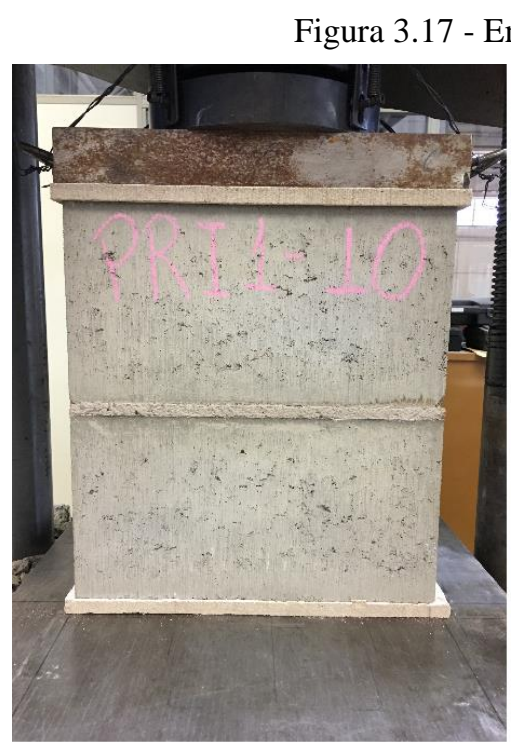

(a) Prisma

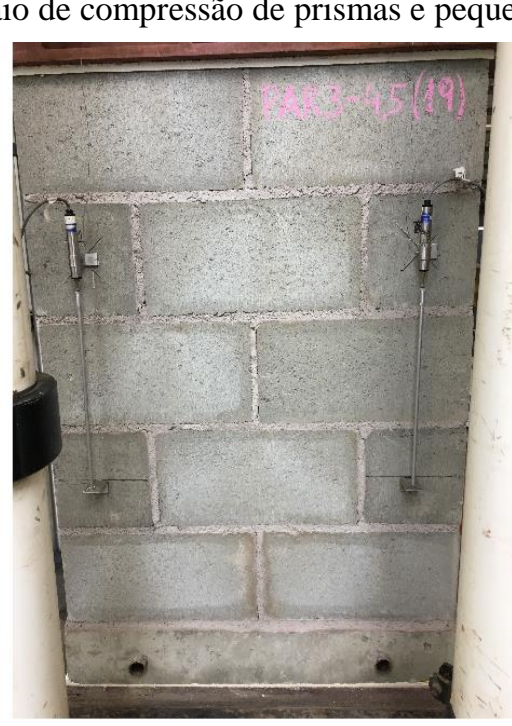

(b) Pequena Parede

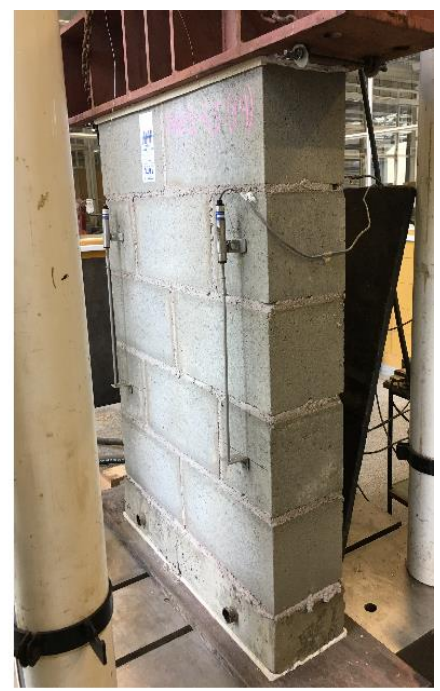

1

Com o valor da carga de ruptura dos prismas foi possível calcular a resistência à compressão média e característica como apresentado na Tabela 3.15. A partir das curvas de tensão $x$ deformação das pequenas paredes apresentadas no APENDICE B calculou-se os módulos de elasticidade médios nos trechos de 5\% e 30\% da máxima resistência à compressão, seguindo as recomendações da ABNT NBR 16522:2016. A Figura 3.18 conta com as curvas médias de cada variação. Obteve-se a resistência à compressão de cada corpo de prova por meio da carga de ruptura, os valores médios e característicos estão apresentados na Tabela 3.16.

O coeficiente de variação do módulo de elasticidade das pequenas paredes de 10,0 MPa e $190 \mathrm{~mm}$ resultou relativamente alto $(28,67)$. Foi realizado o teste estatístico de Grubbs, cujo procedimento está descrito no APÊNDICE D e como resultou na inexistência de valores espúrios, os resultados foram mantidos. Todos as propriedades foram calculadas nas áreas bruta e líquida, sendo que os resultados individuais estão apresentados no APÊNDICE B.

Os prismas apresentaram resistências características de $12 \%$ a $26 \%$ superiores às resistências nominais (de fábrica) dos respectivos blocos. Já as pequenas paredes apresentaram resistências características entre 53\% e 70\% da resistência nominal dos blocos, com exceção da parede com blocos de 4,0 MPa e espessura de $140 \mathrm{~mm}$ que resultou em uma resistência característica pouco maior $(3,5 \%)$ que a nominal do bloco utilizado, sendo que em todos os casos as resistências apuradas para os blocos foram superiores às suas resistências nominais. 
Tabela 3.15 - Resultados médios e característicos da resistência à compressão dos prismas

\begin{tabular}{|c|c|c|c|c|c|}
\hline \multicolumn{6}{|c|}{ "Resistência à compressão } \\
\hline \multicolumn{2}{|c|}{ Tipo de unidade } & & \multicolumn{2}{|c|}{ Prismas } & \multirow{2}{*}{$\begin{array}{c}\text { Blocos } \\
\text { Tensão na área } \\
\text { bruta }(\mathrm{MPa})\end{array}$} \\
\hline $\begin{array}{c}\text { Resistência } \\
\text { característica } \\
\text { nominal }\end{array}$ & $\begin{array}{l}\text { Largura } \\
\text { nominal }\end{array}$ & & Força $(\mathrm{kN})$ & $\begin{array}{c}\text { Tensão na área } \\
\text { bruta (MPa) }\end{array}$ & \\
\hline \multirow{8}{*}{$10,0 \mathrm{MPa}$} & \multirow{4}{*}{$\begin{array}{l}140 \\
\mathrm{~mm}\end{array}$} & Média & 736,09 & 13,54 & 22,03 \\
\hline & & Desvio Padrão & 41,91 & 0,77 & 1,24 \\
\hline & & $\mathrm{CV}(\%)$ & 5,69 & 5,69 & 5,64 \\
\hline & & $f_{\mathrm{pk}}(\mathrm{MPa})$ & & 12,31 & 20,76 \\
\hline & \multirow{4}{*}{$\begin{array}{l}190 \\
\mathrm{~mm}\end{array}$} & Média & 1013,11 & 13,53 & 19,95 \\
\hline & & Desvio Padrão & 30,77 & 0,41 & 1,02 \\
\hline & & $\mathrm{CV}(\%)$ & 3,04 & 3,04 & 5,10 \\
\hline & & $f_{\mathrm{pk}}(\mathbf{M P a})$ & & 12,66 & 17,32 \\
\hline \multirow{8}{*}{ 4,0 MPa } & \multirow{4}{*}{$\begin{array}{l}140 \\
\mathrm{~mm}\end{array}$} & Média & 369,36 & 6,80 & 7,44 \\
\hline & & Desvio Padrão & 22,86 & 0,42 & 0,63 \\
\hline & & $\mathrm{CV}(\%)$ & 6,19 & 6,19 & 8,41 \\
\hline & & $f_{\mathrm{pk}}(\mathbf{M P a})$ & & 5,78 & 6,18 \\
\hline & \multirow{4}{*}{$\begin{array}{l}190 \\
\mathrm{~mm}\end{array}$} & Média & 379,09 & 5,10 & 5,96 \\
\hline & & Desvio Padrão & 19,40 & 0,26 & 0,44 \\
\hline & & $\mathrm{CV}(\%)$ & 5,12 & 5,12 & 7,46 \\
\hline & & $f_{\mathrm{pk}}(\mathrm{MPa})$ & & 4,47 & 5,39 \\
\hline
\end{tabular}

Tabela 3.16 - Resultados médios e característicos da resistência à compressão das pequenas paredes

\begin{tabular}{|c|c|c|c|c|c|c|}
\hline \multicolumn{7}{|c|}{ Resistência à compressão } \\
\hline \multicolumn{2}{|c|}{ Tipo de unidade } & & \multicolumn{3}{|c|}{ Pequenas Paredes } & \multirow{2}{*}{\begin{tabular}{|c|} 
Blocos \\
Tensão na áre \\
bruta (MPa)
\end{tabular}} \\
\hline $\begin{array}{c}\text { Resistência } \\
\text { característica } \\
\text { nominal }\end{array}$ & $\begin{array}{l}\text { Largura } \\
\text { nominal }\end{array}$ & & Força $(\mathrm{kN})$ & $\begin{array}{c}\text { Tensão na área } \\
\text { bruta (MPa) }\end{array}$ & $E_{\text {par }}(\mathrm{GPa})$ & \\
\hline \multirow{8}{*}{$10,0 \mathrm{MPa}$} & & Média & 826,90 & 7,38 & 13,46 & 22,03 \\
\hline & 140 & Desvio Padrão & 82,93 & 0,48 & 1,85 & 1,24 \\
\hline & $\mathrm{mm}$ & $\mathrm{CV}(\%)$ & 10,03 & 6,55 & 13,71 & 5,64 \\
\hline & & $f_{\mathrm{ppk}}(\mathrm{MPa})$ & & 5,48 & & 20,76 \\
\hline & & Média & 1119,62 & 7,48 & 11,06 & 19,95 \\
\hline & 190 & Desvio Padrão & 73,38 & 0,49 & 3,17 & 1,02 \\
\hline & $\mathrm{mm}$ & $\mathrm{CV}(\%)$ & 6,55 & 6,55 & 28,67 & 5,10 \\
\hline & & $f_{\mathrm{ppk}}(\mathrm{MPa})$ & & 5,55 & & 17,32 \\
\hline \multirow{8}{*}{ 4,0 MPa } & & Média & 565,00 & 5,13 & 9,46 & 7,44 \\
\hline & 140 & Desvio Padrão & 4,87 & 0,04 & 0,88 & 0,63 \\
\hline & $\mathrm{mm}$ & $\mathrm{CV}(\%)$ & 0,86 & 0,86 & 9,30 & 8,41 \\
\hline & & $f_{\text {ppk }}(\mathrm{MPa})$ & & 4,08 & & 6,18 \\
\hline & & Média & 552,66 & 3,67 & 7,10 & 5,96 \\
\hline & 190 & Desvio Padrão & 24,31 & 0,16 & 0,58 & 0,44 \\
\hline & $\mathrm{mm}$ & $\mathrm{CV}(\%)$ & 4,40 & 4,40 & 8,11 & 7,46 \\
\hline & & $f_{\mathrm{ppk}}(\mathrm{MPa})$ & & 2,80 & & 5,39 \\
\hline
\end{tabular}


Figura 3.18 - Curvas médias de tensão x deformação específica das pequenas paredes

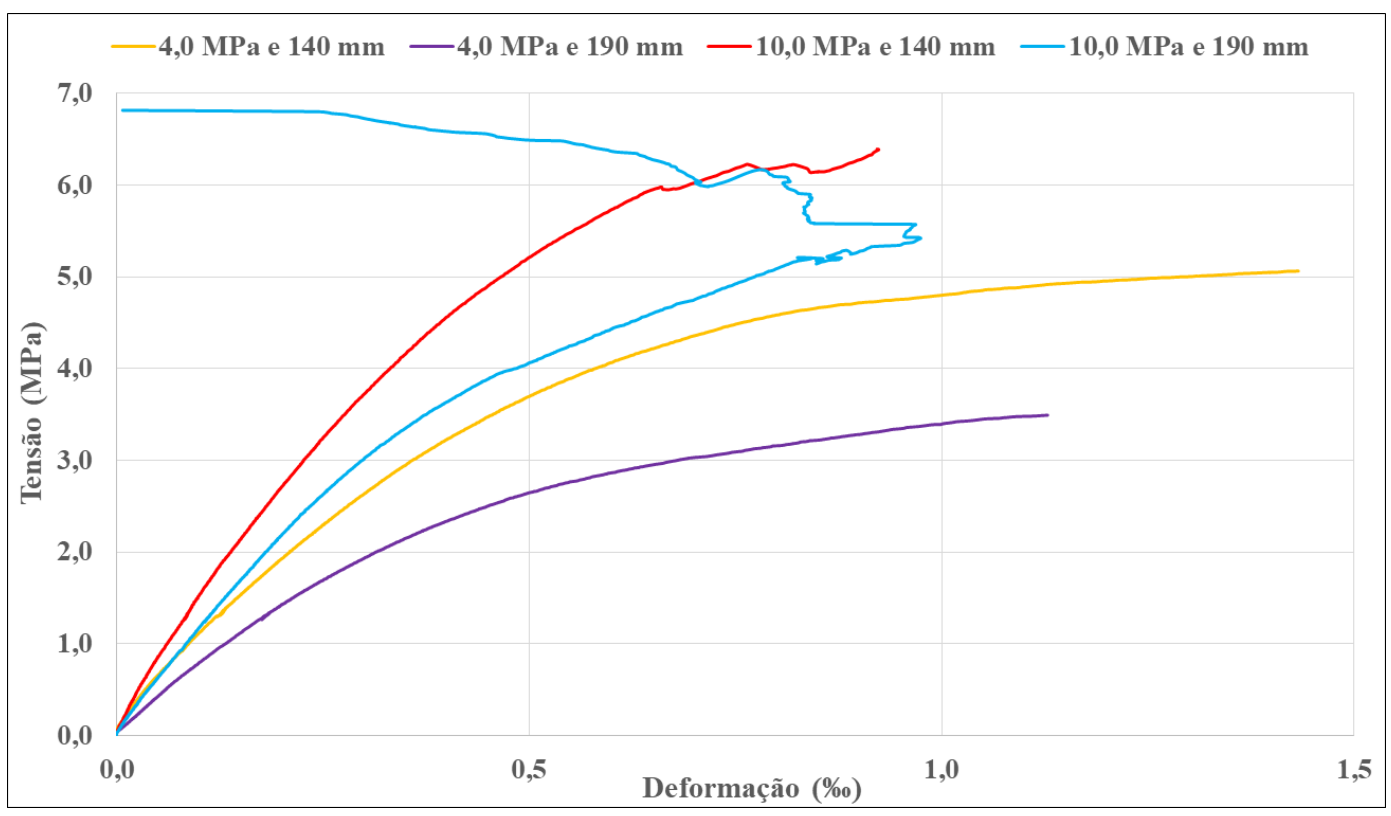

Seguindo a relação recomendada pela ABNT NBR 15961:2011 para estimativa do módulo de elasticidade da alvenaria em 800 vezes a resistência característica do prisma, temse que o módulo de elasticidade encontrado para os elementos de maior resistência está entre 10 e $25 \%$ superiores à estimativa e para os elementos de menor resistência o módulo de elasticidade obtido foi mais de $50 \%$ superior à estimativa.

A Figura 3.19 mostra um exemplo do modo de ruptura dos prismas de 4,0 $\mathrm{MPa}$ e 10,0 MPa. A Figura 3.20 apresenta dois exemplos do modo de ruptura das pequenas paredes. Para os prismas, os padrões de modos de rupturas não foram tão nítidos como para as pequenas paredes, sendo que nos prismas com resistência nominal de 4,0 MPa observou-se primeiramente o surgimento de fissuras verticais e diagonais de pequenas espessuras nas faces laterais dos elementos e em uma faixa de carregamento próxima da carga de ruptura, houve abertura brusca das fissuras diagonais que se estendiam para as faces frontal e posterior dos elementos.

Nos prismas com resistência nominal de 10,0 MPa foram as trincas verticais que abriram com os carregamentos máximos aplicados, caracterizando ruptura bastante frágil e em alguns casos, explosiva, dividindo o elemento através dos septos; observou-se também esmagamento de parte do concreto dos septos longitudinais dos blocos. Tanto as paredes com blocos de resistência nominal de 4,0 $\mathrm{MPa}$ como as com blocos de 10,0 $\mathrm{MPa}$ tiveram suas rupturas definidas pelas trincas e aberturas verticais apresentadas nas faces laterais dos elementos que surgiam de cima para baixo aumentando conforme aumentava-se o carregamento. Em parte das paredes, as primeiras fissuras que apareceram foram na face de maior dimensão da pequena 
parede, mas com o aumento do carregamento aplicado foram as fissuras laterais que abriram até a incapacidade do elemento de receber incrementos de carga. Em alguns casos das paredes de 4,0 MPa e espessura de $140 \mathrm{~mm}$ foi observado também o lascamento ou esmagamento de parte dos blocos próximos ao perfil metálico de aplicação do carregamento.

O APÊNDICE B apresenta mais fotos relacionadas aos ensaios compressão das pequenas paredes.

Figura 3.19 - Modo de ruptura dos prismas de 4,0 MPa

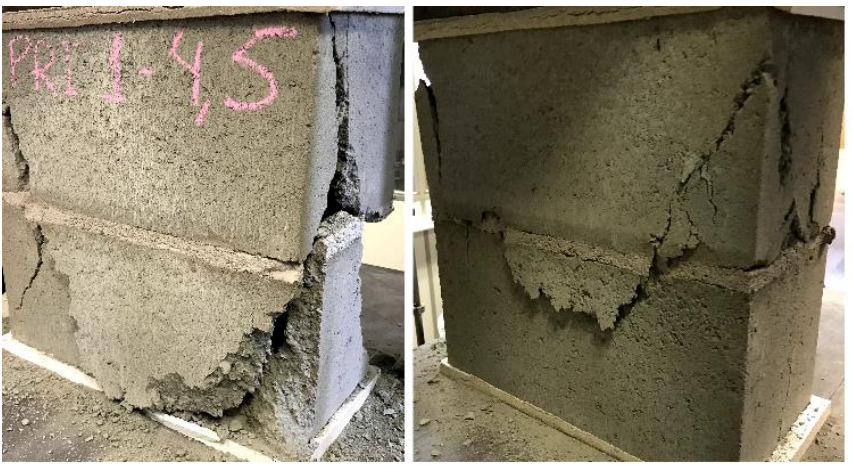

Prisma de 4,0 MPa

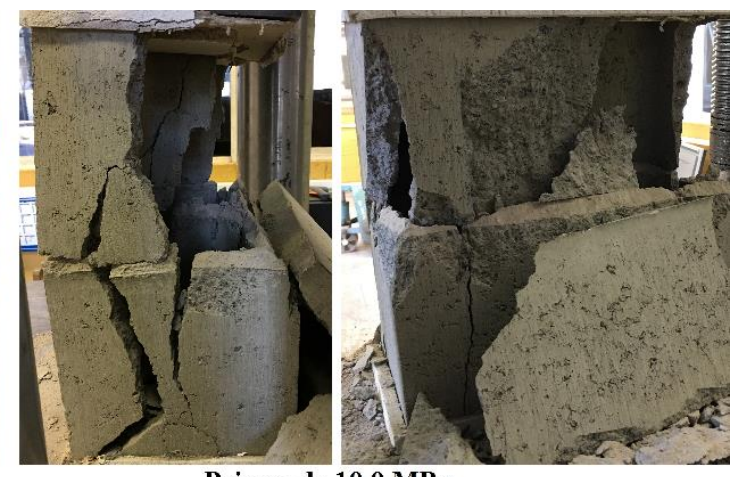

Prisma de 10,0 MPa

Figura 3.20 - Modo de ruptura das pequenas paredes

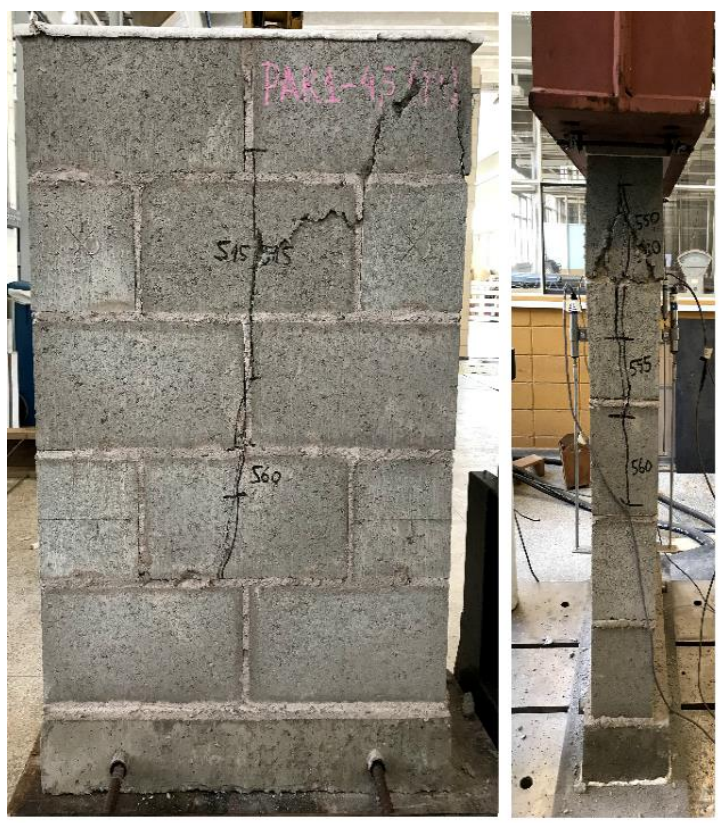

(a) Pequenas paredes de 4,0 $\mathrm{MPa}$
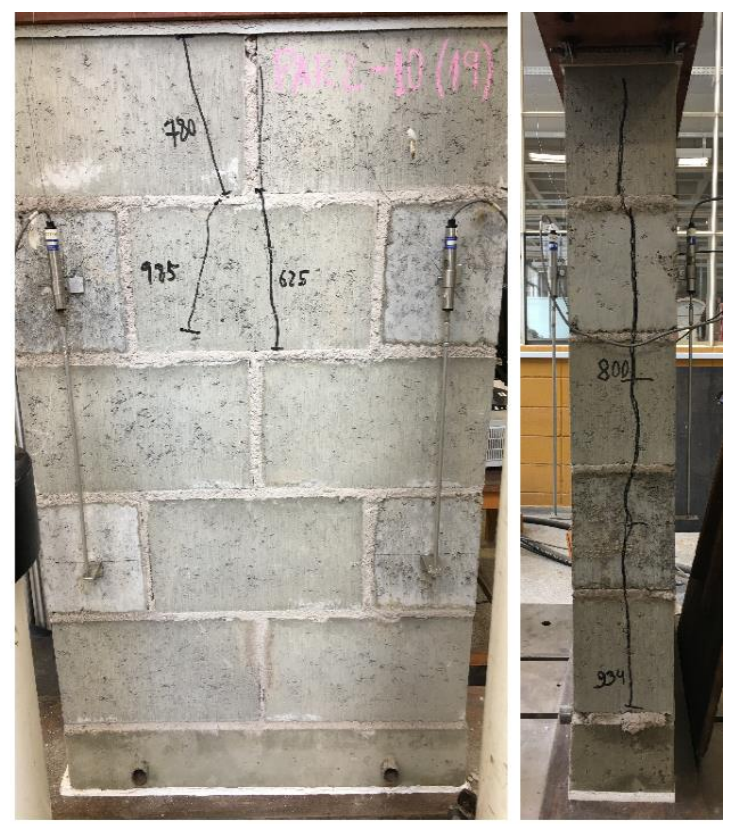

(b) Pequenas paredes de 10,0 MPa

\subsection{Fatores de eficiência entre os elementos de alvenaria}

É possível estabelecer relações entre a resistência dos prismas e das pequenas paredes com a resistência dos blocos, chamadas fatores de eficiência. Também é possível estabelecer a 
relação de resistência entre pequenas paredes e prismas pois é através destas relações préestabelecidas que podem ser empregados ensaios mais econômicos na avaliação da resistência da alvenaria, por exemplo, conhecendo-se a resistência do prisma é possível estimar a resistência da pequena parede. Este trabalho visa também observar se estas relações de resistência serão mantidas após a ação de incêndio.

Considerando que $f_{b k}$ é a resistência característica dos blocos, $f_{p k}$ é a resistência característica dos prismas e $f_{p p k}$ é a resistência característica das pequenas paredes, a Tabela 3.17 apresenta um resumo destas relações de eficiência da resistência à compressão dos elementos.

Tabela 3.17 - Relações de resistência entre os elementos de alvenaria estrutural em temperatura ambiente

\begin{tabular}{|c|c|c|c|c|}
\hline \multicolumn{5}{|c|}{ "Relações de resistência } \\
\hline \multicolumn{2}{|c|}{ Tipo de unidade } & \multirow[b]{2}{*}{$f_{p k} / f_{b k}$} & \multirow[b]{2}{*}{$f_{p p k} / f_{b k}$} & \multirow[b]{2}{*}{$f_{p p k} / f_{p k}$} \\
\hline $\begin{array}{c}\text { Resistência } \\
\text { característica } \\
\text { nominal } \\
\end{array}$ & $\begin{array}{l}\text { Largura } \\
\text { nominal }\end{array}$ & & & \\
\hline \multirow{2}{*}{$10,0 \mathrm{MPa}$} & $\begin{array}{l}140 \\
\mathrm{~mm}\end{array}$ & 0,59 & 0,26 & 0,44 \\
\hline & $\begin{array}{l}190 \\
\mathrm{~mm}\end{array}$ & 0,73 & $\mathbf{0 , 3 2}$ & $\mathbf{0 , 4 4}$ \\
\hline \multirow{2}{*}{ 4,0 MPa } & $\begin{array}{l}140 \\
\mathrm{~mm}\end{array}$ & 0,94 & 0,67 & $\mathbf{0 , 7 2}$ \\
\hline & $\begin{array}{l}190 \\
\mathrm{~mm}\end{array}$ & 0,83 & $\mathbf{0 , 5 3}$ & 0,63 \\
\hline
\end{tabular}

Todos os fatores de eficiência calculados foram menores para os blocos de resistência nominal de 10,0 MPa, ou seja, os elementos executados com os blocos de maior resistência apresentaram menor eficiência. Vale destacar que as resistências características dos blocos de 10,0 MPa na verdade foram de 20,76 MPa para os com espessura de $140 \mathrm{~mm}$ e de 17,32 MPa para os de espessura de $190 \mathrm{~mm}$. Enquanto isso, os blocos de resistência nominal de 4,0 MPa apresentaram fatores de eficiência maiores, sendo que as resistências características obtidas foram no máximo 54\% maiores que a nominal. Para a relação de resistência entre pequenas paredes e primas, as paredes de 10,0 MPa apresentaram a mesma relação que novamente foi menor que os valores encontrados para os elementos com blocos de 4,0 MPa. 


\section{PROGRAMA EXPERIMENTAL II: TEMPERATURAS ELEVADAS E RESISTÊNCIA RESIDUAL}

\subsection{Considerações iniciais}

A segunda etapa do programa experimental deste trabalho consiste em submeter os corpos de prova à situação de incêndio por meio de ensaios que foram realizados no forno a gás do Laboratório de Estruturas da Escola de Engenharia de São Carlos (Figura 4.1), e na sequência submeter estes corpos de prova ao ensaio de compressão simples para avaliar a sua resistência residual.

Figura 4.1 - Forno a gás do Laboratório de Estruturas da EESC

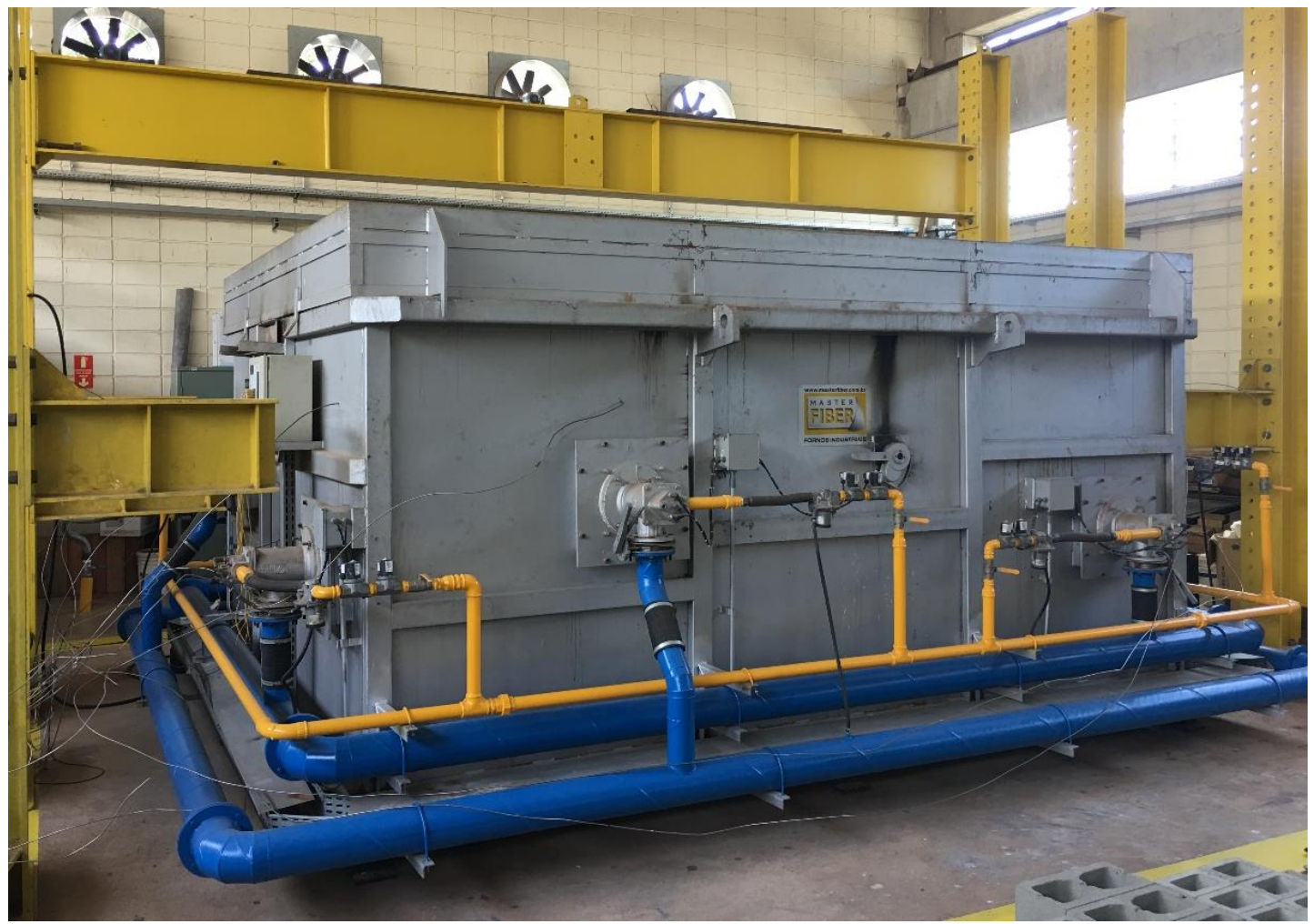

Este capítulo trata dos principais aspectos relacionados à programação, execução e resultados obtidos nos ensaios, tanto de simulação do incêndio como de compressão pós-fogo. Primeiramente foi realizado um teste de instrumentação com dois blocos de $140 \mathrm{~mm}$, um com resistência de 4,0 $\mathrm{MPa}$ e outro com resistência de 10,0 $\mathrm{MPa}$, com o intuito de analisar a capacidade dos termopares em medir as temperaturas nos corpos de prova e também verificar a integridade de diferentes tipos de fixação quando submetidas a elevadas temperaturas. Foi 
dado destaque ao planejamento da instrumentação com termopares para conhecer os níveis de temperatura alcançados pelos materiais ao longo do tempo de exposição ao fogo.

Em seguida foi realizada uma primeira fornada com elementos de blocos de concreto de $140 \mathrm{~mm}$ de espessura e ambas resistências, 4,0 e 10,0 MPa. Os corpos de prova foram ensaiados sem revestimento com a temperatura seguindo a curva de incêndio-padrão por um período de 70 minutos. Nesta etapa também foi submetido à situação de incêndio um trio de pequenas paredes dispostas de maneira a formar em planta um triângulo equilátero e com as aberturas isoladas termicamente de forma a manter o interior compartimentado e livre dos gases aquecidos pelas chamas. Assim foi possível fazer uma breve avaliação da influência da compartimentação na resistência residual das pequenas paredes de blocos de concreto com resistência de 4,0 MPa e $140 \mathrm{~mm}$ de espessura. E também, avaliar por meio de termopares adequadamente posicionados, se estes elementos atendem aos critérios de isolamento térmico das principais normas nacionais e internacionais.

Como estes elementos submetidos a 70 minutos de incêndio-padrão apresentaram resistência residual muito baixas, optou-se por revestir os corpos de prova das demais fornadas com uma camada de $5 \mathrm{~mm}$ de gesso em todas as faces dos elementos, uma vez que seriam submetidos a 120 minutos de incêndio. O gesso foi escolhido por ser atualmente o principal revestimento utilizado em paredes de compartimentação interna nos edifícios de alvenaria estrutural. Portanto, na sequência realizou-se a segunda fornada, em que todos os elementos (blocos, prismas e pequenas paredes) com espessura de $140 \mathrm{~mm}$ e revestidos com gesso foram submetidos a 120 minutos de incêndio-padrão. Por fim, foram feitos os ensaios de compressão após resfriamento lento para avaliação a resistência residual da alvenaria.

\subsection{Instrumentação}

Quando os materiais são submetidos a elevadas temperaturas, as propriedades mecânicas se alteram e estão relacionadas ao seu comportamento térmico, sendo, portanto, importante conhecer as propriedades térmicas destes materiais e a temperatura (ou perfil de temperaturas) alcançada (o). Para obter a curva de temperatura em função do tempo de ensaio que os materiais constituintes dos corpos de prova alcançaram, foi realizada a instrumentação com cabos termopares do tipo K.

Os cabos termopares são formados por dois cabos, um positivo e outro negativo cujos materiais são níquel e alumínio respectivamente e de acordo com a norma ANSI MC 96-1 o cabo positivo deve ser envolto por uma proteção amarela e o negativo vermelha, sendo que 
ambos os cabos são envoltos por uma proteção térmica de cerâmica (Figura 4.2). Para utilização dos cabos termopares como medidores de temperatura é necessário que as pontas de ambos os cabos estejam unidas e soldadas. É necessário que esta solda seja bem executada, formando um material o mais homogêneo possível, pois é neste ponto de união que a temperatura do material em contato será medida. O procedimento de soldagem dos cabos pode ser observado na Figura 4.2, e é feito utilizando-se um equipamento de solda por descarga capacitiva (Figura 4.3).

Figura 4.2 - Procedimento de soldagem do cabo termopar tipo K

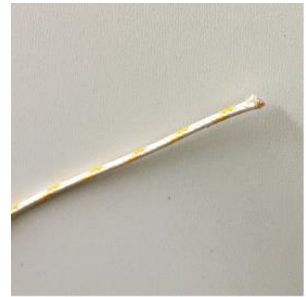

Cabo termopar
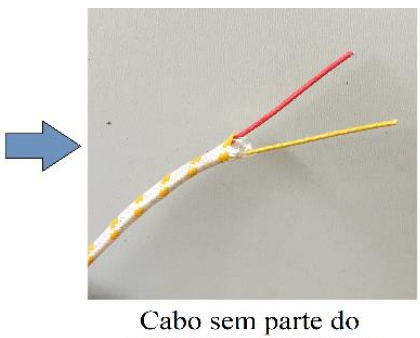
revestimento cerâmico

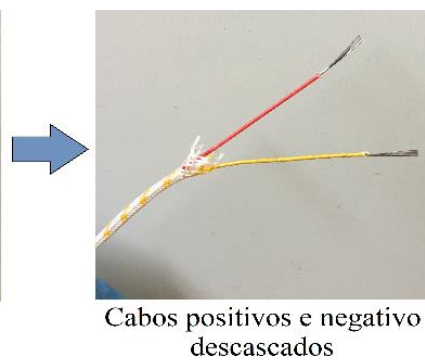
descascados

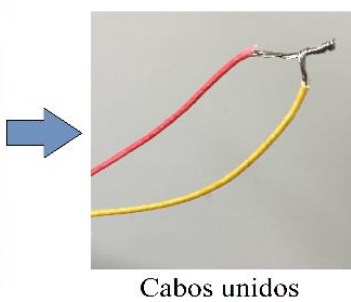

manualmente

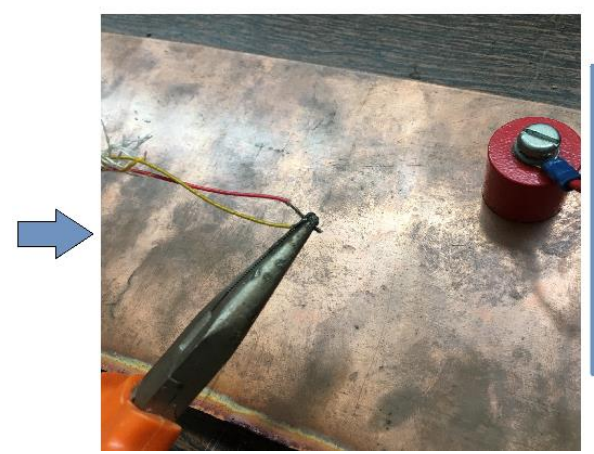

Coloca-se o eletrodo do equipamento de solda em uma chapa de cobre, pegam-se os cabos unidos com o alicate do próprio equipamento e os encostam na chapa. Aperta-se o botão para realizar a descarga capacitiva c após o estalo está realizada a solda.

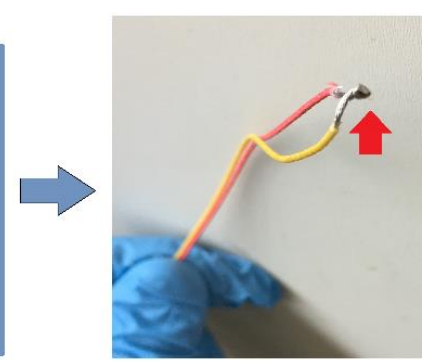

Solda realizada

Figura 4.3 - Equipamento de solda por descarga capacitiva, junto com a placa de cobre utilizada

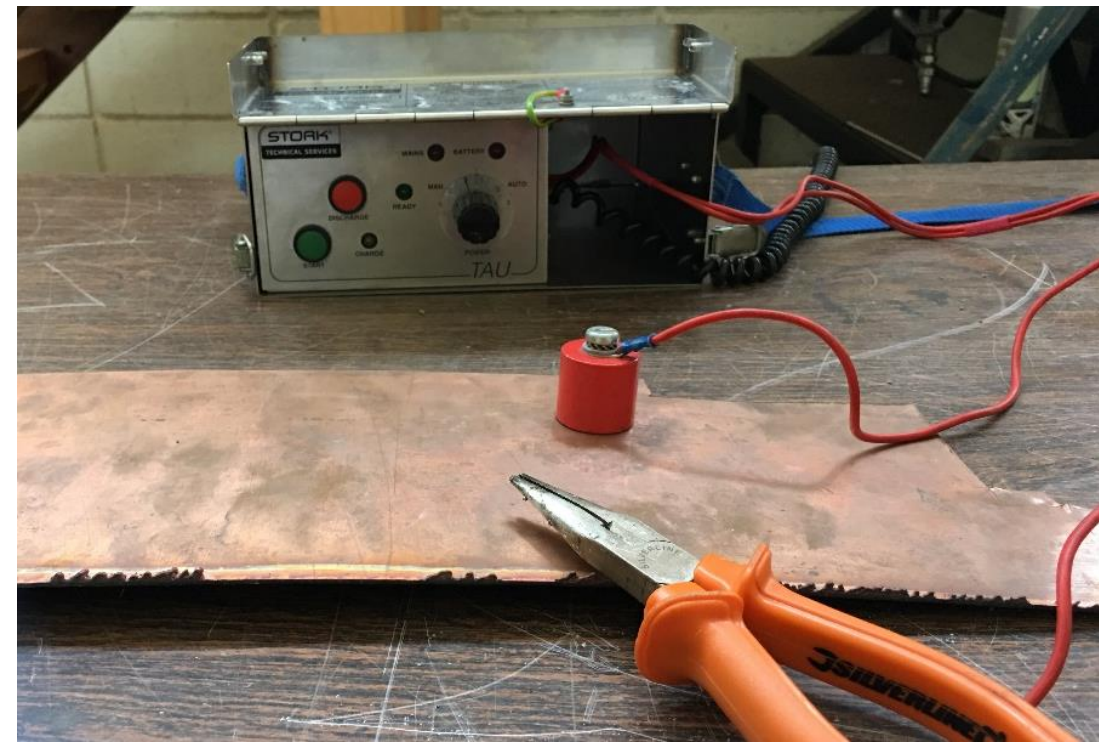




\subsection{Teste para instrumentação dos corpos de prova}

Antes da realização dos ensaios de simulação de incêndio-padrão com os corpos de prova da pesquisa foi realizado um teste com dois blocos, um de 4,0 MPa e outro de 10,0 MPa, ambos com espessura de $140 \mathrm{~mm}$. O teste teve duração de 43 minutos e alcançou temperaturas próximas a $900^{\circ} \mathrm{C}$, visto que o forno conseguiu seguir a curva temperatura x tempo da ISO 8341:1999 dentro das tolerâncias impostas pela ABNT NBR 10636:1989, e os blocos foram submetidos ao aquecimento em todas as faces laterais. Visando obter parâmetros para a melhor instrumentação dos corpos de prova, o teste de instrumentação possuía os seguintes objetivos:

- Avaliar diferentes tipos de fixação dos termopares para verificar aquele que oferece melhor trabalhabilidade sem comprometer as medições de temperatura no material. Para os termopares no interior do concreto, os blocos foram furados com broca de $4 \mathrm{~mm}$ e após a colocação da instrumentação, parte das cavidades foram preenchidas com pasta de cimento e parte com durepóxi. Para a instrumentação na superfície dos blocos, os termopares foram soldados a discos de cobre ou em tarraxas metálicas e fixados apenas com epóxi, visto que neste caso a pasta de cimento não garantiu fixação adequada;

- Verificar o melhor posicionamento dos termopares no bloco, que permitam conhecer a temperatura o mais próximo possível das faces internas e externas das paredes longitudinais dos blocos;

- Verificar se há diferença de medição ao utilizar um termopar mais resistente, com resistência nominal de $700^{\circ} \mathrm{C}$ e o que o será utilizado na pesquisa, que possui resistência nominal de $300^{\circ} \mathrm{C}$.

Os blocos foram instrumentados em pontos estratégicos, como mostra a Figura 4.4.

Figura 4.4 - Fixação dos termopares no bloco para teste de instrumentação
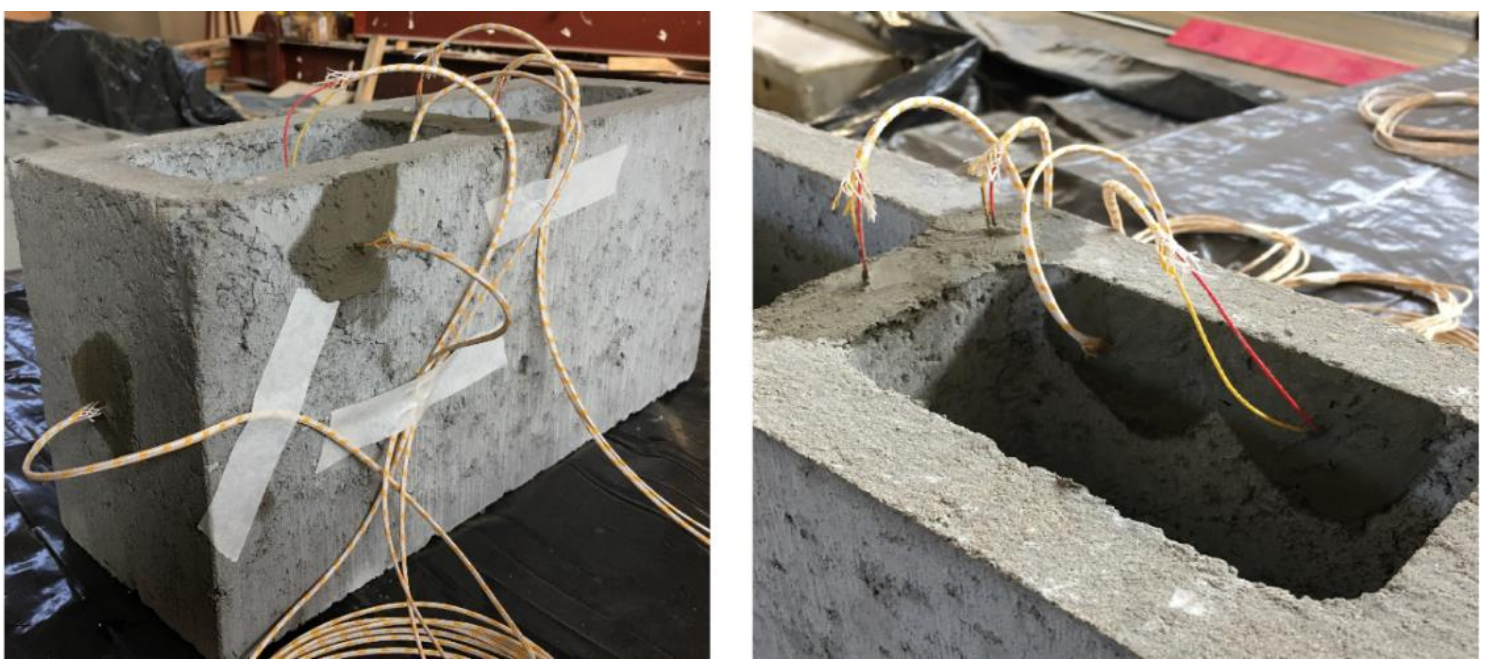
A Figura 4.5 traz um esquema de posicionamento dos termopares no bloco de 4,0 MPa e de 10,0 MPa. A descrição da posição dos termopares e o tipo de fixação segue apresentada na Tabela 4.1.

Figura 4.5 - Posições dos termopares para o teste de instrumentação

Bloco de 10,0 MPa

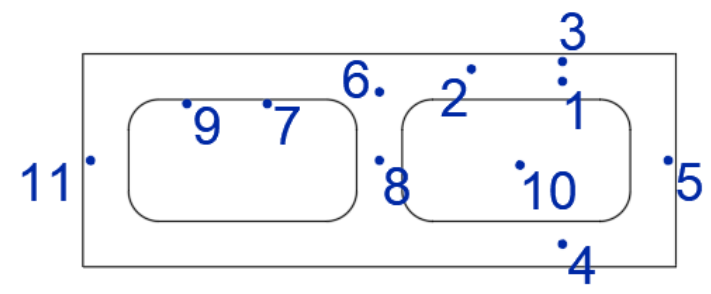

Bloco de 4,0 MPa

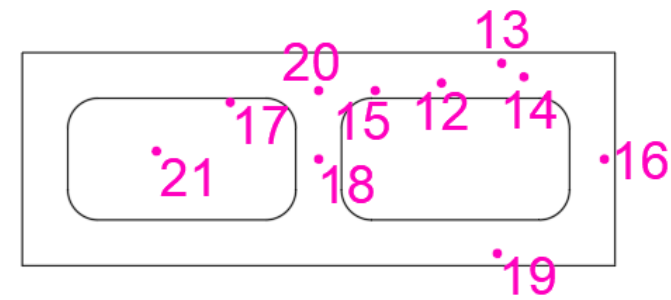

Tabela 4.1 - Relação de termopares do teste de instrumentação e suas respectivas posições

\begin{tabular}{|c|c|c|c|c|c|}
\hline \multicolumn{3}{|c|}{ Bloco de 10,0 MPa } & \multicolumn{3}{|c|}{ Bloco de 4,0 MPa } \\
\hline Termopar & $\begin{array}{l}\text { Material de } \\
\text { fixação }\end{array}$ & $\begin{array}{c}\text { Profundidade } \\
\text { efe tiva }(\mathrm{mm}) / \text { Face }\end{array}$ & Termopar & $\begin{array}{l}\text { Material de } \\
\quad \text { fixação }\end{array}$ & $\begin{array}{c}\text { Profundidade } \\
\text { efe tiva }(\mathrm{mm}) / \text { Face }\end{array}$ \\
\hline 1 & Pasta de cimento & 0,8 / Interna & 12 & Durepóxi & 1,0 / Interna \\
\hline 2 & Pasta de cimento & 1,1 / Interna & 13 & Pasta de cimento & 0,4 / Externa \\
\hline 3 & Pasta de cimento & 0,2 / Externa & 14 & Pasta de cimento & 0,7 / Interna \\
\hline 4 & Durepóxi & 0,9 / Externa & 15 & Pasta de cimento & $0,1 /$ Interna \\
\hline 5 & Pasta de cimento & 0,1 / Externa & 16 & Pasta de cimento & 0,1 / Externa \\
\hline 6 & Pasta de cimento & 1,1 / Superior & 17 & Durepóxi & $\begin{array}{c}\text { Superfície } \\
\text { (disco de cobre) }\end{array}$ \\
\hline 7 & Durepóxi & $\begin{array}{c}\text { Superfície } \\
\text { (disco de cobre) }\end{array}$ & 18 & Pasta de cimento & 2,1 / Superior \\
\hline 8 & Pasta de cimento & 2,5 / Superior & 19 & Durepóxi & 0,4 / Externa \\
\hline 9 & Durepóxi & $\begin{array}{c}\text { Superfície } \\
\text { (tarraxa) }\end{array}$ & 20 & Pasta de cimento & 2,5 / Superior \\
\hline 10 & \multicolumn{2}{|c|}{ Gases internos } & 21 & \multicolumn{2}{|c|}{ Gases internos } \\
\hline 11 & Durepóxi & 0,9 / Externa & & & \\
\hline
\end{tabular}

Os blocos foram posicionados no forno com uma camada de manta cerâmica em cima e outra embaixo de maneira que somente as faces laterais ficassem expostas ao fogo e que o calor não entrasse nos furos internos. Os termopares com resistência nominal de $300^{\circ} \mathrm{C}$ foram protegidos com a manta até a saída do forno e o termopar com resistência nominal de $700^{\circ} \mathrm{C}$ foi deixado sem proteção, pois a intenção era avaliar se ele resistiria mesmo desprotegido, garantindo maior agilidade na montagem dos ensaios. A Figura 4.6 mostra este posicionamento dos elementos dentro do forno. 
Figura 4.6 - Posicionamento dos elementos do teste de instrumentação no forno
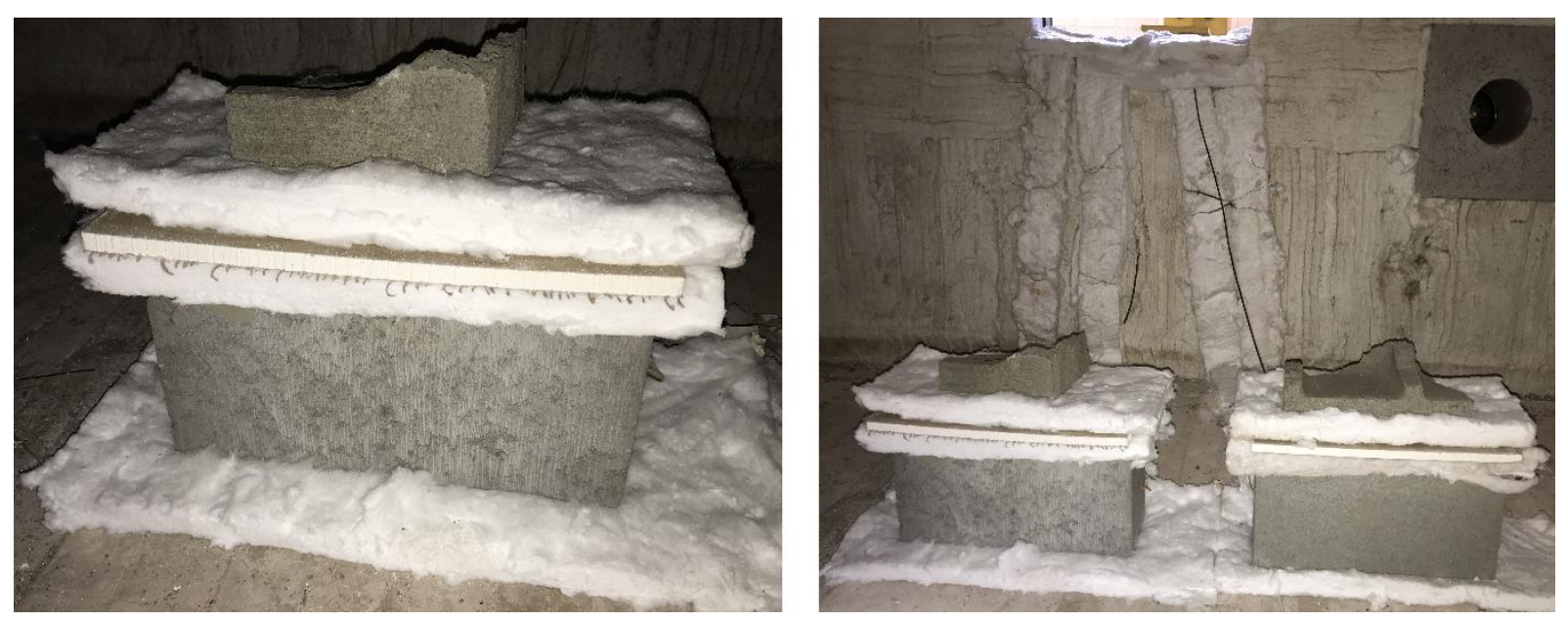

Na Figura 4.7 é possível ver o interior do forno durante o aquecimento, sendo que a foto foi tirada através de uma escotilha de visualização presente no forno.

Figura 4.7 - Ação do fogo durante o teste de instrumentação

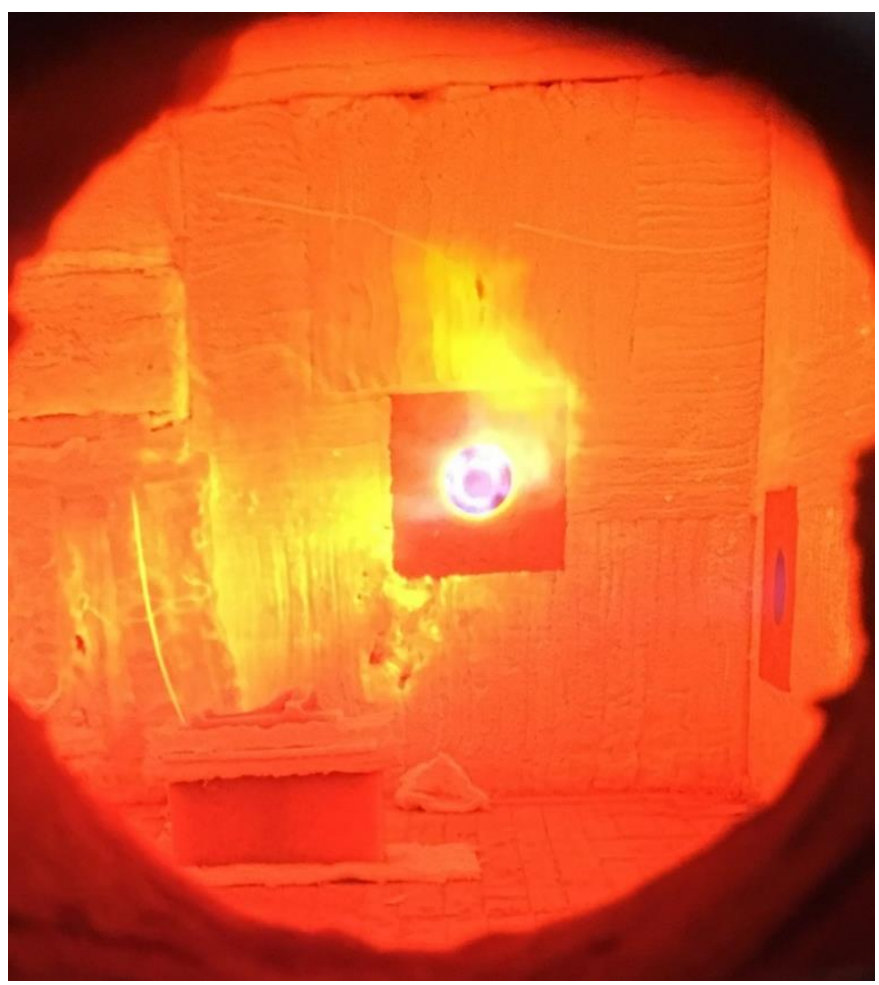

Com os resultados de temperatura em função do tempo obtidos pela instrumentação realizada nos blocos, foi possível traçar curvas de elevação da temperatura nos materiais, mostradas nos gráficos da Figura 4.8 para o bloco de 10,0 MPa e da Figura 4.9 para o bloco de 4,0 MPa. O número entre parênteses na legenda das curvas é correspondente ao número do termopar indicado na Tabela 4.1. 
Figura 4.8 - Gráfico dos resultados do teste de instrumentação para o bloco de 10,0 MPa

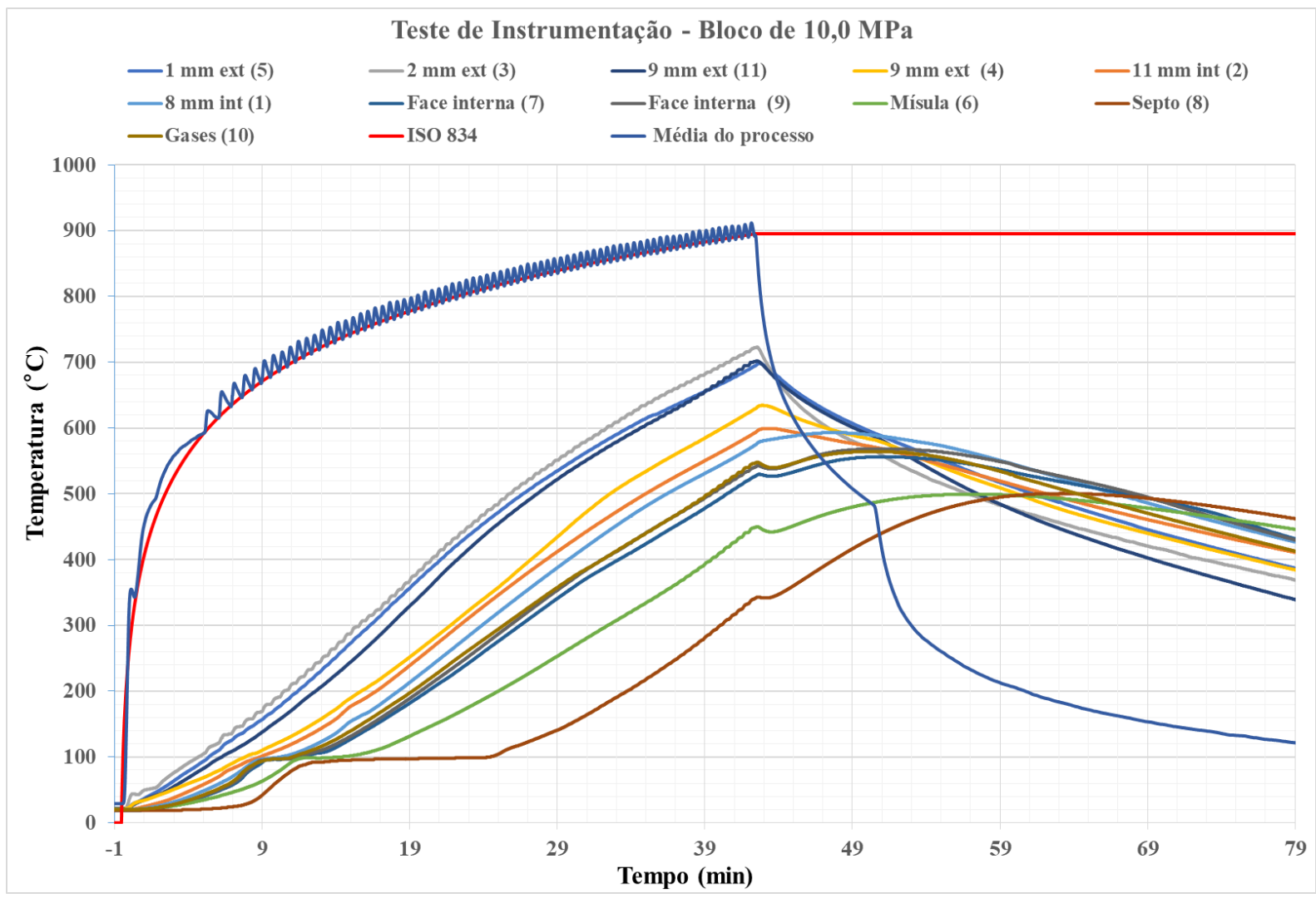

Figura 4.9 - Gráfico dos resultados do teste de instrumentação para o bloco de 4,0 MPa

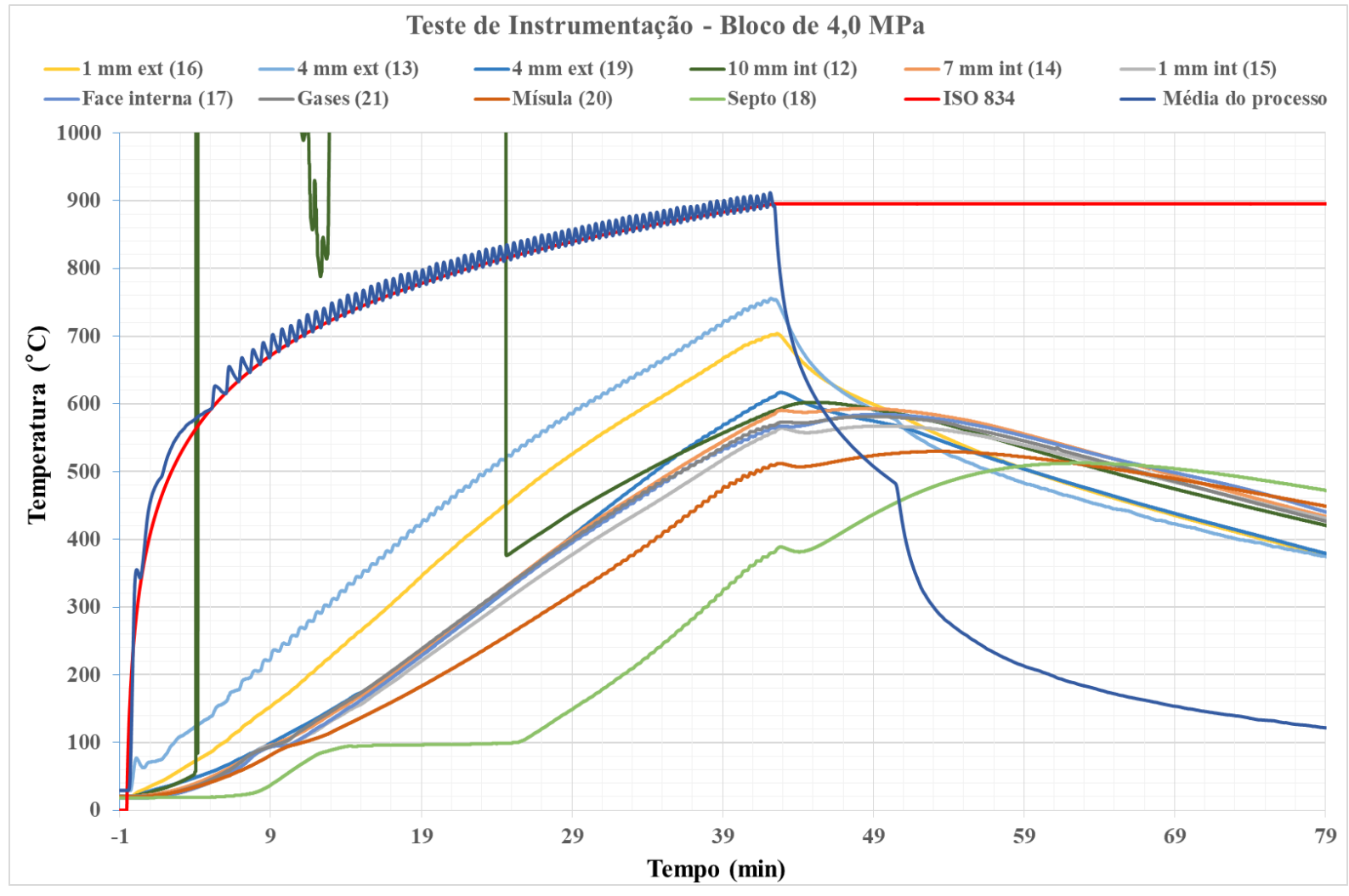


Pode-se observar em ambos os gráficos, pela curva "Média do processo", que as temperaturas médias dos gases dentro do forno acompanharam satisfatoriamente a curva de incêndio-padrão da ISO 834-1:1999 (curva em vermelho). As leituras de temperatura obtidas em ambos os blocos foram condizentes com o comportamento esperado para a transferência de calor, ou seja, para um mesmo material utilizado na fixação dos termopares, as maiores temperaturas atingidas foram sempre para os pontos mais próximos da face externa do bloco.

Quanto ao tipo de fixação utilizada, analisando curvas de termopares posicionados a uma mesma distância da face do bloco, porém com materiais diferentes, foi possível observar que os fixados com durepóxi apresentaram medidas de temperatura ligeiramente menores que os fixados com pasta de cimento. Acredita-se que isso pode ser justificado pela proximidade de propriedades térmicas e físicas entre os blocos de concreto e a pasta de cimento, ou pelo fato de terem ficado eventuais bolsas de ar nos furos preenchidos com durepóxi, uma vez que este material não apresentou boa trabalhabilidade neste procedimento. Portanto, ficou definido que nos ensaios a fixação dos termopares internos seria feita com pasta de cimento.

Para os termopares utilizados na medição da temperatura na face interna das paredes longitudinais do bloco definiu-se que seriam utilizados discos de cobre, que possuem melhor transferência de calor que tarraxas metálicas e também são mais fáceis para soldar os termopares. Respeito a sua fixação, como a pasta de cimento não permitiu o posicionamento da instrumentação, foi utilizado apenas durepóxi, este material apesar de manter o termopar em sua posição mostrou-se muito degradado após a ação do fogo. Portanto, para os ensaios, foi definida a utilização de um cimento-cola cerâmico fornecido pela empresa Unifrax que é apropriado para colar materiais até $1700^{\circ} \mathrm{C}$.

Com a curva do termopar (12) presente no gráfico da Figura 4.9 referente ao termopar com resistência nominal de $700^{\circ} \mathrm{C}$ foi observada uma falha de medição entre o tempo de 5 e 26 minutos, sendo que após este período o termopar apresentou medição coerente com a profundidade na qual foi posicionado. Acredita-se que esta falha possa ser justificada por desconexão dos fios do termopar durante o ensaio em função das movimentações de ar causadas pela ação das chamas, visto que quando ocorre este tipo de falha, o sistema de aquisição de dados registra a temperatura de $1300^{\circ} \mathrm{C}$. Como este termopar é de difícil trabalhabilidade por ser muito rígido, é possível que a solda não tenha ficado tão bem executada como as soldas dos termopares de resistência nominal de $300^{\circ} \mathrm{C}$. Assim, o termopar escolhido para os ensaios foi o de $300^{\circ} \mathrm{C}$ protegido com manta cerâmica nos pontos de exposição direta ao fogo.

Como mencionado, quanto mais internos os pontos de medição, menores os níveis de temperatura apresentados no material, mas para os pontos localizados nas mísulas e 
principalmente nos septos dos blocos foi possível observar nítidos patamares de temperatura a $100^{\circ} \mathrm{C}$. Estes patamares, como observado nos trabalhos de Al Nahhas et al. (2007) e Lopes et al. (2018), podem ser justificados pela energia térmica absorvida pela mudança de fase da água livre contida nos poros dos blocos de concreto e por isso são mais nítidos em pontos mais internos do bloco de concreto, pois a água leva mais tempo para evaporar e encontrar caminhos para sair.

$\mathrm{O}$ resfriamento adotado foi o lento, em que o ventilador do forno ficou ligado para circular o ar interno até que a temperatura dos gases internos atingisse $60^{\circ} \mathrm{C}$, tempo aproximado de 180 minutos, sendo que após o desligamento do ventilador o forno foi aberto. Relacionado ao material, foram observadas fissuras localizadas tanto nas paredes longitudinais dos blocos como nas faces laterais e mais acentuadas no bloco de 10,0 MPa, como pode ser observado na Figura 4.10. Estas fissuras podem ser justificadas por dilatações diferenciais entre os diferentes tipos de agregados do concreto ou por tensões internas que surgem no bloco durante a evaporação da água livre contida nos seus poros.

No dia do ensaio foram medidas as umidades relativas dos blocos que resultaram em $20 \%$ para o bloco de 10,0 MPa e 10\% para o bloco de 4,0 MPa. Após o resfriamento lento estes blocos foram submetidos ao ensaio de compressão simples, resultando em uma resistência residual de 53\% para o bloco de 4,0 MPa e de $\mathbf{3 5 \%}$ para o bloco de 10,0 MPa.

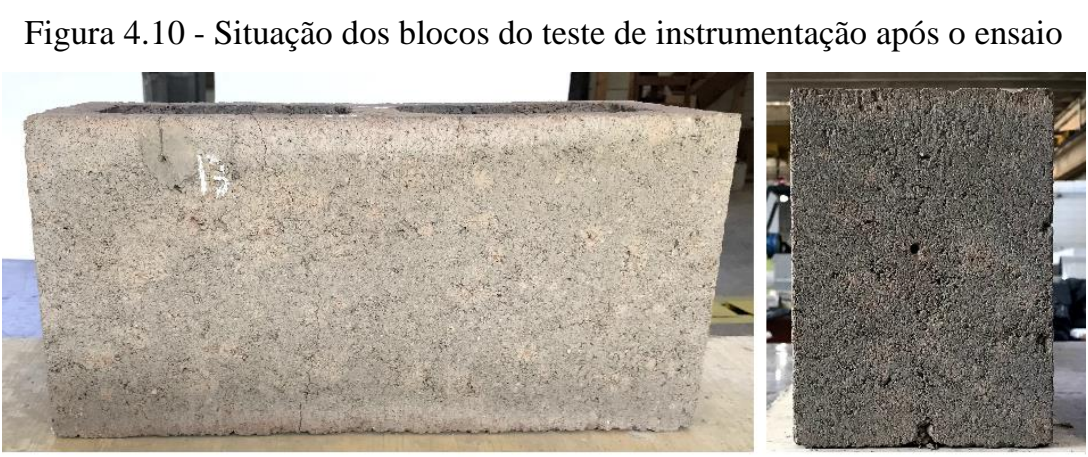

Bloco de 4,0 MPa
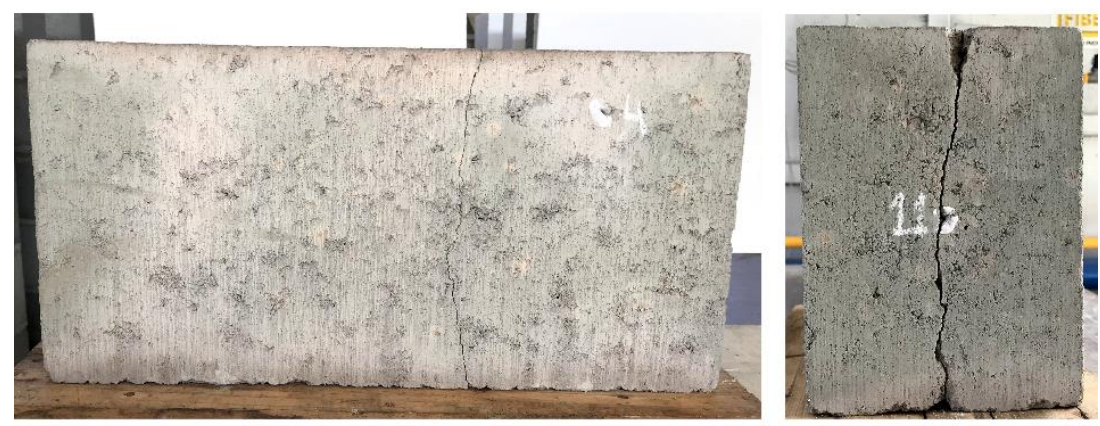

Bloco de 10,0 MPa 


\subsection{Simulação de incêndio-padrão - sem revestimento (primeira fornada)}

Na primeira simulação de incêndio-padrão foram ensaiados elementos sem revestimento de ambas classes de resistência estudadas, mas apenas com espessura de $140 \mathrm{~mm}$, e os corpos de prova foram submetidos à ação do fogo por 70 minutos, chegando à temperatura máxima de $980^{\circ} \mathrm{C}$. Estava previsto para o ensaio ter duração de 120 minutos, que é o máximo de tempo requerido de resistência ao fogo (TRRF) prescrito pela ABNT NBR 14432:2011. No entanto, em função de problemas elétricos no forno, o ensaio precisou ser interrompido com 70 minutos.

O forno utilizado possui 9 termopares que medem a temperatura dos gases controlando automaticamente a potência das chamas nos queimadores para garantir que a temperatura destes termopares siga a evolução de temperatura desejada. Desta forma o forno atingiu satisfatoriamente a curva de incêndio-padrão da ISO 834-1:1999 próxima de todos os corpos de prova, uma vez que os termopares de controle foram posicionados a uma distância de aproximadamente 15 centímetros dos elementos. Durante todo o período de funcionamento a temperatura média se manteve entre os limites superior e inferior sugeridos pela ABNT NBR 10636:1989. A Figura 4.11 mostra a curva de temperatura média do forno em função do tempo de ensaio juntamente com a curva de incêndio-padrão e os limites normalizados.

Figura 4.11 - Temperatura do forno na primeira fornada

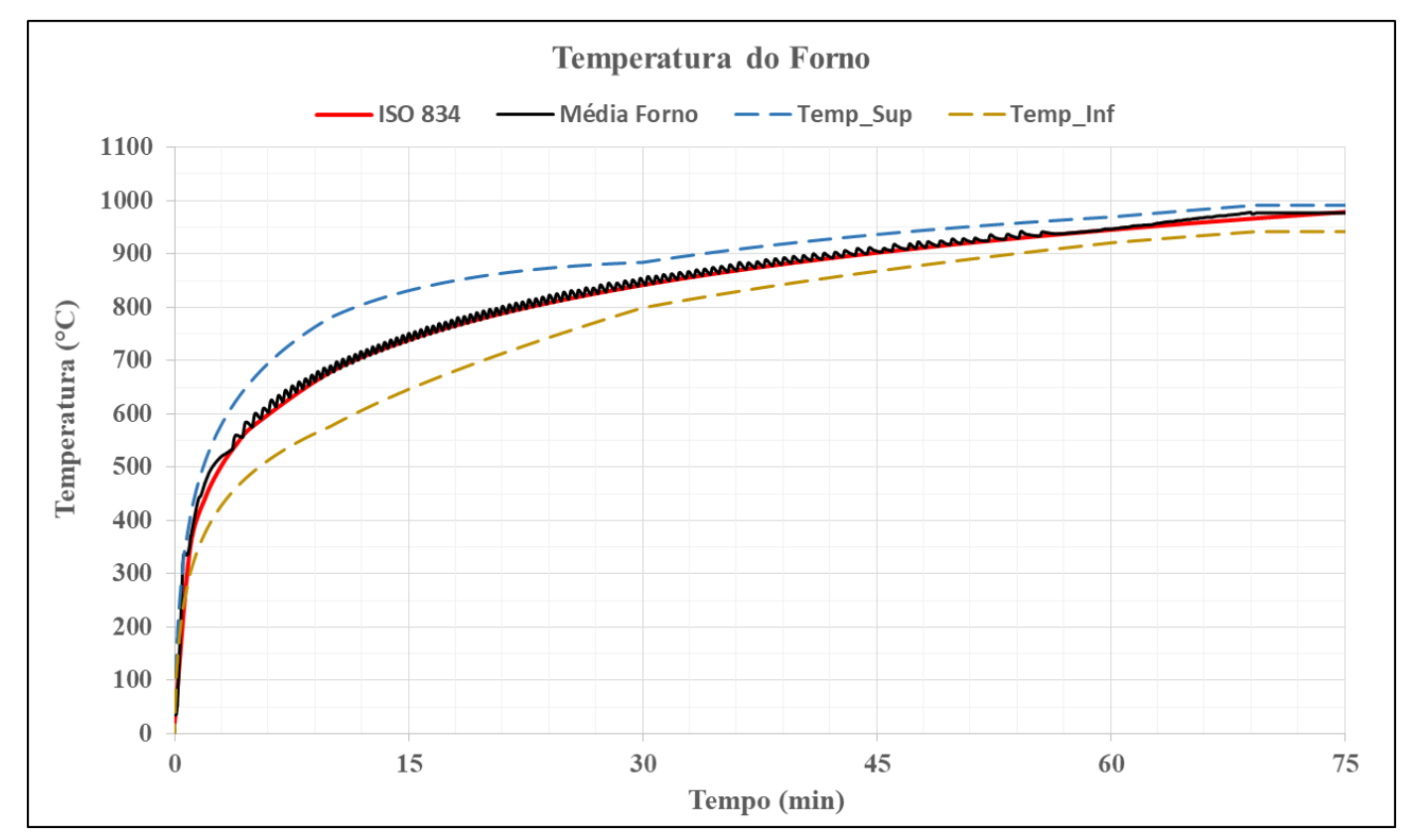

Como visto na literatura, a umidade relativa dos blocos de concreto é um fator importante no comportamento do material frente a elevadas temperaturas pois a presença de água no interior dos poros pode influenciar na fissuração e consequentemente na resistência 
residual dos corpos de prova. Foram medidas as umidades relativas de dois blocos para cada variação de elementos nesta primeira fornada seguindo as recomendações da ABNT NBR 12118:2014, sendo os resultados médios dispostos na Tabela 4.2.

Tabela 4.2 - Umidade relativa dos blocos da primeira fornada

\begin{tabular}{c|c|c}
\hline \hline \multicolumn{2}{c}{ Umidade realtiva dos blocos para $1^{\mathrm{a}}$ fornada } \\
\hline \hline \multicolumn{2}{c}{ Tipo de unidade } & Bloco \\
\hline $\begin{array}{c}\text { Resistência característica } \\
\text { nominal }\end{array}$ & $\begin{array}{c}\text { Largura } \\
\text { nominal }\end{array}$ & Umidade Relativa \\
\hline \hline & $140 \mathrm{~mm}$ & $\mathbf{3 3 \%}$ \\
\hline $4,0 \mathrm{MPa}$ & $140 \mathrm{~mm}$ & $\mathbf{1 1 \%}$ \\
\hline \hline
\end{tabular}

A seguir serão apresentadas especificidades relacionadas à primeira fornada, tais como a execução, a organização dos corpos de prova no forno e a instrumentação realizada. Também serão apresentados os resultados obtidos na análise térmica dos elementos e na análise mecânica de resistência residual pós-fogo.

4.4.1. Corpos de prova - quantidade, execução e preparação da fornada

Foram submetidos à simulação de incêndio-padrão os mesmos corpos de prova utilizados na caracterização do Programa Experimental I, blocos, primas e pequenas paredes. As quantidades para cada elemento também foram mantidas, seguindo as prescrições das normas ABNT NBR 6136:2016 para os blocos, ABNT NBR 15961-1 para os prismas e pequenas paredes e ABNT 13276:2016 para argamassa.

Por questões de limitação de espaço no forno não foram submetidos à ação do fogo prismas com resistência nominal de 10,0 MPa e a principal diferença está na introdução do trio de pequenas paredes com blocos de 4,0 MPa e espessura de $140 \mathrm{~mm}$ que foram posicionadas em planta formando um triângulo equilátero de forma a provocar isolamento do seu interior e exposição ao fogo em apenas uma face.

Os corpos de prova utilizados na primeira fornada foram executados seguindo o mesmo padrão daqueles ensaiados em temperatura ambiente. Foi adotado argamassamento total tanto para os prismas de dois blocos como para as pequenas paredes, com argamassa no traço em volume de $1: 0,5: 4,5$ de cimento, cal e areia, respectivamente. Para que fosse possível o transporte, as pequenas paredes foram executadas sobre bases de concreto, cuja execução 
(formato, traço e armadura) está descrita no item 3.4.1 desta dissertação. Os elementos ensaiados nesta primeira fornada não foram submetidos a nenhum tipo de revestimento externo, sendo os componentes expostos diretamente ao fogo.

A disposição dos corpos de prova dentro do forno foi pensada de modo que todos recebessem calor da maneira mais homogênea possível vindo dos gases do ambiente e não diretamente das chamas que saem dos queimadores. Sendo assim, os corpos de prova mais altos (pequenas paredes) foram posicionados o mais distante possível da saída dos queimadores, para não bloquearem as entradas de gases quentes e também para não impedirem o fluxo de calor gerado pelas movimentações de ar dentro do forno.

A Figura 4.12 mostra a disposição e a quantidade de corpos de prova para a primeira fornada. O desenho conta com uma legenda de cores para identificar os elementos, que foram representados com proporção entre eles e em relação ao forno, os círculos laranjas nas paredes do forno indicam a posição dos queimadores.

Todos os corpos de prova foram posicionados dentro do forno em cima de uma camada de manta cerâmica para evitar que entrasse calor por eventuais frestas entre os mesmos e o piso do forno. Após este posicionamento todas as bases de concreto das pequenas paredes foram cobertas com uma camada de manta cerâmica (Figura 4.13) colada com o cimento-cola cerâmico da Unifrax que resiste a temperaturas de até $1700^{\circ} \mathrm{C}$.

Figura 4.12 - Disposição dos corpos de prova da primeira fornada

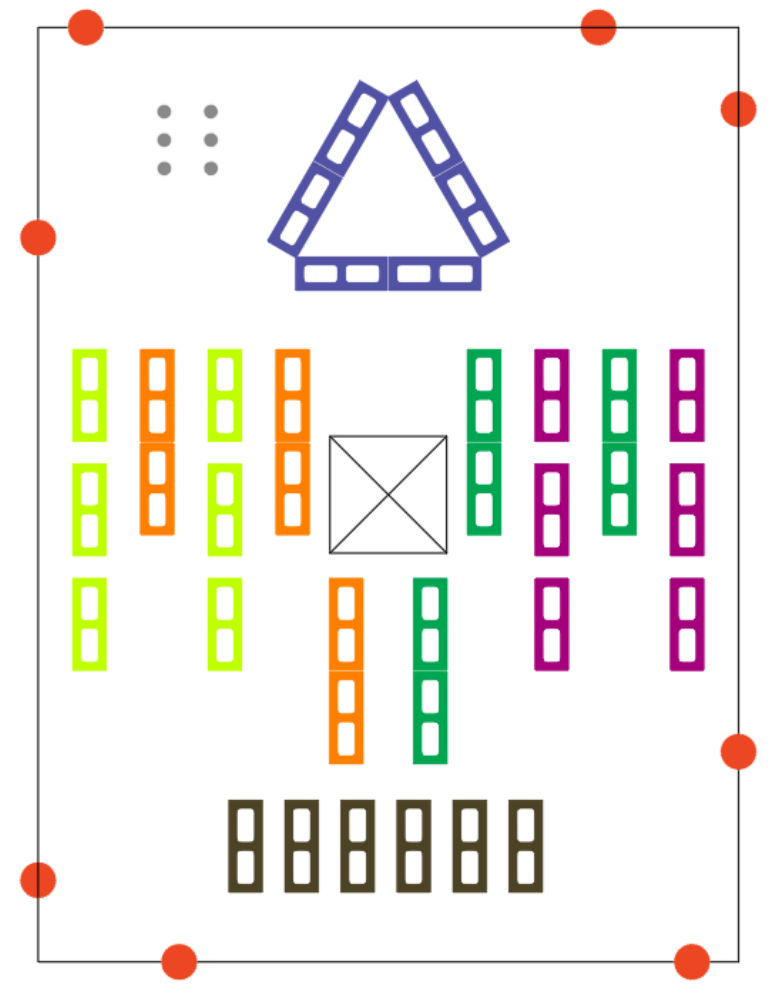

$1^{\text {a }}$ Fornada:

1 Par. Trio 140mm/ 4,0MPa

3 P.Paredes 140mm/ 10,0MPa

3 P.Paredes $140 \mathrm{~mm} / 4,0 \mathrm{MPa}$

6 Prismas $140 \mathrm{~mm} / 4,0 \mathrm{MPa}$

6 Blocos $140 \mathrm{~mm} / 10,0 \mathrm{MPa}$

6 Blocos 140mm/ 4,0MPa

6 CP's de argamassa 
Figura 4.13 - Proteção térmica das bases de concreto com manta cerâmica

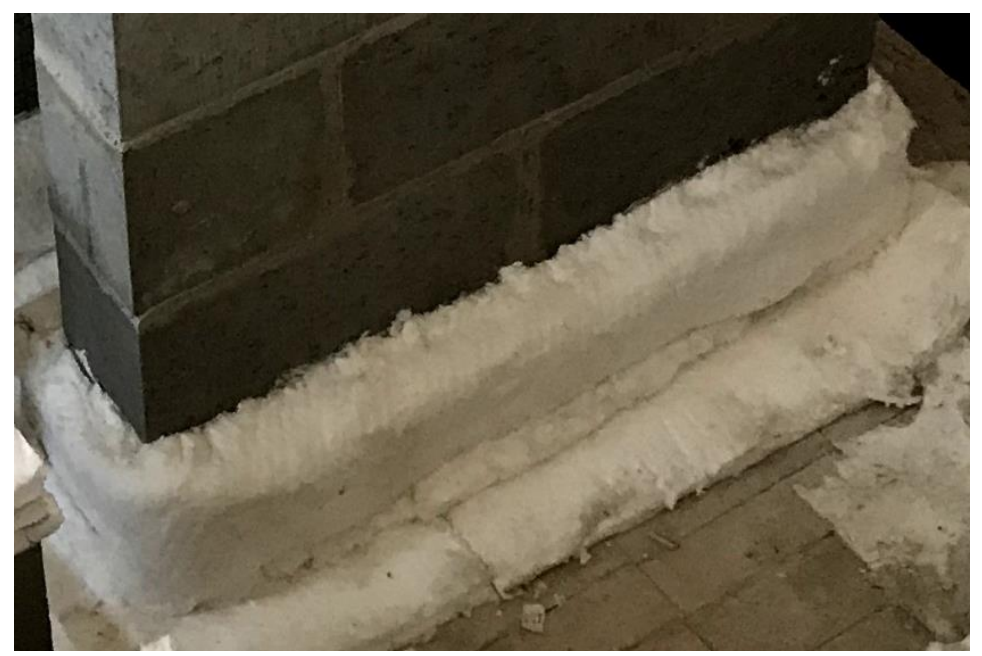

No trio de pequenas paredes, além da camada de manta isolando a base de concreto foi coloca uma camada de manta nos pontos de encontro das paredes, de maneia que a entrada de calor pelas frestas laterais fosse impedida, como mostra a Figura 4.14. Todos os elementos, inclusive o trio de paredes, foram cobertos com uma camada de manta cerâmica, uma placa de gesso e outra camada de manta cerâmica para que os gases quentes não entrassem pela parte superior dos corpos de prova, como pode ser observado na Figura 4.15. Para garantir que a movimentação de ar dentro do forno não deslocasse estas mantas superiores, foram colocados pesos com fragmentos de blocos de concreto em cima dos elementos.

Figura 4.14 - Isolamento lateral do trio de pequenas paredes com manta cerâmica

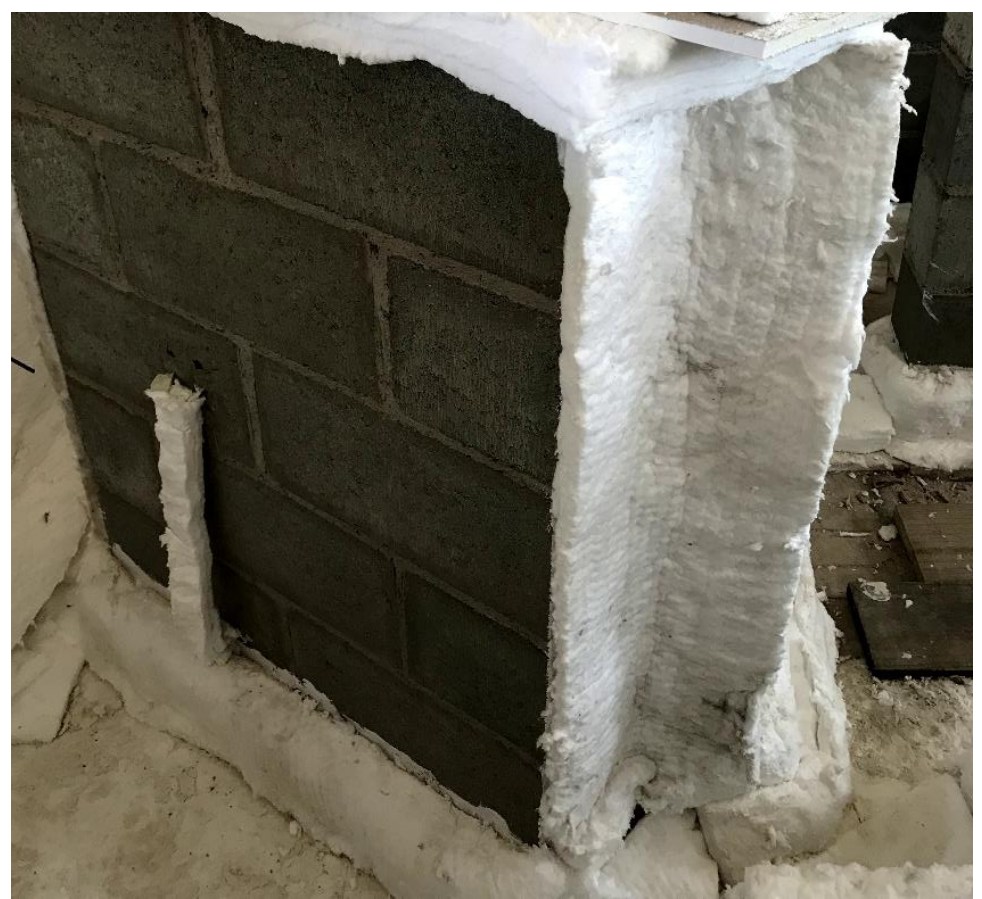


Figura 4.15 - Corpos de prova posicionados no forno para a primeira fornada

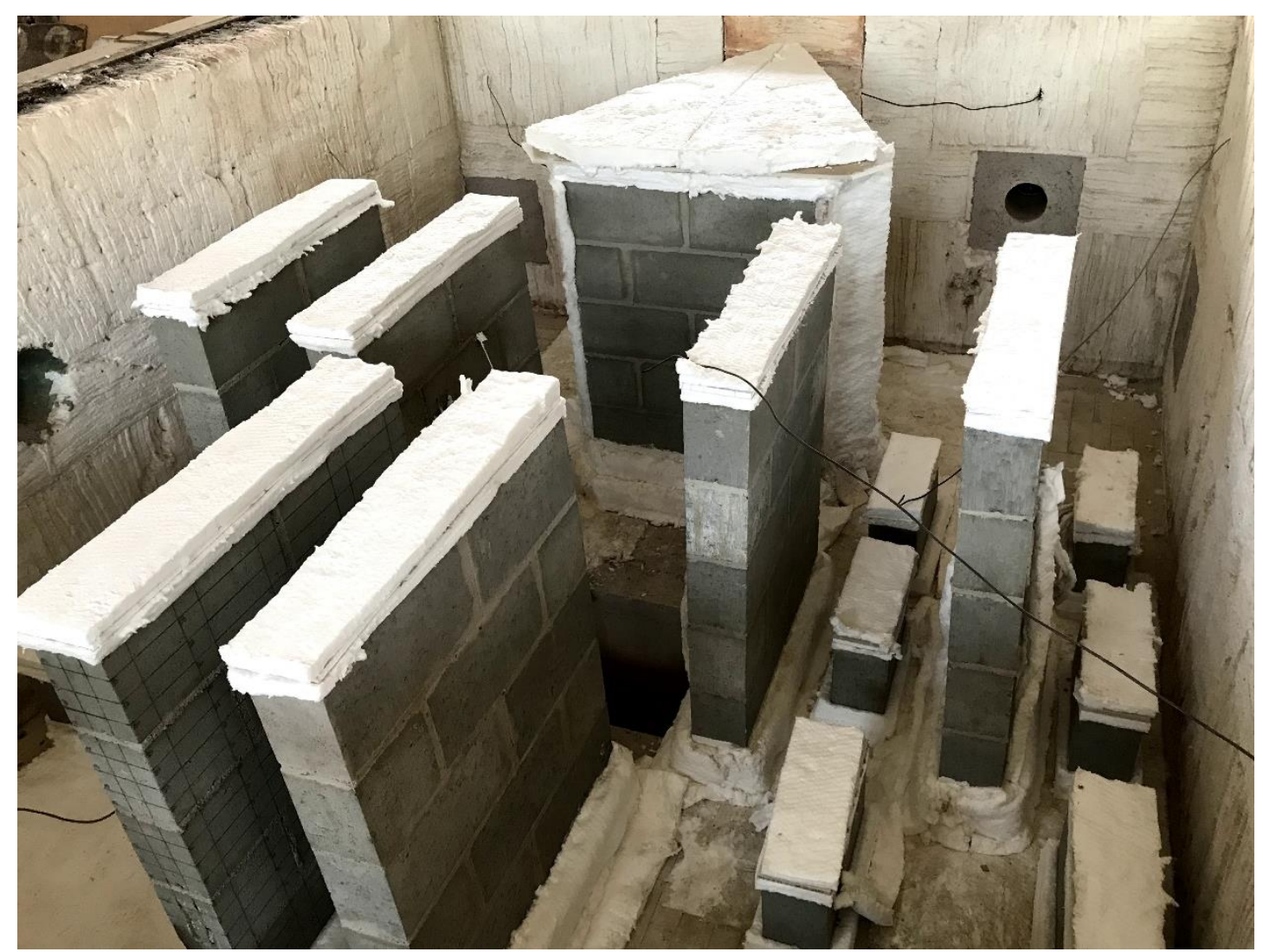

\subsubsection{Instrumentação}

Os corpos de prova foram instrumentados com termopares do tipo K, para que fossem conhecidos os níveis de temperatura atingidos pelos materiais dos elementos ao longo da seção transversal dos mesmos. Em função da quantidade limitada de entradas no sistema de aquisição de dados e trabalho dispendioso para colocação de cada termopar, nem todos os corpos de prova foram instrumentados, além disso é possível relacionar medições de blocos, prismas e paredes por serem constituídos do mesmo material e estarem submetidos ao mesmo tipo de solicitação térmica. Portanto, optou-se por instrumentar as três paredes do trio compartimentado, duas paredes de cada variação ensaiada, dois blocos de cada variação e um prisma.

Os pontos de instrumentação dentro das paredes longitudinais dos blocos e nas juntas de argamassas foram feitos através de uma furação com uma broca de $4 \mathrm{~mm}$ e, após a colocação do termopar, o furo foi preenchido com uma pasta de cimento e água. Nos pontos de medição da superfície interna das paredes longitudinais dos blocos (destacados como "face" nos desenhos e gráficos) a instrumentação foi realizada soldando-se os termopares em discos de cobre, que por sua vez foram colados nos blocos com o cimento-cola cerâmico. Como este 
termopar foi colocado com o intuito principal de avaliar o tempo de transferência de calor ao longo da seção do bloco, foi colocada uma camada fina de manta cerâmica sobre o termopar para garantir que a medição feita fosse da superfície do bloco e não dos gases circundantes. As partes expostas dos cabos termopares foram cobertas com tiras de manta cerâmica.

Os posicionamentos dos termopares, admitidos como adequado para as melhores medições de cada corpo de prova, estão dispostos na Figura 4.16 para os blocos e prismas, na Figura 4.17 para as pequenas paredes de 10,0 MPa, na Figura 4.18 para as pequenas paredes de 4,0 MPa e na Figura 4.19 para o trio de pequenas paredes. $\mathrm{O}$ trio compartimentado ainda conta com o termopar 22 colocado no seu interior para medir a temperatura dos gases internos, já os corpos de prova de argamassa não foram instrumentados pois a furação para colocação do termopar poderia comprometer seu ensaio de resistência pós fogo. Nos desenhos, os pontos em rosa indicam os termopares, juntamente com sua numeração que será relacionada com a numeração das curvas de temperatura no próximo item desta dissertação, sendo que as distâncias colocadas entre parênteses indicam a medida do espaço do termopar até a face externa da parede longitudinal do bloco.

Nesta etapa, para o Programa Experimental II, a nomenclatura de distinção dos corpos de prova adotada é de BL para blocos, PRI para prismas e Par para pequenas paredes; na sequência desta nomenclatura vem o número deste corpo de prova, que varia de 1 até 6 para blocos e prismas e de 1 a 3 para pequenas paredes. A nomenclatura também conta na sequência com a resistência nominal das unidades utilizadas no elemento e a espessura do mesmo entre parênteses. Para as pequenas paredes, a nomenclatura ainda conta com a letra "C" para as compartimentadas e a letra "N" para as expostas ao fogo em ambas as faces. Já os blocos e prismas contam com a letra $\mathrm{P}$ do final do seu nome de distinção para indicar que são elementos pós-fogo. Ou seja, a nomenclatura possui a seguinte formatação para blocos, prismas e pequenas paredes respectivamente: $\underline{B L}$ número - resistência (espessura) - P; PRI número resistência (espessura) - P; Par número - resistência (espessura) - $\mathrm{C}$ ou $\mathrm{N}$.

\section{Figura 4.16 - Instrumentação de blocos e prismas ( $1^{\mathrm{a}}$ Fornada)}
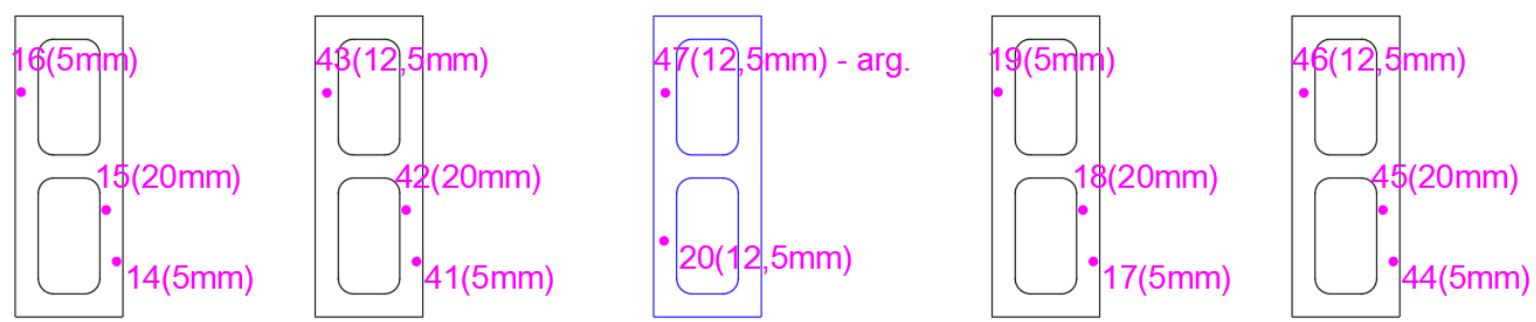

$B L 1-4,0(14)-P$

BL2-4,0(14)-P

PRI1-4,0(14)-P

BL1-10(14)-P

BL2-10(14)-P 
Figura 4.17 - Instrumentação das pequenas paredes de 10,0 MPa ( $1^{\mathrm{a}}$ Fornada)
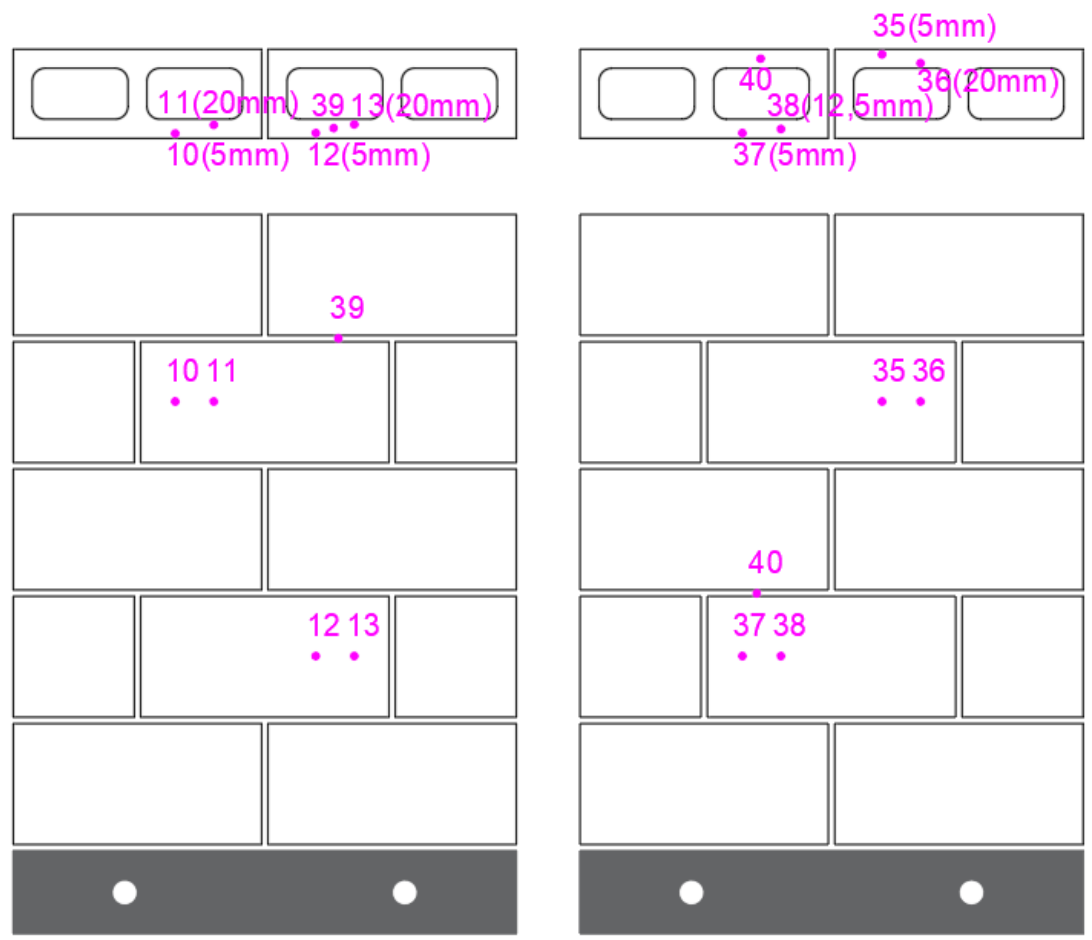

Par1-10(14)-N

Par2-10(14)-N

Figura 4.18 - Instrumentação das pequenas paredes de 4,0 $\mathrm{MPa}$ ( $1^{\mathrm{a}}$ Fornada)
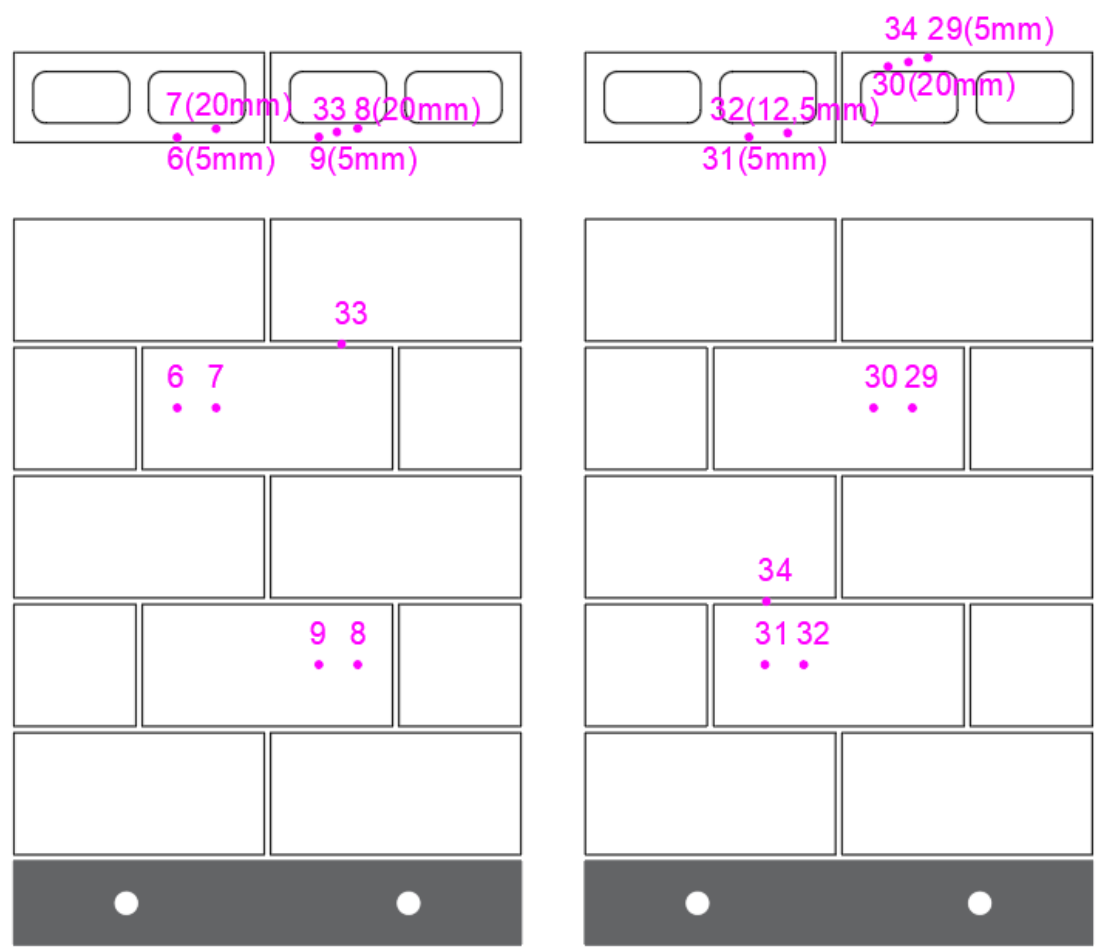

Par1-4,0(14)-N

Par2-4,0(14)-N 
Figura 4.19 - Instrumentação do trio de pequenas paredes ( $1^{a}$ Fornada)
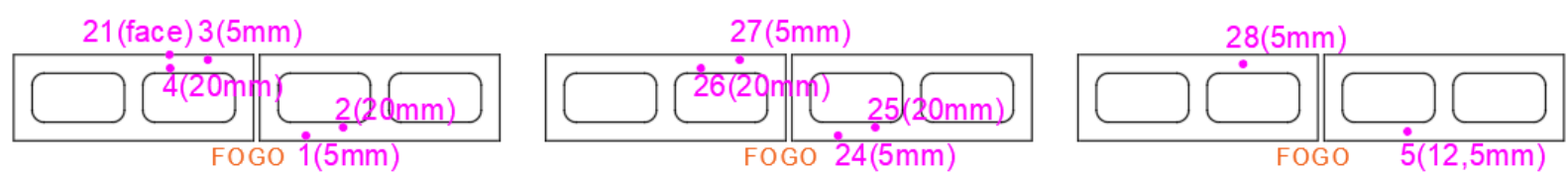

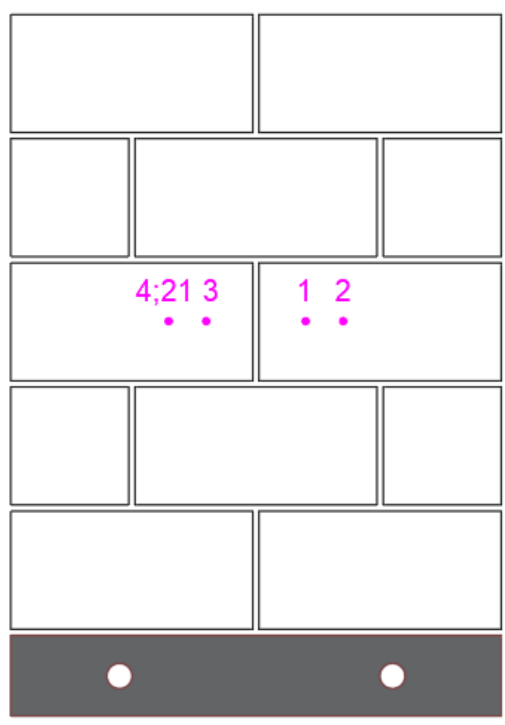

Par1-4,0(14)-C

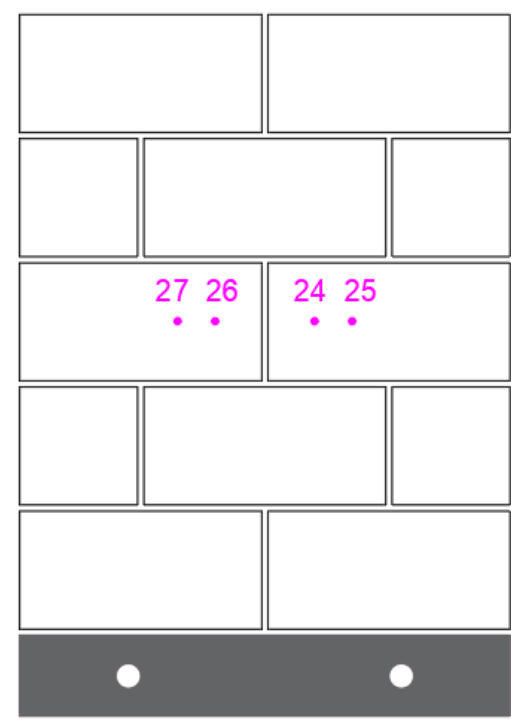

Par2-4,0(14)-C

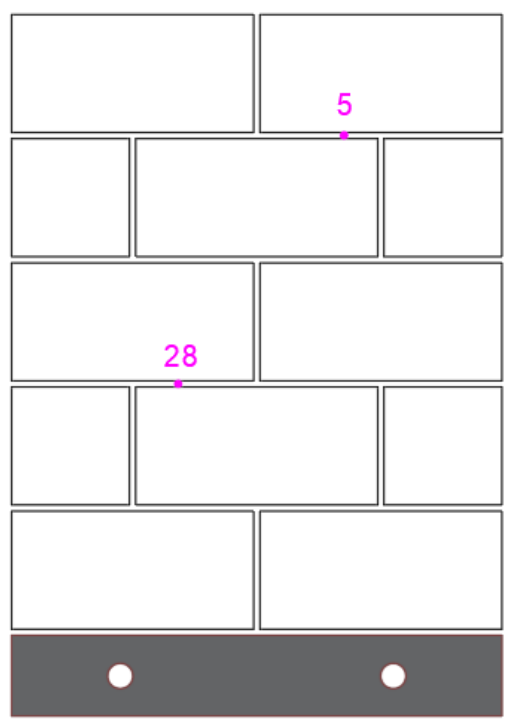

Par3-4,0(14)-C

\subsubsection{Análise térmica}

Ao analisar a resistência residual dos elementos de alvenaria estrutural de blocos de concreto após a ação do fogo, é importante conhecer o seu comportamento térmico durante e após o ensaio de simulação do incêndio-padrão, pois a capacidade resistente dos elementos ensaiados está diretamente relacionada com os níveis de temperaturas atingidos ao longo da seção transversal e com o modo de resfriamento adotado, que influenciam na microestrutura e no perfil de fissuração dos materiais. Neste caso o aquecimento seguiu a curva de incêndiopadrão da ISO 834-1:1999 e o resfriamento foi lento, dentro do forno com ventilador ligado.

Para buscar entender este comportamento térmico, os corpos de prova foram vigiados durante todo o ensaio através da escotilha de vidro presente no forno. Foi observado que após 45 minutos de ensaio começaram a surgir fissuras nas laterais das paredes com blocos de resistência nominal de 10,0 MPa. A Figura 4.20.a mostra a visão da escotilha logo após o desligamento das chamas, com o forno a aproximadamente $1000^{\circ} \mathrm{C}$ e em seu canto inferior esquerdo é possível observar uma linha mais clara (incandescente) na lateral de uma parede de 10,0 MPa. Foi tirada uma foto logo após a abertura do forno como mostra a Figura 4.20.b, na qual é possível ver nitidamente a fissura ocorrida durante o aquecimento. Nesta situação 
também é possível comparar com o estado de uma parede com blocos de 4,0 MPa (à esquerda), em que não houve surgimento desta fissura na lateral da parede.

Figura 4.20 - Situação das paredes logo após desligamento e após abertura do forno

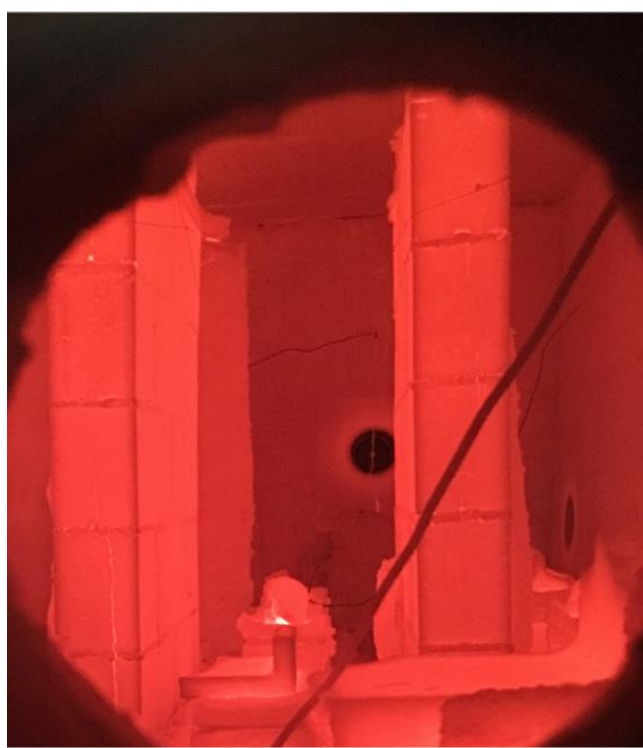

(a) após desligamento

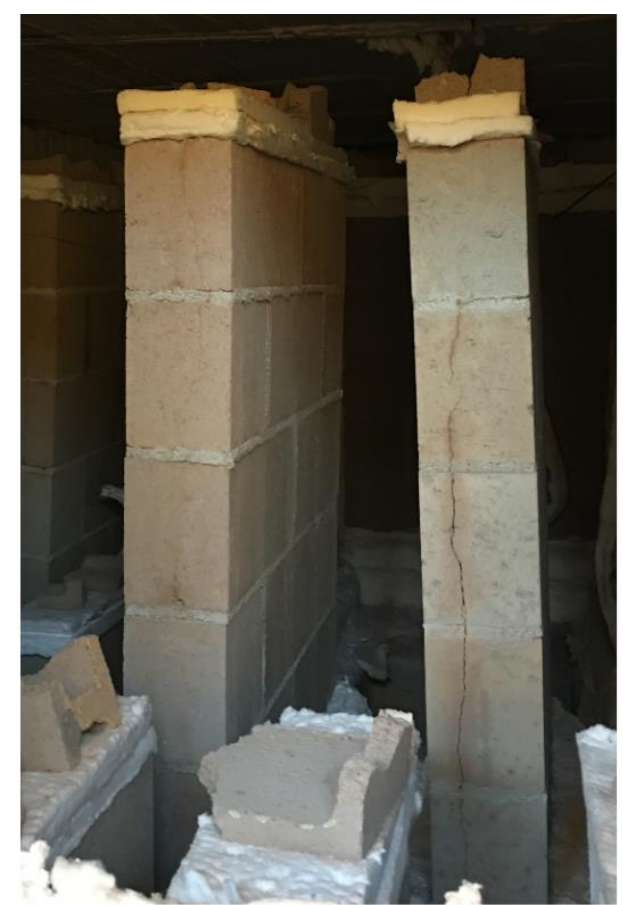

(b) após abertura

A respeito da situação do material após a ação do fogo, de maneira geral, os elementos com blocos de 10,0 MPa apresentaram o material (concreto) mais íntegro se comparados com os elementos de 4,0 MPa, visto que na maioria dos elementos de 4,0 MPa era possível esmagar as paredes dos blocos com as mãos. Nos corpos de prova de menor resistência, a superfície esfarelava com o passar dos dedos e, nos de maior resistência, a textura não era muito diferente da situação em temperatura ambiente.

No entanto, no tocante à fissuração, todos os corpos de prova com blocos de $10,0 \mathrm{MPa}$ apresentaram fissuras visíveis e bastante acentuadas, chegando a dividir em partes no caso das unidades e no caso das pequenas paredes, dando indícios de que tais fissuras comprometeriam os critérios de estanqueidade e isolamento, pois permitiram a passagem de calor e gases quentes. Vale ressaltar que os corpos de prova foram ensaiados sem carregamento e que com tensões aplicadas, como é o caso de estruturas em serviço, o comportamento das dilatações diferenciais é diferente, em função das restrições, e consequentemente o estado de fissuração pode variar.

Visualmente também foi observada uma diferença de coloração dos elementos, principalmente nos corpos de prova com blocos de 4,0 MPa que resultaram em um concreto com tons mais rosados, se comparados com sua cor em temperatura ambiente. Os elementos 
com blocos de 10,0 MPa apresentaram pouca alteração de coloração, mantendo-se mais no tom de cinza com algumas manchas rosadas, principalmente próximo das fissuras. No próximo item desta dissertação, juntamente com a descrição dos ensaios de compressão será destacada a situação de cada elemento antes da realização destes ensaios.

Os elementos foram analisados termicamente pelas medições obtidas na instrumentação com termopares, a fim de se conhecer os níveis de temperatura ao longo da seção transversal. Foram traçados gráficos com curvas de temperatura em função do tempo de ensaio de simulação do incêndio-padrão, agrupando-se as curvas de maneira a facilitar a visualização e interpretação dos resultados. A seguir estão dispostos gráficos que apresentam estas curvas juntamente com uma interpretação dos resultados, e também uma análise do trio de paredes compartimentadas relacionando os resultados obtidos com o critério de isolamento presente na ABNT NBR 10636:1989.

As legendas dos gráficos indicam as profundidades da instrumentação em relação à face dos elementos, no caso dos trios de pequenas paredes a palavra "dentro" indica que a profundidade do ponto foi medida a partir da face não exposta ao fogo, ou seja, de dentro do trio compartimentado. O número em parênteses indica a numeração do termopar correspondente à curva e que pode ser observado nos desenhos das figuras do item 4.4.2 desta dissertação.

Todas as curvas de temperatura dos termopares em função do tempo de ensaio de simulação do incêndio-padrão estão dispostas em gráficos no APÊNDICE C, onde as curvas foram separadas em função do tipo de elemento e classe de resistência ensaiados.

O gráfico da Figura 4.21 apresenta seis curvas de termopares posicionados em elementos de 10,0 MPa. As curvas dos termopares (10) e (19) referem-se às pequenas paredes e às unidades respectivamente e estão relacionadas aos pontos mais próximos à superfície exposta ao fogo, com profundidade de $5 \mathrm{~mm}$. Com distância de $20 \mathrm{~mm}$ da face exposta ao fogo, o gráfico conta com as curvas dos termopares (11) e (18) referentes às pequenas paredes e às unidades respectivamente. Por fim, as duas curvas tracejadas são referentes aos termopares (39) e (40) posicionados na argamassa das pequenas paredes a uma profundidade de 12,5 $\mathrm{mm}$.

Do gráfico é possível observar que, para uma mesma profundidade de colocação dos termopares, os resultados entre pequenas paredes e as unidades foram muito próximos, sinalizando que a distribuição de calor dentro do forno foi satisfatoriamente homogênea. E que, para conhecer apenas o comportamento térmico dos elementos expostos ao fogo em todas as faces é suficiente ensaiar as unidades, ou seja, os ensaios podem ser menos dispendiosos sem a necessidade de ensaiar corpos de prova de grandes dimensões. 
Figura 4.21 - Gráfico com curvas dos termopares dos elementos de 10,0 MPa e $140 \mathrm{~mm}$ (1 ${ }^{\mathrm{a}}$ Fornada)

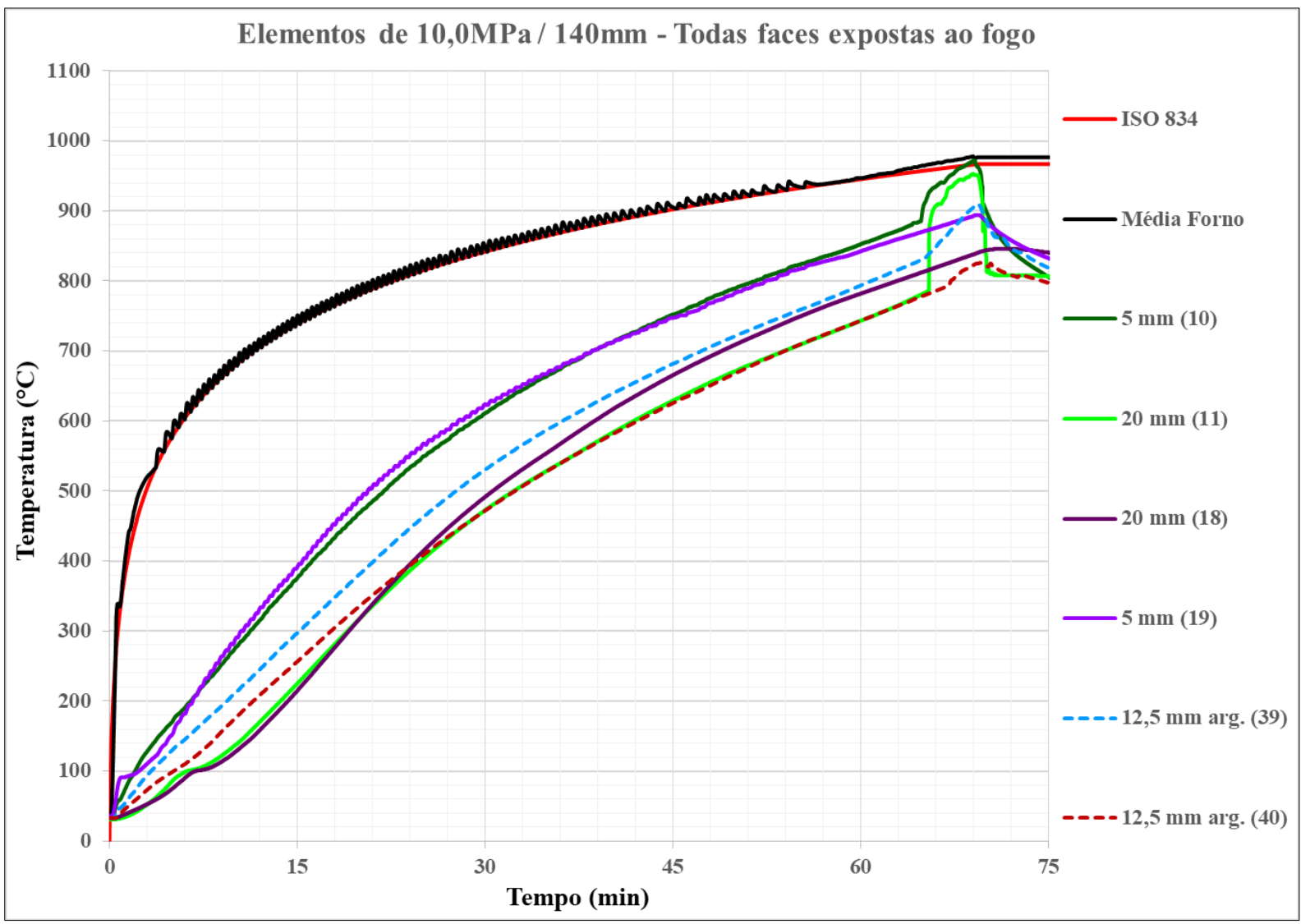

A partir dos 64 minutos de ensaio, alguns termopares começaram a perder suas medições, provavelmente por passarem a ter contato com os gases quentes do forno, o que justifica os saltos de temperatura observados. As curvas selecionadas para este gráfico foram as mais regulares de cada tipo de elemento e as mais condizentes com o comportamento esperado. Algumas curvas apresentaram resultados inconsistentes que podem ser justificados por uma profundidade efetiva diferente daquela programada na instrumentação, uma vez que é difícil controlar a profundidade de fixação do termopar.

Considerando as curvas (10) e (19), referentes aos pontos mais externos da instrumentação, verifica-se que a temperatura no concreto alcançou cerca de $880^{\circ} \mathrm{C}$ durante o ensaio de simulação de incêndio-padrão. Mesmo nos pontos mais internos de instrumentação, com profundidade de $20 \mathrm{~mm}$, foi observado que a temperatura do material ultrapassou os $800^{\circ} \mathrm{C}$, e como visto em Mehta e Monteiro (1997), para estes níveis de temperatura o concreto tem sua microestrutura alterada e a resistência residual comprometida. Como por exemplo, tem-se as recomendações da ABNT NBR 15200:2012 para projetos de estruturas de concreto em situação de incêndio que sugere, para o cálculo da resistência da estrutura, o descarte das camadas de concreto que atingiram $500^{\circ} \mathrm{C}$. 
Quanto às curvas de medição da temperatura na argamassa, termopares (39) e (40), é possível afirmar que a transferência de calor na argamassa ocorre de maneira semelhante ao bloco pois os termopares posicionados a uma profundidade de $12,5 \mathrm{~mm}$ estão com as curvas próximas e acima das curvas dos termopares de profundidade de $20 \mathrm{~mm}$ nos blocos de concreto. Os níveis de temperaturas observados nas argamassas são os mesmos do concreto, o que é capaz de comprometer a capacidade resistente do material das juntas de assentamento.

O gráfico da Figura 4.22 também apresenta seis curvas, mas de termopares posicionados em elementos de 4,0 MPa. As curvas mais acima são referentes aos termopares (14) e (29) posicionados em uma unidade e em uma pequena parede, respectivamente, com profundidade de $5 \mathrm{~mm}$. Referentes aos pontos medidos mais distantes da superfície exposta ao fogo, com profundidade de $20 \mathrm{~mm}$, tem-se as curvas dos termopares (7) e (15) que dizem respeito a uma pequena parede e uma unidade respectivamente. Tem-se também duas curvas tracejadas relacionada aos termopares (33) e (34), que foram posicionados a uma profundidade de 12,5 mm na argamassa das pequenas paredes.

Figura 4.22 - Gráfico com curvas dos termopares dos elementos de 4,0 MPa e $140 \mathrm{~mm}$ (1 ${ }^{\mathrm{a}}$ Fornada)

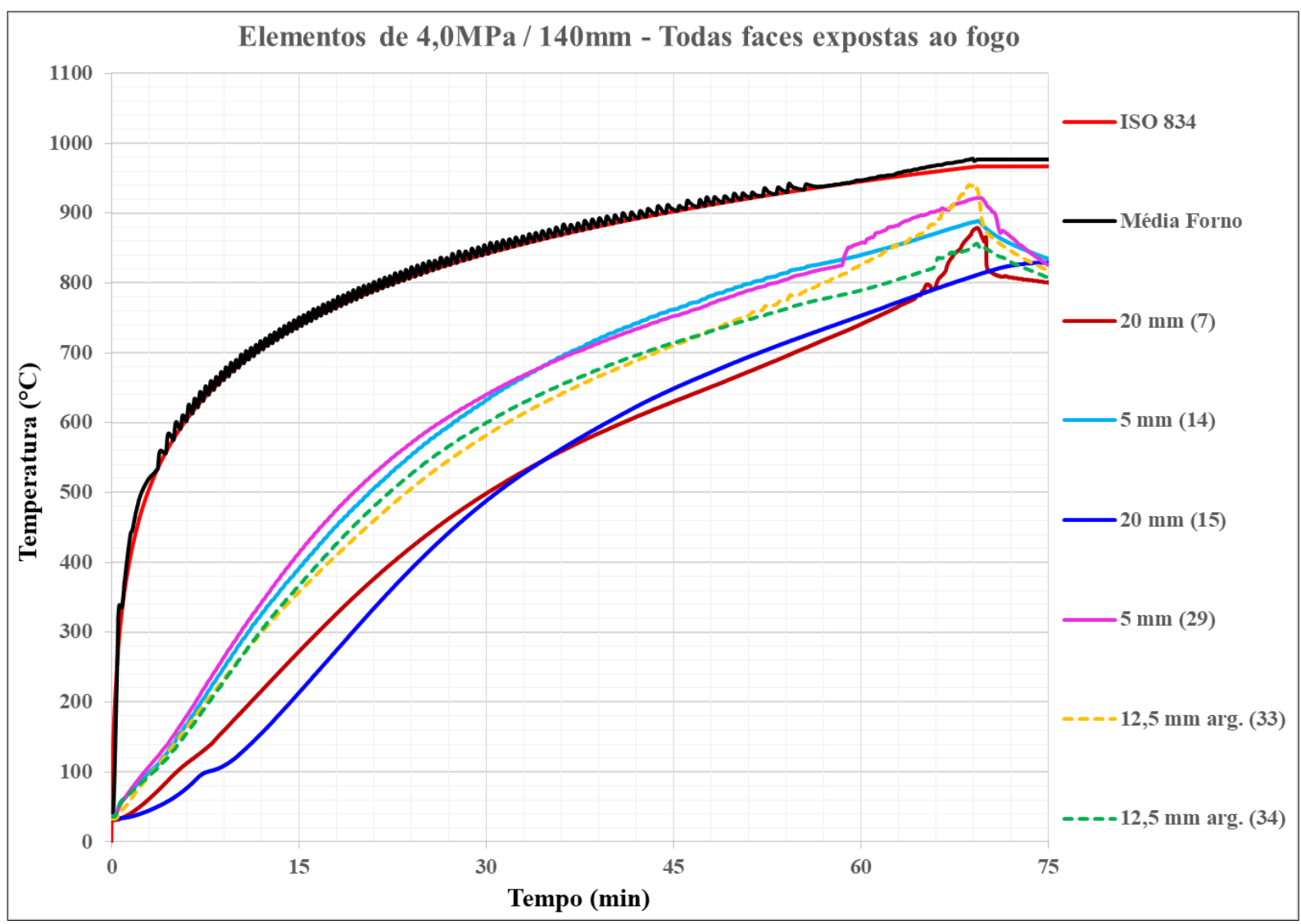


Mais uma vez foram selecionadas as curvas mais regulares de cada tipo de elemento e as mais condizentes com o comportamento esperado. Como pode ser observado, a partir dos 60 minutos algumas curvas apresentaram saltos ou crescimento mais acentuado da temperatura, o que sinaliza contato da instrumentação com os gases quentes do forno e a partir deste ponto as temperaturas registradas não retratam a realidade do comportamento térmico dos elementos durante o ensaio.

Por meio do gráfico da Figura 4.22, verifica-se também para os elementos com blocos de 4,0 MPa que considerando uma mesma profundidade de instrumentação os resultados para unidades e pequenas paredes foram semelhantes. As curvas rosa e azul claro, referentes aos termopares mais externos mostram que a temperatura no material nestes pontos chegou bem próxima dos $900^{\circ} \mathrm{C}$ e nos pontos mais internos, indicados pelas curvas azul escuro e vinho, a temperatura alcançou pouco mais de $800^{\circ} \mathrm{C}$. Nestes elementos, a resistência à compressão também foi comprometida, tendo em vista os níveis de temperatura ao longo de toda a seção transversal dos corpos de prova.

Neste gráfico ficou mais nítida a evolução intermediária da temperatura na argamassa, que foi instrumentada a uma profundidade de $12,5 \mathrm{~mm}$. O comportamento destes pontos está indicado pelas curvas tracejadas em verde e em amarelo, e mostra novamente que a transferência de calor na argamassa ocorre de maneira semelhante ao bloco e que atingiu níveis de temperatura acima $\operatorname{dos} 800^{\circ} \mathrm{C}$, comprometendo a sua resistência.

\subsubsection{Critério de isolamento - Trio de pequenas paredes compartimentadas}

O esquema com o trio de pequenas paredes compartimentadas foi elaborado com o intuito de garantir que as paredes ficassem expostas ao fogo em apenas uma face, permitindo que fosse avaliado o critério de isolamento térmico. Este esquema funcionou de forma satisfatória, ou seja, a utilização de manta cerâmica garantiu isolamento e estanqueidade nos pontos de união entre as paredes e no topo. Como pode ser observado no gráfico da Figura 4.23, existem dois conjuntos de curvas, as com temperaturas mais elevadas são todas dos pontos mais externos do trio de pequenas paredes e as curvas com temperaturas menores são de pontos do lado interno (dentro), evidenciando que durante os 70 minutos de execução da simulação e incêndio-padrão não houve entrada de gases quentes pelas frestas, o aquecimento ocorreu por condução, convecção e radiação do calor ao longo dos elementos de blocos de concreto. 
Figura 4.23 - Gráfico das curvas de temperatura em função do tempo para o trio de pequenas paredes compartimentado

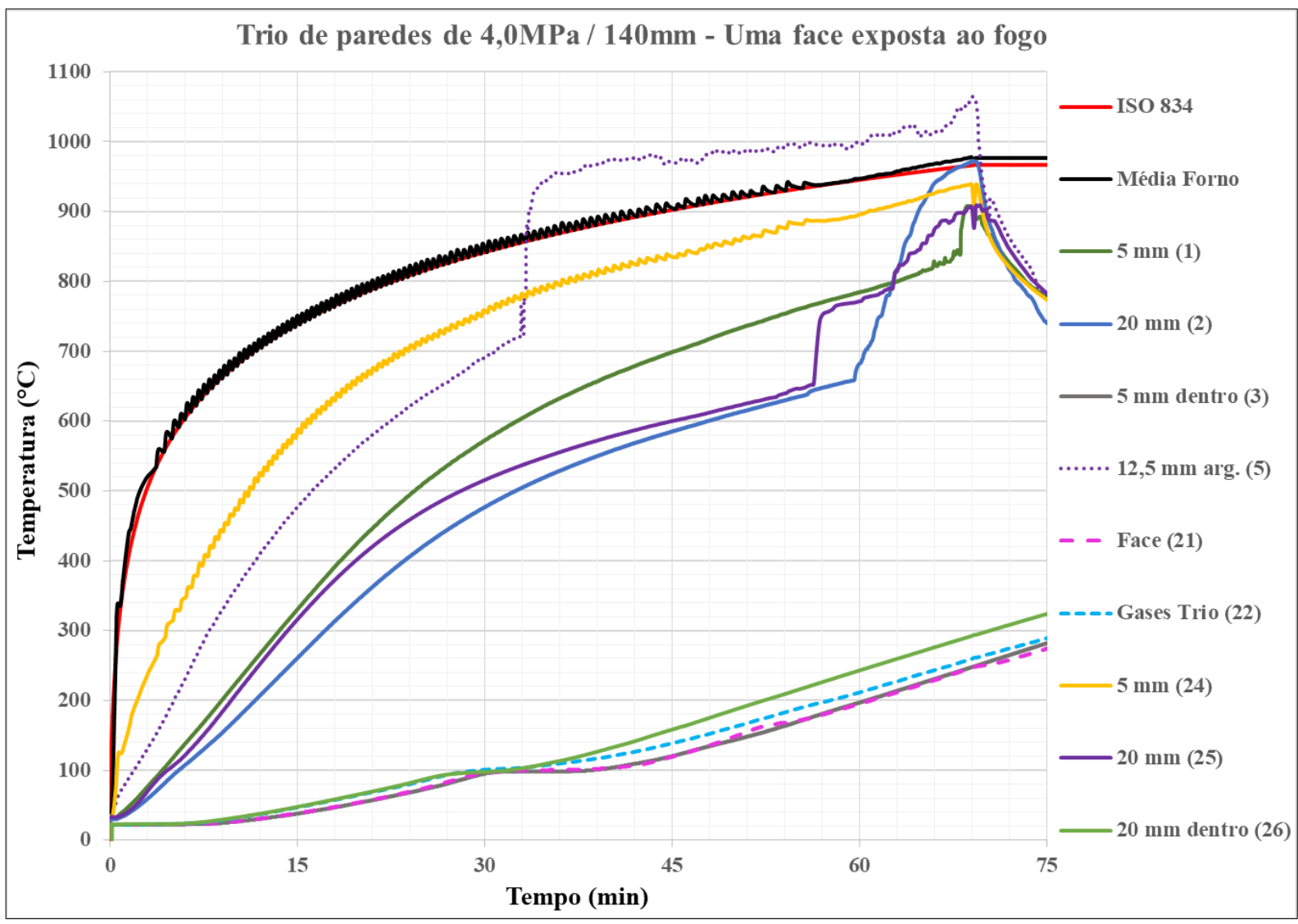

De acordo com a ABNT NBR 10636:1989 pelo critério de isolamento térmico, o corpo de prova não é considerado satisfatório como isolante térmico se a temperatura média dos pontos de medição na superfície indicar um aumento superior a $140^{\circ} \mathrm{C}$, ou se houver em qualquer termopar um aumento superior a $180^{\circ} \mathrm{C}$. A norma propõe para ensaio de paredes pelo menos 5 termopares que vão indicar a média do aumento de temperatura, sendo dispostos um em cada quadrante do corpo de prova e responsável por medir uma área de no máximo $1 \mathrm{~m}^{2}$, mas como este é um ensaio de pequena parede com área de $0,80 \mathrm{~m}^{2}$ foi adotado apenas um termopar na face não exposta ao fogo. Sendo assim, para o critério de isolamento térmico adotou-se como limitante a restrição do aumento máximo de $180^{\circ} \mathrm{C}$ neste termopar.

Considerando que a temperatura ambiente dos corpos de prova de blocos de concreto era de $25^{\circ} \mathrm{C}$ o critério de isolamento térmico deix ou de ser garantido quando o termopar na face não exposta atingiu os $205^{\circ} \mathrm{C}$. Este termopar é o de número (21) e indicado no gráfico pela curva tracejada na cor magenta. Observou-se que para as pequenas paredes com blocos de 4,0 MPa e $140 \mathrm{~mm}$ o critério de isolamento térmico foi atingido aos 62 minutos. Nesta situação o tempo de resistência ao fogo (TRF) seria considerado de 61 minutos, que de acordo com a 
tabela de TRRF da ABNT NBR14432:2001, seria suficiente para atender ao requerido para uma edificação de até 23 metros de altura, não atendendo o TRRF máximo de 120 minutos.

É importante destacar que esta foi uma adaptação realizada no forno horizontal com o intuito de avaliar o critério de isolamento e o perfil de temperatura ao longo da seção transversal de uma parede compartimentada. Nesta situação, a face não exposta ao fogo não realiza trocas de calor com o ambiente, que é uma situação mais crítica do que aquela que ocorre nos ensaios de paredes em forno verticais. Mas como mostra o trabalho de Lopes et al. (2018), em que os ensaios foram realizados com fogo em apenas uma face, aplicação de carregamentos e blocos de concreto (com geometria diferente da utilizada nestes ensaios), os tempos para atingir o critério de isolamento variaram entre 67 e 72 minutos.

Do gráfico da Figura 4.23 também é possível analisar que nos pontos de instrumentação mais internos, indicados pelo conjunto de curvas mais abaixo do gráfico, ocorreu o patamar de temperatura aos $100^{\circ} \mathrm{C}$ que caracteriza a energia absorvida para a evaporação da água presente nos poros dos blocos de concreto. Nas curvas dos pontos a $20 \mathrm{~mm}$ da face exposta ao fogo também é possível observar uma pequena oscilação aos $100^{\circ} \mathrm{C}$, sendo que o patamar é menos nítido pois quanto mais externo o ponto, mais acentuada é a ação da temperatura e menor é o tempo que a água leva para evaporar.

Os saltos de temperatura apresentados em algumas curvas indicam que, a partir de certo tempo, o termopar passou a ter contato com os gases quentes, e as medidas devem ser consideradas somente até esses pontos. A curva em amarelo do termopar (24) mostrou-se muito oscilatória, o que também indica forte influência dos gases externos que oscilam com o ligar e desligar das chamas do forno, algo normal de acontecer considerando que a profundidade do termopar é de apenas $5 \mathrm{~mm}$ e se trata de uma instrumentação de difícil trabalhabilidade. Portanto, para a profundidade de $5 \mathrm{~mm}$ considerou-se como mais confiável a curva em verde do termopar (1), que foi mais consistente, se comparado com curvas de termopares de mesma profundidade das pequenas paredes e unidades de 4,0 MPa expostas ao fogo em todas as faces.

Considerando até o tempo de 60 minutos é possível observar que as temperaturas no concreto nas paredes longitudinais dos blocos na face exposta ao fogo chegaram no ponto mais externo a $780^{\circ} \mathrm{C}$ e a uma profundidade de $20 \mathrm{~mm}$ na temperatura de $670^{\circ} \mathrm{C}$. Considerando a recomendação da ABNT NBR 15200:2012 para descartar no cálculo da resistência as camadas de concreto que atingiram $500^{\circ} \mathrm{C}$, pode-se afirmar que o concreto da face exposta destas pequenas paredes teve sua resistência à compressão seriamente comprometida.

$\mathrm{Na}$ face não exposta, as temperaturas no material atingiram apenas $300^{\circ} \mathrm{C}$ até os 70 minutos de exposição ao fogo, mas continuaram a aquecer mesmo sem ação do fogo, até 
equilibrar com a temperatura de todo o conjunto, como mostra a Figura 4.24. Nesta face interna a temperatura chegou a $450^{\circ} \mathrm{C}$, o que mostra também certo comprometimento da capacidade resistente do concreto. Típico de ambiente compartimentados, na fase do resfriamento a temperatura no interior do trio se manteve superior à temperatura externa, pois, assim como no aquecimento o isolamento oferece resistência à entrada de calor, no resfriamento ele oferece resistência à saída do mesmo.

Figura 4.24 - Gráfico do comportamento do trio de pequenas paredes compartimentados até os 300 minutos

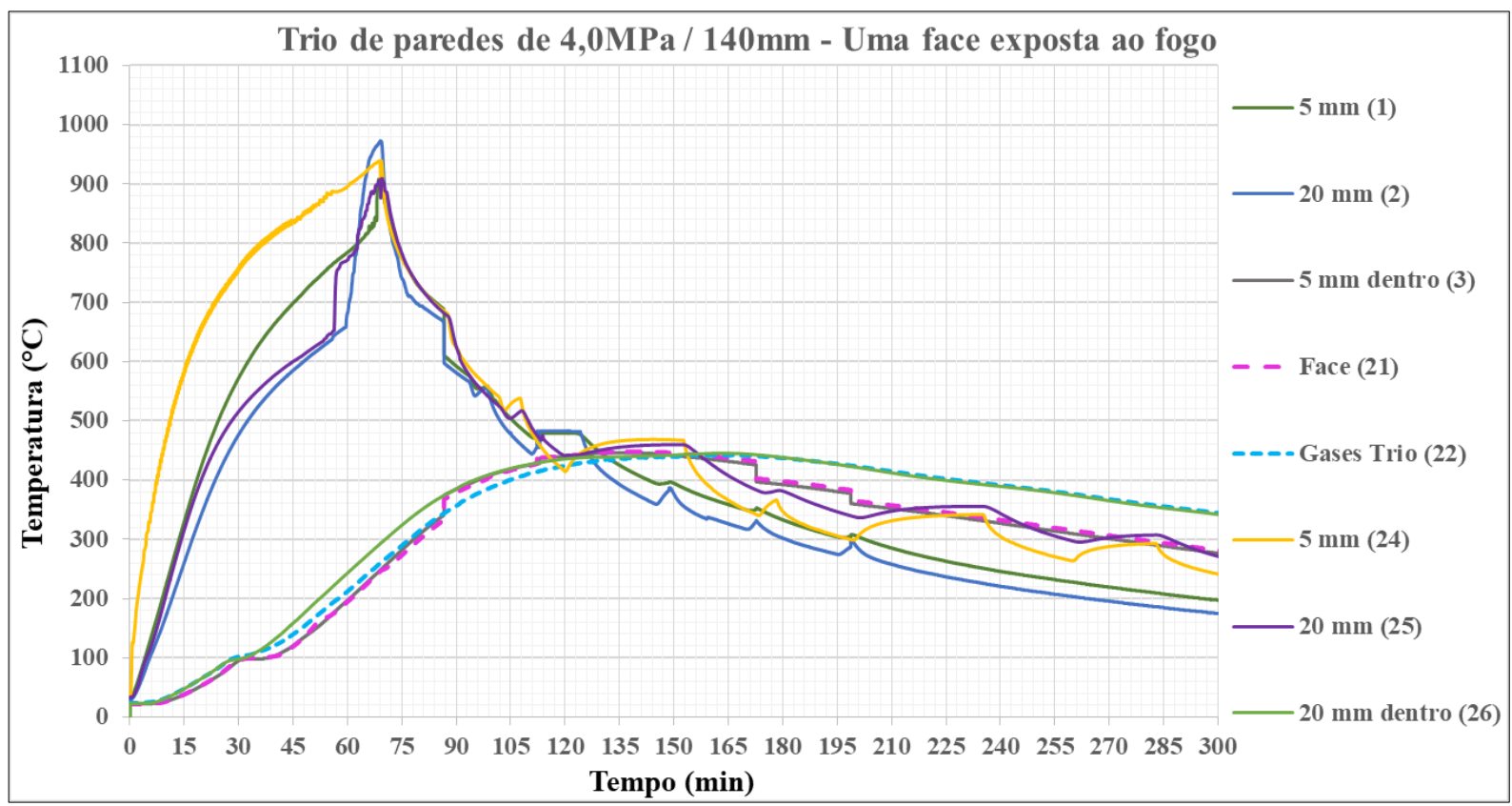

\subsubsection{Compressão após resfriamento lento}

Os ensaios de compressão simples foram realizados 7 dias após a execução do ensaio de simulação do incêndio-padrão. Nesse período os corpos de prova foram resfriados lentamente, adotando o seguinte procedimento: o ventilador do forno ficou ligado para circular o ar interno até que a temperatura dos gases internos atingisse $60^{\circ} \mathrm{C}$ (aproximadamente 9 horas); após o desligamento do ventilador, as portas laterais do forno foram abertas e somente 24 horas após a execução do ensaio é que a tampa superior do forno foi retirada. Os corpos de prova foram mantidos em temperatura e umidade ambientes, protegidos de sol e chuva dentro do barracão do Laboratório de Estruturas, até o instante do ensaio de compressão.

Para garantir que a situação pós fogo das lajes de concreto utilizadas para transportar as pequenas paredes não comprometesse o ensaio de compressão destes elementos, as lajes foram protegidas com manta cerâmica e foi colocado um termopar para avaliar a eficiência deste 
isolamento. As medidas de temperatura na laje de concreto não ultrapassaram os $300^{\circ} \mathrm{C}$ o que garante menor perda de resistência das lajes se comparada com os elementos ensaiados.

Nesta etapa os procedimentos de execução dos ensaios de compressão foram realizados seguindo as mesmas prescrições dos ensaios de compressão simples para caracterização dos blocos, da argamassa e da alvenaria em temperatura ambiente. A seguir tem-se uma descrição dos ensaios para cada um dos tipos de elementos ensaios nesta primeira fornada, juntamente com os resultados obtidos de resistência residual à compressão.

\subsubsection{Argamassa}

Os corpos de prova de argamassa foram muito degradados pela ação térmica, e com 24 horas de resfriamento foi observado que a argamassa apresentava uma textura capaz de esfarelar com o passar dos dedos e, ao aplicar um mínimo de pressão com as mãos, os corpos de prova iam à ruína. Concluiu-se sobre a impossibilidade de ensaiar as argamassas à compressão pois apresentavam resistência praticamente nula. Aos 7 dias, a argamassa sofreu reidratação com a umidade ambiente, o que provocou aumento das fissuras que surgiram com a ação térmica, aumentando a fragilidade dos corpos de prova; com esta idade de resfriamento, uma simples movimentação era capaz de danificá-los, constatando mais uma vez a impossibilidade de ensaiá-los à compressão. A Figura 4.25 mostra no item (a) a situação da argamassa 24 horas após a simulação de incêndio-padrão e no item (b) a situação com 7 dias pós-fogo, em que é possível observar as fissuras.

Figura 4.25 - Situação dos corpos de prova de argamassa pós-fogo

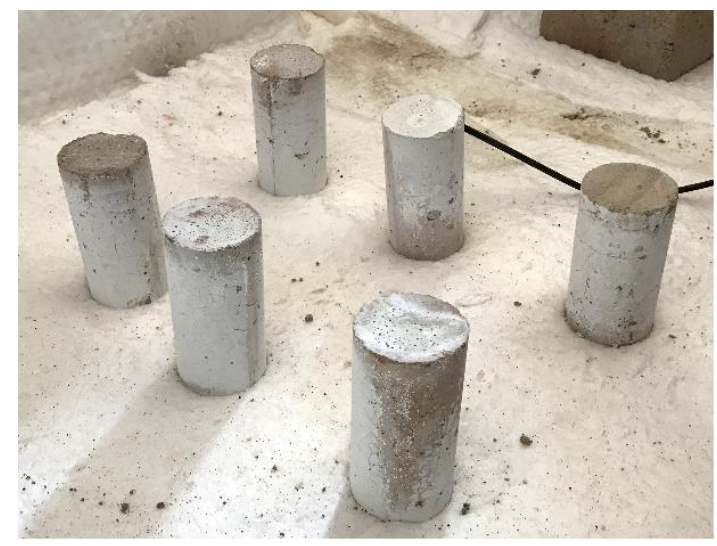

(a) 24 horas

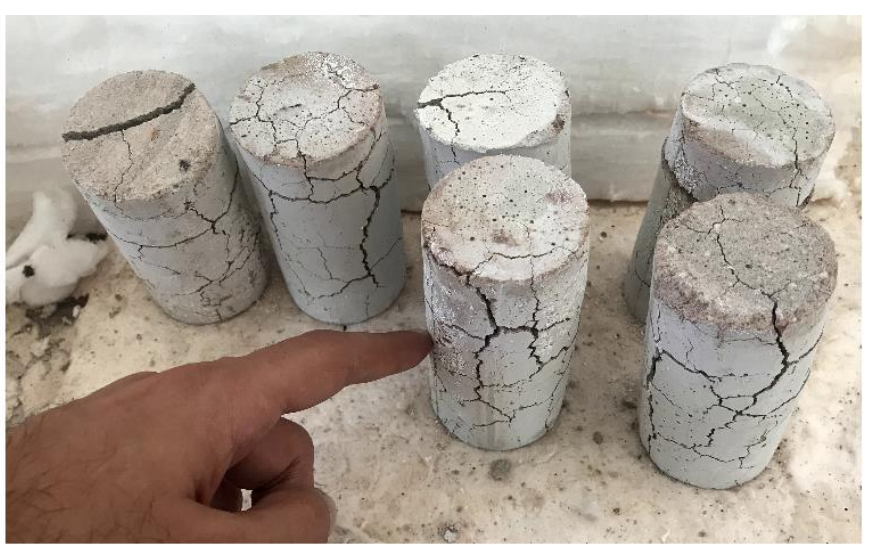

(b) 7 dias 


\subsubsection{Blocos}

O ensaio de compressão pós-fogo dos blocos foi realizado na máquina ELE do Laboratório de Estruturas com controle de carga a uma velocidade de 2,4 kN/s. Tal como utilizado anteriormente, o capeamento foi substituído por placas de forro de fibra mineral, porém neste caso não foram adotados ciclos para escorvamento pois a aplicação de uma tensão prévia poderia comprometer o ensaio de compressão dos blocos, uma vez que não era possível estimar a carga de ruptura dos blocos. A Figura 4.26 mostra como foi realizado este ensaio.

Figura 4.26 - Ensaio de compressão pós-fogo dos blocos

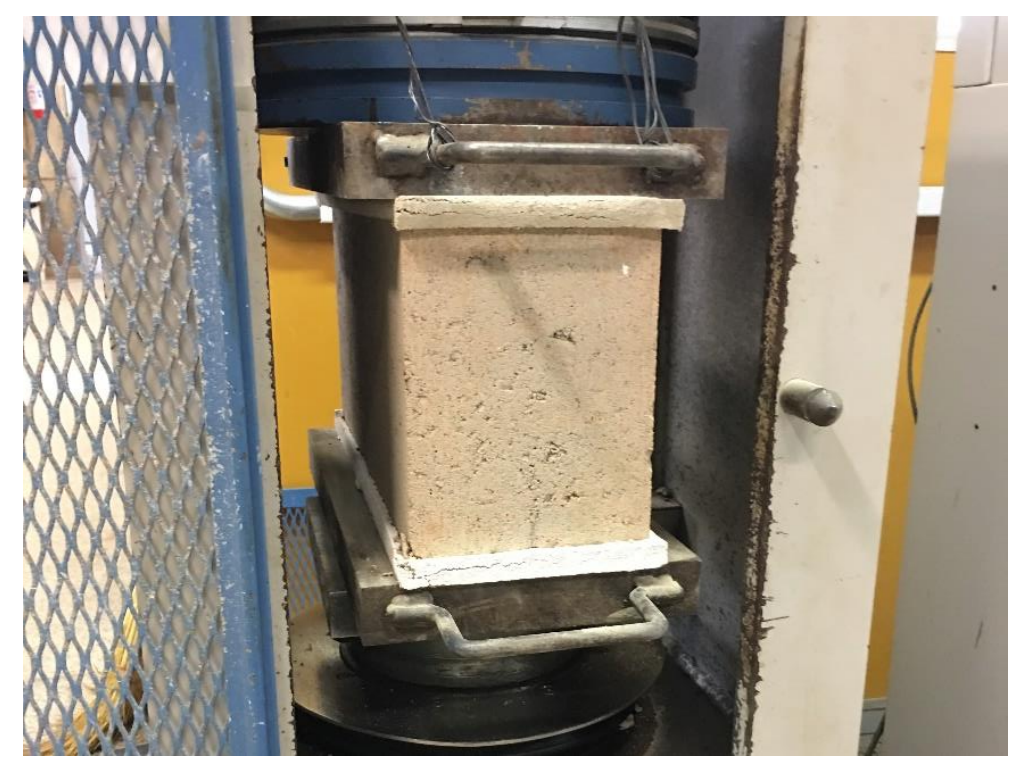

Com as forças de ruptura obtidas, foram calculadas as resistências à compressão dos blocos na área bruta. Os valores de resistência média e característica estão apresentados na Tabela 4.3. Os resultados individuais estão apresentados no APÊNDICE C, e a resistência característica foi calculada de acordo com procedimento estabelecido pela ABNT NBR 16522:2016 e apresentado no APÊNDICE E.

É possível observar que para uma ação térmica de 70 minutos seguindo a curva de incêndio-padrão foi capaz de reduzir drasticamente a resistência à compressão dos blocos de concreto para alvenaria estrutural. As resistências residuais médias encontradas foram de $20 \%$ para os blocos com resistência nominal de 10,0 MPa e de 27\% para os blocos de 4,0 MPa, ou seja, esta redução foi mais severa para os blocos de maior resistência. Mas vale lembrar que estes blocos com espessura de $140 \mathrm{~mm}$ e resistência de 10,0 MPa apresentaram resistência média efetiva de mais que o dobro da resistência nominal. 
Tabela 4.3 - Resistência à compressão pós-fogo dos blocos ( $1^{\mathrm{a}}$ Fornada $)$

\begin{tabular}{|c|c|c|c|c|c|c|}
\hline \multicolumn{7}{|c|}{ Resistência à compressão pós-fogo } \\
\hline \multicolumn{2}{|c|}{ Tipo de unidade } & & \multicolumn{4}{|c|}{ Blocos * } \\
\hline $\begin{array}{c}\text { Resistência } \\
\text { característica } \\
\text { nominal } \\
\end{array}$ & $\begin{array}{l}\text { Largura } \\
\text { nominal }\end{array}$ & & $\begin{array}{c}\text { Resistência } \\
\text { média temp. } \\
\text { ambiente }(\mathrm{kN}) \\
\end{array}$ & Força $(\mathrm{kN})$ & $\begin{array}{c}\text { Tensão na área } \\
\text { bruta (MPa) }\end{array}$ & $\begin{array}{c}F_{\text {fogo }} / F_{a m b} \\
\text { (Resistência } \\
\text { residual) } \\
\end{array}$ \\
\hline \multirow{4}{*}{$10,0 \mathrm{MPa}$} & \multirow{4}{*}{$\begin{array}{l}140 \\
\mathrm{~mm}\end{array}$} & Média & \multirow{4}{*}{1197,77} & 242,34 & 4,46 & \multirow{4}{*}{$20 \%$} \\
\hline & & Desvio Padrão & & 41,89 & 0,77 & \\
\hline & & $\mathrm{CV}(\%)$ & & 17,28 & 17,28 & \\
\hline & & $f_{\mathrm{bk}}(\mathbf{M P a})$ & & & 2,88 & \\
\hline \multirow{4}{*}{ 4,0 MPa } & \multirow{4}{*}{$\begin{array}{l}140 \\
\mathrm{~mm}\end{array}$} & Média & \multirow{4}{*}{404,23} & 108,72 & 2,00 & \multirow{4}{*}{$27 \%$} \\
\hline & & Desvio Padrão & & 21,38 & 0,39 & \\
\hline & & $\mathrm{CV}(\%)$ & & 19,67 & 19,67 & \\
\hline & & $f_{\mathrm{bk}}(\mathrm{MPa})$ & & & $\mathbf{1 , 5 9}$ & \\
\hline
\end{tabular}

* Blocos expostos ao incêndio padrão da ISO 834-1:1999 durante 70 min em todas as faces

A situação dos blocos no momento do ensaio de compressão pós-fogo está mostrada na Figura 4.27. Os blocos de 4,0 MPa, apesar de apresentarem fissuras menores e em menor quantidade, tinham o seu concreto bastante degradado pela ação térmica, sendo capaz de esfarelar sua superfície com o passar dos dedos e necessitando de muito cuidado no manuseio pois uma compressão lateral era capaz de esmagar o concreto dos blocos.

Já os blocos de 10,0 MPa resultaram com o concreto mais integro e com superfície mais rígida, no entanto as fissuras que surgiram foram grandes e capazes de separar os blocos em partes. Ou seja, ficou visível que a resistência residual dos blocos de 4,0 MPa foi comprometida principalmente pela degradação do material e nos blocos de 10,0 MPa este comprometimento se deu pela fratura do concreto. Tanto que o modo de ruptura dos blocos foi predominantemente de esmagamento do material para os blocos de menor resistência e de abertura das trincas préexistentes e surgimentos de novas nos blocos com resistência nominal maior.

Figura 4.27 - Situação dos blocos pós-fogo ( $1^{\mathrm{a}}$ fornada $)$

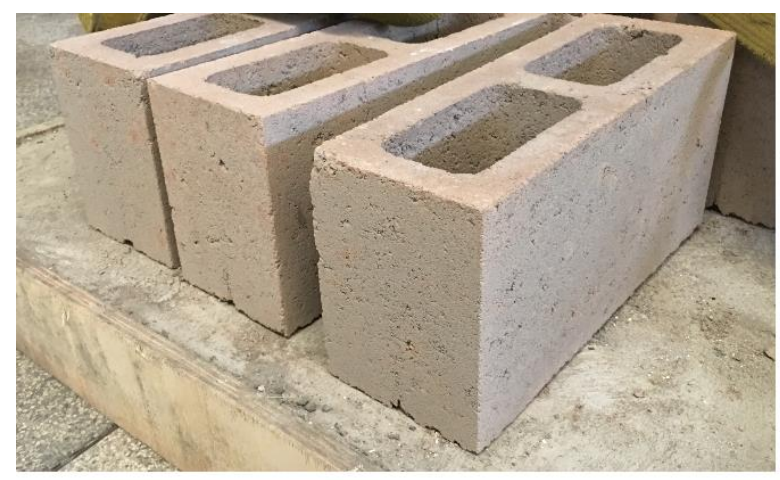

(a) bloco de 4,0 MPa

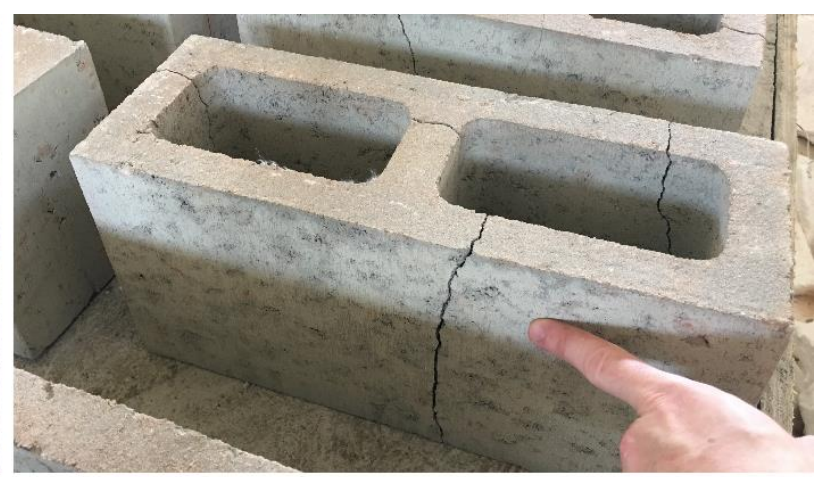

(b) bloco de 10,0 MPa 


\subsubsection{Prismas}

Os prismas submetidos à ação térmica nesta primeira fornada foram apenas os de 4,0 MPa. Assim como nos blocos, foi observado que os materiais, tanto do bloco como da argamassa, saíram bastante deteriorados, com a superfície esfarelando ao passar os dedos e com resistência nitidamente comprometida. Estes prismas foram submetidos ao ensaio de compressão simples de acordo com os procedimentos prescritos na ABNT NBR 15961:2011, foi utilizada uma máquina servo-hidráulica universal da marca Instron. A velocidade de aplicação do carregamento uniformemente distribuído com controle de deslocamentos foi de $0,02 \mathrm{~mm} / \mathrm{s}$, mantendo as mesmas condições dos ensaios de caracterização em temperatura ambiente.

Assim como em todos os ensaios de compressão dos elementos de alvenaria estrutural realizados nesta pesquisa, o capeamento foi substituído pelo forro de fibra mineral, no entanto, em função da condição deteriorada dos prismas não foram aplicados os ciclos com carga reduzida para escorvamento e acomodação do forro. Os resultados médios de força resistente estão dispostos na Tabela 4.4 juntamente com a tensão calculada na área bruta e a porcentagem média de resistência residual. Os resultados individuais estão apresentados no APÊNDICE C, e a resistência característica foi calculada de acordo com procedimento estabelecido pela ABNT NBR 16522:2016 e apresentado no APÊNDICE E.

Tabela 4.4 - Resistência à compressão pós-fogo dos prismas ( $\left(1^{\mathrm{a}}\right.$ Fornada $)$

\begin{tabular}{|c|c|c|c|c|c|c|}
\hline \multicolumn{7}{|c|}{ Resistência à compressão pós-fogo } \\
\hline \multicolumn{2}{|c|}{ Tipo de unidade } & & \multicolumn{4}{|c|}{ Prismas * } \\
\hline $\begin{array}{c}\text { Resistência } \\
\text { característica } \\
\text { nominal }\end{array}$ & $\begin{array}{l}\text { Largura } \\
\text { nominal }\end{array}$ & & $\begin{array}{c}\text { Resistência } \\
\text { média temp. } \\
\text { ambiente }(\mathrm{kN})\end{array}$ & Força $(\mathrm{kN})$ & $\begin{array}{c}\text { Tensão na área } \\
\text { bruta (MPa) }\end{array}$ & $\begin{array}{c}F_{\text {fogo }} / F_{a m b} \\
\text { (Resistência } \\
\text { residual) }\end{array}$ \\
\hline \multirow{4}{*}{ 4,0 MPa } & \multirow{4}{*}{$\begin{array}{l}140 \\
\mathrm{~mm}\end{array}$} & Média & \multirow{4}{*}{369,36} & 52,84 & 1,43 & \multirow{4}{*}{$14 \%$} \\
\hline & & Desvio Padrão & & 12,44 & 0,34 & \\
\hline & & $\mathrm{CV}(\%)$ & & 23,54 & 23,54 & \\
\hline & & $f_{\mathrm{pk}}(\mathrm{MPa})$ & & & $\mathbf{0 , 9 3}$ & \\
\hline
\end{tabular}

* Pris mas expostos ao incêndio padrão da ISO 834-1:1999 durante 70 min em todas as faces

Foi observado que a redução da resistência em função do fogo foi ainda maior para os prismas que para os blocos, resultando em apenas 14\% para a simulação de incêndio-padrão de 70 minutos. Tal diferença pode ser justificada pela influência da argamassa na resistência à compressão dos prismas, visto que este material é severamente danificado pela ação do fogo, como foi observado no item 4.4.4.1 desta dissertação. Como o coeficiente de variação da 
resistência à compressão dos prismas pós-fogo resultou relativamente alto $(23,54 \%)$, foi realizado o teste estatístico de Grubbs com o intuito de verificar a possível presença de valores espúrios na amostra. O procedimento deste teste está descrito no APÊNDICE D e como resultou na inexistência de tais valores, mantiveram-se os resultados obtidos.

O modo de ruptura dos prismas não seguiu um padrão nítido em todos os elementos, sendo que alguns apresentaram trincas nas faces longitudinais e outros nas laterais. Mas foi possível observar que a maioria deles apresentou rompimento por esmagamento do material, havendo eventuais desprendimentos de parte dos blocos nas quinas e principalmente próximos da argamassa que também apresentou esmagamentos localizados na maioria dos casos. A Figura 4.28 mostra um exemplo de ruptura dos primas pós-fogo.

Figura 4.28 - Ruptura dos prismas após ação do fogo ( $1^{\text {a }}$ fornada $)$
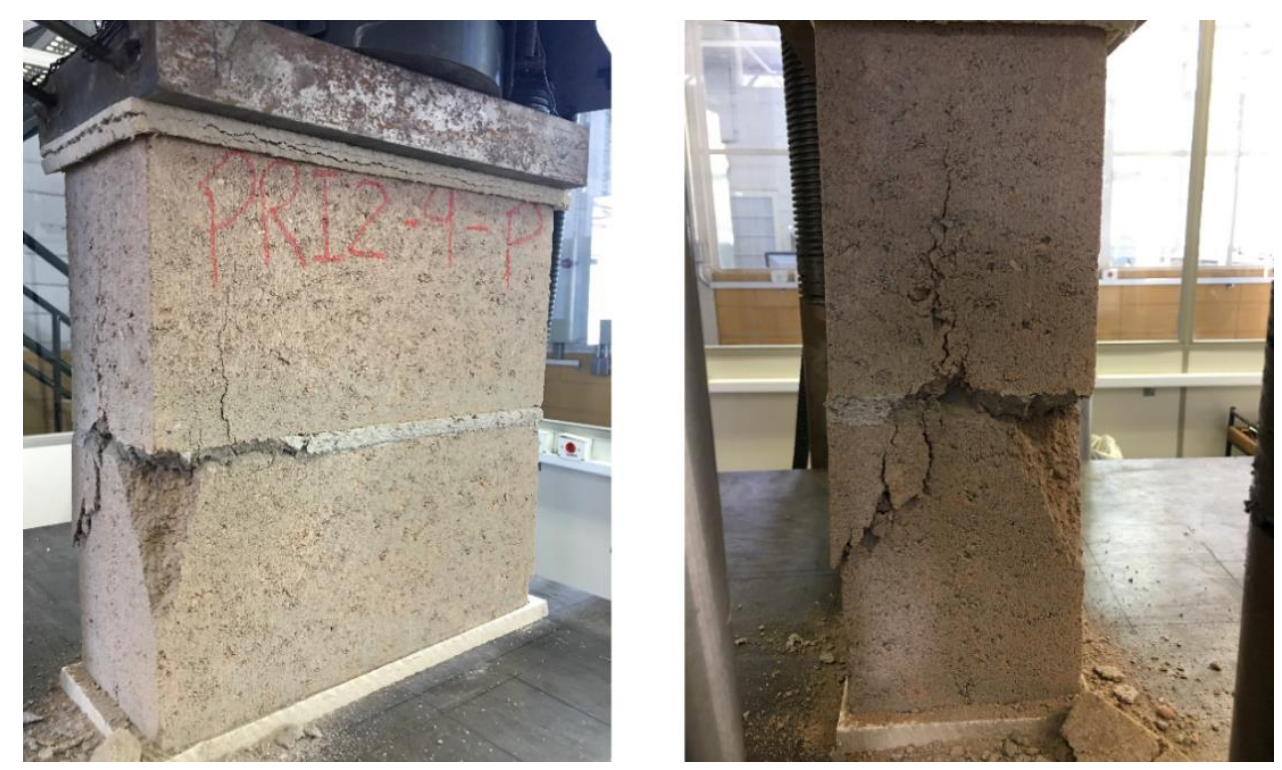

\subsubsection{Pequenas paredes}

As pequenas paredes foram submetidas ao ensaio de compressão simples de acordo com os procedimentos prescritos na ABNT NBR 15961:2011, na máquina servo-hidráulica universal da marca Instron, com controle de deslocamento a uma velocidade de $0,01 \mathrm{~mm} / \mathrm{s}$. Para as pequenas paredes o capeamento também foi substituído pelo forro de fibra mineral, no entanto, em função da condição deteriorada dos corpos de prova não foram aplicados os ciclos com carga reduzida para escorvamento e acomodação do forro.

Mais uma vez foi observada a degradação dos materiais em função da ação térmica. Nas paredes com blocos de 4,0 MPa, de forma semelhante aos blocos e prismas, o material mostrouse com dureza reduzida, esfarelando com o passar dos dedos, mas com intensidade menos 
severa que nos outros dois tipos de elementos. Nas pequenas paredes de 10,0 MPa foram observadas fissuras que surgiram na superfície da face longitudinal e também na lateral das paredes, mas com aberturas menores que aquelas observadas nos blocos.

A Tabela 4.4 traz os resultados médios de força resistente, tensão na área bruta e porcentagem de resistência residual das pequenas paredes estudadas nesta primeira fornada. Os resultados individuais estão apresentados no APÊNDICE C, e a resistência característica foi calculada de acordo com procedimento estabelecido pela ABNT NBR 16522:2016 e apresentado no APÊNDICE E.

Tabela 4.5 - Resistência à compressão pós-fogo das pequenas paredes ( $1^{\mathrm{a}}$ Fornada)

\begin{tabular}{|c|c|c|c|c|c|c|}
\hline \multicolumn{7}{|c|}{ Resistência à compressão pós-fogo } \\
\hline \multicolumn{2}{|c|}{ Tipo de unidade } & & \multicolumn{4}{|c|}{ Pequenas Paredes * } \\
\hline $\begin{array}{c}\text { Resistência } \\
\text { característica } \\
\text { nominal } \\
\end{array}$ & $\begin{array}{l}\text { Largura } \\
\text { nominal }\end{array}$ & & $\begin{array}{l}\text { Resistência } \\
\text { média temp. } \\
\text { ambiente }(\mathrm{kN})\end{array}$ & Força $(\mathrm{kN})$ & $\begin{array}{c}\text { Tensão na área } \\
\text { bruta (MPa) }\end{array}$ & $\begin{array}{c}F_{\text {fogo }} / F_{a m b} \\
\text { (Resistência } \\
\text { residual) } \\
\end{array}$ \\
\hline \multirow{4}{*}{$10,0 \mathrm{MPa}$} & & Média & & 111,45 & $\mathbf{1 , 0 1}$ & \multirow{4}{*}{$13 \%$} \\
\hline & 140 & Desvio Padrão & 82600 & 36,20 & 0,33 & \\
\hline & $\mathrm{mm}$ & $\mathrm{CV}(\%)$ & $0<0,90$ & 32,48 & 32,48 & \\
\hline & & $f_{\text {ppk }}(\mathrm{MPa})$ & & & $\mathbf{0 , 5 8}$ & \\
\hline \multirow{4}{*}{ 4,0 MPa } & \multirow{4}{*}{$\begin{array}{l}140 \\
\mathrm{~mm}\end{array}$} & Média & \multirow{4}{*}{565,00} & 79,25 & $\mathbf{0 , 7 2}$ & \multirow{4}{*}{$14 \%$} \\
\hline & & Desvio Padrão & & 5,38 & 0,05 & \\
\hline & & $\mathrm{CV}(\%)$ & & 6,79 & 6,79 & \\
\hline & & $f_{\text {ppk }}(\mathrm{MPa})$ & & & $\mathbf{0 , 5 3}$ & \\
\hline
\end{tabular}

* Pequenas paredes expostas ao incêndio padrão da ISO 834-1:1999 durante 70 min em todas as faces

A resistência residual obtida para as paredes de ambas as classes de resistência foi próxima, de $13 \%$ para as paredes com blocos de 10,0 MPa e de 14\% para paredes com blocos de 4,0 MPa. As perdas de resistência foram mais significativas nas paredes do que nos blocos, assim como observado para os prismas. Como o coeficiente de variação da resistência à compressão pós-fogo das pequenas paredes com blocos de 10,0 MPa resultou relativamente alto $(32,48 \%)$ foi realizado o teste estatístico de Grubbs com o intuito de verificar a possível presença de valores espúrios na amostra. O procedimento deste teste está descrito no APÊNDICE D e como resultou na inexistência de tais valores, mantiveram-se os resultados obtidos.

O modo de ruptura das pequenas paredes seguiu basicamente o mesmo padrão dos ensaios de caracterização em temperatura ambiente. Para ambas as classes de resistência surgiram fissuras nas faces longitudinais das paredes, mas a ruptura foi guiada pelas trincas de grandes aberturas que surgiram nas faces laterais das paredes, como observado na Figura 4.29. 
Em uma das paredes com blocos de 4,0 MPa foi identificada ruptura por esmagamento pontual de um dos blocos da última fiada da parede, havendo inclusive o desprendimento de parte do bloco, mas, mesmo nesta parede, ocorreu abertura de trincas nas laterais do elemento.

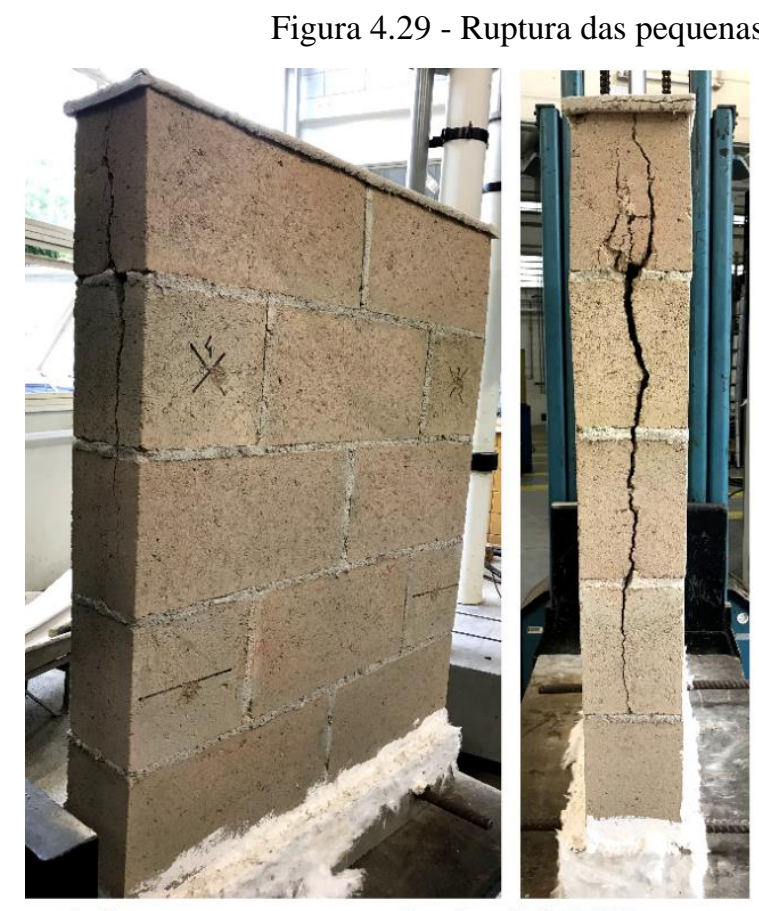

(a) pequena parede de 4,0 MPa

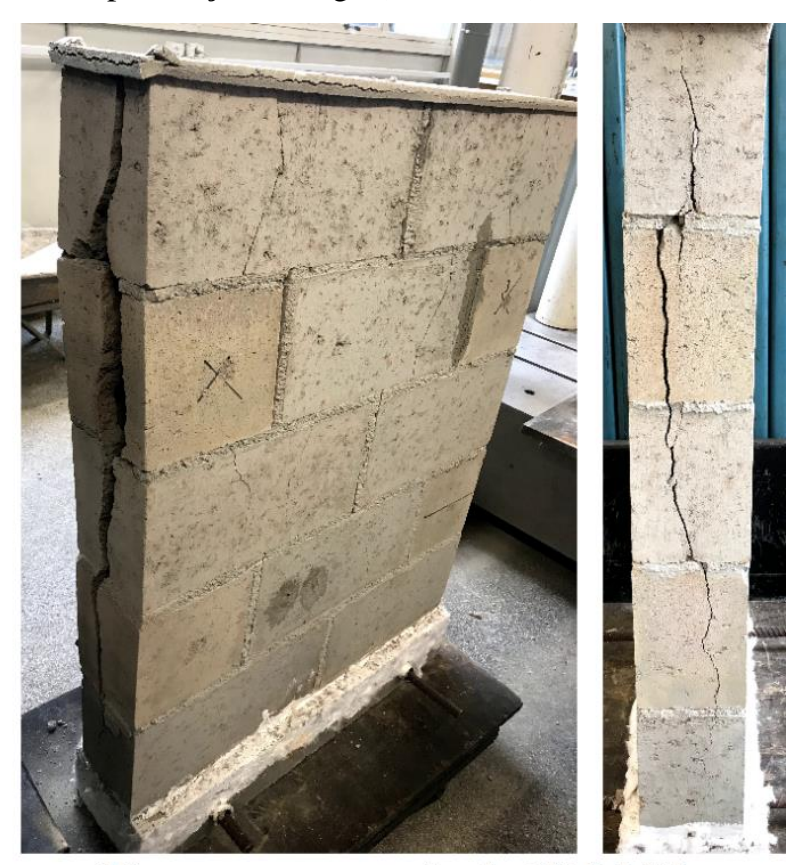

(b) pequena parede de 10,0 MPa

4.4.4.5. Trio de pequenas paredes (compartimentadas)

As pequenas paredes do trio compartimentado também foram submetidas ao ensaio de compressão simples de acordo com os procedimentos prescritos na ABNT NBR 15961:2011, na máquina servo-hidráulica universal da marca Instron, com controle de deslocamento a uma velocidade de $0,01 \mathrm{~mm} / \mathrm{s}$. O mesmo procedimento das demais paredes ensaiadas pós-fogo foi seguido, o capeamento foi substituído pelo forro de fibra mineral, mas não foram aplicados os ciclos com carga reduzida para escorvamento e acomodação do forro em função da condição deteriorada das pequenas paredes.

Estas paredes apresentaram um material nitidamente mais resistente que as submetidas a incêndio em todas as faces. Na face exposta ao fogo, o material apresentava características de redução da dureza, esfarelando com o passar dos dedos, mas na face não exposta a superfície dos blocos sofreu danos significativamente menores, não ficando muito distante da textura em temperatura ambiente. Claramente essa diferença do material ao longo da seção transversal está associada aos níveis de temperatura atingidos durante o ensaio de simulação de incêndio. 
Foi possível identificar ao longo da seção do bloco uma diferença de coloração, mais rosado conforme se aproximava da face exposta ao fogo e mais acinzentado próximo da face não exposta, embora essa diferença visual de coloração não tenha ficado evidente em fotografias para expor nesta dissertação. Outra questão observada foi um arqueamento, na ordem de 2 centímetros, com curvatura para o lado interno do trio compartimentado (não exposto ao fogo) ocorrido em função de dilatações diferenciais entre as faces do elemento, ou seja, a face exposta ao fogo dilatou mais que a não exposta, como mostra a Figura 4.30.

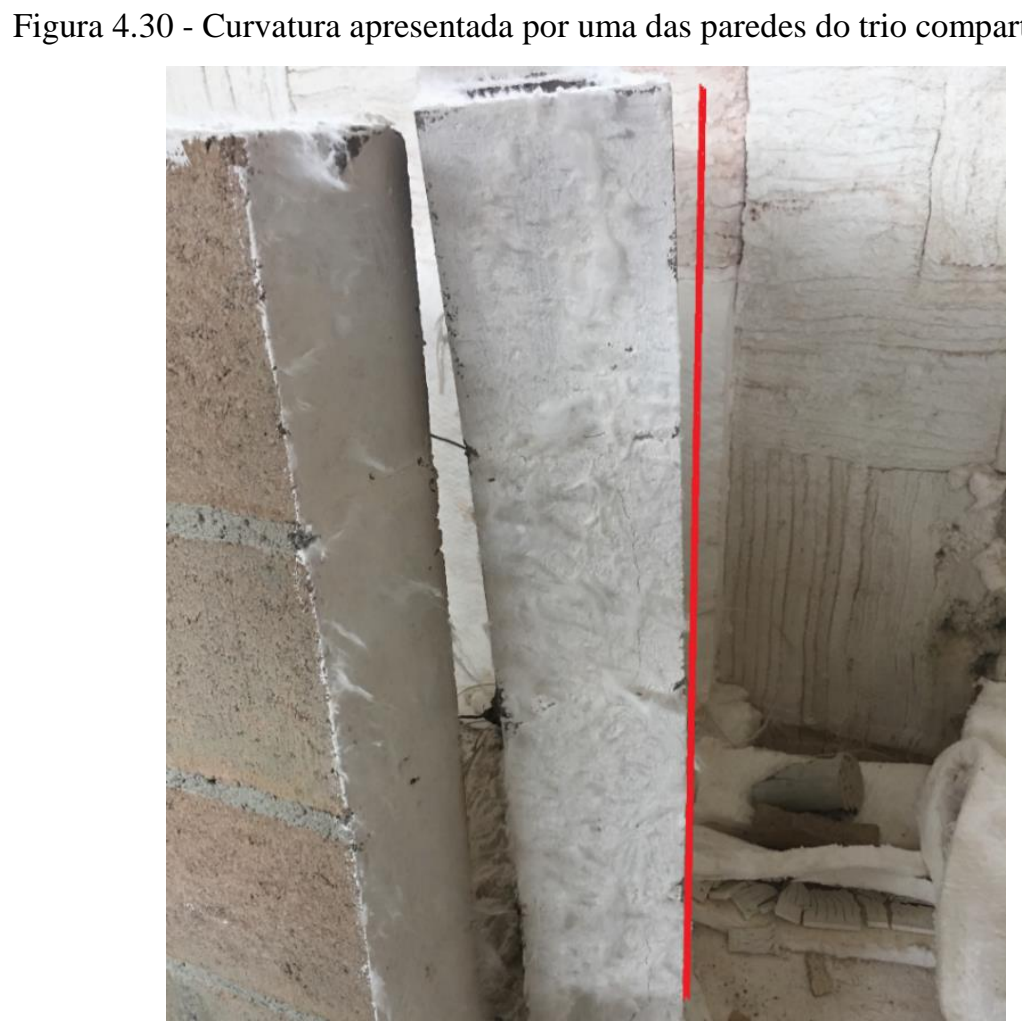

Os resultados médios de força resistente, a tensão calculada na área bruta e da porcentagem de resistência e módulo de elasticidade residual estão dispostos na Tabela 4.6. Os resultados individuais estão apresentados no APÊNDICE C, e a resistência característica foi calculada de acordo com procedimento estabelecido pela ABNT NBR 16522:2016 e apresentado no APÊNDICE E.

A resistência residual de $46 \%$ para as paredes compartimentadas foi muito superior aos $14 \%$ das pequenas paredes com incêndio em todas as faces, ficando claro que a compartimentação oferece uma menor perda de resistência ao elemento estrutural em função dos níveis de temperatura menores atingidos pelos materiais. Como o coeficiente de variação da resistência à compressão pós-fogo do trio de pequenas paredes resultou relativamente alto $(23,72 \%)$ foi realizado o teste estatístico de Grubbs com o intuito de verificar a possível 
presença de valores espúrios na amostra. O procedimento deste teste está descrito no APÊNDICE D e como resultou na inexistência de tais valores, mantiveram-se os resultados obtidos.

Tabela 4.6 - Resistência à compressão pós-fogo das pequenas paredes compartimentadas ( $1^{\text {a }}$ Fornada)

\begin{tabular}{|c|c|c|c|c|c|c|}
\hline \multicolumn{7}{|c|}{ Resistência à compressão pós-fogo } \\
\hline \multicolumn{2}{|c|}{ Tipo de unidade } & & \multicolumn{4}{|c|}{ Pequenas Paredes (compartimentadas) * } \\
\hline $\begin{array}{c}\text { Resistência } \\
\text { característica } \\
\text { nominal }\end{array}$ & $\begin{array}{l}\text { Largura } \\
\text { nominal }\end{array}$ & & $\begin{array}{l}\text { Resistência } \\
\text { média temp. } \\
\text { ambiente }(\mathrm{kN})\end{array}$ & Força $(\mathrm{kN})$ & $\begin{array}{c}\text { Tensão na área } \\
\text { bruta (MPa) }\end{array}$ & $\begin{array}{c}F_{\text {fogo }} / F_{a m b} \\
\text { (Resistência } \\
\text { residual) }\end{array}$ \\
\hline \multirow{4}{*}{ 4,0 MPa } & \multirow{4}{*}{$\begin{array}{l}140 \\
\mathrm{~mm}\end{array}$} & Média & \multirow{4}{*}{565,00} & 258,95 & 2,35 & \multirow{4}{*}{$46 \%$} \\
\hline & & Desvio Padrão & & 61,42 & 0,56 & \\
\hline & & $\mathrm{CV}(\%)$ & & 23,72 & 23,72 & \\
\hline & & $f_{\text {ppk }}(\mathrm{MPa})$ & & & 1,54 & \\
\hline
\end{tabular}

* Pequenas paredes expostas ao incêndio padrão da ISO 834-1:1999 durante 70 min em apenas uma face

Nas pequenas paredes compartimentadas, o modo de ruptura observado foi diferente, com o surgimento de fissuras nas faces laterais, mas que não foram predominantes no colapso dos elementos. Notou-se esmagamento de parte dos blocos entre a última e a penúltima fiadas, que implicaram no desplacamento de parte da superfície dos blocos. Esta diferença no modo de ruptura pode ser justificada pela curvatura que ocorreu nestas paredes e que pode ter implicado em efeitos de segunda ordem durante o ensaio de compressão das pequenas paredes. A Figura 4.31 mostra as pequenas paredes do trio após o ensaio de compressão.

Figura 4.31 - Modo de ruptura das pequenas paredes compartimentadas da $1^{\mathrm{a}}$ Fornada
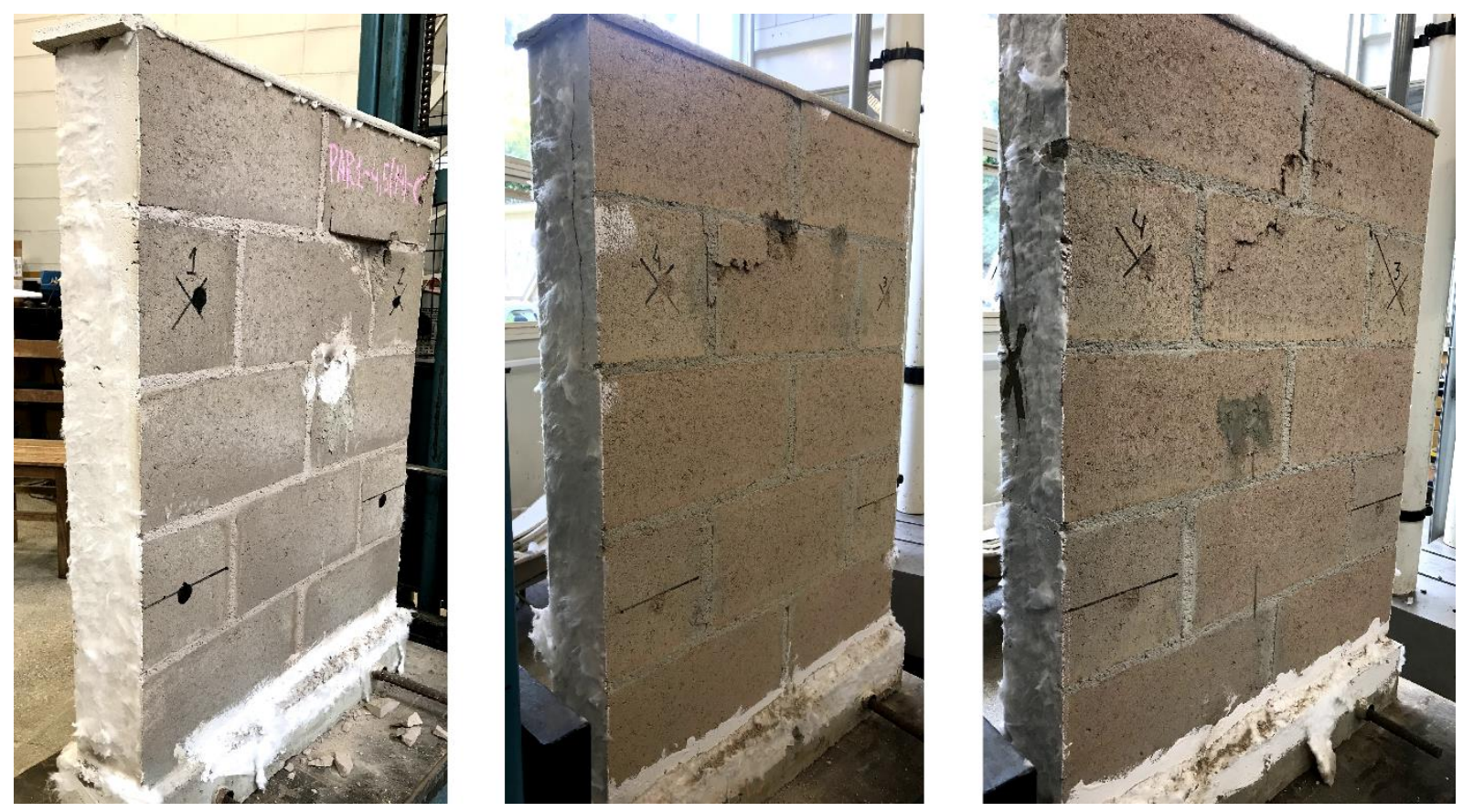


\subsubsection{Considerações sobre os resultados da $1^{\mathrm{a}}$ fornada (sem revestimento)}

Considerando que a primeira fornada durou apenas 70 minutos e que estes elementos estruturais precisam atingir um TRRF mínimo de 120 minutos, de acordo com a IT-08 do corpo de bombeiros do estado de São Paulo, é possível dizer que os elementos não revestidos e com incêndios em todas as faces apresentaram resultado insatisfatório de resistência residual, pois acredita-se que a resistência seria ainda menor para esta ação térmica mais prolongada. Obviamente, por não estar submetida a carregamentos mecânicos, o comportamento da alvenaria é diferente daquela encontrada nas edificações pois como visto em Mehta e Monteiro (1997) a situação não carregada é a crítica para estruturas de concreto armado em elevadas temperaturas por não haver restrições de deslocamentos. Analogamente, acredita-se que esta também seja a situação crítica para a alvenaria estrutural.

A combinação de ações excepcional adotada no dimensionamento de estruturas em situação de incêndio apresenta uma redução, que pode chegar a $50 \%$ da solicitação em relação às combinações para o dimensionamento nos Estados Limites Ultimo de e Serviço. Mesmo que as solicitações de cálculo sejam menores, esta redução não chega a ser tão grande como a redução de resistência encontrada nos elementos estruturais de alvenaria de blocos de concreto (independentemente da classe de resistência). Portanto, optou-se por adotar o revestimento mais comum nas obras atualmente, utilizado como acabamento de paredes internas de compartimentação, que é o gesso, para realizar os ensaios de simulação de incêndio-padrão com 120 minutos de duração. Uma vez que esta camada de proteção pode garantir melhorias no comportamento da alvenaria frente ao fogo.

O APÊNDICE C apresenta mais fotos relacionadas aos ensaios de simulação de incêndio e compressão pós fogo dos elementos da primeira fornada.

\subsection{Simulação de incêndio-padrão - revestidos com gesso (segunda fornada)}

$\mathrm{Na}$ simulação de incêndio-padrão da segunda fornada foram ensaiados elementos com revestimento de $5 \mathrm{~mm}$ de gesso de ambas classes de resistência estudadas, 4,0 e 10,0 MPa, com espessura de $140 \mathrm{~mm}$. Os corpos de prova foram submetidos à ação do fogo por 120 minutos, como estava previsto, chegando à temperatura máxima de aproximadamente $1050^{\circ} \mathrm{C}$.

Através da programação e dos termopares de controle, o forno seguiu a curva de incêndio-padrão da ISO 834-1:1999 satisfatoriamente, sendo que, durante todo o período de funcionamento, a temperatura média manteve-se na faixa entre os limites máximo e mínimo 
sugeridos pela ABNT NBR 10636:1989. O atendimento da curva de incêndio-padrão prevista, juntamente com os seus limites superior e inferior, pode ser observado nos gráficos da Figura 4.32 para a segunda fornada.

Figura 4.32 - Temperatura do forno na $2^{\mathrm{a}}$ fornada

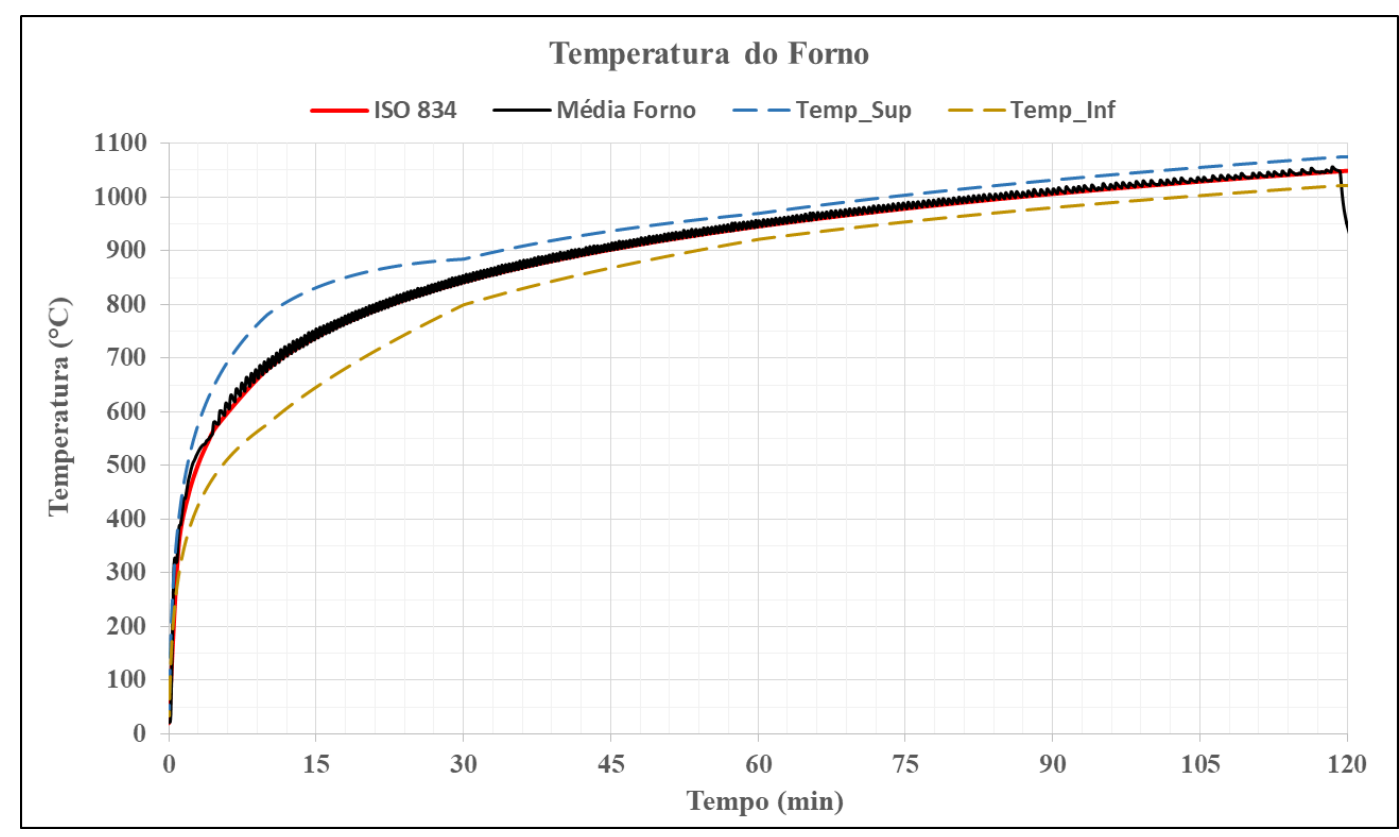

Mais uma vez foi medida a umidade relativa dos blocos no dia de execução dos ensaios de simulação de incêndio, pois, como visto na literatura, a umidade relativa dos blocos de concreto é um fator importante no seu comportamento quando submetido a ações térmicas. Os resultados médios são mostrados na Tabela 4.2, com procedimento realizado seguindo as recomendações da ABNT NBR 12118:2014, mas adotando-se dois blocos de cada variação.

Tabela 4.7 - Umidade relativa dos blocos da $2^{\mathrm{a}}$ fornada

\begin{tabular}{c|c|c}
\hline \hline \multicolumn{2}{c}{ Umidade realtiva dos blocos para $2^{\mathrm{a}}$ fornada } \\
\hline \hline \multicolumn{2}{c}{ Tipo de unidade } & Bloco \\
\hline $\begin{array}{c}\text { Resistência característica } \\
\text { nominal }\end{array}$ & $\begin{array}{c}\text { Largura } \\
\text { nominal }\end{array}$ & Umidade Relativa \\
\hline \hline & $140 \mathrm{~mm}$ & $\mathbf{3 2 \%}$ \\
\hline $4,0 \mathrm{MPa}$ & $140 \mathrm{~mm}$ & $\mathbf{1 3 \%}$ \\
\hline \hline
\end{tabular}

A seguir serão apresentadas a execução, a organização dos corpos de prova no forno e a instrumentação realizada para a segunda fornada, bem como os resultados obtidos na análise térmica dos elementos e na análise mecânica de resistência residual pós-fogo. 
4.5.1. Corpos de prova - quantidade, execução e preparação da fornada

Foram submetidos à simulação de incêndio-padrão os mesmos corpos de prova utilizados na caracterização do Programa Experimental I: blocos, primas e pequenas paredes. As quantidades para cada elemento também foram mantidas, seguindo as prescrições das normas ABNT NBR 6136:2016 para os blocos, ABNT NBR 15961-1 para os prismas e pequenas paredes. Os corpos de prova de argamassa não foram ensaiados nesta fornada, pois verificou-se a impossibilidade de obter a resistência residual após a primeira fornada, com tempo de aquecimento bem menor que o atual.

Os corpos de prova utilizados nesta fornada foram executados seguindo o mesmo padrão de toda a pesquisa. Foi adotado argamassamento total tanto para os prismas de dois blocos como para as pequenas paredes, com argamassa no traço em volume de $1: 0,5: 4,5$ de cimento, cal e areia, respectivamente. Para o transporte das pequenas paredes foram executadas bases de concreto, cuja execução (formato, traço e armadura) está descrita no item 3.4.1 desta dissertação. A diferença desta etapa é que os elementos foram revestidos com uma camada de $5 \mathrm{~mm}$ de gesso.Durante a execução, foram colocadas réguas como guias, medidas com precisão para que a camada de gesso ficasse o mais uniforme possível e próxima dos $5 \mathrm{~mm}$ de espessura.

A disposição dos corpos de prova dentro do forno foi mantida como realizado na primeira fornada, pois foi pensada para que possibilitasse a circulação de ar e garantisse que todos os corpos de prova recebessem calor de maneira homogênea. Dos resultados da primeira fornada foi possível concluir que esta homogeneidade da temperatura dos gases internos foi satisfatória, uma vez que os limites da curva de incêndio-padrão da ISO 834-1:1999 foram atendidos em todos os termopares de controle.

Desta forma, os corpos de prova mais altos (pequenas paredes) foram posicionados o mais distante possível da saída dos queimadores. A Figura 4.33 mostra a disposição e a quantidade de corpos de prova da segunda fornada, em que todos os corpos de prova contam com revestimento de gesso em todas as faces. O desenho conta com uma legenda de cores para identificar os elementos, que foram representados com proporção entre eles e em relação ao forno, os círculos de cor laranja nas paredes do forno indicam a posição dos queimadores em planta.

Para evitar a entrada de calor por eventuais frestas entre os corpos de prova e o piso do forno, os mesmos foram posicionados em cima de uma camada de manta cerâmica e as bases de concreto das pequenas paredes foram cobertas com uma camada de manta cerâmica para evitar que fossem excessivamente degradadas pela ação térmica. Todos os elementos, foram 
cobertos com uma camada de manta cerâmica de $50 \mathrm{~mm}$, para que os gases quentes não entrassem pela parte superior dos corpos de prova. Nesta fornada não foi utilizada uma camada de placa de gesso sobre os corpos de prova, pois na primeira fornada observou-se que apenas uma camada espessa de manta era suficiente para tal isolamento.

Figura 4.33 - Disposição dos corpos de prova da $2^{\mathrm{a}}$ fornada

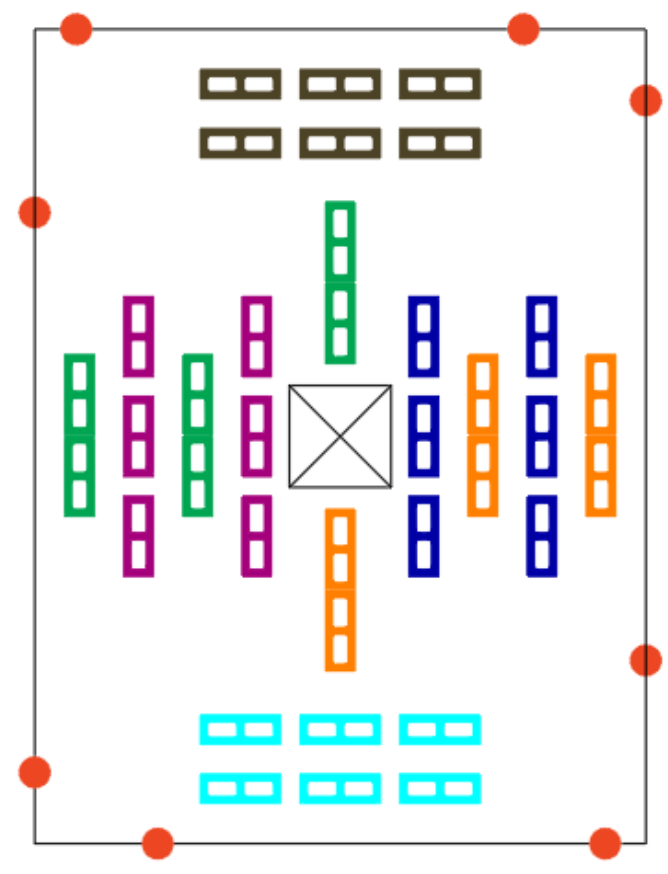

$2^{\mathrm{a}}$ Fornada (com revestimento)

3 P.Paredes 140mm/ 4,0MPa

3 P.Paredes 140mm/ 10,0MPa

6 Prismas 140mm/ 4,0MPa

6 Prismas 140mm/ 10,0MPa

6 Blocos 140mm/4,0MPa

6 Blocos 140mm/ 10,0MPa

A Figura 4.34.(I) mostra os corpos de prova posicionados dentro do forno para a segunda fornada e a Figura 4.34.(II) mostra os mesmos corpos de prova após a colocação de manta cerâmica na parte superior.

Figura 4.34 - Preparação da $2^{\mathrm{a}}$ fornada - Parte 1

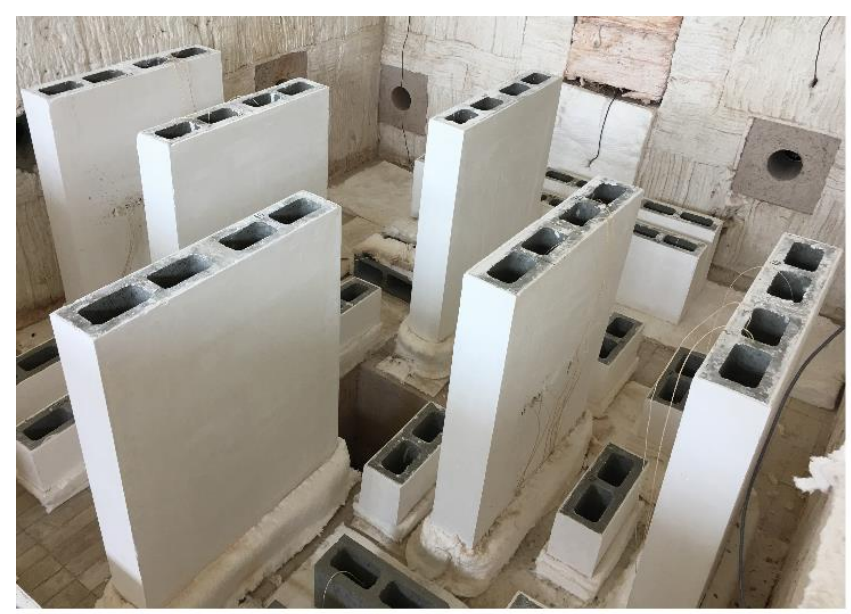

(I)

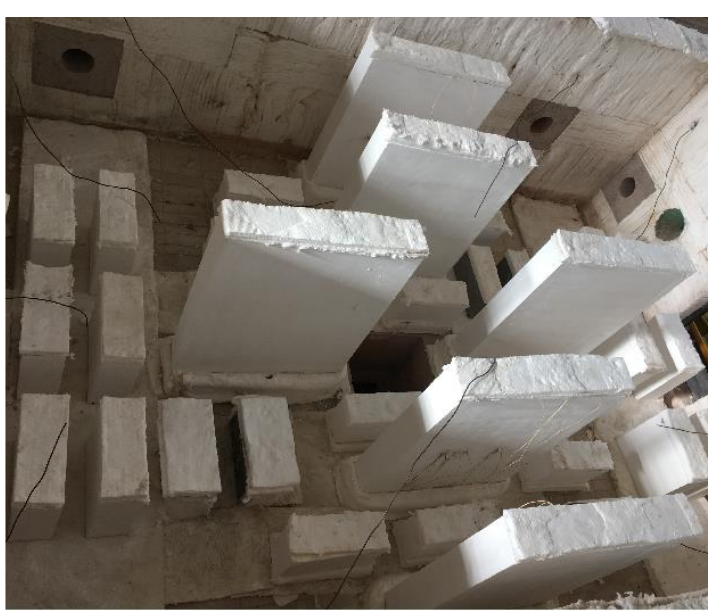

(II) 
A Figura 4.35.(III) apresenta uma parede pronta para ser ensaiada e a Figura 4.35.(IV) mostra a preparação finalizada já com os pesos encima dos corpos de prova para impedir a retirada da manta pela movimentação de ar durante o ensaio.

Figura 4.35 - Preparação da $2^{\mathrm{a}}$ fornada - Parte 2

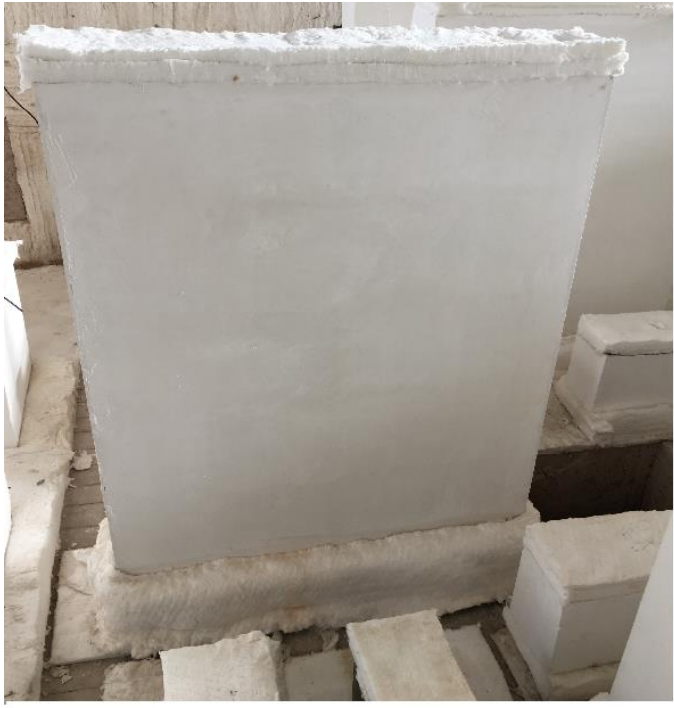

(III)

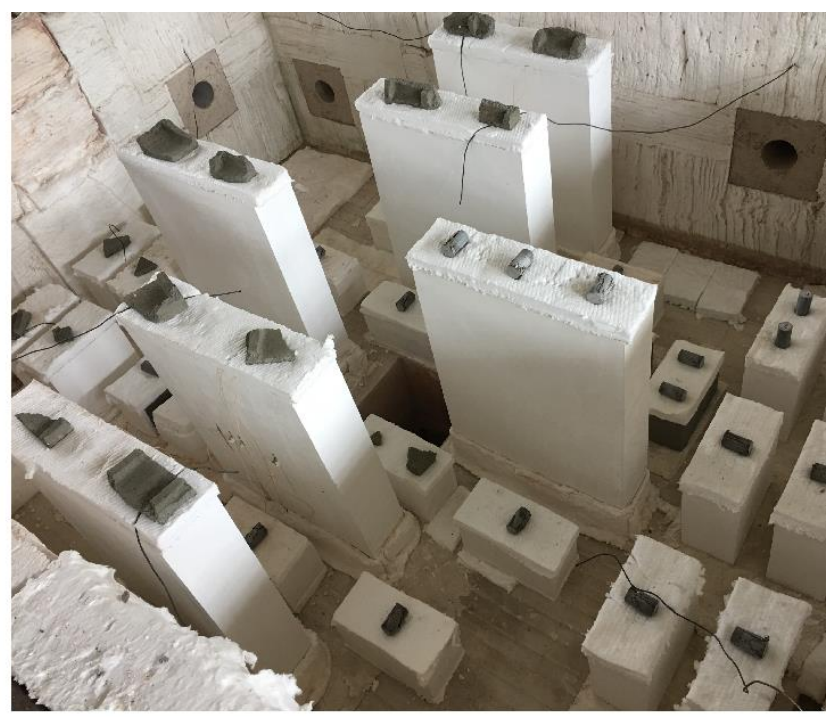

(IV)

\subsubsection{Instrumentação}

Para a segunda fornada os corpos de prova foram instrumentados mais uma vez com termopares do tipo $\mathrm{K}$, a fim de se conhecerem os níveis de temperatura atingidos pelos materiais ao longo da seção transversal dos elementos. Como foi observado nos resultados da primeira fornada, as medidas de temperatura em blocos e pequenas paredes apresentaram poucas diferenças. Assim, optou-se por instrumentar somente as pequenas paredes, uma vez que a quantidade de entradas no sistema de aquisição de dados é limitada e o trabalho para colocação dos termopares é bastante dispendioso.

Foram instrumentadas duas pequenas paredes de cada tipo estudado, repetindo exatamente os pontos de medição para que toda instrumentação fosse feita em pares. Ou seja, todos os pontos foram repetidos em outra parede para permitir comparação dos resultados ou mesmo a aquisição de dados no caso de algum termopar se perder por ação do fogo. Todos os pontos de instrumentação foram colocados no material do bloco (concreto), não foram colocados termopares nas juntas de argamassa, pois estes termopares se perdem com facilidade e, como foi observado nos resultados da primeira fornada, as curvas de pontos na argamassa acompanham com proximidade as curvas dos termopares no concreto. 
A instrumentação nas paredes longitudinais e nos septos dos blocos das pequenas paredes foi realizada através de um furo com broca de $4 \mathrm{~mm}$ preenchido com pasta de cimento para fixação do termopar na posição adequada. Para os pontos na superfície interna das paredes longitudinais (face) os termopares foram soldados em discos de cobre e colados com o cimentocola cerâmico, sendo estes termopares cobertos com uma fina camada de manta cerâmica para evitar a influência dos gases internos nos furos dos blocos, registrando-se a temperatura na superfície do concreto naqueles pontos. A Figura 4.36 ilustra exemplos da instrumentação realizada.

Figura 4.36 - Exemplos de instrumentação para a $2^{\mathrm{a}}$ fornada
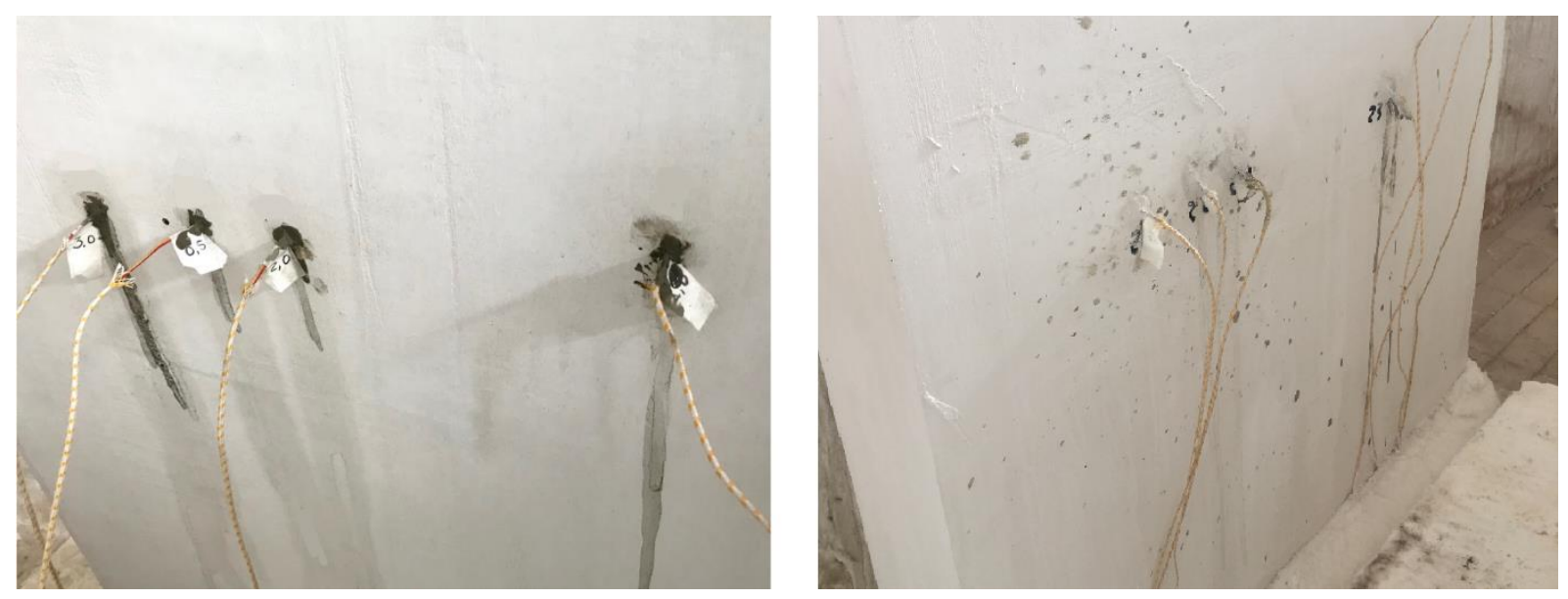

Os posicionamentos dos termopares adotados para a instrumentação das pequenas paredes estão dispostos na Figura 4.37 e na Figura 4.38 para a segunda fornada, que são as pequenas paredes com espessura de $140 \mathrm{~mm}$ e resistências nominais de 10,0 MPa e 4,0 MPa, respectivamente. Nos desenhos, os pontos em azul ( $2^{\mathrm{a}}$ fornada) indicam os termopares, o número associado a cada ponto indica o termopar e permite associá-lo à numeração das curvas de temperatura no item de análise térmica que será apresentado a seguir. O valor colocado entre parênteses indica a distância do ponto de medição do termopar até a face externa da parede, sem considerar os $5 \mathrm{~mm}$ de revestimento.

Para a nomenclatura, continua-se adotando o mesmo sistema, com a diferença da letra "G" que indica que os elementos foram revestidos com gesso. Ou seja, a nomenclatura possui a seguinte formatação para blocos, prismas e pequenas paredes respectivamente: $\underline{\text { BL número - }}$

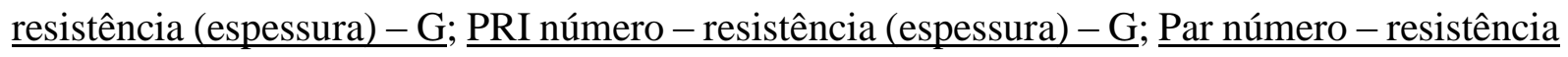
(espessura) - N-G. 
Figura 4.37 - Instrumentação das pequenas paredes de 10,0 MPa / $140 \mathrm{~mm}$ com revestimento (2 ${ }^{\mathrm{a}}$ Fornada)

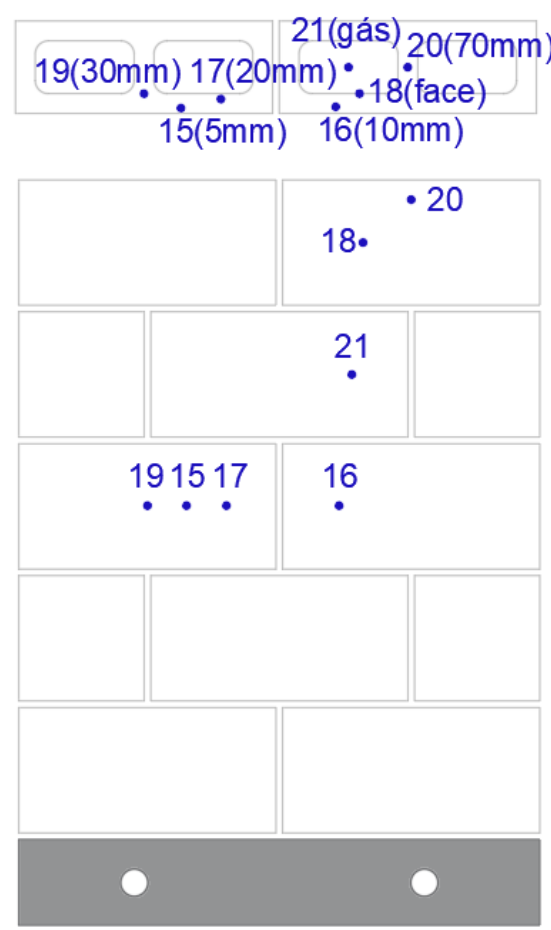

Par1-10,0(14)-N-G
28 (gás) $27(70 \mathrm{~mm})$

$2630 \mathrm{~mm}) 24(20 \mathrm{~mm}) \cdot .25$ (face) $\dot{2} \dot{2} \mathrm{~mm}) \quad \dot{2} 3(10 \mathrm{~mm})$

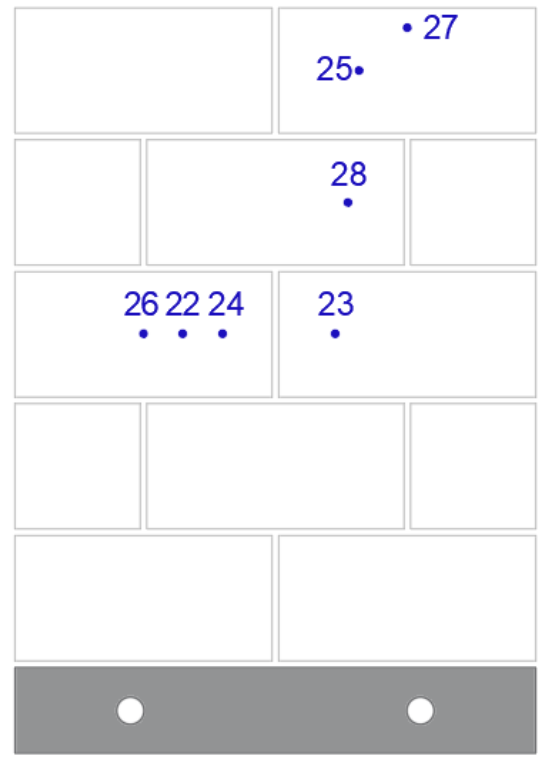

Par2-10,0(14)-N-G

Figura 4.38 - Instrumentação das pequenas paredes de 4,0 MPa / $140 \mathrm{~mm}$ com revestimento (2a Fornada)

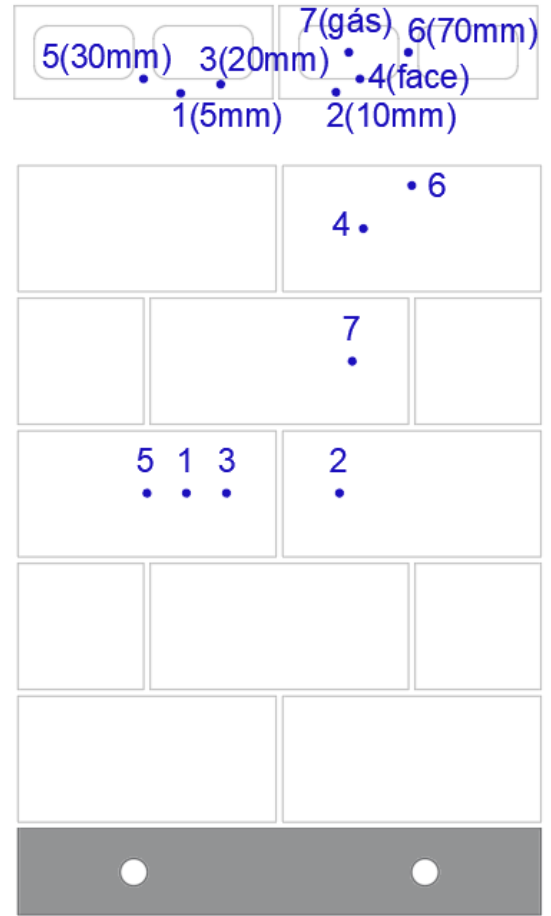

Par1-4,0(14)-N-G
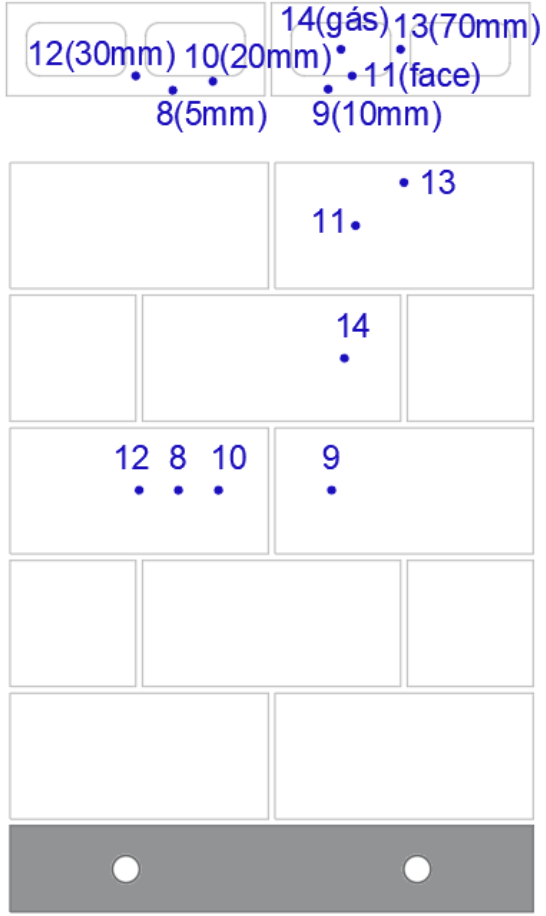

Par2-4,0(14)-N-G 


\subsubsection{Análise Térmica}

A capacidade resistente dos elementos após a ação do fogo está associada aos níveis de temperaturas atingidos e aos modos de aquecimento e resfriamento adotados, que influenciam na microestrutura e no perfil de fissuração dos materiais. Portanto, nesta análise térmica, são apresentados gráficos da temperatura medida por alguns termopares em função do tempo de ensaio e também é discutido o comportamento dos corpos de prova e do revestimento durante a execução da simulação de incêndio-padrão, que foram vigiados durante todo o ensaio através da escotilha de vidro presente no forno. Mais uma vez, o aquecimento seguiu a curva de incêndio-padrão da Isso 834-1:1999 e o resfriamento foi lento, dentro do forno com ventilador ligado.

Foi observado que aos 10 minutos de ensaio, com a temperatura dos gases próxima dos $700^{\circ} \mathrm{C}$, o revestimento de gesso começou se soltar dos corpos de prova com resistência nominal de 10,0 MPa. Nas pequenas paredes foi possível ver o revestimento caindo em placas no chão após se desprender dos blocos de concreto. Nos corpos de prova com resistência nominal de 4,0 MPa, o gesso se manteve fixo aos blocos durante todos os 120 minutos de ação do fogo, no entanto, a partir dos 10 minutos de ação do fogo, já foi possível observar fissuras no revestimento, que aumentaram durante o ensaio, até que as superfícies dos corpos de prova ficassem todas craqueladas.

A Figura 4.39.a mostra uma parede de 10,0 MPa durante a simulação de incêndiopadrão com o gesso se desplacando e a Figura 4.39.b mostra as fissuras que surgiram no gesso de uma parede de 4,0 MPa, ambas fotos foram tiradas com 40 minutos de ensaio. A Figura 4.39.c mostra uma comparação da superfície da pequena parede de 10,0 MPa (esquerda) com a de 4,0 MPa (direita) logo após terem sido retiradas do forno.

De acordo com Gnanachelvam et al. (2018) o material das placas de gesso acartonado possui cerca de $21 \%$ de água quimicamente ligada ao sulfato de cálcio di-hidratado, sendo esta água liberada em forma de vapor durante a desidratação do gesso. Associando o comportamento do gesso acartonado com o gesso utilizado no revestimento dos corpos de prova, é possível concluir que em função da liberação dessa água o gesso sofre retração e por isso ocorre a sua fissuração.

A diferença de comportamento do revestimento em função do tipo de resistência dos elementos está associada provavelmente à rugosidade dos dois materiais, pois os blocos de concreto de 4,0 MPa apresentam a superfície mais rugosa e mais porosa que os blocos de 10,0 $\mathrm{MPa}$. Sendo assim, o gesso do revestimento aderiu melhor à superfície do bloco de menor 
resistência e não se desprendeu em função das dilatações diferenciais provocadas pela ação do calor e consequente desidratação da camada de gesso que envolvia os corpos de prova.

Figura 4.39 - Situação do revestimento de gesso durante e após a ação do fogo

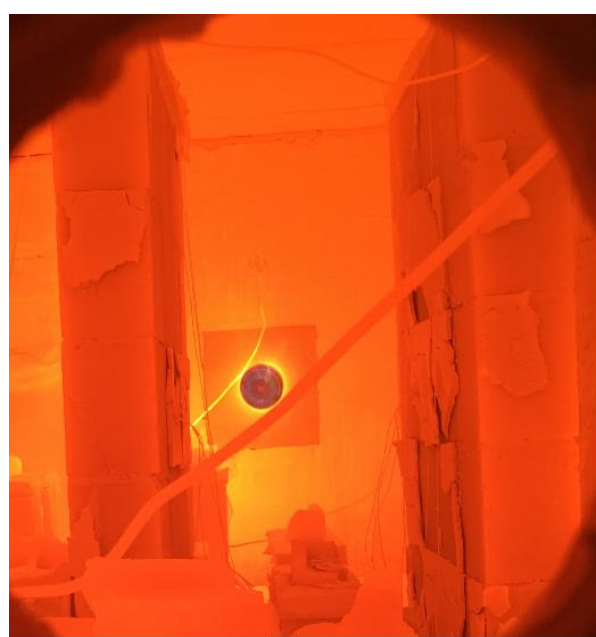

(a)

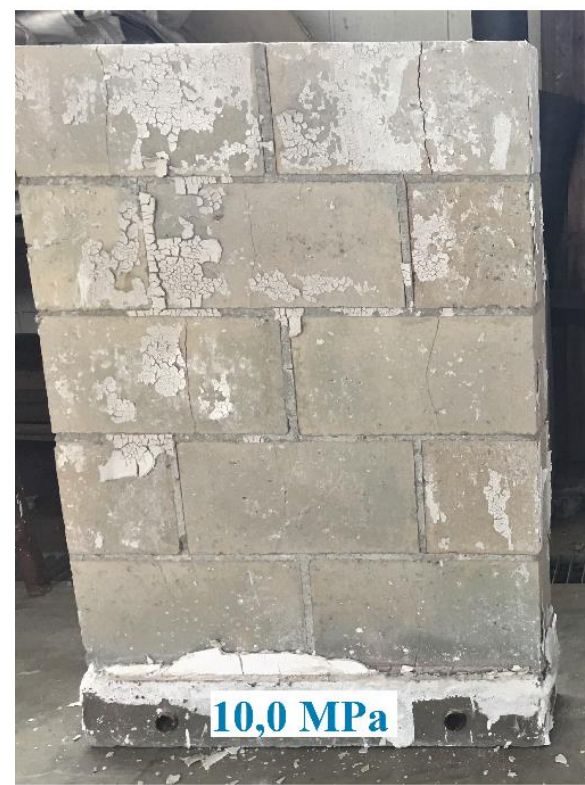

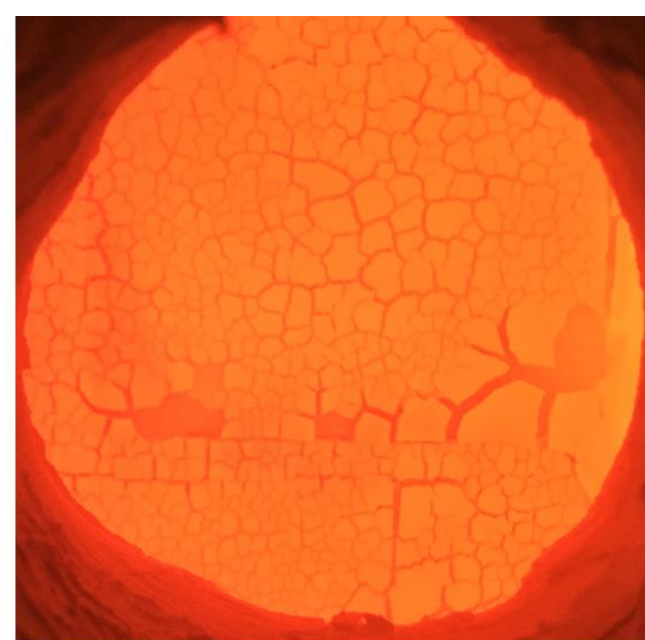

(b)

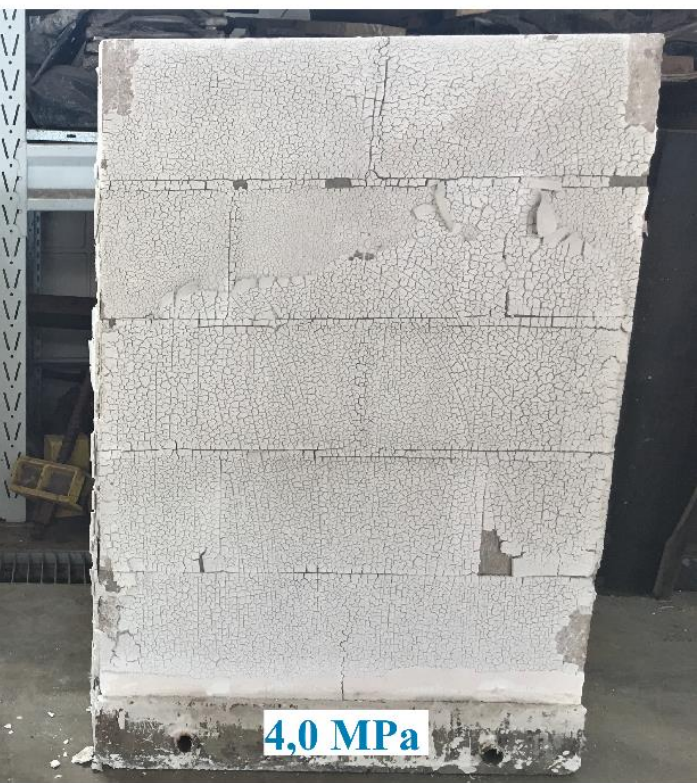

(c)

Buscou-se comparar através de ensaios a diferença de rugosidade entre as superfícies dos blocos de 4,0 e 10,0 MPa, mas por falta de rugosímetros adequados no laboratório esta avaliação não foi possível. Por análise visual e táctil observou-se maior rugosidade e aspereza na superfície dos blocos de 4,0 MPa, é comum que os blocos de maior resistência apresentem superfície menos rugosa uma vez que na composição destes há maior quantidade de cimento e agregados finos e também é adotada maior energia de compactação durante a sua fabricação. Quanto à porosidade da superfície, o ensaio de absorção de água realizado no Programa Experimental I, comprovou que o bloco de menor resistência é mais poroso. 
No tocante ao estado de fissuração, foi observado que as pequenas paredes com blocos de 10,0 MPa começaram a trincar próximo dos 55 minutos de ensaio. Na primeira fornada o início da fissuração nos elementos de 10,0 MPa foi observado aos 45 minutos. Essa diferença de tempo pode ser associada à proteção provocada pelo revestimento de gesso até o momento em que ocorreu o seu desprendimento das pequenas paredes.

As primeiras fissuras surgiram inicialmente na face lateral das pequenas paredes nos blocos da segunda fiada. Conforme o tempo de exposição ao fogo foi passando, as fissuras começaram a se estender por toda a lateral da parede. Após a abertura do forno também foram observadas, nas pequenas paredes de 10,0 MPa, trincas que chegavam a segregar parte dos blocos da última fiada, sendo que estas trincas também foram notadas nos blocos e prismas de 10,0 MPa. Este nível de abertura das trincas é capaz de comprometer os critérios de estanqueidade e isolamento em uma edificação em situação de incêndio compartimentado, valendo destacar novamente que os corpos de prova foram ensaiados sem carregamento e que tensões de compressão aplicadas são capazes de mudar o estado de fissuração devido ao comportamento das restrições para as dilatações diferenciais.

Nos elementos de 4,0 $\mathrm{MPa}$, por permanecerem com a camada de gesso craquelado aderente à sua superfície, não foi possível observar o surgimento de fissuras nas pequenas paredes durante a execução do ensaio. A camada de gesso foi retirada, com auxílio de uma espátula, após o resfriamento dos elementos, e mesmo assim não foram observadas grandes fissuras ou trincas, apenas fissuras sutis, com espessuras menores que $1 \mathrm{~mm}$, no material do bloco e também na sua interface com as juntas de argamassa.

Relacionado à situação do material após a ação do fogo, mais uma vez os elementos com blocos de 10,0 MPa mostraram-se com o concreto mais integro que os elementos com blocos de 4,0 $\mathrm{MPa}$, mesmo tendo o revestimento de gesso se mantido aderente apenas aos elementos de menor resistência. Como a simulação de incêndio padrão nesta segunda fornada foi de 120 minutos, os elementos de maior resistência resultaram, neste caso, mais deteriorados do que os elementos da primeira fornada. Por outro lado, o material dos elementos de menor resistência mostrou-se em situação similar aos da primeira fornada, pois mesmo que o tempo de incêndio tenha sido maior, neste caso o gesso funcionou como uma camada protetora por se manter aderente. Ainda que com o gesso, a superfície dos corpos de prova de 4,0 MPa esfarelava com o passar dos dedos e era possível esmagar partes das paredes dos blocos aplicando-se uma força de pequena intensidade com as mãos.

Quando o material concreto é submetido a uma ação térmica de grande intensidade e atinge elevadas temperaturas, a sua coloração pode mudar e o tom apresentado pelo concreto 
depende do tipo de agregados utilizados em sua composição. Nesta fornada, cujo tempo de exposição ao fogo foi maior, a diferença de coloração dos corpos de prova foi ainda mais nítida, como pode ser observado na Figura 4.40. Os blocos de 10,0 MPa tiveram sua coloração pouco alterada em relação à temperatura ambiente, mantendo-se com tom de cinza, mas com algumas partes em tons róseos, principalmente dentro dos furos. Os blocos de 4,0 MPa tiveram a cor de toda a sua superfície alterada para tons rosáceos. Esta diferença de coloração pode estar diretamente associada com o tipo de agregado utilizado na composição dos blocos, no entanto, esta informação não foi fornecida pela fabricante dos mesmos.

Os elementos foram analisados termicamente por meio dos dados obtidos com a instrumentação dos termopares, com o intuito de conhecer os níveis de temperatura ao longo da seção transversal. Foram traçados gráficos com curvas de temperatura em função do tempo de ensaio de simulação do incêndio-padrão, sendo as curvas agrupadas em função dos 2 tipos de blocos em estudo. Nesta fornada muitos termopares foram perdidos durante a realização do ensaio, seja por interferência dos gases no ponto de medição, que entraram devido às fissuras, seja pela ação direta das chamas que danificaram os cabos em algum ponto dentro do forno. Deste modo, das curvas que puderam ser aproveitadas foram selecionadas as mais adequadas para interpretação dos resultados.

Figura 4.40 - Coloração dos blocos alterada pela ação térmica

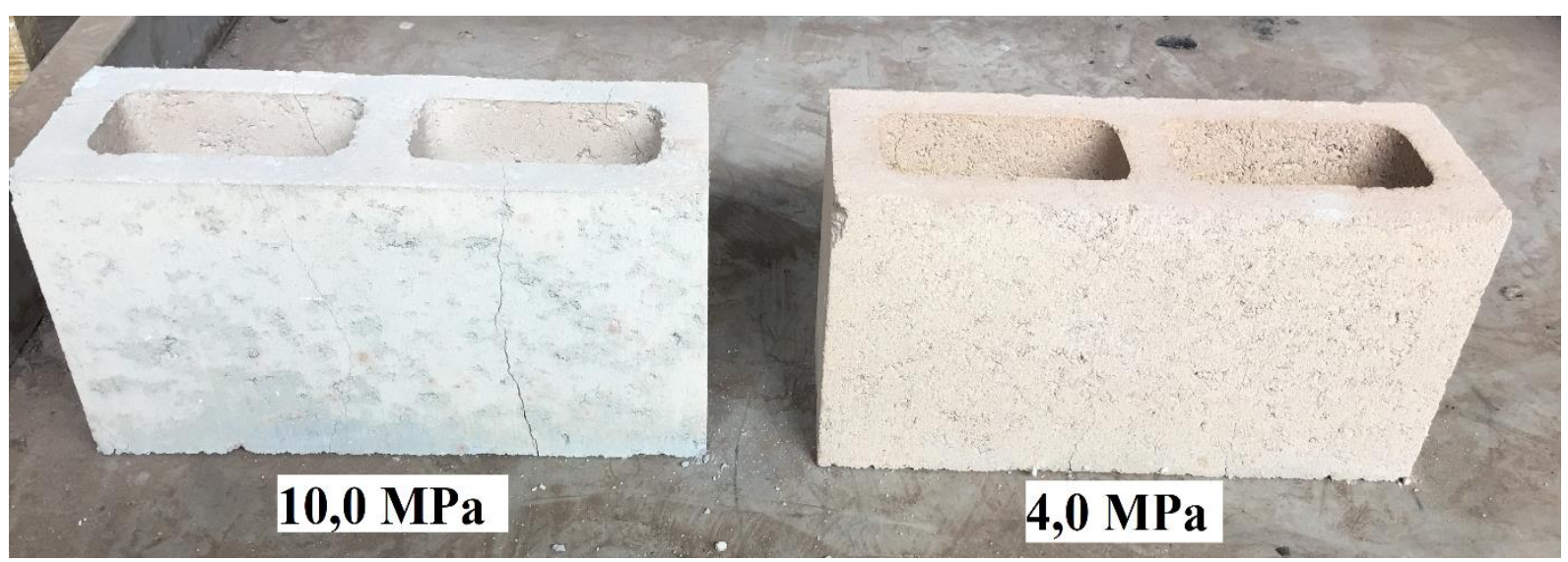

A seguir estão dispostos gráficos que apresentam estas curvas, observando-se que as oscilações nas curvas ocorrem a partir do momento que sofrem influência dos gases, mas ainda são capazes de registar uma tendência média da temperatura no ponto indicado. As legendas dos gráficos indicam as profundidades da instrumentação em relação à face exposta ao fogo dos elementos, e o número entre parênteses indica a numeração do termopar correspondente à curva e que pode ser observado nos desenhos das figuras do item 4.5.2 desta dissertação. 
O gráfico da Figura 4.41 refere-se às medições realizadas nas paredes de 10,0 $\mathrm{MPa}$ e espessura de $140 \mathrm{~mm}$ submetidas ao incêndio-padrão na segunda fornada. São apresentadas 5 curvas de termopares posicionados em diferentes profundidades da seção transversal, sendo que as curvas (15), (16) e (17) são de pontos na parede longitudinal do bloco com profundidades de 5, 10 e 20 mm, respectivamente. A curva (19) é referente ao termopar da mísula e a curva (20) é do termopar fixado no septo.

Figura 4.41 - Gráfico com curvas dos termopares das pequenas paredes de 10,0 MPa e $140 \mathrm{~mm}$ com revestimento de gesso ( $2^{\mathrm{a}}$ Fornada)

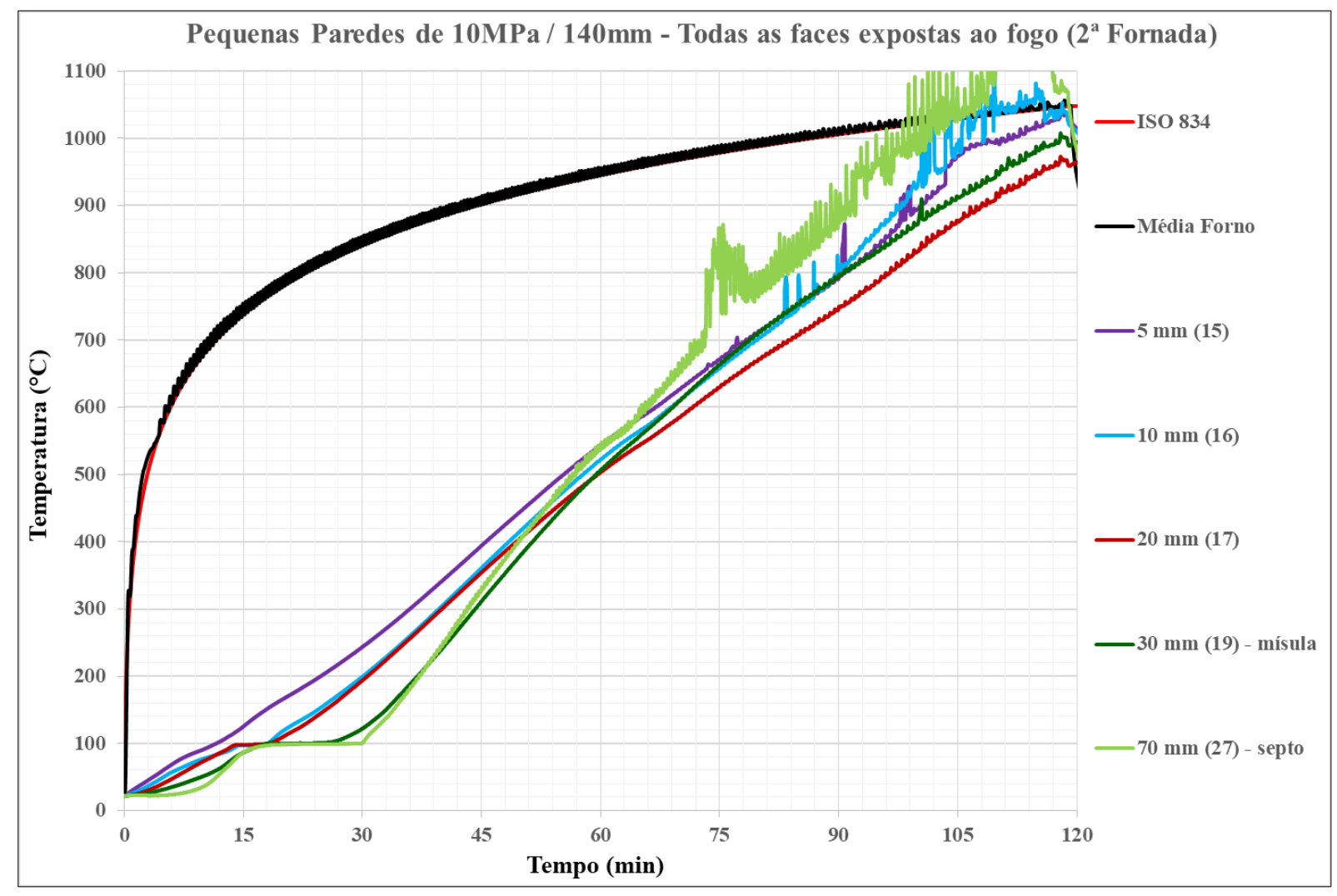

É possível analisar, a partir da curva (15), que nos pontos mais externos dos corpos de prova o concreto atingiu temperaturas próximas dos $1000^{\circ} \mathrm{C}$ aos 120 minutos de ensaio, e mesmo em pontos mais internos, como o da curva (17) a temperatura alcançou mais de $950^{\circ} \mathrm{C}$. Passou-se a esperar severo comprometimento da capacidade resistente dos corpos de prova, pois, como recomendado pela ABNT NBR 15200:2012 para projetos de estruturas de concreto em situação de incêndio, as camadas de concreto que atingiram $500^{\circ} \mathrm{C}$ devem ser descartadas no cálculo da resistência pós-fogo da estrutura.

A partir dos 90 minutos de ensaio a curva (16) passou a apresentar comportamento não condizente com o esperado, provavelmente por interferência dos gases neste ponto, mas até este instante esteve entre as curvas (15) e (17), como esperado em função das profundidades. A 
curva (27) só apresenta resultado confiável durante os primeiros 60 minutos de ensaio, mas por esta curva e pela curva (19) foi possível observar, novamente, que quanto mais interno o ponto no bloco, maior é o patamar de temperatura aos $100^{\circ} \mathrm{C}$, devido à energia absorvida pela mudança de fase da água livre contida nos poros dos blocos de concreto.

O gráfico da Figura 4.42 faz referência às medições realizadas nas paredes de 4,0 MPa e espessura de $140 \mathrm{~mm}$ submetidas ao incêndio-padrão na segunda fornada. A curva (6) referese ao termopar posicionado no septo de um dos blocos, as curvas (8), (9) e (10) são dos pontos na parede longitudinal do bloco com profundidades de 5, 10 e $20 \mathrm{~mm}$ respectivamente, e a curva (12) está relacionada com o termopar colocado na mísula.

Figura 4.42 - Gráfico com curvas dos termopares das pequenas paredes de 4,0 MPa e $140 \mathrm{~mm}$ com revestimento de gesso ( $2^{\mathrm{a}}$ Fornada)

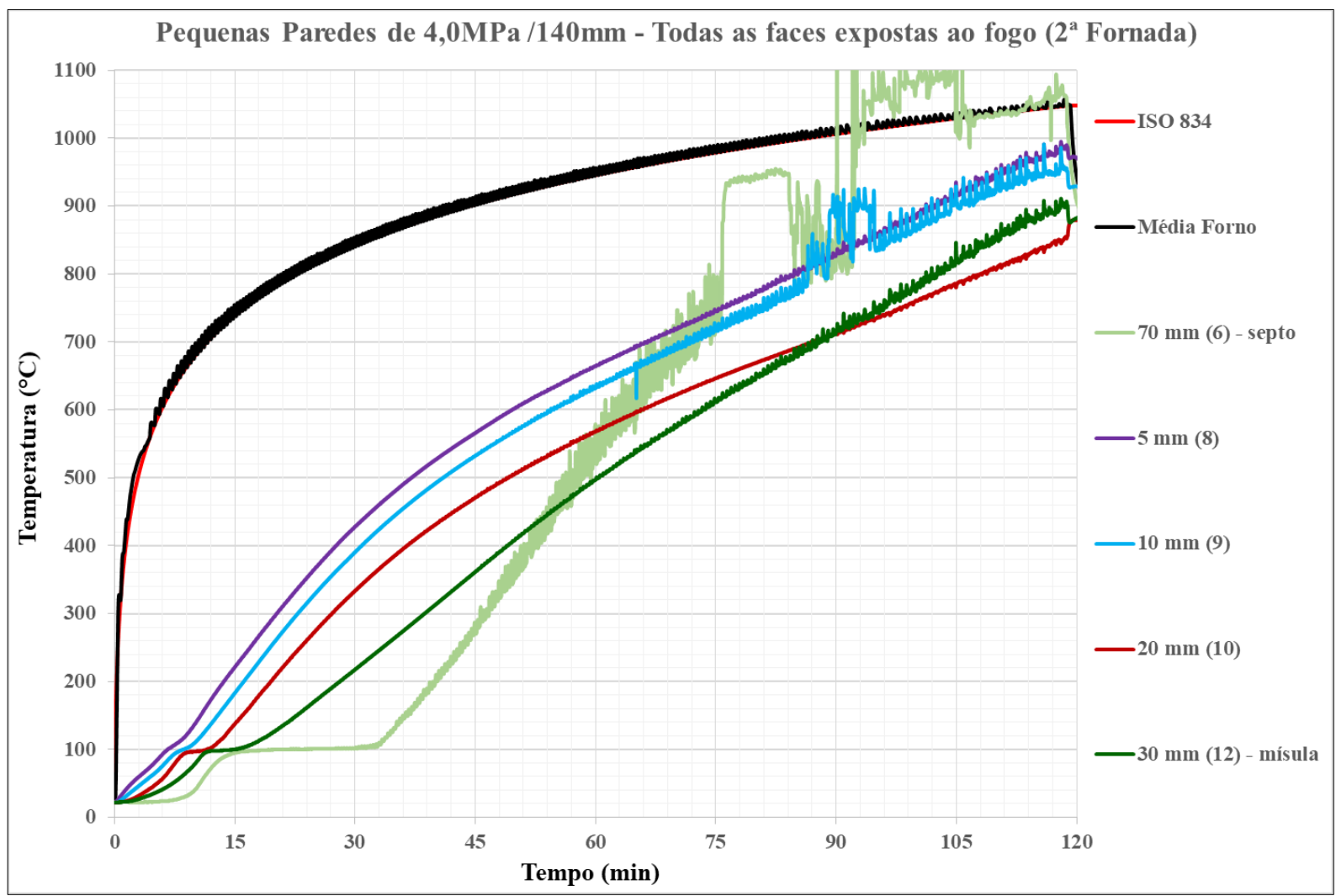

Neste gráfico observam-se nitidamente os patamares de temperatura aos $100^{\circ} \mathrm{C}$ e que são maiores conforme se aumenta a profundidade do ponto de medição e consequentemente maior é o tempo gasto para que a água presente nos poros seja evaporada. Por meio das curvas (8), (9) e (10) é possível concluir que os materiais dos corpos de prova atingiram temperaturas próximas dos $1000^{\circ} \mathrm{C}$ nos pontos mais externos e próximo dos $850^{\circ} \mathrm{C}$ nos pontos mais internos das paredes longitudinais. Isso remete ao comprometimento da resistência residual dos 
elementos com blocos de menor resistência, assim como observado nos corpos de prova de 10,0 MPa.

\subsubsection{Compressão após resfriamento lento}

Seguindo o padrão estabelecido na primeira fornada, os ensaios de compressão simples foram realizados 7 dias após a execução do ensaio de simulação do incêndio padrão. Os corpos de prova foram resfriados lentamente dentro do forno com o ventilador ligado para circulação de ar até que a temperatura média dos gases internos atingisse cerca de $60^{\circ} \mathrm{C}$ (aproximadamente 9 horas para a $2^{\text {a }}$ fornada). Após este período, o ventilador do forno foi desligado e as portas laterais abertas. 24 horas após a realização do ensaio, a tampa do forno foi retirada e os corpos de prova foram mantidos em temperatura e umidade ambientes, protegidos de sol e chuva dentro do barracão do Laboratório de Estruturas até o instante de execução do ensaio de compressão.

Nesta etapa os procedimentos de execução dos ensaios de compressão foram mais uma vez realizados seguindo as mesmas prescrições dos ensaios de compressão simples para caracterização em temperatura ambiente. Na sequência são apresentados os procedimentos adotados para cada um dos tipos de elementos ensaiados e os resultados médios de resistência residual à compressão. Os resultados individuais de cada tipo de elemento estudado estão apresentados no APÊNDICE C, juntamente com os valores de tensão calculados na área bruta e na área líquida. As resistências características foram calculadas de acordo com o procedimento estabelecido pela ABNT NBR 16522:2016 e apresentado no APÊNDICE E.

\subsubsection{Blocos}

O ensaio de compressão simples foi realizado na prensa hidráulica da máquina ELE do Laboratório de Estruturas da Escola de Engenharia de São Carlos, seguindo os critérios da ABNT NBR 12118:2014. Foi adotado carregamento com controle de carga a uma velocidade de $2,4 \mathrm{kN} / \mathrm{s}$ e o capeamento foi substituído por placas de forro de fibra mineral, em função do estado de deterioração dos blocos e da impossibilidade de estimar a carga de ruptura, não foram adotados ciclos de carregamento reduzido para o escorvamento e acomodação do forro.

Com as forças de ruptura obtidas, foram calculadas as resistências à compressão na área bruta para cada tipo de bloco e também o percentual de resistência residual que estes valores representam. Os valores de resistência média e característica estão apresentados na Tabela 4.8. 
É possível observar que, para uma simulação de incêndio padrão de 120 minutos, a resistência à compressão dos blocos sofreu uma drástica redução mesmo com a utilização do revestimento de gesso. Considerando blocos de uma mesma espessura, a redução da resistência foi mais severa para os blocos de maior resistência, assim como foi observado nos resultados da primeira fornada. Observa-se que os blocos de maior resistência apresentaram resistência média efetiva em temperatura ambiente muito maior que a sua resistência nominal.

Tabela 4.8 - Resistência à compressão pós-fogo dos blocos ( $2^{\mathrm{a}}$ Fornada $)$

\begin{tabular}{|c|c|c|c|c|c|c|}
\hline \multicolumn{7}{|c|}{ Resistência à compressão pós-fogo } \\
\hline \multicolumn{2}{|c|}{ Tipo de unidade } & & \multicolumn{4}{|c|}{ Blocos revestidos com gesso* } \\
\hline $\begin{array}{c}\text { Resistência } \\
\text { característica } \\
\text { nominal }\end{array}$ & $\begin{array}{l}\text { Largura } \\
\text { nominal }\end{array}$ & & $\begin{array}{l}\text { Resistência } \\
\text { média temp. } \\
\text { ambiente }(\mathrm{kN})\end{array}$ & Força $(\mathrm{kN})$ & $\begin{array}{c}\text { Tensão na área } \\
\text { bruta (MPa) }\end{array}$ & $\begin{array}{c}F_{\text {fogo }} / F_{a m b} \\
\text { (Resistência } \\
\text { residual) }\end{array}$ \\
\hline \multirow{4}{*}{$10,0 \mathrm{MPa}$} & \multirow{4}{*}{$\begin{array}{l}140 \\
\mathrm{~mm}\end{array}$} & Média & \multirow{4}{*}{1197,77} & $\mathbf{1 3 7 , 1 0}$ & 2,52 & \multirow{4}{*}{$11 \%$} \\
\hline & & Desvio Padrão & & 20,82 & 0,38 & \\
\hline & & $\mathrm{CV}(\%)$ & & 15,19 & 15,19 & \\
\hline & & $f_{\mathrm{bk}}(\mathrm{MPa})$ & & & 1,74 & \\
\hline \multirow{4}{*}{ 4,0 MPa } & \multirow{4}{*}{$\begin{array}{l}140 \\
\mathrm{~mm}\end{array}$} & Média & \multirow{4}{*}{404,23} & 89,63 & 1,65 & \multirow{4}{*}{$22 \%$} \\
\hline & & Desvio Padrão & & 12,64 & 0,23 & \\
\hline & & $\mathrm{CV}(\%)$ & & 14,10 & 14,10 & \\
\hline & & $f_{\text {bk }}(\mathrm{MPa})$ & & & 1,22 & \\
\hline
\end{tabular}

* Blocos expostos ao incêndio padrão da ISO 834-1:1999 durante 120 min em todas as faces

$\mathrm{Na}$ primeira fornada o resultado de resistência residual para os blocos de 10,0 MPa e $140 \mathrm{~mm}$ foi de $20 \%$ e para os blocos de $4,0 \mathrm{MPa}$ e $140 \mathrm{~mm}$ foi de $27 \%$, na segunda fornada os resultados foram $11 \%$ e $22 \%$ respectivamente. Era esperado que a redução fosse maior nesta fornada visto que na primeira os elementos foram expostos ao fogo por apenas 70 minutos, mas agora havia a contribuição do gesso. Como nos blocos de 10,0 MPa o gesso se soltou logo no início, quase não houve sua contribuição e por isso a redução foi ainda mais intensa que nos blocos de 4,0 MPa em que o gesso, mesmo que totalmente craquelado, se manteve aderente até o final do ensaio.

No instante do ensaio de compressão pós-fogo os blocos de 4,0 $\mathrm{MPa}$ ainda estavam cobertos por uma camada craquelada de gesso como mostra a Figura 4.43. Após a retirada deste gesso, foi observado que o concreto apesar de não apresentar um estado de fissuração expressivo, estava bastante degradado pela ação do fogo, sendo que a superfície esfarelava com o passar dos dedos e a compressão lateral com as mãos era capaz de esmagar os blocos, tanto que, alguns desses blocos foram perdidos no transporte até a prensa hidráulica. 
Figura 4.43 - Situação dos blocos de 4,0 MPa antes do ensaio de compressão simples pós-fogo

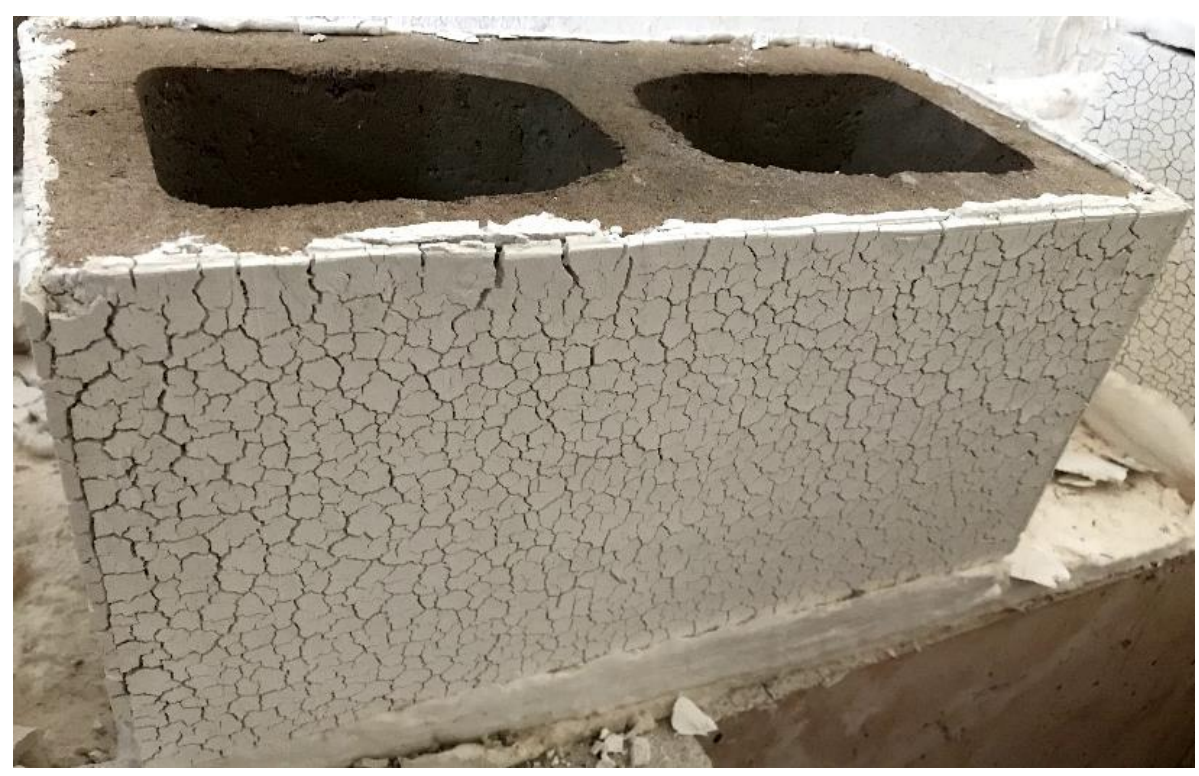

Assim como na situação da primeira fornada, os blocos de 10,0 MPa apresentaram o concreto mais íntegro após a realização do ensaio de simulação do incêndio-padrão, mas surgiram grandes fissuras e trincas que chegaram a separar os blocos em partes. Portanto neste caso a resistência dos blocos foi severamente comprometida em função do seu estado de fissuração. Foi observado que durante o ensaio de compressão, o modo de ruptura dos blocos de maior resistência foi associado à abertura de fissuras pré-existentes e a dos blocos de menor resistência foi pelo esmagamento do material.

\subsubsection{Prismas}

Os prismas foram submetidos ao ensaio de compressão simples de acordo com os procedimentos prescritos na ABNT NBR 15961:2011. Foi utilizada uma máquina servohidráulica universal da marca Instron e o carregamento uniformemente distribuído com controle de deslocamento foi aplicado a uma velocidade de $0,02 \mathrm{~mm} / \mathrm{s}$, assim como nos ensaios de caracterização dos corpos de prova. O capeamento foi substituído pelo forro de fibra mineral e não foram aplicados os ciclos para escorvamento e acomodação do forro, uma vez que o material apresentava severo comprometimento da sua capacidade resistente.

Os resultados médios de força resistente são apresentados na Tabela 4.9 juntamente com a tensão calculada na área bruta e a porcentagem média de resistência residual de cada tipo de prisma analisado. Alguns prismas foram danificados antes mesmo de chegar à máquina para $\mathrm{o}$ ensaio. 
Tabela 4.9 - Resistência à compressão pós-fogo dos prismas ( $2^{\mathrm{a}}$ Fornada)

\begin{tabular}{|c|c|c|c|c|c|c|}
\hline \multicolumn{7}{|c|}{ Resistência à compressão pós-fogo } \\
\hline \multicolumn{2}{|c|}{ Tipo de unidade } & & \multicolumn{4}{|c|}{ Prismas revestidos com gesso* } \\
\hline $\begin{array}{c}\text { Resistência } \\
\text { característica } \\
\text { nominal } \\
\end{array}$ & $\begin{array}{l}\text { Largura } \\
\text { nominal }\end{array}$ & & $\begin{array}{c}\text { Resistência } \\
\text { média temp. } \\
\text { ambiente }(\mathrm{kN})\end{array}$ & Força $(\mathrm{kN})$ & $\begin{array}{c}\text { Tensão na área } \\
\text { bruta (MPa) }\end{array}$ & $\begin{array}{c}F_{\text {fogo }} / F_{\text {amb }} \\
\text { (Resistência } \\
\text { residual) }\end{array}$ \\
\hline \multirow{4}{*}{$10,0 \mathrm{MPa}$} & & Média & & 42,41 & $\mathbf{0 , 5 8}$ & \multirow{4}{*}{$6 \%$} \\
\hline & 140 & Desvio Padrão & 73609 & 13,79 & 0,19 & \\
\hline & $\mathrm{mm}$ & $\mathrm{CV}(\%)$ & נט, & 32,52 & 32,52 & \\
\hline & & $f_{\mathrm{pk}}(\mathrm{MPa})$ & & & $\mathbf{0 , 3 8}$ & \\
\hline \multirow{4}{*}{ 4,0 MPa } & \multirow{4}{*}{$\begin{array}{l}140 \\
\mathrm{~mm}\end{array}$} & Média & \multirow{4}{*}{369,36} & 31,63 & $\mathbf{0 , 8 6}$ & \multirow{4}{*}{ 9\% } \\
\hline & & Desvio Padrão & & 6,79 & 0,18 & \\
\hline & & $\mathrm{CV}(\%)$ & & 21,46 & 21,46 & \\
\hline & & $f_{\mathrm{pk}}(\mathrm{MPa})$ & & & $\mathbf{0 , 5 2}$ & \\
\hline
\end{tabular}

* Prismas expostos ao incêndio padrão da ISO 834-1:1999 durante 120 min em todas as faces

Nos prismas, a redução da resistência após a simulação de incêndio-padrão de 120 minutos foi ainda maior que nos blocos de maior resistência. As resistências residuais ficaram entre 6 e 9\%, na primeira fornada foram ensaiados apenas prismas de 4,0 $\mathrm{MPa}$ e $140 \mathrm{~mm}$ que resultaram em uma resistência residual de 14\% após 70 minutos de ação do fogo, enquanto nesta segunda fornada o resultado foi de $9 \%$. Mesmo com a utilização do gesso o resultado foi menor pois a ação térmica durou 120 minutos.

Os resultados de resistência à compressão dos prismas pós-fogo apresentaram grande variabilidade, com coeficientes de variação de 32\%, 21\% para os prismas de 10,0 MPa e 4,0 MPa respectivamente. Foi realizado o teste estatístico de Grubbs com o intuito de verificar a possível presença de valores espúrios na amostra. O procedimento deste teste está descrito no APÊNDICE D e como resultou na inexistência de tais valores, mantiveram-se os resultados obtidos.

Assim como nos demais casos pós-fogo, o material (concreto) dos prismas de menor resistência mostrou-se mais degradado, esfarelando ao passar a mão, e os prismas de maior resistência apresentaram fissuras e trincas mais expressivas. Ao realizar o ensaio de compressão, o modo de ruptura dos prismas de ambas resistências foi parecido, com abertura de uma fissura na lateral dos corpos de prova que governaram a ruptura. Também surgiram fissuras na face de longitudinal dos prismas de 4,0 MPa e nos de 10,0 MPa as trincas existentes por conta da ação térmica abriram ainda mais em função do carregamento mecânico. O modo de ruptura pode ser observado na Figura 4.44. 
Figura 4.44 - Modo de ruptura dos prismas com revestimento de gesso (2 ${ }^{\mathrm{a}}$ Fornada)

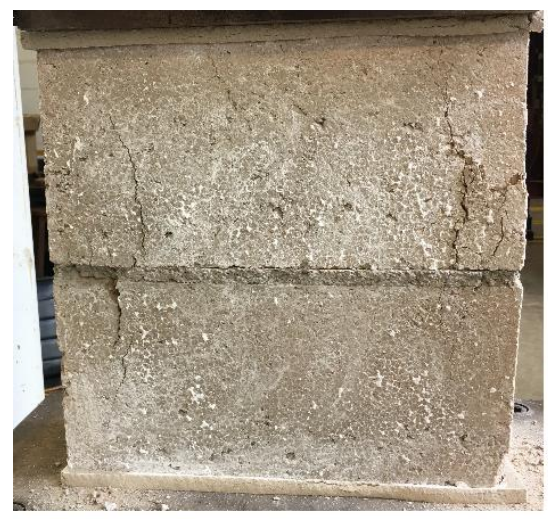

Prisma de 4,0 MPa
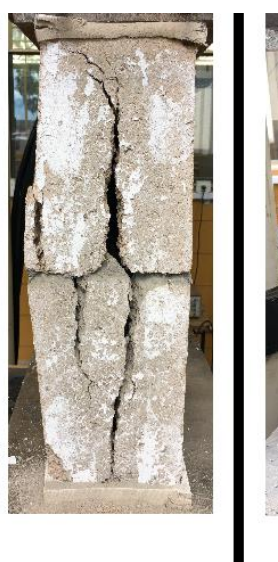

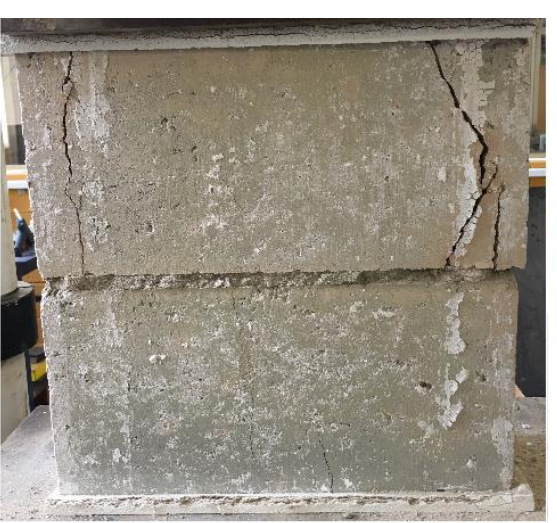

Prisma de 10,0 MPa

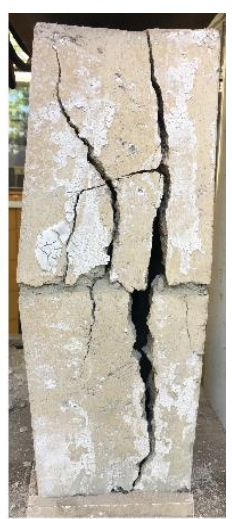

\subsubsection{Pequenas Paredes}

As pequenas paredes foram submetidas ao ensaio de compressão simples na máquina servo-hidráulica universal da marca Instron, em que foi adotado controle de deslocamento a uma velocidade de $0,01 \mathrm{~mm} / \mathrm{s}$. Os procedimentos foram seguidos conforme prescrições da ABNT NBR 15961:2011, mas o capeamento foi substituído pelo forro de fibra mineral e neste caso também não foram aplicados os ciclos com carga reduzida para escorvamento e acomodação do forro, por não conseguir estimar a carga de ruptura dos corpos de prova.

A Tabela 4.10 traz os resultados médios de força resistente, tensão na área bruta e porcentagem de resistência residual das pequenas paredes com revestimento, analisadas nesta fornada.

Tabela 4.10 - Resistência à compressão pós-fogo das pequenas paredes ( $2^{\mathrm{a}}$ Fornada)

\begin{tabular}{|c|c|c|c|c|c|c|}
\hline \multicolumn{7}{|c|}{ Resistência à compressão pós-fogo } \\
\hline \multicolumn{2}{|c|}{ Tipo de unidade } & & \multicolumn{4}{|c|}{ Pequenas paredes revestidas com gesso** } \\
\hline $\begin{array}{c}\text { Resistência } \\
\text { característica } \\
\text { nominal } \\
\end{array}$ & $\begin{array}{l}\text { Largura } \\
\text { nominal }\end{array}$ & & $\begin{array}{c}\text { Resistência } \\
\text { média temp. } \\
\text { ambiente }(\mathrm{kN})\end{array}$ & Força $(k N)$ & $\begin{array}{c}\text { Tensão na área } \\
\text { bruta (MPa) }\end{array}$ & $\begin{array}{c}F_{\text {fogo }} / F_{a m b} \\
\text { (Resistência } \\
\text { residual) } \\
\end{array}$ \\
\hline \multirow{4}{*}{$10,0 \mathrm{MPa}$} & \multirow{4}{*}{$\begin{array}{l}140 \\
\mathrm{~mm}\end{array}$} & Média & \multirow{4}{*}{826,90} & 29,99 & 0,27 & \multirow{4}{*}{$4 \%$} \\
\hline & & Desvio Padrão & & 0,54 & 0,00 & \\
\hline & & $\mathrm{CV}(\%)$ & & 1,79 & 1,79 & \\
\hline & & $f_{\mathrm{ppk}}(\mathrm{MPa})$ & & & 0,22 & \\
\hline \multirow{4}{*}{$4,0 \mathrm{MPa}$} & \multirow{4}{*}{$\begin{array}{l}140 \\
\mathrm{~mm}\end{array}$} & Média & \multirow{4}{*}{565,00} & 63,38 & 0,58 & \multirow{4}{*}{$11 \%$} \\
\hline & & Desvio Padrão & & 12,46 & 0,11 & \\
\hline & & $\mathrm{CV}(\%)$ & & 19,65 & 19,65 & \\
\hline & & $f_{\mathrm{ppk}}(\mathrm{MPa})$ & & & 0,36 & \\
\hline
\end{tabular}

* Pequenas paredes expostas ao incêndio padrão da ISO 834-1:1999 durante 120 min em todas as faces 
A redução da resistência nas pequenas paredes foi tão intensa quanto nos prismas para a simulação de incêndio padrão com 120 minutos de duração. Novamente, a redução da resistência foi maior nos elementos de resistência mais elevada.

$\mathrm{Na}$ primeira fornada foram ensaiadas pequenas paredes com espessura de $140 \mathrm{~mm} \mathrm{e}$ ambas classes de resistência, para um tempo de ensaio de 70 minutos, observando-se que os corpos de prova de 10,0 MPa tiveram resistência residual de $13 \%$ e os de 4,0 MPa resultaram em 14\%. Como nesta fornada a duração do incêndio-padrão foi de 120 minutos, houve maior degradação dos elementos, e como o revestimento de gesso desplacou nas paredes de 10,0 MPa a redução da resistência foi mais intensa nestes elementos, chegando a $4 \%$ da resistência dos elementos ensaiados na caracterização em temperatura ambiente. Nos elementos de 4,0 MPa a redução foi menor, resultando em resistência residual de $11 \%$.

Considerando os três corpos de prova, os resultados de compressão das pequenas paredes de 10,0 MPa e $140 \mathrm{~mm}$ apresentaram uma variabilidade alta, com coeficientes de variação de 50,19\%. Foi realizado o teste estatístico de Grubbs com o intuito de verificar a possível presença de valores espúrios na amostra. O procedimento deste teste está descrito no APÊNDICE D e resultou que a parede PAR 1-N-G teve sua resistência classificada como valor extremo (espúrio) e, portanto, o seu resultado foi desconsiderado no cálculo dos valores médios e característicos deste elemento. O APÊNDICE C conta com uma tabela onde são apresentados os resultados considerando e desconsiderando a resistência desta parede com valor extremo.

Do ponto de vista do material, as pequenas paredes de 10,0 MPa apresentaram muitas fissuras e trincas nos blocos, principalmente na face longitudinal e nos blocos das fiadas mais altas, surgiram fissuras também nas faces laterais. Nas pequenas paredes de 4,0 MPa foi observado que o concreto apresentava dureza reduzida e superfície esfarelando com o passar dos dedos. Algumas fissuras surgiram, mas em quantidade e intensidade muito menores que nas paredes de maior resistência.

O modo de ruptura das pequenas paredes de ambas classes de resistência e espessuras foi semelhante. Foi caracterizado principalmente pela abertura das trincas na face lateral das paredes, tal qual ocorrido na caracterização em temperatura ambiente. Essas trincas guiaram a ruptura na maioria dos casos das pequenas paredes de 10,0 MPa. Mas nestes casos também foram observados esmagamento e desprendimento de parte das unidades das fiadas superiores, ruptura que guiou a maioria das pequenas paredes de 4,0 MPa. Nos corpos de prova de 10,0 $\mathrm{MPa}$, fissuras e trincas pré-existentes na face longitudinal aumentaram concomitantemente à abertura das trincas laterais. A Figura 4.45 mostra um exemplo do modo de ruptura de cada classe de resistência analisada. 
Figura 4.45 - Modo de ruptura das pequenas paredes pós-fogo ( $2^{\mathrm{a}}$ Fornada)

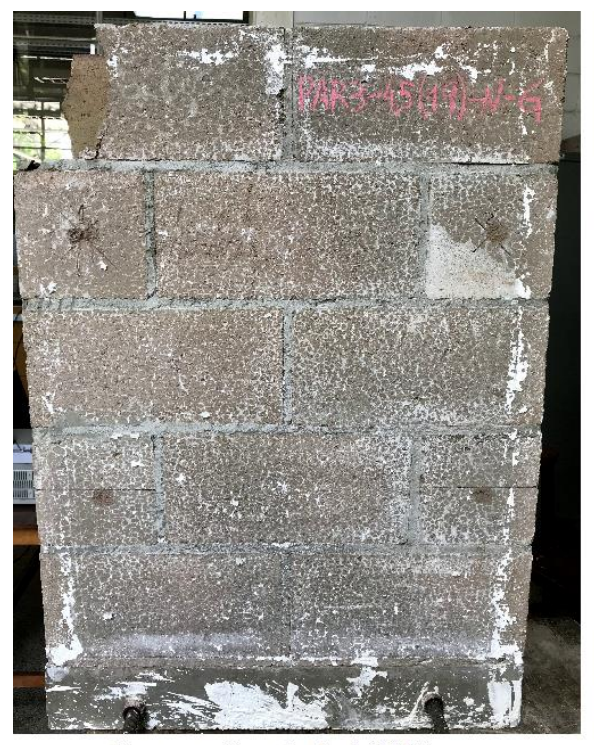

Pequena Parede de 4,0 MPa
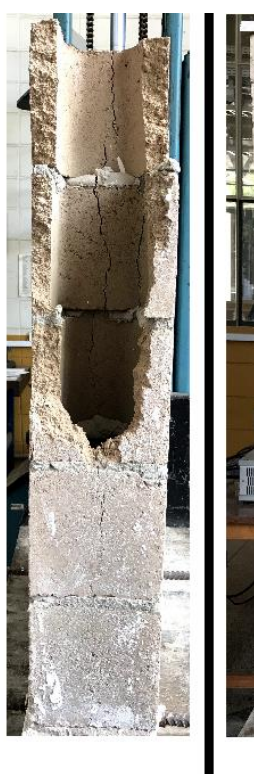

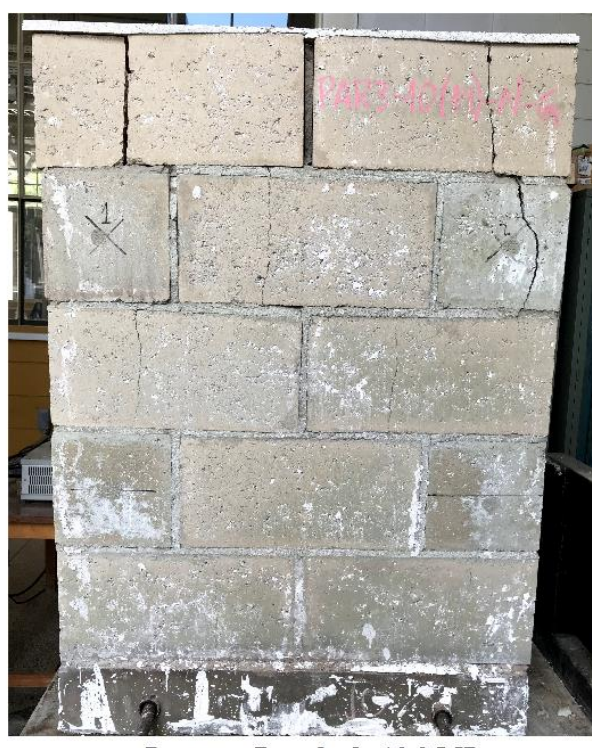

Pequena Parede de 10,0 MPa

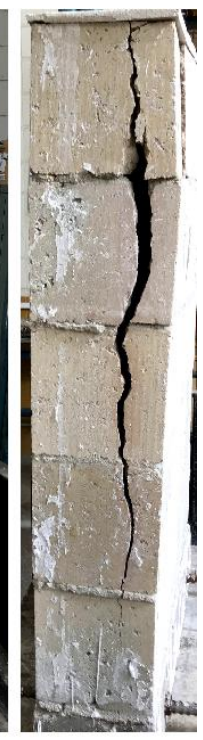

\subsubsection{Considerações sobre os resultados da $2^{\mathrm{a}}$ fornada (com revestimento)}

Considerando a $2^{\mathrm{a}}$ fornada, em que todos os elementos ensaiados foram revestidos com uma camada de $5 \mathrm{~mm}$ de gesso e foram submetidos a simulação de incêndio-padrão com duração de 120 minutos, seguindo o TRRF máximo da IT-08 do corpo de bombeiros de São Paulo, é possível dizer que mesmo os elementos revestidos apresentaram resultado insatisfatório de resistência residual. Tanto os blocos, como prismas e pequenas paredes apresentaram no máximo uma resistência residual de $22 \%$, sendo que a maioria dos resultados não passou de $20 \%$, ou seja, mesmo para combinações acidentais de solicitação de cálculo, que representam de 40 a $50 \%$ da solicitação de cálculo utilizada no dimensionamento, os valores encontrados de resistência não atenderiam com segurança uma situação de incêndio.

Novamente destaca-se o fato de os ensaios serem pós-fogo e que durante a simulação de incêndio não são aplicadas cargas na estrutura. Portanto não há a ação combinada de fogo e carregamento mecânico. Isso implica no comportamento dos elementos de alvenaria estrutural que não é o mesmo daquele encontrado nas edificações em situação de incêndio, mas como visto em Mehta e Monteiro (1997) a situação não carregada é a crítica para estruturas de concreto armado em elevadas temperaturas por não haver restrições de deslocamentos. Analogamente, acredita-se que esta também seja a situação crítica para a alvenaria estrutural.

Para garantir que a resistência residual da alvenaria estrutural não atenderia com segurança uma situação de incêndio seriam necessários ensaios de ação combinada de fogo e 
carregamento, com o intuito de avaliar a influência desse carregamento na alvenaria e observar as diferenças de resultado com os ensaios sem carregamento.

\subsection{Análise dos resultados e comparação dos fatores de eficiência}

Após os ensaios de compressão pós fogo dos corpos de prova submetidos às simulações de incêndio-padrão foi possível estabelecer relações de resistência entre os tipos de corpos de prova estudados, que são chamados fatores de eficiência. Estas relações foram calculadas com o intuito de verificar se os fatores de eficiência se mantêm mesmo após a ação do fogo, tanto para elementos sem revestimento como para os revestidos com gesso.

Considerando que $f_{b k}$ é a resistência característica dos blocos, $f_{p k}$ é a resistência característica dos prismas e $f_{p p k}$ é a resistência característica das pequenas paredes, a Tabela 4.11 apresenta as relações calculadas para os elementos ensaiados na primeira fornada (sem revestimento) e a Tabela 4.12 apresenta um resumo destas relações de eficiência da resistência à compressão dos elementos com revestimento, ensaiados na segunda fornada. Os valores em azul posicionados no canto inferior direito das células indicam o valor desta relação encontrados na caracterização em temperatura ambiente.

Tabela 4.11 - Relações de resistência entre os corpos de prova da primeira fornada

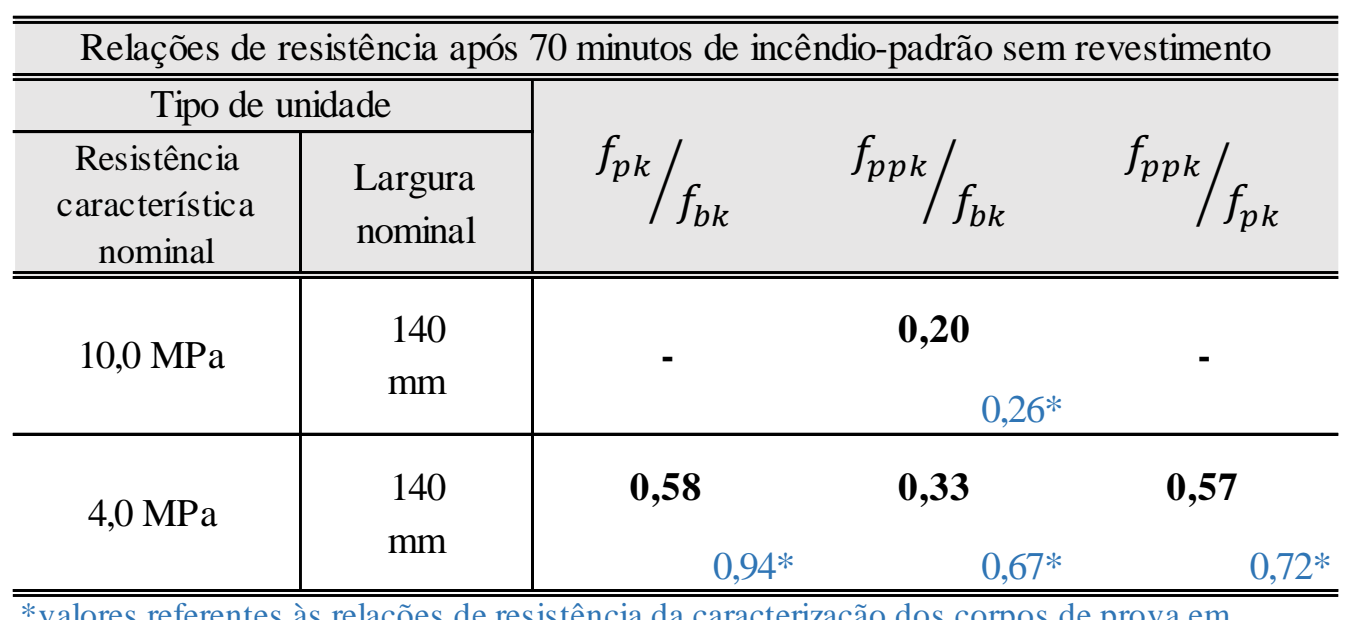

*valores referentes às relações de resistência da caracterização dos corpos de prova em temperatura ambiente

É possível observar que assim como na caracterização em temperatura ambiente os valores de fatores de eficiência encontrados foram menores para os blocos com resistência nominal de 10,0 $\mathrm{MPa}$, se comparados com as relações dos blocos de 4,0 $\mathrm{MPa}$. As relações de resistência entre pequenas paredes e prismas aumentaram para os blocos de 10,0 MPa revestidos 
com gesso, indicando que as perdas de resistência devidas à ação do fogo foram mais intensas nestes prismas de maior resistência.

Tabela 4.12 - Relações de resistência entre os corpos de prova da segunda fornada

\begin{tabular}{|c|c|c|c|c|}
\hline \multicolumn{5}{|c|}{ Relações de resistência após 120 minutos de incêndio-padrão com revestimento } \\
\hline \multicolumn{2}{|c|}{ Tipo de unidade } & \multirow[b]{2}{*}{$f_{p k} / f_{b k}$} & \multirow[b]{2}{*}{$f_{p p k} / f_{b k}$} & \multirow[b]{2}{*}{$f_{p p k} / f_{p k}$} \\
\hline $\begin{array}{c}\text { Resistência } \\
\text { característica } \\
\text { nominal } \\
\end{array}$ & $\begin{array}{c}\text { Largura } \\
\text { nominal }\end{array}$ & & & \\
\hline \multirow{2}{*}{$10,0 \mathrm{MPa}$} & \multirow{2}{*}{$\begin{array}{l}140 \\
\mathrm{~mm}\end{array}$} & $\mathbf{0 , 2 2}$ & $\mathbf{0 , 1 3}$ & $\mathbf{0 , 5 8}$ \\
\hline & & $0,59 *$ & $0,26 *$ & $0,44^{*}$ \\
\hline \multirow{2}{*}{ 4,0 MPa } & \multirow{2}{*}{$\begin{array}{l}140 \\
\mathrm{~mm}\end{array}$} & $\mathbf{0 , 4 3}$ & $\mathbf{0 , 3 0}$ & $\mathbf{0 , 6 9}$ \\
\hline & & $0,94 *$ & $0,67 *$ & $0,72 *$ \\
\hline
\end{tabular}

*valores referentes às relações de resistência da caracterização dos corpos de prova em

temperatura ambiente

Tanto para a situação sem revestimento como para a que foi utilizada a camada de gesso, os fatores de eficiência calculados entre prismas e blocos e entre pequenas paredes e blocos pós-fogo foram menores que as relações encontradas temperatura ambiente. Estas reduções nos fatores de eficiência e o aumento das relações de resistência entre pequenas paredes e prismas indicam que os prismas e as pequenas paredes apresentaram maior redução da resistência que os blocos isolados, sinalizando que as juntas de argamassa podem exercer grande influência na resistência residual da alvenaria estrutural em situação de incêndio. Diferentemente da situação em temperatura ambiente, em que a resistência da argamassa apresenta pouca influência na resistência do conjunto (alvenaria estrutural). 


\section{CONCLUSÕES E SUGESTÕES}

Ao longo do seu desenvolvimento, esta pesquisa foi dividida em duas etapas fundamentais. A primeira consistiu na caracterização dos materiais de alvenaria e no estabelecimento de relações de resistências entre blocos, prismas e pequenas paredes. A segunda etapa, que contemplou o objetivo principal desta pesquisa, versou sobre o estudo do comportamento de elementos de alvenaria com blocos de concreto em elevadas temperaturas, através de ensaios experimentais de simulação de incêndio-padrão.

O estudo realizado abordou questões de isolamento térmico mas teve como foco principal a resistência residual de blocos, prismas e pequenas paredes de blocos de concreto após a ação do fogo. Ressalta-se que este tema é de grande importância para a área de segurança das estruturas em situação de incêndio, uma vez que a alvenaria é atualmente um sistema construtivo muito utilizado no Brasil e estão sendo executados edifícios cada vez mais altos e que requerem maior tempo de resistência ao fogo.

Analisando a Revisão Bibliográfica, pode-se verificar que não há um código normativo nacional que trate de recomendações de segurança para o dimensionamento da alvenaria em situação de incêndio. Tendo em vista a diferença nas propriedades dos materiais constituintes na fabricação dos blocos em cada país, utilizar códigos internacionais pode levar a considerações que não garantam a segurança estrutural.

A seguir, serão apresentadas as principais conclusões obtidas para cada etapa da dissertação desenvolvida, bem como as lacunas no conhecimento que foram observadas e que seriam de interesse para a continuidade do tema abordado neste trabalho.

\subsection{Conclusões}

Na primeira etapa, com os materiais em temperatura ambiente observou-se através das caracterizações física e geométrica que os blocos apresentaram dimensões, massas e umidades relativas dentro dos limites de aceitação das normas NBR 6136:2016 e NBR 15961:2011. Na caracterização mecânica das unidades foi notado que os blocos de $10,0 \mathrm{MPa}$ (Classe A) apresentaram resistências características entre 170 e $200 \%$ da resistência nominal de fábrica, e as unidades de 4,0 MPa (Classe B) apresentaram resistências características entre 135 e 155\% da nominal de fábrica. Neste cenário os blocos utilizados poderiam ser classificados como blocos de resistência nominal maior do que aquelas como foram tratados. Após a compressão 
dos prismas e das pequenas paredes foi possível estabelecer fatores de eficiência em relação aos blocos, que resultaram sempre maiores para os elementos de 4,0 $\mathrm{MPa}$, mas vale destacar que as resistências dos blocos de 10,0 MPa foram bem superiores às nominais de fábrica. Considerando uma mesma classe de resistência, as relações de eficiência foram maiores para blocos com espessura de $140 \mathrm{~mm}$ no caso dos de Classe B e maiores para os de espessura de $190 \mathrm{~mm}$ no caso dos de Classe A.

A segunda etapa foi subdividida basicamente em três fases: teste de instrumentação, primeira fornada com elementos sem revestimento e segunda fornada com os elementos revestidos com uma cama de $5 \mathrm{~mm}$ de gesso.

No teste de instrumentação adotou-se apenas um bloco de cada resistência pois o intuito principal era avaliar questões relacionadas ao posicionamento e fixação da instrumentação, visando a obtenção dos melhores resultados possíveis nas fornadas. No âmbito da fixação dos termopares concluiu-se que para aqueles posicionados no interior das paredes dos blocos o material mais adequado a utilizar seria a pasta de cimento e para pontos na superfície dos blocos nem a pasta de cimento e nem o durepóxi se mostram adequados, por isso adotou-se nos ensaios um cimento-cola cerâmico. Quanto ao tipo de cabo termopar a utilizar concluiu-se que o mais adequado para estes ensaios seria o com resistência nominal de $300{ }^{\circ} \mathrm{C}$, desde que protegidos com manta cerâmica, pois oferece melhor trabalhabilidade e garantem boa confiabilidade dos resultados.

Com os pontos instrumentados ao longo da seção transversal dos blocos observou-se que a evolução da temperatura foi bastante semelhante nos blocos de 4,0 $\mathrm{MPa}$ e de 10,0 MPa, e que o gradiente térmico é bastante nítido em função da resistência do concreto à passagem do calor. Nos pontos mais internos foi observado um nítido patamar de temperatura aos $100^{\circ} \mathrm{C} \mathrm{em}$ função da energia térmica absorvida pela mudança de fase da água livre contida nos poros dos blocos de concreto. Os blocos foram submetidos a 43 minutos de incêndio-padrão, e as resistências residuais foram de 53\% para o bloco de 4,0 MPa e de 35\% para o bloco de 10,0 $\mathrm{MPa}$, o qual apresentou também fissuras maiores.

$\mathrm{Na}$ primeira fornada os elementos com espessura de $140 \mathrm{~mm}$ sem revestimento foram submetidos à simulação de incêndio-padrão durante 70 minutos. Além dos blocos, prismas e pequenas paredes, colou-se nesta fornada um trio de pequenas paredes com o interior compartimentado e isolado termicamente, com o intuito de avaliar o isolamento térmico. Com a análise térmica e os resultados de resistência residual concluiu-se que:

- Os elementos com blocos de maior resistência (10,0 MPa) apresentaram trincas maiores que surgem durante a fase de aquecimento e podem estar relacionadas 
às tensões internas maiores que surgem durante a liberação da água contida nos poros. Estas trincas podem comprometer os critérios de isolamento e estanqueidade durante a ação do incêndio;

- Os elementos com blocos de menor resistência (4,0 $\mathrm{MPa})$ apesar de não trincarem, apresentam fissuras e resultam com material (concreto) mais degradado pela ação térmica que o bloco de maior resistência;

- Visualmente, a mudança de coloração é mais intensa nos blocos de 4,0 MPa, que resultam com tons mais rosados após ação do fogo, provavelmente por apresentar, em sua fabricação, agregados diferentes dos utilizados nos blocos de $10,0 \mathrm{MPa}$

- No âmbito do comportamento térmico ao longo da seção, não foram observadas diferenças significativas entre blocos e pequenas paredes, portanto, para conhecer apenas o comportamento térmico dos elementos expostos ao fogo em todas as faces é suficiente ensaiar as unidades, ou seja, os ensaios podem ser menos dispendiosos sem a necessidade de ensaiar corpos de prova de grandes dimensões. No entanto para o caso de alvenaria submetida a carregamento mecânico e ação térmica, este cenário pode não se repetir;

- No trio compartimentado o critério de isolamento foi atingindo aos 62 minutos de ensaio, não atendendo ao TRRF de edificações residenciais acima de 23 metros de altura, mas vale ressaltar que este ensaio foi uma adaptação e não seguiu a normalização prescrita para esta avaliação;

- Os corpos de prova de argamassa resultaram com resistência praticamente nula para este tempo de simulação de incêndio-padrão, não sendo possível ensaiá-los pois esfarelavam durante o transporte;

- Para situações sem carregamento, a compartimentação garante melhor resistência ao fogo pois nem toda seção da parede atinge os mesmos níveis elevados de temperatura. Como observado, a resistência residual das paredes compartimentadas foi de $46 \%$ enquanto que para as paredes com fogo em ambas as faces foi de $14 \%$;

- Os elementos sem revestimento não apresentaram resistência residual suficiente para garantir a segurança estrutural, mesmo se for levado em conta a redução da solicitação pela combinação de ações excepcional (situação de incêndio), 
considerando que a estrutura esteja solicitada por um carregamento de aproximadamente $50 \%$ da carga máxima de ruptura.

- Se comparados com os resultados em temperatura ambiente os fatores de eficiência dos prismas e pequenas paredes em relação aos blocos foram significativamente menores, enquanto a relação entre pequenas paredes e prismas foi maior. Isso indica maior degradação dos elementos com maior quantidade de juntas de argamassa, comportamento esperado em função da situação observada para os corpos de prova de argamassa após a ação do fogo.

$\mathrm{Na}$ segunda fornada foram ensaiados os blocos, prismas e pequenas paredes com espessura de $140 \mathrm{~mm}$ de ambas classes de resistências estudadas, todos os elementos foram revestidos com uma camada de gesso e a simulação de incêndio-padrão durou 120 minutos. Com a análise térmica e os resultados de resistência residual concluiu-se que:

- Em função da superfície menos rugosa, nos elementos com resistência nominal de 10,0 MPa a camada de gesso inicia o desplacamento após 10 minutos de ensaio, estes elementos perdem totalmente a camada de proteção antes dos 40 minutos;

- Nos elementos com resistência nominal de 4,0 MPa o gesso não desplaca mas fissura totalmente, ficando com a superfície craquelada após os 30 minutos de ensaio, nestas fissuras o calor passa facilmente, portanto o gesso perde boa parte de sua capacidade isolante de proteção;

- O gesso retardou em cerca de 10 minutos o início do surgimento das trincas nos elementos de 10,0 MPa se comparado com a primeira fornada, mas não impediu que após 120 minutos os elementos de maior resistência apresentassem trincas significativas. Apesar de não ser o mesmo material, mas pela proximidade dos das propriedades entre os materiais, é possível relacionar este temo com o fornecido pelo ACI 216.1-14 para contribuição do gesso acartonado com 9,5mm de espessura para o critério de isolamento térmico, que é de 10 minutos;

- Mesmo com o gesso aderente durante todo o ensaio o material (concreto) dos blocos de 4,0 MPa resultaram bastante degradados e com a superfície esfarelando ao tato;

- Para um tempo de 70 minutos de ensaio as temperaturas registradas nos blocos com revestimento foram em torno de $10 \%$ menores que as temperaturas dos blocos na primeira fornada, portanto acredita-se que o gesso tenha oferecido 
certa resistência à passagem do calor, principalmente no início do ensaio em que ele estava integro;

- Mesmo com o gesso proporcionando certa proteção, os elementos alcançaram temperaturas acima de $500^{\circ} \mathrm{C}$ em toda a seção transversal, que é uma temperatura que a literatura trata como crítica para a capacidade resistente do concreto armado;

- Os elementos resultaram com resistência residual menores que os elementos da primeira fornada, mostrando que a contribuição do gesso foi praticamente insignificante no âmbito da resistência residual, mesmo considerando que tempo de exposição ao fogo foi maior. E que as resistências residuais encontradas (próximas de 20\%) não são suficientes para garantir segurança estrutural em situação de incêndio, mesmo considerando uma solicitação de aproximadamente $50 \%$ da carga última de ruptura;

- A perda de resistência foi mais severa nos elementos com juntas de argamassa e acredita-se que seja em função do estado deteriorado que este componente apresenta após a ação térmica;

- Os fatores de eficiência dos prismas e pequenas paredes em relação aos blocos foram menores para a ação térmica mais prolongada, mas a relação de resistência entre pequenas paredes e prismas aumentaram nos elementos de 10,0 $\mathrm{MPa}$. O que indica que um tempo maior de ação do fogo deteriora mais severamente os elementos de 4,0 MPa com maior quantidade de juntas de argamassa, o que não ocorreu nos elementos de maior resistência.

\subsection{Sugestões}

Tendo em vista as considerações feitas durante este trabalho e também as simplificações adotadas para que fosse possível realizar os ensaios dentro das condições desta pesquisa, são apresentadas algumas sugestões para trabalhos futuros, visando aperfeiçoar e dar continuidade ao tema:

- Ensaiar elementos com espessura de $190 \mathrm{~mm}$ e blocos de concreto para avaliar a influência da largura dos blocos na resistência residual; 
- Ensaiar elementos (bloco, prismas e pequenas paredes) com restrições axiais para verificar se há o surgimento de trincas e fissuras, como foi observado nas paredes dos blocos;

- Ensaiar elementos com carregamento para verificar o comportamento termomecânico dos corpos de prova;

- Realizar simulações numéricas balizadas pelos resultados encontrados nesta pesquisa, definindo um modelo que permita mudar condições de contorno sem o elevado custo dos ensaios experimentais;

- Com os modelos numéricos balizados, simular o comportamento de uma parede inteira sob carregamento e ação térmica;

- Ensaiar elementos com preenchimento de graute ou vermiculita para analisar a influência destes materiais na resistência ao fogo.

- Ensaiar elementos com revestimento de argamassa para comparar com o comportamento do gesso. 


\section{REFERÊNCIAS BIBLIOGRÁFICAS}

AL-HADHRAMI, L. M.; AHMAD, A. Assessment of thermal performance of different types of masonry bricks used in Saudi Arabia. Applied Thermal Engineering, v29, 2009. p. 1123-1130.

AL NAHHAS, F.; AMI SAADA, R.; BONNET, G.; DELMOTTE, P. Resistance to fire of walls constituted by hollow blocks: Experimental and termal modeling. Applied Thermal Engeneering, vol 27, $\mathrm{n}^{\circ}$ 1, Jan. 2007. P. 258-267.

ALVES, L; BORBOREMA, M. Dados sobre incêndio podem dar a dimensão real do problema no país. Instituto Sprinkler Brasil. 2015. Disponível em: $<$ http://www.sprinklerbrasil.org.br/imprensa/dados-sobre-incendio-podem-dar-a-dimensaoreal-do-problema-no-pais/>. Acesso em: 01 out. 2017.

AMERICAN CONCRETE INSTITTE, ACI/TMS 216.1: code requirements for determining fire resistance of concrete and masonry construction assemblies. Michigan, 2014.

. ACI-530 - Building Code Requirements and Specification for Masonry Structures, Detroit, Michigan, 2011.

AMERICAN SOCIETY FOR TESTING AND MATERIALS. ASTM C469: Standard Test Method for Static Modulus of Elasticity and Poisson's Ratio of Concrete in Compression. Pennsylvania, 2012.

. ASTM E119: Standard Methods for Fire Test of Building Construction and Materials. West Conshohocken, PA, 2000.

ASTM E119: Standard Specification for Hollow Bricks. West Conshohocken, PA, 2000.

ANDREINI, M.; SASSU, M. Mechanical behaviour of full unit masonry panels under fire action. Fire Safety Journal, Elsevier, 46 (7), p. 440, 2011. 
ASSOCIAÇÃO BRASILEIRA DA CONSTRUÇÃO INDUSTRIALIZADA. Manual Técnico de Alvenaria. São Paulo: ABCI/PROJETO, 1990. 280 p.

ASSOCIAÇÃO BRASILEIRA DE NORMAS TÉCNICAS. NBR 5628: Componentes construtivos estruturais - Determinação da resistência ao fogo. Rio de Janeiro, 2001.

. NBR 6118: Projeto de estruturas de concreto - Procedimento. Rio de Janeiro, 2014.

. NBR 6136: Bloco vazado de concreto simples para alvenaria estrutural. Rio de Janeiro, 2016.

. NBR 10636: Paredes de divisórias sem função estrutural - Determinação da resistência ao fogo. Rio de Janeiro, 1989.

- NBR 12118: Bloco vazado de concreto simples para alvenaria estrutural - Método de ensaio. Rio de Janeiro, 2013.

- NBR 13281: Argamassa para assentamento e revestimento de paredes e tetos Requisitos. Rio de Janeiro, 2015.

- NBR 13860: Glossário de termos relacionados com a segurança contra incêndio. Rio de Janeiro, 1997.

. NBR 14323: Projeto de estruturas de aço e de estruturas mistas de aço e concreto de edifícios em situação de incêndio. Rio de Janeiro, 2013.

. NBR 14432: Exigências de resistência ao fogo de elementos construtivos de edificações - Procedimento. Rio de Janeiro, 2001.

. NBR 15200: Projeto em estruturas de concreto em situação de incêndio. Rio de Janeiro, 2012.

- NBR 15220-1: Desempenho térmico de edificações - Parte 1: Definições, símbolos e unidades. Rio de Janeiro, 2011. 
NBR 15220-2: Desempenho térmico de edificações - Métodos de cálculo da transmitância térmica, da capacidade térmica, do atraso térmico e do fator solar de elementos e componentes de edificações. Rio de Janeiro, 2011.

_. NBR 15812: Alvenaria estrutural - Blocos cerâmicos, Parte 1: Projetos. Rio de Janeiro, 2010.

NBR 15961-1: Alvenaria estrutural - Blocos de concreto, Parte 1: Projeto. Rio de Janeiro, 2011.

NBR 15961-2: Alvenaria estrutural - Blocos de concreto, Parte 2: Execução e controle de obras. Rio de Janeiro, 2011.

NBR 16522: Alvenaria de blocos de concreto - Métodos de ensaio. Rio de Janeiro, 2016.

AUSTRALIAN STANDARD. AS 3700-2011: Masonry Structures. Sydney, 2011.

AYDIN, S. Development of high-temperature-resistance mortar by using slag and pumice. Fire Safety Journal, vol 43, nº 8, Nov. 2008. p. 610-617.

BAILEY, C. Structural fire design: Core or specialist subject?. The Structural Engineer, May 2004. p. 32-38.

BEALL, C. Masonry Design na Detailing: for architects, engeneers and contractors. $5^{\mathrm{a}}$ ed., McGraw-Hill, 2003, 640 p.

BONITESE, K. V. Segurança contra incêndio em edifício habitacional de baixo custo estruturado em aço. 2007. 253 p. Dissertação (Mestrado em Construção Civil) - Universidade Federal de Minas Gerais, Belo Horizonte.

BRICK INDUSTRY ASSOCIATION - BIA. Technical Note 16: Fire resistance of brick masonry. Reston, VA, 2008. 16 p. 
BRITEZ, C. A. Avaliação de pilares de concreto armado colorido de alta resistência submetidos a elevadas temperaturas. 2011. 252p. Tese (Doutorado) - Escola Politécnica da Universidade de São. Departamento de Engenharia de Construção Civil. São Paulo, 2011.

BUCHANAN, A. H. Structural Design for Fire Safety. University of Canterbury, New Zealand. John Wiley \& Sons, LTD. 2002, 421 p.

CÁNOVAS, F. M. Ação do fogo sobre as estruturas. In: CÁNOVAS, F. M. Patologia e terapia do concreto armado. São Paulo: Pini, 1988. Cap. 8, p. 173-201.

CARASEK, H. Aderência de argamassa à base de cimento Portland a substratos porosos - avaliação dos fatores intervenientes e contribuição ao estudo do mecanismo da ligação. Tese (Doutorado), Universidade de São Paulo. São Paulo, 1996.

CASONATO, C. A. Ação de elevadas temperaturas em modelos de paredes de concreto e de alvenaria sob cargas de serviço. 2007, 136 p. Dissertação (Mestrado em Engenharia Civil), Universidade Federal doo Rio Grande do Sul, UFRGS, Porto Alegre, 2007.

CASTRO, L. O. Avaliação experimental da interação de paredes de blocos de concreto de alta resistência sob ações verticais. Dissertação (Mestrado) - Universidade Federal de Viçosa. Voçosa, Minas Gerais, 2015.

CAVAlHEIRO, O. P. Alvenaria estrutural. Universidade Federal de Santa Maria, Santa Maria - $\quad$ RS. $2009 . \quad 8 \quad$ p. $\quad$ Disponível em: <http://www.ceramicapalmadeouro.com.br/downloads/cavalheiro1.pdf>. Acesso em: 29 set. 2017.

CHICHIERCHIO, L. C. Conforto ambiental: Desempenho térmico e acústico e proteção contra o fogo. In: Associação Brasileira da Construção Industrializada - ABCI. Manual técnico de alvenaria. São Paulo, 1990. p. 119-141.

COlVIlle, J.; MiltenberGER, M. A.; WOldE-TINSAE, A. M. Hollow concrete masonry modulus of elasticity. The sixth North American Masonry Conference, Philadelphia, Pennsylvania, 1983. 
CORRÊA, M. R. S. Alvenaria estrutural: Interação de paredes e eficiência do grauteamento sob solicitações combinadas. Projeto de pesquisa. Programa de pós-graduação em engenharia de estruturas, 2012.

Costa, C. N.; SILVA, V. P. Considerações sobre a segurança das estruturas de concreto em situação de incêndio. Núcleo de Pesquisa em Tecnologia da Arquitetura e Urbanismo da Universidade de São Paulo - NUTAU. Universidade de São Paulo, 2004.

Costa, C. N.; SILVA, V. P. Revisão Histórica das curvas padronizadas de incêndio. Núcleo de Pesquisa em Tecnologia da Arquitetura e Urbanismo da Universidade de São Paulo NUTAU. Universidade de São Paulo, 2006.

CTIF, Centre of Fire Statistics (International Association of Fire and Rescue Services). World fire statistics. Report n. 22, 2017. Disponível em: < http://www.ctif.org/sites/default/files/ctif_report22_world_fire_statistics_2017.pdf >. Acesso em: 08 jun. 2018.

CÜLFIK, M. S.; ÖZTURAN, T. Effect of elevated temperatures on the residual mechanical properties of high performance mortar. Cement and Concrete Research, vol 32, $\mathrm{n}^{\circ} 5$, May 2002. P. 809-816.

DRYSDALE, D. An Introduction to Fire Dynamics. University of Edinburgh, UK. John Wiley \& Sons, LTD. 1998. 2. ed. 451 p.

DRYSDALE, R.G.; HAMID, A. A.; BAKER, L. R. Masonry Structures: Behavior and Design. Englewood Cliffs: Prentice-Hall, New JERSEY, 1994. 784 P.

EUROPEAN COMMITTEE FOR STANDARDIZATION. Eurocode 1: Actions on structures Part 1-2: General actions - Actions on structures exposed to fire. Bruxelas 2002.

_ Eurocode 2: Design of Concrete Structures Part 1-1: General rules - Rules for buildings. Bruxelas 2004. 
- Eurocode 2: Design of Concrete Structures Part 1-2: General rules - Structural fire design. Bruxelas 2004.

- Eurocode 6: Design of masonry structures Part 1-1: General rules - Rules for reinforced and unreinforced mansory. Bruxelas, 2005.

- Eurocode 6: Design of masonry structures Part 1-2: General rules - Structural fire design. Bruxelas, 2005.

G1 SÃO PAULO. O que se sabe e o que falta esclarecer sobre o incêndio e o desabamento em São Paulo. Disponível em < https://g1.globo.com/sp/sao-paulo/noticia/o-que-se-sabe-e-oque-falta-esclarecer-sobre-o-incendio-e-o-desabamento-em-sao-paulo.ghtml> Acesso em: 10 de junho de 2018.

GEORGALI, B.; TSAKIRIDIS, P. E. Microstructure off fire-damaged concrete. A case study. Cement and Concrete Composities, vol 27, nº 02, Feb. 2005. P. 255-259.

GOMES, N. S. A resistência das paredes de alvenaria. Dissertação (Mestrado). Escola Politécnica da Universidade de São Paulo. São Paulo, 1983.

GOMES, I R. Simulação numérica do ensaio de compressão de prismas de alvenaria pelo método dos elementos finitos com comportamento de interface. Tese (Doutorado) Universidade Federal de Santa Catarina. Florianópolis, 2011.

GNANACHELVAM, S. et al., Thermal characterisaton and fire performance of phase change material incorporated plasterboards. The $10^{\text {th }}$ International Conference on Structures in Fire, SiF. Ulster University, Belfast, UK, 2018. P. 193-200.

HENDRY, E. A. W. Masonry walls: materials and construction. Construction and Building Materials, vol 15, no 8, 2011. P. 323-330.

INCROPERA, F. P.; DEWITT, D. P. Fundamentos de trsnferencia de calor e de massa. $3^{\text {a }}$ ed. Rio de Janeiro, 1992. 455 p. 
INGHAN, J. Forensic Engineering of Fire-Damaged Structures. ICE, v. 162, 2009. p. 12-17.

INSTITUTO DE PESQUISAS TECNOLÓGICAS (IPT). Relatório de ensaio número 1050 328-203, Determinação da resistência ao fogo em parede sem função estrutural. São Paulo, 2013. 12 p.

INSTITUTO DE PESQUISAS TECNOLÓGICAS (IPT). Relatório de ensaio número 1072 608-203 , Determinação da resistência ao fogo em parede sem função estrutural. São Paulo, 2015. 12 p.

INSTITUTO DE PESQUISAS TECNOLÓGICAS (IPT). Relatório de ensaio número 1081 659-203, Determinação da resistência ao fogo em parede sem função estrutural. São Paulo, 2016. 13 p.

INTERNATIONAL ORGANIZATION FOR STANDARDIZATION. ISO 834: Fire resistance tests - elements of building construction: Part 1. General requirements. Gèneve, 1999.

IZQUIERDO, O.S. Estudo da interface bloco/graute em elementos de alvenaria estrutural. 290f. Tese (Doutorado) - Escola de Engenharia de São Carlos, Universidade de São Paulo, São Carlos, 2015.

JOHNSON, M. Structural Eurocodes and Fire, 2009

KARAHAN, O. Residual compressive strength of fire-damaged mortar after post-fire-aircuring. Fire and Material, vol 35, Issue 8, Dec. 2011. P. 561-567.

KIMURA, E. F. A. Análise termoestrutural de pilares de aço em situação de incêndio. 2009, 225p. Dissertação (Mestrado em Engenharia de Estruturas), Escola de Engenharia de São Carlos, Universidade de São Paulo, São Carlos, 2009.

KIRCHHOF, L.D. Uma contribuição ao estudo de vigas mistas aço-concreto simplesmente apoiadas em temperatura ambiente e em situação de incêndio. 2004. 142p. Dissertação 
(Mestrado em Engenharia de Estruturas) - Escola de Engenharia de São Carlos, Universidade de São Paulo, São Carlos, 2004.

KUMAR, S.; RAO KAMESWARA, C. V. S. Fire load in residencial buildings. Buildings and Enviroment, Vol 30, №2, Apr. 1995, p. 299-305.

LANDI, F. R. Ação do incêndio sobre as estruturas de concreto armado. Boletim técnico 01/86, Escola Politécnica da Universidade de São Paulo, Departamento de Engenharia de Construção Civil, São Paulo, 1986. 22 p.

LEITE, H. A. L.; MORENO JÚNIOR, A. L.; TORRES, D. L. Dimensionamento da alvenaria estrutural em situação de incêndio: contribuição à futura normatização nacional. Ambiente Construído, Porto Alegre, v. 16, n. 2, p. 89-107, abr./jun. 2016.

LEONARDO Da Vinci Pilot Project CZ/02/B/F/PP - 134007. Handbook 5: design of buildings for the fire situation. Implementations of Eurocodes. Luxembourg: European Commission, 2005.

LIMA, R. C. A. Investigação do comportamento de concretos em temperaturas elevadas. 2005. Tese (Doutorado em Construção), Universidade Federal do Rio Grande do Sul -UFRGS, Porto Alegre, 2005.

LOPES, R. F. R.; RODRIGUES, J. P. C.; PEREIRA, J. M.; LOURENÇO, P. B. Análise experimental de uma parede de alvenaria estrutural de blocos de concreto de três células em situação de incêndio. Concreto e Construções, ed. 90. Abr. - Jun. 2018. p. 86 - 94.

MARCATTI, J.; COELHO FILHO, H. S.; BREQUÓ FILHO, J. E. Compartimentação e afastamento entre edificações. In: SEITO, A. I. et al (Coord.). A segurança contra incêndio no Brasil. São Paulo: Projeto Editora, 2008. p. 169-179.

MATA, R.C. Influência do padrão de argamassamento na resistência à compressão de prismas e mini-paredes de alvenaria estrutural de blocos de concreto. 2006. 157p. Dissertação (Mestrado em Engenharia Civil), Universidade Federal de Santa Catarina, Florianópolis, 2006. 
MEDEIROS, J. S.; SABBATINI, F. H. Alvenaria estrutural não armada de blocos de concreto: Produção de componentes e parâmetros de projeto. Boletim Técnico da Escola Politécnica, Universidade de São Paulo, 1993.

MEHTA, P. K.; MONTEIRO, P. J. M. Concreto: estrutura, propriedades e materiais. São Paulo, PINI, 1997. 573 p.

MEYER, U. Extended Application Rules for the fire performance of masonry walls. In 7th International Masonry Conference, Londres, 2006. 4 p. Disponível em < http://www.masonry.org.uk/ >. Acesso em: 10 de junho de 2018.

MITIDIERI, M. L. O comportamento dos materiais e componentes construtivos diante do fogo - reação ao fogo. In: SEITO, A. I. et al. (Coord.). A segurança contra incêndio no Brasil. São Paulo: Projeto Editora, 2008. p. 55-75.

MOHAMAD, G. Comportamento mecânico na ruptura de prismas de blocos de concreto. Dissertação de M. Sc., Programa de Pós-Graduação em Engenharia Civil - PPGEC/UFSC, Florianópolis, 1998.

MOHAMAD, G. Mecanismo de ruptura da alvenaria de blocos à compressão. Tese (Doutorado) - Universidade do Minho, Guimarães, Portugal, 2007.

MORAlES, G.; CAMPOS, A.; FAGANEllo, A. M. P. A ação do fogo sobre os componentes do concreto. Ciência Exatas e Tecnológicas, Londrina, v. 32, n.1, p. 47-55, Jan/Mar. 2011

MORENO JÚNIOR, A. L.; MOLINA, J. C. Considerações de interesse sobre a avaliação em laboratório de elementos estruturais em situação de incêndio: contribuições à revisão da NBR 5628/2001. Ambiente Construído, Porto Alegre, v. 12, n. 4, p. 37-53, out./dez. 2012.

NADJAI, A. et al. Compartment masonry walls in the fire situations. Fire Technology, v 42, no 3, 2006. p. 211-231. 
NATIONAL FIRE PROTECTION ASSOCIATION - NFPA. All about fire. Disponível em: $<$ http://www.nfpa.org/news-and-research/news-and-media/press-room/reporters-guide-to-fireand-nfpa/all-about-fire>. Acesso em: 04 out. 2017.

NEVILLE, A. M. Propriedades do concreto. Salvador E. Giammusso (Tradução), São Paulo, PINI, 2a ed., 1997. 828 p.

NGUYEN, T. et al. The behavior of masonry walls subjected to fire: Modelling and parametrical studies in the case of hollow bunrt-clay bricks. Fire Safety Journal, v 44, n⿳⺈ 4 , 2009. p. 629-641.

O'CONNOR, D. J.; SILCOCK, G. W. H.; MORRIS, B. An investigation of scale modeling of the thermo-structural performance of compartment walls in standard fire tests. In: $4^{\text {th }}$ International Mansonry Conference, 1995, Londres. p. 402-406.

OLIVEIRA, L. A. P. de. Estimativa da resistência ao fogo de paredes de alvenaria pelo critério de isolamento térmico. Boletim Técnico da Faculdade de Tecnologia de São Paulo, $\mathrm{n}^{\circ} \quad$ 05, dezembro $1998 . \quad$ p. Disponível em: <http://bt.fatecsp.br/system/articles/26/original/02luizantonio.pdf $>$. Acesso em: 19 de novembro 2017.

OLIVEIRA, L.M.F. Estudo teórico e experimental do comportamento das interfaces verticais de paredes interconectadas de alvenaria estrutural. Tese (Doutorado em Engenharia de Estruturas) - Escola de Engenharia de São Carlos, Universidade de São Paulo, São Carlos, 2014.

OLIVEIRA Jr., V. Recomendações para projetos de edifícios em alvenaria estrutural. 1992. 273p. Dissertação (Mestrado em Estruturas). Escola de Engenharia de São Carlos. Universidade de São Paulo, São Carlos, 1992.

ONO, R. Parâmetros para garantia da qualidade do projeto de segurança contra incêndio em edifícios altos. Ambiente Construído. Porto Alegre, v.7, n.1, 2007. p. 97-113. 
PARSEKIAN, G. A. Tecnologia de produção de alvenaria estrutural protendida. Tese (Doutorado) - Escola Politécnica da Universidade de São Paulo, São Paulo, 2002.

PARSEKIAN, G. A.; HAMID, A. A.; DRYSDALE R, R. G. Comportamento e dimensionamento de alvenaria estrutural. São Carlos: Edufscar. 2012.

PARSEKIAN, G. A.; SOARES, M. M. Alvenaria Estrutural em Blocos Cerâmicos: projeto, execução e controle. São Paulo: O Nome da Rosa, 2010. 238 p.

POLÍCIA MILITAR DO ESTADO DE SÃO PAULO - CORPO DE BOMBEIROS. Instrução Técnica N 09/2004 - Compartimentação Horizontal e Compartimentação Vertical. Secretaria de Estado dos Negócios da Segurança Pública, São Paulo. 2004. 14 p.

RAMAlHO, M. A.; CORRÊA, M. R. S.. Projeto de edifícios de alvenaria estrutural. São Paulo, Pini, 2003. 174 p.

RIGÃO, A. O. Comportamento de Pequenas Paredes de Alvenaria Estrutural Frente a Altas Temperaturas. Santa Maria, 2012. 142 p. Dissertação (Mestrado em Engenharia Civil) - Escola de Engenharia, Universidade Federal de Santa Maria, São Maria, 2012.

ROCHA, F. M. Modelos numéricos de vigas mistas de aço e concreto pertencentes a sistemas de pisos mistos de pequena altura em situação de incêndio. 2012. 267 p. Dissertação (Mestrado em Engenharia de Estruturas), Escola de Engenharia de São Carlos, Universidade de São Paulo, São Carlos, 2012.

RODOVALHO, F. S. Simulação numérica de blocos e prismas de alvenaria em situação de incêndio. 159 p. Dissertação (Mestrado em Engenharia de Estruturas), Escola de Engenharia de São Carlos, Universidade de São Paulo, São Carlos, 2018.

ROSEMANN, F. Resistência ao fogo de paredes de alvenaria estrutural de blocos cerâmicos pelo critério de isolamento térmico. 2011. 160 p. Dissertação (Mestrado em Engenharia Civil). Universidade Federal de Santa Catarina, Florianópolis, 2011. 
SABBATINI, F. H. Argamassas de assentamento para paredes de alvenaria resistente. Boletim técnico 02/86, Escola Politécnica de São Paulo, Departamento de Engenharia de Construção Civil, USP, São Paulo, 1986. 26 p .

SANTOS, D.B.R. Modelagem numérica de lajes mistas de aço e concreto em situação de incêndio. 2014. 243p. Dissertação (Mestrado em Engenharia de Estruturas) - Escola de Engenharia de São Carlos, Universidade de São Paulo, São Carlos, 2014.

SCHNEIDER, R. R.; DICKEY, W. L. Reinforced masonry design. Englewood Cliffs, New Jersey, Prentice Hall, 1994. 729 p.

SEITO, A. I. et al. A segurança contra incêndios no Brasil. São Paulo: Projeto Editora, 2008. $484 \mathrm{p}$.

SILVA, V.P. Estruturas de aço em situação de incêndio. São Paulo: Zigurate Editora, 2001.

SILVA, V. P. Sobre o coeficiente $\gamma_{s 1}$ do método do tempo equivalente para a determinação do tempo requerido de resistência ao fogo das estruturas. Revista Minerva, $\operatorname{Vol} 5, \mathrm{n}^{\mathrm{o}} 3$, 2008. P. 315-321.

STANCATO, A. C. Determinação da condutividade térmica e da resistência mecânica em argamassa leve. Dissertação (Mestrado) Universidade Estadual de Campinas - Faculdade de Engenharia Civil. Campinas, 184 p. 2000.

TAUIL, C. A.; NESE, F. J. M. Alvenaria Estrutural. Editora Pini, São Paulo, 2010. 183 p.

THINK BRICK AUSTRALIA. Design of clay masonry walls for fire resistance. 2013. Disponível em < http://thinkbrick.blob.core.windows.net/media/1402/manual-05-design-ofclay-masonry-walls-for-fire-resistance.pdf >. Acesso em: 11 de junho de 2018

THOMAZ, E.; HELENE, P. Qualidade no projeto e na execução de alvenaria estrutural e de alvenarias de vedação em edifícios. Boletim Técnico da Escola Politécnica da USP, BT/PCC/252. São Paulo: EPUSP, 2000. 31 p. 
VELARDE, J. S. S. (2008). Sobre o comportamento de pilares de aço em situação de incêndio. Dissertação (Mestrado) - Escola Politécnica, Universidade de São Paulo, São Paulo.

WANG, Y. C. Steel and Composite Structures. Behavior and design for fire safety. London, Spon Press, 2002, New York. 332 p.

WENDT, S.C. Análise da mudança de cor em concretos submetidos a altas temperaturas como indicative de temperature alcançada e da degradação térmica. 2006, 183 p. Dissertação (Mestrado em Engenharia Civil), Universidade Federal do Rio Grande do Sul, UFRGS, Porto Alegre, 2006.

YÜZER, N.; AKÖZ, F.; ÖZTÜRK, L.D. Compressive strength-color change relation in mortars at high temperature. Cement and Concrete Research, vol 34, n ${ }^{\circ}$ 10, Oct. 2004, p. 1803-1807. 


\section{APÊNDICE A}

\section{- Condução}

De acordo com Buchanan (2002), a condução é um mecanismo de transferência de calor entre materiais sólido, sendo um importante fator de ignição das superfícies sólidas e na resistência ao fogo dos elementos estruturais. O calor é transferido pelas interações envolvendo elétrons livres em materiais que são bons condutores de calor, sendo assim estes também são bons condutores de eletricidade. Já em materiais de baixa condutividade térmica, o calor é transferido através de vibrações mecânicas da rede molecular.

Como a condução é um mecanismo de transferência de calor relacionado ao meio sólido, as suas propriedades mecânicas e térmicas influenciam na direção do fluxo de calor e na taxa de aquecimento. Dentre estas propriedades estão: calor específico $\left(c_{p}\right)$, que é a quantidade de calor necessária para elevar em um grau a temperatura da unidade de massa do material; condutividade térmica $(\lambda)$ que representa a taxa de calor transferido através da unidade de espessura do material; e a densidade $(\rho)$ que relaciona a quantidade de massa do material por unidade de volume.

Segundo Drysdale (1998), o fluxo de calor ocorre quando uma região apresenta temperatura mais elevada que outra. Este fluxo de calor ocorre da face com maior temperatura para a de menor temperatura, no caso de paredes de alvenaria, que é constituída por camadas, o fluxo de calor atravessa da face mais aquecida para a de menor temperatura, mas como os blocos são vazados a transferência de calor no seu interior se dá por convecção.

A condução pode ser transiente quando são dependentes do tempo ou estacionária. A deflagração de incêndios é um problema relacionado à condução transiente, diferentemente da análise de revestimentos térmicos em edificações que é estacionária. A condução no estado estacionário em campo unidimensional segue a Lei de Fourier que é expressa pela equação A.1.

$$
\varphi=-\lambda \frac{d \theta}{d x}
$$

Em que:

$\varphi$ é o fluxo de calor por unidade de área $\left[\mathrm{W} / \mathrm{m}^{2}\right]$;

$\lambda$ é a condutividade térmica $[\mathrm{W} / \mathrm{mK}]$;

$\theta$ é a temperatura $[\mathrm{K}]$;

$x$ é a distância na direção do fluxo de calor [m].

O sinal negativo indica que o fluxo ocorre da face mais aquecida para a menos aquecida. 
A condução no estado estacionário em campo unidimensional também pode ocorrer em materiais compósitos de condutividades diferentes, como exemplificado na Figura A.1, com uma situação de três camadas. Neste caso pelo princípio de conservação de energia em que o fluxo de calor através de cada camada permanece constante e assumindo que a condutividade de cada material independe da temperatura, é possível obter o fluxo de calor pela equação A.2 desde que sejam conhecidas as temperaturas nas duas faces externas do compósito.

Figura A.1 - Gráfico de fluxo de calor passando por uma parede infinita e plana composta por camadas

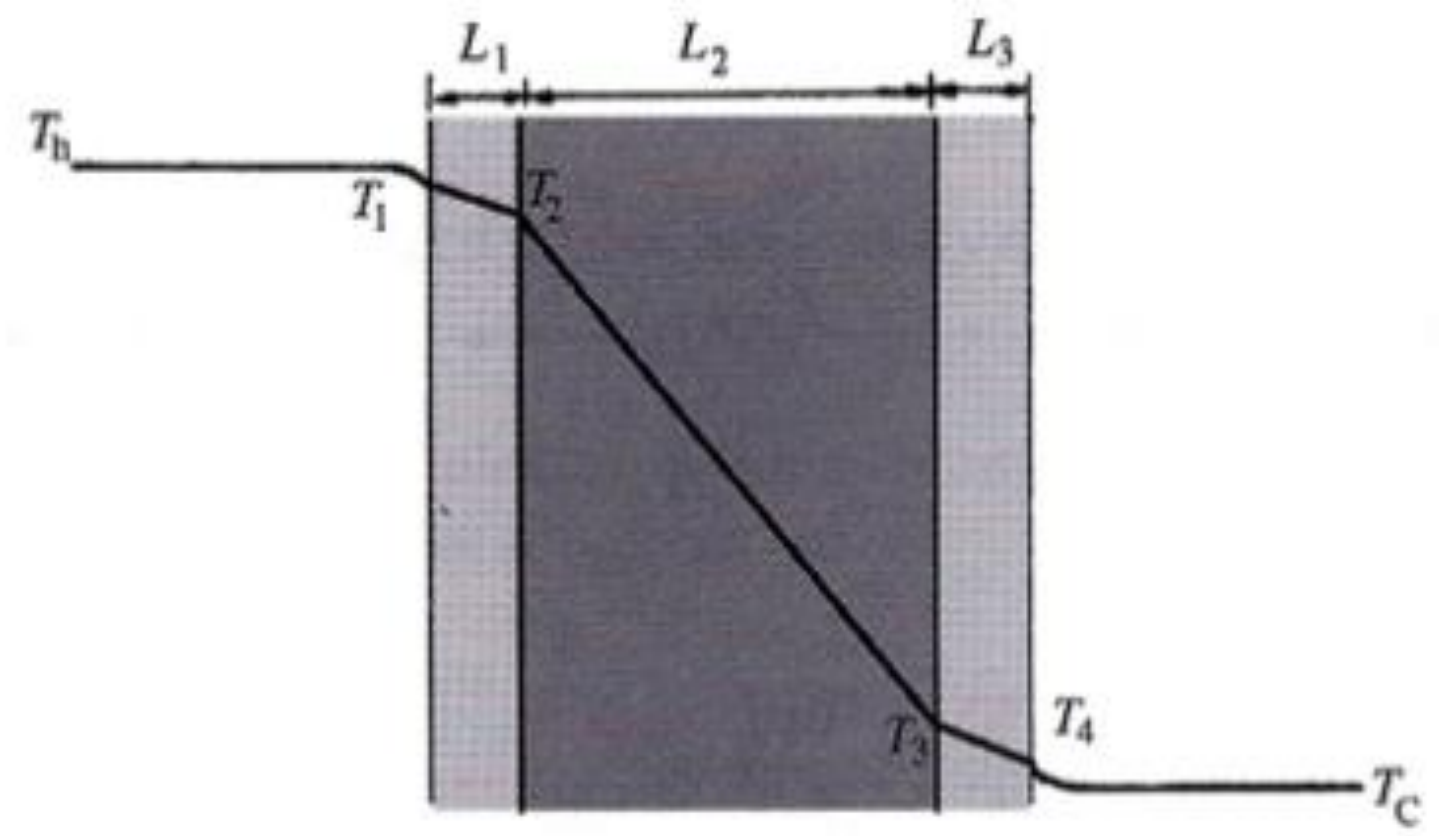

Fonte: Drysdale (1998)

$\theta_{1}-\theta_{n, n+1}=\varphi \sum_{i=1}^{n} R_{i, i+1}$

Em que:

$\theta_{1}$ e $\theta_{n, n+1}$ são as temperaturas externas nas faces do compósito;

$\varphi$ é o fluxo de calor que atravessa o compósito;

$R_{i, i+1}=\frac{\Delta x_{i, i+1}}{\lambda_{i, i+1}}$ é a resistência térmica de cada material do compósito;

$\lambda_{i, i+1}$ é a condutividade térmica de cada camada;

$\Delta x_{i, i+1}$ é a espessura da camada correspondente.

Na condução transiente, também deve ser incluída na formulação a quantidade de calor dissipada na mudança de temperatura do meio. 


\section{- Convecção}

A convecção é a transferência de calor dada por meio do movimento de fluidos, podendo ser gasosos ou líquidos (BUCHANAN, 2002).

De acordo com Drysdale (1998), na situação de incêndio, este modo de transferência de calor é de suma importância pois é o responsável pela disseminação da chama, nesta situação a maior parte do calor liberado pela superfície em chamas é transportado através de movimentos convectivos na fase inicial do incêndio e na sua evolução. $O$ transporte ascendente da fumaça e dos gases quentes também são conduzidos ao teto ou para fora do compartimento em chamas devido à convecção.

Este fenômeno se divide em convecção forçada e natural, relativas ao modo de movimentação do fluído. A convecção natural parte do aquecimento de uma porção do fluído que sofre expansão e tem sua densidade diminuída, elevando-se e tendo sua posição ocupada por uma porção menos aquecida, o processo se repete com todo o fluido formando as correntes convectivas. Por outro lado, a convecção forçada ocorre em razão movimentação mecânica do fluído como, por exemplo, um ventilador ou um exaustor.

Os cálculos referentes à transferência de calor por convecção envolvem normalmente a quantidade de calor transferido de um sólido para um fluido circundante. A velocidade deste fluido na superfície do material define a taxa de aquecimento ou resfriamento. Newton definiu a expressão para o cálculo do fluxo de calor por convecção, a equação A.3 é uma adaptação para o caso da transferência de calor entre as chamas e os materiais (SILVA, 2001).

$$
h_{c}=\alpha_{c}\left(\theta_{g}-\theta_{a}\right)
$$

\section{Em que:}

$h_{c}$ é o fluxo convectivo de calor por unidade de área $\left[\mathrm{W} / \mathrm{m}^{2}\right]$;

$\alpha_{c}$ é o coeficiente de transferência de calor $\left[25 \mathrm{~W} / \mathrm{m}^{2}{ }^{\circ} \mathrm{C}\right.$, adotado pelo Eurocode 3 Part 1.2];

$\theta_{g}$ é a temperatura dos gases quentes $\left[{ }^{\circ} \mathrm{C}\right]$;

$\theta_{a}$ é a temperatura na superfície exposta ao fogo $\left[{ }^{\circ} \mathrm{C}\right]$.

\section{- Radiação}

A radiação térmica envolve a transferência de calor por meio de ondas eletromagnéticas de comprimento situado entre 0,4 e $100 \mu \mathrm{m}$, este intervalo engloba desde a luz visível até grande parte dos raios infravermelhos. Para que a radiação ocorra não é necessário um meio material 
(sólido, líquido ou gasoso), podendo ocorrer no vácuo ou até em meio transparentes. Na situação de incêndio, a radiação atua na transferência de calor das chamas para as superfícies combustíveis, de um edifício em chamas para outro adjacente e também da fumaça quente para os elementos da edificação (BUCHANAN, 2002).

De acordo com Drysdale (1999) estudos apontam que em temperaturas próximas de 150 e $200{ }^{\circ} \mathrm{C}$, a convecção predomina no corpo. Mas, quando a temperatura é superior a $400{ }^{\circ} \mathrm{C}$ a radiação passa a ser predominante, se tornando o principal mecanismo de transferência de calor e a partir de $550{ }^{\circ} \mathrm{C}$ o corpo já emite radiação suficiente para que seja observado um brilho avermelhado sobre o mesmo. Durante o aquecimento de um corpo, parte do calor pode ser perdido por convecção (quando em contato com um fluído) e radiação, o valor destas parcelas de perda é definido pelo coeficiente de transferência de calor por convecção e do valor da emissividade que é o parâmetro relacionado à radiação.

Qualquer objeto dentro de um meio por onde passa energia térmica radiante pode absorver, refletir ou transmitir a radiação. Estes fatores dependem dos parâmetros de absortividade $(\alpha)$, refletividade $(\rho)$ e transmitância $(\tau)$ que representam frações de radiação térmica incidente que um certo corpo absorve, reflete ou transmite, respectivamente conforme equação A.4. Segundo Wang (2002) estes parâmetros basicamente são função da temperatura, comprimento de onda e das propriedades da superfície do corpo atingido pela radiação e vale destacar que na natureza inexiste material capaz de absorver toda radiação nele incidente,

$$
\alpha+\rho+\tau=1
$$

O fluxo de calor por radiação $\left(q_{r}\right)$ transmitido entre uma superfície e um fluido que estejam em contato é determinado em $\mathrm{W} / \mathrm{m}^{2} \mathrm{~K}$ pela equação A.5.

$$
q_{r}=\varepsilon . \Omega \cdot\left(T_{S}^{4}-T_{\infty}^{4}\right)
$$

Em que:

$\varepsilon$ é a emissividade, uma característica de cada superfície e indica a sua eficiência de emissão quando comparada com um radiador ideal;

$\Omega$ é a constante de Stefan-Boltzmann dada por $5,67 \times 10^{-8}\left[\mathrm{~W} /\left(\mathrm{m}^{2} / \stackrel{\circ}{ } C^{4}\right)\right]$;

$T_{S}$ é a temperatura da superfície $[\mathrm{K}]$;

$T_{\infty}$ é a temperatura do fluido [K]. 


\section{APÊNDICE B}

\section{Propriedades geométricas - dimensões efetivas}

Tabela B.1 - Resultados da análise dimensional das unidades de 10,0 MPa e espessura de $140 \mathrm{~mm}$

\begin{tabular}{cccc|cccc}
\hline \hline \multicolumn{7}{c}{ Dimensões Efetivas $(10,0$ MPa e 140 mm $)$} \\
\hline \hline Bloco & $\begin{array}{c}\text { Largura } \\
(\mathrm{mm})\end{array}$ & $\begin{array}{c}\text { Altura } \\
(\mathrm{mm})\end{array}$ & $\begin{array}{c}\text { Comprimento } \\
(\mathrm{mm})\end{array}$ & Meio-bloco & $\begin{array}{c}\text { Largura } \\
(\mathrm{mm})\end{array}$ & $\begin{array}{c}\text { Altura } \\
(\mathrm{mm})\end{array}$ & $\begin{array}{c}\text { Comprimento } \\
(\mathrm{mm})\end{array}$ \\
\cline { 2 - 4 } BL 1 & 139,21 & 191,17 & 390,17 & MBL 1 & 138,41 & 189,17 & 191,00 \\
BL 2 & 139,30 & 189,17 & 390,17 & MBL 2 & 138,55 & 191,17 & 191,33 \\
BL 3 & 139,37 & 190,33 & 390,33 & MBL 3 & 138,60 & 191,17 & 191,17 \\
BL 4 & 139,34 & 190,13 & 390,17 & MBL 4 & 138,09 & 191,33 & 191,17 \\
BL 5 & 139,65 & 190,50 & 389,67 & MBL 5 & 137,91 & 191,67 & 190,67 \\
BL 6 & 139,25 & 191,17 & 390,00 & MBL 6 & 138,49 & 192,17 & 190,93 \\
\hline \hline Média & $\mathbf{1 3 9 , 3 5}$ & $\mathbf{1 9 0 , 4 1}$ & $\mathbf{3 9 0 , 0 8}$ & Média & $\mathbf{1 3 8 , 3 4}$ & $\mathbf{1 9 1 , 1 1}$ & $\mathbf{1 9 1 , 0 4}$ \\
Desvio Padrão & 0,16 & 0,75 & 0,23 & Desvio Padrão & 0,28 & 1,03 & 0,23 \\
CV (\%) & 0,11 & 0,39 & 0,06 & CV (\%) & 0,20 & 0,54 & 0,12 \\
\hline \hline
\end{tabular}

Tabela B.2 - Resultados da análise dimensional das unidades de 10,0 MPa e espessura de $190 \mathrm{~mm}$

\begin{tabular}{cccc|cccc}
\hline \hline \multicolumn{7}{c}{ Dimensões Efetivas $(10,0$ MPa e 190 mm) } \\
\hline \hline \multirow{2}{*}{ Bloco } & $\begin{array}{c}\text { Largura } \\
(\mathrm{mm})\end{array}$ & $\begin{array}{c}\text { Altura } \\
(\mathrm{mm})\end{array}$ & $\begin{array}{c}\text { Comprimento } \\
(\mathrm{mm})\end{array}$ & Meio-bloco & $\begin{array}{c}\text { Largura } \\
(\mathrm{mm})\end{array}$ & $\begin{array}{c}\text { Altura } \\
(\mathrm{mm})\end{array}$ & $\begin{array}{c}\text { Comprimento } \\
(\mathrm{mm})\end{array}$ \\
\cline { 2 - 3 } BL 1 & 191,50 & 191,67 & 391,83 & MBL 1 & 191,40 & 189,90 & 191,67 \\
BL 2 & 191,17 & 192,17 & 391,83 & MBL 2 & 191,50 & 189,73 & 191,33 \\
BL 3 & 191,00 & 191,33 & 391,67 & MBL 3 & 192,17 & 191,33 & 192,03 \\
BL 4 & 191,17 & 192,00 & 391,50 & MBL 4 & 191,33 & 190,67 & 191,83 \\
BL 5 & 191,33 & 191,83 & 391,97 & MBL 5 & 191,83 & 189,33 & 190,83 \\
BL 6 & 190,67 & 192,17 & 392,07 & MBL 6 & 191,83 & 189,67 & 192,43 \\
\hline \hline Média & $\mathbf{1 9 1 , 1 4}$ & $\mathbf{1 9 1 , 8 6}$ & $\mathbf{3 9 1 , 8 1}$ & Média & $\mathbf{1 9 1 , 6 8}$ & $\mathbf{1 9 0 , 1 1}$ & $\mathbf{1 9 1 , 6 9}$ \\
Desvio Padrão & 0,29 & 0,32 & 0,20 & Desvio Padrão & 0,32 & 0,75 & 0,56 \\
CV (\%) & 0,15 & 0,17 & 0,05 & CV (\%) & 0,17 & 0,39 & 0,29 \\
\hline \hline
\end{tabular}

Tabela B.3 - Resultados da análise dimensional das unidades de 4,0 MPa e espessura de $140 \mathrm{~mm}$

\begin{tabular}{cccc|cccc}
\hline \hline \multicolumn{7}{c}{ Dimensões Efetivas (4,0 MPa e 140 mm) } \\
\hline \hline Bloco & $\begin{array}{c}\text { Largura } \\
(\mathrm{mm})\end{array}$ & $\begin{array}{c}\text { Altura } \\
(\mathrm{mm})\end{array}$ & $\begin{array}{c}\text { Comprimento } \\
(\mathrm{mm})\end{array}$ & Meio-bloco & $\begin{array}{c}\text { Largura } \\
(\mathrm{mm})\end{array}$ & $\begin{array}{c}\text { Altura } \\
(\mathrm{mm})\end{array}$ & $\begin{array}{c}\text { Comprimento } \\
(\mathrm{mm})\end{array}$ \\
\cline { 2 - 3 } BL 1 & 139,23 & 189,67 & 389,67 & MBL 1 & 138,02 & 188,50 & 190,27 \\
BL 2 & 139,22 & 189,33 & 390,50 & MBL 2 & 138,67 & 187,67 & 191,07 \\
BL 3 & 139,03 & 189,57 & 390,50 & MBL 3 & 137,47 & 188,00 & 190,23 \\
BL 4 & 139,37 & 189,83 & 390,37 & MBL 4 & 138,87 & 188,00 & 190,83 \\
BL 5 & 139,33 & 190,17 & 390,07 & MBL 5 & 138,50 & 187,67 & 190,43 \\
BL 6 & 139,30 & 190,23 & 390,23 & MBL 6 & 137,67 & 188,17 & 190,67 \\
\hline \hline Média & $\mathbf{1 3 9 , 2 5}$ & $\mathbf{1 8 9 , 8 0}$ & $\mathbf{3 9 0 , 2 2}$ & Média & $\mathbf{1 3 8 , 2 0}$ & $\mathbf{1 8 8 , 0 0}$ & $\mathbf{1 9 0 , 5 8}$ \\
Desvio Padrão & 0,12 & 0,35 & 0,32 & Desvio Padrão & 0,57 & 0,32 & 0,33 \\
CV (\%) & 0,09 & 0,18 & 0,08 & CV (\%) & 0,41 & 0,17 & 0,17 \\
\hline \hline
\end{tabular}


Tabela B.4 - Resultados da análise dimensional das unidades de 4,0 MPa e espessura de 190 mm

\begin{tabular}{cccc|cccc}
\hline \hline \multicolumn{7}{c}{ Dimensões Efetivas $(4,0$ MPa e 190 mm) } \\
\hline \hline BL 1 & $\begin{array}{c}\text { Largura } \\
(\mathrm{mm})\end{array}$ & $\begin{array}{c}\text { Altura } \\
(\mathrm{mm})\end{array}$ & $\begin{array}{c}\text { Comprimento } \\
(\mathrm{mm})\end{array}$ & Meio-bloco & $\begin{array}{c}\text { Largura } \\
(\mathrm{mm})\end{array}$ & $\begin{array}{c}\text { Altura } \\
(\mathrm{mm})\end{array}$ & $\begin{array}{c}\text { Comprimento } \\
(\mathrm{mm})\end{array}$ \\
\cline { 2 - 3 } BL 2 & 190,23 & 190,60 & 390,67 & MBL 1 & 190,37 & 191,67 & 189,83 \\
BL 3 & 190,70 & 190,37 & 390,47 & MBL 2 & 189,70 & 191,23 & 189,50 \\
BL 4 & 190,60 & 189,47 & 390,37 & MBL 3 & 189,00 & 190,33 & 190,00 \\
BL 5 & 190,17 & 189,83 & 390,00 & MBL 4 & 189,77 & 190,03 & 189,57 \\
BL 6 & 190,00 & 191,10 & 390,50 & MBL 5 & 190,17 & 190,60 & 190,77 \\
\hline \hline Média & $\mathbf{1 9 9 , 8 3}$ & 190,50 & 390,83 & MBL 6 & 190,07 & 189,87 & 190,27 \\
Desvio Padrão & 0,34 & $\mathbf{1 9 0 , 3 1}$ & $\mathbf{3 9 0 , 4 7}$ & Média & $\mathbf{1 8 9 , 8 4}$ & $\mathbf{1 9 0 , 6 2}$ & $\mathbf{1 8 9 , 9 9}$ \\
CV (\%) & 0,18 & 0,31 & 0,28 & Desvio Padrão & 0,48 & 0,70 & 0,47 \\
\hline \hline
\end{tabular}

Propriedades geométricas - espessuras, dimensões dos furos e raio das mísulas

Tabela B.5 - Resultados para espessuras, dimensões dos furos e raios das mísulas dos blocos de 10,0 MPa e $140 \mathrm{~mm}$

\begin{tabular}{ccccc|cc|c}
\hline \hline Bloco & \multicolumn{4}{c|}{ Espessura (mm) } & Dimensão dos Furos (mm) & Raio das \\
\cline { 2 - 6 } $\begin{array}{c}\text { (10,0 MPa e } \\
\text { 140 mm) }\end{array}$ & $\begin{array}{c}\text { Paredes } \\
\text { Longitudinais }\end{array}$ & $\begin{array}{c}\text { Paredes } \\
\text { Transversais }\end{array}$ & Septos & $\begin{array}{c}\text { Transversal } \\
\text { Equivalente }\end{array}$ & Longitudinal & Transversal & $\begin{array}{c}\text { Mísulas } \\
(\mathrm{mm})\end{array}$ \\
\hline \hline BL 1 & 25,22 & 25,68 & 26,35 & 263,22 & 148,90 & 79,25 & 40,40 \\
BL 2 & 25,60 & 25,78 & 26,85 & 264,25 & 149,45 & 79,45 & 40,80 \\
BL 3 & 25,43 & 25,78 & 26,40 & 264,13 & 149,40 & 79,65 & 39,90 \\
BL 4 & 25,76 & 25,46 & 26,24 & 260,97 & 149,36 & 79,92 & 41,00 \\
BL 5 & 25,97 & 25,66 & 26,06 & 263,35 & 149,22 & 79,66 & 40,00 \\
BL 6 & 25,65 & 25,45 & 26,65 & 261,03 & 149,09 & 79,46 & 40,30 \\
\hline \hline Média & $\mathbf{2 5 , 6 0}$ & $\mathbf{2 5 , 6 3}$ & $\mathbf{2 6 , 4 3}$ & - & $\mathbf{1 4 9 , 2 4}$ & $\mathbf{7 9 , 5 7}$ & - \\
Desvio Padrão & 0,26 & 0,15 & 0,28 & - & 0,21 & 0,23 & - \\
CV (\%) & 1,03 & 0,57 & 1,08 & - & 0,14 & 0,29 & - \\
\hline \hline
\end{tabular}

Tabela B.6 - Resultados para espessuras, dimensões dos furos e raios das mísulas dos blocos de 10,0 MPa e 190 mm

\begin{tabular}{ccccc|cc|c}
\hline \hline $\begin{array}{c}\text { Bloco } \\
\text { (10,0 MPa e } \\
\text { 190 mm) }\end{array}$ & $\begin{array}{c}\text { Paredes } \\
\text { Longitudinais }\end{array}$ & $\begin{array}{c}\text { Paredes } \\
\text { Transversais }\end{array}$ & Septos & $\begin{array}{c}\text { Transversal } \\
\text { Equivalente }\end{array}$ & Longitudinal & Transversal & $\begin{array}{c}\text { Raio das } \\
\text { Mísulas } \\
\text { (mm) }\end{array}$ \\
\hline \hline BL 1 & 33,09 & 25,58 & 25,35 & 261,08 & 149,40 & 114,35 & 60,00 \\
BL 2 & 32,76 & 25,36 & 25,85 & 258,83 & 149,60 & 114,25 & 59,90 \\
BL 3 & 32,96 & 25,90 & 24,64 & 264,46 & 150,14 & 114,21 & 60,10 \\
BL 4 & 32,59 & 25,40 & 25,90 & 259,46 & 149,95 & 114,25 & 59,90 \\
BL 5 & 32,58 & 25,82 & 25,35 & 263,49 & 150,01 & 114,71 & 58,26 \\
BL 6 & 32,18 & 25,99 & 25,21 & 265,16 & 149,71 & 114,47 & 58,96 \\
\hline \hline Média & $\mathbf{3 2 , 6 9}$ & $\mathbf{2 5 , 6 7}$ & $\mathbf{2 5 , 3 8}$ & - & $\mathbf{1 4 9 , 8 0}$ & $\mathbf{1 1 4 , 3 7}$ & - \\
Desvio Padrão & 0,32 & 0,27 & 0,46 & - & 0,28 & 0,19 & - \\
CV (\%) & 0,99 & 1,04 & 1,83 & - & 0,19 & 0,17 & - \\
\hline \hline
\end{tabular}


Tabela B.7 - Resultados para espessuras, dimensões dos furos e raios das mísulas dos blocos de 4,0 MPa e $140 \mathrm{~mm}$

\begin{tabular}{ccccc|cc|c}
\hline \hline $\begin{array}{c}\text { Bloco } \\
\mathbf{4 , 0} \text { MPa e }\end{array}$ & $\begin{array}{c}\text { Paredes } \\
\mathbf{1 4 0} \mathbf{~ m m})\end{array}$ & \begin{tabular}{c} 
Paredes \\
\cline { 2 - 7 }
\end{tabular} & $\begin{array}{c}\text { Espessura (mm) } \\
\text { Septos }\end{array}$ & $\begin{array}{c}\text { Transversal } \\
\text { Equivalente }\end{array}$ & Longitudinal & Transversal & $\begin{array}{c}\text { Mísulas } \\
\text { (mm) }\end{array}$ \\
\hline \hline BL 1 & 25,46 & 25,48 & 26,58 & 261,51 & 149,55 & 79,65 & 39,10 \\
BL 2 & 25,56 & 25,53 & 26,14 & 261,46 & 149,87 & 79,75 & 41,00 \\
BL 3 & 25,50 & 25,63 & 27,06 & 262,48 & 149,41 & 79,25 & 39,80 \\
BL 4 & 25,79 & 25,43 & 26,16 & 260,52 & 149,65 & 79,80 & 39,90 \\
BL 5 & 25,78 & 25,40 & 26,64 & 260,47 & 149,40 & 79,60 & 39,50 \\
BL 6 & 25,69 & 25,48 & 26,63 & 261,13 & 149,30 & 79,75 & 40,80 \\
\hline \hline Média & $\mathbf{2 5 , 6 3}$ & $\mathbf{2 5 , 4 9}$ & $\mathbf{2 6 , 5 4}$ & - & $\mathbf{1 4 9 , 5 3}$ & $\mathbf{7 9 , 6 3}$ & - \\
Desvio Padrão & 0,14 & 0,08 & 0,34 & - & 0,21 & 0,20 & - \\
CV (\%) & 0,55 & 0,31 & 1,30 & - & 0,14 & 0,25 & - \\
\hline \hline
\end{tabular}

Tabela B.8 - Resultados para espessuras, dimensões dos furos e raios das mísulas dos blocos de 4,0 MPa e $190 \mathrm{~mm}$

\begin{tabular}{|c|c|c|c|c|c|c|c|}
\hline \multirow{2}{*}{$\begin{array}{c}\text { Bloco } \\
(4,0 \mathrm{MPa} \text { e } \\
190 \mathrm{~mm}) \\
\end{array}$} & \multicolumn{4}{|c|}{ Espessura (mm) } & \multicolumn{2}{|c|}{ Dimensão dos Furos (mm) } & \multirow{2}{*}{$\begin{array}{c}\text { Raio das } \\
\text { Mísulas } \\
(\mathrm{mm})\end{array}$} \\
\hline & $\begin{array}{c}\text { Paredes } \\
\text { Longitudinais }\end{array}$ & $\begin{array}{c}\text { Paredes } \\
\text { Transversais }\end{array}$ & Septos & $\begin{array}{l}\text { Transversal } \\
\text { Equivalente }\end{array}$ & Longitudinal & Transversal & \\
\hline$\overline{B L} 1$ & 32,42 & 25,98 & 25,10 & 265,96 & 149,10 & 114,50 & 58,40 \\
\hline BL 2 & 32,55 & 25,15 & 26,25 & 257,64 & 150,25 & 115,00 & 59,20 \\
\hline BL 3 & 32,76 & 25,23 & 25,70 & 258,47 & 150,40 & 114,65 & 58,40 \\
\hline BL 4 & 32,67 & 25,53 & 26,20 & 261,79 & 150,30 & 115,31 & 59,00 \\
\hline BL 5 & 32,56 & 25,78 & 26,20 & 264,02 & 150,15 & 114,40 & 58,44 \\
\hline BL 6 & 32,31 & 26,07 & 25,40 & 266,81 & 149,85 & 115,00 & 59,00 \\
\hline Média & 32,54 & 25,62 & 25,81 & - & 150,01 & 114,81 & - \\
\hline Desvio Padrão & 0,16 & 0,38 & 0,49 & - & 0,48 & 0,35 & - \\
\hline $\mathrm{CV}(\%)$ & 0,49 & 1,50 & 1,88 & - & 0,32 & 0,30 & - \\
\hline
\end{tabular}

Tabela B.9 - Resultados para espessuras e dimensões dos furos dos meios-blocos de 10,0 MPa e $140 \mathrm{~mm}$

\begin{tabular}{cccc|cc}
\hline \hline Meio-bloco & \multicolumn{3}{c|}{ Espessura (mm) } & \multicolumn{2}{c}{ Dimensão dos Furos (mm) } \\
\cline { 2 - 6 }$(\mathbf{1 0 , 0}$ MPa & Paredes & Paredes & Transversal & Longitudinal & Transversal \\
140 mm) & Longitudinais & Transversais & Equivalente & & \\
\hline \hline MBL 1 & 25,20 & 25,20 & 527,64 & 130,40 & 80,20 \\
MBL 2 & 25,04 & 25,68 & 536,76 & 129,70 & 81,72 \\
MBL 3 & 25,32 & 25,50 & 533,57 & 130,70 & 78,70 \\
MBL 4 & 25,45 & 25,56 & 534,72 & 132,00 & 77,80 \\
MBL 5 & 25,05 & 25,46 & 534,13 & 131,00 & 78,50 \\
MBL 6 & 25,44 & 25,73 & 539,04 & 130,50 & 79,08 \\
\hline \hline Mé dia & $\mathbf{2 5 , 2 5}$ & $\mathbf{2 5 , 5 2}$ & - & $\mathbf{1 3 0 , 7 2}$ & $\mathbf{7 9 , 3 3}$ \\
Desvio Padrão & 0,18 & 0,19 & - & 0,76 & 1,41 \\
CV (\%) & 0,73 & 0,74 & - & 0,58 & 1,78 \\
\hline \hline
\end{tabular}


Tabela B.10 - Resultados para espessuras e dimensões dos furos dos meios-blocos de 10,0 MPa e $190 \mathrm{~mm}$

\begin{tabular}{cccc|cc}
\hline \hline Meio-bloco & \multicolumn{3}{c|}{ Espessura (mm) } & \multicolumn{2}{c}{ Dimensão dos Furos (mm) } \\
\cline { 2 - 6 }$(\mathbf{1 0 , 0}$ MPa e & Paredes & Paredes & Transversal & Longitudinal & Transversal \\
$\mathbf{1 9 0}$ mm) & Longitudinais & Transversais & Equivalente & & 128,90 \\
\hline \hline MBL 1 & 25,80 & 25,70 & 536,35 & 130,60 \\
MBL 2 & 25,33 & 25,82 & 539,69 & 128,72 & 130,70 \\
MBL 3 & 25,98 & 26,30 & 547,72 & 129,50 & 130,38 \\
MBL 4 & 25,32 & 25,67 & 535,26 & 129,22 & 130,34 \\
MBL 5 & 25,83 & 25,37 & 531,67 & 130,00 & 130,38 \\
MBL 6 & 26,36 & 25,76 & 535,35 & 128,84 & 129,70 \\
\hline \hline Média & $\mathbf{2 5 , 7 7}$ & $\mathbf{2 5 , 7 7}$ & - & $\mathbf{1 2 9 , 2 0}$ & $\mathbf{1 3 0 , 3 5}$ \\
Desvio Padrão & 0,40 & 0,30 & - & 0,49 & 0,35 \\
CV (\%) & 1,55 & 1,17 & - & 0,38 & 0,27 \\
\hline \hline
\end{tabular}

Tabela B.11 - Resultados para espessuras e dimensões dos furos dos meios-blocos de 4,0 MPa e $140 \mathrm{~mm}$

\begin{tabular}{cccc|cc}
\hline \hline Meio-bloco & \multicolumn{3}{c|}{ Espessura (mm) } & \multicolumn{2}{c}{ Dimensão dos Furos (mm) } \\
\cline { 2 - 6 } (4,0 MPa e & Paredes & Paredes & Transversal & \multirow{2}{*}{ Longitudinal } & Transversal \\
140 mm) & Longitudinais & Transversais & Equivalente & & \\
\hline \hline MBL 1 & 25,31 & 25,45 & 535,04 & 131,50 & 79,90 \\
MBL 2 & 25,73 & 25,25 & 528,51 & 130,80 & 79,10 \\
MBL 3 & 25,00 & 25,32 & 532,29 & 131,80 & 78,60 \\
MBL 4 & 25,70 & 25,13 & 526,64 & 130,70 & 78,60 \\
MBL 5 & 25,08 & 25,18 & 528,90 & 130,40 & 79,10 \\
MBL 6 & 24,80 & 25,38 & 532,34 & 130,40 & 80,80 \\
\hline \hline Média & $\mathbf{2 5 , 2 7}$ & $\mathbf{2 5 , 2 8}$ & - & $\mathbf{1 3 0 , 9 3}$ & $\mathbf{7 9 , 3 5}$ \\
Desvio Padrão & 0,38 & 0,12 & - & 0,59 & 0,85 \\
CV (\%) & 1,50 & 0,48 & - & 0,45 & 1,08 \\
\hline \hline
\end{tabular}

Tabela B.12 - Resultados para espessuras e dimensões dos furos dos meios-blocos de 4,0 MPa e $190 \mathrm{~mm}$

\begin{tabular}{cccc|cc}
\hline \hline Meio-bloco & \multicolumn{3}{c|}{ Espessura (mm) } & \multicolumn{2}{c}{ Dimensão dos Furos (mm) } \\
\cline { 2 - 5 } $\begin{array}{c}\mathbf{4}, \mathbf{0} \text { MPa e } \\
\text { 190 mm) }\end{array}$ & $\begin{array}{c}\text { Paredes } \\
\text { Longitudinais }\end{array}$ & $\begin{array}{c}\text { Paredes } \\
\text { Transversais }\end{array}$ & $\begin{array}{c}\text { Transversal } \\
\text { Equivalente }\end{array}$ & Longitudinal & Transversal \\
\hline \hline MBL 1 & 25,60 & 25,60 & 539,42 & 126,60 & 128,50 \\
MBL 2 & 25,78 & 26,10 & 550,92 & 127,50 & 127,90 \\
MBL 3 & 25,70 & 25,68 & 540,53 & 128,20 & 128,40 \\
MBL 4 & 25,65 & 26,03 & 549,15 & 127,90 & 129,00 \\
MBL 5 & 25,53 & 25,58 & 536,26 & 128,00 & 128,20 \\
MBL 6 & 25,18 & 25,88 & 543,97 & 128,60 & 128,50 \\
\hline \hline Média & $\mathbf{2 5 , 5 7}$ & $\mathbf{2 5 , 8 1}$ & - & $\mathbf{1 2 7 , 8 0}$ & $\mathbf{1 2 8 , 4 2}$ \\
Desvio Padrão & 0,21 & 0,22 & - & 0,69 & 0,37 \\
CV (\%) & 0,83 & 0,87 & - & 0,54 & 0,28 \\
\hline
\end{tabular}




\section{Propriedades geométricas - área bruta e área líquida}

Tabela B.13 - Resultados de área bruta e área liquida dos blocos de 10,0 MPa e 140 mm

\begin{tabular}{|c|c|c|c|c|c|c|}
\hline \multirow{2}{*}{$\begin{array}{c}\text { Bloco } \\
(10,0 \text { MPa e } \\
140 \mathrm{~mm})\end{array}$} & \multicolumn{2}{|c|}{ Massas (g) } & \multirow{2}{*}{$\begin{array}{c}\text { Altura } \\
(\mathrm{mm})\end{array}$} & \multicolumn{2}{|c|}{ Áreas $\left(\mathrm{mm}^{2}\right)$} & \multirow{2}{*}{$\begin{array}{c}A_{\text {liq }} / A_{\text {bruta }} \\
\quad(\%)\end{array}$} \\
\hline & Saturada (g) & Aparente (g) & & Área Bruta & Área Líquida & \\
\hline BL 1 & 12864,00 & 7443,00 & 19191,17 & 254316,40 & 28357,45 & $\overline{52,21}$ \\
\hline BL 2 & 12860,00 & 7476,00 & 189,17 & 54350,22 & 28461,67 & 52,37 \\
\hline BL 3 & 12785,00 & 7402,00 & 190,33 & 54399,46 & 28281,96 & 51,99 \\
\hline BL 4 & 12792,00 & 7399,00 & 190,13 & 54365,82 & 28364,31 & 52,17 \\
\hline BL 5 & 12858,00 & 7458,00 & 190,50 & 54418,25 & 28346,46 & 52,09 \\
\hline BL 6 & 12861,00 & 7446,00 & 191,17 & 54306,20 & 28326,07 & 52,16 \\
\hline "Média & 1212836,67 & 7437,33 & - & $\begin{array}{l}54359,39 \\
\end{array}$ & 28356,32 & $\overline{52,16}$ \\
\hline Desvio Padrão & 37,43 & 30,81 & - & 44,43 & 59,51 & 0,13 \\
\hline CV (\%) & 0,29 & 0,41 & - & 0,08 & 0,21 & 0,24 \\
\hline
\end{tabular}

Tabela B.14 - Resultados de área bruta e área liquida dos blocos de 10,0 MPa e 190 mm

\begin{tabular}{|c|c|c|c|c|c|c|}
\hline \multirow{2}{*}{$\begin{array}{c}\text { Bloco } \\
(10,0 \mathrm{MPa} \text { e } \\
190 \mathrm{~mm}) \\
\end{array}$} & \multicolumn{2}{|c|}{ Massas (g) } & \multirow{2}{*}{$\begin{array}{c}\text { Altura } \\
(\mathrm{mm})\end{array}$} & \multicolumn{2}{|c|}{ Áreas $\left(\mathrm{mm}^{2}\right)$} & \multirow{2}{*}{$\begin{array}{c}A_{\text {liq }} / A_{\text {bruto }} \\
\quad(\%)\end{array}$} \\
\hline & Saturada (g) & Aparente (g) & & Área Bruta & Área Líquida & \\
\hline BL 1 & 18428,00 & 10862,00 & 191,67 & 75036,08 & 39474,78 & 52,61 \\
\hline BL 2 & 18298,00 & 10777,00 & 192,17 & 74905,47 & 39137,90 & 52,25 \\
\hline BL 3 & 18333,00 & 10825,00 & 191,33 & 74808,33 & 39240,42 & 52,45 \\
\hline BL 4 & 18211,00 & 10690,00 & 192,00 & 74841,75 & 39171,88 & 52,34 \\
\hline BL 5 & 18410,00 & 10884,00 & 191,83 & 74996,29 & 39231,97 & 52,31 \\
\hline BL 6 & 18254,00 & 10758,00 & 192,17 & 74754,04 & 39007,81 & 52,18 \\
\hline Média & 18322,33 & 10799,33 & - & 74890,33 & 39210,79 & 52,36 \\
\hline Desvio Padrão & 85,58 & 71,99 & - & 109,87 & 154,30 & 0,15 \\
\hline $\mathrm{CV}(\%)$ & 0,47 & 0,67 & - & 0,15 & 0,39 & 0,29 \\
\hline
\end{tabular}

Tabela B.15 - Resultados de área bruta e área liquida dos blocos de 4,0 MPa e $140 \mathrm{~mm}$

\begin{tabular}{|c|c|c|c|c|c|c|}
\hline \multirow{2}{*}{$\begin{array}{c}\text { Bloco } \\
(4,0 \mathrm{MPa} \text { e } \\
140 \mathrm{~mm}) \\
\end{array}$} & \multicolumn{2}{|c|}{ Massas (g) } & \multirow{2}{*}{$\begin{array}{c}\text { Altura } \\
(\mathrm{mm})\end{array}$} & \multicolumn{2}{|c|}{ Áreas $\left(\mathrm{mm}^{2}\right)$} & \multirow{2}{*}{$\begin{array}{c}A_{\text {liq }} / A_{\text {brutc }} \\
\quad(\%)\end{array}$} \\
\hline & Saturada (g) & Aparente (g) & & Área Bruta & Área Líquida & \\
\hline BL 1 & 12335,00 & 6980,00 & 189,67 & 54254,59 & 28233,74 & 52,04 \\
\hline BL 2 & 12408,00 & 7078,00 & 189,33 & 54365,41 & 28151,41 & 51,78 \\
\hline BL 3 & 12345,00 & 7045,00 & 189,57 & 54289,91 & 27958,50 & 51,50 \\
\hline BL 4 & 12405,00 & 7035,00 & 189,83 & 54404,10 & 28287,97 & 52,00 \\
\hline BL 5 & 12588,00 & 7206,00 & 190,17 & 54346,69 & 28301,49 & 52,08 \\
\hline BL 6 & 12678,00 & 7277,00 & 190,23 & 54359,50 & 28391,45 & 52,23 \\
\hline Média & 12459,83 & 7103,50 & - & 54336,70 & 28220,76 & 51,94 \\
\hline Desvio Padrão & 140,35 & 113,69 & - & 54,62 & 150,95 & 0,26 \\
\hline $\mathrm{CV}(\%)$ & 1,13 & 1,60 & - & 0,10 & 0,53 & 0,50 \\
\hline
\end{tabular}


Tabela B.16 - Resultados de área bruta e área liquida dos blocos de 4,0 MPa e 190 mm

\begin{tabular}{|c|c|c|c|c|c|c|}
\hline \multirow{2}{*}{$\begin{array}{c}\text { Bloco } \\
(4,0 \mathrm{MPa} \text { e } \\
190 \mathrm{~mm}) \\
\end{array}$} & \multicolumn{2}{|c|}{ Massas (g) } & \multirow{2}{*}{$\begin{array}{c}\text { Altura } \\
(\mathrm{mm})\end{array}$} & \multicolumn{2}{|c|}{ Áreas $\left(\mathrm{mm}^{2}\right)$} & \multirow{2}{*}{$\begin{array}{c}A_{\text {liq }} / A_{\text {bruta }} \\
\quad(\%)\end{array}$} \\
\hline & Saturada (g) & Aparente (g) & & Área Bruta & Área Líquida & \\
\hline 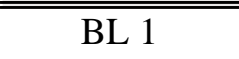 & 17034,00 & 9766,00 & 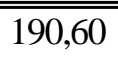 & 74317,82 & 38132,21 & "51,31 \\
\hline BL 2 & 17035,00 & 9695,00 & 190,37 & 74461,99 & 38557,17 & 51,78 \\
\hline BL 3 & 16804,00 & 9525,00 & 189,47 & 74403,89 & 38418,37 & 51,63 \\
\hline BL 4 & 16756,00 & 9530,00 & 189,83 & 74165,00 & 38064,97 & 51,32 \\
\hline BL 5 & 17146,00 & 9790,00 & 191,10 & 74195,00 & 38492,94 & 51,88 \\
\hline BL 6 & 16908,00 & 9615,00 & 190,50 & 74193,19 & 38283,46 & 51,60 \\
\hline Média & 16947,17 & 9653,50 & - & 74289,48 & 38324,85 & 51,59 \\
\hline Desvio Padrão & 150,58 & 115,12 & - & 124,37 & 198,66 & 0,23 \\
\hline $\mathrm{CV}(\%)$ & 0,89 & 1,19 & - & 0,17 & 0,52 & 0,45 \\
\hline
\end{tabular}

Tabela B.17 - Resultados de área bruta e área liquida dos meios-blocos de 10,0 MPa e 140 m

\begin{tabular}{|c|c|c|c|c|c|c|}
\hline \multirow{2}{*}{$\begin{array}{c}\text { Meio-bloco } \\
(10,0 \text { MPa e } \\
140 \mathrm{~mm})\end{array}$} & \multicolumn{2}{|c|}{ "Massas (g) } & \multirow{2}{*}{$\begin{array}{l}\text { Altura } \\
(\mathrm{mm})\end{array}$} & \multicolumn{2}{|c|}{ Áreas $\left(\mathrm{mm}^{2}\right)$} & \multirow{2}{*}{$\begin{array}{c}A_{\text {liq }} / A_{\text {bruta }} \\
\quad \%)\end{array}$} \\
\hline & Saturada (g) & Aparente (g) & & Área Bruta & Área Líquida & \\
\hline MBL 1 & 6655,00 & 3864,00 & 189,17 & 26435,67 & 14754,19 & 55,81 \\
\hline MBL 2 & 6867,00 & 4018,00 & 191,17 & 26509,87 & 14903,23 & 56,22 \\
\hline MBL 3 & 6857,00 & 3988,00 & 191,17 & 26495,70 & 15007,85 & 56,64 \\
\hline MBL 4 & 6908,00 & 4035,00 & 191,33 & 26398,84 & 15015,68 & 56,88 \\
\hline MBL 5 & 6785,00 & 3943,00 & 191,67 & 26294,20 & 14827,83 & 56,39 \\
\hline MBL 6 & 6961,00 & 4085,00 & 192,17 & 26442,99 & 14966,18 & 56,60 \\
\hline Média & $6 \mathbf{6 8 3 8 , 8 3}$ & 3988,83 & - & 26429,55 & 14912,49 & 56,42 \\
\hline Desvio Padrão & 107,26 & 77,35 & - & 77,85 & 104,82 & 0,38 \\
\hline $\mathrm{CV}(\%)$ & 1,57 & 1,94 & - & 0,29 & 0,70 & 0,67 \\
\hline
\end{tabular}

Tabela B.18 - Resultados de área bruta e área liquida dos meios-blocos de 10,0 MPa e 190 mm

\begin{tabular}{|c|c|c|c|c|c|c|}
\hline \multirow{2}{*}{$\begin{array}{c}\text { Meio-bloco } \\
(10,0 \mathrm{MPa} \text { e } \\
190 \mathrm{~mm})\end{array}$} & \multicolumn{2}{|c|}{ Massas (g) } & \multirow{2}{*}{$\begin{array}{l}\text { Altura } \\
(\mathrm{mm})\end{array}$} & \multicolumn{2}{|c|}{ Áreas $\left(\mathrm{mm}^{2}\right)$} & \multirow{2}{*}{$\begin{array}{c}A_{\text {liq }} / A_{\text {bruta }} \\
(\%)\end{array}$} \\
\hline & Saturada (g) & Aparente (g) & & Área Bruta & Área Líquida & \\
\hline MBL 1 & 8256,00 & 4863,00 & 189,90 & 36685,00 & 17867,30 & 48,70 \\
\hline MBL 2 & 8258,00 & 4885,00 & 189,73 & 36640,33 & 17777,58 & 48,52 \\
\hline MBL 3 & 8575,00 & 5116,00 & 191,33 & 36902,41 & 18078,40 & 48,99 \\
\hline MBL 4 & 8408,00 & 4994,00 & 190,67 & 36704,11 & 17905,59 & 48,78 \\
\hline MBL 5 & 8226,00 & 4859,00 & 189,33 & 36608,19 & 17783,45 & 48,58 \\
\hline MBL 6 & 8480,00 & 5036,00 & 189,67 & 36915,13 & 18158,17 & 49,19 \\
\hline Média & 8367,17 & 4958,83 & - & 36742,53 & 17928,42 & 48,79 \\
\hline Desvio Padrão & 142,69 & 106,30 & - & 133,14 & 157,04 & 0,25 \\
\hline $\mathrm{CV}(\%)$ & 1,71 & 2,14 & - & 0,36 & 0,88 & 0,52 \\
\hline
\end{tabular}


Tabela B.19 - Resultados de área bruta e área liquida dos meios-blocos de 4,0 MPa e $140 \mathrm{~mm}$

\begin{tabular}{|c|c|c|c|c|c|c|}
\hline \multirow{2}{*}{$\begin{array}{c}\text { Meio-bloco } \\
(4,0 \mathrm{MPa} \text { e } \\
140 \mathrm{~mm})\end{array}$} & \multicolumn{2}{|c|}{ Massas (g) } & \multirow{2}{*}{$\begin{array}{l}\text { Altura } \\
(\mathrm{mm})\end{array}$} & \multicolumn{2}{|c|}{ Áreas $\left(\mathrm{mm}^{2}\right)$} & \multirow{2}{*}{$\begin{array}{c}A_{\text {liq }} / A_{\text {bruta }} \\
\quad(\%)\end{array}$} \\
\hline & Saturada (g) & Aparente (g) & & Área Bruta & Área Líquida & \\
\hline MBL 1 & 6548,00 & 3773,00 & 188,50 & 26259,97 & 14721,49 & 56,06 \\
\hline MBL 2 & 6492,00 & 3718,00 & 187,67 & 26494,58 & 14781,53 & 55,79 \\
\hline MBL 3 & 6382,00 & 3650,00 & 188,00 & 26150,74 & 14531,91 & 55,57 \\
\hline MBL 4 & 6521,00 & 3737,00 & 188,00 & 26500,39 & 14808,51 & 55,88 \\
\hline MBL 5 & 6541,00 & 3770,00 & 187,67 & 26375,02 & 14765,54 & 55,98 \\
\hline MBL 6 & 6473,00 & 3719,00 & 188,17 & 26248,44 & 14635,96 & 55,76 \\
\hline Média & $\overline{6492,83}$ & $\mathbf{3 7 2 7 , 8 3}$ & 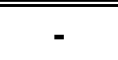 & 26338,19 & 14707,49 & $\overline{55,84}$ \\
\hline Desvio Padrão & 61,38 & 45,02 & - & 142,43 & 105,07 & 0,17 \\
\hline $\mathrm{CV}(\%)$ & 0,95 & 1,21 & - & 0,54 & 0,71 & 0,31 \\
\hline
\end{tabular}

Tabela B.20 - Resultados de área bruta e área liquida dos meios-blocos de 4,0 MPa e 190 mm

\begin{tabular}{|c|c|c|c|c|c|c|}
\hline \multirow{2}{*}{$\begin{array}{c}\text { Meio-bloco } \\
(4,0 \mathrm{MPa} \text { e } \\
190 \mathrm{~mm})\end{array}$} & \multicolumn{2}{|c|}{ Massas (g) } & \multirow{2}{*}{$\begin{array}{l}\text { Altura } \\
(\mathrm{mm})\end{array}$} & \multicolumn{2}{|c|}{ Áreas $\left(\mathrm{mm}^{2}\right)$} & \multirow{2}{*}{$\begin{array}{c}A_{\text {liq }} / A_{\text {bruta }} \\
(\%)\end{array}$} \\
\hline & Saturada (g) & Aparente (g) & & Área Bruta & Área Líquida & \\
\hline "MBL 1 & 7917,00 & "4506,00 & 191,67 & 36137,94 & 17796,52 & 499,25 \\
\hline MBL 2 & 7949,00 & 4526,00 & 191,23 & 35948,15 & 17899,60 & 49,79 \\
\hline MBL 3 & 7873,00 & 4469,00 & 190,33 & 35910,00 & 17884,41 & 49,80 \\
\hline MBL 4 & 7937,00 & 4512,00 & 190,03 & 35973,43 & 18023,15 & 50,10 \\
\hline MBL 5 & 8006,00 & 4564,00 & 190,60 & 36277,46 & 18058,76 & 49,78 \\
\hline MBL 6 & 7896,00 & 4499,00 & 189,87 & 36163,35 & 17891,50 & 49,47 \\
\hline Média & 7929,67 & 4512,67 & - & 36068,39 & 17925,66 & 49,70 \\
\hline Desvio Padrão & 46,39 & 31,47 & - & 145,69 & 97,41 & 0,30 \\
\hline $\mathrm{CV}(\%)$ & 0,58 & 0,70 & - & 0,40 & 0,54 & 0,60 \\
\hline
\end{tabular}

\section{Propriedades físicas - absorção}

Tabela B.21 - Resultados da absorção das unidades de 10,0 MPa e 140 mm

\begin{tabular}{|c|c|c|c|c|c|c|c|}
\hline \multirow{2}{*}{$\begin{array}{c}\text { Bloco } \\
(10,0 \mathrm{MPa} \text { e } \\
140 \mathrm{~mm})\end{array}$} & \multicolumn{2}{|c|}{ Massas (g) } & \multirow[b]{2}{*}{$\begin{array}{c}\text { Absorção } \\
(\%)\end{array}$} & \multirow{2}{*}{$\begin{array}{c}\text { Meio-bloco } \\
(10,0 \mathrm{MPa} \text { e } \\
140 \mathrm{~mm})\end{array}$} & \multicolumn{2}{|c|}{ Massas (g) } & \multirow{2}{*}{$\begin{array}{c}\text { Absorção } \\
(\%)\end{array}$} \\
\hline & Seca $(g)$ & $\begin{array}{c}\text { Saturada } \\
(\mathrm{g})\end{array}$ & & & Seca $(g)$ & $\begin{array}{c}\text { Saturada } \\
(\mathrm{g})\end{array}$ & \\
\hline BL 1 & 12311,00 & 1212864,00 & "4,49 & 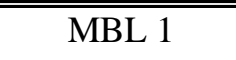 & 6326,00 & 6655,00 & (5,20 \\
\hline BL 2 & 12365,00 & 12860,00 & 4,00 & MBL 2 & 6547,00 & 6867,00 & 4,89 \\
\hline BL 3 & 12237,00 & 12785,00 & 4,48 & MBL 3 & 6523,00 & 6857,00 & 5,12 \\
\hline BL 4 & 12242,00 & 12792,00 & 4,49 & MBL 4 & 6584,00 & 6908,00 & 4,92 \\
\hline BL 5 & 12337,00 & 12858,00 & 4,22 & MBL 5 & 6466,00 & 6785,00 & 4,93 \\
\hline BL 6 & 12289,00 & 12861,00 & 4,65 & MBL 6 & 6650,00 & 6961,00 & 4,68 \\
\hline Média & 12296,83 & 12836,67 & 4,39 & Média & 6516,00 & 6838,83 & 4,96 \\
\hline Desvio Padrão & 51,20 & 37,43 & 0,24 & Desvio Padrão & 111,53 & 107,26 & 0,19 \\
\hline $\mathrm{CV}(\%)$ & 0,42 & 0,29 & 5,35 & $\mathrm{CV}(\%)$ & 1,71 & 1,57 & 3,73 \\
\hline
\end{tabular}


Tabela B.22 - Resultados da absorção das unidades de 10,0 MPa e 190 mm

\begin{tabular}{|c|c|c|c|c|c|c|c|}
\hline \multirow{2}{*}{$\begin{array}{c}\text { Bloco } \\
(10,0 \mathrm{MPa} \text { e } \\
190 \mathrm{~mm}) \\
\end{array}$} & \multicolumn{2}{|c|}{ Massas (g) } & \multirow{2}{*}{$\begin{array}{c}\text { Absorção } \\
(\%)\end{array}$} & \multirow{2}{*}{$\begin{array}{c}\text { Meio-bloco } \\
\text { (10,0 MPa e } \\
190 \mathrm{~mm})\end{array}$} & \multicolumn{2}{|c|}{ Massas (g) } & \multirow{2}{*}{$\begin{array}{c}\text { Absorção } \\
(\%)\end{array}$} \\
\hline & $\operatorname{Seca}(g)$ & $\begin{array}{c}\text { Saturada } \\
(\mathrm{g})\end{array}$ & & & Seca $(g)$ & $\begin{array}{l}\text { Saturada } \\
(\mathrm{g})\end{array}$ & \\
\hline BL 1 & 17758,00 & 18428,00 & 3,77 & MBL 1 & 7978,00 & 8256,00 & 3,48 \\
\hline BL 2 & 17633,00 & 18298,00 & 3,77 & MBL 2 & 8061,00 & 8258,00 & 2,44 \\
\hline BL 3 & 17778,00 & 18333,00 & 3,12 & MBL 3 & 8360,00 & 8575,00 & 2,57 \\
\hline BL 4 & 17575,00 & 18211,00 & 3,62 & MBL 4 & 8216,00 & 8408,00 & 2,34 \\
\hline BL 5 & 17794,00 & 18410,00 & 3,46 & MBL 5 & 7993,00 & 8226,00 & 2,92 \\
\hline BL 6 & 17647,00 & 18254,00 & 3,44 & MBL 6 & 8332,00 & 8480,00 & 1,78 \\
\hline Média & 17697,50 & 18322,33 & 3,53 & Média & 8156,67 & 8367,17 & 2,59 \\
\hline Desvio Padrão & 90,74 & 85,58 & 0,25 & Desvio Padrão & 169,39 & 142,69 & 0,58 \\
\hline $\mathrm{CV}(\%)$ & 0,51 & 0,47 & 6,99 & $\mathrm{CV}(\%)$ & 2,08 & 1,71 & 22,22 \\
\hline
\end{tabular}

Tabela B.23 - Resultados da absorção das unidades de 4,0 MPa e 140 mm

\begin{tabular}{|c|c|c|c|c|c|c|c|}
\hline \multirow{2}{*}{$\begin{array}{c}\text { Bloco } \\
(4,0 \mathrm{MPa} \text { e } \\
140 \mathrm{~mm})\end{array}$} & \multicolumn{2}{|c|}{ Massas (g) } & \multirow{2}{*}{$\begin{array}{c}\text { Absorção } \\
(\%)\end{array}$} & \multirow{2}{*}{$\begin{array}{c}\text { Meio-bloco } \\
(4,0 \mathrm{MPa} \text { e } \\
140 \mathrm{~mm})\end{array}$} & \multicolumn{2}{|c|}{ Massas (g) } & \multirow{2}{*}{$\begin{array}{c}\text { Absorção } \\
(\%)\end{array}$} \\
\hline & Seca $(g)$ & $\begin{array}{c}\text { Saturada } \\
(\mathrm{g})\end{array}$ & & & Seca $(g)$ & $\begin{array}{c}\text { Saturada } \\
(\mathrm{g})\end{array}$ & \\
\hline BL 1 & 11523,00 & 12335,00 & 7,05 & MBL 1 & 6198,00 & 6548,00 & 5,65 \\
\hline BL 2 & 11662,00 & 12408,00 & 6,40 & MBL 2 & 6116,00 & 6492,00 & 6,15 \\
\hline BL 3 & 11583,00 & 12345,00 & 6,58 & MBL 3 & 6012,00 & 6382,00 & 6,15 \\
\hline BL 4 & 11600,00 & 12405,00 & 6,94 & MBL 4 & 6147,00 & 6521,00 & 6,08 \\
\hline BL 5 & 11834,00 & 12588,00 & 6,37 & MBL 5 & 6170,00 & 6541,00 & 6,01 \\
\hline BL 6 & 11910,00 & 12678,00 & 6,45 & MBL 6 & 6122,00 & 6473,00 & 5,73 \\
\hline Média & 11685,33 & 12459,83 & 6,63 & Média & 6127,50 & 6492,83 & 5,96 \\
\hline Desvio Padrão & 153,12 & 140,35 & 0,29 & Desvio Padrão & 64,28 & 61,38 & 0,22 \\
\hline $\mathrm{CV}(\%)$ & 1,31 & 1,13 & 4,40 & $\mathrm{CV}(\%)$ & 1,05 & 0,95 & 3,68 \\
\hline
\end{tabular}

Tabela B.24 - Resultados da absorção das unidades de 4,0 MPa e 190 mm

\begin{tabular}{|c|c|c|c|c|c|c|c|}
\hline \multirow{2}{*}{$\begin{array}{c}\text { Bloco } \\
(4,0 \mathrm{MPa} \text { e } \\
190 \mathrm{~mm}) \\
\end{array}$} & \multicolumn{2}{|c|}{ Massas (g) } & \multirow{2}{*}{$\begin{array}{c}\text { Absorção } \\
(\%)\end{array}$} & \multirow{2}{*}{$\begin{array}{c}\text { Meio-bloco } \\
(4,0 \mathrm{MPa} \text { e } \\
190 \mathrm{~mm}) \\
\end{array}$} & \multicolumn{2}{|c|}{ Massas (g) } & \multirow{2}{*}{$\begin{array}{c}\text { Absorção } \\
(\%)\end{array}$} \\
\hline & Seca $(g)$ & $\begin{array}{c}\text { Saturada } \\
(\mathrm{g})\end{array}$ & & & Seca $(g)$ & $\begin{array}{c}\text { Saturada } \\
(\mathrm{g})\end{array}$ & \\
\hline$\overline{\text { BL } 1}$ & $\begin{array}{l}15986,00 \\
\end{array}$ & 1717034,00 & 6,56 & "MBL 1 & $7 \overline{7387,00}$ & 7917,00 & 7,17 \\
\hline BL 2 & 15917,00 & 17035,00 & 7,02 & MBL 2 & 7415,00 & 7949,00 & 7,20 \\
\hline BL 3 & 15653,00 & 16804,00 & 7,35 & MBL 3 & 7281,00 & 7873,00 & 8,13 \\
\hline BL 4 & 15660,00 & 16756,00 & 7,00 & MBL 4 & 7391,00 & 7937,00 & 7,39 \\
\hline BL 5 & 16065,00 & 17146,00 & 6,73 & MBL 5 & 7465,00 & 8006,00 & 7,25 \\
\hline BL 6 & 15754,00 & 16908,00 & 7,33 & MBL 6 & 7363,00 & 7896,00 & 7,24 \\
\hline Média & $15 \mathbf{1 5 8 3 9 , 1 7}$ & 16947,17 & $\overline{77,00}$ & Média & 7383,67 & 79929,67 & $\overline{77,40}$ \\
\hline Desvio Padrão & 174,72 & 150,58 & 0,32 & Desvio Padrão & 61,04 & 46,39 & 0,37 \\
\hline $\mathrm{CV}(\%)$ & 1,10 & 0,89 & 4,53 & $\mathrm{CV}(\%)$ & 0,83 & 0,58 & 4,96 \\
\hline
\end{tabular}




\section{Propriedades mecânicas - resistência à compressão das unidades}

Tabela B.25 - Resultados de resistência à compressão das unidades de 10,0 MPa e $140 \mathrm{~mm}$

\begin{tabular}{|c|c|c|c|c|c|c|c|}
\hline $\begin{array}{c}\text { Bloco } \\
(10,0 \mathrm{MPa} \text { e } \\
140 \mathrm{~mm})\end{array}$ & $\begin{array}{c}\text { Força } \\
(\mathrm{kN})\end{array}$ & $\begin{array}{c}\text { Tensão na } \\
\text { Área Bruta } \\
(\mathrm{MPa})\end{array}$ & $\begin{array}{c}\text { Tensão na } \\
\text { Área Líquida } \\
\text { (MPa) }\end{array}$ & $\begin{array}{c}\text { Meio-bloco } \\
(10,0 \mathrm{MPa} \text { e } \\
140 \mathrm{~mm})\end{array}$ & $\begin{array}{c}\text { Força } \\
(\mathrm{kN})\end{array}$ & $\begin{array}{c}\text { Tensão na } \\
\text { Área Bruta } \\
\text { (MPa) }\end{array}$ & $\begin{array}{c}\text { Tensão na } \\
\text { Área } \\
\text { Líquida }\end{array}$ \\
\hline BL 1 & 1172,12 & 21,58 & 41,33 & MBL 1 & 537,35 & 20,33 & 36,42 \\
\hline BL 2 & 1224,10 & 22,52 & 43,01 & MBL 2 & 478,34 & 18,04 & 32,10 \\
\hline BL 3 & 1169,60 & 21,50 & 41,35 & MBL 3 & 512,67 & 19,35 & 34,16 \\
\hline BL 4 & 1155,51 & 21,25 & 40,74 & MBL 4 & 409,49 & 15,51 & 27,27 \\
\hline BL 5 & 1324,67 & 24,34 & 46,73 & MBL 5 & 437,90 & 16,65 & 29,53 \\
\hline BL 6 & 1140,60 & 21,00 & 40,27 & MBL 6 & 535,85 & 20,26 & 35,80 \\
\hline Média & 1197,77 & 22,03 & 42,24 & Média & 485,27 & 18,36 & 32,55 \\
\hline Desvio Padrão & 68,27 & 1,24 & 2,39 & Desvio Padrão & 53,02 & 1,98 & 3,61 \\
\hline $\mathrm{CV}(\%)$ & 5,70 & 5,64 & 5,65 & $\mathrm{CV}(\%)$ & 10,93 & 10,78 & 11,11 \\
\hline$f_{\mathrm{bk}}(\mathrm{MPa})$ & & 20,76 & 39,65 & $f_{\mathrm{bk}}(\mathrm{MPa})$ & & 14,12 & 24,71 \\
\hline
\end{tabular}

Tabela B.26 - Resultados de resistência à compressão das unidades de 10,0 MPa e 190 mm

\begin{tabular}{|c|c|c|c|c|c|c|c|}
\hline $\begin{array}{c}\text { Bloco } \\
(10,0 \mathrm{MPa} \text { e } \\
190 \mathrm{~mm}) \\
\end{array}$ & $\begin{array}{c}\text { Força } \\
(\mathrm{kN})\end{array}$ & $\begin{array}{c}\text { Tensão na } \\
\text { Área Bruta } \\
(\mathrm{MPa})\end{array}$ & $\begin{array}{c}\text { Tensão na } \\
\text { Área Líquida } \\
(\mathrm{MPa})\end{array}$ & $\begin{array}{c}\text { Meio-bloco } \\
(10,0 \mathrm{MPa} \text { e } \\
190 \mathrm{~mm}) \\
\end{array}$ & $\begin{array}{c}\text { Força } \\
(\mathrm{kN})\end{array}$ & $\begin{array}{c}\text { Tensão na } \\
\text { Área Bruta } \\
(\mathrm{MPa})\end{array}$ & $\begin{array}{c}\text { Tensão na } \\
\text { Área } \\
\text { Líquida } \\
\end{array}$ \\
\hline BL 1 & 1397,00 & 18,62 & 35,39 & MBL 1 & 912,37 & 24,87 & 51,06 \\
\hline BL 2 & 1568,00 & 20,93 & 40,06 & MBL 2 & 909,36 & 24,82 & 51,15 \\
\hline BL 3 & 1550,00 & 20,72 & 39,50 & MBL 3 & 984,16 & 26,67 & 54,44 \\
\hline BL 4 & 1502,00 & 20,07 & 38,34 & MBL 4 & 966,46 & 26,33 & 53,98 \\
\hline BL 5 & 1408,00 & 18,77 & 35,89 & MBL 5 & 900,63 & 24,60 & 50,64 \\
\hline BL 6 & 1541,00 & 20,61 & 39,50 & MBL 6 & 1134,46 & 30,73 & 62,48 \\
\hline Média & 1494,33 & 19,95 & 38,12 & Média & 967,91 & 26,34 & 53,96 \\
\hline Desvio Padrão & 74,42 & 1,02 & 2,00 & Desvio Padrão & 88,37 & 2,32 & 4,47 \\
\hline $\mathrm{CV}(\%)$ & 4,98 & 5,10 & 5,26 & $\mathrm{CV}(\%)$ & 9,13 & 8,81 & 8,29 \\
\hline$f_{\mathrm{bk}}(\mathrm{MPa})$ & & 17,32 & 32,93 & $f_{\mathrm{bk}}(\mathrm{MPa})$ & & 24,55 & 50,73 \\
\hline
\end{tabular}

Tabela B.27 - Resultados de resistência à compressão das unidades de 4,0 MPa e 140 mm

\begin{tabular}{|c|c|c|c|c|c|c|c|}
\hline $\begin{array}{c}\text { Bloco } \\
(4,0 \mathrm{MPa} \text { e } \\
140 \mathrm{~mm})\end{array}$ & $\begin{array}{c}\text { Força } \\
(\mathrm{kN})\end{array}$ & $\begin{array}{c}\text { Tensão na } \\
\text { Área Bruta } \\
(\mathrm{MPa})\end{array}$ & $\begin{array}{c}\text { Tensão na } \\
\text { Área Líquida } \\
\text { (MPa) }\end{array}$ & $\begin{array}{c}\text { Meio-bloco } \\
(4,0 \mathrm{MPa} \text { e } \\
140 \mathrm{~mm})\end{array}$ & $\begin{array}{c}\text { Força } \\
(\mathrm{kN})\end{array}$ & $\begin{array}{c}\text { Tensão na } \\
\text { Área Bruta } \\
\text { (MPa) }\end{array}$ & $\begin{array}{c}\text { Tensão na } \\
\text { Área } \\
\text { Líquida }\end{array}$ \\
\hline BL 1 & 338,53 & 6,24 & 11,99 & MBL 1 & 254,29 & 9,68 & 17,27 \\
\hline BL 2 & 433,67 & 7,98 & 15,40 & MBL 2 & 288,59 & 10,89 & 19,52 \\
\hline BL 3 & 405,47 & 7,47 & 14,50 & MBL 3 & 264,97 & 10,13 & 18,23 \\
\hline BL 4 & 402,81 & 7,40 & 14,24 & MBL 4 & 327,96 & 12,38 & 22,15 \\
\hline BL 5 & 424,66 & 7,81 & 15,00 & MBL 5 & 286,49 & 10,86 & 19,40 \\
\hline BL 6 & 420,24 & 7,73 & 14,80 & MBL 6 & 273,78 & 10,43 & 18,71 \\
\hline Média & 404,23 & $7 \overline{7,44}$ & 14,32 & Média & 282,68 & 10,73 & 19,21 \\
\hline Desvio Padrão & 34,24 & 0,63 & 1,21 & Desvio Padrão & 25,69 & 0,93 & 1,66 \\
\hline $\mathrm{CV}(\%)$ & 8,47 & 8,41 & 8,46 & $\mathrm{CV}(\%)$ & 9,09 & 8,64 & 8,62 \\
\hline$f_{\mathrm{bk}}(\mathbf{M P a})$ & & 6,18 & 11,73 & $f_{\mathrm{bk}}(\mathbf{M P a})$ & & 9,39 & 16,80 \\
\hline
\end{tabular}


Tabela B.28 - Resultados de resistência à compressão das unidades de 4,0 MPa e 190 mm

\begin{tabular}{|c|c|c|c|c|c|c|c|}
\hline $\begin{array}{c}\text { Bloco } \\
(4,0 \mathrm{MPa} \text { e } \\
190 \mathrm{~mm}) \\
\end{array}$ & $\begin{array}{c}\text { Força } \\
(\mathrm{kN})\end{array}$ & $\begin{array}{c}\text { Tensão na } \\
\text { Área Bruta } \\
(\mathrm{MPa})\end{array}$ & $\begin{array}{c}\text { Tensão na } \\
\text { Área Líquida } \\
(\mathrm{MPa})\end{array}$ & $\begin{array}{c}\text { Meio-bloco } \\
(4,0 \mathrm{MPa} \text { e } \\
190 \mathrm{~mm})\end{array}$ & $\begin{array}{c}\text { Força } \\
(\mathrm{kN})\end{array}$ & $\begin{array}{c}\text { Tensão na } \\
\text { Área Bruta } \\
\text { (MPa) }\end{array}$ & $\begin{array}{c}\text { Tensão na } \\
\text { Área } \\
\text { Líquida }\end{array}$ \\
\hline$\overline{B L ~} 1$ & 451,38 & 6,07 & 11,84 & $\overline{M B L} 1$ & 337,57 & 9,34 & 18,97 \\
\hline BL 2 & 462,14 & 6,21 & 11,99 & MBL 2 & 330,23 & 9,19 & 18,45 \\
\hline BL 3 & 411,12 & 5,53 & 10,70 & MBL 3 & 260,49 & 7,25 & 14,57 \\
\hline BL 4 & 423,87 & 5,72 & 11,14 & MBL 4 & 294,18 & 8,18 & 16,32 \\
\hline BL 5 & 495,82 & 6,68 & 12,88 & MBL 5 & 286,37 & 7,89 & 15,86 \\
\hline BL 6 & 413,92 & 5,58 & 10,81 & MBL 6 & 275,12 & 7,61 & 15,38 \\
\hline Média & 443,04 & 5,96 & 11,56 & Média & 297,32 & 8,24 & 16,59 \\
\hline Desvio Padrão & 33,03 & 0,44 & 0,83 & Desvio Padrão & 30,60 & 0,85 & 1,75 \\
\hline $\mathrm{CV}(\%)$ & 7,46 & 7,46 & 7,22 & $\mathrm{CV}(\%)$ & 10,29 & 10,30 & 10,54 \\
\hline$f_{\mathrm{bk}}(\mathrm{MPa})$ & & 5,39 & 10,38 & $f_{\mathrm{bk}}(\mathrm{MPa})$ & & 6,97 & 14,08 \\
\hline
\end{tabular}

\section{Caracterização da argamassa de assentamento}

Tabela B.29 - Resultados de resistência à compressão e módulo de elasticidade da argamassa de assentamento

\begin{tabular}{ccccc}
\hline \hline & \multicolumn{4}{c}{ Resistência à Compressão e Módulo de Elasticidade } \\
& $\begin{array}{c}\text { Força } \\
(\mathrm{kN})\end{array}$ & $\begin{array}{c}\text { Área Média } \\
\left(\mathrm{cm}^{2}\right)\end{array}$ & $\begin{array}{c}\text { Resistência à } \\
\text { Compressão (MPa) }\end{array}$ & $\begin{array}{c}\text { Módulo de } \\
\text { Elasticidade }(\mathrm{GPa})\end{array}$ \\
\cline { 2 - 5 } CP 1 & 25,91 & 13,20 & 16,12 \\
CP 2 & 21,88 & & 11,15 & 13,69 \\
CP 3 & 21,93 & & 11,17 & 14,62 \\
CP 4 & 21,66 & 19,63 & 11,03 & 12,83 \\
CP 5 & 24,17 & & 12,31 & 16,43 \\
CP 6 & 20,51 & & 10,45 & 15,46 \\
\hline Média & $\mathbf{2 2 , 6 8}$ & $\mathbf{1 9 , 6 3}$ & $\mathbf{1 1 , 5 5}$ & $\mathbf{1 4 , 8 6}$ \\
Desvio Padrão & 1,98 & & 1,01 & 1,41 \\
CV (\%) & 8,74 & 8,74 & 9,50 \\
\hline \hline
\end{tabular}

Tabela B.30 - Resultados de resistência à tração por compressão diametral da argamassa de assentamento

\begin{tabular}{ccc}
\hline \hline \multicolumn{3}{c}{ Resistência à Tração por Compressão Diametral } \\
\hline \hline & $\begin{array}{c}\text { Força } \\
(\mathrm{kN})\end{array}$ & $f_{c t, s p}(\mathrm{MPa})$ \\
\cline { 2 - 3 } CP 1 & 8,60 & 1,09 \\
CP 2 & 9,80 & 1,25 \\
CP 3 & 9,20 & 1,17 \\
CP 4 & 10,10 & 1,29 \\
CP 5 & 6,50 & 0,83 \\
CP 6 & 6,50 & 0,83 \\
\hline Média & $\mathbf{8 , 4 5}$ & $\mathbf{1 , 0 8}$ \\
Desvio Padrão & 1,60 & 0,20 \\
CV (\%) & 18,89 & 18,89 \\
\hline \hline
\end{tabular}




\section{Caracterização da alvenaria - Resistência à compressão dos prismas}

Tabela B.31 - Resultados do ensaio de compressão dos prismas de 10,0 MPa e $140 \mathrm{~mm}$

\begin{tabular}{|c|c|c|c|c|c|}
\hline & \multicolumn{5}{|c|}{ Prismas de 10,0 MPa e $140 \mathrm{~mm}$} \\
\hline & $\begin{array}{l}\text { Força } \\
(\mathrm{kN})\end{array}$ & $\begin{array}{c}\text { Área Bruta } \\
\left(\mathrm{cm}^{2}\right)\end{array}$ & $\begin{array}{c}\text { Tensão na Área } \\
\text { Bruta (MPa) }\end{array}$ & $\begin{array}{l}\text { Área Líquida } \\
\qquad\left(\mathrm{cm}^{2}\right)\end{array}$ & $\begin{array}{c}\text { Tensão na Área } \\
\text { Líquida (MPa) }\end{array}$ \\
\hline PRI 1 & 674,53 & \multirow{6}{*}{543,59} & 12,41 & \multirow{6}{*}{283,56} & 23,79 \\
\hline PRI 2 & 766,01 & & 14,09 & & 27,01 \\
\hline PRI 3 & 715,71 & & 13,17 & & 25,24 \\
\hline PRI 4 & 745,17 & & 13,71 & & 26,28 \\
\hline PRI 5 & 720,95 & & 13,26 & & 25,42 \\
\hline PRI 6 & 794,14 & & 14,61 & & 28,01 \\
\hline Média & 736,09 & & 13,54 & & 25,96 \\
\hline Desvio Padrão & 41,91 & & 0,77 & & 1,48 \\
\hline $\mathrm{CV}(\%)$ & 5,69 & & 5,69 & & 5,69 \\
\hline$f_{\mathrm{pk}}(\mathrm{MPa})$ & & & 12,31 & & 23,60 \\
\hline
\end{tabular}

Tabela B.32 - Resultados do ensaio de compressão dos prismas de 10,0 MPa e $140 \mathrm{~mm}$

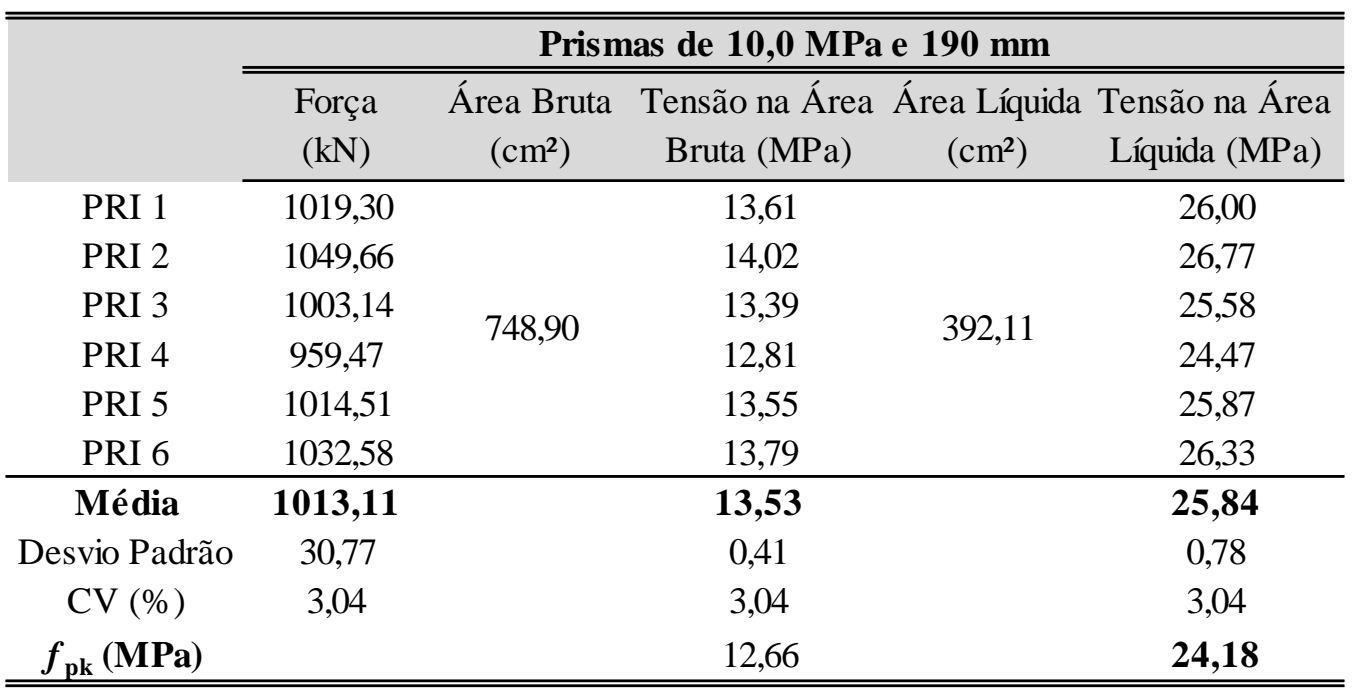

Tabela B.33 - Resultados do ensaio de compressão dos prismas de 10,0 MPa e $140 \mathrm{~mm}$

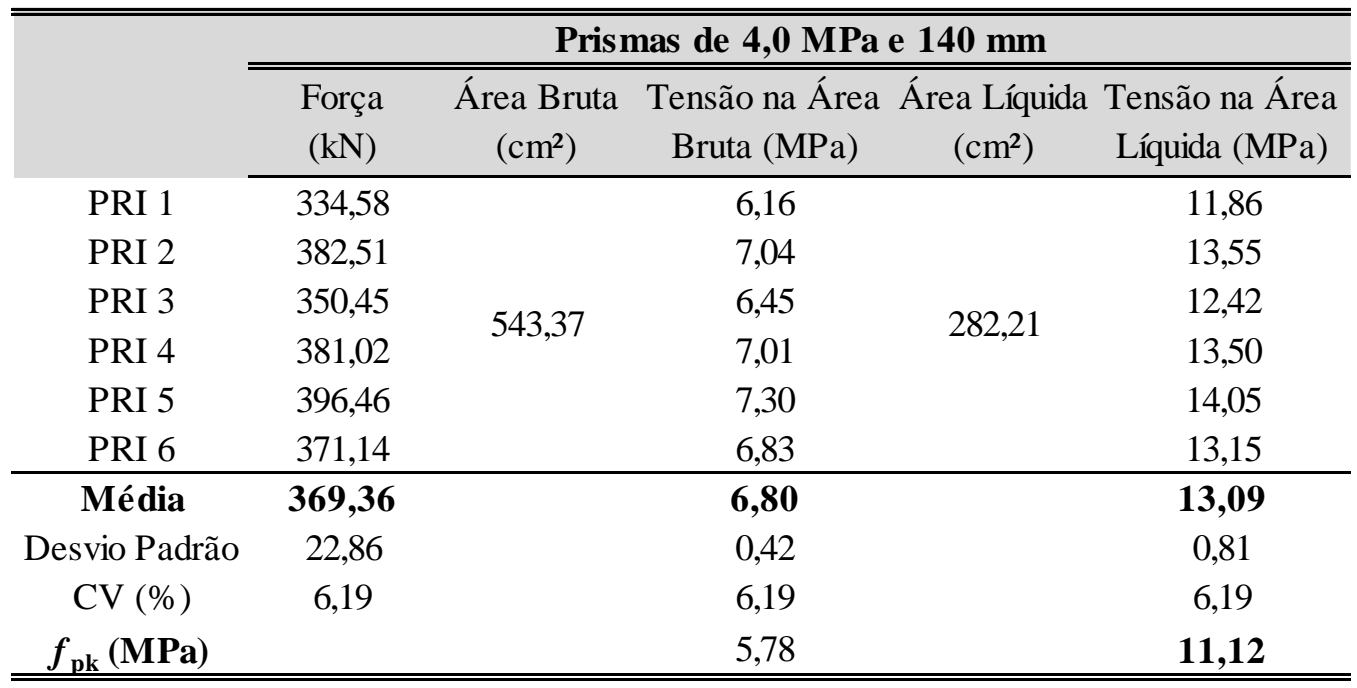


Tabela B.34 - Resultados do ensaio de compressão dos prismas de 10,0 MPa

\begin{tabular}{cccccc}
\hline \hline & \multicolumn{4}{c}{ Prismas de 4,0 MPa e 190 mm } \\
\cline { 2 - 6 } & $\begin{array}{c}\text { Força } \\
(\mathrm{kN})\end{array}$ & $\begin{array}{c}\text { Área Bruta } \\
\left(\mathrm{cm}^{2}\right)\end{array}$ & $\begin{array}{c}\text { Tensão na Área Área Líquida Tensão na Área } \\
\text { Bruta }(\mathrm{MPa})\end{array}$ & $\begin{array}{c}\left(\mathrm{cm}^{2}\right) \\
\text { Líquida (MPa) }\end{array}$ \\
\cline { 2 - 5 } PRI 1 & 366,96 & & 4,94 & & 9,57 \\
PRI 2 & 346,25 & & 4,66 & & 9,03 \\
PRI 3 & 396,22 & 742,89 & 5,33 & 383,25 & 10,34 \\
PRI 4 & 395,45 & & 5,32 & & 10,32 \\
PRI 5 & 388,70 & & 5,23 & & 10,14 \\
PRI 6 & 380,95 & 5,13 & 9,94 \\
\hline Média & $\mathbf{3 7 9 , 0 9}$ & $\mathbf{5 , 1 0}$ & $\mathbf{9 , 8 9}$ \\
Desvio Padrão & 19,40 & 0,26 & & 0,51 \\
CV (\%) & 5,12 & 5,12 & 5,12 \\
$\boldsymbol{f}_{\mathbf{p k}}$ (MPa) & & 4,47 & $\mathbf{8 , 6 7}$ \\
\hline \hline
\end{tabular}

Caracterização da alvenaria - Resistência à compressão e módulo de elasticidade das pequenas paredes

Tabela B.35 - Resultados do ensaio de compressão das pequenas paredes de 10,0 MPa e $140 \mathrm{~mm}$

\begin{tabular}{ccccccc}
\hline \hline \multicolumn{6}{c}{ Ensaio de compressão - Pequenas pare des de 10,0 MPa e 140 mm } \\
\hline \hline & $\begin{array}{c}\text { Força } \\
(\mathrm{kN})\end{array}$ & $\begin{array}{c}\text { Área } \\
\text { Bruta } \\
\left(\mathrm{cm}^{2}\right)\end{array}$ & $\begin{array}{c}\text { Tensão na } \\
\text { Área Bruta } \\
(\mathrm{MPa})\end{array}$ & $\begin{array}{c}\text { Área } \\
\text { Líquida } \\
\left(\mathrm{cm}^{2}\right)\end{array}$ & $\begin{array}{c}\text { Tensão na } \\
\text { Área Líquida } \\
(\mathrm{MPa})\end{array}$ & $\begin{array}{c}\text { Módulo de } \\
\text { Elasticidade } \\
(\mathrm{GPa})\end{array}$ \\
\hline PAR 1 & 874,36 & & 7,94 & & 15,42 & 11,38 \\
PAR 2 & 731,14 & 1101,19 & 6,64 & 567,13 & 12,89 & 14,92 \\
PAR 3 & 875,20 & & 7,95 & & 15,43 & 14,07 \\
\hline Média & $\mathbf{8 2 6 , 9 0}$ & & $\mathbf{7 , 5 1}$ & & $\mathbf{1 4 , 5 8}$ & $\mathbf{1 3 , 4 6}$ \\
Desvio Padrão & 82,93 & & 0,75 & & 1,46 & 1,85 \\
CV (\%) & 10,03 & & 10,03 & & 10,03 & 13,71 \\
$\boldsymbol{f}_{\text {ppk }}$ (MPa) & & $\mathbf{5 , 3 1}$ & & $\mathbf{1 0 , 3 1}$ & \\
\hline \hline
\end{tabular}

Tabela B.36 - Resultados do ensaio de compressão das pequenas paredes de 10,0 MPa e $140 \mathrm{~mm}$

\begin{tabular}{ccccccc}
\hline \hline \multicolumn{6}{c}{ Ensaio de compressão - Pequenas pare des de 10,0 MPa e 190 mm } \\
\hline \hline & $\begin{array}{c}\text { Força } \\
(\mathrm{kN})\end{array}$ & $\begin{array}{c}\text { Área } \\
\text { Bruta } \\
\left(\mathrm{cm}^{2}\right)\end{array}$ & $\begin{array}{c}\text { Tensão na } \\
\text { Área Bruta } \\
(\mathrm{MPa})\end{array}$ & $\begin{array}{c}\text { Área } \\
\text { Líquida } \\
\left(\mathrm{cm}^{2}\right)\end{array}$ & $\begin{array}{c}\text { Tensão na } \\
\text { Área Líquida } \\
(\mathrm{MPa})\end{array}$ & $\begin{array}{c}\text { Módulo de } \\
\text { Elasticidade } \\
(\mathrm{GPa})\end{array}$ \\
\hline PAR 1 & 1038,64 & & 6,85 & & 13,24 & 11,66 \\
PAR 2 & 1181,71 & 1516,81 & 7,79 & 784,22 & 15,07 & 7,64 \\
PAR 3 & 1138,52 & & 7,51 & & 14,52 & 13,90 \\
\hline Média & $\mathbf{1 1 1 9 , 6 2}$ & & $\mathbf{7 , 3 8}$ & & $\mathbf{1 4 , 2 8}$ & $\mathbf{1 1 , 0 6}$ \\
Desvio Padrão & 73,38 & & 0,48 & & 0,94 & 3,17 \\
CV (\%) & 6,55 & & 6,55 & & 6,55 & 28,67 \\
$\boldsymbol{f}_{\text {ppk }}$ (MPa) & & $\mathbf{6 , 2 3}$ & $\mathbf{1 2 , 0 5}$ & \\
\hline \hline
\end{tabular}


Tabela B.37 - Resultados do ensaio de compressão das pequenas paredes de 4,0 MPa e $140 \mathrm{~mm}$

\begin{tabular}{ccccccc}
\hline \hline \multicolumn{6}{c}{ Ensaio de compressão - Pequenas pare des de 4,0 MPa e 140 mm } \\
& $\begin{array}{c}\text { Força } \\
(\mathrm{kN})\end{array}$ & $\begin{array}{c}\text { Área } \\
\text { Bruta } \\
\left(\mathrm{cm}^{2}\right)\end{array}$ & $\begin{array}{c}\text { Tensão na } \\
\text { Área Bruta } \\
(\mathrm{MPa})\end{array}$ & $\begin{array}{c}\text { Área } \\
\text { Líquida } \\
\left(\mathrm{cm}^{2}\right)\end{array}$ & $\begin{array}{c}\text { Tensão na } \\
\text { Área Líquida } \\
(\mathrm{MPa})\end{array}$ & $\begin{array}{c}\text { Módulo de } \\
\text { Elasticidade } \\
(\mathrm{GPa})\end{array}$ \\
\hline PAR 1 & 561,75 & & 5,10 & & 9,95 & 9,49 \\
PAR 2 & 562,66 & 1100,73 & 5,11 & 564,42 & 9,97 & 10,33 \\
PAR 3 & 570,60 & & 5,18 & & 10,11 & 8,57 \\
\hline Média & $\mathbf{5 6 5 , 0 0}$ & & $\mathbf{5 , 1 3}$ & & $\mathbf{1 0 , 0 1}$ & $\mathbf{9 , 4 6}$ \\
Desvio Padrão & 4,87 & & 0,04 & & 0,09 & 0,88 \\
CV (\%) & 0,86 & & 0,86 & & 0,86 & 9,30 \\
$\boldsymbol{f}_{\mathbf{p p k}}$ (MPa) & & $\mathbf{4 , 0 8}$ & $\mathbf{7 , 9 6}$ & \\
\hline \hline
\end{tabular}

Tabela B38 - Resultados do ensaio de compressão das pequenas paredes de 4,0 MPa e $190 \mathrm{~mm}$

\begin{tabular}{ccccccc}
\hline \hline \multicolumn{6}{c}{ Ensaio de compressão - Pequenas pare des de 4,0 MPa e 190 mm } \\
\hline \hline & $\begin{array}{c}\text { Força } \\
(\mathrm{kN})\end{array}$ & $\begin{array}{c}\text { Área } \\
\text { Bruta } \\
\left(\mathrm{cm}^{2}\right)\end{array}$ & $\begin{array}{c}\text { Tensão na } \\
\text { Área Bruta } \\
(\mathrm{MPa})\end{array}$ & $\begin{array}{c}\text { Área } \\
\text { Líquida } \\
\left(\mathrm{cm}^{2}\right)\end{array}$ & $\begin{array}{c}\text { Tensão na } \\
\text { Área Líquida } \\
(\mathrm{MPa})\end{array}$ & $\begin{array}{c}\text { Módulo de } \\
\text { Elasticidade } \\
(\mathrm{GPa})\end{array}$ \\
\hline PAR 1 & 526,65 & & 3,50 & & 6,87 & 7,73 \\
PAR 2 & 556,56 & 1504,79 & 3,70 & 766,50 & 7,26 & 6,95 \\
PAR 3 & 574,79 & & 3,82 & & 7,50 & 6,61 \\
\hline Média & $\mathbf{5 5 2 , 6 6}$ & & $\mathbf{3 , 6 7}$ & & $\mathbf{7 , 2 1}$ & $\mathbf{7 , 1 0}$ \\
Desvio Padrão & 24,31 & & 0,16 & & 0,32 & 0,58 \\
CV (\%) & 4,40 & & 4,40 & 4,40 & 8,11 \\
$\boldsymbol{f}_{\text {ppk }}$ (MPa) & & $\mathbf{2 , 8 0}$ & $\mathbf{5 , 5 0}$ & \\
\hline \hline
\end{tabular}


Figura B.1 - Gráfico de tensão x deformação das pequenas paredes de 10,0 MPa e $140 \mathrm{~mm}$

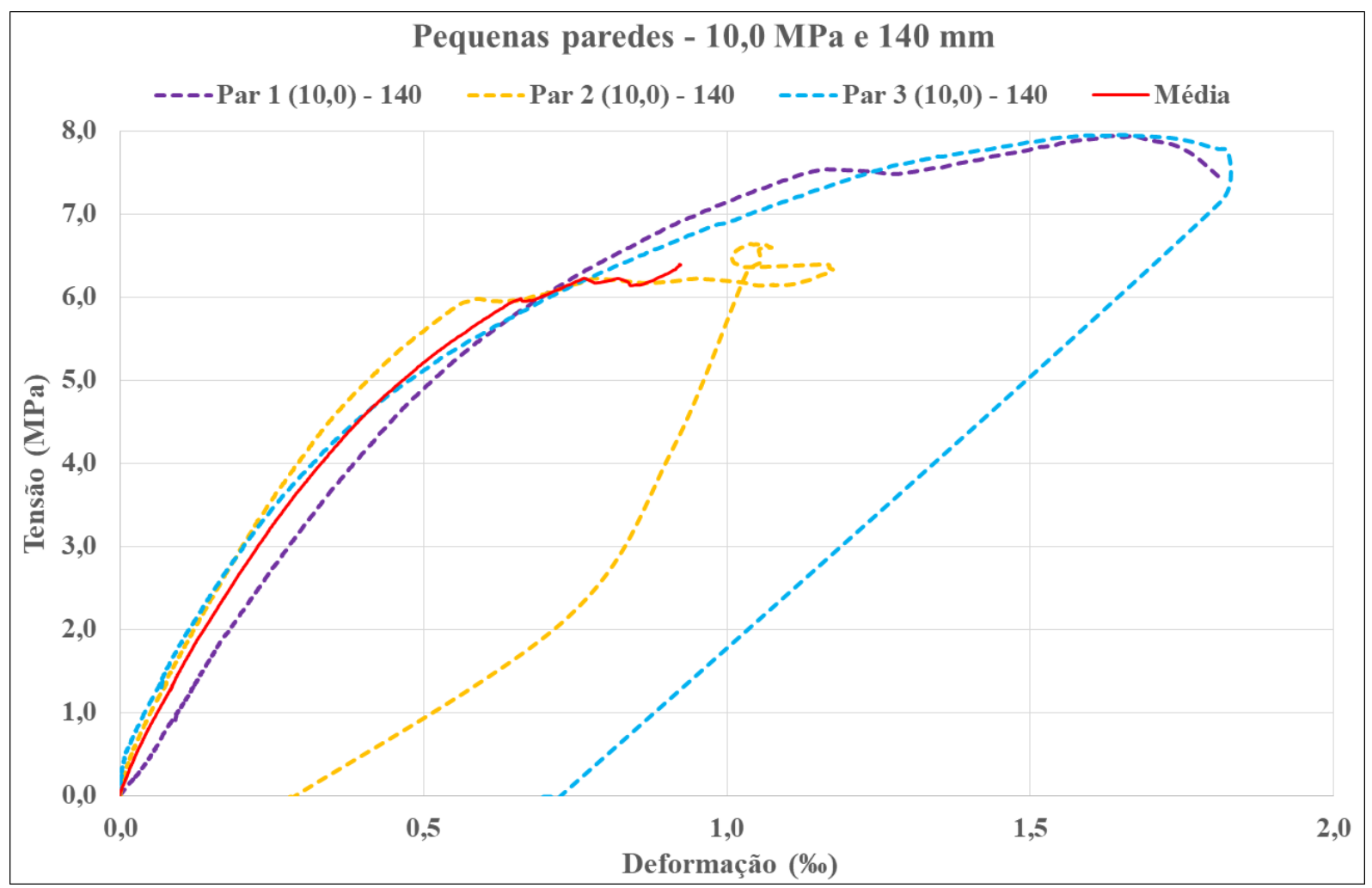

Figura B.2 - Gráfico de tensão x deformação das pequenas paredes de 10,0 MPa e $190 \mathrm{~mm}$

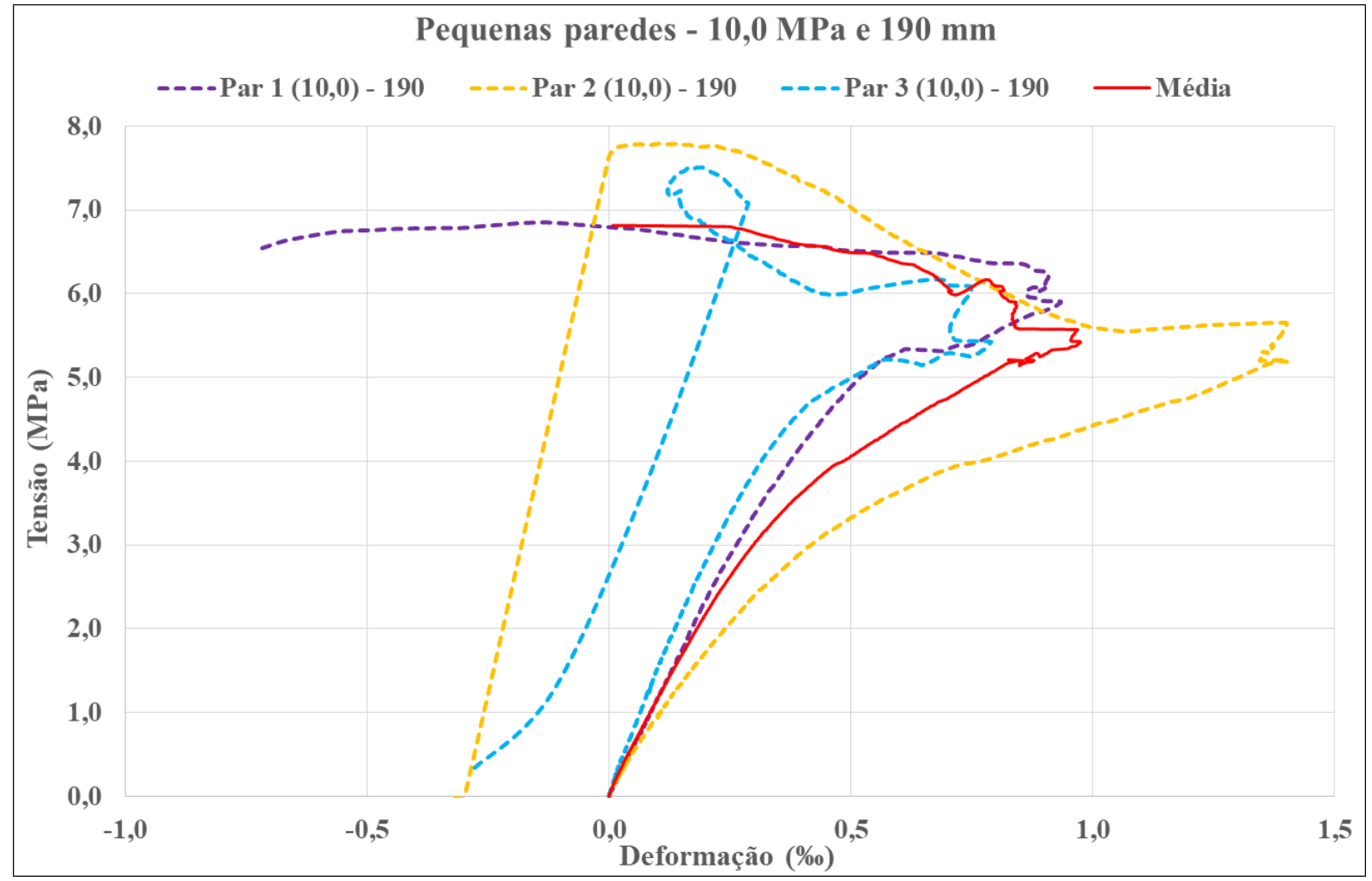


Figura B.3 - Gráfico de tensão x deformação das pequenas paredes de 4,0 MPa e $140 \mathrm{~mm}$

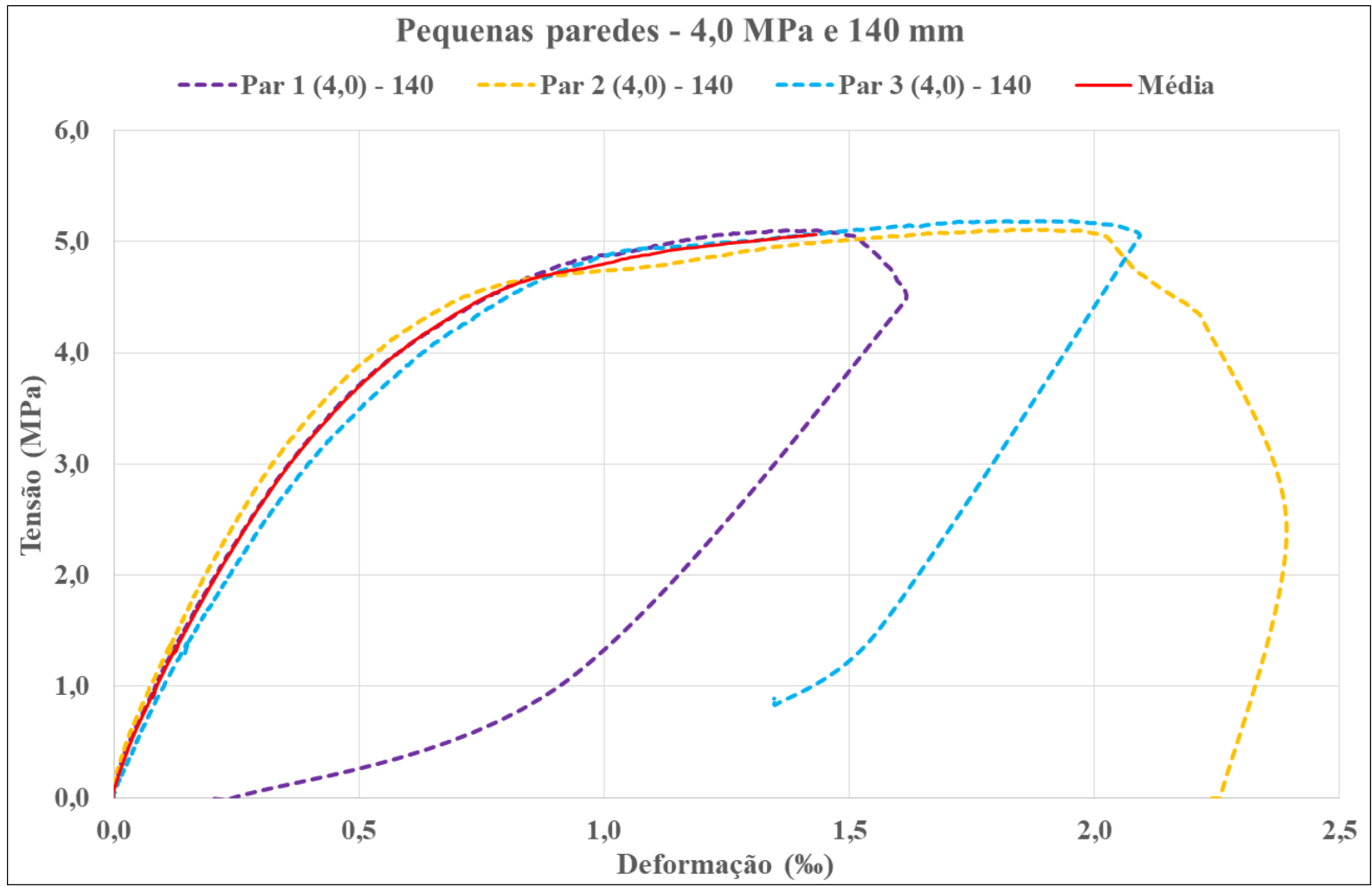

Figura B.4 - Gráfico de tensão x deformação das pequenas paredes de 4,0 MPa e $190 \mathrm{~mm}$

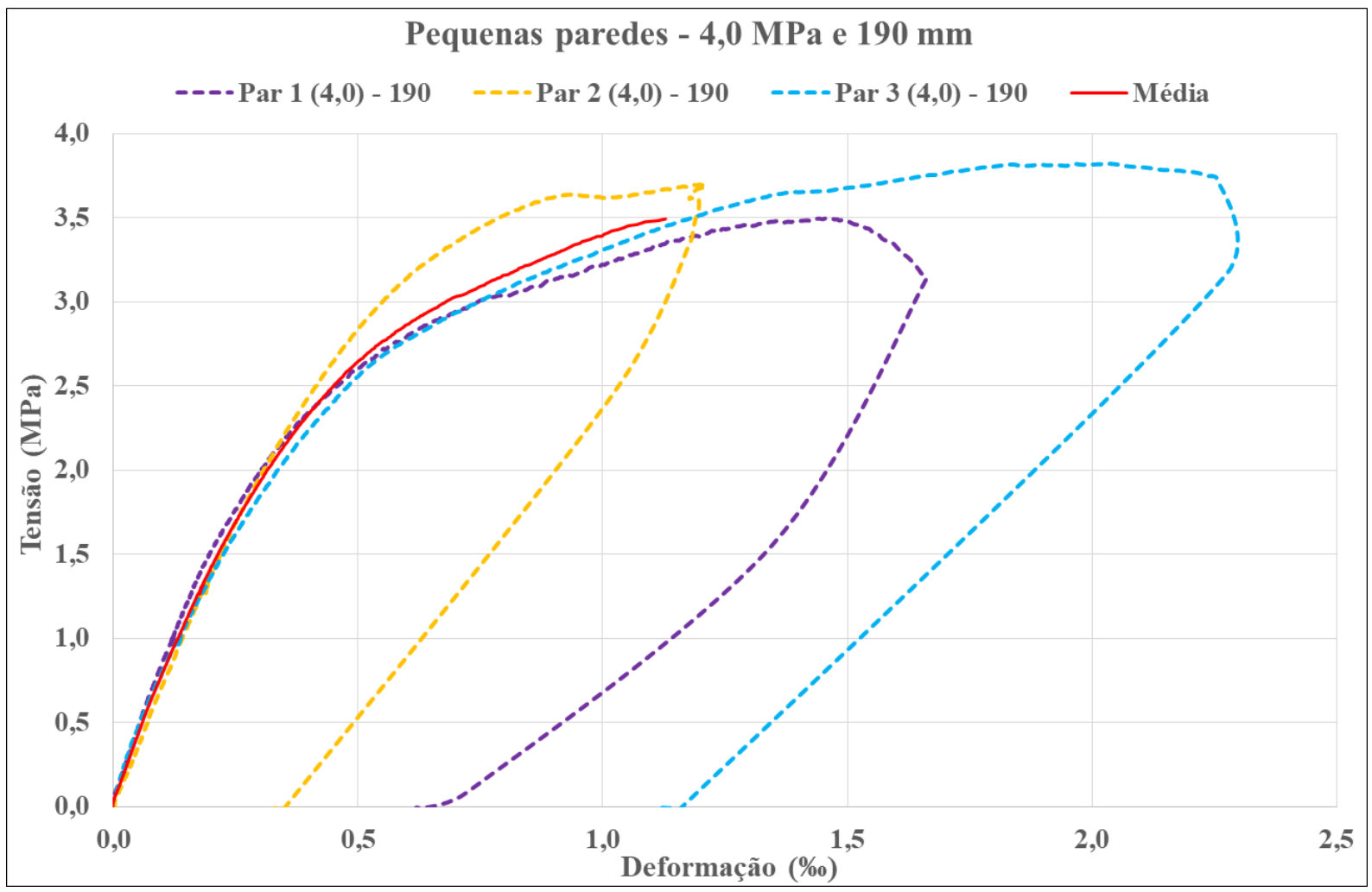


Caracterização da alvenaria - Fotos dos ensaios de compressão das pequenas paredes

Figura B.5 - Ensaios de compressão das pequenas paredes de 4,0 MPa e $140 \mathrm{~mm}$
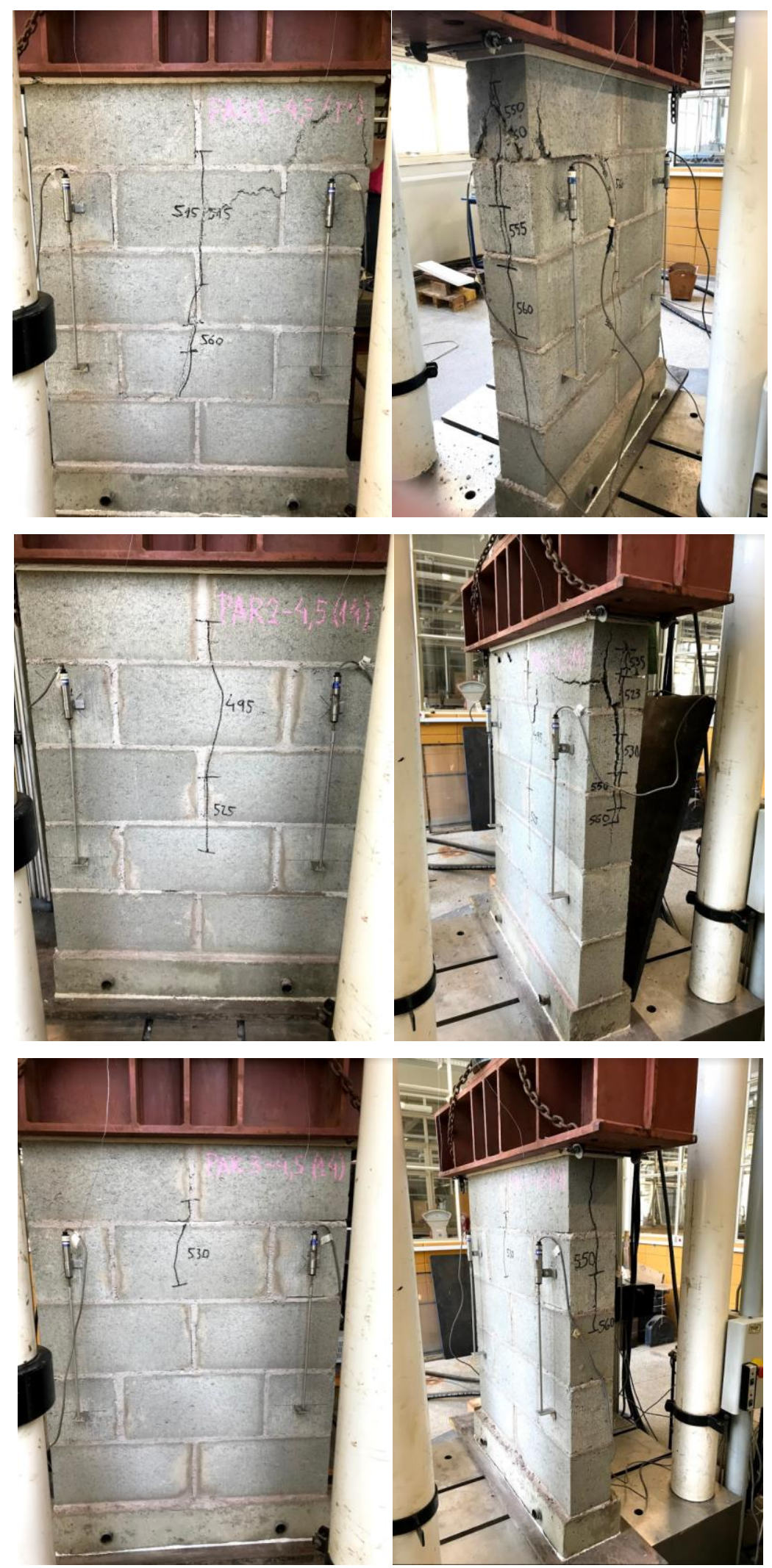
Figura B.6 - Ensaios de compressão das pequenas paredes de 4,0 MPa e $190 \mathrm{~mm}$
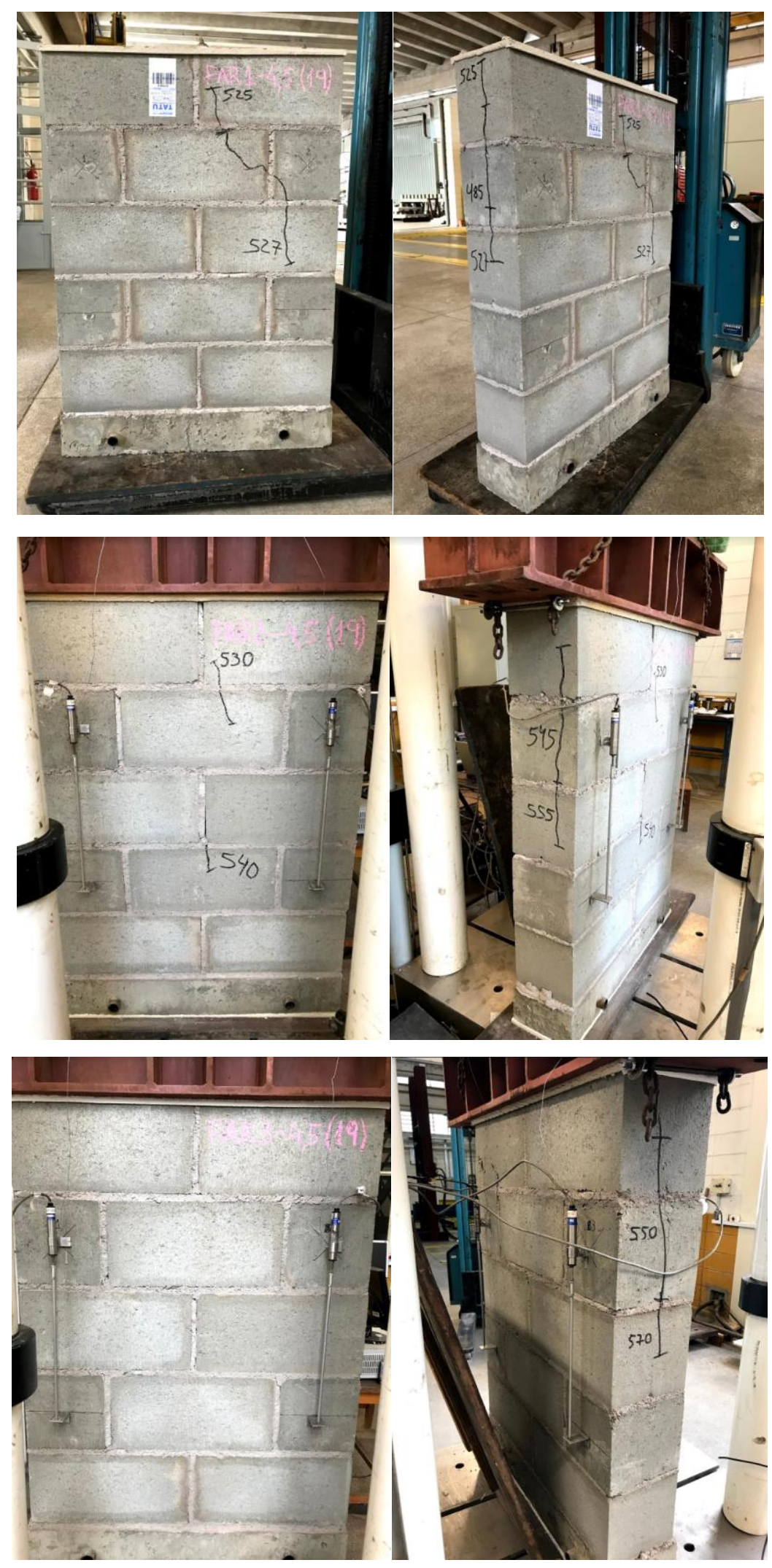


\section{APÊNDICE C}

\section{Temperatura dos elementos durante a simulação de incêndio-padrão - $1^{\text {a }}$ Fornada}

Figura C. 1 - Gráfico de temperatura por tempo dos termopares trio de paredes de 4,0 $\mathrm{MPa}$ ( $1^{\mathrm{a}}$ Fornada)

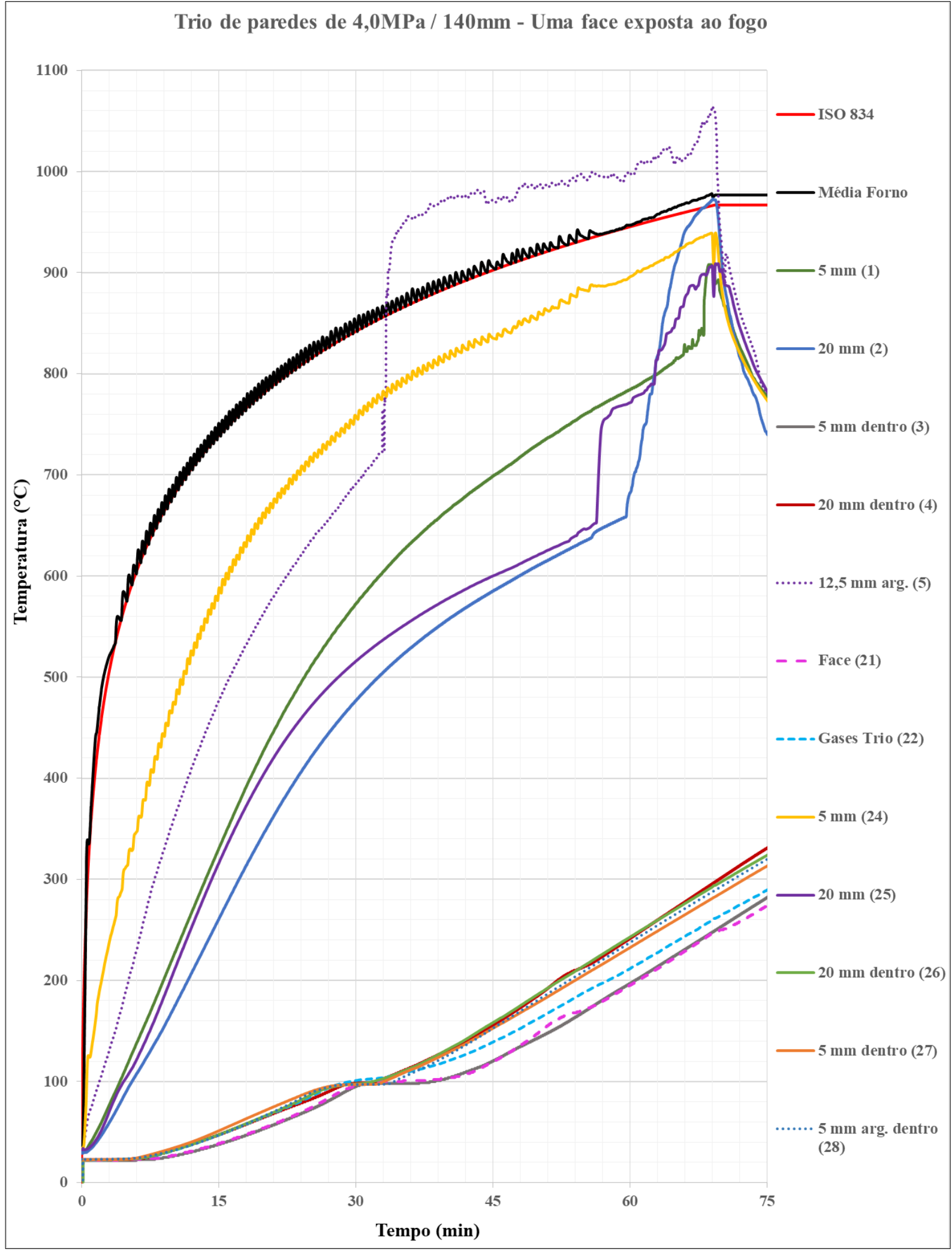


Figura C.2 - Gráfico de temperatura por tempo dos termopares dos blocos de 10,0 MPa ( $1^{\mathrm{a}}$ Fornada)

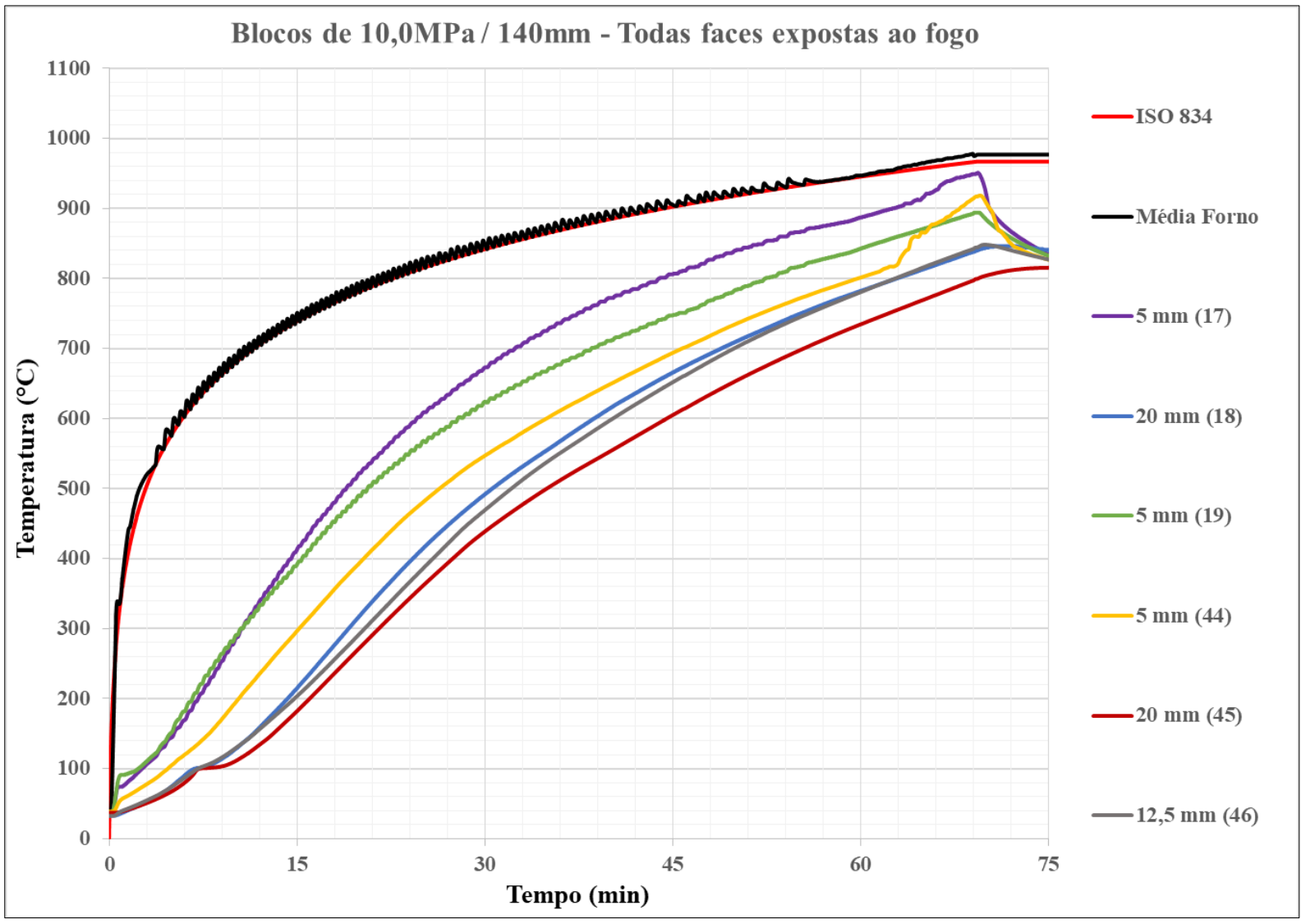

Figura C.3 - Gráfico de temperatura por tempo dos termopares dos blocos e prisma de 4,0 MPa ( $1^{\mathrm{a} F o r n a d a)}$

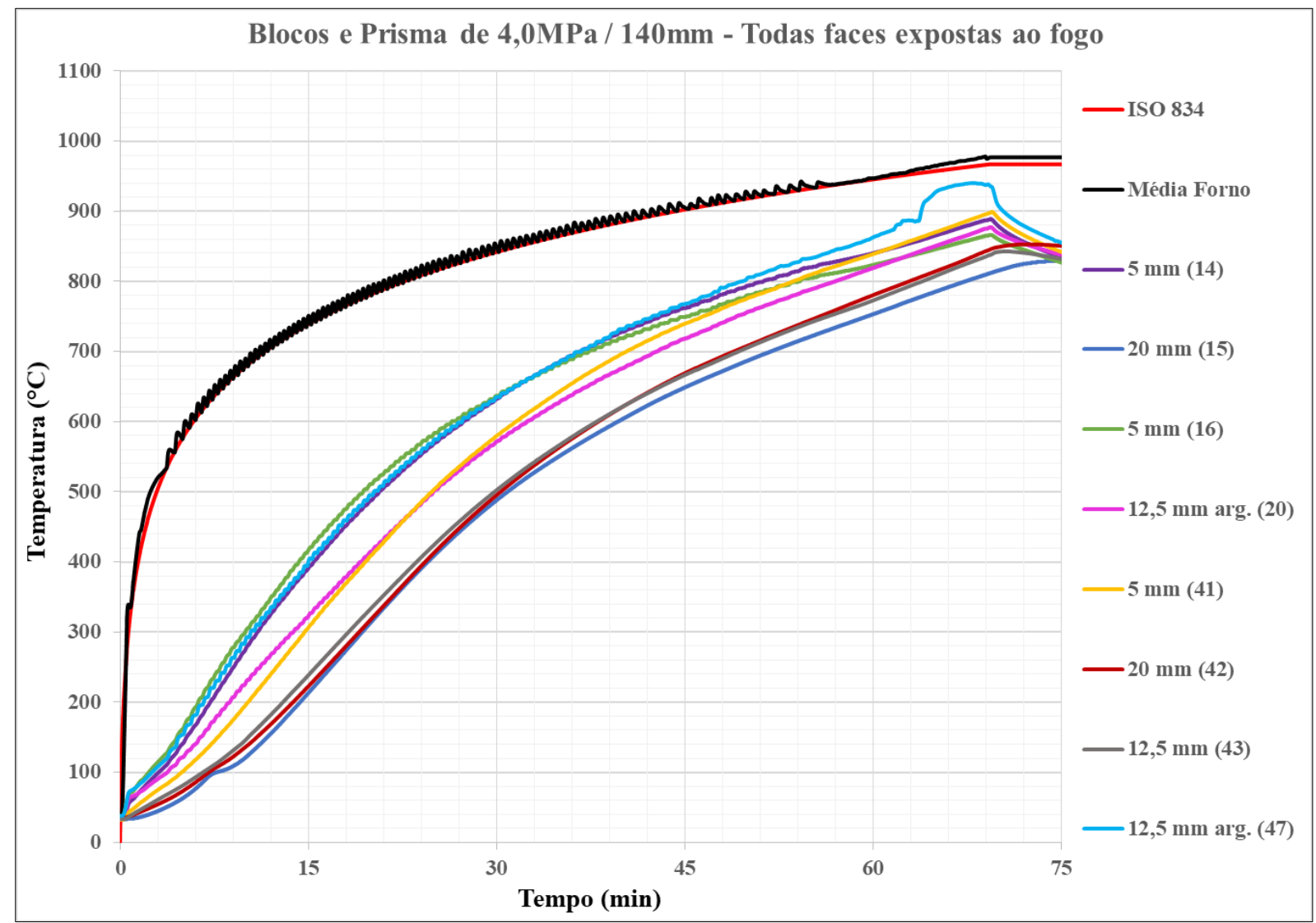


Figura C.4 - Gráfico de temperatura por tempo dos termopares das pequenas paredes de 10,0 MPa ( $\left.1^{\mathrm{a} F o r n a d a}\right)$

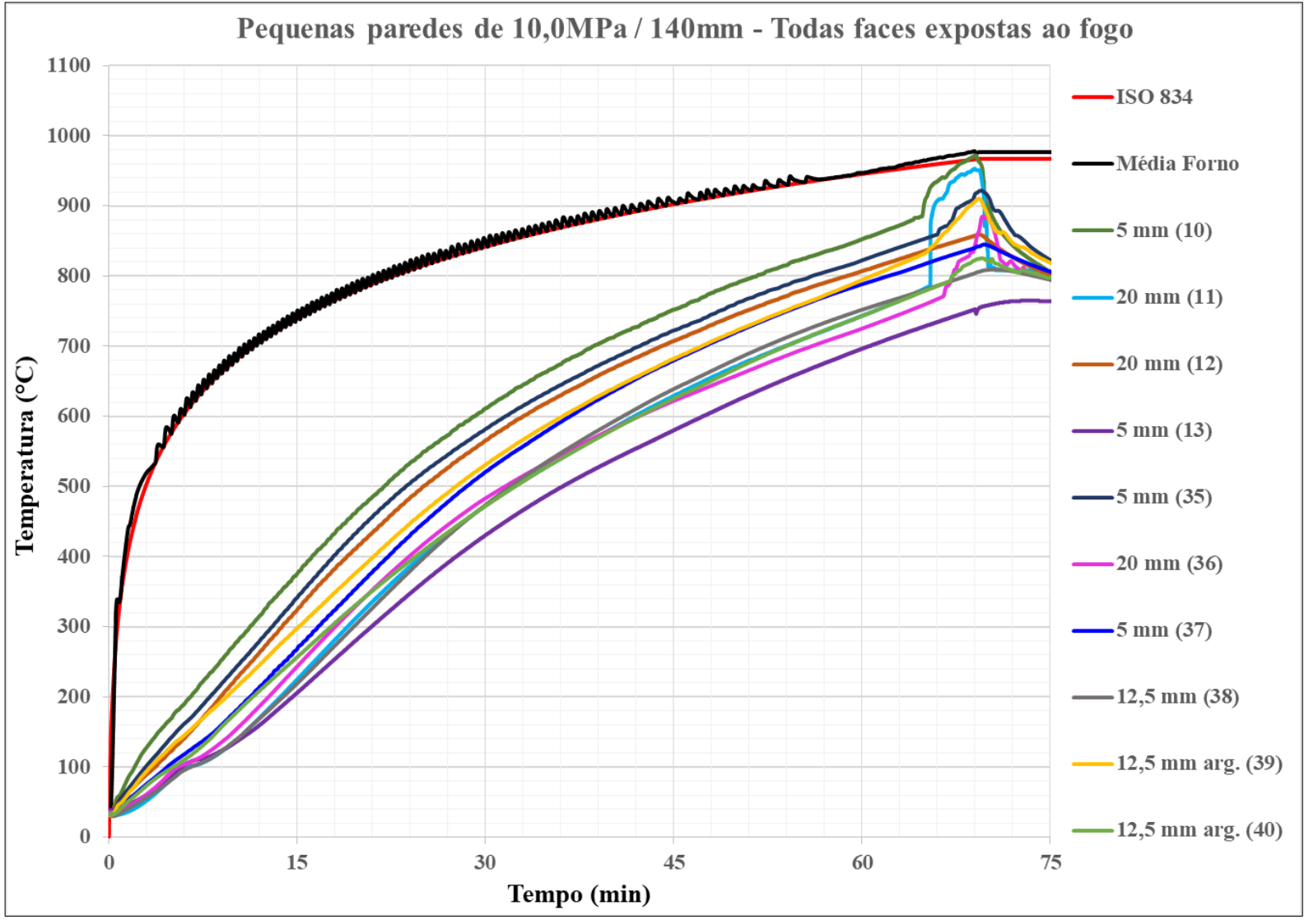

Figura C. 5 - Gráfico de temperatura por tempo dos termopares das pequenas paredes de 4,0 MPa ( $1^{\mathrm{a}}$ Fornada)

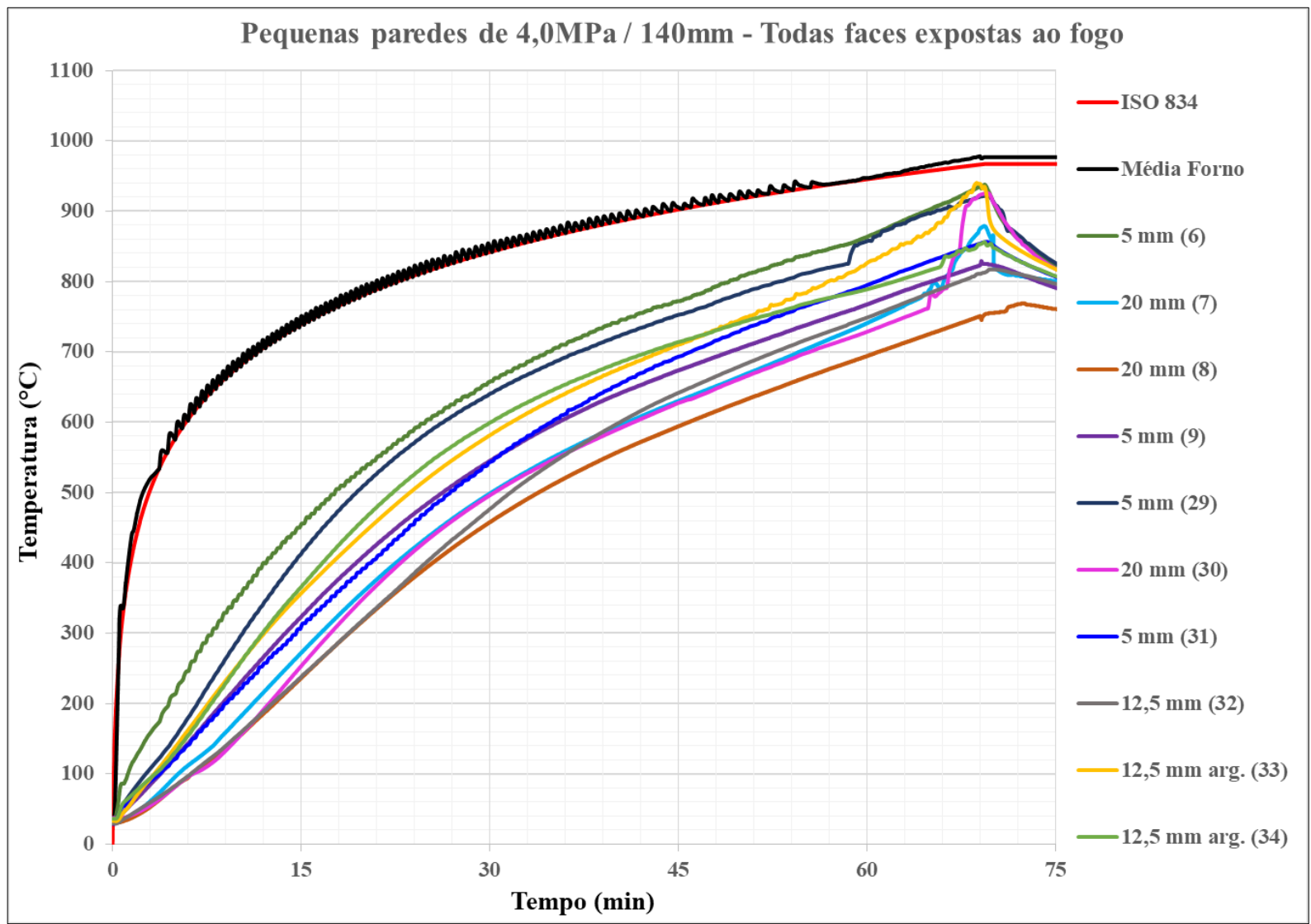




\section{Resistência à compressão pós-fogo $-1^{\mathrm{a}}$ Fornada}

Tabela C.1 - Resultados da resistência à compressão pós-fogo dos blocos de 10,0 MPa e 140 mm

\begin{tabular}{|c|c|c|c|c|c|c|c|}
\hline \multicolumn{8}{|c|}{ Ensaio de compressão pós-fogo - Blocos de 10,0 MPa e 140 mm } \\
\hline & $\begin{array}{c}\text { Resistência } \\
\text { média temp. } \\
\text { ambiente }(\mathrm{kN})\end{array}$ & $\begin{array}{l}\text { Força } \\
(\mathrm{kN})\end{array}$ & $\begin{array}{c}\text { Área Bruta } \\
\left(\mathrm{cm}^{2}\right)\end{array}$ & $\begin{array}{c}\text { Tensão na } \\
\text { Área Bruta } \\
(\mathrm{MPa})\end{array}$ & $\begin{array}{c}\text { Área } \\
\text { Líquida } \\
\left(\mathrm{cm}^{2}\right)\end{array}$ & $\begin{array}{c}\text { Tensão na } \\
\text { Área Líquida } \\
(\mathrm{MPa})\end{array}$ & $\mathrm{F}_{\mathrm{fogo}} / \mathrm{F}_{\mathrm{amb}}$ \\
\hline BL 1-P & \multirow{6}{*}{1197,77} & 175,80 & \multirow{6}{*}{543,59} & 3,23 & \multirow{6}{*}{283,56} & 6,20 & $15 \%$ \\
\hline BL 2-P & & 243,40 & & 4,48 & & 8,58 & $20 \%$ \\
\hline BL 3-P & & 302,70 & & 5,57 & & 10,67 & $25 \%$ \\
\hline BL 4-P & & 258,90 & & 4,76 & & 9,13 & $22 \%$ \\
\hline BL 5-P & & 223,20 & & 4,11 & & 7,87 & $19 \%$ \\
\hline BL 6-P & & 250,06 & & 4,60 & & 8,82 & $21 \%$ \\
\hline Média & & 242,34 & & 4,46 & & 8,55 & $20 \%$ \\
\hline Desvio Padrão & & 41,89 & & 0,77 & & 1,48 & \\
\hline $\mathrm{CV}(\%)$ & & 17,28 & & 17,28 & & 17,28 & \\
\hline$f_{\mathrm{bk}}(\mathrm{MPa})$ & & & & 2,88 & & $\mathbf{5 , 5 2}$ & \\
\hline
\end{tabular}

* Blocos expostos ao incêndio padrão da ISO 834-1:1999 durante 70 min em todas as faces

Tabela C.2 - Resultados da resistência à compressão pós-fogo dos blocos de 4,0 MPa e 140 mm

\begin{tabular}{|c|c|c|c|c|c|c|c|}
\hline \multicolumn{8}{|c|}{ Ensaio de compressão pós-fogo - Blocos de 4,0 MPa e 140 mm } \\
\hline & $\begin{array}{c}\text { Resistência } \\
\text { média temp. } \\
\text { ambiente }(\mathrm{kN})\end{array}$ & $\begin{array}{l}\text { Força } \\
(\mathrm{kN})\end{array}$ & $\begin{array}{c}\text { Área Bruta } \\
\left(\mathrm{cm}^{2}\right)\end{array}$ & $\begin{array}{c}\text { Tensão na } \\
\text { Área Bruta } \\
(\mathrm{MPa})\end{array}$ & $\begin{array}{c}\text { Área } \\
\text { Líquida } \\
\left(\mathrm{cm}^{2}\right)\end{array}$ & $\begin{array}{c}\text { Tensão na } \\
\text { Área Líquida } \\
\quad(\mathrm{MPa})\end{array}$ & $\mathrm{F}_{\mathrm{fogo}} / \mathrm{F}_{\mathrm{amb}}$ \\
\hline BL 1-P & \multirow{6}{*}{404,23} & 144,80 & \multirow{6}{*}{543,37} & 2,66 & \multirow{6}{*}{282,21} & 5,13 & $36 \%$ \\
\hline BL 2-P & & 96,20 & & 1,77 & & 3,41 & $24 \%$ \\
\hline BL 3-P & & 106,00 & & 1,95 & & 3,76 & $26 \%$ \\
\hline BL 4-P & & 86,60 & & 1,59 & & 3,07 & $21 \%$ \\
\hline BL 5-P & & 122,20 & & 2,25 & & 4,33 & $30 \%$ \\
\hline BL 6-P & & 96,50 & & 1,78 & & 3,42 & $24 \%$ \\
\hline Média & & 108,72 & & 2,00 & & 3,85 & $27 \%$ \\
\hline Desvio Padrão & & 21,38 & & 0,39 & & 0,76 & \\
\hline $\mathrm{CV}(\%)$ & & 19,67 & & 19,67 & & 19,67 & \\
\hline$f_{\mathrm{bk}}(\mathrm{MPa})$ & & & & 1,59 & & 3,06 & \\
\hline
\end{tabular}

\footnotetext{
* Blocos expostos ao incêndio padrão da ISO 834-1:1999 durante 70 min em todas as faces
} 
Tabela C.3 - Resultados da resistência à compressão pós-fogo dos prismas de 4,0 MPa e 140 mm

\begin{tabular}{|c|c|c|c|c|c|c|c|}
\hline \multicolumn{8}{|c|}{ Ensaio de compressão pós-fogo - Prismas de 4,0 MPa e 140 mm } \\
\hline & $\begin{array}{c}\text { Resistência } \\
\text { média temp. } \\
\text { ambiente }(\mathrm{kN})\end{array}$ & $\begin{array}{l}\text { Força } \\
(\mathrm{kN})\end{array}$ & $\begin{array}{c}\text { Área Bruta } \\
\quad\left(\mathrm{cm}^{2}\right)\end{array}$ & $\begin{array}{c}\text { Tensão na } \\
\text { Área Bruta } \\
(\mathrm{MPa})\end{array}$ & $\begin{array}{c}\text { Área } \\
\text { Líquida } \\
\left(\mathrm{cm}^{2}\right)\end{array}$ & $\begin{array}{c}\text { Tensão na } \\
\text { Área Líquida } \\
(\mathrm{MPa})\end{array}$ & $\mathrm{F}_{\mathrm{fogo}} / \mathrm{F}_{\mathrm{amb}}$ \\
\hline PRI 1-P & \multirow{6}{*}{369,36} & 49,39 & \multirow{6}{*}{543,37} & 1,34 & \multirow{6}{*}{282,21} & 1,75 & $13 \%$ \\
\hline PRI 2-P & & 66,81 & & 1,81 & & 2,37 & $18 \%$ \\
\hline PRI 3-P & & 66,79 & & 1,81 & & 2,37 & $18 \%$ \\
\hline PRI 4-P & & 34,02 & & 0,92 & & 1,21 & $9 \%$ \\
\hline PRI 5-P & & 50,95 & & 1,38 & & 1,81 & $14 \%$ \\
\hline PRI 6-P & & 49,09 & & 1,33 & & 1,74 & $13 \%$ \\
\hline Média & & 52,84 & & 1,43 & & 1,87 & $14 \%$ \\
\hline Desvio Padrão & & 12,44 & & 0,34 & & 0,44 & \\
\hline $\mathrm{CV}(\%)$ & & 23,54 & & 23,54 & & 23,54 & \\
\hline$f_{\mathrm{bk}}(\mathrm{MPa})$ & & & & $\mathbf{0 , 9 3}$ & & 1,22 & \\
\hline
\end{tabular}

* Pris mas expostos ao incêndio padrão da ISO 834-1:1999 durante 70 min em todas as faces

Tabela C.4 - Resultados da resistência à compressão pós-fogo das pequenas paredes de 10,0 MPa e $140 \mathrm{~mm}$

\begin{tabular}{|c|c|c|c|c|c|c|c|}
\hline \multicolumn{8}{|c|}{ Ensaio de compressão pós-fogo - Pequenas paredes de 10,0 MPa e 140 mm } \\
\hline & $\begin{array}{c}\text { Resistência } \\
\text { média temp. } \\
\text { ambiente }(\mathrm{kN})\end{array}$ & $\begin{array}{c}\text { Força } \\
(\mathrm{kN})\end{array}$ & $\begin{array}{c}\text { Área Bruta } \\
\left(\mathrm{cm}^{2}\right)\end{array}$ & $\begin{array}{c}\text { Tensão na } \\
\text { Área Bruta } \\
(\mathrm{MPa})\end{array}$ & $\begin{array}{c}\text { Área } \\
\text { Líquida } \\
\left(\mathrm{cm}^{2}\right) \\
\end{array}$ & $\begin{array}{c}\text { Tensão na } \\
\text { Área Líquida } \\
(\mathrm{MPa})\end{array}$ & $\mathrm{F}_{\mathrm{fogo}} / \mathrm{F}_{\mathrm{amb}}$ \\
\hline PAR1-N & & 103,62 & & 0,94 & & 1,83 & $13 \%$ \\
\hline PAR2-N & 826,9 & 79,81 & 1101,19 & 0,72 & 567,13 & 1,41 & $10 \%$ \\
\hline PAR3-N & & 150,93 & & 1,37 & & 2,66 & $18 \%$ \\
\hline Média & & 111,45 & & 1,01 & & 1,97 & $13 \%$ \\
\hline Desvio Padrão & & 36,20 & & 0,33 & & 0,64 & \\
\hline $\mathrm{CV}(\%)$ & & 32,48 & & 32,48 & & 32,48 & \\
\hline$f_{\mathrm{bk}}(\mathrm{MPa})$ & & & & $\mathbf{0 , 5 8}$ & & 1,13 & \\
\hline
\end{tabular}

* Pequenas paredes expostas ao incêndio padrão da ISO 834-1:1999 durante 70 min em todas as faces

Tabela C.5 - Resultados da resistência à compressão pós-fogo das pequenas paredes de 4,0 MPa e $140 \mathrm{~mm}$

\begin{tabular}{|c|c|c|c|c|c|c|c|}
\hline \multicolumn{8}{|c|}{ Ensaio de compressão pós-fogo - Pequenas paredes de 4,0 MPa e 140 mm } \\
\hline & $\begin{array}{c}\text { Resistência } \\
\text { média temp. } \\
\text { ambiente }(\mathrm{kN})\end{array}$ & $\begin{array}{l}\text { Força } \\
(\mathrm{kN})\end{array}$ & $\begin{array}{c}\text { Área Bruta } \\
\left(\mathrm{cm}^{2}\right)\end{array}$ & $\begin{array}{c}\text { Tensão na } \\
\text { Área Bruta } \\
(\mathrm{MPa}) \\
\end{array}$ & $\begin{array}{c}\text { Área } \\
\text { Líquida } \\
\left(\mathrm{cm}^{2}\right) \\
\end{array}$ & $\begin{array}{c}\text { Tensão na } \\
\text { Área Líquida } \\
(\mathrm{MPa})\end{array}$ & $\mathrm{F}_{\mathrm{fogo}} / \mathrm{F}_{\mathrm{amb}}$ \\
\hline PAR1-N & & 81,57 & & 0,74 & & 1,45 & $14 \%$ \\
\hline PAR2-N & 565,00 & 83,09 & 1100,73 & 0,75 & 564,42 & 1,47 & $15 \%$ \\
\hline PAR3-N & & 73,10 & & 0,66 & & 1,30 & $13 \%$ \\
\hline Média & & 79,25 & & 0,72 & & 1,40 & $14 \%$ \\
\hline Desvio Padrão & & 5,38 & & 0,05 & & 0,10 & \\
\hline $\mathrm{CV}(\%)$ & & 6,79 & & 6,79 & & 6,79 & \\
\hline$f_{\text {bk }}(\mathrm{MPa})$ & & & & $\mathbf{0 , 5 3}$ & & 1,04 & \\
\hline
\end{tabular}

\footnotetext{
* Pequenas paredes expostas ao incêndio padrão da ISO 834-1:1999 durante 70 min em todas as faces
} 
Tabela C.6 - Resultados da resistência à compressão pós-fogo do trio de pequenas paredes compartimentadas de 4,0 MPa e $140 \mathrm{~mm}$

\begin{tabular}{cccccccc}
\hline \hline \multicolumn{6}{c}{ Ensaio de compressão pós-fogo - Trio de pe que nas pare des de 4,0 MPa e 140 mm } \\
\hline \hline & $\begin{array}{c}\text { Resistência } \\
\text { média temp. } \\
\text { ambiente }(\mathrm{kN})\end{array}$ & $\begin{array}{c}\text { Força } \\
(\mathrm{kN})\end{array}$ & $\begin{array}{c}\text { Área Bruta } \\
\left(\mathrm{cm}^{2}\right)\end{array}$ & $\begin{array}{c}\text { Tensão na } \\
\text { Área Bruta } \\
(\mathrm{MPa})\end{array}$ & $\begin{array}{c}\text { Área } \\
\text { Líquida } \\
\left(\mathrm{cm}^{2}\right)\end{array}$ & $\begin{array}{c}\text { Tensão na } \\
\text { Área Líquida } \\
(\mathrm{MPa})\end{array}$ & $\mathrm{F}_{\text {fogo }} / \mathrm{F}_{\text {amb }}$ \\
\hline PAR1-C & & 328,41 & & 2,98 & & 5,82 & $58 \%$ \\
PAR2-C & 565,00 & 236,62 & 1100,73 & 2,15 & 564,42 & 4,19 & $42 \%$ \\
PAR3-C & 211,82 & & 1,92 & & 3,75 & $37 \%$ \\
\hline Média & $\mathbf{2 5 8 , 9 5}$ & & $\mathbf{2 , 3 5}$ & & $\mathbf{4 , 5 9}$ & $\mathbf{4 6 \%}$ \\
Desvio Padrão & 61,42 & & 0,56 & & 1,09 & \\
CV (\%) & 23,72 & & 23,72 & & 23,72 & \\
$\boldsymbol{f}_{\text {bk }}$ (MPa) & & & $\mathbf{1 , 5 4}$ & & $\mathbf{3 , 0 0}$ & \\
\hline \hline
\end{tabular}

* Pequenas paredes expostas ao incêndio padrão da ISO 834-1:1999 durante 70 min em apenas uma face

\section{Fotos do ensaio $-\mathbf{1}^{\text {a }}$ Fornada}

Figura C.6 - Preparação da primeira fornada (posicionamento dos corpos de prova)
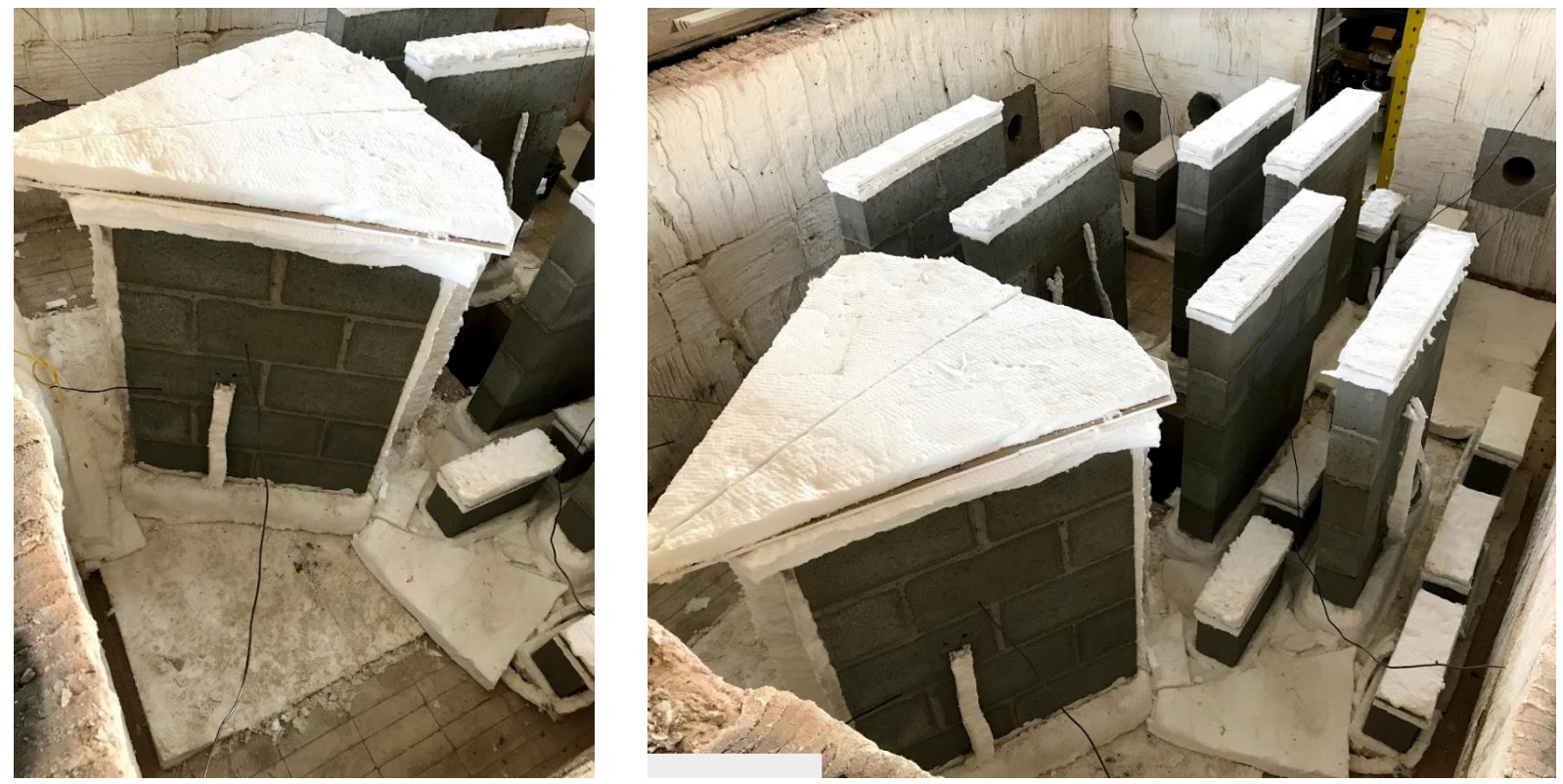
Figura C.7 - Primeira fornada durante a execução do ensaio
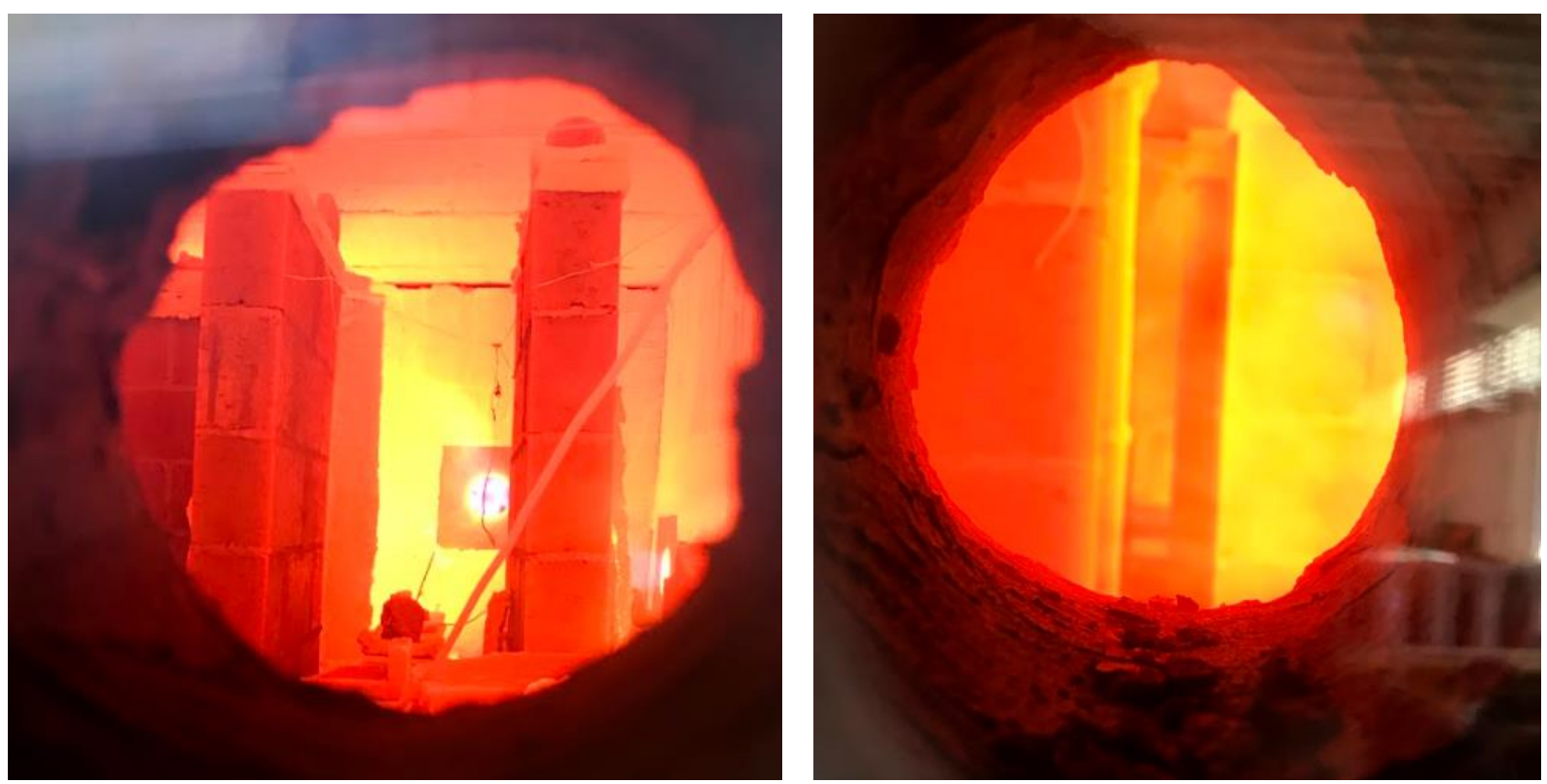

Figura C.8 - Situação dos corpos de prova logo após a abertura do forno
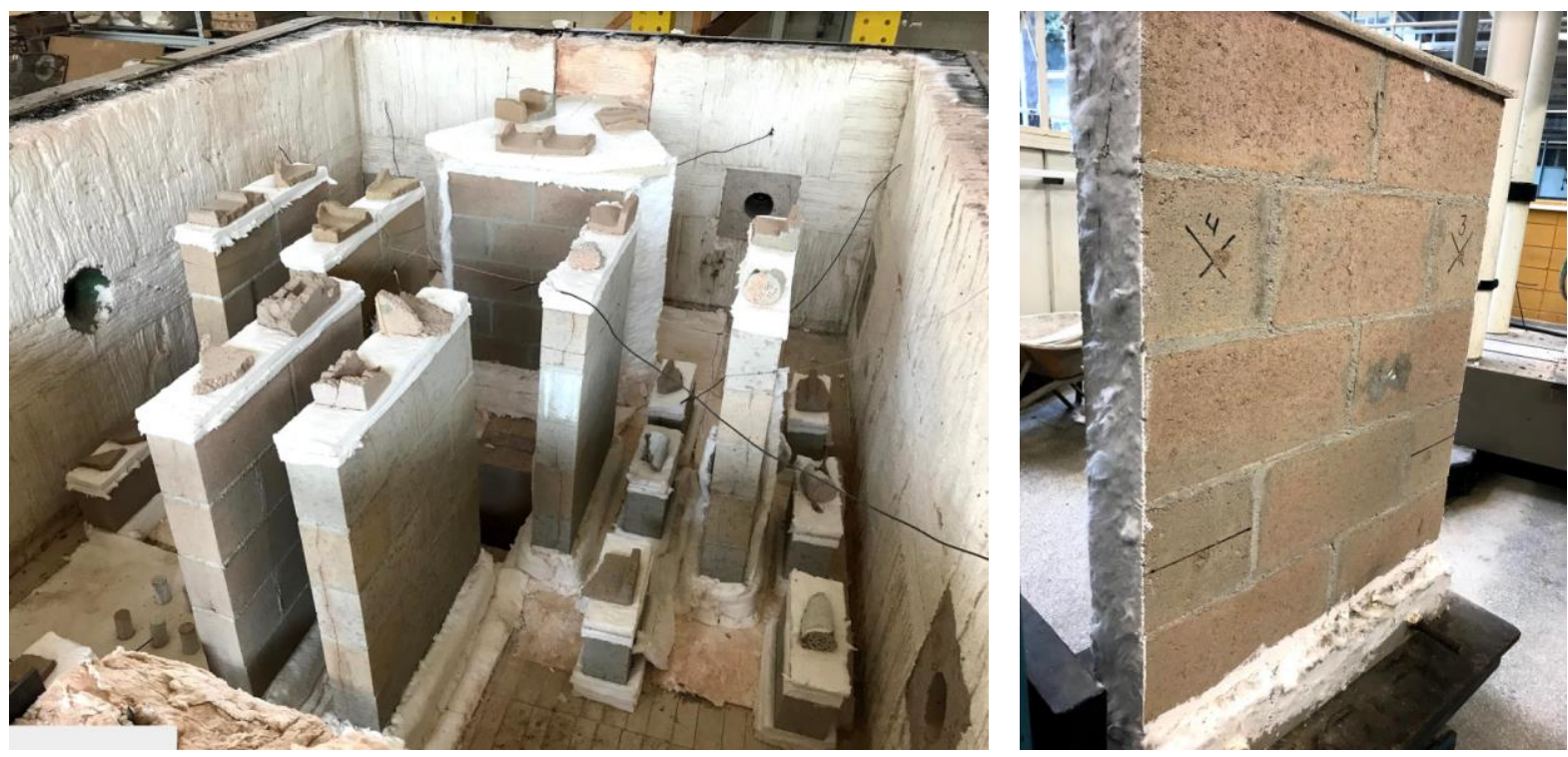
Figura C. 9 - Trio de pequenas paredes de 4,0 MPa e $140 \mathrm{~mm}$ após a simulação de incêndio
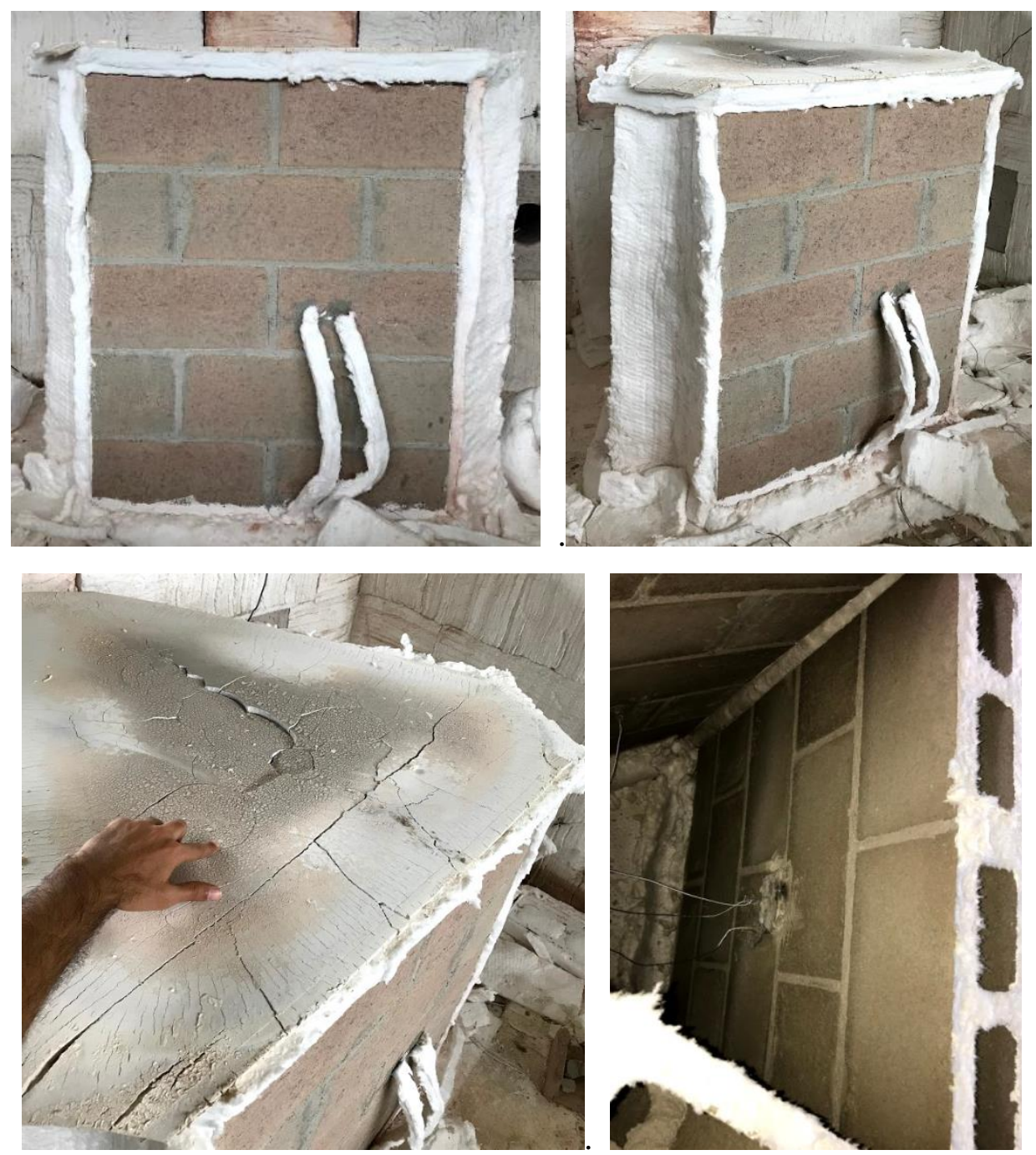

\section{Resistência à compressão pós-fogo $-2^{\mathrm{a}}$ Fornada}

Tabela C.7 - Resultados da resistência à compressão pós-fogo dos blocos de 10,0 MPa e 140 mm com gesso

\begin{tabular}{|c|c|c|c|c|c|c|c|}
\hline \multicolumn{8}{|c|}{ Ensaio de compressão pós-fogo - Blocos de 10,0MPa e $140 \mathrm{~mm}$ revestidos com gesso* } \\
\hline & $\begin{array}{l}\text { Resistência em } \\
\text { Temp. } \\
\text { Ambiente }(\mathrm{kN})\end{array}$ & $\begin{array}{l}\text { Força } \\
(\mathrm{kN})\end{array}$ & $\begin{array}{c}\text { Área Bruta } \\
\left(\mathrm{cm}^{2}\right)\end{array}$ & $\begin{array}{c}\text { Tensão na } \\
\text { Área Bruta } \\
(\mathrm{MPa})\end{array}$ & $\begin{array}{c}\text { Área } \\
\text { Líquida } \\
\left(\mathrm{cm}^{2}\right)\end{array}$ & $\begin{array}{c}\text { Tensão na } \\
\text { Área Líquida } \\
\text { (MPa) }\end{array}$ & $\mathrm{F}_{\mathrm{fogo}} / \mathrm{F}_{\mathrm{amb}}$ \\
\hline BL 1-G & \multirow{6}{*}{1197,77} & 143,20 & \multirow{6}{*}{543,59} & 2,63 & \multirow{6}{*}{283,56} & 5,05 & $12 \%$ \\
\hline BL 2-G & & 138,90 & & 2,56 & & 4,90 & $12 \%$ \\
\hline BL 3-G & & 155,20 & & 2,86 & & 5,47 & $13 \%$ \\
\hline BL 4-G & & 135,90 & & 2,50 & & 4,79 & $11 \%$ \\
\hline BL 5-G & & 152,00 & & 2,80 & & 5,36 & $13 \%$ \\
\hline BL 6-G & & 97,40 & & 1,79 & & 3,43 & $8 \%$ \\
\hline Média & & 137,10 & & 2,52 & & 4,83 & $11 \%$ \\
\hline Desvio Padrão & & 20,82 & & 0,38 & & 0,73 & \\
\hline $\mathrm{CV}(\%)$ & & 15,19 & & 15,19 & & 15,19 & \\
\hline$f_{\text {bk }}(\mathbf{M P a})$ & & & & 1,74 & & 3,33 & \\
\hline
\end{tabular}

\footnotetext{
* Blocos expostos ao incêndio padrão da ISO 834-1:1999 durante 120 min em todas as faces
} 
Tabela C.8 - Resultados da resistência à compressão pós-fogo dos blocos de 4,0 MPa e $140 \mathrm{~mm}$ com gesso

\begin{tabular}{|c|c|c|c|c|c|c|c|}
\hline \multicolumn{8}{|c|}{ Ensaio de compressão pós-fogo - Blocos de 4,0MPa e $140 \mathrm{~mm}$ revestidos com gesso* } \\
\hline & $\begin{array}{l}\text { Resistência em } \\
\text { Temp. } \\
\text { Ambiente }(\mathrm{kN})\end{array}$ & $\begin{array}{c}\text { Força } \\
(\mathrm{kN})\end{array}$ & $\begin{array}{c}\text { Área Bruta } \\
\left(\mathrm{cm}^{2}\right)\end{array}$ & $\begin{array}{c}\text { Tensão na } \\
\text { Área Bruta } \\
(\mathrm{MPa})\end{array}$ & $\begin{array}{c}\text { Área } \\
\text { Líquida } \\
\left(\mathrm{cm}^{2}\right)\end{array}$ & $\begin{array}{c}\text { Tensão na } \\
\text { Área Líquida } \\
\text { (MPa) }\end{array}$ & $\mathrm{F}_{\mathrm{fog} o} / \mathrm{F}_{\mathrm{amb}}$ \\
\hline BL 1-G & \multirow{6}{*}{404,23} & 93,60 & \multirow{6}{*}{543,37} & 1,72 & \multirow{6}{*}{282,21} & 3,32 & $23 \%$ \\
\hline BL 2-G & & 107,90 & & 1,99 & & 3,82 & $27 \%$ \\
\hline BL 3-G & & 91,30 & & 1,68 & & 3,24 & $23 \%$ \\
\hline BL 4-G & & 74,50 & & 1,37 & & 2,64 & $18 \%$ \\
\hline BL 5-G & & 75,80 & & 1,40 & & 2,69 & $19 \%$ \\
\hline BL 6-G & & 94,70 & & 1,74 & & 3,36 & $23 \%$ \\
\hline Média & & 89,63 & & 1,65 & & 3,18 & $22 \%$ \\
\hline Desvio Padrão & & 12,64 & & 0,23 & & 0,45 & \\
\hline $\mathrm{CV}(\%)$ & & 14,10 & & 14,10 & & 14,10 & \\
\hline$f_{\mathrm{bk}}(\mathrm{MPa})$ & & & & 1,22 & & 2,35 & \\
\hline
\end{tabular}

* Blocos expostos ao incêndio padrão da ISO 834-1:1999 durante 120 min em todas as faces

Tabela C.9 - Resultados da resistência à compressão pós-fogo dos prismas de 10,0 MPa e 140 mm com gesso

\begin{tabular}{|c|c|c|c|c|c|c|c|}
\hline \multicolumn{8}{|c|}{ Ensaio de compressão pós-fogo - Pris mas de 10,0MPa e 140 mm revestidos com gesso* } \\
\hline & $\begin{array}{l}\text { Resistência em } \\
\text { Temp. } \\
\text { Ambiente }(\mathrm{kN})\end{array}$ & $\begin{array}{c}\text { Força } \\
(\mathrm{kN})\end{array}$ & $\begin{array}{c}\text { Área Bruta } \\
\left(\mathrm{cm}^{2}\right)\end{array}$ & $\begin{array}{l}\text { Tensão na } \\
\text { Área Bruta } \\
(\mathrm{MPa})\end{array}$ & $\begin{array}{c}\text { Área } \\
\text { Líquida } \\
\left(\mathrm{cm}^{2}\right)\end{array}$ & $\begin{array}{c}\text { Tensão na } \\
\text { Área Líquida } \\
(\mathrm{MPa})\end{array}$ & $\mathrm{F}_{\mathrm{fog} o} / \mathrm{F}_{\mathrm{amb}}$ \\
\hline PRI 1-G & & 51,36 & & 0,70 & & 1,81 & $7 \%$ \\
\hline PRI 2-G & & 62,26 & & 0,85 & & 2,20 & $8 \%$ \\
\hline PRI 3-G & 736,09 & 35,29 & 543,59 & 0,48 & 283,56 & 1,24 & $5 \%$ \\
\hline PRI 4-G & & 31,09 & & 0,42 & & 1,10 & $4 \%$ \\
\hline PRI 5-G & & 32,03 & & 0,44 & & 1,13 & $4 \%$ \\
\hline Média & & 42,41 & & $\mathbf{0 , 5 8}$ & & 1,50 & $6 \%$ \\
\hline Desvio Padrão & & 13,79 & & 0,19 & & 0,49 & \\
\hline $\mathrm{CV}(\%)$ & & 32,52 & & 32,52 & & 32,52 & \\
\hline$f_{\text {bk }}(\mathbf{M P a})$ & & & & $\mathbf{0 , 3 8}$ & & 0,98 & \\
\hline
\end{tabular}

* Prismas expostos ao incêndio padrão da ISO 834-1:1999 durante 120 min em todas as faces

Tabela C.10 - Resultados da resistência à compressão pós-fogo dos prismas de 4,0 MPa e 140 mm com gesso

\begin{tabular}{|c|c|c|c|c|c|c|c|}
\hline \multicolumn{8}{|c|}{ Ensaio de compressão pós-fogo - Prismas de 4,0MPa e $140 \mathrm{~mm}$ revestidos com gesso* } \\
\hline & $\begin{array}{c}\text { Resistência em } \\
\text { Temp. } \\
\text { Ambiente }(\mathrm{kN})\end{array}$ & $\begin{array}{c}\text { Força } \\
(\mathrm{kN})\end{array}$ & $\begin{array}{c}\text { Área Bruta } \\
\left(\mathrm{cm}^{2}\right)\end{array}$ & $\begin{array}{c}\text { Tensão na } \\
\text { Área Bruta } \\
(\mathrm{MPa})\end{array}$ & $\begin{array}{c}\text { Área } \\
\text { Líquida } \\
\left(\mathrm{cm}^{2}\right)\end{array}$ & $\begin{array}{c}\text { Tensão na } \\
\text { Área Líquida } \\
(\mathrm{MPa})\end{array}$ & $\mathrm{F}_{\text {fogo }} / \mathrm{F}_{\mathrm{amb}}$ \\
\hline PRI 1-G & & 31,69 & & 0,86 & & 1,12 & $9 \%$ \\
\hline PRI 2-G & & 38,67 & & 1,05 & & 1,37 & $10 \%$ \\
\hline PRI 3-G & 369,36 & 36,86 & 543,37 & 1,00 & 282,21 & 1,31 & $10 \%$ \\
\hline PRI 4-G & & 21,51 & & 0,58 & & 0,76 & $6 \%$ \\
\hline PRI 5-G & & 29,40 & & 0,80 & & 1,04 & $8 \%$ \\
\hline Média & & 31,63 & & 0,86 & & 1,12 & $9 \%$ \\
\hline Desvio Padrão & & 6,79 & & 0,18 & & 0,24 & \\
\hline $\mathrm{CV}(\%)$ & & 21,46 & & 21,46 & & 21,46 & \\
\hline$f_{\text {bk }}($ MPa) & & & & $\mathbf{0 , 5 2}$ & & $\mathbf{0 , 6 8}$ & \\
\hline
\end{tabular}

* Pris mas expostos ao incêndio padrão da ISO 834-1:1999 durante 120 min em todas as faces 
Tabela C.11 - Resultados da resistência à compressão pós-fogo das pequenas paredes de 10,0 MPa e 140 mm com gesso

\begin{tabular}{|c|c|c|c|c|c|c|c|}
\hline \multicolumn{8}{|c|}{ Ensaio de compressão pós-fogo - Pequenas paredes de $10,0 \mathrm{MPa}$ e $140 \mathrm{~mm}$ revestidos com gesso* } \\
\hline & $\begin{array}{l}\text { Resistência em } \\
\text { Temp. } \\
\text { Ambiente }(\mathrm{kN})\end{array}$ & $\begin{array}{c}\text { Força } \\
(\mathrm{kN})\end{array}$ & $\begin{array}{c}\text { Área Bruta } \\
\left(\mathrm{cm}^{2}\right)\end{array}$ & $\begin{array}{c}\text { Tensão na } \\
\text { Área Bruta } \\
(\mathrm{MPa})\end{array}$ & $\begin{array}{c}\text { Área } \\
\text { Líquida } \\
\left(\mathrm{cm}^{2}\right)\end{array}$ & $\begin{array}{c}\text { Tensão na } \\
\text { Área Líquida } \\
(\mathrm{MPa})\end{array}$ & $\mathrm{F}_{\mathrm{fogo}} / \mathrm{F}_{\mathrm{amb}}$ \\
\hline PAR 1-N-G** & \multirow{3}{*}{826,9} & 66,69 & \multirow{3}{*}{1101,19} & 0,61 & \multirow{3}{*}{567,13} & 1,18 & $8 \%$ \\
\hline PAR 2-N-G & & 30,37 & & 0,28 & & 0,54 & $4 \%$ \\
\hline PAR 3-N-G & & 29,61 & & 0,27 & & 0,52 & $4 \%$ \\
\hline Média*** & & 42,22 & & 0,38 & & 0,74 & $5 \%$ \\
\hline Desvio Padrão * & $* * *$ & 21,19 & & 0,19 & & 0,37 & \\
\hline $\mathrm{CV}(\%) * * *$ & & 50,19 & & 50,19 & & 50,19 & \\
\hline Média & & 29,99 & & $\mathbf{0 , 2 7}$ & & $\mathbf{0 , 5 3}$ & $4 \%$ \\
\hline Desvio Padrão & & 0,54 & & 0,005 & & 0,01 & \\
\hline $\mathrm{CV}(\%)$ & & 1,79 & & 1,79 & & 1,79 & \\
\hline$f_{\mathrm{bk}}(\mathbf{M P a})$ & & & & 0,22 & & 0,42 & \\
\hline
\end{tabular}

* Pequenas paredes expostas ao incêndio padrão da ISO 834-1:1999 durante 120 min em todas as faces

** Parede considerada como valor extremo (espúrio)

*** Valores calculados considerando o valor extremo (espúrio)

Tabela C.12 - Resultados da resistência à compressão pós-fogo das pequenas paredes de 4,0 MPa e 140 mm com gesso

\begin{tabular}{cccccccc}
\hline \hline \multicolumn{6}{c}{ Ensaio de compressão pós-fogo - Pequenas pare des de 4,0MPa e 140 mm revestidos com gesso* } \\
\hline \hline & $\begin{array}{c}\text { Resistência em } \\
\text { Temp. } \\
\text { Ambiente }(\mathrm{kN})\end{array}$ & $\begin{array}{c}\text { Força } \\
(\mathrm{kN})\end{array}$ & $\begin{array}{c}\text { Área Bruta } \\
\left(\mathrm{cm}^{2}\right)\end{array}$ & $\begin{array}{c}\text { Tensão na } \\
\text { Área Bruta } \\
(\mathrm{MPa})\end{array}$ & $\begin{array}{c}\text { Área } \\
\text { Líquida } \\
\left(\mathrm{cm}^{2}\right)\end{array}$ & $\begin{array}{c}\text { Aensão na } \\
\text { Área Líquida } \\
(\mathrm{MPa})\end{array}$ & $\mathrm{F}_{\text {fogo }} / \mathrm{F}_{\text {amb }}$ \\
\hline PAR 1-N-G & & 74,85 & & 0,68 & & 1,33 & $13 \%$ \\
PAR 2-N-G & 565,00 & 65,16 & 1100,73 & 0,59 & 564,42 & 1,15 & $12 \%$ \\
PAR 3-N-G & 50,13 & & 0,46 & & 0,89 & $9 \%$ \\
\hline Média & $\mathbf{6 3 , 3 8}$ & & $\mathbf{0 , 5 8}$ & & $\mathbf{1 , 1 2}$ & $\mathbf{1 1 \%}$ \\
Desvio Padrão & 12,46 & & 0,11 & & 0,22 & \\
CV (\%) & 19,65 & & 19,65 & & 19,65 & \\
$\boldsymbol{f}_{\text {bk }}$ (MPa) & & & $\mathbf{0 , 3 6}$ & & $\mathbf{0 , 7 1}$ & \\
\hline \hline
\end{tabular}

* Pequenas paredes expostas ao incêndio padrão da ISO 834-1:1999 durante 120 min em todas as faces 


\section{APÊNDICE D}

\section{Teste de valor espúrio (Grubbs)}

Trata-se de um teste desenvolvido para verificar se há em amostras a presença de valores extremos, que podem ser considerados como manifestações da variabilidade aleatória inerente aos dados, ou somente um erro de cálculo ou aquisição de dados durante o ensaio.

O teste de Grubbs é um dos inúmeros critérios utilizados para avaliar valores espúrios, assim como os demais, neste teste desenvolve-se o cálculo numérico amostral para comparar com um valor crítico baseado na teoria de amostras aleatórias. Isso permite concluir se há ou não os valores extremos. A estatística utilizada é fornecida pela equação D.1.

$Z=\frac{\left|x_{i}-\bar{x}\right|}{S}$

Em que:

$x_{i}$ é uma observação da amostra $x_{1}, x_{2}, \ldots, x_{n}$;

$\bar{x}$ é a média amostral;

$S$ é o desvio padrão amostral.

Assim duas hipóteses são testadas com esta estatística:

Hipótese 1: $x_{i}$ é uma observação considerada valor extremo

Hipótese 2: $x_{i}$ não é uma observação considerada valor extremo

A Hipótese 1 pode ser rejeitada se $Z>Z_{c}$ com nível de significância $\alpha$. Em que $Z_{c}$ é um valor crítico com base na distribuição de $Z$ e pode ser obtido pela Tabela D.1 em função dos valores de $\alpha$, com $N$ sendo o número de amostras.

Tabela D.1 - Tabela de valores críticos de Grubbs $\left(Z_{c}\right)$

\begin{tabular}{c|cc|c|cc|c|cc}
\hline \hline $\boldsymbol{N}$ & $\boldsymbol{\alpha}=\mathbf{5} \%$ & $\boldsymbol{\alpha}=\mathbf{1} \%$ & $\boldsymbol{N}$ & $\boldsymbol{\alpha}=\mathbf{5} \%$ & $\boldsymbol{\alpha}=\mathbf{1} \%$ & $\boldsymbol{N}$ & $\boldsymbol{\alpha}=\mathbf{5} \%$ & $\boldsymbol{\alpha}=\mathbf{1} \%$ \\
\hline $\mathbf{3}$ & 1,15 & 1,15 & $\mathbf{1 2}$ & 2,41 & 2,64 & $\mathbf{2 5}$ & 2,82 & 3,14 \\
$\mathbf{4}$ & 1,48 & 1,50 & $\mathbf{1 3}$ & 2,46 & 2,70 & $\mathbf{3 0}$ & 2,91 & 3,24 \\
$\mathbf{5}$ & 1,72 & 1,76 & $\mathbf{1 4}$ & 2,51 & 2,76 & $\mathbf{4 0}$ & 3,04 & 3,38 \\
$\mathbf{6}$ & 1,89 & 1,97 & $\mathbf{1 5}$ & 2,55 & 2,81 & $\mathbf{5 0}$ & 3,13 & 3,48 \\
$\mathbf{7}$ & 2,02 & 2,14 & $\mathbf{1 6}$ & 2,59 & 2,85 & $\mathbf{6 0}$ & 3,20 & 3,56 \\
$\mathbf{8}$ & 2,13 & 2,27 & $\mathbf{1 7}$ & 2,62 & 2,89 & $\mathbf{7 0}$ & 3,26 & 3,62 \\
$\mathbf{9}$ & 2,22 & 2,39 & $\mathbf{1 8}$ & 2,65 & 2,93 & $\mathbf{8 0}$ & 3,31 & 3,67 \\
$\mathbf{1 0}$ & 2,29 & 2,48 & $\mathbf{1 9}$ & 2,68 & 2,97 & $\mathbf{9 0}$ & 3,35 & 3,72 \\
$\mathbf{1 1}$ & 2,35 & 2,56 & $\mathbf{2 0}$ & 2,71 & 3,00 & $\mathbf{1 0 0}$ & 3,38 & 3,75 \\
\hline \hline
\end{tabular}


Considerando para um nível de significância de 5\% e o número de amostras igual a 6, o valor crítico $\left(Z_{c}\right)$ é de 1,89. Foi realizado o teste de Grubbs para o índice de absorção dos meios-blocos de 10,0 MPa e espessura de $190 \mathrm{~mm}$ que apresentou um coeficiente de variação relativamente alto $(22,22)$, mas não foi detectada a presença de nenhum valor extremo (espúrio) como mostrado na Tabela D.2.

Tabela D.2 - Resultados do teste de Grubbs para o índice de absorção dos meios-blocos de 10,0 MPa e 190 mm

\begin{tabular}{cccccc}
\hline \hline Meio Bloco & Absorção (\%) & Média & Desvio Padrão & Valor de Z & Espúrio \\
\hline \hline MBL1 & 3,48 & & & 1,56 & Não \\
MBL 2 & 2,44 & & & 0,25 & Não \\
MBL3 & 2,57 & \multirow{2}{*}{2,59} & 0,58 & 0,03 & Não \\
MBL4 & 2,34 & & & 0,44 & Não \\
MBL5 & 2,92 & & 0,57 & Não \\
MBL6 & 1,78 & & 1,41 & Não \\
\hline \hline CV (\%) & 22,22 & & & \\
\hline \hline
\end{tabular}

Considerando para um nível de significância de 5\% e o número de amostras igual a 3, o valor crítico $\left(Z_{c}\right)$ é de 1,15 . Foi realizado o teste de Grubbs para o módulo de elasticidade das pequenas paredes de 10,0 MPa e espessura de $190 \mathrm{~mm}$ que apresentou um coeficiente de variação relativamente alto $(28,67)$, mas não foi detectada a presença de nenhum valor extremo (espúrio) como mostrado na Tabela D.2.

Tabela D.3 - Resultados do teste de Grubbs para o módulo de elasticidade das pequenas paredes de 10,0 MPa e $190 \mathrm{~mm}$

\begin{tabular}{cccccc}
\hline \hline $\begin{array}{c}\text { Pequenas } \\
\text { Paredes }\end{array}$ & $\begin{array}{c}\text { Módulo de Elasticidade } \\
(\mathrm{GPa})\end{array}$ & Média & $\begin{array}{c}\text { Desvio } \\
\text { Padrão }\end{array}$ & Valor de Z & Espúrio \\
\hline \hline PAR 1 & 11,66 & & & 0,19 & Não \\
PAR 2 & 7,64 & 11,06 & 3,17 & 1,08 & Não \\
PAR 3 & 13,90 & & & 0,90 & Não \\
\hline \hline CV (\%) & 28,67 & & & \\
\hline \hline
\end{tabular}

Considerando para um nível de significância de 5\% e o número de amostras igual a 6, o valor crítico $\left(Z_{c}\right)$ é de 1,89 . Foi realizado o teste de Grubbs para a resistência a compressão dos prismas de blocos de 4,0 MPa e $140 \mathrm{~mm}$ da $1^{\text {a }}$ fornada, que apresentou um coeficiente de variação relativamente alto $(23,54)$, mas não foi detectada a presença de nenhum valor extremo (espúrio) como mostrado na Tabela D.4. 
Tabela D.4 - Resultados do teste de Grubbs para a resistência a compressão dos prismas de blocos de 4,0 MPa e $140 \mathrm{~mm}$ da $1^{\mathrm{a}}$ fornada

\begin{tabular}{|c|c|c|c|c|c|}
\hline Prismas & $\begin{array}{c}\text { Força resistente de } \\
\text { compressão pós-fogo }(\mathrm{kN})\end{array}$ & Média & $\begin{array}{l}\text { Desvio } \\
\text { Padrão }\end{array}$ & Valor de Z & Espúrio \\
\hline PRI 1-P & 49,39 & \multirow{6}{*}{52,84} & \multirow{6}{*}{12,44} & 0,28 & Não \\
\hline PRI 2-P & 66,81 & & & 1,12 & Não \\
\hline PRI 3-P & 66,79 & & & 1,12 & Não \\
\hline PRI 4-P & 34,02 & & & 1,51 & Não \\
\hline PRI 5-P & 50,95 & & & 0,15 & Não \\
\hline PRI 6-P & 49,09 & & & 0,30 & Não \\
\hline CV (\%) & 23,54 & & & & \\
\hline
\end{tabular}

Considerando para um nível de significância de 5\% e o número de amostras igual a 3, o valor crítico $\left(Z_{c}\right)$ é de 1,15 . Foi realizado o teste de Grubbs para a resistência a compressão pequenas paredes de blocos de $10,0 \mathrm{MPa}$ e $140 \mathrm{~mm}$ da $1^{\mathrm{a}}$ fornada, que apresentou um coeficiente de variação relativamente alto $(32,48)$, mas não foi detectada a presença de nenhum valor extremo (espúrio) como mostrado na Tabela D.5.

Tabela D.5 - Resultados do teste de Grubbs para a resistência a compressão das pequenas paredes de blocos de $10,0 \mathrm{MPa}$ e $140 \mathrm{~mm}$ da $1^{\mathrm{a}}$ fornada

\begin{tabular}{cccccc}
\hline \hline $\begin{array}{c}\text { Pequenas } \\
\text { Paredes }\end{array}$ & $\begin{array}{c}\text { Força resistente de } \\
\text { compressão pós-fogo }(\mathrm{kN})\end{array}$ & Média & $\begin{array}{c}\text { Desvio } \\
\text { Padrão }\end{array}$ & Valor de Z & Espúrio \\
\hline \hline PAR1-N & 103,62 & & & 0,22 & Não \\
PAR2-N & 79,81 & 111,45 & 36,20 & 0,87 & Não \\
PAR3-N & 150,93 & & & 1,09 & Não \\
\hline \hline CV $(\%)$ & 32,48 & & & \\
\hline \hline
\end{tabular}

Considerando para um nível de significância de 5\% e o número de amostras igual a 3, o valor crítico $\left(Z_{c}\right)$ é de 1,15 . Foi realizado o teste de Grubbs para a resistência a compressão do trio de pequenas paredes compartimentadas com blocos de 4,0 MPa e $140 \mathrm{~mm}$ da $1^{\mathrm{a}}$ fornada, que apresentou um coeficiente de variação relativamente alto $(32,48)$, mas não foi detectada a presença de nenhum valor extremo (espúrio) como mostrado na Tabela D.6. 
Tabela D.6- Resultados do teste de Grubbs para a resistência a compressão do trio de pequenas paredes compartimentadas com blocos de 4,0 $\mathrm{MPa}$ e $140 \mathrm{~mm}$ da $1^{\mathrm{a}}$ fornada

\begin{tabular}{cccccc}
\hline \hline $\begin{array}{c}\text { Pequenas } \\
\text { Paredes }\end{array}$ & $\begin{array}{c}\text { Força resistente de } \\
\text { compressão pós-fogo }(\mathrm{kN})\end{array}$ & Média & $\begin{array}{c}\text { Desvio } \\
\text { Padrão }\end{array}$ & Valor de Z & Espúrio \\
\hline \hline PAR1-C & 328,41 & & & 1,08 & Não \\
PAR2-C & 236,62 & 258,95 & 64,42 & 0,35 & Não \\
PAR3-C & 211,82 & & & 0,73 & Não \\
\hline \hline CV $(\%)$ & 32,48 & & & \\
\hline \hline
\end{tabular}

Considerando para um nível de significância de 5\% e o número de amostras igual a 5, o valor crítico $\left(Z_{c}\right)$ é de 1,72 . Foi realizado o teste de Grubbs para a resistência a compressão dos prismas de 10,0 MPa e $140 \mathrm{~mm}$ com revestimento de gesso da $2^{\text {a }}$ fornada, que apresentou um coeficiente de variação relativamente alto $(32,52)$, mas não foi detectada a presença de nenhum valor extremo (espúrio) como mostrado na Tabela D.7.

Tabela D.7- Resultados do teste de Grubbs para a resistência a compressão dos prismas de 10,0 MPa e 140 mm revestidos com gesso da $2^{\mathrm{a}}$ fornada

\begin{tabular}{|c|c|c|c|c|c|}
\hline $\begin{array}{c}\text { Prismas } \\
10,0 \mathrm{MPa} / 140 \mathrm{~mm}\end{array}$ & $\begin{array}{c}\text { Força resistente de } \\
\text { compressão pós-fogo }(\mathrm{kN})\end{array}$ & Média & $\begin{array}{l}\text { Desvio } \\
\text { Padrão }\end{array}$ & Valor de $\mathrm{Z}$ & Espúrio \\
\hline PRI 1-G & $\bar{~} 51,36$ & & & 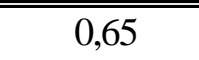 & "Não \\
\hline PRI 2-G & 62,26 & & & 1,44 & Não \\
\hline PRI 3-G & 35,29 & 42,41 & 13,79 & 0,52 & Não \\
\hline PRI 4-G & 31,09 & & & 0,82 & Não \\
\hline PRI 5-G & 32,03 & & & 0,75 & Não \\
\hline $\mathrm{CV}(\%)$ & 32,52 & & & & \\
\hline
\end{tabular}

Considerando para um nível de significância de 5\% e o número de amostras igual a 5, o valor crítico $\left(Z_{c}\right)$ é de 1,72 . Foi realizado o teste de Grubbs para a resistência a compressão dos prismas de 4,0 MPa e $140 \mathrm{~mm}$ com revestimento de gesso da $2^{\mathrm{a}}$ fornada, que apresentou um coeficiente de variação relativamente alto $(21,46)$, mas não foi detectada a presença de nenhum valor extremo (espúrio) como mostrado na Tabela D.8. 
Tabela D.8- Resultados do teste de Grubbs para a resistência a compressão dos prismas de 4,0 MPa e $140 \mathrm{~mm}$ revestidos com gesso da $2^{a}$ fornada

\begin{tabular}{cccccc}
\hline \hline $\begin{array}{c}\text { Prismas } \\
\text { 4,0 MPa/140 mm }\end{array}$ & $\begin{array}{c}\text { Força resistente de } \\
\text { compressão pós-fogo }(\mathrm{kN})\end{array}$ & Média & $\begin{array}{c}\text { Desvio } \\
\text { Padrão }\end{array}$ & Valor de Z & Espúrio \\
\hline \hline PRI 1-G & 31,69 & & & 0,01 & Não \\
PRI 2-G & 38,67 & \multirow{2}{*}{31,63} & 6,79 & 0,77 & Não \\
PRI 3-G & 36,86 & & & 1,49 & Não \\
PRI 4-G & 21,51 & & & 0,33 & Não \\
PRI 5-G & 29,40 & & & \\
\hline \hline CV (\%)
\end{tabular}

Considerando para um nível de significância de 5\% e o número de amostras igual a 3, o valor crítico $\left(Z_{c}\right)$ é de 1,15 . Foi realizado o teste de Grubbs para a resistência a compressão das pequenas paredes de $10,0 \mathrm{MPa}$ e $140 \mathrm{~mm}$ com revestimento de gesso da $2^{\mathrm{a}}$ fornada, que apresentou um coeficiente de variação relativamente alto $(50,19)$, e foi detectada a presença de um valor extremo (espúrio) como mostrado na Tabela D.9, para a paredes PAR 1-N-G, portanto este valor foi desconsiderado no cálculo médio dos resultados.

Tabela D.9- Resultados do teste de Grubbs para a resistência a compressão das pequenas paredes de 10,0 MPa e $140 \mathrm{~mm}$ revestidos com gesso da $2^{\mathrm{a}}$ fornada

\begin{tabular}{cccccc}
\hline \hline $\begin{array}{c}\text { Pequenas } \\
\text { Paredes }\end{array}$ & $\begin{array}{c}\text { Força resistente de } \\
\text { compressão pós-fogo }(\mathrm{kN})\end{array}$ & Média & $\begin{array}{c}\text { Desvio } \\
\text { Padrão }\end{array}$ & Valor de Z & Espúrio \\
\hline \hline PAR 1-N-G & 66,69 & & & 1,15 & Sim \\
PAR 2-N-G & 30,37 & 42,22 & 21,19 & 0,56 & Não \\
PAR 3-N-G & 29,61 & & & 0,60 & Não \\
\hline \hline CV $(\%)$ & 50,19 & & & \\
\hline \hline
\end{tabular}




\section{APÊNDICE E}

A ABNT NBR 16522:2016 estabelece dois procedimentos de cálculo para obtenção dos valores estimados de resistência característica à compressão dos elementos de alvenaria de blocos de concreto $\left(f_{e k, e s t}\right)$ em função do tipo de desvio padrão $\left(s_{d}\right)$ : quando o valor do desviopadrão de fábrica não é conhecido e para valores conhecidos.

Para o caso em que o desvio-padrão da fábrica não é conhecido, o valor estimado da resistência característica à compressão dos blocos de concreto do lote referida à área bruta pode ser obtido pela equação C.1.

$f_{e k, e s t(1)}=2\left[\frac{f_{e(1)}+f_{e(2)}+\cdots+f_{e(i-1)}}{i-1}\right]-f_{e(i)}$

sendo:

$f_{e k, e s t(2)}=\psi * f_{e(1)}$;

$f_{e k, e s t(3)}=$ maior valor entre $f_{e k, e s t ~(1)}$ e $f_{\text {ek,est (2) }}$;

$f_{\text {ek,est (4) }}=0,85 * f_{\text {em }}$;

$f_{e k, e s t}=$ menor valor entre $f_{e k, e s t ~(3)}$ e $f_{e k, e s t ~(4)}$

Em que:

$f_{e k, e s t}$ é a resistência característica estimada da amostra [MPa];

$f_{b(1)}, f_{b(2)}, \ldots, f_{b(i-1)}$ são os valores de resistência à compressão individuais dos corpos de prova da amostra, em ordem crescente $[\mathrm{MPa}]$;

$n$ é igual à quantidade de blocos da amostra e $i=n / 2$, se $n$ for par; e $i=(n-1) / 2$, se $n$ for ímpar;

$f_{\text {em }}$ é a média de tosos os resultados da amostra;

$\Psi$ é o fator de incerteza em função da quantidade de resultados.

$\mathrm{O}$ valor de $f_{e k, e s t}$ não deve ser tomado menor que $\psi \cdot f_{e(1)}$, adotando para $\psi$ os valores apresentados na Tabela E.1, em função da quantidade de blocos da amostra. 
Tabela E.1- Valores de $\Psi$ em função da quantidade de blocos

\begin{tabular}{c|c|c|c|c|c|c|c|c|c|c|c|c|c|c|c}
\hline \hline $\begin{array}{c}\text { Quantidade } \\
\text { de blocos }\end{array}$ & 3 & 4 & 5 & 6 & 7 & 8 & 9 & 10 & 11 & 12 & 13 & 14 & 15 & 16 & 18 \\
\hline$\psi$ & 0,80 & 0,84 & 0,87 & 0,89 & 0,91 & 0,93 & 0,94 & 0,96 & 0,97 & 0,98 & 0,99 & 1,00 & 1,01 & 1,02 & 1,04 \\
\hline \hline
\end{tabular}

Fonte: ABNT NBR 6136:2016

Para ensaios com o número de elementos menor do que seis, a resistência característica deve ser calculada pela equação C.2:

$f_{e k, e s t}=\psi * f_{e(1)}$

No caso em que o desvio-padrão da fábrica é conhecido, o valor estimado da resistência característica à compressão dos blocos de concreto do lote referida à área bruta, deve ser determinado pela equação C.3.

$f_{e k, e s t}=f_{e m}-1,65 \cdot s_{d}$

Em que, $f_{e m}$ é a resistência média da amostra [MPa]; e $s_{d}$ é o desvio-padrão do fabricante. O cálculo do desvio padrão do fabricante deve considerar ao menos 30 corpos de prova, retirados em intervalos regulares de produção para cada faixa de resistência, e devem ser obtidos por laboratório qualificado. 